UNIVERSIDADE DE SÃO PAULO

FACULDADE DE FILOSOFIA, LETRAS E CIÊNCIAS HUMANAS

DEPARTAMENTO DE LINGUÍSTICA

PROGRAMA DE PÓS-GRADUAÇÃO EM SEMIÓTICA E LINGUÍSTICA GERAL

MARCELO SEGRETO

\title{
A canção e a oralização: sílaba, palavra e frase
}

(versão corrigida) 
UNIVERSIDADE DE SÃO PAULO

FACULDADE DE FILOSOFIA, LETRAS E CIÊNCIAS HUMANAS

DEPARTAMENTO DE LINGUÍSTICA

PROGRAMA DE PÓS-GRADUAÇÃO EM SEMIÓTICA E LINGUÍSTICA GERAL

\title{
A canção e a oralização: sílaba, palavra e frase
}

(versão corrigida)

\author{
MARCELO SEGRETO \\ contato@marcelosegreto.com.br
}

Tese apresentada ao Programa de PósGraduação em Semiótica e Linguística Geral

do Departamento de Linguística da Faculdade de Filosofia, Letras e Ciências Humanas da Universidade de São Paulo para a obtenção do título de Doutor em Linguística.

Orientador: Prof. Dr. Luiz Augusto de Moraes Tatit

São Paulo 


\title{
FICHA CATALOGRÁFICA
}

\author{
Catalogação na Publicação \\ Serviço de Biblioteca e Documentação
}

Faculdade de Filosofia, Letras e Ciências Humanas da Universidade de São Paulo

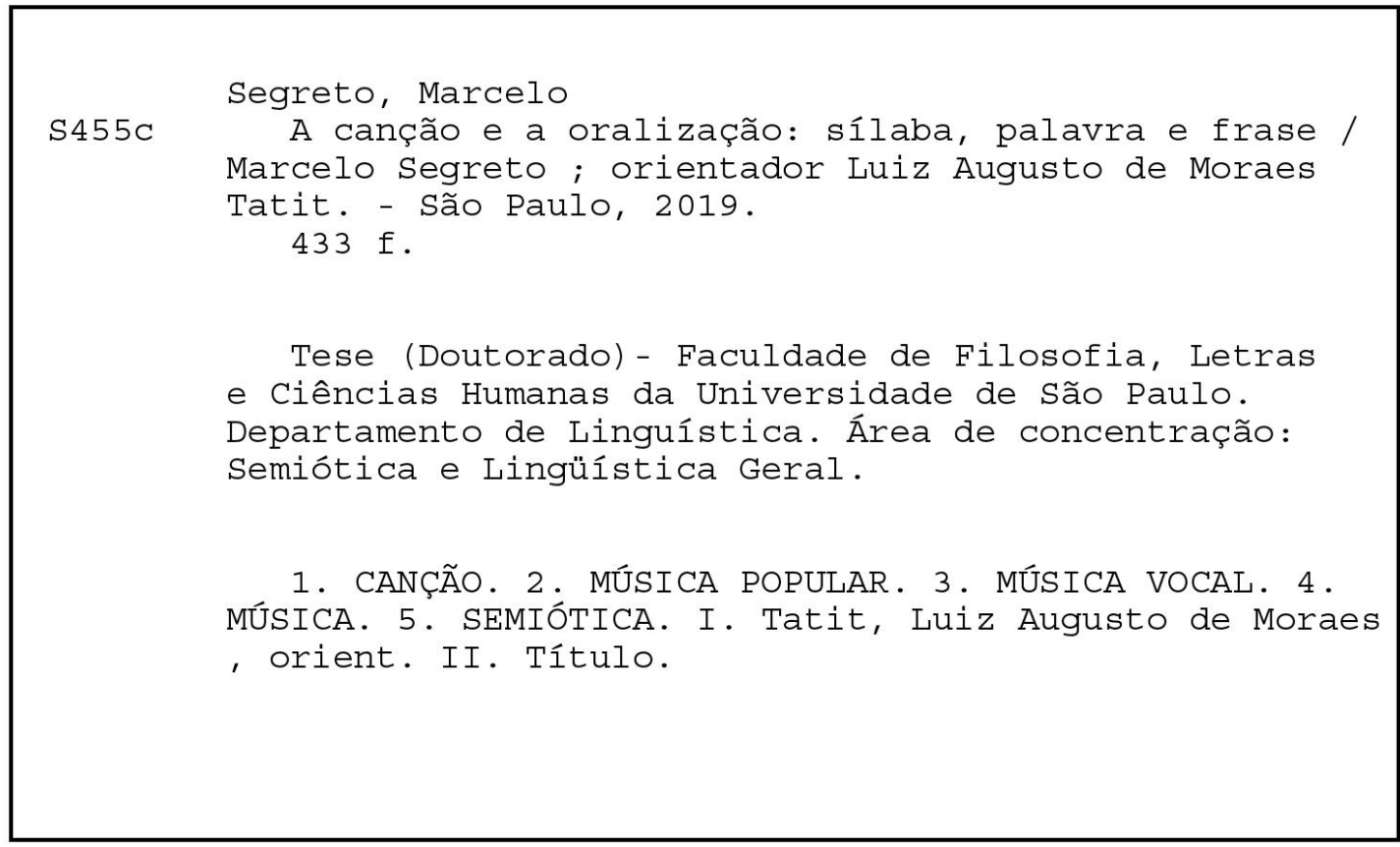

Título em inglês: Songwriting and oral language: syllable, word and phrase.

Keywords: popular song; music; semiotics of song

Titulação: Doutorado em Linguística

Área de concentração: Semiótica e Linguística Geral

Banca examinadora:

Prof. Dr. José Miguel Wisnik

Prof. Dr. Walter Garcia

Prof. Dr. Regina Machado

Data da defesa: 28 de março de 2019 


\section{ENTREGA DO EXEMPLAR CORRIGIDO DA TESE}

\section{Termo de Ciência e Concordância do orientador}

Nome do aluno: Marcelo Segreto

Data da defesa: 28/03/2019

Nome do Prof: orientador: Luiz Augusto de Moraes Tatit

Nos termos da legislação vigente, declaro ESTAR CIENTE do conteúdo deste EXEMPLAR CORRIGIDO elaborado em atenção às sugestões dos membros da comissão Julgadora na sessão de defesa do trabalho, manifestando-me plenamente favorávell ao seu encaminhamento e publicação no Portal Digital de Teses da USP.

São Paulo, 24 de maio de 2019

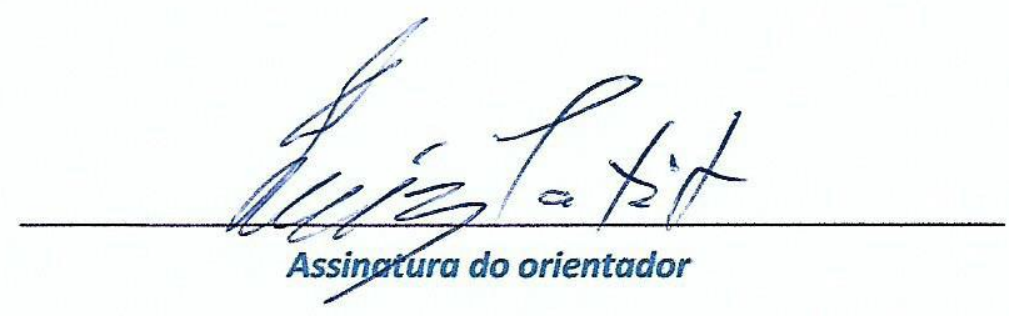




\title{
BANCA EXAMINADORA DA TESE DE DOUTORADO
}

\author{
Aluno: Marcelo Segreto \\ Orientador: Prof. Dr. Luiz Augusto de Moraes Tatit
}

Membros:

Prof. Dr.: José Miguel Wisnik

Julgamento:

Prof. Dr.: Walter Garcia

Julgamento:

Prof. Dr.: Regina Machado

Julgamento:
Instituição: FFLCH - USP

Assinatura:

Instituição: IEB - USP

Assinatura:

Instituição: IAR - UNICAMP

Assinatura: 


\section{AGRADECIMENTOS}

Ao professor Luiz Tatit, pela atenção, confiança e orientação sempre valiosa.

Aos professores José Miguel Wisnik, Walter Garcia e Regina Machado, pela apreciação do trabalho final.

Ao professor Ivã Carlos Lopes, pelas importantes observações realizadas no exame de qualificação.

Aos professores Aylton Escobar e Paulo de Tarso Salles que, desde o início, acolheram minhas canções e minha vontade de estudar canção popular no Departamento de Música da ECA-USP.

Aos amigos e parceiros Marcus Preto e Wagner Barbosa, pelas despretensiosas e profundas conversas sobre letra e música.

Aos parceiros da Filarmônica de Pasárgada, pelas experiências de canção e amizade.

Ao Conselho Nacional de Desenvolvimento Científico e Tecnológico (CNPq), pela bolsa concedida para a realização deste trabalho. 


\section{RESUMO}

SEGRETO, Marcelo. A canção e a oralização: sílaba, palavra e frase. 2019. Tese (Doutorado) - Faculdade de Filosofia, Letras e Ciências Humanas, Universidade de São Paulo, São Paulo, 425 p.

A canção popular conquistou, desde o início do século XX, uma significativa importância na sociedade brasileira. Sua presença cultural marcante pode ser constatada, atualmente, pela grande quantidade de publicações acadêmicas dedicadas ao assunto, ligadas às mais diversas áreas do conhecimento. Nesta pesquisa, estudaremos a relação entre a composição e a linguagem oral, adotando a abordagem da semiótica da canção desenvolvida por Luiz Tatit (teoria que sistematiza os processos específicos da canção vislumbrando-a como linguagem artística autônoma). Pretendemos, por meio da análise de exemplos (bem como mediante a atividade de recriação linguística e melódica de alguns deles), elucidar os diferentes graus de presença da fala na canção e as diferentes formas de oralização. Examinaremos as suas sutis nuances entoativas a partir de três patamares de análise (a sílaba, a palavra e a frase), tentando esquadrinhar esse misterioso encontro entre a sua letra e a sua melodia.

Palavras-chave: canção popular, música, semiótica da canção 


\begin{abstract}
SEGRETO, Marcelo. Songwriting and oral language: syllable, word and phrase. 2019. Tese (Doutorado) - Faculdade de Filosofia, Letras e Ciências Humanas, Universidade de São Paulo, São Paulo, 425 p.

Popular song has obtained an important role in Brazilian culture since the beginning of the $20^{\text {th }}$ century. Nowadays, it is widely recognised across various disciplines of academia. Based on the song semiotics theory developed by Luiz Tatit (a systematisation of songwriting concepts and practices in which song is considered an independent artistic language, separate from poetry and music), this study intends to analyse the relationship between song composition and oral speech. Drawing on the analysis and re-creation of some examples, we want to study the different levels of oral language in song. The focus of this thesis is to observe these nuances of speech through three linguistic levels: syllable, word and phrase. Results obtained from this inquiry will help us to understand the mysterious combination of lyrics and tunes.
\end{abstract}

Keywords: popular song, music, semiotics of song. 


\section{SUMÁRIO}

\section{PARTE I}

10 CANTO E A FALA .18

\section{A FIGURATIVIZAÇÃO NA SEMIÓTICA DA CANÇÃO}

2.1 A relação entre a melodia e a letra: eficácia e encanto .50

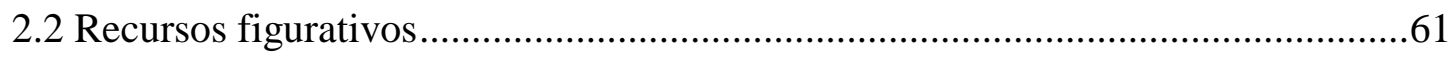

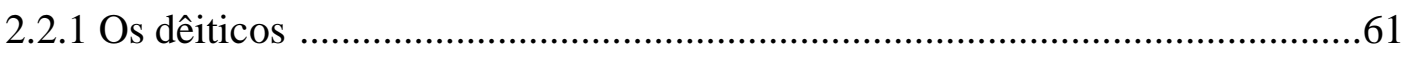

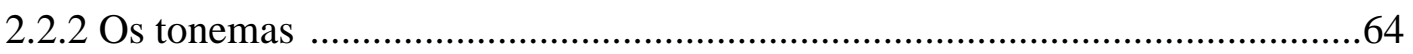

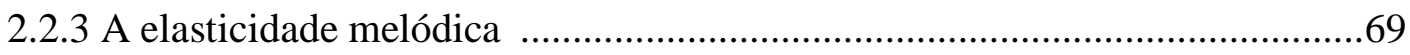

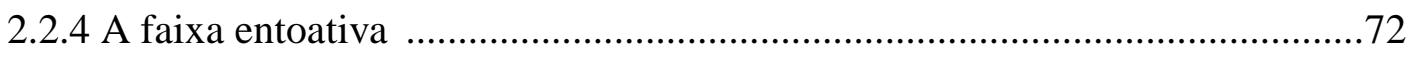

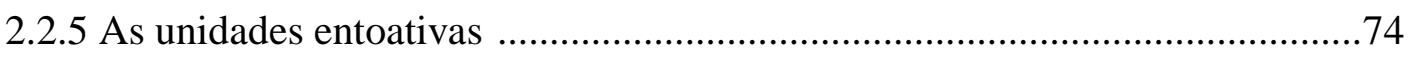

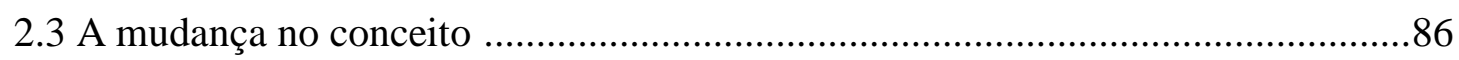

2.4 Plausibilidade: a fala como baliza da composição ...............................................91

2.5 A tematização e a passionalização .....................................................................99

2.6 A oscilação entre a força entoativa e a forma musical .......................................118

3 A FIGURATIVIZAÇÃO NA SEMIÓTICA GERAL ........................................129

3.1 Da manifestação concreta à estrutura abstrata: o percurso gerativo do sentido ..133

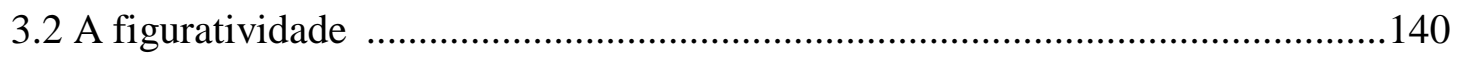

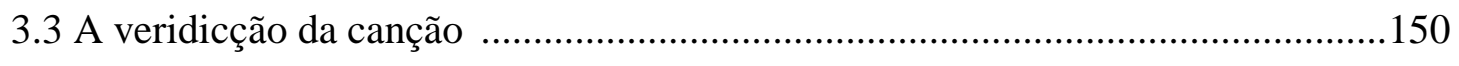

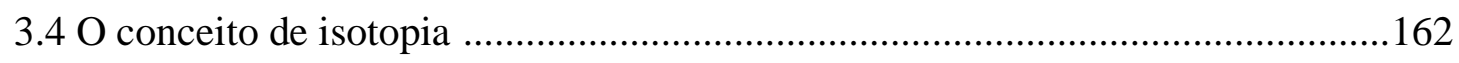




\section{PARTE II}

ORALIZAÇÃO LINEAR E ORALIZAÇÃO NÃO-LINEAR

1 A SÍLABA

1.1 A alteração da acentuação silábica pela intensidade 188

1.2 A alteração da acentuação silábica pela duração 206

1.3 A alteração da acentuação silábica pela altura 220

1.4 A simultaneidade dos três parâmetros .225

$1.5 \mathrm{O}$ abrandamento dos desvios acentuais 235

$1.6 \mathrm{O}$ aproveitamento artístico do deslocamento acentual 255

$1.7 \mathrm{O}$ conflito entre o padrão melódico e a naturalidade oral 259

2 A PALAVRA 268

2.1 O campo de força exercido pela palavra núcleo 272

2.2 A alteração da acentuação lexical .................................................................286

2.3 Aprofundando a questão dos monossílabos .....................................................293

2.4 O abrandamento dos desvios no nível lexical ..................................................309

2.5 A desconformidade entre a palavra escrita e a palavra cantada ..........................314

2.6 O léxico e os seus diferentes níveis de referencialidade .....................................318

2.7 O aproveitamento artístico da alteração da acentuação lexical ...........................329

3 A FRASE 335

3.1 As unidades entoativas e seus diferentes graus de proximidade com a fala .......339

3.2 Encontros e desencontros entre a frase verbal e a frase melódica .......................344

3.3 A formação de unidades entoativas a partir de unidades melódicas reduzidas ..381

3.4 A fluência da frase e a simultaneidade dos três níveis .......................................392

3.5 O abrandamento dos desvios no nível da frase .................................................396

3.6 O aproveitamento artístico dos desvios no nível da frase ..................................405

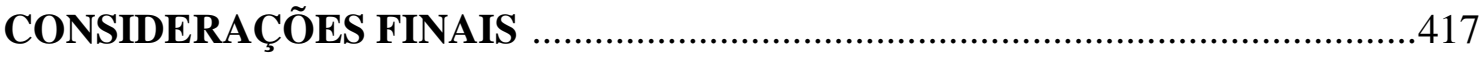

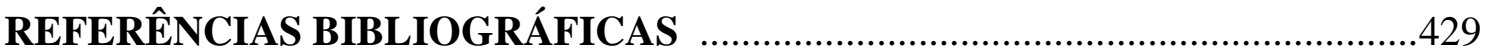




\section{INTRODUÇão}

A canção popular comercial obteve, ao longo do século $\mathrm{XX}$, um lugar de significativo destaque na cultura brasileira. O seu prestígio, potencializado pela popularização do rádio, na década de 1930, e da televisão, a partir dos anos 1960, produziu, ao final do século, uma fortíssima demanda em nossa sociedade. De fato, o gênero passou a despertar interesse cada vez maior de artistas e pensadores pertencentes às mais diversas áreas e estratos sociais. Na universidade, começou a ser estudado por pesquisadores de diferentes campos do conhecimento, da literatura à musicologia, passando pela história e pela sociologia ${ }^{1}$.

Todavia, embora constatemos esse crescente interesse pela canção, sua presença no meio acadêmico é, ainda hoje, um tanto controversa. Nos poucos cursos superiores de música popular existentes no país, quando contemplada pelo programa curricular, é, em geral, estudada a partir de uma perspectiva predominantemente musical, literária ou histórica, o que, a nosso ver, não abarca toda a sua dimensão e complexidade. Via de regra, uma parte considerável do repertório brasileiro de canções é negligenciada pela universidade. Expliquemos. Uma vez que a canção articula, sobretudo, elementos musicais e linguísticos, é natural a tendência de estudá-la pelo viés da musicologia e da literatura, a partir de suas ferramentas específicas. No entanto, nem uma, nem outra, possui, como principal questão, o estudo dessa articulação, o que torna essas análises algo escorregadias e restritas, ainda que riquíssimas e indispensáveis. Um crítico literário encontrará canções cujas letras contêm aspectos poéticos cultivados pelos poetas mais importantes de nossa língua. Um musicólogo se deparará com interessantes obras de nosso cancioneiro que utilizam procedimentos criativos usados pelos compositores da

\footnotetext{
${ }^{1}$ Evidentemente, o seu desenvolvimento se deve a numerosas razões. Fatores de ordem artística, social e política ligados à sua história também colaboraram para a sua forte presença na cultura brasileira atual. Exemplos notórios podem ser rapidamente citados: a relação do samba com a Era Vargas, o elo entre o surgimento da chamada MPB e o período da ditadura militar, o vínculo entre o rap e a eclosão da violência nas grandes cidades, a aproximação entre autores eruditos (da poesia e da música de vanguarda) e movimentos musicais como o tropicalismo e a bossa nova etc. Enfim, há um número abundante de aspectos que ajudaram a delinear a sua complexa fisionomia atual.
} 
música erudita contemporânea. Ambos deixarão de lado, no entanto, uma enorme quantidade de canções que não incluem nenhum desses aspectos. Afinal, suas letras não são poemas e suas usuais melodias acompanhadas não constituem peças musicais de grande interesse.

Essa canção, desconsiderada pelos estudos literários e musicais, é aquela que prolifera nas rádios, nos canais de televisão e na internet. É a canção excluída dos meios acadêmicos. Essa intrigante conjuntura constitui, talvez, um dos catalisadores de nossa pesquisa. Interessa-nos, então, a análise que possa abarcar todo e qualquer tipo de obra, do campo erudito à produção mais comercial, e não somente determinados perfis artísticos, mais restritos, nos quais encontramos aspectos poéticos e musicais afinados com a evolução mais recente dessas linguagens. Caso contrário, transpondo o mesmo raciocínio para outras áreas do conhecimento, é como se a linguística optasse por estudar exclusivamente a norma culta da língua, a biologia apenas o reino animal e a história somente a civilização ocidental. Esses exemplos, esdrúxulos quando transplantados para esses campos, no universo de estudos acadêmicos da canção, parecem perfeitamente normatizados. Por isso, a nosso ver, a maneira mais adequada de incorporar a canção na universidade (ao que tudo indica em cursos superiores de música popular), é aquela que encerra um olhar mais abrangente da matéria. Num ambiente acadêmico ideal, portanto, poderíamos articular o estudo específico da canção (aquele que sistematiza o seu artesanato intrínseco) com pesquisas, igualmente imprescindíveis, ligadas à música popular, à música erudita, à literatura, à dança, à sociologia, à história, ao cinema etc.

Nesse sentido, um dos principais objetivos desta tese é tentar contribuir para o fomento de uma perspectiva mais globalizante da canção. Desejamos ajudar a construir, pouco a pouco, uma bagagem metodológica mais robusta para que ela receba, na universidade, um tratamento mais fundamentado. Nosso objetivo mais específico é, a partir de nossas análises, embasar um futuro curso de composição de canção, apresentando o artesanato do cancionista de maneira técnica. Assim como em outras disciplinas ligadas à criação artística (composição musical, artes plásticas, cinema etc.), acreditamos haver habilidades e procedimentos para serem praticados e aprendidos. Desejamos, desse modo, começar a formar o arcabouço para uma possível disciplina prática de composição de canção, com princípios técnicos que a norteiem e ultrapassem as questões ligadas ao gosto e à ideologia, pelo menos num momento inicial de aprendizagem e treinamento. 
Para suprir a carência de uma abordagem específica de nosso assunto, adotamos, nesta tese, o aparato teórico da semiótica da canção sem dispensar, é claro, aspectos provenientes de outras áreas que possam enriquecer as análises. No nosso entendimento, essa disciplina oferece diversos benefícios metodológicos. Em primeiro lugar, concebe a canção como linguagem autônoma, dado crucial para nossa pesquisa. Além disso, tendo suas raízes ligadas à linguística moderna, ela nos oferece uma interessante visão analítica que, de maneira técnica e descritiva, privilegia o estudo do funcionamento da linguagem, superando posições doutrinárias. Ela nos concede, então, a possibilidade de estudar toda e qualquer canção, sem indicar caminhos preferenciais. O seu conceito de figurativização (ou oralização) ${ }^{2}$ caminha nesse mesmo sentido: o compositor, ao unir letra e música, independentemente de sua vontade, formará modos de dizer mais ou menos usuais do ponto de vista da língua oral. A teoria é construída para abarcar todos esses fenômenos. O seu principal propósito é descrevê-los, não os julgar esteticamente ${ }^{3}$.

Entendendo a canção como linguagem autônoma, desejamos ainda abordar o que nos parece constituir um verdadeiro mistério: por que certas canções cujas letras ou melodias, analisadas isoladamente, nos parecem banais, nos despertam tamanho interesse e emoção? Quais são os fatores próprios da canção que objetivamente contribuem para a sua expressividade? No decorrer desta tese, teremos a oportunidade de investigar alguns desses aspectos.

$\mathrm{Na}$ parte teórica inicial, formada pelos capítulos "O canto e a fala", "A figurativização na semiótica da canção" e “A figurativização na semiótica geral”, traçaremos um caminho de estudo incomum. Como forma de tornar nosso percurso teórico mais convidativo ao leitor interessado em canção popular (mas que não possui intimidade com os conceitos semióticos), optamos por realizar um percurso que parte das ocorrências mais concretas (obras, compositores e movimentos artísticos que trazem a questão oral de modo proeminente) para, em seguida, pouco a pouco, incorporar, primeiramente, os conceitos lançados pela semiótica específica da canção e, por fim, as noções mais fundamentais oriundas da semiótica geral.

\footnotetext{
${ }^{2}$ Esse é, para o objetivo de nossa pesquisa, o conceito mais importante dentre as noções propostas pela semiótica da canção. É preciso salientar para o leitor que "figurativização" e "oralização" se referem exatamente ao mesmo processo. Na teoria desenvolvida por Luiz Tatit, o segundo termo está, pouco a pouco, substituindo o primeiro. É o que constatamos em suas publicações mais recentes.

${ }^{3}$ A avaliação estética deve vir num momento posterior, munida de critérios fundamentados na linguagem específica da canção. Acreditamos que os elementos estudados pela semiótica da canção poderão até mesmo participar de análises sociológicas e históricas das obras.
} 
Assim, no primeiro capítulo, comentaremos diversas questões relacionadas à essa interessante imbricação da música vocal e da fala. Destacaremos alguns assuntos relevantes já apontados por autores que se dedicaram à matéria e elencaremos, ao longo da história da música popular e erudita, certos compositores e estilos que, de alguma forma, possibilitam reflexões interessantes acerca desse vínculo entre o canto e a oralidade. Na música popular, passaremos pela obra do poeta barroco Gregório de Matos Guerra (1636-1696), pelas composições setecentistas de Domingos Caldas Barbosa (1739-1800), pelos primeiros sambistas, por intérpretes como Carmem Miranda, Mário Reis, Marília Batista e João Gilberto e por gêneros como o samba de breque, o repente nordestino e o rap. Na música erudita, comentaremos a cultura musical da Grécia Antiga, o cantochão (ou canto gregoriano), as composições polifônicas do período da Ars Antiqua (séculos XII e XIII), as óperas, o desenvolvimento do Lied alemão (ao longo do século XVIII) e algumas peças vocais do século XX. Dessa maneira, a título de introdução, apresentaremos para o leitor exemplos mais concretos e familiares por meio dos quais ele poderá, de modo mais seguro, iniciar sua reflexão sobre a oralização na canção.

No segundo capítulo, dedicado ao estudo da figurativização na semiótica da canção, trataremos da primeira teoria que tentou, entre outras questões, sistematizar a relação entre o canto e a fala. Aqui, o leitor entrará em contato com ferramentas analíticas que pretendem explicar os dados concretos brevemente comentados em nosso primeiro capítulo. Abordaremos os principais tópicos da semiótica da canção dedicados à presença da língua oral, fazendo, igualmente, uma espécie de apanhado geral e revisão da teoria, do seu início, na década de 1980, até as suas publicações mais recentes. Trataremos, entre outros assuntos, da relação entre a melodia e a letra, elemento fundador da canção como linguagem autônoma, dos cinco recursos figurativos (dêiticos, tonemas, elasticidade melódica, faixa entoativa e unidade entoativa), da noção de plausibilidade entoativa e, por fim, da oscilação entre a força entoativa e a forma musical.

No terceiro capítulo, utilizando conceitos ainda mais abstratos, desejamos observar como as questões tratadas anteriormente (os dados concretos tratados em nosso primeiro capítulo e os raciocínios empreendidos pela semiótica da canção acerca da presença da língua oral no canto) podem ser abordadas pela teoria mais geral da semiótica. Traçaremos um brevíssimo panorama histórico e metodológico da teoria desde sua fundação para, em seguida, tratarmos de alguns de seus conceitos e ferramentas: o percurso gerativo (modelo clássico de análise do sentido criado pela semiótica francesa) e seus três níveis (fundamental, narrativo e discursivo); o campo de estudo da 
figuratividade e o entendimento do processo da figurativização como um continuum; a questão da veridicção (essencial para a experiência comunicativa da canção); e, por último, o conceito de isotopia.

A segunda parte de nossa tese, ao contrário da primeira, mais teórica, possui um conteúdo mais analítico, dedicado ao exame do encaixe entre a letra e a melodia a partir de diferentes perspectivas. Separamos esse estudo em três patamares de análise (a sílaba, a palavra e a frase), dedicando, a cada um deles, um capítulo à parte. Antes, para embasar essas análises, discutimos a existência de modos de dizer mais usuais ou menos usuais, considerando o processo de oralização a partir de duas novas subcategorias, a figurativização linear e a figurativização não-linear. Além de analítica, essa parte propõe uma atividade prática de recriação de determinados exemplos como forma de testar diferentes possibilidades de sentido entoativo. Combinando análise e criação, ao reelaborarmos a letra ou a melodia de algumas obras de nosso cancioneiro, desejamos explicitar a técnica do cancionista e avaliar os diferentes graus de presença da fala na canção.

No primeiro capítulo, “A sílaba”, examinaremos os deslocamentos de acentuação silábica produzidos pelos parâmetros musicais da intensidade, da duração e da altura e veremos casos em que os três fatores agem em conjunto. Estudaremos igualmente exemplos nos quais observamos diferentes formas de abrandamento desses desvios acentuais, quando fatores musicais ou linguísticos mitigam a sua sensação de distanciamento em relação à língua falada. Discutiremos também as diversas possibilidades de aproveitamento artístico dos deslocamentos silábicos, visto que o compositor, ainda que de modo intuitivo, os utiliza esteticamente. Por fim, visualizaremos o encaixe entre a melodia e a letra como um permanente conflito entre os padrões melódicos e as tendências ligadas à oralização.

No segundo capítulo, "A palavra", passando a um patamar linguístico superior, examinaremos o que consideramos um possível campo de força exercido pelo termo núcleo do enunciado. Comentaremos diversos exemplos do que entendemos constituir deslocamentos de acentuação lexical (quando deveremos aprofundar o estudo dos vocábulos monossilábicos). Abordaremos o conflito, no nível da palavra, entre a letra escrita e a letra cantada (casos em que termos presentes no texto linguístico, ao combinarem com a linha melódica, são desvalorizados ou anulados), bem como os diferentes níveis de referencialidade suscitados pelas letras de canção. Também 
estudaremos os artifícios de abrandamento dos desvios lexicais e o aproveitamento artístico dos mesmos.

No terceiro e derradeiro capítulo analítico de nossa tese, "A frase", chegaremos ao último estágio de análise de nossa pesquisa. Retomaremos a questão das unidades entoativas, examinando suas possibilidades criativas e seus diferentes modos de relação com a fala. Discutiremos os diferentes tipos de encaixe entre as frases verbais e as frases melódicas, seus encontros e desencontros. Observaremos, além das questões ligadas ao abrandamento e ao aproveitamento artístico dos desvios no nível da frase (seguindo uma estrutura similar à organização dos dois capítulos anteriores), a simultaneidade dos três níveis linguísticos (sílaba, palavra e frase) como garantidora de uma maior fluência oral. Acreditamos que essa discussão pode ajudar a aclarar a intrigante questão levantada acima, acerca das canções que sensibilizam os ouvintes, independentemente do valor literário de suas letras ou do valor musical de suas melodias e arranjos instrumentais.

Por fim, desejamos salientar que, para ilustrar nossas análises, tentamos selecionar exemplos presentes no repertório dos compositores de canção mais conhecidos pelo grande público. Ainda que esse critério seja bastante discutível, nosso intuito é fazer com que o leitor identifique, de pronto, a canção analisada, como se a soubesse de cor. Ocasionalmente, foi preciso pinçar exemplos de canções menos familiares, mas que traziam contribuições importantes à nossa pesquisa. Ademais, ainda que nosso material e interesse principal seja a canção popular comercial, acreditamos que os estudos aqui realizados podem servir de base para analisar qualquer tipo de canção, do repertório erudito ao tradicional. 
PARTE I

A RELAÇÃO ENTRE A CANÇÃO E A LÍNGUA ORAL 


\section{O CANTO E A FALA}

A relação entre a música cantada e a linguagem oral é uma questão que perpassa a história do homem desde os tempos mais remotos e corresponde a um assunto frequentemente discutido por estudiosos e praticantes da canção ao longo da história. Não poderia ser diferente, na medida em que ambos, canto e fala, similarmente veiculam um discurso formado pela união de um texto verbal com um texto sonoro, com seus parâmetros de altura, duração, intensidade e timbre mais ou menos estáveis. O mesmo aparelho fonador que dá suporte à nossa comunicação linguística cotidiana também veicula um incrível espectro de estilos cancionais. A voz que fala é, afinal, a mesma voz que canta. E ainda que a linha melódica não carregue consigo uma letra ou que não seja possível compreender as palavras emitidas pelo intérprete, ainda sim, nossa experiência cotidiana com a oralidade nos faz naturalmente estabelecer essa conexão.

Trataremos de diversos aspectos ligados à essa fascinante relação entre canto e oralidade no decorrer desta tese. Por ora, antes de examinarmos o papel exercido pela fala na semiótica da canção, bem como aprofundarmos o mesmo tema a partir das ferramentas analíticas da semiótica geral, desejamos somente destacar alguns tópicos importantes já levantados por autores que se dedicaram à matéria, ainda que pontualmente. O propósito deste capítulo inicial é, afinal, elencar, ao longo da história da música, erudita ou popular, os estudos, os movimentos artísticos, os compositores e os cantores cujo exame pode suscitar reflexões significativas sobre esse interessante vínculo entre a música vocal e a fala. Acreditamos que esse panorama geral, como um ponto de partida propositadamente mais sucinto e de caráter ilustrativo, nos proporcionará maior discernimento sobre a efetiva importância do tema dentro de nossa área de estudo ${ }^{4}$. Estaremos, então, aptos a

\footnotetext{
${ }^{4}$ Evidentemente, tendo em vista o caráter conciso deste primeiro capítulo, não trataremos de diversos gêneros, compositores e outras questões históricas. Na música popular brasileira, por exemplo, nos concentraremos sobretudo na canção comercial, deixando para pesquisas futuras aspectos ligados à música folclórica, negra, indígena etc.
} 
aprofundá-lo por meio das ferramentas analíticas oferecidas pelas teorias da semiótica da canção e da semiótica geral.

O pensador Jean-Jacques Rousseau (1712-1778) em seu Ensaio Sobre a Origem das Línguas já examinava a modulação musical da língua oral como consequência direta das emoções vividas pelo sujeito: "os acentos são nela mais frequentes ou mais raros, as inflexões mais ou menos agudas segundo o sentimento que se acrescenta" (ROUSSEAU, 1978:186). Em outro fragmento, mais do que perceber a musicalidade sugerida pelas diversas possibilidades de enunciação, o autor claramente estabelece um elo entre a voz de quem canta e a voz de quem se expressa pela fala:

\footnotetext{
A melodia, imitando as inflexões da voz, exprime as lamentações, os gritos de dor ou de alegria, as ameaças, os gemidos. Devem-se-lhe todos os sinais vocais das paixões. Imita as inflexões das línguas e os torneios ligados, em cada idioma, a certos impulsos da alma. Não só imita como fala, e sua linguagem, inarticulada mas viva ardente e apaixonada, possui cem vezes mais energia do que a própria palavra. Disso provém a força das imitações musicais e nisso reside o império do canto sobre corações sensíveis (ROUSSEAU, 1978:190)
}

A melodia cantada é ressaltada não somente por sua motivação na entoação, mas também por potencializar as palavras da fala, envolvendo o ouvinte de maneira arrebatadora, como uma espécie de "império do canto". O indivíduo não apenas reconhece os torneios familiares de seu idioma, mas é atingido por uma energia que advém da união entre a música e a língua. Desse modo, parece supor que o público possui uma expectativa de sentir, por trás da música da canção, uma pessoa em sua aparência de vida real. É como se realizássemos, mesmo que intuitivamente, um cruzamento entre diferentes instâncias, fundindo o cantor e o "eu" do discurso verbal em uma única entidade.

Nessa mesma direção, analisando a prática musical do Renascimento, Lynn Liptak Budd (1976: 53), conforme citado por Carin Zwilling (2007:84), comenta que o cantor "deveria manifestar envolvimento com a mensagem da canção. A música era concebida como uma manifestação direta da situação: a canção e as palavras formavam a unidade da mensagem. Deveriam retratar as convicções dos sentimentos interiores do homem". A fusão entre o cantor e o "eu" discursivo é tratada aqui como uma espécie de "envolvimento com a mensagem da canção". Evidentemente, no vasto repertório de música cantada, esse comprometimento pode produzir variadas configurações artísticas. O compositor pode até mesmo se distanciar radicalmente da entoação da fala 
privilegiando questões especificamente musicais e, mesmo assim, reivindicar o seu engajamento com o texto linguístico, ao menos no nível do conteúdo. São casos muito raros, mas igualmente possíveis. Via de regra, parece haver um equilíbrio entre a música e a fala na canção ${ }^{5}$.

Roland Barthes em "A música, a voz, a língua”, investigando o porquê de sua preferência por certo cantor lírico em oposição a outro, identifica em sua voz um modo de entoar característico da canção popular tradicional, o canto com uma "voz nua".

Porque se a canção popular se cantava tradicionalmente com uma voz nua, é por que era importante que se ouvisse bem a história: algo é contado, que é preciso que eu receba a $n u$. (BARTHES, 1984: 229)

Colocar a história a ser contada em primeiro plano é tirar a atenção da voz enquanto instrumento musical. Nesse sentido, observamos que o jogo de forças entre a língua e a música não se aplica somente ao nível da composição da melodia e da letra, mas também à colocação timbrística da voz pelo cantor. Supomos que o canto com o timbre de uma "voz nua" comentado por Barthes pende mais para o lado da linguagem oral do que para o lado da música, como uma emissão mais coloquial da letra. $\mathrm{O}$ efeito gerado por tal uso atinge uma certa impressão de verdade, uma verossimilhança relacionada a uma situação conversacional cotidiana. É como se o tempo da canção se confundisse com o tempo da vida.

Mário de Andrade, em Aspectos da música brasileira (1965), conforme citado por Luiz Tatit em sua dissertação de mestrado $^{6}$, assim como Rousseau, discorre sobre a musicalização da fala ainda no âmbito do discurso oral, descrevendo ocasiões em que a emissão ganha certa estabilidade sonora. Também comenta a respeito do que considera a melhor maneira de se compor uma canção erudita, na qual os compositores muitas vezes possuem um poema escrito ou um texto em prosa como ponto de partida.

\footnotetext{
5 Ao longo desta tese veremos que a canção, fundada na relação entre um texto verbal e uma melodia, inevitavelmente apresenta casos mais ou menos usuais do ponto de vista da naturalidade oral. Todos esses casos devem ser contemplados por nossa pesquisa. Essa discussão será realizada de modo mais aprofundado no início da segunda parte da tese, ao tratarmos dos diferentes tipos de figurativização (linear e não-linear). ${ }^{6}$ No início de sua dissertação de mestrado, Por uma semiótica da canção popular (1982), Luiz Tatit coleciona e articula reflexões de autores diversos acerca da relação entre a música vocal e o discurso linguístico oral, bem como sobre a íntima associação entre melodia e letra, assunto que discutiremos no segundo capítulo desta tese, dedicado à semiótica da canção.
} 
(...) e quando a palavra falada quer atingir longe, o grito, no apelo e na declamação, ela se aproxima caracteristicamente do canto e vai deixando aos poucos de ser instrumento oral para se tornar instrumento musical (ANDRADE, 1965: 43 apud TATIT, 1982: 23-24)

O sistema ideal de compor canções eruditas será, portanto, o compositor escolhido um texto, aprendê-lo de cór e repetí-lo muitas e muitas vezes, até que esse texto se dilua, por assim dizer, num esqueleto rítmico sonoro (ANDRADE, 1965:48 apud TATIT, 1982: 24-25)

Repetir o texto "muitas e muitas vezes" até decorá-lo, o que implicitamente inclui a questão oral, é enfatizar um tratamento entoativo do texto linguístico, criando a melodia ou o seu "esqueleto rítmico sonoro" a partir da transformação do texto escrito em música por meio da fala. Essa preocupação de Mário de Andrade parece significar uma tentativa de valorização da canção nacional a partir da língua portuguesa falada no Brasil, seguindo a ideologia nacionalista de seu tempo. Afinal, como se sabe, certa prática do canto erudito, amparada pela tradição musical europeia, é recorrentemente criticada por seu distanciamento em relação ao registro coloquial do português brasileiro. Bruno Kiefer discorre sobre esse hipotético engessamento desses compositores em contraposição ao estilo mais próximo da língua oral praticado pelos criadores da canção popular.

Hoje em dia, em nosso meio, os compositores populares têm uma vantagem sobre os eruditos: possuem mais liberdade para serem espontâneos. Embora mais restritos quanto aos recursos, quanto ao âmbito de vivências expressas, suas melodias, muitas vezes, nascem diretamente do ritmo e do conteúdo dos versos. O compositor erudito tem demasiadamente melodias italianas, francesas ou alemãs no ouvido. (KIEFER, 1973: 44 apud TATIT, 1982: 29)

Em todos os autores citados acima percebemos certa preocupação com a presença da fala na melodia musical da canção, seja ela erudita ou popular. São estudiosos que se atentaram para o fascínio provocado pela forte imbricação entre uma manifestação artística, o canto, e uma faculdade humana, a língua. Navarro Tomás, em seus estudos sobre a entoação, observa a dificuldade de realizar uma separação entre o canto e a fala em certos idiomas?

\footnotetext{
${ }^{7}$ Se hace dificil comprender hasta que punto es posible establecer una separación definida y precisa entre el canto y la entonación de la palabra en pueblos como el chino, por ejemplo, cuyo idioma posse acento tónico semántico, o con el persa y el árabe cuya escala musical se sirve de cuartos de tono o de medidas aun menores como unidad de intervalo.
} 
Torna-se difícil compreender até que ponto é possível estabelecer uma separação clara e precisa entre o canto e entoação da palavra em povos como o chinês, por exemplo, cuja língua possui acento tônico semântico, ou com o persa e o árabe cuja escala musical utiliza quartos de tom ou medidas ainda menores como unidades de intervalo (TOMÁs, 1966: 18 apud TATIT, 1982: 32-33)

Na língua chinesa a fala parece musicalizar-se. No árabe, ao contrário, é a música que, aos olhos da cultura ocidental, parece se entoativizar. As características de uma linguagem estão igualmente presentes na outra, como se fala e canto constantemente se tocassem. Esse fato, algo possivelmente intuído por todos aqueles que cultivam a canção, é um importante ponto de partida para esta pesquisa. Devemos observar que, antes dos estudos ligados à semiótica da canção ${ }^{9}$, essa questão foi tratada, ainda que de forma pontual, por diferentes pesquisadores pertencentes a diversas áreas do conhecimento. Esses estudiosos constatavam a característica entoativa do canto sem, no entanto, aprofundar suas investigações. É o caso do linguista belga Nicolas Ruwet, conforme trecho citado por Luiz Tatit.

As significações linguísticas, de todo modo, mantêm sua presença no interior da música. Aliás, na medida em que a voz é para o homem, antes de tudo, o órgão da fala, no momento em que ela se manifesta na música, a linguagem [oral] em si está presente, mesmo que o canto se converta em puros melismas e mesmo que o texto se torne totalmente incompreensível. Assim, os esteticistas deveriam atribuir mais importância ao fato de que jamais, por assim dizer, a música vocal poderia prescindir do suporte das palavras: parecenos impossível ver na voz um instrumento como os demais (RUWET, 1972: 52 apud TATIT, 2016: 93$)^{10}$

A essas constatações pontuais que pressentem uma possível relação entre a canção e a fala podemos adicionar alguns comentários sobre certas passagens da história da música, popular ou erudita, nas quais essa associação possui relevância. No desenvolvimento da canção popular brasileira, por exemplo, podemos recuperar alguns antecedentes históricos que, de certa maneira, apontam para a vocação entoativa dos compositores de canção.

\footnotetext{
8 Tradução nossa.

${ }^{9}$ A teoria da semiótica da canção será abordada de maneira detalhada no capítulo seguinte.

10 Tradução de Luiz Tatit.
} 
Já no século XVII, os documentos que registram a vida e a obra do poeta barroco Gregório de Matos Guerra (1636-1696) nos mostram, como bem assinala José Ramos Tinhorão, que é possível fazer certa aproximação entre a produção do artista e o que atualmente entendemos como as criações dos nossos compositores de canção popular. Conforme Tinhorão, sua obra "deveria ser estudada quase toda não como obra poética, mas como versos de música popular urbana" (TINHORÃO, 1998: 57). Destaca ainda a possível filiação do poeta à herança dos trovadores, assinalando certas características como, por exemplo, o acompanhamento de sua música vocal ser realizado por um único instrumento harmônico (a viola), a sua predileção por formas poéticas populares e as suas construções linguísticas que nos sugerem um tratamento marcadamente entoativo da melodia.

Em seu caso pessoal Gregório de Matos não apenas continuava a tradição daqueles desocupados escudeiros "trovadores" quinhentistas, cultivadores de romances acompanhados à viola, mas entregava-se já à glosa de quadras e estribilhos de cantigas populares do tempo sob a forma de décimas (tão comuns duzentos anos depois em Portugal, com o advento da moda dos "fados" na segunda metade do século XIX), ao desenvolvimento de motes visivelmente fornecidos por frases populares (como o "Ó meu pai, tu qués, que eu morra?" (TINHORÃO, 1998: 56)

Referindo-se ao mesmo capítulo ao qual pertence o fragmento acima, Luiz Tatit também destaca o fato de que o poeta configura uma espécie de prenunciador do que observaremos mais tarde com o advento e consolidação da canção popular no Brasil. Decerto, sua fama de poeta satírico e improvisador liga-se convenientemente com a ideia que temos do compositor-cantador andarilho, próprio do espaço urbano, como nossos sambistas do início do século XX, por exemplo.

José Ramos Tinhorão destaca com bastante procedência o lado cancionista do poeta, apontando sua predileção pelo "fundo de acompanhamento à viola" e pela "forma de canto falado". Fruto dos primeiros sinais de urbanização na Bahia, o literato Gregório de Matos teria sido um compositor popular avant la lettre, autor de letras memoráveis, que também se aventurava com êxito pela poesia erudita (TATIT, 2004: 23) 
No século XVIII, podemos apontar como possível continuador dessa tradição cancionista $^{11}$, o compositor brasileiro de modinhas e lundus Domingos Caldas Barbosa (1739-1800). Esse "poeta carioca, tocador de "viola de arame"” (TINHORÃO, 1998: 115), cujas cantigas estão reunidas na coletânea Viola de Lereno, pseudônimo do autor, notabilizou-se como trovador na corte portuguesa setecentista, concebendo uma obra que igualmente insinua uma possível proximidade com a língua oral.

Suas peças baseavam-se num aparato rítmico oriundo dos batuques, suas melodias deixavam entrever gestos e meneios da fala cotidiana, o que lhe permitia "dizer" o texto com graça e com força persuasiva, e, finalmente, suas inflexões românticas, expandindo o campo de tessitura das canções, introduziam um certo grau de abstração sublime (distante do chão), mas, mesmo assim, não se desprendiam do corpo do intérprete (considerado como o sujeito que sente) (TATIT, 2004: 27)

No início do século $\mathrm{XX}$, com a recente chegada dos primeiros sistemas de gravação ao país, os primeiros intérpretes brasileiros a serem gravados, tais como Baiano, Cadete, Eduardo das Neves e, na sequência, os diversos compositores que frequentavam a célebre casa da Tia Ciata, são continuadores, segundo Tatit, da mesma tradição cancional que vimos sutilmente se formando nas obras de Gregório de Matos e Caldas Barbosa: aquela afeita aos valores entoativos e ao improviso, produzindo "melodias e letras concebidas no calor da hora sem qualquer intenção de perenidade" (TATIT, 2004: $35)$.

\begin{abstract}
Alheios a qualquer formação escolar, de ordem musical ou literária, esses sambistas retiravam suas melodias e seus versos da própria fala cotidiana. Serviam-se das entoações que acompanham a linguagem oral e das expressões usadas em conversa (TATIT, 2004: 34)
\end{abstract}

Comentando sobre a consolidação comercial da canção brasileira com o sucesso do rádio nas décadas de 1930 e 1940, o mesmo autor observa que a fala exerceu papel fundamental para o envolvimento do público ouvinte com as vozes radiofônicas, como

11 O termo "cancionista", lançado pela primeira vez em seu ensaio "Vocação e perplexidade dos cancionistas" de 1983, possui sentido mais amplo do que a expressão inglesa "songwriter". É empregado por Luiz Tatit para denominar não apenas o compositor de canção, mas também todos os envolvidos em seu processo e atentos à sua especificidade: os arranjadores de canção, os intérpretes de canção, os ouvintes de canção etc. Nesta tese, no entanto, o utilizaremos principalmente para nomear o compositor da letra e da melodia. 
forma de assegurar a credibilidade em relação ao enunciador bem como configurar os mais variados personagens. Descreve assim a função desempenhada pela entoação:

Ela acusa a presença de um “eu” pleno (sensível e cognitivo) conduzindo o conteúdo dos versos e inflete seus sentimentos como se pudesse traduzi-los em matéria sonora. De posse dessa força entoativa, e valendo-se do poder de difusão das ondas radiofônicas, os cancionistas se esmeraram em fazer dos intérpretes personagens definidos pela própria entoação. Ouvia-se então a voz do malandro, a voz do romântico, a voz do traído, a voz do embevecido, a voz do folião, todas revelando a intimidade, as conquistas ou o modo de ser do enunciador. (TATIT, 2004: 75)

Há, é claro, gêneros da canção popular brasileira que salientam de maneira mais contundente essa relação com a fala. O samba de breque, por exemplo, consolidado sobretudo na voz do cantor carioca Moreira da Silva (1902-2000), é recorrentemente lembrado por sua típica remissão à língua oral, sendo sua característica específica o fato de permitir "interromper a linha rítmico-melódica para encaixar frases faladas, sem quebra da unidade da composição" (TINHORÃO, s/d:165).

No âmbito da interpretação vocal do samba na época da consolidação do rádio, há cantores que são frequentemente associados a um estilo de canto mais próximo à fala, sobretudo pela contraposição ao estilo empostado de alguns de seus companheiros de emissora. Intérpretes como Carmem Miranda, Mário Reis, Marília Batista e mesmo o compositor Noel Rosa são expoentes de um estilo de samba que liberta o canto "da quadratura rítmica e da versificação romântica" e abandona "a estética da emissão operística, abrindo espaço à voz falada" (TATIT, 2004: 149). Augusto de Campos em Balanço da bossa e outras bossas, além de detectar a raiz entoativa do estilo de João Gilberto nos mesmos intérpretes mencionados acima, assinala como característica fundamental do movimento da bossa nova essa mesma emissão "quase-falada".

Dentre as características revolucionárias da $\mathrm{BN}$, uma das mais essenciais foi o seu estilo interpretativo, decididamente antioperístico. João Gilberto e depois dele tantos outros - na esteira, é verdade, de uma tradição detectável na velha guarda (Noel Rosa, Mário Reis) adotaram um tipo de interpretação discreta e direta, quase-falada, que se opunha de todo em todo aos estertores sentimentais do bolero e aos campeonatos de agudos vocais - ao bel canto em suma, que desde muito impregnou a música popular ocidental. (CAMPOS, 1974: 53) 
Observamos a presença de um movimento pendular na história da música popular brasileira, isto é, a contínua alternância entre um estilo ligado ao registro vocal do canto lírico e uma maneira de cantar mais próxima da fala. A oposição que se fazia entre a interpretação de Mário Reis e as vozes empostadas oriundas da tradição romântica do século XIX é a mesma oposição que se verificará, mais tarde, entre os cantores da bossa nova e os do movimento precedente do samba-canção.

É interessante analisarmos o caso de João Gilberto de uma forma um pouco mais aprofundada. Como comentado por diversos de seus estudiosos, o cantor baiano carrega consigo um duplo movimento, um canto ao mesmo tempo musical e entoativo, aspectos opostos que o artista concilia com maestria. A questão concentra-se em sua concepção de fraseado. Em depoimento de 1971 para o jornalista Tárik de Souza o cantor destaca o fato de seu canto "'flutuar' e de pronunciar as palavras 'como se estivesse conversando", (PINHEIRO, 2012: 423). Esse canto que flutua, evitando a repetição das frases musicais ou propondo ligeiras variações rítmico-melódicas, atende não somente ao desejo de "cantar falando", mas igualmente à vontade de despertar no ouvinte um interesse marcadamente musical.

Parece que, neste momento, faz sentido destacar a característica do canto falado de João. Não que a impostação nos remeta à fala, mas que um sentido de tempo menos métrico e mais “dialógico" ou "falado", por falta de termos melhores, transparece nesses exemplos, em que a prosódia tem uma relação artisticamente criativa com a métrica musical. Essas constantes mudanças no fraseado são um dos recursos de João Gilberto para evitar a monotonia, a repetição literal do ritmo das frases. (PINHEIRO, 2012: 422)

Essa "relação artisticamente criativa" entre a prosódia e a métrica musical, simultaneamente o protege de uma possível invariabilidade entediante e o aproxima de um estilo interpretativo despojado, que renuncia à grandiloquência dos cantores da década de 1940 e 1950. Trata-se de um sutil equilíbrio no qual a métrica musical, que flutua e varia, não chega a corromper a acentuação natural das palavras: "apesar de as partes não acentuadas coincidirem com os primeiros tempos de um compasso binário, como já dito anteriormente, a ênfase do canto é a da prosódia correta, como se uma pessoa estivesse cantando e outra estivesse tocando violão" (PINHEIRO, 2012: 423). Lorenzo Mammì, em seu texto "João Gilberto e o projeto utópico da bossa nova", salienta essa mesma coexistência entre os aspectos puramente sonoros e os aspectos entoativos, resultando numa espécie de fala "sublimada": 
João Gilberto tenta reproduzir na melodia todos os parâmetros do som, sem que por isso a voz se torne instrumento - ao contrário, aproximando sempre mais o canto à fala. É uma aspiração recorrente na música ocidental colher a articulação com que a melodia se destaca da palavra, mas ainda manter uma ligação necessária com ela, encontrar um momento exato em que o canto adquire forma própria, sem que esta seja outra coisa além da forma do falar, sublimada. (MAMMÌ, 2012: 160)

Pensando novamente nos gêneros de canção, o repente nordestino, de maneira similar, apresenta características que o aproximam da língua oral, sobretudo nos desafios ou duelos entre cantadores, nos quais o embate por meio do diálogo cantado traz implícita a presença da fala. Sob outro ponto de vista, essa proximidade do repente com a oralidade pode ser constatada pelo abrandamento dos níveis de musicalização, nos quais o canto e os instrumentos musicais acompanhadores são muitas vezes colocados em segundo plano.

Embora os cantadores considerem a si mesmos como poetas e não como músicos, a música na cantoria é, ao mesmo tempo, secundária e fundamental, assessória e indispensável. Por um lado, alguns afirmam que ser 'bom repentista' é ser bom na criação poética; o canto e o acompanhamento instrumental são 'um complemento', algo para realçar a poesia e a sonoridade dos versos (cf. Ayala, 1988:133) ou mesmo que 'a cantoria não é uma arte musicada. Ela não tem recurso de instrumento. Porque o que os cantadores usam são duas simples violas, que vão só acompanhar ali como se você tivesse tocando um sino e rezando (Severino Feitosa em depoimento a Oliveira, 1999: 89)' (SAUTCHUK, 2009: 34) ${ }^{12}$

Interessante notar que essa diminuição do teor musical no repente não exclui um nível mínimo de estabilidade sonora. Cantar como se estivesse "rezando" nos indica ao mesmo tempo uma ênfase na entoação da fala, mas igualmente certa regularidade melódica, algo que possui homogeneidade ou algum tipo de formalização.

Encontramos essa mesma dualidade em um fenômeno artístico relativamente recente na história da canção brasileira: o rap. Esse gênero de canção é talvez o que estabelece a mais forte ligação com a língua oral, o que muitas vezes o distancia do que popularmente se entende por um gênero musical: “A dicção do rap utiliza um mínimo de

\footnotetext{
12 As referências citadas por Sautchuk são, respectivamente, o livro No arranco do grito: aspectos da cantoria nordestina de Maria Ignez Novais Ayala (São Paulo: Ática, 1988) e a dissertação de mestrado A música na cantoria em Campina Grande (PB): estilo musical dos principais gêneros poéticos de Luciano Py de Oliveira (Salvador: UFBA, 1999).
} 
música para fazer, da fala, canto - apenas o suficiente para cristalizá-la e tornar sua memorização possível. O rap seria a menor distância possível entre a fala e o canto (...)" (TEPERMAN, 2011: 88). Além disso, essa presença mínima da música no rap liga-se mais às questões rítmicas do que às questões ligadas à altura de notas musicais estáveis ou de progressões harmônicas tonais, características usuais de grande parte do cancioneiro brasileiro ${ }^{13}$.

\footnotetext{
Buscando as características comuns entre o "rap escrito" e o freestyle, imediatamente se destaca um certo tipo de canto-falado, rimado e ritmado, que podemos definir a partir de um uso "precário" das alturas e uma organização rítmica específica, baseada nos beats, as batidas e bases musicais típicas do rap. (TEPERMAN, 2011: 82)
}

Ainda que o ritmo e a rima estabilizem a emissão da letra, o fato de o rapper entoar sua canção tratando o parâmetro altura de modo "precário", isto é, sem definir notas musicais ligadas a padrões escalares tonais ou modais, o torna fortemente próximo da nossa experiência cotidiana com a fala. Ao estudarmos o gênero de maneira mais detida, no entanto, começamos a perceber a presença de importantes nuances no tratamento dessa questão. Na sua história, no conjunto da obra de um mesmo artista ou ainda no interior de uma mesma canção, é possível identificar elementos mais ou menos próximos da língua oral. É o caso do grupo Racionais MC's, o mais importante grupo de rap brasileiro, no qual os próprios integrantes apresentam estilos vocais diferenciados.

\footnotetext{
O acompanhamento feito por KL Jay orienta as performances de Mano Brown, canto falado mais próximo da fala e do intelecto, e de Ice Blue, canto falado mais próximo do canto e da dança (GARCIA, 2007: 196)
}

Na história da música europeia ou da chamada música erudita, podemos igualmente examinar o estilo artístico de certos movimentos ou compositores a partir do parâmetro entoativo. É possível detectar a fala como critério de distinção estética em diversos momentos de sua história: no cantochão (ou canto gregoriano), com as melodias silábicas (mais entoativas) e as melodias melismáticas (musicalmente mais ornamentadas); nas composições polifônicas do período da Ars Antiqua (séculos XII e

\footnotetext{
${ }^{13}$ Em nossa dissertação de mestrado estudamos as características entoativas e musicais presentes no gênero rap e pudemos observar que, ainda que a presença da língua oral seja proeminente, há elementos musicais ligados a reiteração rítmica e ao alargamento das durações e da tessitura bastante significativos (ver SEGRETO, 2015).
} 
XIII), com as inclinações mais orais do conductus e a disposição mais vocal do organum e do moteto; nas óperas, com o recitativo (mais ligado à fala) e a ária (com sua forma musical mais desenvolvida). Analisemos, então, esses e outros casos com maior detalhamento.

Costuma-se situar o início da história da música ocidental a partir do começo da prática musical da igreja cristã, após a queda do Império Romano no século V d.C. Há, contudo, uma tradição artística que remonta à Antiguidade grega e latina cujos aspectos podem enriquecer a discussão acerca da presença do elemento entoativo na música vocal. Comecemos nossa investigação, então, pela Antiguidade Clássica, período da história europeia geralmente situado entre o século VIII a.C. e o século V d.C.

Coincidentemente, a cultura musical da Grécia Antiga possui algumas características similares às que observamos em alguns gêneros ou artistas da música popular comercial no Brasil, especialmente no rap. É o que destaca o compositor e pesquisador Livio Tragtenberg em seu prefácio para o livro A música grega, de Théodore Reinach.

Um outro aspecto que ilustra a atualidade e a pertinência do universo grego se refere à relação entre o texto e a música. $\mathrm{O}$ gênero musical mais praticado nos dias de hoje é a canção. Produto industrial que mobiliza compositores, músicos, cantores e a indústria do entretenimento. Poucos têm ideia de que as bases da forma canção, que se pratica hoje de tantas formas, foram estabelecidas, em grande parte, na prática musical da Grécia antiga (REINACH, 2011: 22)

E mais adiante:

Por fim, podemos dizer que mesmo o rap (ritmo e poesia) retoma essa articulação básica, o que levou uma legião de músicos não literatos a manipular, num corpo a corpo, as situações e soluções de ritmo e acento, cujas bases encontramos apresentadas neste livro. (REINACH, 2011: 22)

As relações entre música e texto (ou ritmo e acento) observadas na prática musical grega, segundo Tragtenberg, "continua a ser praticada, mesmo que inconscientemente, pelos fazedores de canções, em qualquer gênero ou estilo musical" (REINACH, 2011: 22). O autor identifica uma "articulação básica" que acreditamos perpassar a história da música, erudita ou popular, dos mais diferentes povos e culturas. Trata-se da conexão entre a língua oral e o canto que, já presente na Grécia, pontua diversas manifestações 
artísticas porvindouras: "A ideia grega de que a música se ligava indissociavelmente à palavra falada ressurgiu, sob diversas formas, ao longo de toda história da música (...)" (GROUT \& PALISCA, 2007:20). Acredita-se que o compositor possuía um compromisso com a emissão natural do texto verbal, amparado pelas características sonoras atribuídas à língua grega falada no período.

É conveniente também assinalar, na música vocal, a interdependência que existia, em certa época, entre o desenho melódico e as palavras do texto poético. Entre nós, um músico ponderado evita fazer cair um tempo forte da melodia sobre uma sílaba muda; em línguas como o alemão, o italiano etc., em que o acento de intensidade ressalta com vigor, a necessidade se impõe mais ainda ao compositor para, de alguma forma, modelar o desenho rítmico da frase musical sobre o do texto corretamente pronunciado. Na Grécia, o acento de intensidade não existia; em compensação, o compositor submetia-se, em razão do texto, a uma dupla servidão: uma rítmica (de que se tratará mais adiante) devido ao fato de a pronúncia e a prosódia estarem fundamentadas nas durações das sílabas; a outra, melódica, proveniente do caráter musical do acento tônico, de que cada palavra grega está munida, e que fazia da linguagem, mesmo na conversação ordinária, uma espécie de melopeia (...) (REINACH, 2011: 77)

A língua falada é considerada uma espécie de guia para a criação melódica. No caso do idioma grego antigo, a sua estrutura ligada às durações das sílabas e aos acentos marcados pela variação de frequência direcionavam o compositor ${ }^{14}$. Segundo o mesmo autor, um verso de uma obra atribuída à Homero, por exemplo, quando pronunciado "com certa ênfase", já constituía uma "verdadeira linha musical": "As durações naturais das sílabas determinam a divisão em pés (métricas), a posição dos acentos tônicos e circunflexos desenha um contorno melódico rudimentar, mas sensível" (REINACH, 2011: 77). Dessa maneira, a sonoridade da língua oral atuava como uma espécie de molde por meio do qual o compositor ajustava e estabilizava a sua criação:

Quando um compositor "punha em música" uma série de hexâmetros desse gênero, encontrava sua tarefa já cumprida, em parte, pelo poeta. Tudo o que lhe restava fazer era escolher a altura exata das notas destinadas às sílabas sucessivas, de maneira a evitar a monotonia, mas cuidando para fazer coincidir os cimos melódicos de cada palavra com os

\footnotetext{
${ }^{14}$ Os gramáticos especializados na língua grega demonstram "que a sílaba marcada pelo acento tônico comportava uma entonação mais aguda do que as outras sílabas da palavra, aproximadamente de uma quinta; entretanto, se o acento recaísse sobre a última sílaba, e esta aqui estivesse ligada pelo sentido às palavras seguintes, o intervalo era menor (uma terça?); as sílabas marcadas pelo acento circunflexo comportavam uma dupla entonação, com um desenho descendente" (REINACH, 2011: 77).
} 
acentos tônicos plenos, os de altura média com os "barítonos", e só desdobrar melodicamente as sílabas circunflexas. (REINACH, 2011: 77)

A associação entre a música e a linguagem verbal é consenso entre os pesquisadores da cultura da Antiguidade Clássica. Por vezes, essa conexão é assinalada não a partir da ligação da prática musical grega com a língua oral propriamente dita, mas por sua relação com a língua já formalizada pelos poetas: "a sua melodia e o seu ritmo ligavam-se intimamente à melodia e ao ritmo da poesia" (GROUT \& PALISCA, 2007:19). Assim, as regras composicionais, sobretudo no que se refere às questões rítmicas, são fortemente determinadas pela configuração métrica dos versos.

$\mathrm{Na}$ arte antiga, a música vocal possuía uma tal preponderância que o ritmo musical era visto, principalmente, sob o aspecto verbal: a rítmica, na origem, quase se confundia com a métrica. Em uma língua como a grega, em que a pronúncia e a versificação estão fundamentadas essencialmente sobre o princípio quantitativo, essa confusão era inevitável; o ritmo das palavras impunha-se à melopeia sobre elas aplicada. (REINACH, 2011: 83)

Evidentemente, não devemos presumir que a música vocal da Grécia Antiga tenha permanecido com as mesmas características composicionais ao longo de toda a sua história, isto é, no decorrer de um vasto espaço temporal que se inicia na época préhomérica (2000-1100 a.C.) e finda no período helenístico (338-146 a.C.), quando o seu território é anexado pelo Império Romano. Reinach aponta, por exemplo, uma transformação significativa nas composições vocais entre os séculos VI a.C. e II a.C. São mudanças que representam o mesmo movimento pendular entre a música e a fala, já observado na propensão entoativa de João Gilberto em oposição ao caráter mais musical de seus antecessores e que será posteriormente notado em outros movimentos artísticos da música europeia.

Conforme o autor, a música vocal grega nos séculos VI a.C. e V a.C. era dominada pela chamada estrutura estrófica, processo no qual as diversas estrofes de uma composição são cantadas com uma mesma melodia. Assim, uma dificuldade apresentavase para a realização do texto verbal: o poeta deveria dispor as sílabas tônicas e átonas de seus versos de modo equivalente para todas as estrofes, já que a acentuação musical deveria permanecer inalterada. Não sendo possível manter esse rígido esquema métrico, essa limitação acabou gerando uma forma artística na qual os criadores deixavam de buscar a confluência entre a configuração melódica e os acentos tônicos do texto, que 
“desapareciam inteiramente na execução vocal" (REINACH, 2011: 78). Nesse momento, a língua oral tendia a se submeter aos padrões musicais do canto estrófico.

A partir do século IV a.C., no entanto, uma espécie de "confecção livre" substitui esse modelo musical permitindo a "colocação dos acentos naturais na melopeia vocal" (REINACH, 2011: 79), fato observado em gêneros como o ditirambo e a monodia trágica. Não sabendo ao certo se essa prática se manteve ao longo dos séculos IV e III, o autor apenas assinala um exemplo, pertencente ao final do período helenístico, no qual ainda é possível constatar a integridade acentual do texto poético. Aqui, a música volta a se submeter às necessidades entoativas da língua.

Até que ponto os grandes compositores dos séculos IV e III se conformaram com esse princípio? Nós o ignoramos, mas no fim do século II os dois hinos délficos mostram-no aplicado de maneira rigorosa. Nenhuma sílaba de uma palavra traz uma nota mais aguda do que aquela em que recai a sílaba tônica; o final de uma palavra, marcado por um acento e ligado às palavras seguintes, não é nunca mais alto do que a primeira sílaba plenamente tônica que se segue; e os circunflexos comportam, geralmente, um desenho melódico descendente, de duas notas. (REINACH, 2011: 79)

Ainda que não tenhamos registros históricos que nos façam compreender a música vocal grega de modo mais detalhado, podemos observar que algumas de suas características fundamentais foram legadas à prática musical do início da Idade Média, sobretudo no que se refere ao uso frequente da monodia e à forte ligação entre a música e a palavra, "especialmente no tocante ao ritmo e à métrica" (GROUT \& PALISCA, 2007:33). É na música praticada pela Igreja primitiva que geralmente se situa o início da história da música ocidental propriamente dita e uma de suas primeiras manifestações artísticas é o chamado cantochão. Trata-se do repertório vocal que, ao que tudo indica, teria sido organizado e compilado pelo papa Gregório I (540-604 d.C.), recebendo também, por isso, o nome de canto gregoriano ${ }^{15}$.

Pois bem, o tipo de classificação empregado para o estudo dessas obras, baseado na relação entre as notas e as sílabas do texto, nos leva novamente a observar um movimento que oscila entre a música e a fala. Há, no gregoriano, a convivência de duas

\footnotetext{
${ }^{15}$ Ainda que o papa Gregório I tenha realizado a organização desse repertório no final do século VI d.C., os diversos manuscritos nos quais estão grafadas as melodias de cantochão datam somente do século IX em diante. Ao examinarmos esses documentos, pertencentes a diferentes locais e épocas históricas, é comum encontrarmos o registro de uma mesma melodia em manuscritos distintos, fato que levou os estudiosos da área a constatarem a existência de uma fonte comum, geralmente atribuída à Gregório (sobre esse assunto, ver GROUT \& PALISCA, 2007: 57).
} 
tendências composicionais opostas. A primeira, na qual cada sílaba do texto corresponde à uma única nota da melodia, configura o que denominamos de canto silábico. A segunda, quando a melodia apresenta diversas notas sobre uma única sílaba, resulta no que chamamos de canto melismático. No primeiro caso, há uma valorização maior da acentuação natural do texto, uma aproximação em relação à oralidade: não encontramos tanta ênfase no desenvolvimento melódico e as sílabas que devem ser acentuadas recaem sobre notas mais agudas ou de maior duração. É quando compreendemos sem grande dificuldade o texto linguístico de determinada obra. No segundo caso, no entanto, as ornamentações ligadas aos longos melismas sobre uma única sílaba (por vezes, átona) fazem com que o aspecto sonoro prejudique a compreensão do texto. Nesse caso, priorizase o acento melódico em detrimento dos acentos verbais. É quando nossa percepção se volta predominantemente à música.

\begin{abstract}
Além disso, nas peças mais ornamentadas o acento melódico tem muitas vezes maior importância do que a acentuação das palavras; e é assim que podemos encontrar longos melismas sobre sílabas átonas, especialmente nas sílabas finais, como, por exemplo, o último $a$ de aleluia ou a última sílaba de palavras como dominus, exultemos ou kyrie. (GROUT \&
\end{abstract} PALISCA, 2007:60)

Além do cantochão, a liturgia da igreja católica também contempla certas práticas de leitura de rezas e de passagens do texto sagrado que, ainda que muito próximas do registro oral, apresentam um tratamento sonoro levemente desenvolvido, como uma espécie de etapa anterior à melodia cantada propriamente dita. A preocupação com a emissão natural do texto e a busca pelos recursos musicais que possam embasá-la ficam claras no final do fragmento seguinte, no que se refere à acentuação silábica.

\footnotetext{
Os cantos para a recitação de orações e leituras da Bíblia estão na fronteira entre a fala e o canto. Consistem numa única nota de recitação (geralmente lá ou dó), ao som da qual cada versículo ou período do texto é rapidamente entoado. Esta nota de recitação é também designada por tenor; uma vez por outra a nota que lhe fica imediatamente acima ou abaixo pode ser também introduzida para destacar uma sílaba importante. (GROUT \& PALISCA, 2007:61)
}

Refletir sobre esse movimento que oscila entre a fala e a música pode ser significativo não apenas para a abordagem de práticas monódicas como o canto 
gregoriano ou as recitações da Bíblia, nas quais uma única linha vocal veicula o texto linguístico. Podemos examinar igualmente as peças em que duas ou mais melodias são trabalhadas simultaneamente. Nos séculos XII e XIII, nas composições polifônicas do período conhecido como Ars Antiqua, momento histórico ligado ao início do desenvolvimento da polifonia, também identificamos composições com inclinações mais orais e outras com propensões mais musicais ${ }^{16}$.

Uma primeira oposição pode ser constatada entre o gênero do conductus polifônico e o do organum. O primeiro, do qual temos alguns exemplos do início do século XIII escritos por Pérotin e por outros compositores da Escola de Notre-Dame, possui uma estrutura menos complexa do que a do segundo, apresentando uma textura predominantemente homorrítmica na qual todas as vozes seguem praticamente o mesmo padrão métrico. Sua construção sonora "contrasta com a maior variedade rítmica das vozes no organum", ao mesmo tempo em que "a letra era quase sempre tratada de forma silábica" (GROUT \& PALISCA, 2007:114). Essas características fazem do conductus um estilo composicional que valoriza em maior grau a inteligibilidade do texto. A partir de 1250, ambos os gêneros começam a cair em desuso e, no final do século XIII, o moteto passa a ser o estilo de composição polifônica mais cultivado pela igreja ${ }^{17}$.

Curiosamente, a origem do moteto liga-se ao desenvolvimento do organum. Léonin, antecessor de Pérotin na Catedral de Notre-Dame, havia introduzido em seus organa seções distintas denominadas cláusulas. Essas partes posteriormente se tornam independentes do organum e, já consideradas composições autônomas, recebem o nome de moteto. Surgido em Paris, espalha-se por toda a Europa Ocidental. Com o seu aparecimento, a oposição da qual falávamos acima passa a se dar entre esse gênero e o conductus. Assim, por originar-se a partir de uma parte do organum, o moteto traz naturalmente uma complexidade sonora mais elevada. Vejamos.

Primeiramente, a maioria dessas peças apresenta um texto diferente para cada voz, cantados de forma simultânea. São os chamados motetos politextuais. Trazendo combinações muito heterogêneas, fazem coexistir, numa mesma obra, canções de amor,

\footnotetext{
${ }^{16} \mathrm{O}$ período da Ars Antiqua pode ser situado de maneira mais abrangente entre os séculos X e XIII. Entretanto, seu momento mais relevante se dá nos séculos XII e XIII com a chamada Escola de Notre Dame, grupo de compositores ligados à música praticada na recém construída Catedral de Notre-Dame em Paris, dos quais se destacam Léonin (1135-1201) e seu continuador Pérotin (1160-1236). A denominação do período surge apenas posteriormente por oposição ao movimento musical seguinte, denominado Ars Nova (século XIV).

${ }^{17}$ Evidentemente, o conductus e o organum, ainda que com menor frequência, continuam a ser praticados pela liturgia católica. De todo modo, constituem, juntamente com o moteto, os três tipos de composição polifônica característicos do período da Ars Antiqua.
} 
refrãos populares e hinos litúrgicos. Além disso, os textos são frequentemente escritos em idiomas distintos, constituindo os chamados motetos polilinguísticos. Aqui, os elementos composicionais, musicais ou verbais, são apropriados com menor rigidez e uma mesma melodia pode veicular tanto um texto sagrado quanto um texto profano. Por outro lado, a sua maior experimentação com a trama polifônica, desfavorece ainda mais a inteligibilidade das palavras, já prejudicada pela emissão simultânea de excertos diversos. O conduto, como vimos anteriormente, ao contrário, apresenta uma polifonia mais contida, o que permite uma compreensão linguística mais efetiva. Enquanto o moteto quer ampliar as possibilidades musicais ligadas a polifonia, o conduto restringe seu trabalho musical para não se distanciar excessivamente do elemento verbal:

O estilo das defasagens declaradas, representado pelo moteto, em que o texto poético praticamente desaparece soterrado pela polifonia, não deixa de ser complementado por um outro mais próximo da canção [o conductus], em que o sentido das palavras se preserva e em que se trabalha com defasagens atenuadas, mantendo-se a linearidade do texto e da melodia. (WISNIK, 1989:122)

Obviamente, a música vocal europeia não se restringia àquela praticada no interior da liturgia católica. Ainda nos séculos XII e XIII, mas no âmbito da música profana, destacamos o canto dos trovadores, ligados à região da Provença no sul da França, e o dos troveiros, localizados no norte do país, ambos oriundos de círculos aristocráticos. Assim, ao mesmo tempo em que, dentro das igrejas, executavam-se os três tipos de composição polifônica comentados acima (organum, conductus e motete), fora dela, eram cantadas peças vocais relativamente próximas do que conhecemos hoje como uma canção popular. Os estudiosos costumam assinalar até mesmo o seu aspecto entoativo: "Eram melodias que davam clara ideia do tom, mas não dos valores reais das notas, que advinham certamente do ritmo natural das palavras" (BENNETT, 1986: 18). Semelhantemente, Grout \& Palisca, além de ressaltar a mesma incerteza quanto ao aspecto rítmico, também caracteriza a produção dos trovadores e troveiros de maneira muito similar ao que vimos em relação à música vocal grega.

Há alguma incerteza quanto ao ritmo das canções, especialmente no que diz respeito às mais antigas melodias conhecidas, cuja notação não indica os valores temporais das diversas notas. Certos estudiosos defendem que estas cantigas eram cantadas num ritmo livre, não sujeito a compasso, tal como a notação parece sugerir; outros, porém, crêem que o ritmo devia ser 
bastante regular e que a melodia seria medida em notas longas e breves, correspondendo genericamente às sílabas acentuadas e não acentuadas das palavras. (GROUT \& PALISCA, 2007:87)

No contexto musical medieval descrito acima, podemos observar certa complementaridade entre duas tendências distintas, uma mais ligada à música (mais ornamentada ou sonoramente mais complexa) e outra mais ligada à fala (mais atenta à compreensão do texto). Assim, ora a composição prioriza de maneira mais acentuada a musicalidade, como no organum e no moteto, ora investe nos aspectos entoativos, como no conductus e nas cantigas dos trovadores e troveiros.

Começamos, então, a recolher indícios de que há, ao longo da história, certa necessidade de se reequilibrar esses parâmetros, compensando os níveis de oralidade e musicalidade. É o que ocorre em meados do século XVI, com a crítica dirigida aos motetos politextuais pelo Concílio de Trento (1545-1563), contrário a esse gênero de polifonia pela sua ininteligibilidade em relação às palavras bíblicas. Há, portanto, uma espécie de tentativa de reestabelecimento de um equilíbrio, pois o moteto parecia estar pendendo demasiadamente para o lado da música. Ligado ao contexto da Contra-Reforma comandada pela Igreja Católica, após a Reforma Protestante iniciada por Lutero em 1517, o Concílio de Trento dedicou uma pequena parte de seus trabalhos à questão da música sacra. Os líderes eclesiásticos, no entanto, dirigiam duras críticas "ao seu espírito frequentemente profano, evidenciado nas missas baseadas em cantus firmus profanos ou na imitação de chansons, e à complexa polifonia que impossibilitava a compreensão das palavras da liturgia" (GROUT \& PALISCA, 2007:284). Ao final do concílio, apesar desses questionamentos, as autoridades da Igreja não chegaram a proibir nem a polifonia vocal nem a utilização dos elementos seculares mencionados acima. Interessa-nos, contudo, assinalar a existência desse descontentamento em relação às peças musicais que se afastavam demasiadamente do texto verbal.

Podemos identificar uma outra manifestação desse mesmo descontentamento na origem da ópera no final do século XVI, momento que marca o início do período barroco. O seu nascimento está ligado a uma reação estética contrária à polifonia renascentista que, em virtude de sua complexidade contrapontística, colocava o texto linguístico em segundo plano. Em resposta a esse tipo de tratamento musical, praticado sobretudo nos madrigais italianos, organizou-se na cidade italiana de Florença um grupo de intelectuais helenistas interessados nos estudos da cultura musical da Antiguidade e no seu estilo de 
canto monódico, mais favorável à compreensão do texto poético. O grupo, uma espécie de academia informal onde se discutia literatura, ciência e arte e se executava a "nova música", ficou conhecido como Camerata Fiorentina, ou Camerata Bardi, já que seus encontros se davam no palácio do conde Giovanni Bardi (1534-1612), aproximadamente entre os anos de 1573 e 1592.

Um de seus mais importantes membros, Girolamo Mei, erudito florentino que já editara diversas tragédias gregas, mostrava-se particularmente interessado no estudo da música antiga. Mei já publicara um tratado de quatro livros intitulado Acerca dos modos musicais dos antigos, resultado do seu estudo, no original grego, de grande parte das obras sobre música escritas na Antiguidade. Giovanni Bardi correspondia-se frequentemente com Mei, cujas cartas sobre música grega eram geralmente discutidas nas reuniões da Camerata. O autor estava convicto de que "os Gregos conseguiam obter efeitos singulares com a música porque ela consistia numa única melodia, quer cantada a solo, com acompanhamento, quer por um coro" e que essa melodia "tinha o poder de afectar os sentimentos do ouvinte, uma vez que explorava a expressividade natural das subidas e descidas de altura, do registro da voz e das mudanças de ritmo e andamento" (GROUT \& PALISCA, 2007:319). Observamos aqui, mais uma vez, a busca por uma criação vocal menos complexa e mais próxima da fala.

Outro documento importante dentro desse contexto é a obra Dialogo dela musica antica e dela moderna (1581), escrito por Vincenzo Galilei, pai do conhecido astrônomo Galileu e outro correspondente assíduo de Mei. Nesse livro, apoiado pelas ideias do helenista, Galilei tece duras críticas ao complexo contraponto vocal do madrigal italiano.

Em resumo, a sua tese era a de que só uma única linha melódica, com alturas de som e ritmos apropriados, podia exprimir um dado verso. Por conseguinte, quando várias vozes cantavam simultaneamente melodias e letras diferentes, em registros e ritmos diferentes, a música nunca conseguia transmitir a mensagem emotiva do texto; quando certas vozes eram graves e outras agudas, umas ascendentes e outras descendentes, umas evoluindo em notas lentas e outras em notas rápidas, o consequente caos de impressões contraditórias apenas servia para exibir o engenho do compositor e a capacidade dos executantes num estilo musical que, se algum valor tinha, só se adequava a um conjunto instrumental. Galilei rejeitava como recursos pueris a descrição de palavras, a imitação de suspiros e outros processos similares, tão comuns no madrigal do século XVI. O modo correcto de musicar um texto, afirmava Galilei, era utilizar uma melodia a solo que pusesse em relevo as inflexões naturais da fala de um bom orador ou actor. (GROUT \& PALISCA, 2007:319) 
Na mesma direção, Harnoncourt assinala o ideário dos membros da Camerata Bardi, fundado em uma reaproximação com o aspecto entoativo, após o largo período de desenvolvimento da polifonia vocal europeia:

A "nova música" deveria ser essencialmente monódica, a linha melódica regida pela palavra e o acompanhamento do baixo (o baixo contínuo) composto em harmonias simples que sublinhassem determinadas palavras, sem jamais atrair a atenção "musicalmente". Era preciso estudar o modo de falar das diversas camadas da população, para imitá-lo nas novas obras. (HARNONCOURT, 1993:27)

Ainda examinando a ópera, talvez a mais popular e a mais desenvolvida dentre as expressões da música vocal europeia, é curioso destacarmos que esse embate entre a música e a fala está presente não somente na história de seu surgimento. A sua própria estruturação interna igualmente explicita o trânsito entre um pensamento mais entoativo e uma concepção mais musical. Como se sabe, esse gênero se organiza basicamente pela alternância entre recitativos e árias.

O recitativo apresenta uma remissão maior à fala, pois o cantor atua com um registro mais próximo da entoação e com maior liberdade rítmica. Além disso, possui um acompanhamento instrumental muito contido que favorece o entendimento das palavras. Esse estilo vocal surge amparado pelo mesmo movimento de estudo e resgate da música grega da Antiguidade. Atribui-se ao compositor Jacopo Peri (1561-1633) a possível origem do recitativo a partir de sua busca por uma linguagem mais apropriada às características da poesia dramática. Peri e seus contemporâneos almejavam criar um estilo vocal próximo da entoação da língua oral e acreditavam que estavam reavivando um tipo de canto já praticado no teatro antigo ou nos poemas épicos.

Enquanto o idioma dos solos vocais de Caccini se baseava na ária improvisada e no madrigal polifónico, Peri procurou uma solução nova que respondesse às necessidades de representação dramática. No seu prefácio à Euricice Peri recordava a distinção que na teoria antiga se estabelecia entre a contínua mudança da altura do som na fala e o movimento diastemático, ou por intervalos, no canto. O seu objetivo era encontrar uma espécie de canção falada intermédia entre ambos, como a que se dizia ter sido usada na recitação dos poemas heroicos. Ao sustentar as notas do baixo contínuo, enquanto a voz se movia, passando por consonâncias e dissonâncias - assim simulando o movimento contínuo da fala -, libertou suficientemente a voz da harmonia para fazer com que se assemelhasse a uma declamação livre e sem altura definida. Depois, quando chegava a uma sílaba que devia ser sublinhada 
ou "entoada" na fala, Peri tinha o cuidado de a pôr em consonância com o baixo e a respectiva harmonia. (GROUT \& PALISCA, 2007:321)

As nuances entre a oralidade e a música podem ser ainda mais aprofundadas quando notamos que a ópera italiana do século XVIII, por exemplo, passa a apresentar dois tipos de recitativo, um mais "falado" e outro mais "musicado". O recitativo secco (geralmente acompanhado somente pelo cravo e pelo apoio de um instrumento baixo) era usado sobretudo "para musicar longos trechos de diálogo ou monólogo, de forma tão próxima quanto possível da fala" (GROUT \& PALISCA, 2007:363). Diferentemente, o recitativo obligato (sempre acompanhado pela orquestra) era empregado para exprimir situações dramáticas de tensão e rápidas mudanças de emoção sugeridas pelos diálogos dos libretos. Utilizava "um tipo de melodia que não era nem ritmicamente livre como o recitativo [leia-se recitativo secco] nem tão regular como a ária, situando-se algures entre um e outra; dá-se-lhe o nome de arioso, ou seja, recitativo arioso, ou 'recitativo à maneira da ária"” (GROUT \& PALISCA, 2007:363).

Especificamente em relação ao recitativo, é igualmente interessante observarmos os variados resultados estéticos alcançados pelos compositores de diferentes nações que importaram para as suas práticas musicais o gênero da ópera italiana. Na França, por exemplo, o compositor Lully foi o responsável pela tentativa de adaptação do recitativo italiano "aos ritmos da língua e da versificação francesa". Uma significativa dificuldade surgia durante esse processo de adequação, na medida em que "nem o rápido recitativo secco nem o semimelódico arioso da ópera italiana se adequavam ao ritmo e à acentuação da língua francesa" (GROUT \& PALISCA, 2007:364). Como forma de contornar essa questão, Lully teria então buscado modelos de combinação entre texto e música já consagrados na cultura de seu país e, por isso, mais propícios à expressão de seu idioma.

Diz-se que Lully terá resolvido o problema estudando o estilo de declamação utilizado no teatro francês e imitando-o tão facilmente quanto possível, mas esta ideia, embora sedutora, é difícil de comprovar. É verdade que o ritmo, as pausas, e muitas vezes também as inflexões, se assemelham as da declamação teatral. Mas o baixo rítmico e a linha vocal melodiosa atenuam a ilusão de fala que o recitativo italiano conseguia produzir. (GROUT \& PALISCA, 2007: 364)

Diferentemente do recitativo e de sua pretensa "ilusão de fala", nas árias, há certamente um maior teor de musicalização. Nela, observamos uma clara proeminência 
do aspecto sonoro, sendo o momento no qual compositor e intérprete podem potencializar as características próprias da linguagem musical. O desenvolvimento melódico em si passa a ser mais relevante do que a emissão do texto linguístico de maneira próxima à língua oral. Nesse sentido, ao propor uma reforma da ópera no século XVIII, o compositor Christoph Willibald Gluck (1714-1787), preocupado com a simplicidade e a verdade dramática na musicalização do texto, dirigiu suas principais críticas aos exibicionismos musicais do bel canto presentes nas árias de seu tempo.

\begin{abstract}
No prefácio e dedicatória a esta última obra Gluck exprimiu a decisão de suprimir os excessos que até então tinham desvirtuado a ópera italiana, “confinar a música à sua função natural de servir a poesia na expressão e nas situações da intriga”, pondo de parte, quer as convenções gastas da ária da capo, quer o desejo dos cantores de exibirem os seus dotes em variações ornamentais, e, além disso, fazer ainda da abertura parte integrante da ópera, adaptar a orquestra às exigências dramáticas e atenuar o contraste entre ária e recitativo. (GROUT \&
\end{abstract} PALISCA, 2007:499)

A intenção de Gluck de submeter a melodia à poesia e excluir elementos que considerava ornamentos inúteis e supérfluos explicitam a sua busca por uma espécie de "beleza simples" ou por certa "clareza" da composição. Poderíamos dizer que sua pretensão consistia em potencializar musicalmente a emissão do texto verbal, sem, contudo, desfigurar as características fundamentais da língua: “Cheguei à conclusão de que a música deve acrescentar à poesia aquilo que o brilho das cores e a boa distribuição da luz e das sombras trazem a um desenho correcto e bem concebido, animando as figuras sem alterar os seus contornos" (GROUT \& PALISCA, 2007:499).

Ainda no século XVIII, os escritos de Rousseau também fazem referência à coexistência dessas diferentes maneiras de se trabalhar a música cantada. Na obra Ensaio sobre a origem das línguas já citada anteriormente, o filósofo questiona de forma incisiva o que seria uma deturpação da música vocal de seu tempo. Para Rousseau, a melodia do canto estava distanciando-se demasiadamente do discurso linguístico. Essa separação, que gerava uma independência da música em relação às palavras, consistia na causa direta do que o autor entendia como a perda do efeito moral sobre os ouvintes. Para ele, ao abandonar o acento oral a música perdia a sua energia:

Eis como o canto aos poucos se tornou uma arte inteiramente separada da palavra, da qual se origina, como as harmônicas do som determinaram o esquecimento das inflexões da voz, e 
como, por fim, limitada ao efeito puramente físico do concurso de vibrações, viu-se a música privada dos efeitos morais, que produzira quando era duplamente a voz da natureza. (ROUSSEAU, 1978:198)

O que aponta Rousseau nesse último fragmento é uma predominância da música sobre a palavra. Nesse caso, o compositor interessa-se mais pelas possibilidades sonoras do canto do que pelas inflexões de fala sugeridas pelo texto. Sintomaticamente, ao mesmo tempo em que o autor se debruçava sobre o assunto, iniciava-se uma nova tradição de música vocal na Europa. Ao longo do século XVIII, presenciamos o início do desenvolvimento do Lied alemão, gênero que também abandona práticas vocais mais complexas em favor do texto:

O centro mais importante de composição a partir de meados do século foi Berlim, onde J.J. Quantz (1697-1773), J.H. Graun e C.P.E. Bach exerceram a sua atividade de compositores. Os compositores de Berlim preferiam os Lieder em forma estrófica, com melodias num estilo natural, expressivo, próximo do das canções populares, com uma única nota para cada sílaba; só eram permitidos acompanhamentos muito simples (...) (GROUT \& PALISCA, 2007:505)

Como se sabe, o lied se consolida no século XIX com as obras de três principais compositores: Franz Schubert (1797-1828), que compôs mais de 600 lieder, Robert Schumann (1810-1856), compositor de cerca de 250 peças do gênero e Johannes Brahms (1833-1897), autor de 260 obras. Esse último, conhecido por ter escrito diversos arranjos para canções populares alemãs, preza, segundo Grout \& Palisca, pela "simplicidade" da composição e pela "preocupação de nunca prejudicar a melodia com um acompanhamento complicado ou harmonicamente inadequado", tendo declarado "que o seu ideal era a canção popular" (GROUT \& PALISCA, 2007:583).

Contemporâneo de Brahms, mas no contexto do nacionalismo russo, Modest Musorgsky (1839-1881), um dos componentes do chamado Grupo dos Cinco que reunia os principais compositores da Rússia na segundo metade do século XIX, foi igualmente um importante compositor de canções. As suas obras desse gênero também nos sugerem a preferência por uma expressão mais ligada à oralidade.

A originalidade de Musorgsky evidencia-se em todos os aspectos da sua música. A abordagem dos textos baseia-se nos métodos de Dargomïzhsky e visa a adesão o mais perfeita possível às inflexões naturais da palavra falada; daí que na sua música vocal Musorgsky tenha 
geralmente evitado as linhas melódicas líricas e o fracasso simétrico. (GROUT \& PALISCA, 2007:669)

Observamos novamente o contraste entre as "inflexões naturais da palavra falada" e um desenvolvimento mais musical da melodia, aqui representado pelas "linhas melódicas líricas" (o que nos faz pensar nas melodias com andamento desacelerado, notas longas e, possivelmente, com uma maior expansão da tessitura) e pelo caráter "simétrico" (ligado provavelmente ao canto estrófico, cuja característica principal é a reiteração

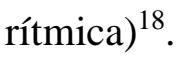

No início do século XX, Arnold Schoenberg (1874-1951) passa a utilizar em algumas de suas peças um novo tratamento vocal com uma ênfase radical no aspecto entoativo do canto. Marco desse novo estilo é a peça Pierrot Lunaire (1912), importante obra do compositor austríaco na qual "a solista deve recorrer ao Sprechgesang, tipo de vocalização entre o canto e a fala" (GRIFFITHS, 1998: 34). Essa espécie de "canto falado", propícia a uma estética musical que desejava evitar a remissão à tonalidade ${ }^{19}$, garantia igualmente uma emissão mais próxima da língua oral e uma inteligibilidade maior do texto.

A música da segunda metade do século XX, sobretudo após o advento da música concreta e eletrônica, também apresenta diversas peças que trabalham a voz humana de maneira inusual, por vezes estabelecendo fortes elos com a linguagem oral, por vezes distanciando-se dela de modo radical. Em Gesang der Jünglinge (1955-1956), conhecida como $O$ canto dos jovens ou $O$ cântico dos adolescentes, Karlheinz Stockhausen (19282007) utiliza sons naturais (a gravação da voz de um menino entoando o texto "Cântico dos Três Jovens na Fornalha Ardente" do Livro de Daniel presente no Antigo Testamento) e sons produzidos eletronicamente por meio de geradores de onda senoidal e de geradores de ruídos e de impulsos (MENEZES, 2009: 39). A obra, uma combinação entre a música

\footnotetext{
${ }^{18}$ Como dissemos no início deste capítulo, estamos, por ora, apenas identificando ao longo da história da música erudita europeia e da música popular brasileira, alguns fenômenos ligados à música vocal que tragam a questão oral. Em breve, em nosso próximo capítulo, pretendemos, embasados pela teoria da semiótica da canção, delinear de maneira mais objetiva o funcionamento desses mecanismos composicionais. Constataremos, então, como essas noções citadas por Grout \& Palisca (a adesão "às inflexões naturais da palavra falada", "as linhas melódicas líricas" e o "fracasso simétrico") podem ser retomadas a partir dos processos da figurativização, passionalização e tematização, respectivamente.

${ }^{19}$ A peça Pierrot Lunaire é considerada uma obra atonal do compositor. Nela, Schoenberg ainda não utiliza a técnica dodecafônica (na qual baseará suas peças somente a partir da década de 1920).
} 
concreta e a música eletrônica "pura" 20 , é composta para ser executada por cinco grupos de alto-falantes, sendo um exemplo da busca de Stockhausen por diferentes possibilidades espaciais para a música eletrônica. Ainda que seja possível captar os elementos orais na voz do menino utilizada pelo compositor, a força maior da peça está, sem dúvida, em sua composição sonora. No entanto, a presença da oralidade não deixa de possuir um valor significativo. Segundo Flo Menezes, esse fenômeno histórico da "concretização da música eletrônica", mediante a inserção do elemento verbal, liga-se historicamente à mesma necessidade dos compositores europeus de restabelecerem a "semântica" de suas composições:

Por outro lado, a necessidade de se enriquecer, por meio da inserção da linguagem verbal, a semântica das obras fazia-se sentir. Trata-se na verdade da terceira vez, na história da música ocidental, que os compositores, em período de crise, apelavam à semântica verbal, recorrendo à utilização da voz e à inteligibilidade do verbo na organização estrutural das obras (MENEZES, 2009: 40)

Segundo assinala o próprio autor, os outros dois acontecimentos ligados à história da música ocidental nos quais observamos o mesmo fenômeno de semantização por meio do elemento verbal são a invenção do recitativo e da ópera (como contraposição à ininteligibilidade do texto presente nos madrigais e nos motetos politextuais renascentistas) e o "apelo dos três vienenses - Schoenberg, Berg e Webern -, em plena fase do atonalismo-livre, ao discurso verbal", sobretudo pela invenção do Sprechgesang pelo primeiro compositor (MENEZES, 2009: 40).

O compositor italiano Luciano Berio (1925-2003), cuja criação de música vocal contemplou desde o canto tradicional até o extremamente experimental, também possui peças que ilustram muito bem essa tendência mais musical no tratamento da voz. Obras como Thema (Omaggio a Joyce) (1958), Sequenza III (1966) e Sinfonia (1968-1969) apresentam novas propostas de utilização sonora da voz humana. Nesse caso, não se trata de explorar os elementos entoativos latentes nas melodias, mas sim avançar em relação ao desenvolvimento dos seus aspectos essencialmente timbrísticos, ainda que essas peças apresentem trechos que se aproximam fortemente do registro oral. O compositor permanece atento às exigências poéticas do texto, mas de uma forma diferente da

\footnotetext{
${ }^{20}$ A obra é considerada um marco inicial da música eletroacústica por sua combinação entre a prática musical de Paris (berço da música concreta) e a prática musical de Colônia (onde originou-se a música eletrônica).
} 
empregada na canção popular, por exemplo. Ocorre que, na tradição da composição erudita, geralmente, o trabalho com a palavra se baseia sobretudo na leitura e posterior musicalização de um poema escrito, sem considerar, por vezes, aspectos da expressão falada.

Esse é o caso da obra Thema (Omaggio a Joyce), para quatro canais, que tem como material o início do capítulo XI do romance Ulysses de James Joyce. Curiosamente, essa peça trabalha diretamente com a matéria sonora verbal, a gravação em fita magnética da leitura do texto. Contudo, o intuito principal é a sua modulação sonora, por exemplo, com a formação de stacattos, glissandos e trinados. Assim, por intermédio de manipulações tecnológicas, o compositor se entrega à exploração das possibilidades sonoras das palavras, sílabas e fonemas. Trata-se de uma experiência em estúdio que, posteriormente, transformará significativamente sua obra vocal não eletrônica (ZUBEN, 2007:12), como é o caso de Sequenza III, para voz solo, por exemplo. Ainda sobre o Thema, em seu texto "Poesia e música: uma experiência" (1959), Berio expõe a sua intenção de desvencilhar as palavras de sua entoação e significado em favor dos elementos puramente musicais ${ }^{21}$.

Após se ter considerado o tema - como sistema sonoro - [a página inicial do capítulo XI de Joyce] enquanto tal, tratou-se então de dissociá-lo paulatinamente de sua própria expressão enunciativa, linear de sua condição significativa (...) tratou-se de levar em conta seu aspecto fonético sobretudo em função de suas possibilidades de transformação eletroacústica. (BERIO, 2009:124)

O significado do texto, tal como o alcançamos por meio da leitura ou da escuta, já não é compreendido pelo ouvinte. A atenção está predominantemente voltada para a sonoridade da obra. A combinação entre as traduções do texto para o francês e para o italiano com o original em inglês também atua nesse mesmo sentido. Em relação a outros procedimentos vocais presentes na obra do mesmo compositor, é necessário fazer uma importante observação. Em Sequenza III (1966), além da segmentação do texto linguístico em elementos mínimos como as sílabas e os fonemas (procedimento puramente sonoro já observado na peça anterior), podemos notar um trabalho com o universo da oralidade a partir da exploração de certos gestos e expressões emotivas como,

${ }^{21}$ Utilizamos aqui a tradução de Flo Menezes presente no livro Música eletroacústica: história e estéticas (MENEZES, 1996: 121-129). 
por exemplo, o riso e a respiração ofegante. Esse trabalho com a gestualidade oral, no entanto, centra-se paradoxalmente em seu aspecto mais musical, o que se distancia dos projetos entoativos realizados pelos artistas da canção popular. Acreditamos que a expressividade, no caso de Berio, ultrapassa em muito a relação com a entoação da linguagem verbal. É outro o contrato com o ouvinte. Voltando à reflexão de Menezes acerca da inclusão da semântica verbal na música eletrônica, é curiosa essa ambivalência de sentidos: por um lado, sob a perspectiva desses compositores, essa inserção provoca realmente um contato significativo com o ouvinte a partir da remissão à língua oral. Por outro, sob o ponto de vista da canção popular, a fruição dessas obras parece se ligar preponderantemente às especulações puramente sonoras.

Enfim, os últimos exemplos de peças musicais do século XX citados acima, de Schoenberg a Berio, continuam a nos indicar a pertinência dessa perspectiva de análise do repertório cantado erudito, a partir da qual observamos um movimento pendular entre a oralidade e a música. Como vimos anteriormente, esse permanente vagar pôde ser notado no decorrer de toda a história da música erudita. Livio Tragtenberg, em seu prefácio à obra de Reinach, já assinalava a mesma questão:

Se formos considerar as idas e vindas da criação vocal da chamada música erudita, esse movimento pendular se torna ainda mais claro. Períodos em que a criação melódica se sobrepõe ao texto, com alongamentos e ornamentação que, muitas vezes, ofuscavam a clareza semântica e mesmo sintática do texto; períodos de restabelecimento de um equilíbrio entre linha melódica e verso, que buscava propiciar o entendimento semântico do texto e suas estruturas métricas. Mesmo a música do século XX apresentou essa alternância de comportamento com relação ao texto cantado, ora como reação à uma herança romântica cheia de clichês, ora como reação a um uso praticamente abstrato do texto. (REINACH, 2011: 22)

Em suma, o principal objetivo deste capítulo inicial foi realizar um levantamento dos estudos que abordam a relação entre o canto e a fala, ainda que circunstancialmente, bem como assinalar os autores e os movimentos artísticos, na área erudita e na popular, que apresentam essa oscilação entre a música e a oralidade. É claro que os diversos depoimentos e concepções propostos pelos compositores e estudiosos da história da música mencionados acima, por vezes, trazem implícitas as suas preferências estéticas (como, por exemplo, o gosto pela oralidade de Mei, Galilei, Gluck etc.). São, afinal, pensadores envolvidos com as tendências artísticas de suas respectivas épocas, 
intelectuais que não se limitaram a um exame apenas técnico dos fenômenos. Nosso objetivo aqui, ao contrário, não é defender a canção mais próxima da fala, mas sim observar essa natural oscilação entre a música e a entoação (visto que ambos os processos, musicalização e oralização, são igualmente determinantes para a linguagem da canção). Ao elencarmos os diversos estilos e obras ao longo da história, nosso intuito foi também demonstrar a significativa relevância do tema desta pesquisa, isto é, a presença da fala na composição de canção. Nesse momento, estamos aptos a dar um passo adiante no sentido de aprofundar essa mesma questão. Para isso, utilizaremos a teoria da semiótica da canção desenvolvida por Luiz Tatit, primeiro estudioso a se debruçar de maneira sistemática sobre o aspecto entoativo das composições. Passemos então para o segundo capítulo da tese. 


\section{A FIGURATIVIZAÇÃO NA SEMIÓTICA DA CANÇÃO}

A presença da língua oral na canção, seja ela erudita ou popular, embora tenha sido mencionada por diversos pensadores e notada em muitas práticas musicais ao longo da história, jamais havia sido tratada de forma aprofundada e sistemática. A semiótica da canção, teoria desenvolvida por Luiz Tatit a partir da década de 1980, representa, nesse sentido, o primeiro enfoque científico da matéria. Neste capítulo, estudaremos o seu conceito de figurativização, noção que nos auxilia no esclarecimento dessa relação entre a fala e a música vocal ${ }^{22}$. Mais do que definir esse conceito, desejamos, sobretudo, examinar o seu desenvolvimento ao longo da evolução da teoria, observando aspectos que permanecem desde as suas primeiras publicações e novas perspectivas que representam mudanças significativas dentro de sua abordagem.

A semiótica da canção, como indica o próprio nome, decorre de uma teoria mais abrangente, a semiótica geral, proposta e aprofundada pelo linguista lituano Algirdas Julien Greimas a partir da década de 1960 e, desde então, desenvolvida por diversos estudiosos, dentre os quais se destaca Claude Zilberberg, por suas contribuições mais recentes $^{23}$. Inicialmente ligada aos estudos linguísticos e literários, a semiótica foi progressivamente sendo aplicada no exame de outras áreas e linguagens artísticas. Projetava-se, assim, a possibilidade do surgimento de teorias específicas como, por exemplo, uma semiótica das artes visuais, da dança, da música etc.

O surgimento da semiótica da canção faz parte desse contexto no qual o pesquisador, a princípio fundamentado pela semiótica geral, reutiliza seus conceitos e cria novas noções a partir do embate com sua matéria específica. As suas formulações são inspiradas na teoria de Greimas e Zilberberg e, ainda que preservem algumas de suas

\footnotetext{
${ }^{22}$ Como mencionamos anteriormente, o autor tem utilizado, em publicações recentes, o termo "oralização" para nomear o mesmo processo. Nesta tese, adotaremos, sobretudo, o vocábulo "figurativização", tendo em vista a maior presença desse termo nos estudos da semiótica da canção até o momento. Ambos, no entanto, poderão aparecer em nossa pesquisa, fazendo referência ao mesmo procedimento.

${ }^{23}$ Esse assunto será tratado de maneira mais detalhada no capítulo sobre a figurativização na semiótica geral.
} 
ideias e definições, alteram significativamente certas noções "a ponto de adquirir uma autonomia de uso específico para o universo da canção popular" (TATIT, 2002: 26) ${ }^{24}$. Por essa razão, além do fato de esta tese interessar sobretudo aos pesquisadores da canção popular (que geralmente possuem pouca intimidade com os estudos semióticos), preferimos abordar a semiótica da canção antes de tratarmos da semiótica geral, na qual pretendemos chegar pouco a pouco.

Sob outra perspectiva, devemos observar que o surgimento da semiótica da canção nos anos 1980 e 1990, sobretudo no que se refere à sua ênfase concedida aos aspectos entoativos, não pode ser desvinculado do contexto artístico e intelectual proveniente das décadas de 1960 e 1970, no qual havia uma fortíssima valorização da novidade na arte, nos seus mais diferentes campos de criação. Isto porque, interessantemente, as carreiras acadêmica e artística de Tatit, bastante entrelaçadas, nascem concomitantemente e representam o mesmo anseio de situar a canção como uma linguagem autônoma e de provar a sua capacidade de inovação estética a partir de seus próprios recursos composicionais.

O autor, cuja geração fora formada por essa ideologia do novo, deve ter se deparado com um impasse de difícil resolução. Ao apaixonar-se pela canção popular e optar por trabalhar com ela na área artística e acadêmica, almejava uma produção criativa e intelectual que contemplasse uma proposta cancional inovadora. $\mathrm{O}$ ambiente, no entanto, mostrava-se particularmente hostil à essa empreitada. Nos concentrando em seu percurso universitário, ao cursar simultaneamente, desde 1972, as graduações em música e em letras na Universidade de São Paulo, Tatit parecia estar buscando uma instituição que pudesse acolher as suas aspirações cancionais. Entretanto, no incipiente Departamento de Música da Escola de Comunicações e Artes, voltado essencialmente para a prática e o estudo da música erudita, a canção popular permanecia ausente do currículo escolar. Por esse viés, parecia impossível detectar algum tipo de inovação na canção na medida em que a formação musical intuitiva da maioria dos cancionistas jamais os levariam a trabalhar com sonoridades distantes da tonalidade ou dos padrões rítmicos ligados aos gêneros populares. As suas soluções sonoras, do ponto de vista musical, tornavam-se, assim, muito ultrapassadas, o que justificava o natural desinteresse dos músicos eruditos e dos críticos musicais de então.

\footnotetext{
${ }^{24} \mathrm{Na}$ medida em que este capítulo será dedicado ao estudo da semiótica da canção a partir das publicações de Luiz Tatit, grande parte das referências se remeterá ao mesmo autor. Nesses casos, indicaremos a bibliografia somente com a data e o número da página.
} 
O curso de letras, por outro lado, não lhe oferecia, a priori, métodos de análise específicos, limitando-se, muitas vezes, a uma avaliação literária das letras das canções. Embora houvesse trabalhos excelentes nessa área, esse tipo de estudo não contemplava o exame integral das obras, isto é, a junção entre a letra e a linha melódica. Desse modo, não sendo possível abordar a canção pelo viés musical, tampouco pelo viés literário, o autor, unindo os seus recentes estudos de linguística e semiótica às suas intuições provenientes de sua prática artística como compositor, encontra no aspecto entoativo da canção o terreno propício para germinar a sua aspiração pela novidade estética. A essência de sua inovação criativa fundamentava-se, então, em um mecanismo que pertencia especificamente aos cancionistas e que raramente era experimentado pelos músicos: ao invés de trabalhar a sonoridade a partir dos parâmetros da composição erudita, o fazia a partir das modulações entoativas.

Parece-nos, realmente, bastante interessante debruçarmo-nos sobre esse momento decisivo na carreira artística e intelectual de Tatit e sobre a sua subsequente tomada de posição. Interessante pelo fato de ser perfeitamente possível, para o autor, realizar uma canção musicalmente experimental utilizando procedimentos composicionais aos quais tinha acesso no curso de música, como, por exemplo, as técnicas seriais de composição. Esse caminho, no entanto, devia lhe parecer demasiadamente exterior à tradição da canção popular. Na história da música erudita, ao contrário, era possível observar uma evidente continuidade entre o serialismo de Schoenberg e a música atonal do final do século XIX, no contexto do colapso do sistema tonal, paulatinamente minado pela intensificação do cromatismo.

Nesse sentido, compor uma canção popular serial corresponderia a reafirmar que nesse campo artístico não haveria espaço para a inovação estética, possível somente por meio da importação de elementos estranhos, oriundos de linguagens adjacentes, como a música ou a literatura. A vontade de se afirmar como criador inovador, contrapondo-se ao percurso da música de concerto, e o entendimento da canção como uma linguagem autônoma o faz, enfim, seguir por outro caminho artístico e acadêmico. Em vista disso, ao adentrarmos no estudo da semiótica da canção e na sua ênfase dada ao aspecto entoativo, não devemos esquecer de sua relação com a ideologia ligada às vanguardas estéticas do momento. De certa maneira, ambas as propostas, artística e teórica, podem ser consideradas propostas vanguardistas ${ }^{25}$.

\footnotetext{
${ }^{25}$ De fato, o início da pesquisa acadêmica de Tatit confunde-se com o começo do seu trabalho artístico à frente do Grupo Rumo, banda em que atuou como uma espécie de mentor intelectual e principal compositor
} 


\subsection{A relação entre a melodia e a letra: eficácia e encanto}

A primeira preocupação de Tatit, desde seus estudos iniciais, foi a de assinalar o seu objeto principal de investigação: a relação entre a melodia e a letra. Essa nova perspectiva representa uma contribuição extremamente importante para o estudo da matéria na medida em que, pela primeira vez, delineia de forma sistemática a atividade específica do compositor de canções. Possivelmente, por sua forte penetração na cultura brasileira, bem como por conjugar elementos igualmente presentes em outras linguagens estéticas, a canção popular sempre foi alvo de pesquisas provenientes de diversas áreas de conhecimento (literatura, música, sociologia etc.) ou de publicações dos mais variados gêneros (jornalístico, biográfico etc.). Grande parte delas, no entanto, jamais se debruçou sistematicamente sobre o que o autor denomina "núcleo de identidade da canção" (1986: 3), isto é, a combinação entre uma linha melódica e um texto verbal. De maneira isolada, preocupava-se em reconhecer os valores literários das letras, os valores musicais das melodias, das harmonias e dos arranjos e os valores sociais das temáticas, sem observarem o valor que se produzia na associação entre esses mesmos elementos. Como veremos mais adiante, o criador de canções ou, como prefere chamar o autor, o "cancionista", seria aquele que, diferentemente do músico e do poeta, tem como atividade principal a compatibilização entre o componente linguístico e o componente melódico.

A inadequação entre o objeto de estudo e as ferramentas analíticas acima mencionadas fez com que o autor, em sua dissertação de mestrado, Por uma semiótica da canção popular (1982), iniciasse a pesquisa fundamentando a sua primeira hipótese: a associação entre a melodia e a letra é a característica diferencial desse tipo de trabalho criativo. É uma questão central para o cancionista. Também deve ser uma questão central para o analista. Para isso, articula passagens e declarações de estudiosos e compositores que já haviam explorado o assunto (algo parecido com o que realizamos no capítulo anterior). Esses pensadores, amantes da canção e intrigados com o encanto por ela produzido, chegavam até mesmo a mencionar a questão da integração entre o texto verbal

no período entre 1974 e 1992. O Rumo vincula-se, então, à uma concepção artística ao mesmo tempo acadêmica e vanguardista. Curiosamente, em seus primeiros shows, evidenciando uma vocação muitas vezes mais teórica do que prática, o grupo propunha debates com o público ao final do espetáculo para que se discutissem as novas proposições estéticas presentes nas composições. Além disso, juntamente com Arrigo Barnabé, Itamar Assumpção, Premeditando o Breque e Língua de Trapo, participou do movimento musical Vanguarda Paulistana, cuja denominação, contestada por alguns de seus membros, foi dada pelos jornalistas e críticos da época. Como o próprio nome evidencia, o movimento, ocorrido aproximadamente entre os anos de 1979 e 1985, representa esse mesmo anseio de novidade estética cultivado pela geração de Tatit. 
e o texto musical "sem, contudo, arriscarem uma aproximação descritiva do produto desse encontro", reservando essa questão "ao segredo estético" (1982: 12). Conforme citado pelo autor (1982: 13), Augusto de Campos, em seu poema-homenagem ao poeta Torquato Neto, presente em Balanço da Bossa e Outras Bossas, volta-se com perplexidade para esse mesmo segredo (CAMPOS, 1974: 309).

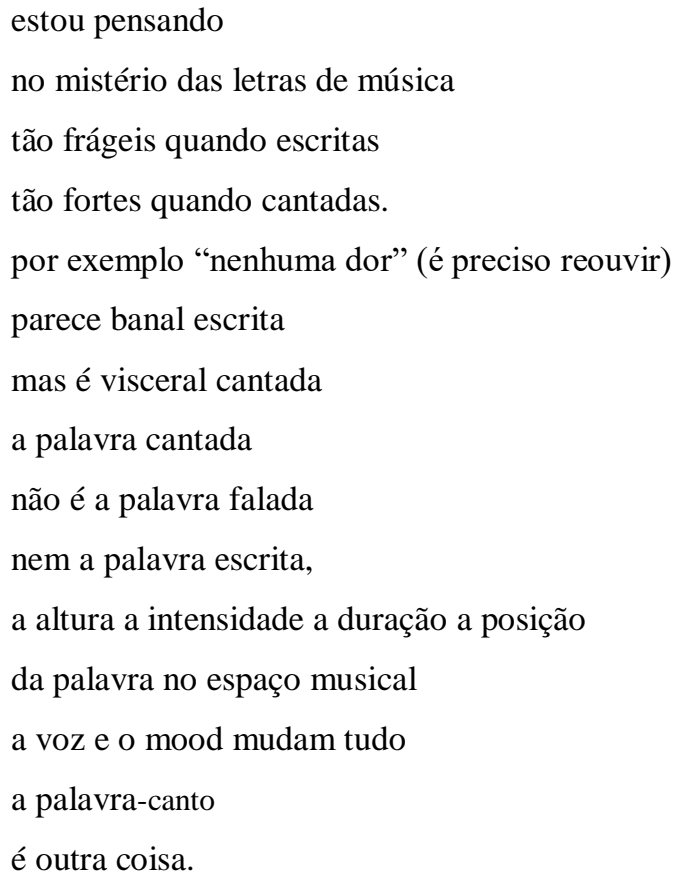

Semelhantemente, o sociólogo francês Edgar Morin menciona, de passagem, a união entre o texto e a música na canção, mas, em seguida, realiza uma análise de caráter mais historicista, sem averiguar a conjugação das duas instâncias: "Em princípio, a canção tem uma dupla substância: musical e verbal. Pode-se perguntar se o mais importante da canção, de seu sucesso, não reside, antes de tudo, na parte musical. O caso é que sempre a canção se apresenta como uma totalidade música-letra" (MORIN, 1973, 145 apud TATIT, 1982:13). O poeta carioca José Lino Grünewald, em artigo para o jornal O Estado de São Paulo, a partir da leitura do mesmo texto de Morin, também assinala o entrelaçamento entre a linha melódica e as palavras.

A canção não possui historiadores - a observação é de Edgar Morin. Sua bibliografia é escassa, quase nada de estrutural, atacando a essência. Nela, os versos não são autônomos: a sua expressividade é condicionada por uma convergência triplificada, além do mundo verbal, aqueles da música e do canto. (GRÜNEWALD, 1974 apud TATIT, 1982: 13) 
$\mathrm{Na}$ mesma direção, em entrevista à revista Manchete, o compositor Chico Buarque, criticando o que julgava ser um "preconceito intelectual" relacionado à canção popular, explicita o seu entendimento de que esse gênero atua na junção entre o aspecto entoativo e o aspecto musical e jamais no tratamento isolado de cada um deles.

Não se pode tratar assim a música brasileira; música popular brasileira é "música" e "letra". Se você tomar separadamente, é claro que não vai se comparar com o instrumental do Stravinsky, porque não comportaria uma letra, e não é música popular, não será nunca. E a letra também, se quiser comparar com os poetas mais avançados, também não dá. Música popular é uma combinação das duas coisas. A parte literária é mais pobre que a literatura mais avançada, e a parte musical talvez seja mais pobre que Stravinsky. Agora, a combinação das duas na música popular brasileira é inédita. Já quiseram lançar livro com letras, e discos com músicas minhas - lançaram um, agora, sem eu saber -, sou contra. Não vou competir com Stravinsky, musicalmente, nem literariamente com James Joyce. A música popular brasileira - isso é reconhecido por gente que entende - é riquíssima, pela combinação das duas formas. Existe um preconceito intelectual muito grande com relação à música popular. (BUARQUE, 1980 Apud TATIT, 1982: 13)

Também citado por Tatit, o pesquisador Celso Favaretto, em Tropicália: Alegoria, Alegria, comenta sobre o mesmo assunto, enfatizando a ideia de que a letra de canção apresenta especificidades que a diferenciam de um poema escrito.

Por ser inseparavelmente musical e verbal, é difícil tanto compor a canção como analisá-la. Ela remete a diferentes códigos e, ao mesmo tempo, apresenta uma unidade que os ultrapassa: como não é um poema musicado, o texto não pode ser examinado em si, independentemente da melodia - se isso for feito, pode-se ter, quando muito, uma análise temática (FAVARETTO, 1979: 18 Apud TATIT, 1982:13)

Todos esses pensadores apontados pelo autor apresentam um entendimento similar: a canção deve ser compreendida como a conjugação de dois componentes principais e a quebra desse vínculo, isto é, o exame da letra ou da melodia em separado, distancia o estudioso de seu objeto de análise, pois desintegra-o. Nenhum deles, no entanto, dirige sua respectiva pesquisa ou reflexão no sentido de investigar a fundo os mecanismos que fundamentam essa integração essencial. Afinal, por que a união entre o componente linguístico e o componente musical, mesmo que tenhamos uma letra literariamente imatura ou uma melodia musicalmente banal, gera tamanho encantamento 
nos ouvintes? Quais são as suas diferentes possibilidades combinatórias? Como abordar a canção a partir de ferramentas analíticas próprias que consigam dar conta de sua especificidade? Ao investigar essas e outras questões, a semiótica da canção tentará preencher o que nos parece configurar um certo "vazio" teórico.

Comecemos examinando a ideia da combinação dos componentes. Na semiótica, ela está intimamente ligada à noção de "eficácia" que consiste no "êxito de uma comunicação entre destinador e destinatário cujo objeto comunicado é a própria canção" (1986: 3$)^{26}$. É justamente por meio dos diferentes modos de unir um texto verbal a uma melodia que o cancionista (destinador) proporciona ao ouvinte (destinatário) um sentimento de verdade enunciativa, dando-lhe a impressão de que "a cena relatada pela canção é viva" (1986: 10). Com isso, conquista o envolvimento do público. É nesse sentido que a comunicação da canção se torna eficaz. O público intuitivamente reconhece na execução do cantor um "compromisso" entre o modo de dizer e o que está sendo dito.

Não há canção sem impressão enunciativa, sem a sensação de que o que está sendo dito está sendo dito de maneira envolvida. Por isso, o reconhecimento dos cantores e de seus estilos é, por si só, um fator de credibilidade e confiança (1997: 89)

Seja durante o ato de composição, seja durante a interpretação, a "maneira envolvida" com que o cancionista trabalha sua canção pressupõe uma relação significativa com a entoação da fala. A língua oral assume, então, grande importância dentro da teoria da semiótica da canção, tornando-se um elemento chave para a investigação de como ocorrem as compatibilidades entre o que está sendo dito (letra) e a maneira de dizer (melodia).

É produto de um hábito social. Seria impossível eliminarmos, no ato de composição, de interpretação ou de audição de algo que possui texto e melodia, nossa vasta experiência,

\footnotetext{
${ }^{26}$ O autor identifica a instância do "destinador" com a figura do locutor (cantor) e a do "destinatário" com a do ouvinte e analisa o processo no qual o primeiro comunica sua canção ao segundo "tentando envolvêlo" (1986: 10) a partir de diferentes procedimentos de persuasão (persuasão figurativa, persuasão passional e persuasão decantatória). Esse esquema é estudado pelo autor em seu primeiro trabalho publicado, $A$ canção, eficácia e encanto de 1986, um pequeno livro que resume questões estudadas em sua tese de doutorado Elementos semióticos para uma tipologia da canção popular brasileira (1986). Essa publicação, por seu caráter sintético e tamanho muito reduzido (quando comparada à tese que a originou), traz esquematizações e conceitos que, como veremos adiante, o autor abandona em publicações posteriores. No entanto, a ideia da eficácia e do encanto, fundados nos diferentes modos de compatibilizar texto e música, permanecem presentes em suas pesquisas mais atuais.
} 
acumulada durante todos os dias de toda a vida, com uma linguagem que também possui texto e melodia (1986:8)

A "vasta experiência" que acumulamos como falantes de nossa língua materna nos permite reconhecer em qualquer canção, ainda que inconscientemente, elementos próprios da linguagem oral que praticamos cotidianamente. Nesse sentido, a canção congregaria duas tendências distintas: a voz que fala e a voz que canta. Por um lado, a emissão de um cantor nos sugere de imediato alguma relação com gestos de oralidade trazendo para a experiência auditiva a presença de um "corpo vivo", um "corpo que respira". Por outro, essa mesma emissão oferece para o ouvinte uma voz sonoramente estável, estetizada e distante da fala, acusando simultaneamente a presença de um "corpo imortal", "materializado nas durações melódicas". É justamente dessa "singular convivência entre o corpo vivo e o corpo imortal que brota o efeito de encanto e o sentido de eficácia da canção popular" (2002: 16).

Ao longo do desenvolvimento de sua pesquisa sobre a "singular convivência" entre a fala e a música, o autor se deparou com produções de importantes intelectuais nas quais havia, mesmo que indiretamente, significativas reflexões a respeito dessa mesma questão. Destacamos as considerações de Roland Barthes sobre o "grão da voz", os estudos de Jacques Attali e José Miguel Wisnik acerca da oposição entre "som" e "ruído" e os escritos de Paul Valéry a respeito das funções artísticas e utilitárias das práticas significantes.

O "efeito de encanto" e o "sentido de eficácia" resultante dessa presença simultânea da voz que fala e da voz que canta se liga intimamente ao que Barthes denominou "grão da voz", fenômeno que ocorre somente "quando a música e fala estão em dinâmica de influência mútua" (1994: 226). É quando a voz "se encontra em dupla postura, em dupla produção" (BARTHES, 1984: 218): ao mesmo tempo em que emite os contornos melódicos estabilizados, expressa igualmente a gestualidade oral do cancionista. Essa singular interceção seria então um requisito fundamental para o "efeito de verdade da obra" (TATIT: 1997: 92).

O "grão" da voz não é - ou não é só - o seu timbre; a significância que ele abre não pode precisamente definir-se melhor que pela própria fricção da música e de outra coisa, que é a língua (e nunca a mensagem). É preciso que o canto fale (...) (BARTHES, 1984: 221) 
Tatit aponta João Gilberto como um caso exemplar de realização do chamado grão da voz (TATIT, 1994: 269). Segundo o autor, o compositor baiano atua congregando duas intenções distintas, particularidade artística sobre a qual comentamos no capítulo anterior. Ao mesmo tempo em que dá vazão ao elemento entoativo proporcionando momentos de "execução exclusiva" (como um trecho falado quase impossível de ser fielmente repetido), também procura a ordenação musical baseada nos acordes e nos padrões rítmicos do acompanhamento. Como se o processo criativo de João Gilberto fosse a transformação de rupturas (características entoativas que representam uma transgressão em relação à estabilidade musical, mas que, ao mesmo tempo, concedem naturalidade ao canto) em continuidades musicais. Como se os limites entre a voz cantada e a voz falada se desfizessem no grão da voz de João Gilberto. Como se a provisoriedade da fala encontrasse a longevidade musical (1994: 269).

\footnotetext{
Em outros termos, o grão da voz depende do ruído, da entonação e da velocidade para se manifestar, embora esteja necessariamente fundado numa forma do som, nas leis melódicas e no rito de desaceleração da linguagem cotidiana. É na canção transcorrendo no limiar da fala que se configura o corpo do cancionista, o grão, a voz que canta porque diz e que diz porque canta. (1994: 267)
}

A ideia explorada no fragmento acima (na qual observamos a oposição entre o "ruído" e a "velocidade", de um lado, e as "leis melódicas" e a desaceleração", de outro) nos conduz ao exame dos conceitos estudados por Jacques Attali (ATTALI, 1977) e José Miguel Wisnik (WISNIK, 1989). Antes, no entanto, devemos analisar de maneira mais detalhada o que significa dizer que nossa fala cotidiana possui como principal característica sonora a instabilidade. Essa questão, sempre pontuada por Tatit em suas publicações (uma vez que constitui um tópico essencial para a compreensão das diferenças entre a música e a fala) pode ser tratada nos seguintes termos: diferentemente da música na qual observamos uma evidente organização sonora, sobretudo em relação aos parâmetros altura e duração que estabelecem reiterações intervalares e motívicas, a fala, desvinculada do texto, é sonoramente irregular, inconstante e descartável. O seu ritmo é desordenado e suas frases não apresentam frequências estáveis, dado que sua principal finalidade é a transmissão de mensagens abstratas cuja sonoridade, após cumprido este objetivo, pode ser prontamente abandonada. 
Por sua natureza utilitária e imediata a voz que fala é efêmera. Ela ordena uma experiência, transmite-a e desaparece. Sua vida sonora é muito breve. Sua função é dar formas instantâneas a conteúdos abstratos e estes sim devem ser apreendidos. O invólucro fônico é descartável. Por isso, a melodia da fala não se estabiliza, não se repete e não adquire autonomia. (2002: 15)

O centro dessa questão reside justamente na diferença de funções praticadas pela fala e pela música. O papel utilitário da primeira, evidenciando o teor cognitivo das mensagens e o aspecto funcional inerente à língua oral, cujo propósito é "assegurar a intercompreensão dos falantes" (1997: 88), faz com que sua materialização fônica não receba um tratamento estável e regular, ao contrário de seu componente linguísticogramatical, perfeitamente ordenado. Isto é, em nossa comunicação cotidiana, mais importa a rápida transmissão do conteúdo pelos falantes da língua do que propriamente a conservação da sonoridade que o veicula. A inteligibilidade dos discursos orais, isto é, o sucesso da comunicação, depende, aliás, dessa irrelevância sonora: "quanto menos atrair para si a atenção do falante mais contribui para a clareza final do discurso linguístico" (1997: 88). O seu papel, paradoxalmente indispensável e secundário, consiste em enfatizar certas partes do discurso linguístico, porém, "sem se configurar como processo autônomo" (1997: 88).

No canto, diferentemente da fala na qual a relevância está no conteúdo da mensagem, o interesse encontra-se justamente na maneira de dizê-lo. Nesse sentido, a atividade do cancionista pode ser entendida como a criação de uma "responsabilidade sonora" (2002:12), isto é, a configuração de uma ordenação musical estável que possibilite a preservação da melodia que veicula o texto verbal. As relações entre som e ruído estudadas por Attali e Wisnik casam-se perfeitamente com essa oposição entre canto e fala.

$\mathrm{Na}$ perspectiva do escritor francês, o ruído, por sua sonoridade instável e indisciplinada, seria o "representante das forças antagonistas constantemente sacrificado pelo rito musical que representa a afirmação de uma ordem sócio-política" (1994: 238). Nesse ritual de sacrifício, a música, por meio de suas leis sonoras, acaba por dominar as desordens ameaçadoras do ruído. Para aprofundar essa discussão, ou melhor, semiotizála, Tatit incorpora em suas análises a categoria, ao mesmo tempo semiótica e musical, de andamento, passando a examinar a oposição entre a aceleração e seus valores descontínuos (o ruído caótico e fugidio) e a desaceleração e seus valores contínuos, 
representada pela música ordenada e perene (1997: 90). É o que o autor observa no excerto abaixo, ao comentar a abordagem do mesmo assunto realizada por Wisnik.

Embora não mencione explicitamente a categoria do andamento como princípio geral de sua abordagem, Wisnik emprega diversas vezes o termo aceleração para definir a "turbulência" do mundo ruidoso em oposição aos estados duráveis e "constantes" criados pelo som musical. Tudo ocorre como se a música respondesse às intervenções antagonistas com o rito, a solenidade, a periodicidade, a ordenação, enfim, com todos os recursos que reafirmam as expectativas sociais e consequentemente, a integração do sujeito com seus valores. Depreende-se do texto de $O$ som e o sentido que a aceleração imposta pelo ruído constitui um verdadeiro atentado contra a espera pacientemente construída pelo som. (1997: 91)

O mesmo ocorre com a língua oral e a música, cuja associação funda a canção. A rapidez e o imediatismo da primeira são aplacados, desse modo, pela ritualização e preservação estética da segunda. Por outro lado, ainda que as canções promovam a estabilização da matéria sonora, o autor destaca a importância da permanência, mesmo que mínima, da instabilidade e da aceleração, como elementos responsáveis pela dinamização das obras (1997: 90). No caso dos cancionistas, um teor mínimo de instabilidade, representado pela incorporação de gestualidades orais, não permite que a canção "se encerre numa gramática predeterminada e adquira a monotonia dos processos estereotipados" (1994: 280). Ele é o antídoto contra a cristalização musical excessiva. Dessa maneira, o compositor de canções se sente ao mesmo tempo atraído pelo ruído da fala (por seu valor enunciativo) e estimulado a rejeitá-lo em prol da organização regular do som, tendo em vista a inevitável necessidade de perenizar a sua criação bem como, é claro, o prazer de sua fruição musical. Há um movimento pendular constante entre as duas tendências.

Liga-se a isso a reflexão realizada pelo poeta francês Paul Valéry acerca da função utilitária da prosa, do caminhar e da fala em contraposição à função estética da poesia, da dança e do canto (VALÉRY, 1991). Estas são práticas significantes que exercem sua função artística a partir de materiais vinculados às funções utilitárias. É baseado nos gestos corporais que o bailarino forma o projeto estético de uma coreografia, assim como é a partir das inflexões prosódicas de nossa língua natural que se constrói o canto. As práticas utilitárias recusam as leis de estabilidade do plano da expressão já que seu valor está centrado justamente na transmissão ou realização eficaz de algo abstrato, sem enfatizar a presença do significante (1994: 251). Não valorizamos cada elemento gestual 
executado por um motorista que conduz um automóvel, pois o significado de seu projeto global, contendo todos os gestos por ele realizados, consiste somente em sair de uma localidade e chegar a outra. As etapas parciais se atonizam, ou melhor, se “dessemantizam" para valorizar o sentido do todo (1994: 254). Ao contrário, em uma exibição de manobras radicais com automóveis, passamos a prestigiar cada uma de suas etapas, agora enriquecidas de significados pontuais. É como se desacelerássemos o projeto global para atermo-nos a cada uma de suas fases. Nesse sentido, podemos identificar na efemeridade das práticas utilitárias a noção de celeridade, enquanto reconhecemos na vocação perenizadora das práticas estéticas a noção de duração (1997: 90).

Os impulsos de ritualização, de musicalização ou de estetização de modo geral são manifestações de defesa do corpo, da substância e do presente contra a rapidez e a efemeridade das práticas cotidianas. (1994: 255)

Essas reflexões a respeito da oposição entre fala e música serão, como veremos adiante, fundamentais para o entendimento do sentido das obras analisadas pela semiótica da canção, inseridas num permanente vagar entre a instabilidade entoativa e a estabilidade musical. Por ora, na medida em que partiremos para o estudo de canções que estabelecem relações significativas com elementos característicos da língua oral, nos interessa somente ressaltar a especificidade da fala, como vimos, refratária às ordenações regulares da música.

Na primeira parte do livro Todos entoam: ensaios conversas e canções, uma espécie de memórias de sua relação com a canção popular, notamos que a presença ao mesmo tempo óbvia e dissimulada da fala na canção desde cedo intrigou Tatit. Como narra o próprio autor, em uma certa noite de 1975, acompanhado por seus parceiros do Grupo Rumo, escutava a canção "Minha nega na janela" (Doca/Germano Matias) cantada por Gilberto Gil quando, de repente, se deu, como ele mesmo denomina, sua óbvia descoberta: "as melodias das canções não tinham origem propriamente musical mas sim entoativa" (2007: 29) ${ }^{27}$. A partir de então, fundamentado pelo arcabouço teórico da semiótica francesa, o autor mune-se de ferramentas com as quais consegue desenvolver

\footnotetext{
${ }^{27}$ Essa reflexão, uma espécie de lampejo do autor, foi registrada pela primeira vez em $O$ Cancionista, nos seguintes termos: "Tive, em 1974, uma espécie de insight ou de susto quando, ouvindo Gilberto Gil reinterpretando antigas gravações de Germano Matias, me ocorreu a possibilidade de toda e qualquer canção popular ter sua origem na fala" (1996: 11-12).
} 
sua intuição inicial até que se transforme em uma robusta teoria da linguagem cancional. Para dar conta desse primeiro aspecto composicional (a relação entre a melodia da canção e a entoação da fala), o autor emprega o conceito semiótico de figurativização ${ }^{28}$. Utilizao no sentido de criar referências de fala cotidiana no interior da canção, ou seja, elaborar oralizações que se reportem à nossa maneira de falar, tanto no contorno melódico como na construção das frases linguísticas. Em outras palavras, o canto se figurativiza ao incorporar inflexões entoativas e expressões coloquiais:

\begin{abstract}
Esse processo geral de programação entoativa da melodia e estabelecimento coloquial do texto pode ser denominado figurativização por sugerir ao ouvinte verdadeiras cenas (ou figuras) enunciativas. Pela figurativização captamos a voz que fala no interior da voz que canta. Pela figurativização, ainda, o cancionista projeta-se na obra, vinculando o conteúdo do texto ao momento entoativo de sua execução. (2002: 21)
\end{abstract}

No fragmento acima, percebemos as duas naturais consequências, claramente indissociáveis, geradas pelo processo figurativo na canção: a projeção do sujeito no texto cancional e a instituição de um tempo presente. Primeiramente, elas delineiam a presença de um "eu" sensível e cognitivo que carrega para o canto todos os seus sentimentos e pensamentos, configurando, dessa maneira, a personalidade do enunciador. É por meio dessa "sinceridade melódica" (2004: 77-78) que somos capazes de ouvir um sujeito convicto, vacilante, aflito ou realizado.

No capítulo anterior, comentamos como, na história da canção brasileira, segundo o mesmo autor, esse aspecto teve papel crucial na conformação dos estilos dos grandes cantores e cantoras do rádio que criavam "personagens definidos pela própria entoação" (2004: 75): Fundavam-se, então, diversos tipos de enunciadores: o desafortunado, o sedutor, o malandro, o apaixonado etc. Ademais, para além dessa configuração de figuras estereotipadas, os cantores naturalmente interpretam obras com as quais se identificam, cientes de que a letra não pode ser veiculada "sem envolvimento emocional" (2016: 129). Assim, em virtude dessa "ilusão enunciativa” (2016: 129), ao escutarmos uma canção, é patente a associação do conteúdo da letra com a persona do cantor.

Não podemos, por outro lado, dissociar esse comprometimento do sujeito com a instauração de um efeito de tempo presente: “alguém cantando é sempre alguém dizendo,

\footnotetext{
${ }^{28}$ No capítulo seguinte, dedicado ao estudo da figurativização na semiótica geral, abordaremos mais detalhadamente a origem dessa noção e poderemos melhor compreender as semelhanças e diferenças entre a aplicação de Tatit e o conceito original.
} 
e dizer é sempre aqui e agora" (2002: 20). Portanto, o gesto oral do cancionista consiste na utilização, geralmente inconsciente, de recursos figurativos com os quais ele presentifica a relação entre o enunciador e o enunciatário (eu/tu) num aqui/agora, dandonos a impressão de que "a canção relata algo cujas circunstâncias são revividas a cada execução" (1997: 103). 


\subsection{Recursos figurativos}

Se considerarmos o conjunto da obra de Tatit, no que concerne à figurativização, constataremos o reconhecimento de cinco principais recursos composicionais indicadores dessa presença da entoação da fala no processo criativo dos cancionistas: os dêiticos, os tonemas, a elasticidade melódica, a faixa entoativa e o recorte das unidades entoativas. Este último, aprofundado pelo autor em pesquisas mais recentes, aponta, aliás, para uma mudança significativa na abordagem da semiótica da canção, transformação teórica que constitui, talvez, o principal propósito de estudo deste capítulo. Vejamos então cada um desses recursos.

\subsubsection{Os dêiticos}

Os dêiticos, cuja nomenclatura possui origem etimológica grega (deiktikós) e significa "próprio para mostrar" (1986: 15), são unidades linguísticas que apontam para uma circunstância enunciativa. Dessa maneira, a deitização, explicitada por meio do uso de imperativos, vocativos e demonstrativos, é um ingrediente essencial para a figurativização melódica na medida em que traz para a canção indicadores de tempo, de espaço e dos indivíduos envolvidos no processo de comunicação da canção, enfatizando, desse modo, a própria situação de locução.

Os dêiticos vocativos e imperativos compartilham a mesma função: mostrar a presença do interlocutário. No início deste capítulo, quando apresentamos a noção semiótica da "eficácia", estudamos a relação de comunicação estabelecida entre o destinador (cantor) e o destinatário (ouvinte), configurando a locução principal. Há, contudo, um patamar comunicativo secundário no qual um interlocutor (que podemos identificar como o "eu-lírico" da letra) interage com um interlocutário, o "tu" ao qual o sujeito do texto se dirige (1986: 9). O encanto gerado pela canção em muito decorre das nuances presentes na relação entre esses dois níveis comunicativos.

Em Saudosa maloca de Adoniran Barbosa, por exemplo, um interlocutor se dirige a um interlocutário: "Se o senhor não está lembrado, dá licença de contar". Como analisa Tatit, por um lado, esse "senhor" não é o ouvinte, assim como o "eu" implícito na letra não é propriamente o cantor. Por outro, essas instâncias podem facilmente se sincretizar no momento de execução da obra. Dessa forma, o processo de presentificação locutiva desencadeado durante a interpretação de uma canção geralmente incorpora esse jogo de 
identificações e afastamentos entre destinador (cantor) e interlocutor ("eu" do discurso) e, consequentemente, entre destinatário (ouvinte) e interlocutário (o "tu" da letra).

Os dêiticos vocativos, quando localizados em início de frase, têm, segundo o autor, função de "chamamento" (1986: 17). Aparecem, geralmente, isolados do conjunto melódico, às vezes por um contraste no campo de tessitura (em região mais grave ou mais aguda em relação ao restante da frase), mas, sobretudo, por meio de pausas que separam o elemento vocativo do que vem adiante. Destacando-o, enfatizam a figura do interlocutário ${ }^{29}$ :

Carolina, nos seus olhos fundos

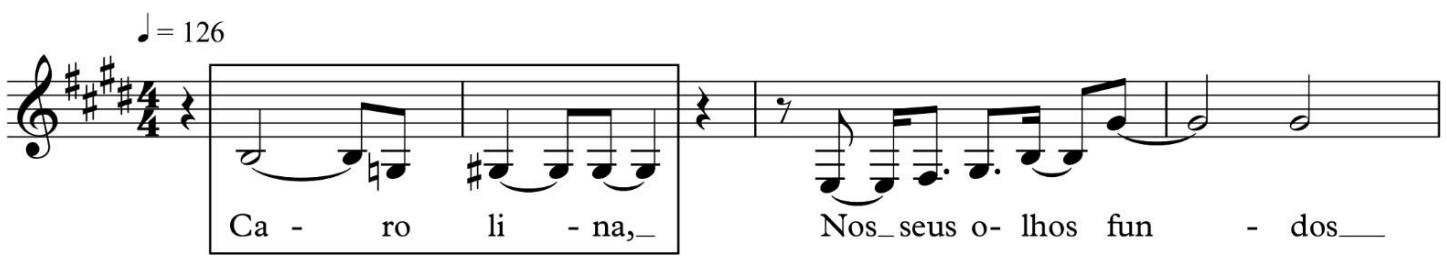

Figura 1. Dêitico vocativo em início de frase em Carolina (Chico Buarque)

Garçom, aqui nesta mesa de bar

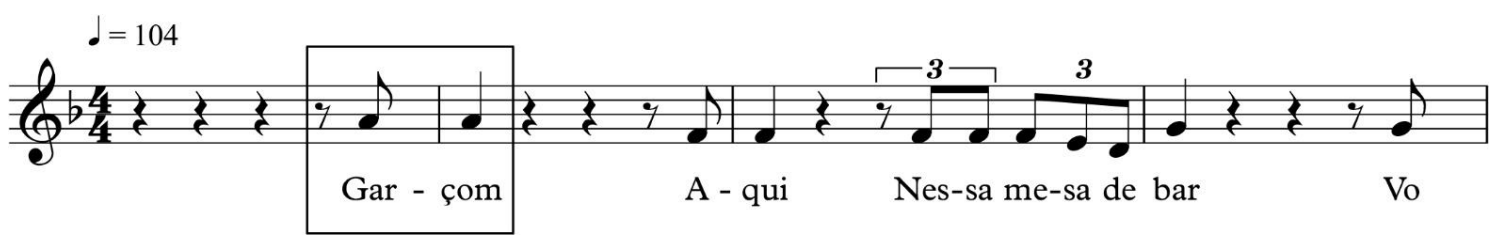

Figura 2. Dêitico vocativo em início de frase em Garçom (Reginaldo Rossi)

Pai, afasta de mim esse cálice

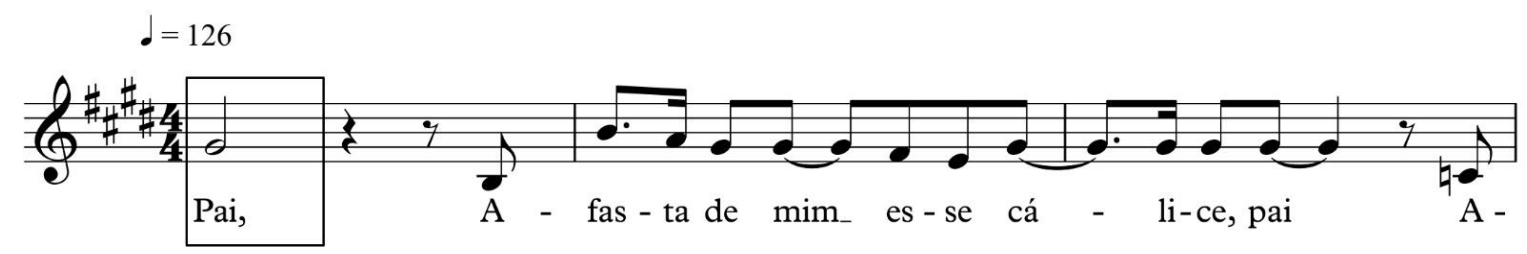

Figura 3. Dêitico vocativo em início de frase em Cálice (Gilberto Gil/Chico Buarque)

\footnotetext{
${ }^{29}$ Para ilustrar as análises de letra e melodia, o autor costuma utilizar um diagrama com linhas horizontais que indicam a sequência de tons e semitons da escala musical. Nesse diagrama, posiciona cada sílaba da letra nos seus respectivos degraus de frequência para que o leitor, geralmente não acostumado com a notação musical em partitura, possa perceber as ascendências e descendências do perfil melódico. Nesta pesquisa, no entanto, optamos por utilizar a partitura tradicional, pois somente ela é capaz de indicar com precisão a duração e a divisão rítmica da melodia, questão importante para diversas análises que faremos adiante. Acreditamos igualmente que a posição das notas na pauta não deixa de indicar as ascendências e descendências melódicas, mesmo para o leitor não familiarizado. Além disso, cremos que esse tipo de notação pode até mesmo auxiliar na própria atividade do analista, na medida em que explicita elementos sonoros que muitas vezes são percebidos apenas quando grafados.
} 
A instância do enunciatário pode aparecer de forma menos enfática quando está presente no meio dos segmentos linguísticos, frequentemente em região mais grave, "como se a melodia assinalasse que está entre vírgulas" (1986: 17). São exemplares nesse sentido as canções Leãozinho de Caetano Veloso e Você já foi à Bahia? de Dorival Caymmi. Em ambas, o dêitico vocativo parece descolar-se das frases melódicas de seu entorno, encaminhando-se para o grave para destacar o chamamento.

Gosto muito de te ver, leãozinho,

Caminhando sob o sol

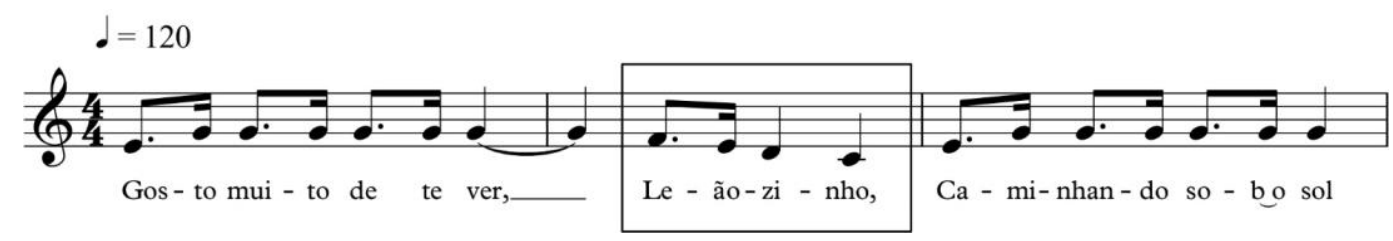

Figura 4. Dêitico vocativo em meio de frase em Leãozinho (Caetano Veloso)

Você já foi à Bahia, nega?

Não?

Então vá

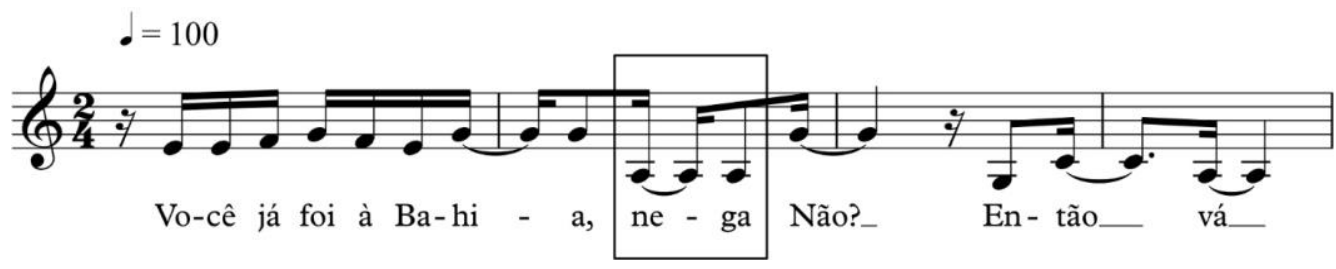

Figura 5. Dêitico vocativo em meio de frase em Você já foi à Bahia? (Dorival Caymmi)

Da mesma maneira, os dêiticos imperativos também têm como função principal convocar a figura do interlocutário. Por vezes, o interlocutário se funde totalmente com a instância do destinatário (ouvinte) gerando um envolvimento emocional diferenciado do público com a canção: "Veja, não diga que a canção está perdida / Tenha fé em Deus, tenha fé na vida / Tente outra vez" (Tente outra vez, de Raul Seixas e Paulo Coelho); "Pensem nas crianças mudas telepáticas / Pensem nas meninas cegas inexatas" (Rosa de Hiroshima, de Vinicius de Moraes e Gerson Conrad). Em outros momentos, o interlocutário é enfatizado sem que haja um sincretismo com o ouvinte, normalmente quando um vocativo nomeia o interlocutário, delimitando-o: "Vem cá, Luiza, me dá tua mão" (Luiza, de Tom Jobim). Em outros ainda, a ambiguidade entre os dois modos acima 
gera na canção uma multiplicidade de sentidos: "Bico calado, toma cuidado, que o homem vem aí" (Passaredo, de Francis Hime e Chico Buarque).

Os dêiticos espaciais e temporais indicarão a configuração do ambiente e do momento nos quais ocorre a situação locutiva, contribuindo igualmente para a presentificação da cena (1986: 20). É como se o destinador (cantor) e o destinatário (ouvinte) "vivessem a situação durante o tempo da canção" (1986: 21): "Eu, você, nós dois, aqui neste terraço à beira-mar" (Fotografia, de Tom Jobim); “Agora é cinza, tudo acabado e nada mais" (Agora é cinza, de Bide e Marçal). Podemos igualmente identificar em certos segmentos linguísticos como as interjeições, as exclamações, as gírias e as “expressões prontas” (1986: 24), diferentes formas de deitização. São elementos de grande valor linguístico que, ao serem inseridos na letra de uma canção prontamente explicitam a presença do processo figurativo: "Mas eu fiz de conta que não ouvi, hein?" (Hein?, de Vivente Barreto e Tom Zé); "Meu Deus do céu, que palpite infeliz" (Palpite infeliz, de Noel Rosa); “Ah, por que tudo é tão triste” (Garota de Ipanema, de Tom Jobim e Vinicius de Moraes); “Ai, ai que saudade eu tenho da Bahia” (Saudade da Bahia, de Dorival Caymmi). Todos os dêiticos citados acima são marcas da linguagem oral que afloram durante o processo de comunicação entre o interlocutor e o interlocutário. Durante a interpretação de uma canção, eles ajudam a presentificar a situação locutiva e exercem, segundo Tatit, mútua atração: "o vocativo atrai o imperativo, que atrai a presentificação espaço-temporal, que atrai as interjeições, a gestualidade, a gíria etc.” (1986: 20). É esperado, dessa maneira, que uma canção que explicita a fala de forma mais proeminente, contenha simultaneamente diversos tipos de dêiticos.

\subsubsection{Os tonemas}

O estudo dos tonemas é uma questão central para a semiótica da canção e está presente em grande parte das análises desenvolvidas por Tatit. Quando não dedica um capítulo à parte ao seu exame, o autor invariavelmente destaca a sua presença em canções de múltiplas fisionomias, como se os tonemas representassem um artifício figurativo elementar compartilhado por todas elas. O tonema é, nesse sentido, um ponto fundamental para o entendimento da figurativização na canção popular.

Antes de tratarmos do tonema, no entanto, observemos um importante aspecto da entoação na linguagem oral. Como assinala o autor, a partir dos estudos entoativos 
realizados pelo linguista espanhol Navarro Tomas ${ }^{30}$, a enunciação se dá por meio de três fases entoativas. Há uma etapa inicial de ascendência que geralmente introduz um determinado assunto a ser tratado na comunicação. Nessa primeira fase, observamos um acréscimo inicial de tensividade melódica para indicar a continuidade do percurso entoativo e "manter acesa a atenção do ouvinte" (2002: 258-259), já que o enunciado ainda não foi concluído. Em seguida, há um segundo momento de declínio que sinaliza a terminação iminente do discurso e no qual podemos encontrar a opinião do enunciador ou o objeto principal da comunicação. Finalmente, temos a terceira e mais importante etapa, o tonema (TOMAS, 1966: 69), que pode sustentar o significado elaborado anteriormente ou modificá-lo radicalmente. É no tonema, ou seja, na inflexão presente na terminação da curva entoativa, que se observa a maior concentração de tensividade. Por meio das articulações entoativas que configura (descendência, ascendência e suspensão melódica), o tonema revela o tipo de vínculo estabelecido entre o enunciador e o seu discurso (afirmativo, interrogativo, suspensivo, hesitante etc.). Consequentemente, é nele que se concentra a maior parte da significação produzida pelas frases entoativas. Dessa maneira, a semiótica da canção não poderia deixar de examinar a proximidade entre o sentido criado por essas "figuras" da fala e o significado das terminações melódicas encontradas nas composições dos cancionistas.

Seja na língua oral, seja na canção, o tonema com articulação descendente produz na maioria dos casos um sentido conclusivo, como uma frase que não necessita de qualquer tipo de complementação, não aceita nenhum comentário ou dúvida. A relação entre a descendência melódica e o sentido terminativo é, segundo diversos linguistas, um princípio geral que faz parte do funcionamento de todas as línguas naturais já descritas (2007: 170) ${ }^{31}$. Assim, podemos dizer que as culturas entendem a inflexão da voz para a região grave da tessitura como uma procura de "repouso fisiológico" (2002: 21), um necessário relaxamento do esforço de emissão, o que naturalmente se associa à ideia de asseveração ou conclusão de um conteúdo. Nessa canção de Caymmi, o sentido terminativo da frase condiz com a descendência para a nota $\mathrm{Si}$ natural no quarto compasso.

\footnotetext{
${ }^{30}$ Tatit fundamenta sua reflexão no livro Manual de entonacion española (TOMAS, 1966), no qual o termo "tonema" já é utilizado pelo autor espanhol.

${ }^{31}$ Em relação a este aspecto do funcionamento das línguas naturais, o autor cita os trabalhos de alguns linguistas como Pierre Léon e Philippe Martin (1969: 80) e Eric Buyssens (1974: 127). Em A canção: eficácia e encanto (1986: 33), o autor também menciona como obras importantes para a análise da entoação da fala os estudos de T. N. Tomás (1966: 72) e M. Rossi (1981: 196-197).
} 
Toda gente no mundo

Tem amor, tem seu bem

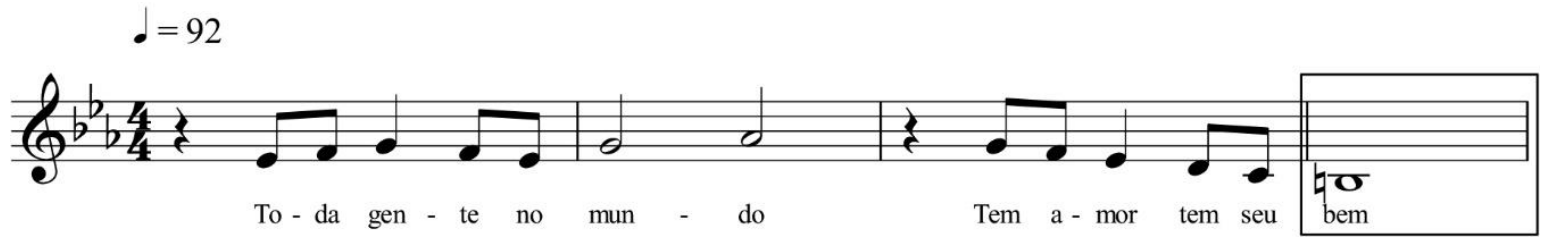

Figura 6. Tonema descendente em Cantiga (Dorival Caymmi)

O processo pode ser compreendido de modo menos pontual, pois, geralmente, essa inflexão terminativa consiste em uma resolução de tensões acumuladas pelo cantor/falante ao longo de toda sua enunciação. É quando a descendência final asseverativa é antecedida por uma ou mais ascendências, obedecendo ao princípio da tensão-distensão: os segmentos iniciais apresentam a tensão necessária para despertar no ouvinte o interesse pelo assunto e por sua posterior conclusão distensiva. Desse modo, a afirmação final descendente depende fortemente da tensão do segmento ascendente que o precede e o seu rendimento "é tanto maior quanto mais acentuada for a ascendência anterior" (2007:172).

Apesar de as terminações de frases melódicas, os tonemas, serem consideradas o núcleo do sentido entoativo, suas nuanças asseverativas são demarcadas pelas oscilações de todo o perfil descrito pela frase. Uma ascendência acentuada no primeiro segmento da frase pode transformar a descendência, do segundo segmento, em asseveração categórica (1986: 33).

Os tonemas ascendentes e suspensivos, por sua vez, ao buscarem uma frequência mais aguda ou sustentarem a altura sem a descendência melódica conclusiva, fazem com que a tensão se mantenha e apontam para a necessária continuidade do discurso.

Essa ladeira

Que ladeira é essa?

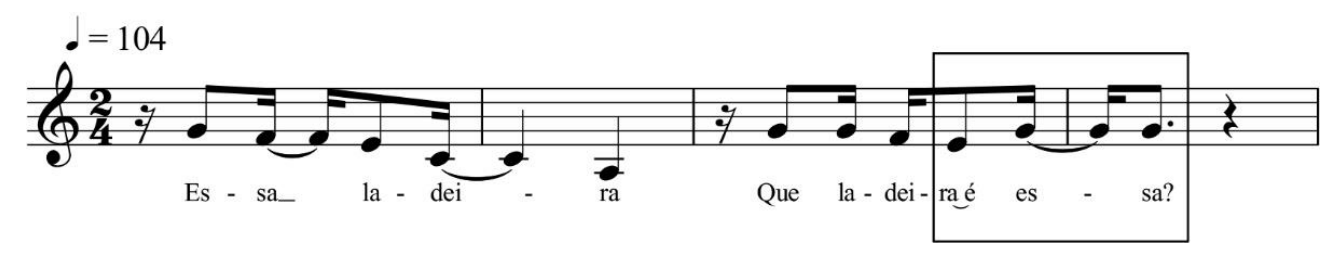

Figura 7. Tonema ascendente em Ladeira de preguiça (Gilberto Gil) 
No palco, na praça, no circo, num banco de jardim

Correndo no escuro, pichado no muro

Você vai saber de mim

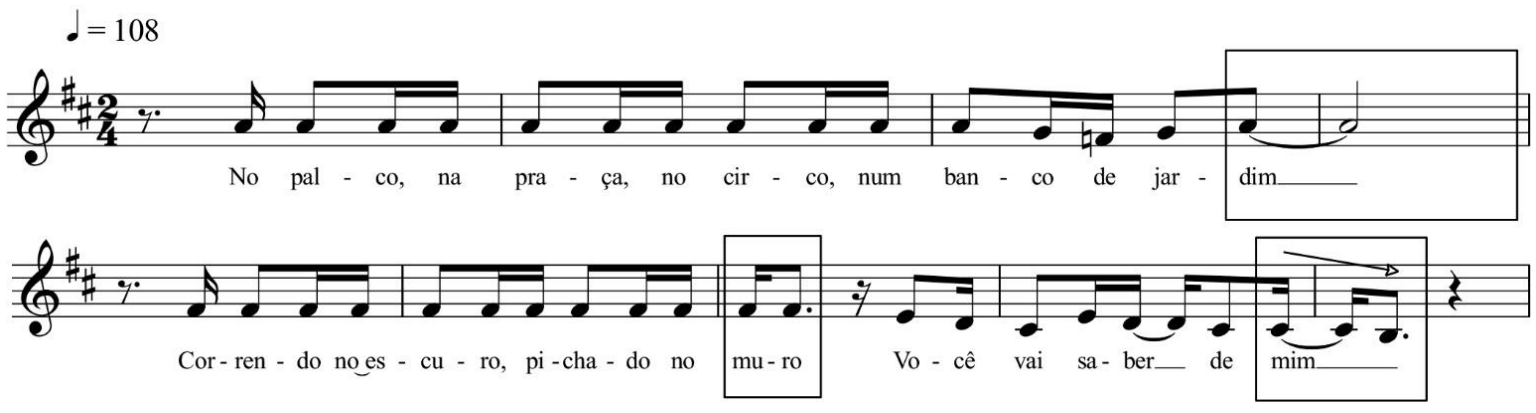

Figura 8. Tonema suspensivo em Mambembe (Chico Buarque)

No primeiro caso, podemos ter uma frase interrogativa requisitando uma resposta. No segundo, a impressão de que algo está pendente e requer algum tipo de seguimento: "outras frases devem vir em seguida a título de complementação, ou mesmo como prorrogação das incertezas ou das tensões emotivas de toda sorte" (2002: 21).

Por seu papel central na análise da canção, o tonema foi recebendo, no decorrer do tempo, novas abordagens a partir de diferentes ferramentas teóricas provenientes da semiótica geral. Isso possibilitou o surgimento de novas perspectivas sobre o assunto e, consequentemente, o aparecimento de nuances até então inexploradas. A descrição inicial dos tonemas na canção, presente desde a primeira publicação de $\mathrm{Tatit}^{32}$, ganha, por exemplo, no artigo Da tensividade musical à tensividade entoativa de $1999^{33}$, uma nova interpretação a partir da articulação das categorias "ascendência" e "descendência" no quadrado semiótico ${ }^{34}$. Se a curva melódica conjugar os termos descendência/nãoascendência estará configurando a finalização, traduzindo um sentido eminentemente terminativo. Ao contrário, quando o tom se eleva (combinação ascendência/nãodescendência), temos o conceito de prossecução, significando a necessidade de algum tipo de continuidade. Por outro lado, se o canto tende a se manter no agudo sem baixar

\footnotetext{
${ }^{32}$ Curiosamente, em A canção: eficácia e encanto (1986), o estudo dos três tipos de tonemas (nomeados nessa primeira obra como "asseveração" para o tonema descendente, "interrogação" para o tonema ascendente e "insuficiência modal" para o tonema suspensivo), é inserido no capítulo dedicado à "Persuasão Passional" e não na parte que analisa o processo da figurativização, como passou a prevalecer nas publicações posteriores. Nessa ocasião, o autor enfatizou a relação entre os tonemas e o estudo da modalização do sujeito e dos movimentos de conjunção e disjunção, o que possivelmente o levou a encaixar este tópico separado da "Persuasão Figurativa".

${ }^{33} \mathrm{O}$ artigo foi posteriormente publicado em Todos entoam (2007:170)

34 Estudaremos o quadrado semiótico com maior detalhamento no capítulo seguinte dedicado à figurativização na semiótica geral.
} 
nem elevar a altura, configura-se a noção de suspensão (não-ascendência/nãodescendência) exprimindo a ideia de um conteúdo inacabado. Por fim, quando associamos ascendência/descendência caracterizando a asseveração, temos a sucessão de um perfil crescente seguido por um perfil decrescente, obedecendo o princípio da tensãodistensão já comentado acima.

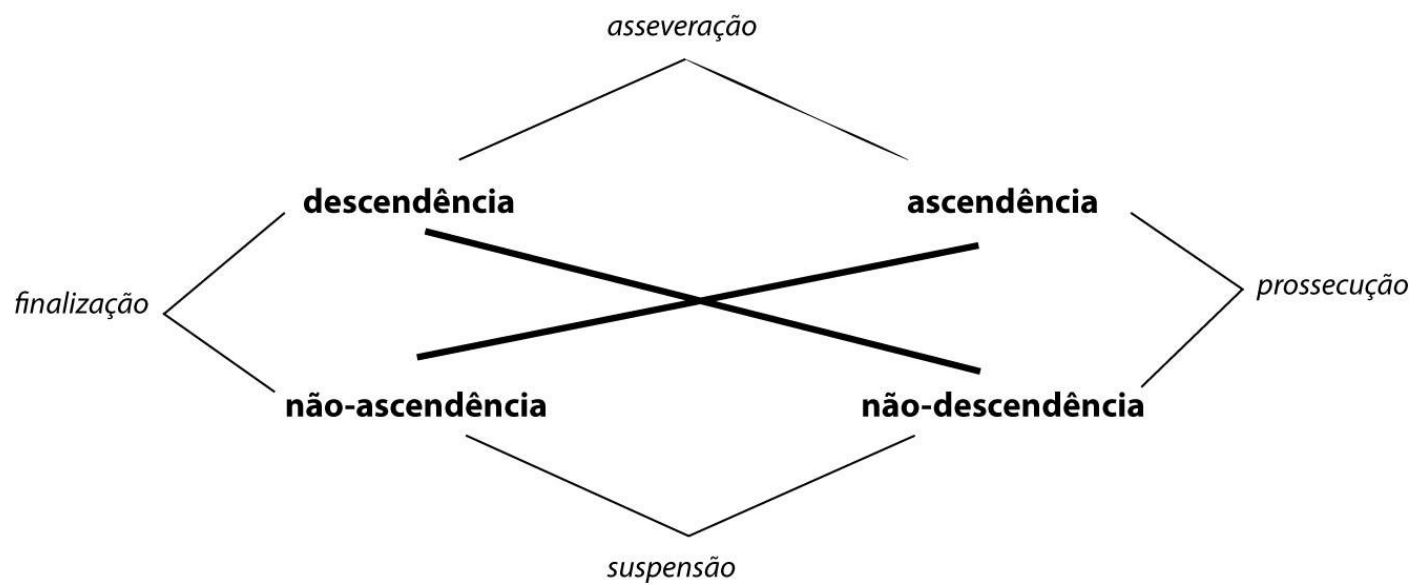

Figura 9. Projeção dos tonemas no quadrado semiótico (In: TATIT, 2007:174)

Outra perspectiva sobre os tonemas é proposta em Musicando a semiótica (1997) quando o autor incorpora conceitos de Louis Hjelmslev que, mais tarde, serão reelaborados pela semiótica tensiva. Trata-se das categorias intensas e extensas, que o linguista dinamarquês associava respectivamente às funções localizantes do substantivo e às funções globalizantes do verbo. Assim, Tatit define duas formas de atuação da figurativização no nível dos tonemas (1997:13). A primeira forma, intensa, consiste na descendência com sentido de afirmação e certeza, delineando uma significação mais precisa e circunscrita. A forma extensa, por sua vez, se identifica com as inflexões entoativas ascendentes e suspensivas. O seu caráter extenso deve-se à ausência de uma restrição de sentido (restrito, na primeira forma, à asseveração terminativa), podendo manifestar, portanto, um espectro mais amplo de significados (interrogação, indecisão, insuficiência, emoção etc.) ou mesmo assinalar a necessária continuação do discurso.

O exame dos tonemas, tal como realizamos acima, indica uma significativa relação entre a canção e a língua oral. Assim, havendo uma compatibilidade entoativa entre a letra e a curva melódica adotada pelo compositor (por exemplo, uma descendência melódica recobrindo uma frase linguística com sentido conclusivo), instaura-se um elo 
entre o cancionista e o ouvinte, ambos em sintonia (consciente ou inconsciente) pelo fato de o canto se basear na língua materna por eles compartilhada.

No entanto, como aponta o próprio autor (1986:36-37), podemos examinar a questão dos tonemas não somente por meio dessa correspondência entre canto e fala, mas igualmente mediante um enfoque musical. É quando, por exemplo, o significado terminativo e distensivo é alcançado não por meio de uma finalização descendente da linha melódica, mas sim por intermédio de elementos essencialmente musicais, como uma cadência tonal (melódica ou harmônica). Desse modo, até mesmo uma curva melódica ascendente, quando apoiada por uma sequência determinada de acordes que enfatizam o percurso de tensão e distensão, pode produzir uma asseveração contundente, sem o uso da descendência entoativa. Assim, o ouvinte, por seu forte hábito de escuta da música tonal, certamente reconhecerá como terminativa uma passagem que, após o acúmulo de tensão sonora gerado pelo uso de acordes distantes da tônica, retorna à tonalidade inicial. Enfim, pretendemos, com isso, salientar que o sentido gerado pela canção está sujeito à inúmeros fatores, não apenas entoativos, ainda que possamos delinear um conjunto de princípios que orientam a relação entre o texto verbal e a melodia.

\subsubsection{A elasticidade melódica}

A diferença entre o trabalho artístico do compositor-cancionista e a atividade criativa do compositor-músico é significativamente explicitada quando nos dedicamos ao estudo da elasticidade melódica. Esse recurso, frequentemente utilizado em nosso cancioneiro popular e mais ou menos presente nas obras de acordo com o estilo de cada autor, é um indício consistente que acusa certa proximidade entre a fala e a canção, característica nem sempre estimada por todos os compositores de música vocal, sobretudo no campo erudito ${ }^{35}$. Segundo Tatit, no universo da canção popular, esse procedimento

\footnotetext{
${ }^{35}$ De fato, para certos compositores eruditos que trabalham com peças vocais, marcadamente os do período clássico e romântico, esse tipo de ligação com a fala chega a ser evitado, uma vez que esses autores prioritariamente dedicam sua atenção para a música em si (e não para os aspectos entoativos da melodia que recobre a letra). Obviamente, sobretudo na música erudita do século XX, diversos compositores passaram a explorar recursos vocais característicos da fala em suas peças, assunto já tratado anteriormente. São bons exemplos a obra Sequenza III de Luciano Berio e a técnica vocal do sprechgesang utilizada por Arnold Schoenberg, ambas citadas em nosso capítulo inicial. No entanto, o valor e o uso desses procedimentos por parte desses criadores são muito diferentes do que encontramos nas obras dos nossos cancionistas populares.
} 
delineia dois tipos diferentes de compositores: aqueles que operam com o controle musical da letra e aqueles que trabalham sem essa restrição (2002: 212).

O cancionista que trabalha com o controle musical da letra, caso da maioria dos compositores, geralmente realiza uma adaptação constante do material verbal para que a linha melódica não sofra alterações nem perca a sua regularidade sonora. É quando o autor prefere substituir as palavras do texto do que remodelar a sua melodia. Ocorre que, por vezes, durante o processo de criação de uma letra, certas palavras escolhidas pelos compositores possuem dimensão e acentuação silábica que não coincidem com a estrutura rítmica predeterminada pela linha do canto. Esse tipo de cancionista tentará então encontrar outro vocábulo que não perturbe a configuração melódica inicial e jamais realizará "emendas" ou variações para conseguir abarcar palavras que não cabiam na versão original da melodia (por exemplo, acrescentando algumas notas ao mesmo perfil ou ainda alterando a acentuação rítmica do canto). Nesse caso, o texto linguístico está fortemente subordinado à programação melódica.

Diferentemente, os cancionistas que não trabalham com o controle musical da letra frequentemente subvertem o padrão melódico, adicionando notas em seu interior ou até mesmo expandindo-o consideravelmente para que possa encaixar mais sílabas, palavras ou frases. Nesse caso, para que possa “dizer” sua ideia sem restrições melódicas, o autor faz com que sua melodia se submeta à letra. Essa submissão do material sonoro ao conteúdo do texto verbal se assemelha a um procedimento típico da linguagem oral e configura, portanto, um importante recurso figurativo.

\footnotetext{
Em nossa comunicação cotidiana, a entoação está totalmente a serviço da mensagem linguística. Jamais deixamos de dizer algo por não caber numa medida prefixada pela melodia. Temos a segurança, plenamente subentendida, de que a entoação possui elasticidade infinita, adaptável a qualquer texto. A adoção dessa conduta na criação de canções é, por si só, um gesto figurativo no sentido de evidenciar a voz que fala subjacente à voz que canta e, consequentemente, o momento enunciativo em que a entoação acompanha a linguagem coloquial (2002: 219)
}

Essa elasticidade que adultera o padrão melódico, como se incorporasse resíduos indesejáveis, aproxima-se da noção de ruído estudada por Attali e Wisnik, como se os cancionistas "estivessem em busca dos mistérios ruidosos da fala" (1994: 267). O acréscimo de notas e a expansão/contração do tamanho da frase de acordo com a letra gera, sem dúvida, instabilidade na forma musical, na medida em que as frases jamais se 
repetem da mesma maneira. O modelo exemplar desse tipo de procedimento é, como afirma Tatit em diversas publicações, a obra de Jorge Ben Jor. Ainda que suas canções se fundamentem numa forte recorrência rítmica (no acompanhamento instrumental do arranjo e na repetição dos refrãos), a linha melódica do canto frequentemente desrespeita as regularidades métricas para atender "às digressões temáticas (linguísticas e melódicas) típicas do autor" (1994: 267). Assim, para Ben Jor, mais interessa dar vazão ao conteúdo linguístico e ao seu ímpeto enunciativo do que procurar soluções poéticas complexas e exatidões métricas. Trabalha como se qualquer fragmento linguístico estivesse apto a se tornar uma letra de canção, uma vez que todo e qualquer texto pode ser melodizado com naturalidade entoativa (2002: 220). Como se compusesse com a mesma naturalidade com que fala. Nos exemplos abaixo, podemos constatar esse tipo de procedimento no qual uma melodia inicial é alterada em favor do texto.

Lá fora está chovendo

Pois ela vem toda de branco

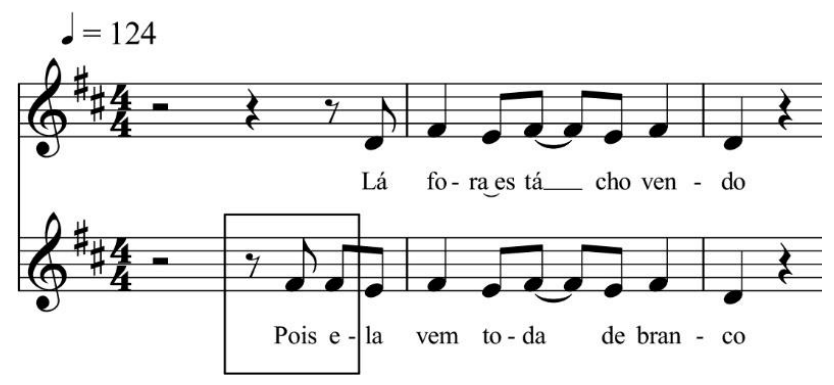

Figura10. Elasticidade melódica em Que maravilha (Toquinho/Jorge Ben Jor)

Mas assim mesmo eu vou correndo

Só pra ver o meu amor

Toda molhada linda e despenteada

Que maravilha, que coisa linda que é o meu amor

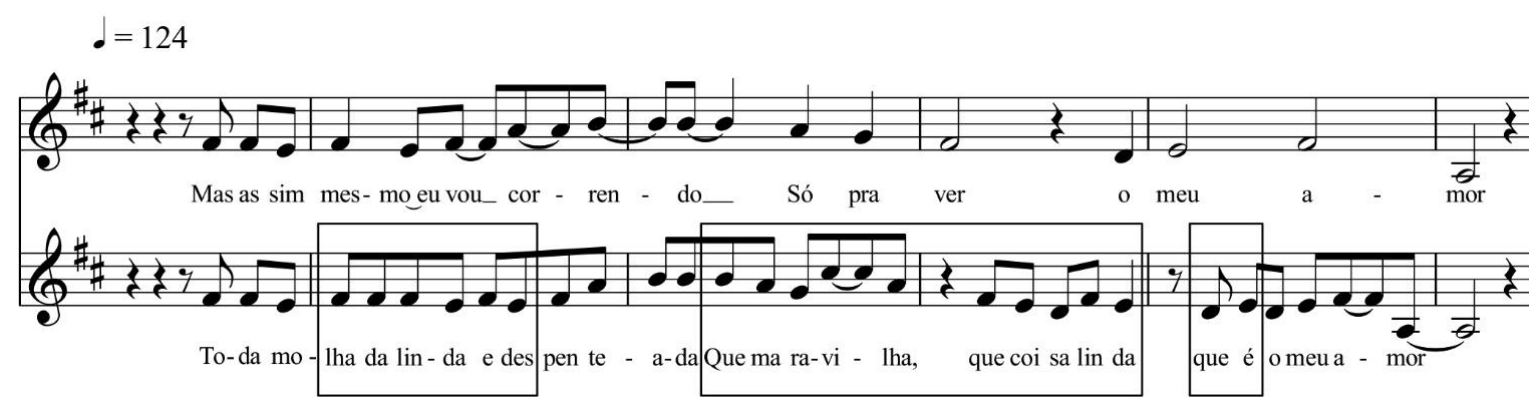

Figura 11. Elasticidade melódica em Que maravilha (Toquinho/Jorge Ben Jor) 
No primeiro exemplo, observamos uma alteração mais sutil entre a melodia do pentagrama superior e a do pentagrama inferior. Neste, apenas duas notas são acrescentadas no início da frase para possibilitar o encaixe das palavras "pois" e "ela", o que não seria possível se mantivéssemos o padrão rítmico anterior. Esse tipo de procedimento, com transformações mais comedidas do perfil melódico, é muito frequente na canção popular e, muitas vezes, passa despercebido pelos ouvintes e até mesmo pelos próprios compositores.

Diferentemente, no segundo exemplo, temos uma transformação bem mais acentuada da melodia original. Essa mudança já fica muito evidente quando observamos a ampliação radical do tamanho do texto linguístico. O trecho musical que apoiava a frase “mas assim mesmo vou correndo só pra ver o meu amor" agora embasa um enunciado bem mais extenso: "toda molhada linda e despenteada, que maravilha, que coisa linda que é o meu amor". Dessa maneira, o compositor expande a melodia e acrescenta novas notas/sílabas para atender a sua necessidade de dizer mais coisas do que a linha do canto inicialmente poderia comportar.

\subsubsection{A faixa entoativa}

O recurso figurativo da faixa entoativa se refere à uma linha melódica de canção que contém uma oscilação entre duas notas relativamente próximas, notas que geralmente formam intervalos de $2^{\mathrm{a}}$ ou $3^{\mathrm{a}}$ (maiores ou menores). Temos, então, uma frase que repete um mesmo intervalo por toda a sua extensão, sendo que a nota aguda geralmente recai sobre as sílabas tônicas dos vocábulos, enquanto as suas sílabas átonas normalmente são recobertas pela nota mais grave. Em virtude dessa coincidência entre as notas agudas e as sílabas tônicas, o que destaca ainda mais a faixa superior de frequência, o ouvinte capta auditivamente esse tipo de construção como se a melodia fosse formada apenas pela nota mais alta do intervalo. Isso fez com que Tatit denominasse esse procedimento como "efeito de frase dita num só tom" (2002: 78). Esse fenômeno aproxima-se significativamente de nossa fala cotidiana, uma vez que uma frase na língua oral apresenta igualmente uma oscilação de altura, mesmo que imperceptível, entre as sílabas tônicas e as átonas. Os falantes, no entanto, tendem a ter a impressão de que a sonoridade da fala não oscila. São, de fato, alterações muito sutis, até porque, como vimos anteriormente, o material fônico da língua oral, submetido ao conteúdo, não deve chamar atenção e precisa ser prontamente descartado após a emissão da mensagem. Quando a canção trabalha com 
a articulação dessas faixas entoativas, está, sem dúvida, tonificando o seu teor oral. Vejamos então um exemplo concreto desse tipo de recurso. Na figura abaixo, destacamos uma frase melódica que opera com uma oscilação de $2^{\mathrm{a}} \mathrm{M}$, entre as notas Mi e Fá\#, na qual as sílabas tônicas coincidem predominantemente com a altura mais aguda do fragmento.

Não adianta nem tentar

Me esquecer

Durante muito tempo em sua vida

Eu vou viver

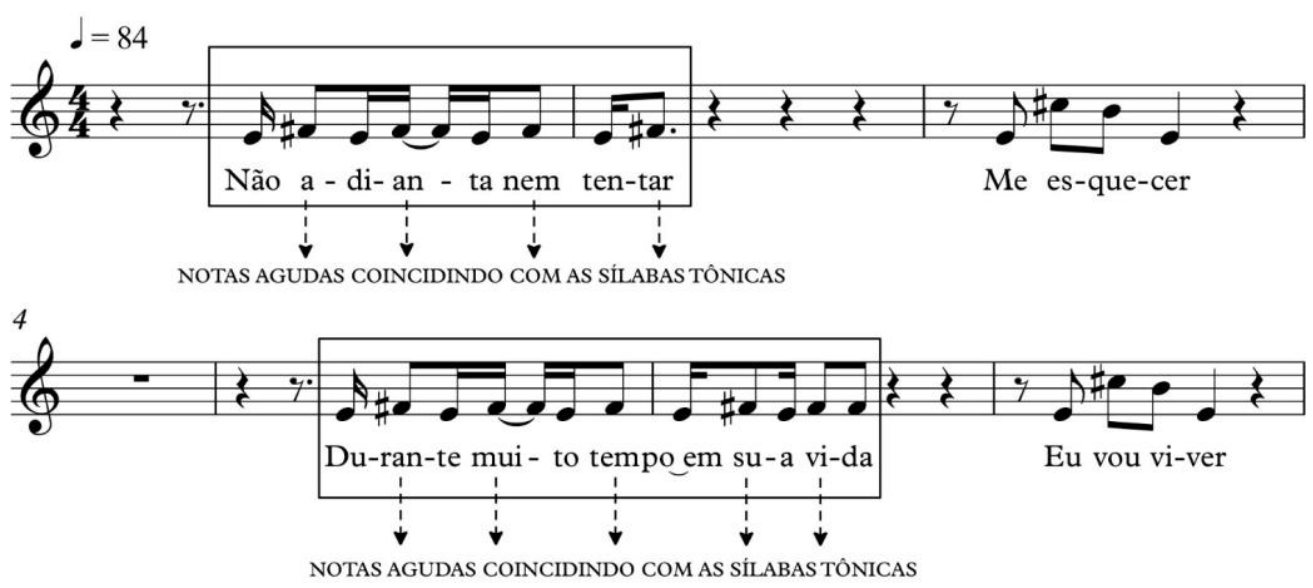

Figura 12. Detalhes (Roberto Carlos/Erasmo Carlos)

A faixa superior de frequência (no exemplo acima, localizada na nota Fá\#), é o eixo entoativo da frase, o que Tatit denominou de linha mestra da melodia (2002: 123). Desse modo, quando escutamos os primeiros versos da canção Detalhes, é justamente essa linha mestra, por sua altura mais elevada e coincidência acentual com o texto linguístico, que ficará "em nossa memória durante e depois da audição" (2002: 123). O ouvinte lembrará dela como o tom único da frase. Diferentemente, as notas que recobrem as sílabas átonas dos vocábulos (no exemplo em questão, a nota Mi) possivelmente serão esquecidas ou cantadas com imprecisão, como se a sua função fosse somente sustentar a configuração da linha superior.

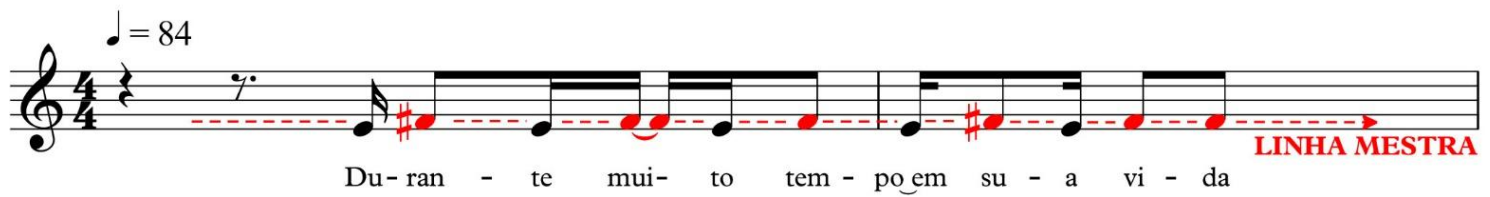

Figura 13. Linha mestra em Detalhes (Roberto Carlos/Erasmo Carlos) 


\subsubsection{As unidades entoativas}

As unidades entoativas configuram o quinto e último recurso figurativo estudado pela semiótica da canção. Esse processo, a nosso ver, possui uma posição de especial destaque para a análise das composições, pois, mais do que estabelecer uma relação entre a canção e a linguagem coloquial, ele é o responsável pelo próprio estabelecimento de cada obra, isto é, o encarregado de definir o recorte linguístico da melodia que, em última instância, funda o sentido da canção. Por isso, ele está no centro da discussão que desenvolveremos neste capítulo a respeito do que acreditamos ser uma importante mudança conceitual na teoria da semiótica da canção que deixa de tratar a criação cancional como um processo de imitação da fala. Primeiramente, então, observemos de maneira mais detida o procedimento das unidades entoativas.

Diferentemente de outros recursos figurativos que aparecem com maior frequência em suas publicações (nas quais se destaca a presença mais constante dos tonemas e da elasticidade melódica), as unidades entoativas serão tratadas com maior profundidade apenas em escritos mais recentes ${ }^{36}$. Há, no entanto, análises anteriores que prenunciam a sua chegada à teoria. Em O cancionista (1996), por exemplo, embora não utilize o termo "unidades entoativas", o autor aborda a mesma questão do recorte textual da melodia. Com o propósito de analisar o estilo cancional do compositor Lamartine Babo, toma como exemplo a canção Serra da boa esperança.

Serra da boa esperança

Esperança que encerra

No coração do Brasil

Um punhado de terra

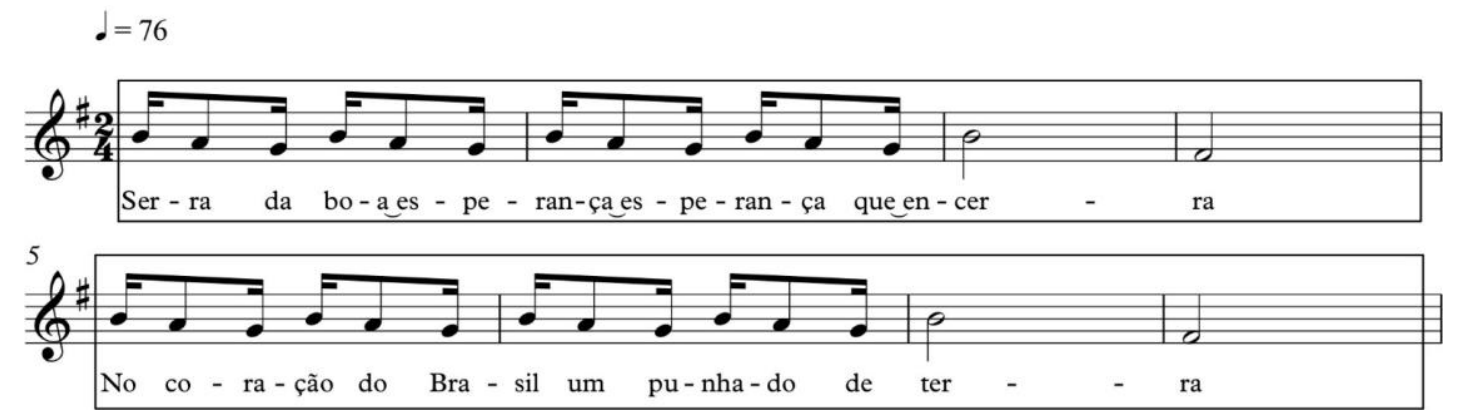

Figura 14. Serra da boa esperança ( $1^{\mathrm{a}}$ estrofe) (Lamartine Babo)

\footnotetext{
${ }^{36}$ Estimar canções: estimativas íntimas na formação do sentido (TATIT, 2016) é a primeira publicação em livro que aprofunda a questão das unidades entoativas. A obra reúne artigos publicados separadamente em anos anteriores.
} 
Neste fragmento, como observa Tatit, notamos um descompasso entre o sentido terminativo da linha melódica inicial (primeiros quatro compassos do exemplo) e o sentido inacabado do texto linguístico. Expliquemos. A melodia que recobre o primeiro verso ("Serra da Boa Esperança, esperança que encerra") possui, ao final, um tonema descendente que, como vimos anteriormente, produz um sentido conclusivo de asseveração. Seu respectivo verso, no entanto, ainda necessita de complementação, considerando o uso de um verbo transitivo: a esperança encerra, "no coração do Brasil, um punhado de terra”. Isto é, há uma ligação de conteúdo linguístico entre o primeiro e o segundo verso da letra, mas a melodia os separa como se fossem independentes. Mais do que isso, a linha do canto "dá ao verbo um efeito intransitivo" (2002: 78). Na segunda parte, observamos igualmente um recorte textual que novamente gera um desacordo entre a letra e a melodia:

Parto levando saudades

Saudades deixando

Murchas caídas na serra

Lá perto de Deus

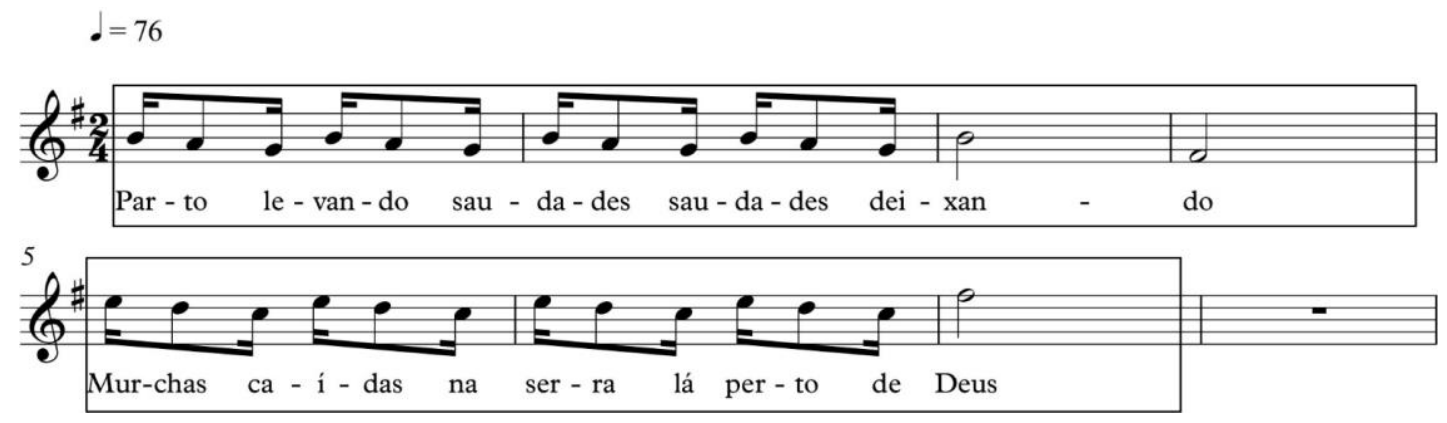

Figura 15. Serra da boa esperança ( $2^{\mathrm{a}}$ estrofe)

A presença do mesmo tonema descendente (notas Si e Fá\# localizadas no terceiro e quarto compasso) gera uma sonoridade de sentido terminativo para o verso "Parto levando saudades, saudades deixando", como se não houvesse necessidade de complementação. O compositor, no entanto, inicia o verso seguinte complementando o anterior com o vocábulo "murchas", adjetivando "saudades". O ouvinte passa a ter, então, dificuldade em compreender o conteúdo da letra de forma mais imediata, pois a sonoridade geral o faz pensar que a segunda frase melódica (compasso 5 a 7) iniciará um novo conteúdo. Ao contrário, na canção de Lamartine, ela complementa o conteúdo 
anterior. Assim, determinados recortes linguísticos da melodia escolhidos pelos compositores poderão diminuir a relação da canção com a entoação da fala. $\mathrm{O}$ estilo cancional de Lamartine Babo pode ser delineado a partir desse exemplo no qual o pensamento figurativo está submetido ao pensamento musical. O cancionista, nesse caso, preocupa-se primeiramente com a estrutura sonora e só depois com as questões entoativas levantadas acima, ligadas aos recortes linguísticos (2002: 82).

Em sua dissertação de mestrado Por uma semiótica da canção popular (1982), o autor analisa a canção Feitiço da Vila (Vadico/Noel Rosa) examinando os mecanismos de recorte linguístico e cobertura melódica para avaliar as "diferentes unidades entoativas investindo o mesmo perfil melódico asseverativo" (1982: 194). Observa então o recorte da letra realizado sobre a melodia descendente que encerra cada uma das quatro estrofes que constituem a parte $\mathrm{A}$ da composição. Abaixo, destacando-as em negrito, transcrevemos somente as frases melódicas analisadas:

Quem nasce lá na Vila

Nem sequer vacila

Ao abraçar o samba

Que faz dançar os galhos do arvoredo

E faz a lua nascer mais cedo

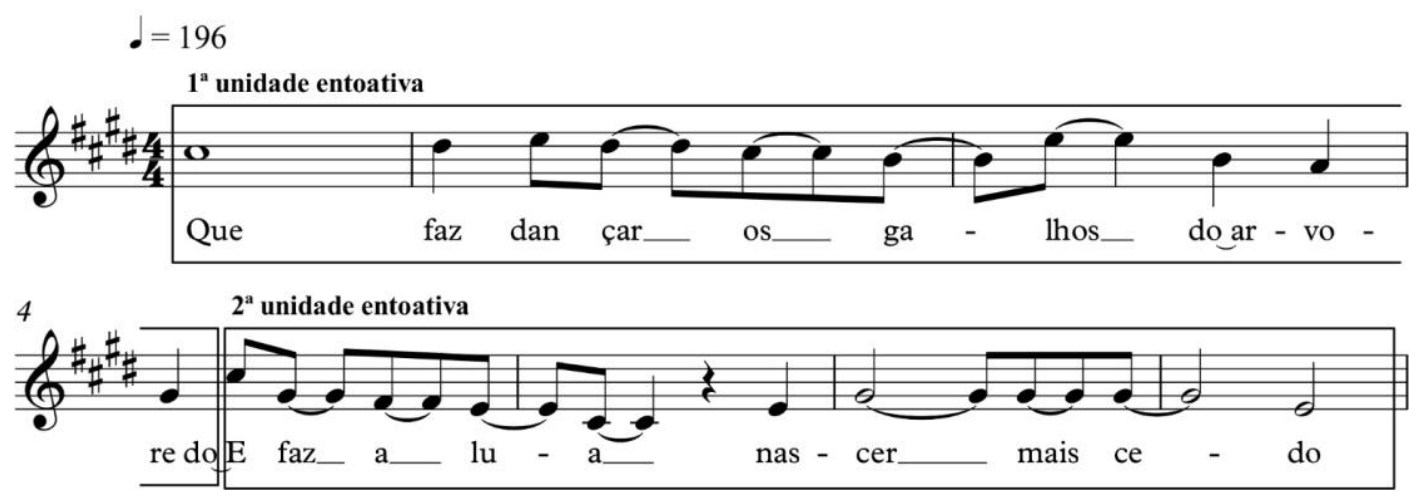

Figura 16. Feitiço da Vila (1 ${ }^{\text {a }}$ estrofe) (Vadico/Noel Rosa)

O sol da Vila é triste

O samba não assiste

Porque a gente implora:

Sol, pelo amor de Deus, não venha agora

Que as morenas vão logo embora 


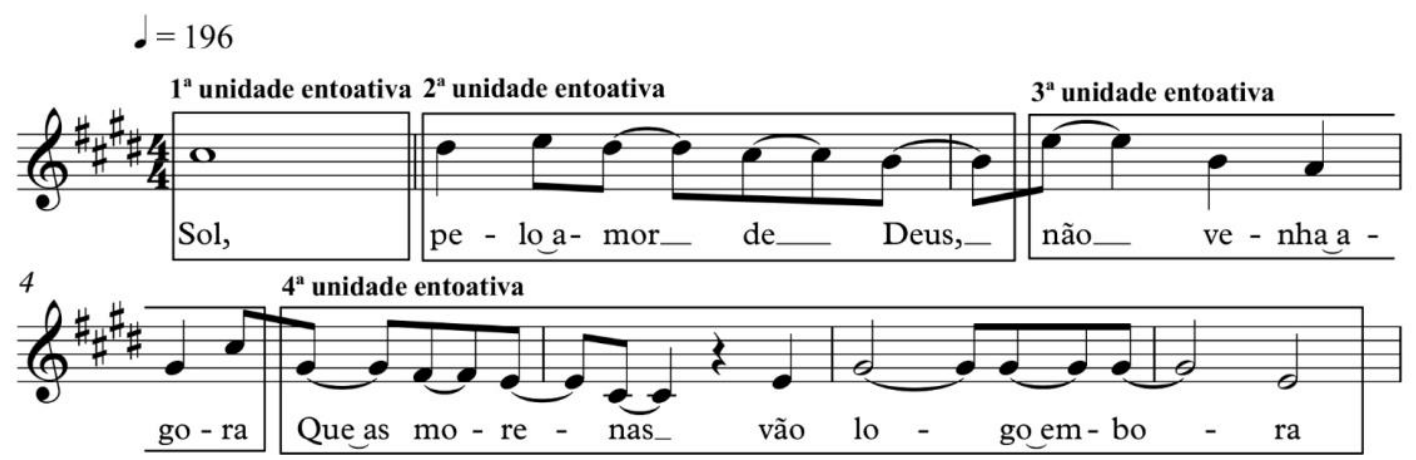

Figura 17. Feitiço da Vila (2 ${ }^{\mathrm{a}}$ estrofe)

Lá, em Vila Isabel

Quem é bacharel

Não tem medo de bamba

São Paulo dá café, Minas dá leite

E a Vila Isabel dá samba

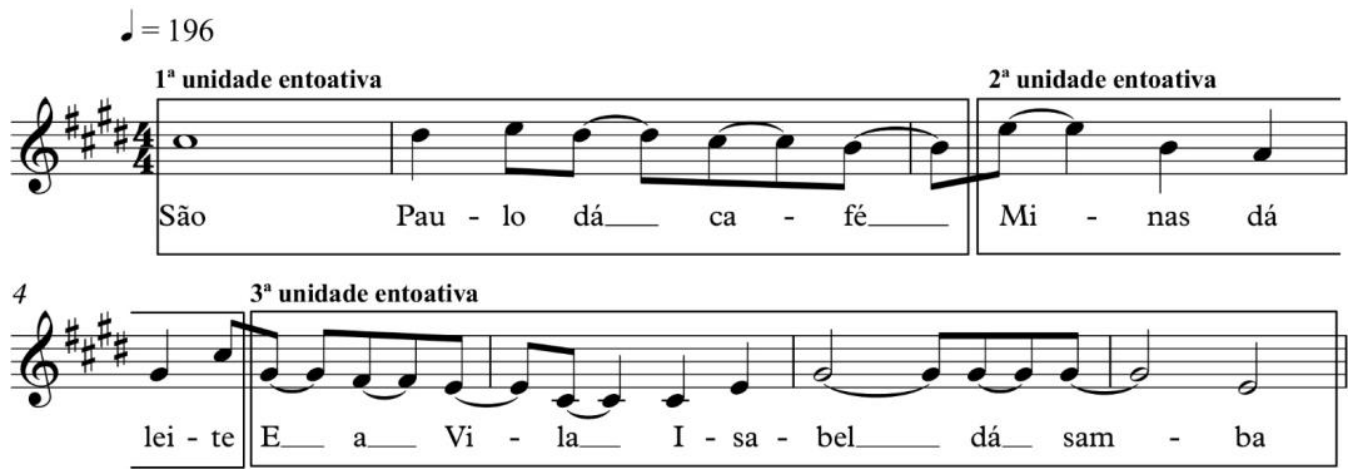

Figura 18. Feitiço da Vila ( $3^{\mathrm{a}}$ estrofe)

Eu sei tudo que faço

Sei por onde passo

Paixão não me aniquila

Mas, tenho que dizer, modéstia à parte,

Meus senhores, eu sou da Vila. 


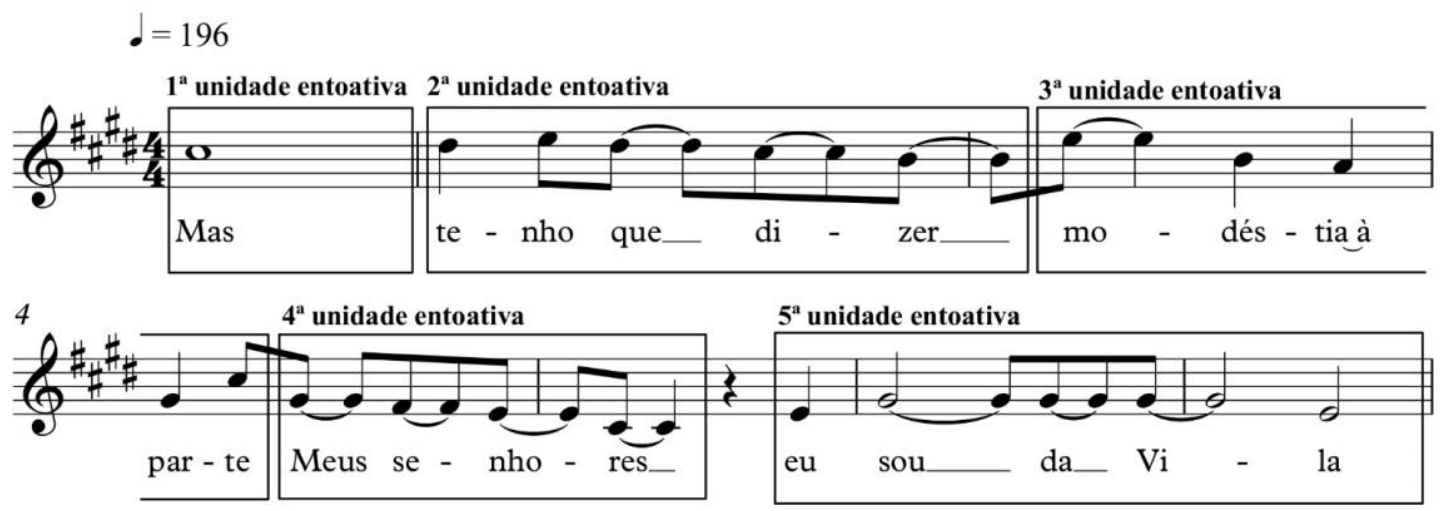

Figura 19. Feitiço da Vila (4 $4^{\mathrm{a}}$ estrofe)

Feitiço da Vila configura-se como um caso típico de composição no qual, a partir de um desenho melódico pré-estabelecido, o letrista realiza recortes com textos verbais distintos para formar diversas versões para uma mesma parte A. É um fenômeno comum na canção em geral. A melodia se mantém praticamente intacta, mas a letra, alterando-se, apresenta diferentes propostas entoativas, algumas vezes mais próximas da fala, outras vezes mais distantes. São fenômenos que apreciaremos de maneira mais detida em diversos momentos desta tese, quando analisarmos questões ligadas à acomodação da sílaba, da palavra e da frase.

Nesses exemplos, Tatit examina o sentido da linha melódica que recobre os dois últimos versos de cada estrofe (bem como o sentido dos segmentos que a compõem) para avaliar se a sua combinação com o texto verbal foi eficiente. Quando o segmento linguístico é incorporado integralmente pelo segmento melódico, isto é, quando a frase musical não divide a frase verbal de maneira anormal do ponto de vista de nossa experiência com a língua oral, temos uma "unidade entoativa perfeita" (1982: 201).

Como assinala o autor, os versos finais das estrofes de Feitiço da Vila apresentam diferentes propostas de unidades entoativas. A primeira (figura 16) propõe duas unidades: "Que faz dançar os galhos do arvoredo" e "E faz a lua nascer mais cedo". A segunda (figura 17), quatro: "Sol”, "pelo amor de Deus", "não venha agora" e "Que as morenas vão logo embora". Na terceira estrofe (figura 18), observamos três ocorrências: "São Paulo dá café", "Minas dá leite" e "E a Vila Isabel dá samba". Finalmente, a última estrofe (figura 19) apresenta cinco unidades: "Mas", "tenho que dizer", "modéstia à parte", "Meus senhores" e "eu sou da Vila". Como a linha melódica é a mesma para todas as estrofes (e possui um número restrito, ainda que múltiplo, de possibilidades plausíveis 
para o recorte textual), o árduo trabalho do cancionista consiste em conseguir um resultado entoativo satisfatório com opções variadas de letra.

Assim, geralmente, tendo em vista essa restrição imposta pela melodia, o letrista fatalmente produzirá, do ponto de vista oral, combinações mais ou menos usuais e, certas vezes, impedirá que unidades entoativas previstas no texto verbal se formem na canção. Na figura 18, por exemplo, a frase "São Paulo dá café", quando combinada com a melodia, "apresenta um lexema mutilado o que afasta a possibilidade de termos uma segmentação melódica instaurando unidade entoativa" (1982: 196). Como observamos acima, ao colocar a sílaba "São" sobre uma nota longa (a semibreve do primeiro compasso) o compositor a distancia demasiadamente da palavra "Paulo", seccionando o lexema "São Paulo".

Analisando o sentido asseverativo dessa parte melódica de Feitiço da Vila, por sua curva descendente, o autor observa que, nas três primeiras estrofes (figuras 16, 17 e 18), tendo em vista a ocorrência dessas unidades entoativas "imperfeitas", não há um sentido afirmativo contundente. Na figura 19, ao contrário, o autor destaca "a solução mais perfeita de aproveitamento das virtualidades temáticas" (1982: 209), quando, por um lado, não há segmentações indesejáveis dos corpos linguísticos e, por outro, há uma adequação perfeita entre a descendência melódica (que vai se delineando pouco a pouco com os cinco trechos que compõem a melodia completa transcrita acima) e os elementos ("tenho que dizer", "modéstia à parte", "meus senhores") que também preparam aos poucos uma contundente afirmação: "eu sou da Vila". Assim, precisamos salientar que o impacto do sentido entoativo é mais forte quando constatamos um encaixe pleno entre as unidades da letra e as unidades da melodia. No caso desse exemplo, o sentido entoativo da asseveração é mais vigoroso na quarta estrofe, na medida em que essas unidades apresentam maior coincidência.

Baseado nos exemplos de Feitiço da Vila, o autor cogita a possibilidade de haver uma relação entre a quantidade de unidades entoativas em determinado excerto de melodia e letra e o grau de proximidade com a entoação da fala apresentado por essa combinação. De fato, nas figuras 17 e 19, nas quais notamos um maior número de unidades entoativas, observamos igualmente um teor oral mais acentuado, pela presença marcante do discurso direto. 
isto é presumível, uma vez que tal instauração torna o vínculo com a língua natural não apenas pressuposto mas indisfarçavelmente posto ou instalado pela desembreagem; o discurso então passa a ser mais figurativo o que, frequentemente, repercute no número de figuras utilizado (1982: 207)

Temos dúvidas quanto à validade dessa proposta e o próprio autor, por não ter desenvolvido esse pensamento em publicações posteriores, deve ter percebido a sua inviabilidade. Julgamos que, em relação a esse aspecto, o que observamos na canção de Noel Rosa não deve ser aplicado de modo generalizante. Acreditamos que a linha melódica apresenta previamente um número limitado, embora mais variável, de recortes a serem realizados pela letra, mas não cremos na relação direta entre a quantidade de ocorrências e o seu grau de proximidade com a fala. No fragmento melódico de Feitiço da Vila, nos parece que o autor identifica cinco unidades virtualizadas, quase todas perfazendo descendências pontuais que, num contexto musical mais amplo, constituem uma única grande descendência:

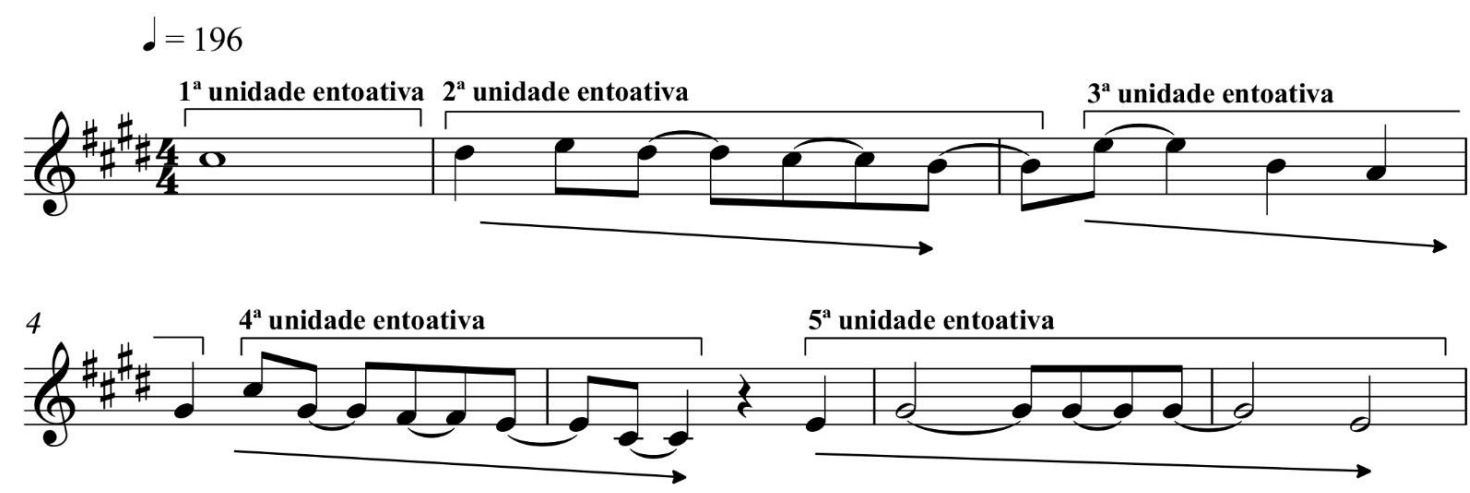

Figura 20. As unidades entoativas preestabelecidas pela melodia de Feitiço da Vila

A quarta estrofe de Feitiço da Vila (figura 19), como comentamos anteriormente, é a que melhor adequa o texto à essas cinco unidades entoativas destacadas acima. Com exceção do recorte da terceira para a quarta unidade, quando a última sílaba da expressão "modéstia à parte" ocupa o início da unidade seguinte (a nota Dó\# do compasso 4) ${ }^{37}$, essa estrofe combina satisfatoriamente os segmentos melódicos com os segmentos linguísticos da letra. Caso quiséssemos obter um recorte verbal que mantivesse integralmente as proposições virtualizadas pela melodia deveríamos encontrar novas palavras para a terceira unidade para que a unidade seguinte não fosse por ela ocupada. Apenas para

\footnotetext{
${ }^{37}$ Acreditamos que a quarta unidade entoativa se inicia na nota Dó\# tendo em vista o salto intervalar em relação à nota anterior (Sol\#) bem como por ser a nota aguda que inicia um novo percurso descendente.
} 
podermos visualizar essa hipotética letra, propomos um novo recorte da linha melódica da canção.

Sai

Sai que eu vou passar

Eu sou assim

Eu sou do samba

Eu sou passista

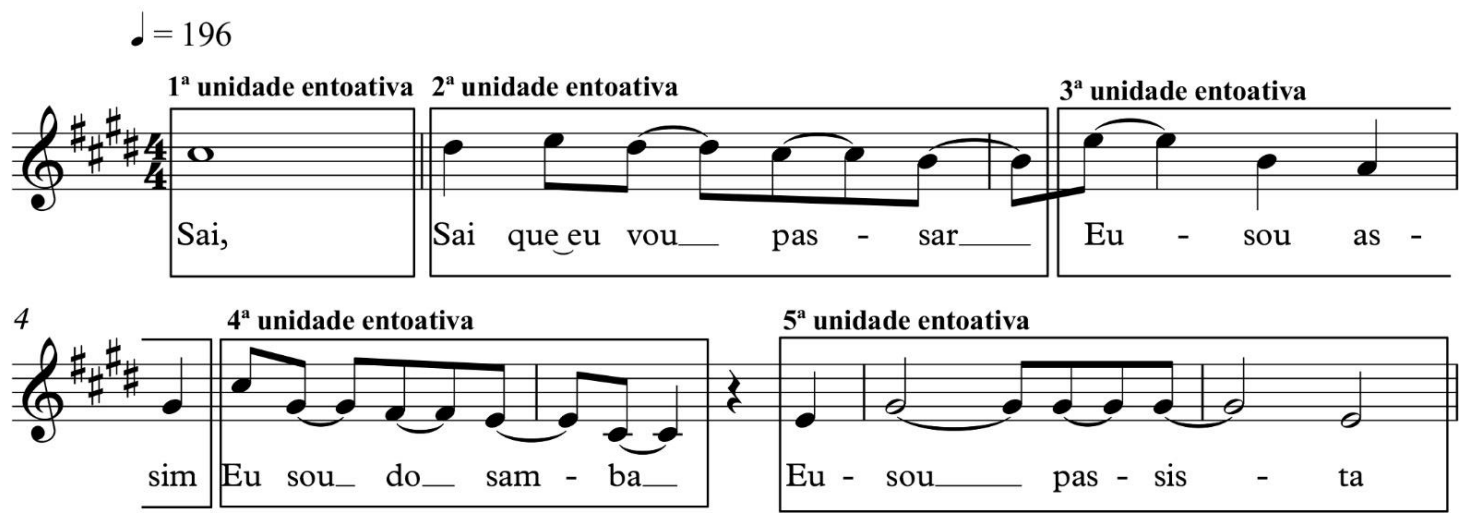

Figura 21. Outra possibilidade de recorte linguístico para a melodia de Feitiço da Vila

No final da terceira unidade, ao substituirmos a frase "modéstia à parte" por "Eu sou assim" permutando a última palavra paroxítona ("parte”) por uma oxítona ("assim") e adiantando a posição da mesma na frase musical, propomos um recorte no qual a unidade seguinte mantém-se intacta. No entanto, ainda que visualizemos essa configuração ideal com cinco unidades entoativas (figura 20), e sabendo que um recorte linguístico com menos ocorrências prejudicaria a naturalidade entoativa (figura 18, por exemplo), podemos propor para essa mesma linha melódica um recorte com um número maior de unidades. Na figura abaixo, experimentamos um desenho com sete unidades entoativas sem, contudo, relacionar esse aumento do número de ocorrências com um acréscimo de teor oral, ou melhor, sem enfatizar a presença do discurso direto. Aqui, propomos uma nova letra para toda a estrofe e transcrevemos em partitura somente o trecho das descendências finais para destacarmos o aumento do número das unidades entoativas.

Sim, sina paulistana

Lida desumana

E eu chego antes do dono 


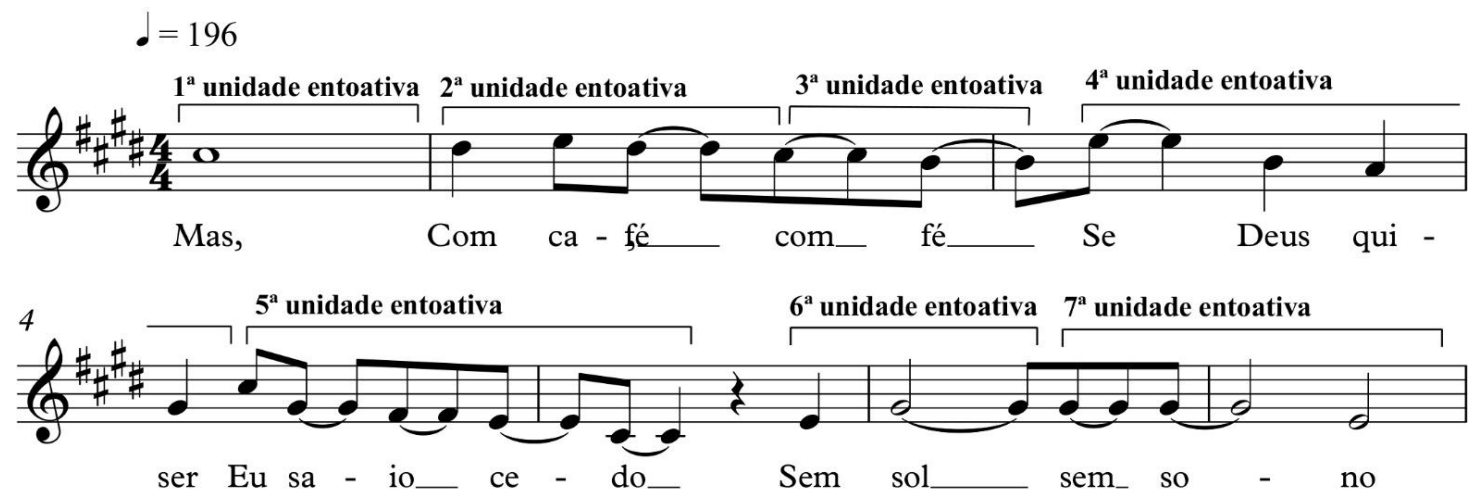

Figura 22. Reescrita da letra de Feitiço da Vila com maior número de unidades entoativas

Enfim, ainda que não tenhamos um número ilimitado de possibilidades, podemos aventar outras formas de recorte textual com maior ou menor número de unidades e igualmente aceitáveis do ponto de vista da naturalidade oral.

Essas reflexões do autor, presentes em sua dissertação de mestrado (1982) e em $O$ Cancionista (1996), proporcionarão, posteriormente, o desenvolvimento mais profundo da noção de "unidade entoativa". Nesse momento inicial de sua pesquisa, contudo, não aprofunda o conceito ao mesmo tempo em que não vai além no detalhamento de outros casos similares. É também curioso observar que em texto de 1999, Da tensividade musical à tensividade entoativa ${ }^{38}$, Tatit resgata o termo utilizado em 1982, mas limita-se ao estudo do que considerava a zona sonora de maior significação, o tonema:

Uma unidade entoativa, no domínio da canção, não pode ser definida apenas por critérios acústicos baseados na distribuição interna dos acentos. Em contato com a letra, esses segmentos sonoros perdem a autonomia e passam a depender das sequências linguísticas para uma exata definição de cada unidade. De todo modo, uma vez determinada a unidade, sua região acústica mais importante em termos de concentração de tensividade é a terminação. Trata-se do componente que N. Tomás chamou de tonema. (2007: 170)

\footnotetext{
${ }^{38}$ Esse texto, posteriormente compilado ao lado de outros textos e artigos em Todos entoam: ensaios, conversas e canções (2007), foi inicialmente publicado na Revista da ANAPOLL (número 6/7, São Paulo: Humanitas, 1999).
} 
Nesse momento, Tatit compreende os tonemas como responsáveis pela delimitação de uma unidade entoativa, assim como em Serra da boa esperança, a finalização descendente do terceiro e quarto compasso configurava a autonomia de uma frase melódica asseverativa. Não há aqui, no entanto, maiores desdobramentos conceituais. É somente em Estimar canções: estimativas íntimas na formação do sentido (2016) que o autor aprofunda a questão. Nessa obra, nos parece que há o entendimento de que a formulação das unidades entoativas é um dos procedimentos mais fundamentais para a atividade de criação cancional. Examinemos esse tópico de maneira mais detida.

Durante o processo de composição, o cancionista frequentemente se depara com fragmentos melódicos puros ou "vazios", isto é, que ainda não foram preenchidos por uma letra. "Vazio", nesse caso, não se refere, obviamente, à ausência completa de significado. Afinal, nesse estado inicial, mesmo que não tenhamos a presença do texto linguístico, a melodia certamente possui diversas possibilidades latentes de sentido, uma vez que o próprio material sonoro já aponta para determinadas significações (tensão, relaxamento, continuidade etc.). O trabalho do cancionista é, portanto, recortar esse fragmento melódico com um texto verbal que se encaixe em alguma dessas múltiplas possibilidades de sentido, formando, então, as chamadas unidades entoativas. Para um mesmo trecho melódico, demonstrando muita habilidade, o letrista é capaz de propor diferentes recortes linguísticos, "quase nos explicando que sua principal missão consiste em extrair das melodias unidades entoativas até então virtuais" (2016: 82). Podemos examinar essa técnica criativa a partir da canção Leãozinho de Caetano Veloso, observando as diferentes formas com que o compositor recorta textualmente o último verso de cada um dos tercetos abaixo.

Gosto muito de te ver, Leãozinho

Caminhando sob o sol

Gosto muito de você, Leãozinho

Para desentristecer, Leãozinho

O meu coração tão só

Basta eu encontrar você no caminho

Um filhote de leão, raio da manhã

Arrastando o meu olhar como um ímã

O meu coração é o sol pai de toda cor

Quando ele lhe doura a pele ao léu 
Gosto de te ver ao sol, Leãozinho

De te ver entrar no mar

Tua pele, tua luz, tua juba

Gosto de ficar ao sol, Leãozinho

De molhar minha juba

De estar perto de você e entrar numa
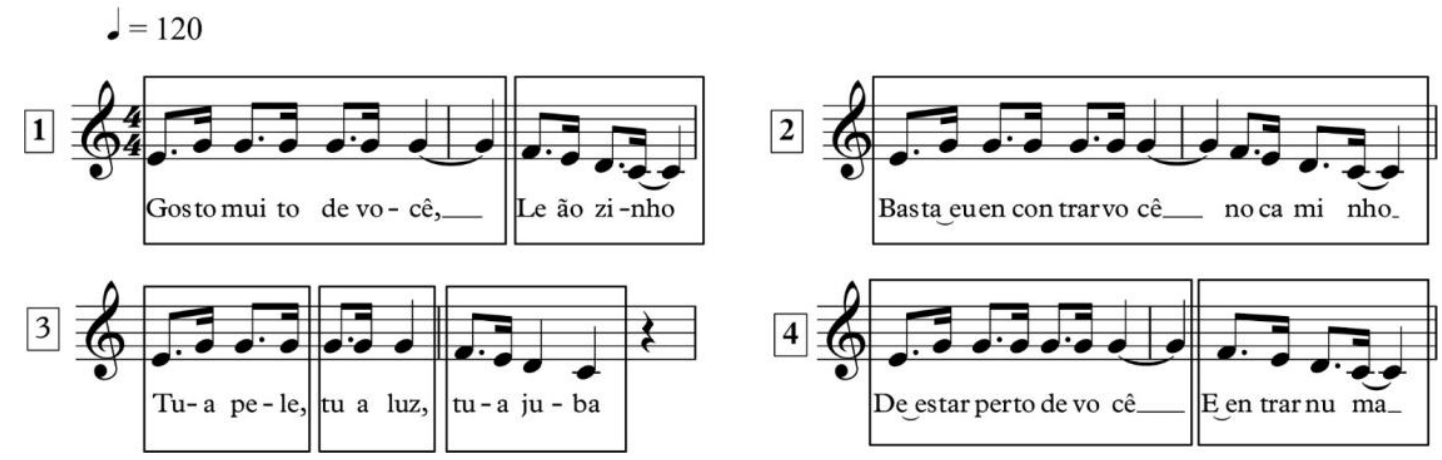

Figura 23. Leãozinho (Caetano Veloso)

Como observamos na figura acima, para o mesmo trecho melódico o compositor criou preenchimentos linguísticos diferentes. Nesse caso, acabou propondo quatro maneiras distintas de segmentação, produzindo organizações variadas das unidades entoativas a partir de uma mesma linha do canto que é, por sua vez, sempre acompanhada pela mesma progressão harmônica. O primeiro e o quarto excertos segmentam a melodia em duas partes. No primeiro, a divisão decorre do uso de um vocativo, "Leãozinho", e, no segundo, de um período composto formado por duas orações: "De estar perto de você" e "E entrar numa". No segundo trecho, notamos a formação de apenas uma unidade entoativa com a frase "Basta eu encontrar você no caminho". Por fim, o terceiro excerto é constituído por três unidades entoativas: "tua pele", "tua luz" e "tua juba". Dessa maneira, podemos observar que esse fragmento melódico composto por Caetano Veloso, antes do recorte textual, possuía diversas possibilidades virtuais de preenchimento linguístico. O seu perfil, é claro, já propunha sugestões de segmentação entoativa ao cancionista como, por exemplo, uma divisão após a nota longa (nota Sol) entre o primeiro e o segundo compasso. As possibilidades, no entanto, são numerosas, ainda que não sejam infinitas.

No caso de um cancionista que cria a melodia a partir de uma letra já composta, a essência do procedimento se mantém intacta: a configuração dos modos de dizer. Nessa situação, o melodista, geralmente de maneira intuitiva, avaliará o texto linguístico do 
letrista no sentido de identificar as continuidades e descontinuidades do discurso (as pausas, as possíveis ligações entre os versos etc.), além de movimentos de tensão e relaxamento no nível do conteúdo que influenciarão na escolha da configuração melódica. Certamente, ao criar o seu texto, o letrista já terá indicado implicitamente segmentações possíveis para as unidades. O melodista, no entanto, poderá enfatizá-las ou até mesmo anulá-las (2016: 82), propondo conformações não imaginadas por seu parceiro.

Enfim, é importante sublinhar que a junção da melodia com o texto verbal, formando essas unidades entoativas, é a responsável não apenas pela introdução de um conteúdo para a canção, isto é, de uma temática a ser tratada pela letra, mas, sobretudo, é a encarregada da conformação de um "modo de dizer entoativo que substitui a abstração musical pela enunciação concreta de um personagem, normalmente associado à imagem do cantor" (2016: 126), como se transferisse "as obras do mundo musical para o mundo cancional" (2016: 144). Desse modo, salientando a sua importância, percebemos que a questão das unidades entoativas estabelece fortes relações com tópicos essenciais para a configuração da canção como arte autônoma. São essas segmentações entoativas que definem, em última instância, a relação figurativa entre a melodia e a letra, determinando as "maneiras de dizer" de cada composição. As unidades entoativas fazem parte do processo de criação de qualquer tipo de música vocal (até mesmo de canções com baixíssimo teor oral). Constitui, assim, o recurso figurativo por excelência, pois é a partir do recorte linguístico produzido pelo cancionista, que poderemos avaliar a maior ou menor proximidade de determinada canção com a experiência de fala dos ouvintes. 


\subsection{A mudança no conceito}

Os cinco recursos figurativos estudados acima (dêiticos, tonemas, elasticidade melódica, faixa entoativa e unidades entoativas) perpassam as análises de Tatit em diversas fases do seu desenvolvimento teórico, embora sejam mais ou menos enfatizados de acordo com cada publicação. Os três primeiros, sobretudo, estão presentes desde os estudos iniciais e nunca foram abandonados. No entanto, ainda que esses recursos tenham permanecido ao longo da evolução de sua teoria, houve uma significativa mudança de visão em relação ao processo criativo do cancionista, no que concerne à questão da figurativização. Isto é, as ferramentas figurativas foram mantidas pelo autor, mas o processo passou a ser entendido a partir de uma nova perspectiva.

Essa mudança, deve-se, sem dúvida, ao aprofundamento do exame das unidades entoativas, realizado em seus escritos mais recentes. Trata-se da superação de uma visão equivocada na qual a canção é fruto da imitação da língua oral. Como observaremos adiante, se, por um lado, há certos trechos do autor que revelam de maneira mais explícita o entendimento do processo como mimetização da fala, por outro, o que ocorre na grande maioria dos casos, é justamente por uma falta de precisão teórica que a ideia de imitação acaba prevalecendo para o leitor. Assim, muitas vezes, ainda que Tatit não afirme de maneira categórica que a canção imita a entoação do discurso oral, é isso o que fíca subentendido. No momento em que essa insuficiência teórica é sanada pelo estudo mais detido das unidades entoativas, o semioticista não apenas abandona esse conceito, como também enfatiza fortemente a alteração do seu pensamento. Vejamos como se processou essa significativa transformação na semiótica da canção.

Em certas passagens presentes em suas primeiras publicações, observamos a existência de um conceito de canção ligado à ideia de simulação da língua oral, uma "ação simulada" ou "simulacro" (1986: 6).

Importante sublinhar que toda e qualquer canção apresenta tais características variando apenas a intensidade. Há canções que explicitam a simulação de linguagem coloquial. Outras, menos explícitas, deixam transparecer, nos finais de frases melódicas (nos chamados “tonemas"), as elevações e descendências de tom típicas do discurso linguístico oral. Uma análise que verifique a coerência do texto com a melodia paralela, facilmente constata a presença de uma raiz entoativa justificando a escolha melódica (1986: 7) 
Ainda que exista um fundamento entoativo no trabalho do cancionista, como veremos adiante, não é esse o seu ponto de partida. $\mathrm{O}$ fragmento acima dá a entender que as canções propositadamente simulam a linguagem coloquial, como se a "escolha melódica" figurativa fosse feita pelo compositor de maneira consciente. Outra formulação recorrente, na qual acreditamos haver certa imprecisão teórica, é a ideia de canção como "musicalização da fala", como constatamos nos trechos abaixo, todos presentes em publicações da década de 1990.

Constituída na tangente da linguagem oral e a partir da musicalização dos mesmos recursos empregados por qualquer falante em sua comunicação diária, a canção sempre correu o risco de perder-se no fluxo itinerante e provisório das mensagens corriqueiras. (1994: 250)

A própria existência da maioria dos cancionistas está assegurada pela possibilidade de transformação da fala em canto. A pulsação, a acentuação ou a batucada não explicam, por si sós, o nascimento do maxixe, do samba e da marcha. A "audácia" de se compor melodias sem formação musical só pode se apoiar nas entoações naturais da linguagem oral. (2002: $22)^{39}$

Ora, a musicalização da fala corresponde a um processo de ritualização de uma sonoridade que, a princípio, teria função totalmente passageira. (1997: 89)

Sua habilidade, como já propusemos em trabalhos anteriores, está em converter os discursos orais, cuja sonoridade é por natureza instável, em canções estabilizadas do ponto de vista melódico e linguístico (2007: 157) $)^{40}$

Nos excertos acima notamos o raciocínio já tratado anteriormente que ressalta a diferença entre a inconstância da fala e o canto sonoramente estável. Os quatro fragmentos enfatizam o mesmo entendimento de que a sobrevivência da canção depende fortemente da estabilização sonora: "a canção sempre correu o risco de perder-se no fluxo itinerante e provisório das mensagens corriqueiras" (fragmento 1); "A própria existência da maioria dos cancionistas está assegurada pela possibilidade de transformação da fala em canto" (fragmento 2); "processo de ritualização" (fragmento 3) e "converter os

\footnotetext{
${ }^{39}$ Sendo importante situar esses apontamentos de Tatit na década de 1990, devemos assinalar que a primeira edição do livro $O$ cancionista é de 1996.

40 Esse excerto pertence ao texto "Da tensividade musical à tensividade entoativa" que, como já mencionamos acima, foi publicado inicialmente na Revista da ANAPOLL em 1999.
} 
discursos orais, cuja sonoridade é por natureza instável, em canções estabilizadas" (fragmento 4). No que se refere a esse ponto, não questionamos a validade dessas afirmações, afinal, é justamente a constituição de uma forma estável que garante o surgimento e permanência das obras musicais e cancionais. No entanto, acreditamos haver nessas passagens uma noção ainda imatura no que diz respeito à gênese da canção, pois, ao leitor, fica subentendido que o trabalho do compositor consiste na "transformação da fala em canto" e não na formação das unidades entoativas a partir da combinação entre a letra e a melodia.

Nos exemplos acima, o uso dos termos "simulação" ou "musicalização" da fala, recorrentes nos estudos iniciais do autor, podem sugerir o sentido de imitação da linguagem oral. Há, contudo, publicações que se referem a essa ideia de modo bem mais explícito.

Antes de tudo, o que assegura a adequação entre melodias e letras e a eficácia de suas inflexões é a base entoativa. De maneira geral, as melodias de canção mimetizam as entoações da fala justamente para manter o efeito de que cantar é também dizer algo, só que de um modo especial. Os compositores baseiam-se na própria experiência como falantes de uma língua materna para selecionar os contornos compatíveis com o conteúdo do texto. (2004: 73)

Nesse excerto, observamos reflexões igualmente comentadas no início deste capítulo, como a questão da "eficácia" da canção fundada na relação com a entoação. Isso demonstra o quanto essa mudança teórica na qual estamos interessados consiste em uma reformulação bastante sutil que, de maneira alguma, inviabiliza todos os demais princípios estudados pela semiótica da canção. Ou seja, desejamos sublinhar que se, por um lado, o entendimento da canção como imitação da língua oral ("as melodias de canção mimetizam as entoações da fala", no trecho acima) representa uma imprecisão teórica reconhecida posteriormente pelo próprio autor, por outro, suscitou diversos conceitos paralelos que são válidos até os dias de hoje.

Essa readequação teórica, a nosso ver, decorreu de maneira gradativa. Antes do seu pleno estabelecimento, podemos reconhecer antecedentes significativos que apontam, ainda que de maneira tímida, o abandono do conceito de "mimetização". São considerações que, no nosso entendimento, traduzem uma perspectiva diferente em relação à presença da fala na canção. Os termos empregados pelo autor vão então abandonando a ideia de imitação e enfatizando certa espontaneidade no surgimento do 
sentido da canção, a partir da combinação entre a letra e a melodia. Localizamos, por exemplo, no texto "Gabrielizar a vida" ${ }^{41}$, uma maneira distinta de tratar o recurso figurativo dos tonemas.

As terminações entoativas exercem um papel todo especial em nossa fala cotidiana, na medida em que determinam o sentido (continuativo, terminativo, suspensivo etc.) de todo o segmento prosódico anterior. Ao compor, os autores acabam expressando essas terminações, que são reconhecidas facilmente pelos ouvintes-falantes da mesma língua (2004: 86)

Ao dizer que os cancionistas, durante a sua atividade de criação, "acabam expressando essas terminações" que "são reconhecidas" pelos ouvintes, Tatit evita as associações com a ideia de imitação e ressalta um fazer artístico, geralmente inconsciente, que se fundamenta num reconhecimento mútuo da própria língua, mas jamais na sua imitação pura e simples. Em estudo posterior, o autor segue na mesma direção:

Baseados nessas indicações, consideramos que a canção reconstrói em seu interior uma compatibilidade com a qual estamos acostumados a conviver: tudo que enunciamos já vem com melodia. Trata-se, portanto, da produção de um efeito figurativo de locução (2008: 18)

A figurativização melódica, jamais abandonada, passa então a ser compreendida mais como uma invenção, uma "reconstrução das modulações da fala cotidiana no interior da canção" (2008: 143), do que como uma cópia das entoações da linguagem oral. O cancionista produz a impressão de fala e não a própria fala. Esse novo ponto de vista é consumado em Estimar canções, de 2016. Neste estudo, o autor enfatiza a ideia de uma “ilusão enunciativa" (2016: 21) ${ }^{42}$ criada por meio de "uma combinação entre melodia e letra admissível no âmbito da linguagem oral em diversas comunidades linguísticas" (2016: 148).

Longe de ser mera imitação das modulações que acompanham a fala, esses modos são criados no momento em que o letrista estabelece o seu recorte linguístico do componente melódico ou, ao contrário, quando o melodista concebe suas inflexões para uma letra já feita. Surgem desses procedimentos as mencionadas unidades entoativas, sempre acompanhadas de suas principais características: são inusitadas e, ao mesmo tempo, plausíveis. (2016:144)

\footnotetext{
${ }^{41}$ Texto publicado em 2004 no livro Três canções de Tom Jobim, organizado por Arthur Nestrovski.

${ }^{42}$ A expressão "ilusão enunciativa" já se encontra na semiótica greimasiana, embora não se refira à relação entre a melodia e a letra da canção (GREIMAS, 2012: 161).
} 
Isso equivale a dizer que as canções não imitam a fala cotidiana, mas criam-na a cada nova composição. Servindo-se de tessitura sonora bem mais extensa que a da linguagem oral, os cancionistas podem propor incontáveis tipos de relação entre melodia e letra nas regiões grave, média e aguda (...) Na verdade, inventam modos de dizer até então desconhecidos, visto que versos particulares combinados com inflexões melódicas igualmente específicas num determinado contexto cancional soam sempre como algo inédito. (2016: 145)

Doravante, o autor passa a valorizar mais fortemente esse momento único em que a melodia encontra um determinado recorte textual, instante em que se formam as unidades entoativas. Estas, ainda que incomuns se comparadas com a materialidade da fala, são entoativamente aceitáveis e, por isso, "produzem efeitos de entoação da linguagem oral coexistindo com a linha do canto" (2016: 17). A mudança conceitual, ainda que sutil, é clara: os cancionistas não copiam a fala, mas inventam contornos melódicos que nos dão "a impressão de que as frases cantadas poderiam também ser frases ditas no cotidiano" (2016: 125). 


\subsection{Plausibilidade: a fala como baliza da composição}

Os meandros da atividade criativa de grande parte dos cancionistas, desconhecidos pela maioria dos seus ouvintes, estão relacionados à invenção dos modos melódicos de dizer ${ }^{43}$. Geralmente, são linhas vocais que o compositor elabora apoiado pela execução de determinadas progressões harmônicas. Em se tratando da canção popular brasileira, podemos imaginar a habitual circunstância de alguém tocando uma combinação de acordes ao violão e cantarolando fraseados embrionários, experimentando, simultaneamente, inflexões melódicas e o encaixe de certas palavras. Em grande parte dos casos, no entanto, esse conjunto de melodias compostas sobre os acordes, estará arrematado antes de finalizado o texto linguístico. A música, ou melhor, o modo de dizer, é definido antes da letra. É a partir das configurações rítmicas das melodias e de suas indicações de tensão e relaxamento que o compositor, pouco a pouco, vai delimitando o assunto da canção, inserindo vocábulos soltos e fragmentos confusos de frases linguísticas ou completando os espaços vagos com sons vocais que muitas vezes servirão apenas para fixar as rimas entre os versos. Esse texto verbal inicialmente desconexo que o cancionista vai paulatinamente transformando até considerar pronto, é popularmente - e, por vezes, jocosamente - conhecido como uma "letra monstro" 44 . Como define Tatit ao comentar acerca do processo criativo do sambista Noel Rosa, a letra monstro nada mais é do que um mapeamento linguístico da melodia no qual o cancionista pode localizar os possíveis recortes silábicos e pontos de acento que nortearão o futuro preenchimento verbal. Trata-se, então, de um processo criativo um tanto peculiar. Tudo se dá como se essa atividade composicional fosse totalmente inconsciente e intuitiva. Nesse sentido, os cancionistas desenvolvem ao longo de suas vidas uma habilidade extremamente complexa, "mas, por destino ou ironia, não sabem bem em que consiste" (2002: 51). Ao analista, cabe responder a seguinte pergunta: se, nesse processo, tudo nos parece tão intuitivo e involuntário, o que afinal controla essa atividade composicional? Ou melhor, quais são os princípios que regem a junção entre a melodia e a letra resultando nas já mencionadas unidades entoativas? Para respondermos a essas perguntas devemos

\footnotetext{
${ }^{43}$ Essa definição está presente no texto "O momento de criação na canção popular" originalmente publicado nos Anais do IV Congresso Abralic: Literatura e diferença (São Paulo, agosto de 1994). Ver TATIT, 2007: 140 .

${ }^{44}$ Esse termo, segundo Tatit, já fazia parte do vocabulário dos compositores no início do século XX (2007: 140).
} 
nos ater sobretudo à noção de plausibilidade entoativa, sem desconsiderarmos, é claro, a formação musical dos cancionistas ${ }^{45}$.

Podemos entender o princípio da plausibilidade como um apoio baseado em nossa experiência cotidiana com a língua oral. Mais do que partir da oralidade para desenvolver a sua criação (o que poderia nos levar novamente a uma definição equivocada de canção como "imitação da fala"), o compositor utiliza a fala como uma baliza que orienta a relação que está produzindo entre melodia e letra. O compositor não principia sua canção na entoação. Serve-se dela, no entanto, como termômetro. Desse modo, é capaz de garantir o estabelecimento de um conjunto de signos linguísticos universais, isto é, que também são compartilhados por sua comunidade de ouvintes.

O cancionista, como de resto todos os seus compatriotas, é, antes de tudo, um praticante da língua materna. Isso já implica numa perícia natural para estabelecer relações coerentes entre melodia e letra, dado que a escolha de uma entoação adequada ao que se vai dizer faz parte dos aprendizados mais elementares de toda comunidade. Apesar de os contornos entoativos constituírem um universo aberto de possibilidades, o hábito cultural restringe bastante as escolhas do falante, disciplinando-as de acordo com o conteúdo linguístico a ser transmitido (2007: 157)

A língua pode ser compreendida como uma espécie de consenso cultural estabelecido entre os falantes. Em vista disso, dentro de sua comunidade linguística, os indivíduos jamais formularão frases incoerentes do ponto de vista da linguagem oral, pois todos possuem conhecimentos profundos, ainda que intuitivos, sobre o funcionamento de seu próprio idioma.

A intuição do falante é o único critério da gramaticalidade ou da agramaticalidade da frase - conceitos que não se confundem com a gramática normativa. É a competência do falante que vai organizar os elementos linguísticos que constituem uma sentença, conferindo-lhes gramaticalidade. Uma sequência de palavras é agramatical (*) quando não respeita as regras gramaticais do sistema linguístico, do conhecimento internalizado de que dispõe o falante, como: (*) Problema este muito seu difícil é (PETTER, 2002: 22)

\footnotetext{
45 A formação artística dos cancionistas é composta tanto por padrões de natureza musical quanto por padrões de natureza entoativa, sendo que a associação entre essas duas tendências sempre foi um dos principais campos de investigação para a semiótica da canção. Em seu último trabalho, Estimar Canções, Tatit intensifica essa reflexão tratando-a nos termos de uma oscilação entre "musicalização" e "oralização". Adiante, abordaremos esse assunto de maneira mais detida, mais precisamente no item dedicado ao estudo da alternância entre a "força entoativa" e a "forma musical".
} 
Esse tipo de incongruência sintática jamais seria cometido por um falante do português brasileiro que, certamente, formularia a frase de maneira gramatical: "Este seu problema é muito difícil". Na canção observamos fundamentalmente o mesmo fenômeno, mas incorporando em seu processo gramatical as formas de compatibilização entre melodia e letra, já que, nesse caso, o fluxo melódico terá também que se estabilizar ao lado da frase linguística. Tendo a língua natural como um componente de seu trabalho artístico e, portanto, fazendo parte do consenso comunitário que estabelece os modos de entoar as frases orais, o cancionista sempre realizará combinações entre segmentos melódicos e linguísticos admissíveis em seu ambiente cultural e mesmo em outros ambientes com os quais mantenha alguma proximidade. Assim, quando o compositor efetuar o recorte da melodia com o texto verbal, esse recorte já se mostrará plausível do ponto de vista entoativo, isto é, naturalmente reconhecível pelos falantes de sua língua. A melodia, entendida como "um conjunto de virtualidades figurativas que podem ou não ser atualizadas pelo letrista" (TATIT, 2016: 79), poderá abarcar diversas possibilidades de recorte da letra. No entanto, todas elas deverão ser cotejadas com a experiência linguística - e a essa altura também cancional - dos falantes. Em certa medida, é como se a própria comunidade linguística à qual pertence o cancionista fosse, a priori, a compositora virtual de todas as uniões de melodia e letra propostas em suas canções. Num certo sentido, o compositor apenas dá vazão e singularidade a esse conhecimento compartilhado.

Esse consenso, obviamente, não deve ser entendido como uma restrição que atravanca o processo criativo. Em primeiro lugar, é um conhecimento que o cancionista coloca em prática sem esforço algum, na medida em que seu saber linguístico e cancional é algo já plenamente interiorizado. Além disso, as possibilidades de recorte verbal da melodia são numerosas e dificilmente o ouvinte estranhará alguma das soluções adotadas pelo compositor.

Uma espécie de integração "natural" entre o que está sendo dito e o modo de dizer, algo bem próximo de nossa prática cotidiana de emitir frases entoadas. Assim como não há sentido em dizer que um falante nativo entoa erroneamente seus enunciados, também não podemos negar que um compositor produz, via de regra, melodias adequadas ao teor de suas letras (2008: 17-18) 
Acreditamos que, em geral, o cancionista, imbuído das relações entre segmentos verbais e suas entoações características dentro de um contexto cultural, ao recriar essas mesmas relações no ato de composição, certamente produzirá unidades entoativas plausíveis. Em contrapartida, é comum que compositores de música vocal, cujo interesse artístico não leva em conta a satisfação desse consenso entoativo, produzam relações pouco convincentes entre melodia e letra, causando estranhamentos dificilmente identificados pelos críticos. O seu foco é distinto. Geralmente, pretendem atingir soluções puramente musicais.

Além da plausibilidade entoativa, não devemos desconsiderar os padrões musicais que fazem parte da formação artística dos cancionistas. É justamente pelo fato de o trabalho de criação cancional ser muito bem definido pela ideia de "combinação" entre uma linha vocal e um texto linguístico que o aspecto musical certamente representa um componente significativo em sua prática. No momento de seu surgimento, a semiótica da canção, preocupada em salientar a presença da fala na relação entre a melodia e a letra (numa época absolutamente carente de estudos sobre essa linguagem artística ${ }^{46}$ ), muitas vezes precisou deixar de lado a reflexão sobre a formação musical do cancionista ou preferiu tratá-la em outros termos. Assim, pôde destacar mais claramente a sua diferença em relação ao músico. Selecionamos três passagens que nos ajudarão a realizar uma reflexão sobre esse assunto. Na primeira, presente em "Vocação e perplexidade dos cancionistas", texto de 1983 escrito para o suplemento Folhetim do jornal Folha de S. Paulo, Tatit sublinha a incompatibilidade entre as atividades do músico e do cancionista. No segundo e no terceiro fragmento, o autor salienta a desnecessidade do aprendizado formal em música para a composição de canções.

\footnotetext{
Mas se o cancionista é ainda iniciante, não sabendo exatamente como desenvolver sua aptidão, fica à mercê das mais absurdas orientações. As mais comuns são aquelas que o conduzem às faculdades de música (não há nada de mal nessas faculdades de música, a não ser o fato de nada dizerem a respeito da canção de consumo), aos conservatórios - onde vão se alfabetizar musicalmente, aprendendo harmonia, contraponto e a escrita em partitura, sem levar em conta que suas canções são compostas com melodias da própria fala, suas harmonizações são elaboradas de ouvido e suas canções, depois de prontas, são registradas em suportes sonoros (fitas, CDS etc.) e não em partituras (...) (2007: 100)
}

\footnotetext{
${ }^{46}$ Referimo-nos à presença de estudos sobre a linguagem da canção propriamente dita, entendida aqui como a relação entre a melodia e a letra. Outros importantes estudos já haviam sido publicados enfocando de maneira mais isolada, no entanto, os aspectos musicais, poéticos ou sociológicos.
} 
Além de demarcarem um estilo exemplar de composição, essas criações de Caymmi e de Bide/Marçal exibem os principais recursos de estabilização sonora - rítmica e melódica, respectivamente - desenvolvidos para a fixação musical das canções, já que todas elas brotam do universo instável da fala cotidiana. Longe de qualquer alfabetização musical, os cancionistas chegam à música por outro caminho: vão abstraindo as funções utilitárias da linguagem oral e convertendo as entoações que acompanham suas conversas em melodia estável e regular. Camuflam, assim, a imprevisibilidade entoativa com os processos de recorrência, acentuação e identificação precisa das alturas melódicas $(2007: 154)^{47}$

A “audácia” de se compor melodias sem formação musical só pode se apoiar nas entoações naturais da linguagem oral. (2002: 22)

Não desejamos abordar a perspectiva, já superada pelo próprio autor, que concebe a canção como imitação da fala, concepção implícita em frases como "suas canções são compostas com melodias da própria fala" e "convertendo as entoações que acompanham suas conversas em melodia estável". Nesse momento, desejamos somente nos ater à ideia da desvalorização do conhecimento musical do cancionista, presente, nos últimos dois fragmentos, nas seguintes sentenças: "Longe de qualquer alfabetização musical, os cancionistas chegam à música por outro caminho" e "A 'audácia' de se compor melodias sem formação musical". Obviamente, Tatit se refere aqui à educação formal na área de música, ensinada nos conservatórios e faculdades, o que realmente está distante do universo da maioria dos cancionistas. Contudo, as passagens acima não chegam a tratar de algo que nos parece de suma importância: a cultura musical do compositor de canções. Acreditamos que, atrelada à sua formação cancional, há uma perícia musical apreendida pelos compositores de maneira intuitiva ao longo de anos e anos de convívio com a sonoridade das canções do rádio, da televisão, da internet etc. Nas sociedades ocidentais, a grande parte desses artistas possui uma bagagem sonora extremamente consolidada e predominantemente ligada à música tonal. Essa cultura sonora certamente influenciará na composição do cancionista.

Por outro lado, a presença ou a ausência de alfabetização musical não deve ser um fator tão decisivo para a diferenciação entre a atividade do músico e a do cancionista.

\footnotetext{
${ }^{47}$ Excerto do texto "Música popular urbana" originalmente publicado no final da década de 1990 (In: Livro Aberto, Ano II, no. 7, março/abril de 1998).
} 
Afinal, a presença da notação musical é relativamente recente na história da humanidade (na cultura ocidental remonta ao século VIII) e a escrita em partitura não é uma condição imprescindível para o desenvolvimento da prática musical. Assim, em certa medida, tanto o cancionista quanto o músico dispensam a necessidade de alfabetização e, a nosso ver, possuem a intuição como fator decisivo de criação. No momento em que o autor destaca que as "harmonizações são elaboradas de ouvido" (o que já é em si indício da formação musical intuitiva do cancionista), podemos pensar nas elaborações sonoras criadas igualmente "de ouvido" pelos compositores eruditos. Em certo sentido, o fenômeno é similar, pois, ainda que a tradição da música de concerto se baseie no contato com as partituras, no momento da criação, mais importante será a cultura sonora de cada artista, espontaneamente ativada. Isto é, ambos, cancionista e músico, compõem o que escutam, repetindo padrões com os quais estão acostumados ${ }^{48}$.

Assim, num certo sentido, pensando nos padrões musicais empregados nas obras, não acreditamos haver grande diferença entre o impulso criador utilizado na invenção de peças instrumentais ou de canções. A diferença encontra-se, como sempre indicou Tatit, na configuração de duas linguagens absolutamente distintas. O compositor músico permanece trabalhando com questões puramente musicais. Por isso, o seu trabalho sonoro geralmente alcança maior complexidade. De modo diverso, o cancionista, prioritariamente se preocupará em elaborar relações entre letra e melodia, formando as mencionadas unidades entoativas. As suas propostas sonoras, igualmente brotadas de seu universo de escuta, coerentes com sua bagagem musical, representam apenas um dos componentes dessa elaboração. Serão provavelmente mais simples, pois não constituem o foco de seu projeto artístico. O que gostaríamos de enfatizar, no entanto, é que, numa perspectiva na qual se articule simultaneamente as questões orais com as questões musicais, ambos os componentes devem possuir importância equivalente na criação cancional.

Acreditamos, então, que a discussão acerca da gênese da canção deve ser encaminhada de maneira distinta. Vejamos. Como constatamos anteriormente, a semiótica da canção, em seus estudos iniciais, sugere que certas obras podem proceder

\footnotetext{
48 Tatit utiliza a expressão "de ouvido" para destacar o caráter intuitivo da habilidade musical do cancionista desejando, com isso, evidenciar a dificuldade das escolas de música em atender as suas necessidades pedagógicas específicas. Os conservatórios e faculdades, ao desconhecerem a competência entoativa dos cancionistas, não conseguem contribuir para o seu progresso criativo (que deveria ser conduzido pelo trabalho de combinação entre melodia e letra, a sua principal vocação).
} 
diretamente da fala. Contudo, baseando-nos nas propostas trazidas pelas publicações mais recentes de Tatit, podemos dizer que as canções jamais decorrem diretamente da linguagem oral. Na verdade, originam-se do embate entre os processos de musicalização e oralização. Isso abre espaço para que possamos apontar dois importantes fatores musicais. Primeiramente, julgamos que há sempre alguma musicalidade guiando o recorte textual. Quando um rapper se põe a compor, por exemplo, o seu trabalho também consiste em combinar um texto com uma melodia, ou melhor, com uma forma sonora estável. No caso desse gênero cancional, contudo, essa forma estável possui algumas particularidades: não dispõe de grandes alterações de altura e nem de estabilizações escalares e harmônicas. Há, no entanto, questões rítmicas que delimitam um continuum musical específico a partir do qual o compositor proporá os seus recortes textuais. Assim, queremos dizer que há sempre uma base sonora a partir da qual o cancionista experimentará os seus encaixes linguísticos. No samba, no sertanejo e até mesmo no rap. Além disso, supomos que o próprio processo criativo se encarrega de gerar essas delimitações sonoras. Nesse sentido, uma primeira frase de melodia e letra composta pelo rapper muito provavelmente influenciará a criação de suas frases subsequentes. Por outro lado, os padrões sonoros absorvidos pelo compositor ao longo de anos de escuta do gênero que pratica poderão igualmente lhe fornecer conformações rítmicas prévias. Afinal, foi escutando a produção de outros artistas que os MC's passaram a compor os seus próprios raps. Nesse caso, constatamos que a fala não está propriamente guiando a composição, pois notamos a presença de uma forma musical que também orienta a criação, ainda que corresponda apenas a uma regulação métrica entre os versos ou a indicações do acompanhamento instrumental. Enfim, essa forma sonora, sem dúvida, indica pontos de início, desenvolvimento e terminação. O rapper forma suas unidades entoativas da mesma maneira que o faz um compositor de marchinhas. Ambos possuem uma base musical sobre a qual uma letra será combinada.

Por fim, consideramos não ser apropriado tratar o processo criativo do cancionista a partir da noção de "procedência", analisando se as canções se originam na fala ou na música. Em suas primeiras publicações, a semiótica da canção nos dá a entender que existe uma possível procedência, isto é, um ponto de partida para cada canção, como se as obras nascessem da língua oral ou das melodias instrumentais ${ }^{49}$. Supomos que essa não

\footnotetext{
${ }^{49}$ Mais preciso é o conceito de "oscilação" entre "forma musical" e "força entoativa", enfatizado cada vez mais ao longo do desenvolvimento teórico da semiótica da canção. Como mencionamos anteriormente, reservaremos uma parte da tese para analisar esse conceito de modo mais detido.
} 
é a maneira mais adequada de abordarmos a questão. Obviamente, são comuns os casos em que o letrista recebe de seu parceiro uma linha melódica finalizada. Contudo, devemos ter em mente que essa linha vocal composta pelo melodista, a priori, não faz parte do trabalho do cancionista. Este, só dá início ao seu trabalho no momento em que está combinando uma letra com uma base sonora, formando as unidades entoativas. Tanto a linha melódica pronta que o letrista recebe de seu parceiro quanto as conformações sonoras que o rapper possui a partir do acompanhamento rítmico criado pelo DJ consistem ambos no mesmo continuum musical a partir do qual o cancionista formará suas unidades entoativas. O seu ofício é combinar e o trabalho do analista é examinar essa combinação. Assim, pouco importa para o estudioso de canção se as obras surgiram de uma melodia instrumental ou de uma interjeição típica da linguagem oral. No âmbito da figurativização, o analista deverá centrar-se somente na verificação de que certas uniões de letra e melodia resultam em construções mais ou menos próximas da experiência que temos com a fala. 


\subsection{A tematização e a passionalização}

A semiótica da canção, ao se dedicar ao estudo da relação entre melodia e letra, não analisa somente os elementos de oralização comentados acima, mas igualmente procedimentos ligados à musicalização. Assim, situa o trabalho do cancionista num permanente vagar entre as leis linguísticas da figurativização e as leis musicais da tematização e da passionalização (2002: 73). Neste item, veremos como a teoria define esses dois processos e as possíveis relações que eles estabelecem com a figurativização. Observaremos que alguns de seus aspectos, ainda que musicais, podem sugerir efeitos francamente figurativos, tais como, por exemplo, a regularidade da enumeração entoativa e os sinais emotivos de contentamento ou lamento. Além disso, desejamos traçar um breve histórico do desenvolvimento desses dois conceitos, indicando aspectos que permaneceram ou se alteraram ao longo da produção de Tatit.

As canções ligadas à tematização expressam essencialmente a celebração do encontro. Suas letras retratam relações amorosas bem-sucedidas ou enaltecem personagens, lugares, fatos, gêneros musicais etc. Enfim, apresentam "todo tipo de conjunção narrativa" (2016: 117), manifestando a comunhão entre o sujeito e o seu objeto de valor. Sob o ponto de vista musical, suas melodias em geral apresentam andamento acelerado e figuras rítmicas de curta duração, num processo que valoriza os ataques consonantais e os acentos vocálicos do texto verbal (2008: 19). Caracterizam-se pela formação de temas e motivos a partir de "procedimentos de reiteração" (2008: 19). Há, nesse sentido, uma ênfase nas "relações de identidade" (2016: 117), pois os elementos musicais, ao serem repetidos, tornam-se aparentados entre si, gerando, para o ouvinte, certa previsibilidade melódica. Esse tipo de construção sonora casa-se perfeitamente com o conteúdo de uma letra que igualmente reitera ou enumera as qualidades de uma personagem, por exemplo.

Primeiramente, as sucessivas caracterizações do objeto enaltecido na letra ressoam na recorrência dos motivos melódicos. Depreendemos uma enumeração ao mesmo tempo linguística e melódica. Mas o que torna mais convincente a integração das duas faces é a relação de identidade do sujeito (um personagem caracterizado na letra ou o próprio enunciador) com os valores atribuídos ao objeto, identidade essa que se reproduz na semelhança dos temas sonoros emitidos durante o canto. (2008: 19) 
A canção Isso aqui tá bom demais, composta por Dominguinhos e Nando Cordel, é um exemplo típico desse tipo de procedimento cancional. O conteúdo da letra está ligado à celebração simultânea da festa e do amor e este estado de empatia entre o sujeito e o que ele está cantando é reforçado por uma forte reiteração, tanto de elementos linguísticos quanto de elementos musicais. Comecemos pelo refrão, trecho muitas vezes repetido ao longo da canção.

Olha, isso aqui tá muito bom

Isso aqui tá bom demais

Olha, quem tá fora quer entrar

Mas quem tá dentro não sai

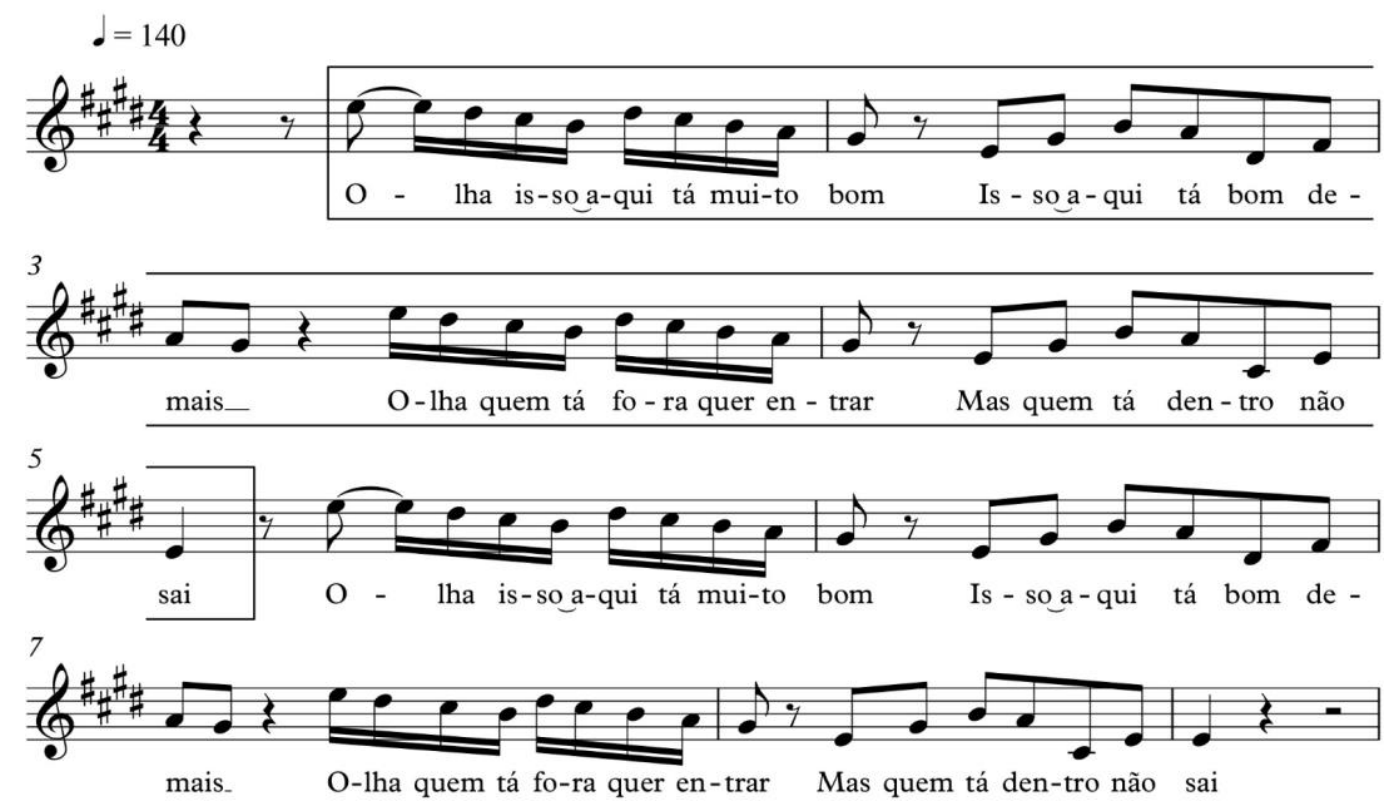

Figura 24. Refrão de Isso aqui tá bom demais (Dominguinhos / Nando Cordel)

A priori, todo refrão corresponde a uma conformação tipicamente ligada ao processo da tematização, pois, em geral, consiste em um trecho musical que se repete ao longo da obra, contribuindo para o estabelecimento das relações de identidade comentadas acima. Nessa canção de Dominguinhos, essa repetição é marcante, sobretudo se selecionarmos como exemplo o fonograma incluído no LP Isso aqui tá bom demais (1985), também incorporado à trilha musical da novela Roque Santeiro (1985) da Rede Globo. Ao final da faixa, o refrão continuamente se repete e o áudio termina em fade 
$o u t^{50}$, como se sugerisse ao ouvinte uma reiteração infinita do estribilho. Essa característica reiterativa, no entanto, não está somente na repetição integral do refrão no decorrer da canção. Quando analisamos a figura acima, constatamos que a reiteração se dá igualmente no âmbito dos segmentos menores, pois o refrão (que destacamos nos quatro compassos iniciais do exemplo) é formado pela repetição de dois motivos. O primeiro corresponde à sequência de semicolcheias que recobre o verso "Olha isso aqui tá muito bom" (e que, posteriormente, recebe a letra "Olha quem tá fora quer entrar"). O segundo consiste na sequência de colcheias que recobre a frase "Isso aqui tá bom demais" (e, em seguida, "Mas quem tá dentro não sai"). Dessa maneira, a recorrência é observada não apenas na reincidência integral do estribilho, mas igualmente na reapresentação de suas partes mínimas.

Na construção da letra, verificamos o mesmo caráter. Há um forte paralelismo e repetição de elementos, como na recorrência dos vocábulos e expressões "isso aqui tá", "muito bom". "bom demais", "olha", "quem tá" etc. A forma cruzada de organizar a posição das expressões "muito bom” e "bom demais" ressalta o mesmo caráter reiterativo. O significado se mantém praticamente o mesmo, ainda que tenhamos uma leve alteração com a troca do adjunto adverbial "muito" por "demais". A semelhança formal e a complementariedade verificada nas sentenças "quem tá fora quer entrar" e "quem tá dentro não sai" repercute o mesmo princípio reiterativo. Essa construção da letra propõe um fortíssimo entrelaçamento cujo intuito é reiterar uma única ideia: a euforia com a festa e com o amor. Nos parece que ela instaura uma espécie de imã que conecta o sujeito com o momento prazeroso descrito na letra, além do encantamento e atração exercido sobre o próprio ouvinte. Em suma, ela enfatiza o encontro entre o sujeito e o seu objeto de valor. Em termos sonoros, observamos exatamente os mesmos aspectos tematizantes comentados anteriormente. $\mathrm{O}$ andamento é acelerado, com a velocidade da pulsação situada aproximadamente em 140 batimentos por minuto, como indicado no pentagrama acima. Esse pulso, combinado com as figuras de duração de semicolcheia e colcheia, faz com que se valorize fortemente os ataques dos sons consonantais presentes na letra. Essas aliterações, sobretudo pela repetição das consoantes oclusivas [t], [k] e [b], são também mais um índice de reiteração temática. Após a reapresentação do refrão, o cantor segue para a parte $\mathrm{B}$ :

\footnotetext{
${ }^{50}$ Este artifício, comumente aplicado nos finais das faixas, consiste na diminuição gradativa do volume do áudio.
} 
Vou me perder, me afogar no teu amor

Vou desfrutar, me lambuzar deste calor

Te agarrar pra descontar minha paixão

Aproveitar o gosto dessa animação

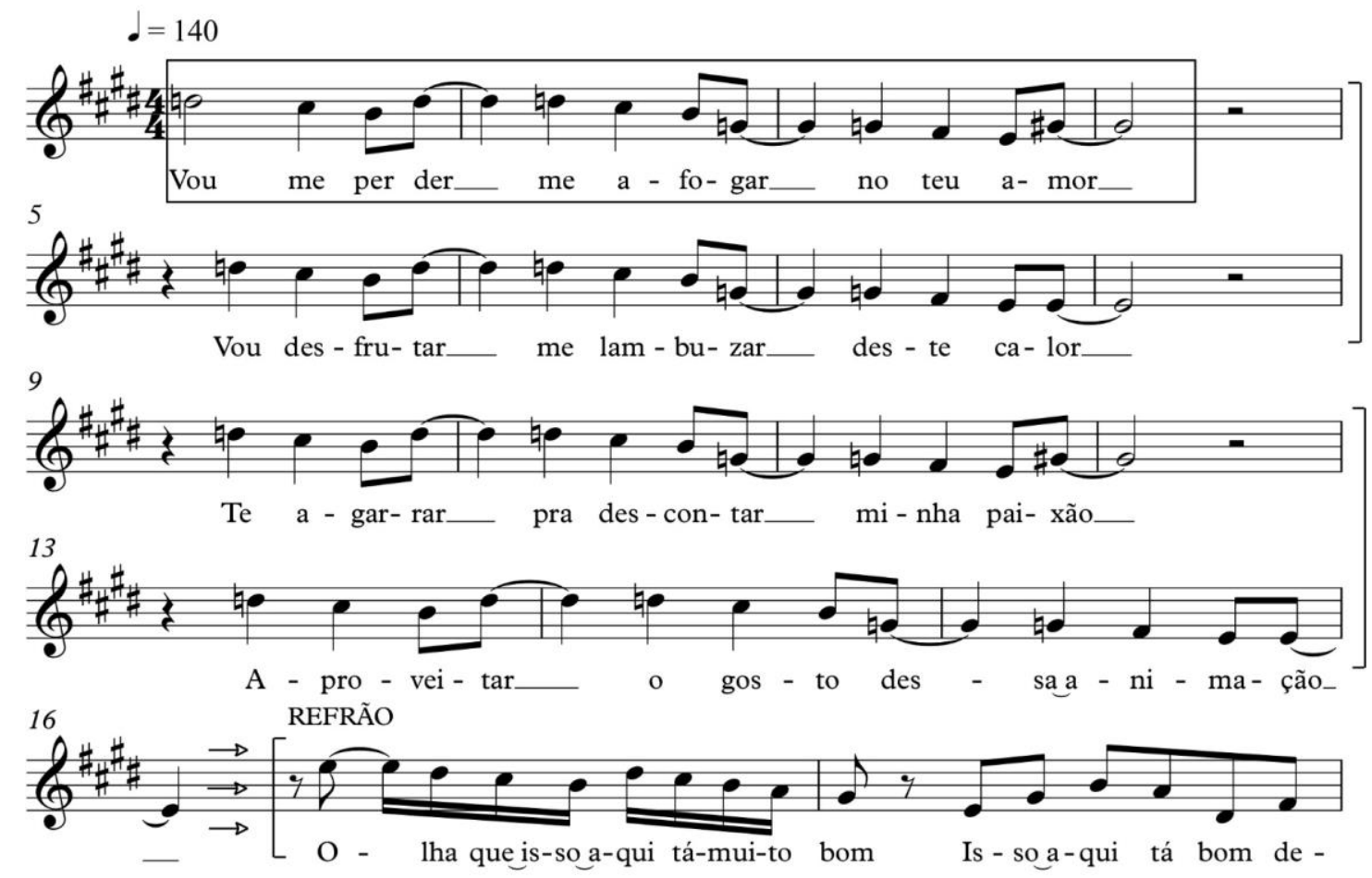

Figura 25. Parte B de Isso aqui tá bom demais (Dominguinhos / Nando Cordel)

A parte B, ao mesmo tempo em que se distancia do refrão, também prepara e valoriza o seu iminente retorno. Do ponto de vista musical, mas igualmente no conteúdo da letra, observamos um contraste entre as duas partes. Sonoramente, constatamos a presença de figuras de duração mais alongadas, com a predominância de semínimas e algumas mínimas nos finais de cada frase, o que indica uma evidente desaceleração da melodia em relação à maior rapidez verificada no refrão. O texto poético, por sua vez, exibe outra conformação linguística. No estribilho, há uma valorização do próprio instante em que se dá a festa, por meio do uso do tempo verbal no presente ("tá", "quer entrar" e "sai") e da utilização de dêiticos e marcas da enunciação ("olha", "isso" e “aqui"). De maneira distinta, a parte B apresenta uma projeção de ação no futuro, marcada pela estrutura que combina um verbo auxiliar no futuro ("vou") com um verbo no infinitivo que indica as várias ações do sujeito ("vou me perder", "(vou) me afogar", "vou desfrutar" etc.). Nesse momento da letra, o sujeito encontra-se afastado da festa, imaginando as ações que realizará quando a ela retornar. Do mesmo modo, nesse 
momento da canção, o cantor encontra-se afastado do refrão, nos dando diversos indícios de que em breve voltará a entoá-lo. Nesse sentido, as expressões "deste calor" e "dessa animação" indicam a recuperação do tempo presente e do refrão, representando a ligação necessária para a volta do estribilho.

Contudo, ainda que a parte B represente esse contraste sonoro e semântico que até mesmo valoriza o retorno ao refrão, a tendência à reiteração, entendida aqui como a principal característica do processo da tematização, ainda se mantém. Por um lado, no texto linguístico, as ações exercidas pelo sujeito são enumeradas: ele vai se perder, afogarse, desfrutar, lambuzar-se, agarrar e aproveitar. Por outro, na construção musical, as frases melódicas também repetem o mesmo padrão melódico-rítmico, o que combina perfeitamente com o ímpeto de inventariação das ações do sujeito.

Passando para o exame do conceito seguinte, as canções ligadas à passionalização geralmente apresentam letras que retratam o desencontro entre o sujeito e o seu objeto de valor. São as canções que cantam a saudade, a perda amorosa, a distância dolorosa em relação a um objeto de desejo (a pessoa amada, a terra natal, a liberdade etc.) e a busca por este objeto perdido. Enfim, descrevem essencialmente o sentimento de falta: "Na letra, temos em geral a descrição dos estados passionais que acusam a ausência do outro, o sentimento (presente, passado ou futuro) de distância, de perda, e a necessidade de reconquista" (2008: 21).

Sob a perspectiva musical, se contrapondo às canções tematizantes, apresentam uma desaceleração do andamento e a "valorização das durações vocálicas" (2008: 21), com a presença de figuras rítmicas mais alongadas. Em relação ao parâmetro altura, há maior presença dos saltos intervalares e a exploração mais ampla do campo de tessitura, ambas indicando a ideia de descontinuidade melódica. Nesse sentido, o autor analisa um recurso muito utilizado pelos cancionistas, a chamada transposição. É quando a primeira parte da obra se encontra em região mais grave e a segunda, por vezes de modo repentino, passa a explorar uma faixa bem mais aguda da tessitura ${ }^{51}$. Além disso, diferentemente da tematização que valoriza a identidade entre os motivos, a passionalização evidencia a noção de alteridade a partir de uma "desigualdade temática" (2008: 21). Por não formar frases melódicas reiterativas, essas canções acabam por reproduzir no âmbito sonoro uma ideia de distanciamento que já está presente no conteúdo de suas letras, que, como dissemos acima, expressam o desencontro.

\footnotetext{
${ }^{51} \mathrm{O}$ autor costuma exemplificar esse procedimento com a canção Travessia de Fernando Brant e Milton
} Nascimento. 
Tudo ocorre como se a distância entre sujeito/sujeito ou sujeito/objeto, relatada na letra, se convertesse em percurso de busca na melodia. Quanto menor o grau de uniformidade dos motivos, maior a distância entre os elementos melódicos (no sentido de que a melodia da canção, em última instância, procura a si própria e se encontra nos processos de reiteração) e maior o caminho a percorrer. (2008: 21-22)

A canção Lamento sertanejo, de Dominguinhos e Gilberto Gil, é um exemplo interessante de utilização do processo da passionalização. Vejamos como se configura a relação entre o conteúdo de sua letra e as construções melódicas adotadas pelos cancionistas.

Por ser de lá

Do sertão, lá do cerrado

Lá do interior do mato

Da caatinga, do roçado

Eu quase não saio

Eu quase não tenho amigo

Eu quase que não consigo

Ficar na cidade sem viver contrariado

Por ser de lá

$\mathrm{Na}$ certa, por isso mesmo

Não gosto de cama mole

Não sei comer sem torresmo

Eu quase não falo

Eu quase não sei de nada

Sou como rês desgarrada

Nessa multidão, boiada caminhando a esmo 

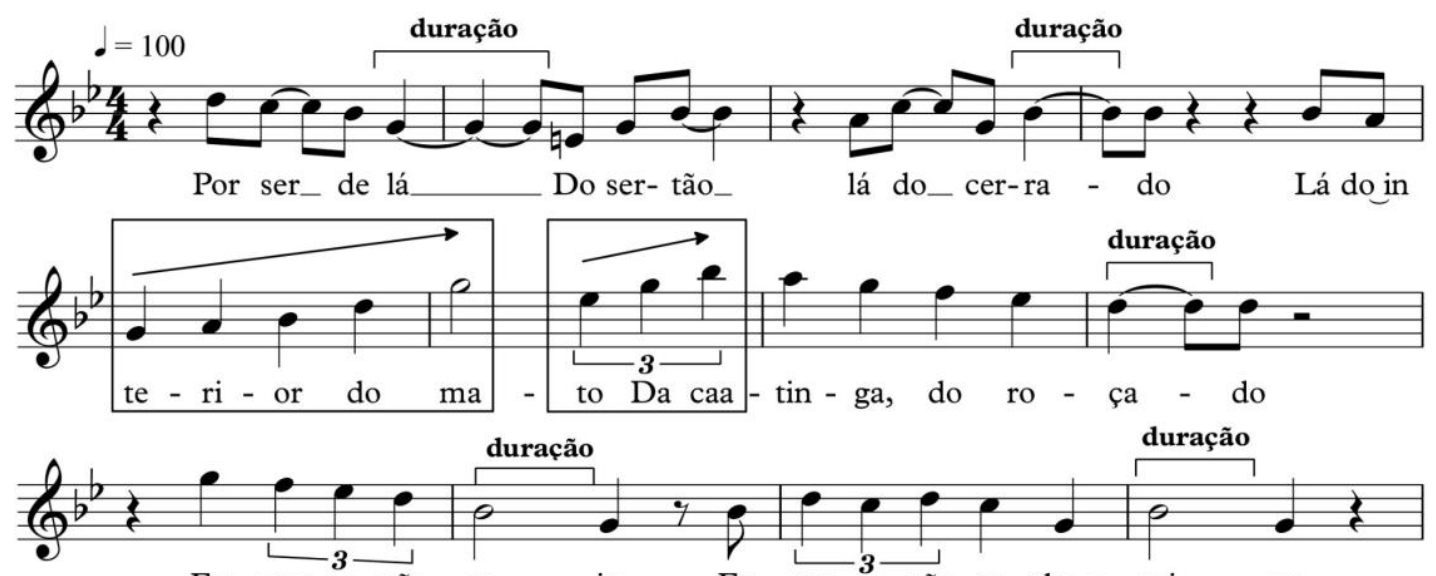

Eu qua-se não sa - iu Eu qua-se não te -nho a - mi - go

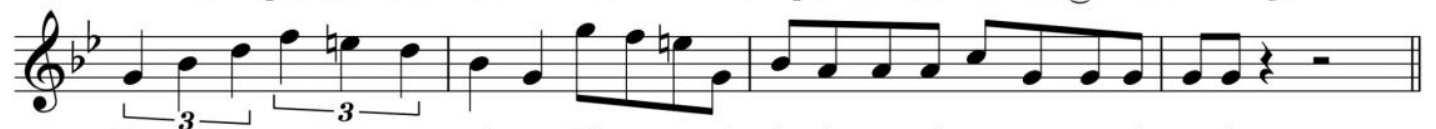

Eu qua-se que não con - si - go Fi-car na ci - da-de sem vi-ver con-tra-ri - a-do
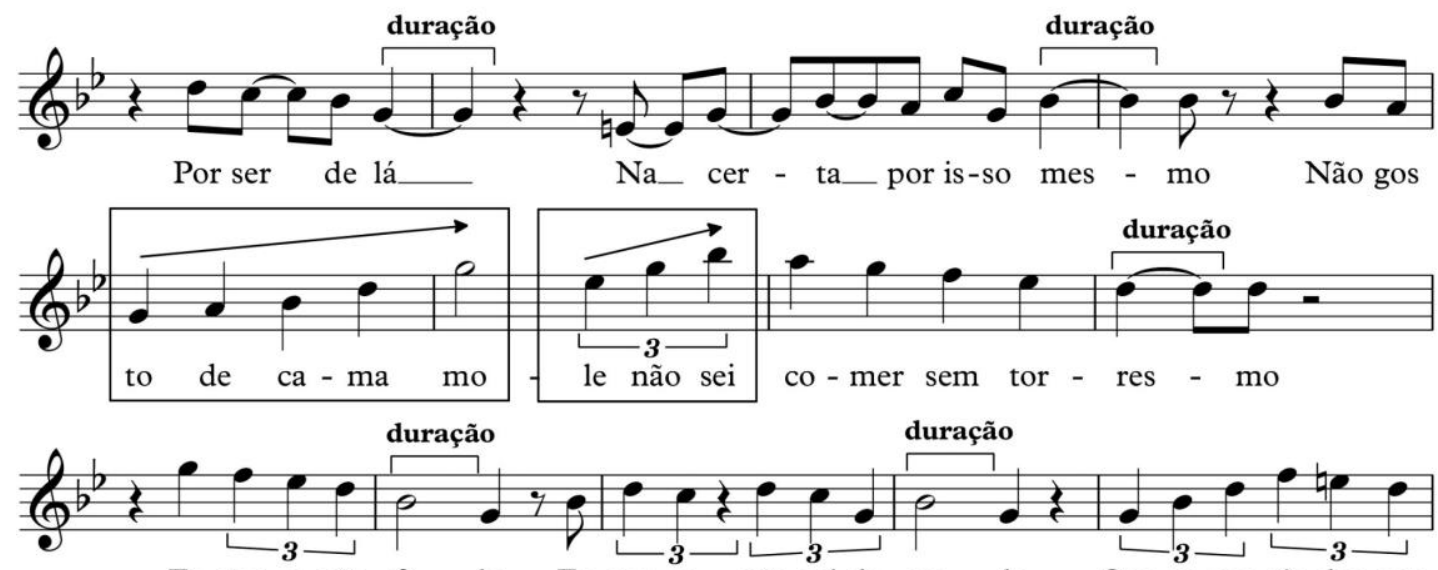

Eu qua-se não fa - lo Eu qua-se não sei de na - da Sou co-mo rês des-gar

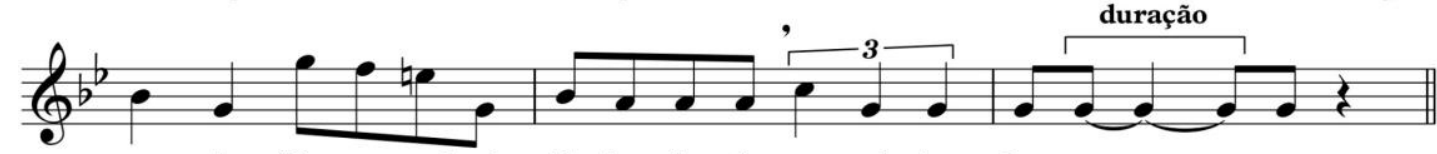

ra - da Nes-sa mul-ti - dão bo - ia - da ca - mi-nhan-do a es - mo

Figura 26. Lamento sertanejo (Dominguinhos/Gilberto Gil)

A letra da canção retrata o desencontro entre o sujeito e o seu lugar de origem. Faz referência à diversos ambientes rurais ("sertão", "cerrado", "caatinga", "roçado" etc.) para enfatizar a oposição entre o campo e a cidade e, com isso, ressaltar a desilusão vivida pelo eu-lírico. O próprio título da canção já indica o seu estado de disjunção narrativa, já que "lamento" refere-se sempre a algum tipo de desencontro ou privação. Na cidade, o sentimento de falta desse sujeito manifesta-se de diferentes formas: ele quase não sai, quase não tem amigos, quase não fala, quase não sabe de nada, vive contrariado e se autodenomina "rês desgarrada", configurando a imagem de um indivíduo solitário e perdido, que não participa da coletividade citadina. Além disso, sob a perspectiva do olhar 
desse sujeito, mais uma disjunção é sugerida pela canção: o desencontro entre a população urbana e o horizonte de um futuro positivo. Na cidade, os habitantes oprimidos ("boiada") caminham a esmo, com destino incerto.

Esse desencontro observado no conteúdo de seu texto verbal se compatibiliza perfeitamente com a desigualdade de seus motivos melódicos, ao contrário do que observamos em Isso aqui tá muito bom. Em Lamento Sertanejo, a melodia parece seguir um percurso bem menos previsível, traçando um perfil menos reiterativo. Essa descontinuidade é constatada, por exemplo, nos diferentes tamanhos de frases propostos pelo cancionista. Sob o ponto de vista da duração, o andamento se desacelera e notamos a presença de figuras longas, sobretudo nas terminações de frase, como destacamos na figura acima. Esse alongamento das notas finais de cada verso contribui para a valorização da emissão das vogais, algo que enfatiza o caráter lamurioso da obra. Em relação ao parâmetro altura, há uma acentuada expansão da tessitura, muito bem ilustrada pela ascendência melódica que recobre, na primeira estrofe, o verso "Lá do interior do mato, da caatinga, do cerrado" e, na segunda, o verso "Não gosto de cama mole, não sei comer sem torresmo". Com isso, a canção ganha um espectro de frequência bem amplo, situado entre a nota Mi natural, no grave, e a nota Si bemol, no agudo, como constatamos abaixo.

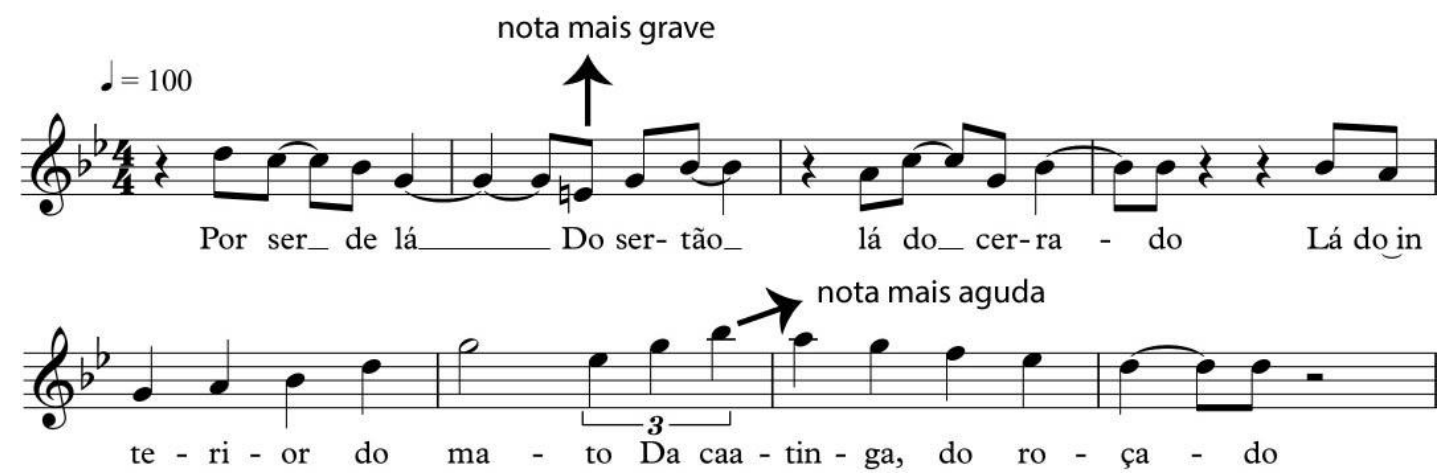

Figura 27. Expansão da tessitura em Lamento Sertanejo

Acabamos de realizar uma breve exposição dos processos de tematização e passionalização. No entanto, devemos destacar que, assim como no caso da figurativização, esses procedimentos foram pouco a pouco desenvolvidos. Ao longo das publicações de Tatit, o estudo desses conceitos sofreu importantes transformações: terminologias foram abandonadas, aspectos foram aprofundados e novas noções foram lançadas. 
Inicialmente, por exemplo, para referir-se à tematização, o autor utilizava o termo “decantação" (1986: 60, 53) ou "reiterações decantatórias" (2002:17). Em certas publicações as duas nomenclaturas coexistem: os termos "tematização" (1994: 46) e “canções decantatórias" (1994: 92) são ambos utilizados para apontar a mesma configuração melódica reiterativa. Como afirma o próprio autor, o verbo "decantar" se encaixa muito bem a esse processo já que possui tanto o significado de "celebrar ou exaltar alguém em cantos ou em versos" quanto o de "repetir sempre a mesma coisa, repisar" (1986: 53). No decorrer de seu desenvolvimento teórico, no entanto, o termo tematização passa a ser cada vez mais utilizado até que o vocábulo "decantação" é abandonado por completo. É possível que a denominação "tematização" tenha lhe parecido mais apropriada à teoria da semiótica da canção na medida em que enfatiza a ideia da criação de temas (algo mais próximo da experiência musical e, consequentemente, cancional). Além disso, consiste em um termo de origem semiótica, assim como passionalização e figurativização, o que lhe proporciona maior coerência terminológica. Acreditamos ainda que o segundo significado da palavra "decantar" ("repetir" ou "repisar"), que se refere justamente à principal característica formal do processo tematizante, não seja tão acessível aos falantes do português brasileiro. $\mathrm{O}$ significado que logo nos vem à mente se associa mais fortemente à ideia de exaltação do que a de repetição. É possível que isso também tenha colaborado para essa alteração de nomenclatura. Contudo, apesar do abandono do termo, o entendimento do processo como a "materialização (linguístico-melódica) de uma ideia" (2002: 23) se manteve ao longo de toda a sua produção.

Podemos constatar igualmente que o autor deixa de explorar o uso do termo "persuasão". Em sua primeira publicação denomina os três processos de compatibilidade como "persuasão figurativa" (1986: 6), "persuasão passional” (1986: 26) e "persuasão decantatória" (1986: 47), o que posteriormente denominará apenas como figurativização, passionalização e tematização, respectivamente. Além disso, utiliza os termos “persuasão somática" (1986: 50) para denominar as canções reiterativas que valorizam a pulsação e convidam à dança e "persuasão cognitiva" (1986: 50), quando "a mente reconhece o contexto rítmico (o gênero)" dessas canções pulsantes. Acreditamos que, mais do que apenas abandonar esse tipo de nomenclatura, Tatit deixa de enfatizar a própria ideia de persuasão. Se ao longo dessa obra inicial podemos notar um foco muito intenso no estudo da relação persuasiva entre o "destinador-locutor" (o cantor ou o cancionista) e o "destinatário-ouvinte" (o público ouvinte), na locução principal, e entre o "interlocutor" 
(o eu da canção) e interlocutário (o tu da canção), na locução secundária, em publicações futuras, o objetivo passa a ser outro. Isto é, ainda que Tatit não negue essas postulações e que elas não sejam incoerentes com os desenvolvimentos mais atuais da semiótica da canção, acreditamos que o autor deixa de enfatizar a relação persuasiva, sobretudo entre cantor e ouvinte (o que nos parece de certa forma algo exterior à canção), para se dedicar mais firmemente à análise dos componentes internos de cada obra.

As publicações que se seguiram ao livro A canção: eficácia e encanto (1986) foram incorporando novas noções ligadas aos processos da tematização e da passionalização, muitas vezes aprofundando aspectos já presentes nessa obra inicial. Em O cancionista (1996) $)^{52}$, o autor destaca duas tendências composicionais do compositor de canções: a "segmentação" e a "continuidade" (2002: 10), identificando a primeira com a tematização (pela redução da duração das vogais e pelos repartimentos e acentuações geradas pelos ataques consonantais) e a segunda com a passionalização (pelo alongamento das durações vocálicas e expansão da tessitura).

Em Semiótica da canção (1994), a partir da teoria da silabação surgida com Saussure, continuada por Hjelmslev e incorporada aos estudos mais recentes à época realizados por Zilberberg, Tatit incorpora novos conceitos ao exame da tematização e da passionalização, enriquecendo a sua abordagem da canção. $O$ modelo silábico saussuriano aborda a sonoridade dos fonemas a partir de duas tendências gradativas: os sons que se abrem e os sons que fecham, ritmicamente. Os primeiros perfazem um movimento explosivo e os segundos, um movimento implosivo (1994: 62). Podemos utilizar como exemplo a palavra "prato". Como observamos na figura abaixo, há um momento inicial com ausência total de sonoridade ao qual se segue uma abertura máxima do som, incidindo sobre o núcleo vocálico.

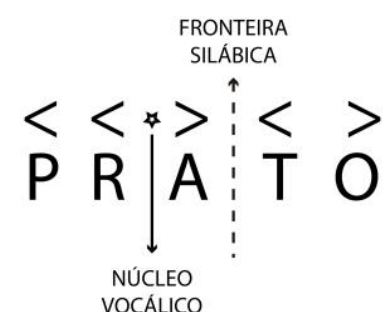

Figura 28. O modelo silábico de Saussure

\footnotetext{
${ }^{52}$ Como dissemos anteriormente, estamos utilizando a segunda edição da obra, publicada em 2002.
} 
Constatamos acima um movimento gradativo de abertura e fechamento. No núcleo vocálico, ponto de maior abertura ou continuidade, há a presença do fonema [a] que constitui, aliás, o som mais aberto das línguas naturais. Em contraposição, na fronteira silábica que segmenta o vocábulo, encontramos o ponto de maior descontinuidade ou fechamento. Para a semiótica, o interesse está em constatar que essa estrutura aplicada ao estudo silábico pode ser transposta para o plano do conteúdo, como se o elemento que regesse a silabação também regesse o nosso ritmo de vida e os sentidos que produzimos ao longo de nossa existência.

Conforme Tatit, é Zilberberg quem faz essa passagem da dimensão linguística para a dimensão semiótica, abstraindo da sequência de implosões e explosões estudadas pelo linguista suíço, o seu novo modelo teórico (1994: 68). Assim, para além da análise da cadeia de fonemas abertos ou fechados, o estudo empreendido por Saussure ${ }^{53}$ possibilitou, décadas após a sua publicação, o exame do conteúdo por meio da categoria abstrata abertura, da qual Zilberberg depreendeu a sua função de expansão. Esta, articulase a partir dos componentes "abertura crescente" (identificada com a noção de extensão) e "abertura decrescente" (ligada à noção de concentração) (1994: 69). São justamente essas duas noções que Tatit reutiliza para enriquecer o estudo sobre os dois processos de compatibilização entre melodia e letra analisados aqui, passionalização e tematização, vinculando-os, ao mesmo tempo, aos conceitos de evolução e involução melódica, respectivamente. A aceleração das canções temáticas, constatada na elevação da velocidade da pulsação e na curta duração das figuras rítmicas, consiste, então, em uma "força de concentração na medida em que aproxima as identidades, abrevia os percursos e acirra os contrastes" (1994: 93). É como se esse movimento de concentração fizesse a melodia "involuir", isto é, ao invés de expandir-se para outras configurações, o perfil melódico perfaz um contínuo retorno à informação já conhecida. É quando a canção parece não sair do lugar. O refrão, nesse sentido, é a sua expressão mais categórica. A passionalização, ao contrário, liga-se à noção de extensão na medida em que propõe melodias que se expandem explorando espaços mais amplos de tessitura, bem como alargando o seu percurso melódico, tendo em vista a desaceleração do andamento e o uso de figuraras rítmicas mais alongadas (1994: 108).

\footnotetext{
${ }^{53}$ Sobre o seu modelo silábico ver o capítulo "O fonema na cadeia falada" presente no apêndice "Princípios de fonologia" do Curso de Linguística Geral (SAUSSURE, 2006).
} 
Verificamos, então, que, pouco a pouco, Tatit incorpora ao seu estudo ferramentas analíticas advindas das mais recentes pesquisas semióticas ${ }^{54}$, enriquecendo com importantes nuances o arcabouço teórico da semiótica da canção. Nessa perspectiva, o autor aprimora a sua abordagem dos processos de tematização e passionalização, tornando-a cada vez mais complexa e menos imobilizada. Cada um deles passa a ser entendido como um procedimento melódico que possui características centrais e características complementares. A tematização, ligada à aceleração e à concentração, traz como elementos centrais a recorrência temática e o refrão que, como vimos anteriormente, são índices de identidade e conjunção. Os seus elementos complementares são os desdobramentos melódicos que se diferenciam do tema reiterado de maneira mais pontual e a inserção de partes suplementares $\left(2^{\mathrm{a}}\right.$ parte, $3^{\mathrm{a}}$ parte etc.) que se distinguem do motivo de um modo mais global. Esses elementos complementares se opõem, então, ao seu traço dominante ligado à recorrência, como se a desestabilizasse momentaneamente. A passionalização, por sua vez, caracterizada pela desaceleração e pela extensão, possui o salto intervalar e a transposição de registro $\left(1^{\mathrm{a}}\right.$ parte da canção em região grave e $2^{\mathrm{a}}$ parte no agudo) como elementos centrais, indicadores de alteridade e disjunção. Os seus elementos complementares são o uso de graus imediatos (os graus conjuntos de uma escala musical) e a gradação, ambos recursos musicais que abrandam a descontinuidade, estabelecendo para o ouvinte uma certa previsibilidade sonora. Assim, os recursos complementares têm sempre a função de atenuar as características centrais de cada processo. Tatit resume esses conceitos no seguinte quadro (2016: 57) ${ }^{55}$ :

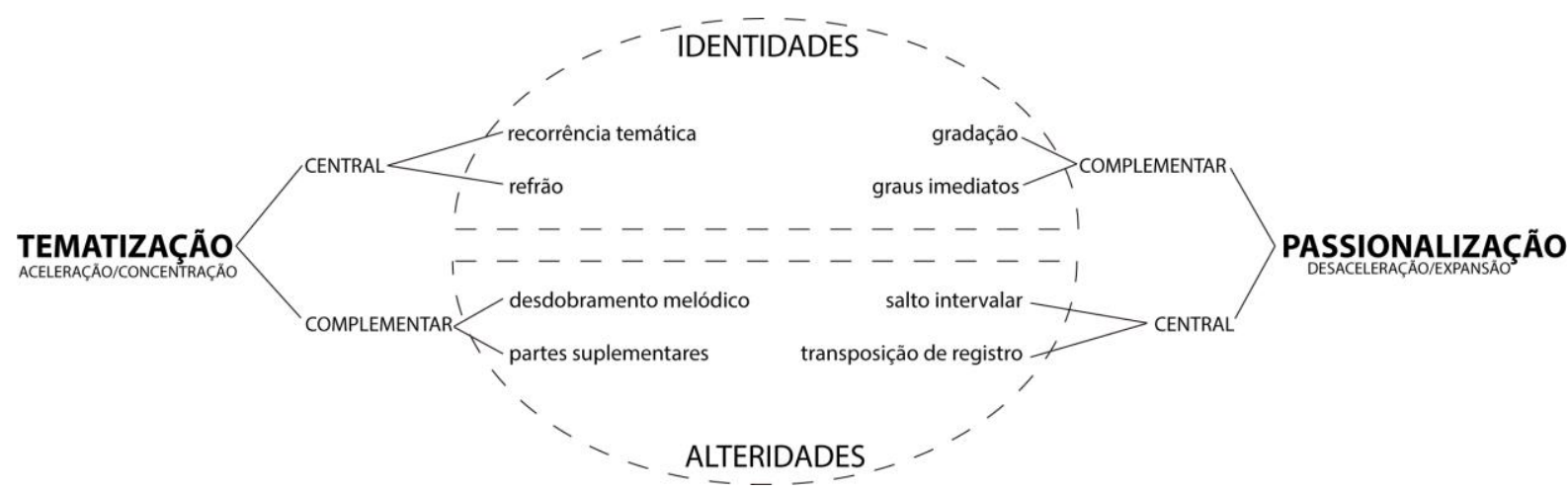

Figura 29. Tematização e passionalização (elementos centrais e complementares)

\footnotetext{
${ }^{54}$ Nos referimos aqui aos estudos empreendidos pelos autores ligados à semiótica tensiva. Abordaremos esse tema no capítulo seguinte.

55 Efetuamos pequenas alterações na diagramação do quadro, bem como algumas mudanças de nomenclatura.
} 
Voltando aos dois exemplos brevemente analisados acima, somos agora capazes de enriquecer nossa abordagem. A parte B de Isso aqui tá bom demais (figura 25) constitui, nessa perspectiva, uma seção que contrasta com o refrão e que ameniza a sua recorrência e aceleração. Da mesma maneira, em Lamento sertanejo (figura 26), notamos que a ascendência melódica que amplia fortemente a tessitura da canção no verso "Lá do interior do mato, da caatinga, do roçado" se dá em grande parte por meio de graus conjuntos, o que também diminui o grau de descontinuidade passional. Enfim, com isso, podemos constatar o quanto essa visão renovada dos processos de tematização e passionalização (incorporando a oscilação entre termos centrais e complementares) representou um amadurecimento para a semiótica da canção, permitindo uma leitura mais próxima da real complexidade encontrada nas obras.

Ao compreender melhor o entrosamento entre essas duas tendências melódicas, bem como suas sutis variações de aumento (mais) e diminuição (menos) no campo das predominâncias, o analista poderá transcender o ímpeto de classificação sumária das canções. Com exceção dos exemplos didáticos, úteis para o reconhecimento das categorias básicas que definem essa linguagem artística, quase nunca temos composições exclusivamente "temáticas" (ou de concentração) nem exclusivamente "passionais" (ou de expansão). O declínio provocado pelos traços complementares de uma tendência é o melhor indício de que pode estar em crescimento a tendência oposta. Se forem observadas todas essas nuances do componente melódico, teremos elementos mais consistentes para avaliar o seu grau de compatibilidade com os argumentos da letra. (2016: 163)

À essa altura, desejamos retornar ao exame da figurativização, mas a partir de suas diferenças e proximidades em relação a esses dois outros processos de compatibilização entre melodia e letra. Tatit sempre delimitou muito bem a diferença entre, de um lado, as melodias passional e temática, regidas pelas "leis musicais" e, de outro, a melodia figurativa, conduzida pelas "leis linguísticas" (2002:73). A diferença entre elas, no entanto, não se restringe a uma simples distinção de linguagem. A tematização e a passionalização, como vimos anteriormente, manifestam, respectivamente, conteúdos eufóricos e disfóricos, concedendo à melodia um investimento semântico a partir de configurações de duração e frequência que geram diversos tipos de tensões e emoções nos ouvintes. Em Isso aqui tá bom demais, a melodia expressa, em consonância com a letra, um forte contentamento, produzindo no ouvinte reações psíquicas (o próprio sentimento de alegria) e físicas, salientando a corporeidade da dança (quando a canção 
parece convidar o ouvinte a adentrar na festa). Em Lamento sertanejo, por sua vez, o desencontro e o sentimento de infelicidade materializam-se nas inflexões melódicas agudas e alongadas. Há sempre, portanto, sentimentos de satisfação ou insatisfação vinculados às melodias temáticas e passionais. Ao contrário, a figurativização caracterizase como um processo melódico neutro, como se o seu conteúdo se dessemantizasse.

O terceiro modelo de construção equivale ao processo inverso de distensão e, consequentemente, de desinvestimento do percurso melódico, como se esse componente tendesse a atingir um grau zero de significação, por intermédio de um tratamento que esbarra no limiar da pura entoação linguística. Tanto a reiteração dos motivos quanto a configuração dos contornos melódicos perdem sua força tensiva reduzindo-se às ondulações essenciais próximas ao discurso oral (1997: 120)

Esse "desinvestimento do percurso melódico" e a sua consequente perda de "força tensiva" se referem a essa neutralização da significação da melodia. Em oposição aos exemplos comentados acima, a melodia figurativa, assim como a entoação da fala, não veicula, em sua sonoridade, o contentamento de Isso aqui tá bom demais, nem o sentimento de falta de Lamento sertanejo. Na língua oral e nesse processo cancional (aqui, artificialmente isolado), mais importa a compreensão abstrata do texto verbal: "A melodia radicalmente figurativa não pretende dizer além do que já está no texto linguístico. Passaria muito bem sem ser notada: figurativiza a fala cotidiana" (1997: 143).

Essa oposição entre a semantização dos processos temático e passional e a neutralidade do procedimento figurativo não impede, contudo, que se estabeleçam entre eles relações significativas. Queremos, nesse momento, indicar possíveis elos entre as conformações melódicas regidas pelas leis musicais e sentidos que presenciamos em nossas experiências linguísticas cotidianas. Como veremos no capítulo seguinte, a noção de figurativização, na semiótica geral, se refere à remissão dos discursos às figuras do mundo natural. Supomos, então, que melodias temáticas ou passionais também podem sugerir determinadas figuras entoativas. Assim, por exemplo, a regularidade do perfil, no primeiro caso, também pode suscitar um sentido de enfado e monotonia ou uma forma de enumeração, tão presente na oralidade. Além disso, em ambos os processos, o investimento semântico ligado aos estados de conjunção e disjunção produzem igualmente feições figurativas presentes em nosso universo linguístico. Conforme o autor, esses estados de satisfação e insatisfação "se manifestam através de inúmeras figuras (desespero, ódio, frustação... alívio, esperança, admiração etc.)” (1986: 46). 
A regularidade melódica observada na canção Cotidiano de Chico Buarque, por exemplo, além de enfatizar o mesmo ritmo periódico das ações repetitivas que a personagem da letra executa, pode sugerir a figura de uma entoação entediada. A maneira como o cantor articula as sílabas ou acentua o ponto forte de cada pulsação pode até mesmo enfatizar essa feição linguística ligada à monotonia.

Todo o dia ela faz tudo sempre igual

Me sacode às seis horas da manhã

Me sorri um sorriso pontual

E me beija com a boca de hortelã

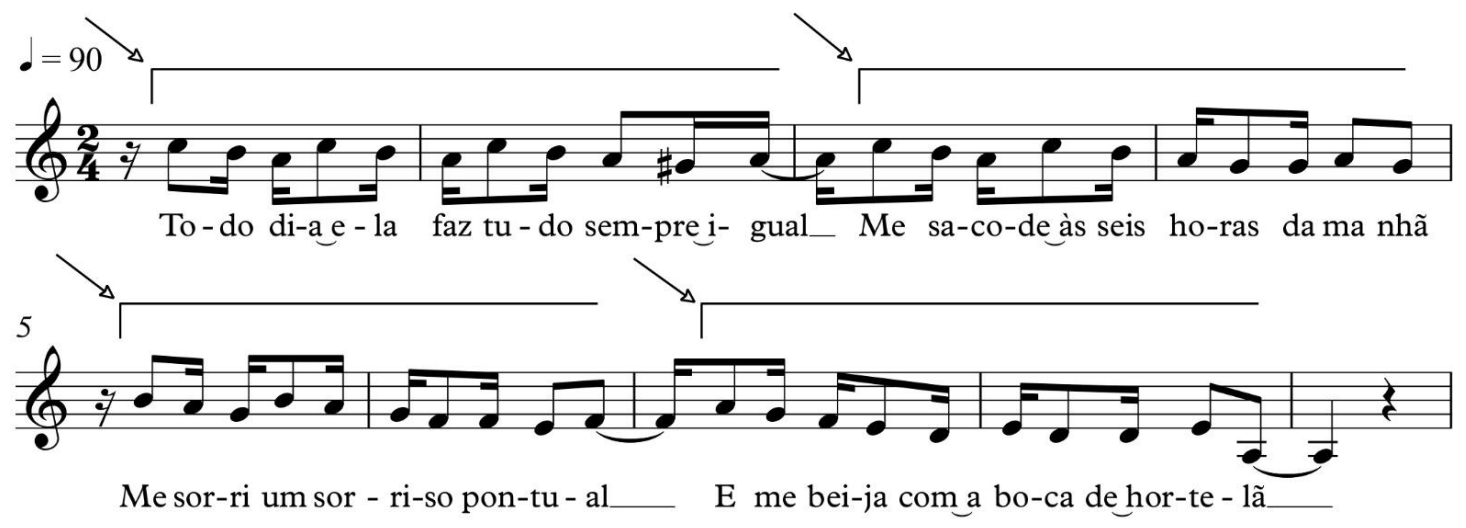

Figura 30. Cotidiano (Chico Buarque)

A regularidade da melodia tematizante também se refere ao que Tatit denomina "enumeração entoativa" (2002: 255). Ao analisar a canção O que será, do mesmo compositor, o autor constata que a sua reiteração melódica não chega a configurar um tema de conteúdo. A canção, nesse caso, não pretende decantar uma personagem ou algum objeto de valor: "ao invés de tematização, trata-se de enumeração entoativa de dois módulos interrogativos" (2002: 255). Dessa maneira, percebemos que há casos nos quais a identidade observada entre os motivos melódicos mais sugere uma figura de fala do que o processo de tematização propriamente dito. De fato, na língua oral, ao enumerarmos itens de mesma natureza, geralmente o fazemos por meio da repetição do mesmo perfil entoativo (1997: 109). Para situarmos o leitor, examinemos primeiramente fragmentos enumerativos em canções explicitamente temáticas. Em Paratodos (Chico Buarque), a letra enumera a genealogia do eu-lírico, mas com o propósito final de exaltar uma profusão de músicos e compositores brasileiros. Em Corcovado (Tom Jobim), notamos a 
mesma formação enumerativa, porém, fundamentada na presença de um sentimento de plenitude com o amor e com a paisagem.

O meu pai era paulista

Meu avô, pernambucano

O meu bisavô, mineiro

Meu tataravô, baiano

Meu maestro soberano

Foi Antonio Brasileiro

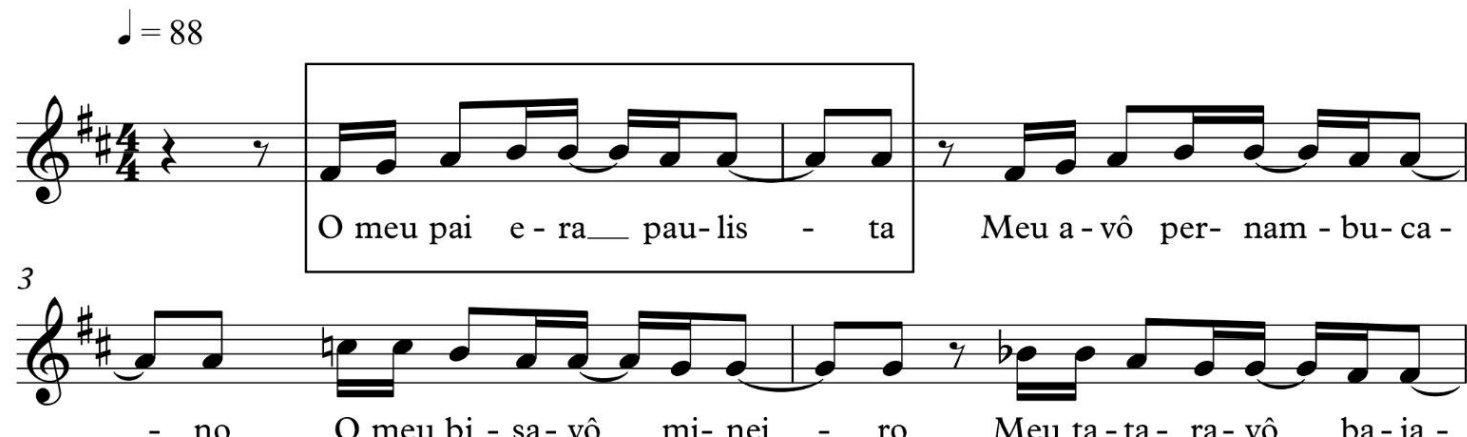

5

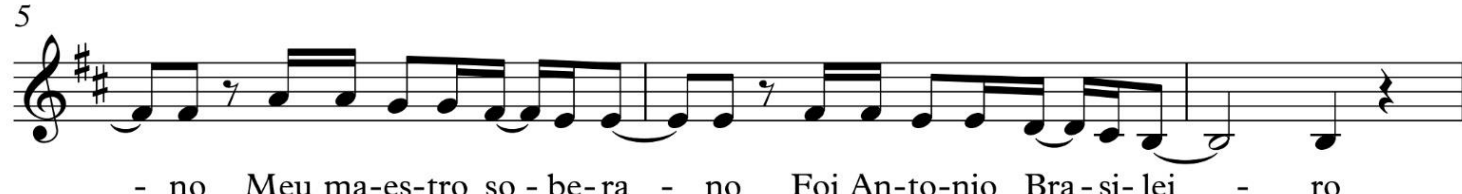

Figura 31. Paratodos (Chico Buarque)

Um cantinho, um violão

Este amor, uma canção

Pra fazer feliz a quem se ama

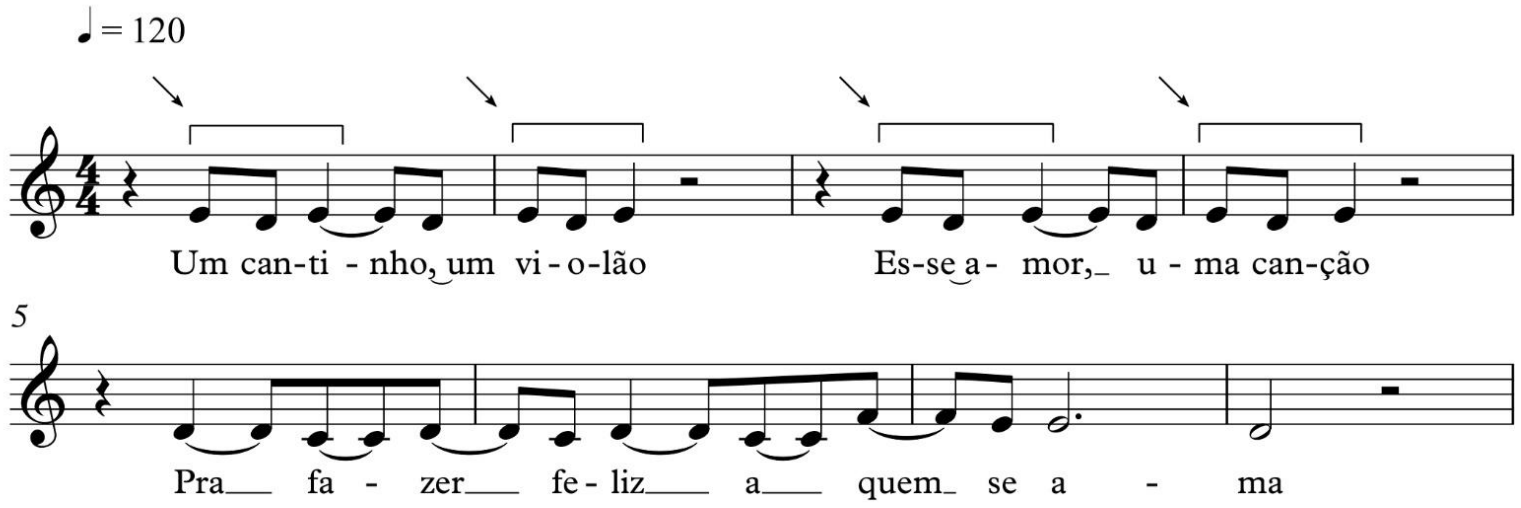

Figura 32. Corcovado (Tom Jobim) 
Em ambas notamos uma espécie de listagem linguístico-melódica. Todavia, os dois exemplos são claramente regidos, sobretudo em Paratodos, pelo procedimento da tematização. Nessa primeira canção, as frases melódicas que cobrem a letra que enumera os antepassados do eu-lírico são, como assinalamos na figura acima, ritmicamente idênticas. Em Corcovado, por sua vez, como destacamos no primeiro pentagrama de sua respectiva figura, percebemos a repetição de um mesmo motivo formado pelas notas Mi, Ré e Mi.

Diferentemente, também constatamos o mesmo tipo de construção em canções que apresentam maior proximidade com a fala. São fragmentos mais pontuais que, em certo momento da letra, passam a elencar elementos. É o que verificamos, por exemplo, em certos trechos das canções Doralice, de Dorival Caymmi, e Acontece, de Cartola:

Doralice eu bem que lhe disse

Amar é tolice, é bobagem, é ilusão

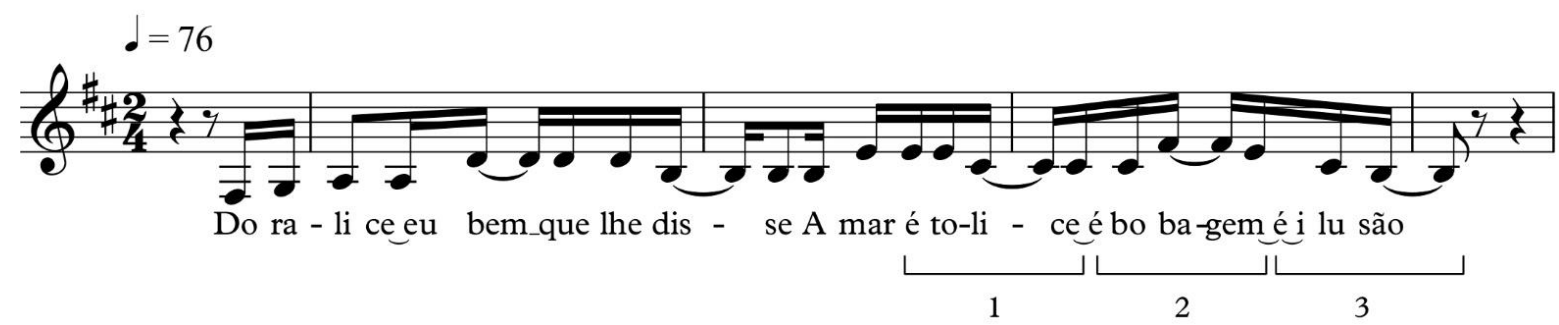

Figura 33. Doralice (Dorival Caymmi)

E acontece que já não sei mais amar

Vai chorar, vai sofrer

E você não merece

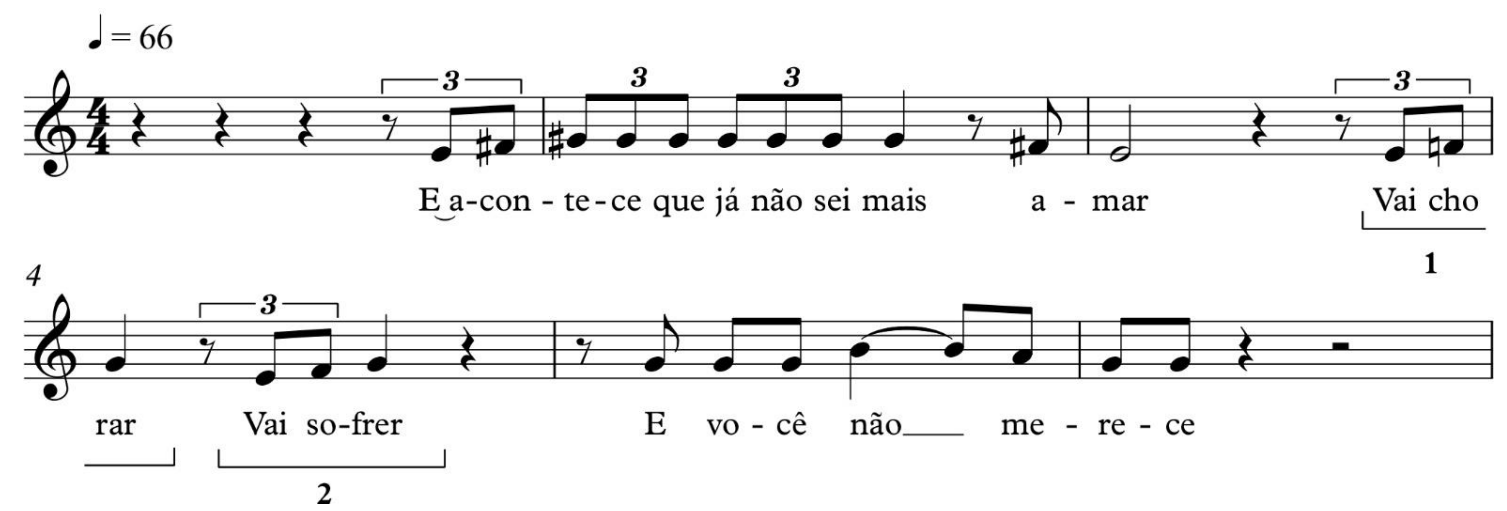

Figura 34. Acontece (Cartola) 
Em Doralice, notamos que o cancionista, para enumerar as características relacionadas à ação de amar, lança mão de três substantivos consecutivos: "é tolice", "é bobagem" e "é ilusão". Como observamos na figura 33, todos eles são recobertos com o mesmo motivo rítmico. Ainda que as alturas sejam diferentes, o padrão de semicolcheias, com síncopas que valorizam as sílabas tônicas dos vocábulos, se mantém o mesmo. Em Acontece, notamos o mesmo tipo de construção, sendo que, nesse caso, a identidade sonora é ainda mais evidente. As frases "Vai chorar" e "Vai sofrer", que enumeram o que o eu-lírico da letra imagina como possíveis ações realizadas por seu interlocutor, possuem exatamente a mesma formação melódica, no ritmo e nas alturas.

Além disso, podemos estabelecer outro possível elo entre as melodias ligadas aos processos de tematização e passionalização e as figuras entoativas. Reavaliando a oposição entre a semantização temática e passional e a dessemantização do processo figurativo, podemos dizer que essa polarização não deve ser compreendida de maneira tão rígida. Queremos, com isso, afirmar que as tensões emocionais decorrentes dos variados estados juntivos em que se encontra o sujeito também podem ser tomadas sob o ponto de vista figurativo. Ou seja, o caráter de lamentação encontrado em certas melodias passionais, por exemplo, também está presente em figuras entoativas com as quais convivemos cotidianamente. Ao analisar a segunda parte da canção Eu sei que vou te amar (Tom Jobim/Vinicius de Moraes), Tatit destaca a sua característica passional, sobretudo pelos saltos intervalares presentes na frase "E cada verso meu será pra te dizer". Ao mesmo tempo, contudo, aponta o valor figurativo que esse mesmo trecho pode suscitar.

São tentativas de abreviar o trajeto melódico, subtraindo-lhe as etapas intermediárias previamente inscritas nas escalas diatônicas e representando, assim, a expressão de um sujeito que deseja, o quanto antes, se aproximar do objeto. Esse esforço de aceleração no interior de um regime desacelerado parece-nos ser, como já frisamos, a forma central da passionalização melódica. E se tais inflexões ecoam também como lamentos entoativos do enunciador, isso significa que, mais uma vez, os efeitos figurativos se manifestam detrás das soluções passionais $(2008,144)$

O autor ressalta, então, que a melodia passional também pode sugerir figuras de fala, como uma espécie de "lamento entoativo" do enunciador. Assim, uma melodia plangente, acusa a presença de um ser que chora. Da mesma forma, uma melodia repetitiva é propícia para veicular uma enumeração entoativa. Supomos, desse modo, que 
diante de qualquer união entre letra e melodia, o ouvinte (por meio de sua vivência cotidiana com o seu idioma) naturalmente buscará expressões ligadas à oralidade, ainda que essas estejam encobertas por conformações musicais.

Por fim, mais do que identificar as construções melódicas passionais ou temáticas que também podem suscitar efeitos figurativos, devemos salientar que a semiótica da canção, desde as publicações iniciais, entende os três processos como conceitos ativos, isto é, sempre presentes nas obras, de maneira dominante, recessiva ou residual. Ainda que um deles predomine sobre os demais (a figurativização que se sobressai sobre os outros dois processos, no caso do rap, por exemplo), todos estão sempre em permanente atuação. Esse cruzamento entre os processos temático, passional e figurativo é um ponto crucial para a compreensão mais aprofundada da teoria, cujo modelo de análise torna-se cada vez mais operacional na medida em que incorpora esse entrelaçamento. Nesse sentido, no item seguinte, abordaremos o embate entre o aspecto entoativo e as leis musicais presentes na canção. 


\subsection{A oscilação entre a força entoativa e a forma musical}

Desde suas primeiras publicações, Tatit assinala a simultaneidade dos três modos de compatibilidade, seja em uma mesma canção ou no conjunto da obra de certo compositor, seja no universo cancional de determinada cultura. Paulatinamente, de livro a livro, o autor desenvolve a questão da concomitância dos processos até tratá-la como uma espécie de movimento dialético entre a música e a fala, tópico que podemos certamente considerar como um ponto central em suas propostas mais recentes.

Em A canção: eficácia e encanto (1986), o autor já aponta a concomitância dos três procedimentos. Ainda utilizando uma terminologia que, como vimos acima, seria abandonada em publicações posteriores, examina a coexistência das diferentes “persuasões". De acordo com Tatit, ainda que uma canção possa apresentar um modo de compatibilidade hegemônico, geralmente as obras desencadeiam "os três processos e com tal simultaneidade que, por vezes, não conseguimos identificar a persuasão predominante" (1986: 60). Nessa mesma obra, identifica como um indício dessa simultaneidade a existência de diferentes linhas interpretativas para uma mesma canção. Um exemplo conhecido desse tipo de procedimento é a reinterpretação de Asa branca realizada por Caetano Veloso, cuja versão original de Luiz Gonzaga pende para o lado tematizante. A proposta do compositor baiano, ao contrário, explora o potencial passionalizante da canção. Nesse sentido, o autor situa o trabalho do intérprete, sobretudo aquele que se debruça sobre uma obra já gravada, como a procura por uma "nova inflexão persuasiva": "Talvez, seja a própria razão de ser de uma reinterpretação. Afinal, as canções já trazem, em seu bojo, as possibilidades interpretativas. Basta detectá-las" (1986: 62).

Em $O$ cancionista, deixando claro que o estudo isolado de cada modo de compatibilidade, ainda que seja bastante conveniente para fins didáticos, produz considerações "um tanto quanto estáticas" $(2002: 24)^{56}$, o autor recoloca a questão da

\footnotetext{
${ }^{56} \mathrm{O}$ intuito de, num primeiro momento, estudar separadamente os três processos para, em seguida, tratar das canções como elas são, isto é, complexas e heterogêneas, fica claro na proposta de análise da canção Mania de você (Rita Lee/Roberto de Carvalho) em Semiótica da canção (1994: 50). Longe de constituir um exemplo didático, a canção selecionada parece trazer uma letra eufórica, tematizante, recoberta por uma melodia disfórica, passional. Obviamente, não nos interessa repetir a análise desenvolvida pelo autor. É interessante, contudo, destacar a escolha de canções menos "estereotipadas". Trata-se de um esforço do autor em demonstrar a maior funcionalidade de sua teoria. Em Canção: eficácia e encanto (1986), ainda que tenhamos comentários a respeito da simultaneidade de "persuasões", não há análises de canções que tragam maiores complexidades. Os seus exemplos são mais pontuais e didáticos.
} 
criação de canções nos termos de uma combinação entre as leis musicais e as leis linguísticas.

\begin{abstract}
Valendo-se de leis musicais, o compositor detona os processos de tematização e passionalização. Com o que chamo de leis linguísticas, a figurativização. Partindo de um lado ou de outro, o cancionista só termina seu trabalho quando opera a integração entre leis musicais e leis linguísticas (2002: 73)
\end{abstract}

Essa integração (que prevê, é claro, a variação do nível de presença de seus diferentes componentes) pode ser notada na canção popular em geral, na medida em que o cancionista, como comentamos anteriormente, conjuga elementos da língua oral (a naturalidade e a presentificação enunciativa) com formas sonoras estáveis, próprias da linguagem musical. Assim, a canção "necessita das duas instâncias de apreensão para construir o seu sentido" (1997: 89). Essa concomitância dos processos musicais e orais, e o consequente "revezamento das dominâncias de um processo sobre o outro" formam, segundo Tatit, "o projeto geral de dicção do cancionista" (1997: 103). Ou seja, em certa medida, as diferentes maneiras de conjugação dos modos de compatibilidade delinearão os diferentes estilos de cada compositor ou cantor. Nesse sentido, nos auxilia a distinguir Jorge Ben Jor (figurativo e temático) de Racionais MC's (predominantemente figurativo) ou Tim Maia (temático e passional) de Roberto Carlos (predominantemente passional), por exemplo.

O autor costuma aplicar esse modelo até mesmo para analisar a história da canção popular brasileira que, segundo ele, "apresenta uma constante flutuação entre o canto musicado e o canto falado, como se um compensasse a existência do outro" (2002:13). A musicalização, em geral, se mantém associada à ideia de "estabilidade do canto" (2004: 42) ou de "ordenação" capaz de apaziguar a velocidade desagregadora da fala (1994: 266). A oralização, por sua vez, é tratada sobretudo como uma força que garante "naturalidade à elocução da letra" (2004: 42), enfatizando o teor linguístico e comunicativo da obra, mas também como um estímulo que sugere caminhos estéticos diferenciados. São "avanços" de linguagem (1994: 266) que, explorados pelos compositores, podem auxiliá-los a vencer uma indesejada hipertrofia em certo gênero cancional $^{57}$. É como se a fala impedisse uma demasiada padronização sonora, ao propor

\footnotetext{
${ }^{57}$ Esses "avanços" de linguagem, pautados no desenvolvimento do aspecto entoativo da canção, consistem justamente na técnica que embasa as proposições vanguardistas que marcam o começo dos estudos da semiótica da canção, bem como as propostas artísticas do Grupo Rumo. São mecanismos que, como
} 
contornos que, à serviço da entoação, muitas vezes desconfiguram os motivos melódicos. Enfim, imbuído desse princípio de oscilação entre oralização e musicalização, o autor detecta, na história da canção brasileira, a presença de canções e cancionistas que ora pendem para o lado da fala, ora para o lado da música.

Sinhô mandando recados a seus desafetos através da canção, Noel Rosa e Wilson Batista criando polêmica e desenvolvendo farta argumentação em suas obras, as vozes entoativas de Noel, Lamartine Babo e Mário Reis, o tom de oratória dos sambas de exaltação, o samba de breque, os ditos populares estampados nas marchinhas de carnaval, isso tudo sempre realçou a atração exercida pela fala. Da mesma forma, em direção oposta, o canto cerimonioso, e por vezes empolado, de diversos intérpretes (de Silvio Caldas a Vicente Celestino, passando pela última fase de Francisco Alves), a estabilização dos gêneros rítmicos, a letra "quase-literária" (de Cândido das Neves, algumas de Sinhô, de Pixinguinha e dos mestres do samba-canção como Cartola, Nelson Cavaquinho e mesmo Lupicínio Rodrigues), agiam no sentido de negar, ou sublimar, a presença incômoda da fala que, enquanto tal, não contribuía para a liturgia artística. (1994: 263)

Se notamos essa oscilação nos diferentes estilos cancionais de cada compositor ou no conteúdo de diferentes movimentos artísticos, devemos igualmente salientar que, em geral, em uma mesma canção, estão mobilizados simultaneamente os dois processos musicais (tematização e passionalização) e o processo da figurativização. A canção Coqueiro de Itapoã de Dorival Caymmi exemplifica muito bem essa coexistência dos três mecanismos.

Coqueiro de Itapoã, coqueiro

Areia de Itapoã, areia

Morena de Itapoã, morena

Saudade de Itapoã me deixa

Ó vento que faz cantiga nas folhas

No alto do coqueiral

Ó vento que ondula as águas

Eu nunca tive saudade igual

Me traga boas notícias

Daquela terra toda manhã

comentamos no início deste capítulo, fazem parte de um contexto maior ligado à arte experimental realizada no Brasil a partir da década de 1960, no qual acreditava-se que o valor artístico de uma obra se ligava, sobretudo, ao que ela propunha como "novidade estética". 
E joga uma flor no colo

De uma morena em Itapoã
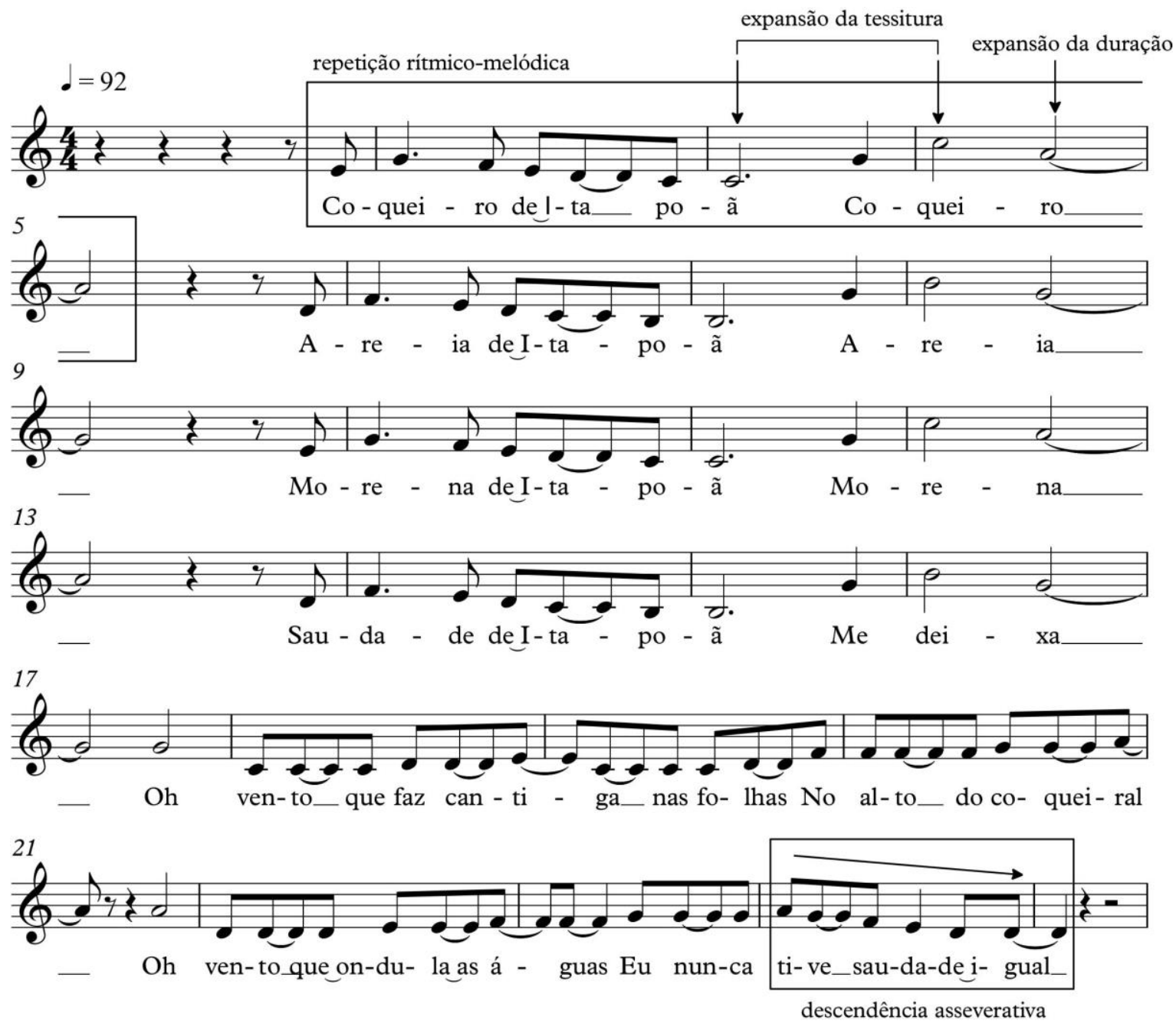

Figura 35. Saudade de Itapoã (Dorival Caymmi)

Como notamos, o sentimento de falta expresso na letra (sobretudo pelos versos "Saudade de Itapoã, me deixa" e "Eu nunca tive saudade igual") se compatibiliza com o andamento desacelerado, com a expansão das durações (principalmente nos finais de cada verso) e com a ampliação da tessitura, quando o cantor repete os itens dos quais o sujeito sente falta: "coqueiro", "areia" e "morena". Nesse momento, a melodia perfaz a distância de uma oitava. Essas características sonoras, aliadas ao conteúdo disjuntivo, configuram uma típica canção passional. Por outro lado, no entanto, podemos observar uma disposição fortemente reiterativa que atenua esse mesmo teor passionalizante, pois, como destacamos na figura acima, os quatro primeiros versos são recobertos por quase idêntica conformação rítmico-melódica. Além disso, o texto verbal também valoriza a identidade entre as partes: a palavra Itapoã está presente em todos os segmentos e todos os itens 
pertencentes à famosa localidade são repetidos ao final de cada verso, misto de lamento e homenagem. Essa reiteração, pois bem, expressa a conjunção vivida à distância pelo sujeito. Ao mesmo tempo em que está distante de Itapoã (distância que justifica o tom de lamento do canto), o sujeito expressa a conjunção já vivida com o objeto, decantando-o. Passionalização e tematização aparecem aqui entrelaçadas.

Pairando sobre esses movimentos musicais e afetivos, os indícios de entoação não deixam de estar presentes, sobretudo pelas descendências asseverativas, como em "Eu nunca tive saudade igual" (compasso 24 e 25). Além disso, a interjeição "ó" formando o vocativo “ó vento", própria do discurso direto, é, por isso, uma expressão típica da língua oral, conferindo ênfase ao chamamento. Enfim, sem realizarmos uma análise mais detida da obra, desejamos somente pontuar de forma breve a concomitância dos três processos cancionais, em geral, sempre atuantes nas canções.

Partindo da ideia da simultaneidade dos processos musicais da tematização e da passionalização e do processo da figurativização, podemos tratar o fenômeno cancional como uma oscilação entre forma musical e força entoativa, conceitos que o autor desenvolve em publicações mais recentes, apesar de estarem potencialmente presentes desde o início de sua pesquisa. Em Elos de melodia e letra: análise semiótica de seis canções (2008), livro escrito juntamente com o semioticista Ivã Carlos Lopes, notamos pela primeira vez o aparecimento dessas denominações.

Precisamos lembrar ainda que a melodia da canção brasileira - assim como a de numerosos tipos de canção que grassam pelo planeta - oscila entre a força criadora que emana das entoações de nossa linguagem oral e a forma estruturadora que pertence à linguagem musical propriamente dita $(2008,52)$

Nesse momento, novos termos são utilizados para abordar um fenômeno já presente em publicações anteriores, como registramos em fragmento de $O$ cancionista citado acima, cuja primeira edição é de 1996: trata-se do entendimento da canção como a "constante flutuação entre o canto musicado e o canto falado" (2002:13). Agora, opondo forma e força e situando a canção nesse permanente vagar entre os dois extremos, tornase possível delimitar de maneira mais objetiva os limites da linguagem cancional. Ou seja, para efeitos de análise, a partir dessa perspectiva, somos capazes de avaliar o grau de influência de cada um dos polos em determinada obra e localizá-la dentro de uma escala que parte da ausência absoluta da fala até a ausência absoluta da música. Quando uma 
canção atinge algum desses limiares, temos, segundo o autor, "certa paralisação do funcionamento regular da linguagem cancional" (2016:47). De um lado, "a palavra falada enquanto tal, sem música" e, de outro, uma "peça musical e não mais numa canção" (2016:157). Segundo Tatit, uma atuação exclusiva de uma dessas instâncias impede que se configure a linguagem cancional, já que, nesses casos hipotéticos, observaríamos somente a linguagem musical ou verbal, isoladas. Via de regra, no entanto, os cancionistas jamais atingem essas duas extremidades, sempre equilibrando a fala e a música em suas combinações de letra e melodia. Afinal, a extinção total da fala significaria a perda do "efeito enunciativo que toda canção alimenta" (2002:12), essencial para o envolvimento dos ouvintes com o conteúdo da letra. Do mesmo modo, a extinção completa da música, além de inviabilizar a perenização da obra (destituída de forma sonora estável), retiraria igualmente todas as ricas possibilidades de sentido geradas pela relação entre o texto verbal e os parâmetros puramente musicais (maior ou menor duração, alturas graves ou agudas, aceleração ou desaceleração etc.). Assim, intuitivamente, os cancionistas fazem a dosagem das intensidades de fala e música "restabelecendo o que está prestes a se extinguir e atenuando o que se mostra excessivo" (2016: 62). Esses ajustes foram sistematizados pela semiótica tensiva por meio do quadro das direções tensivas, como observamos na figura abaixo (2016:36).

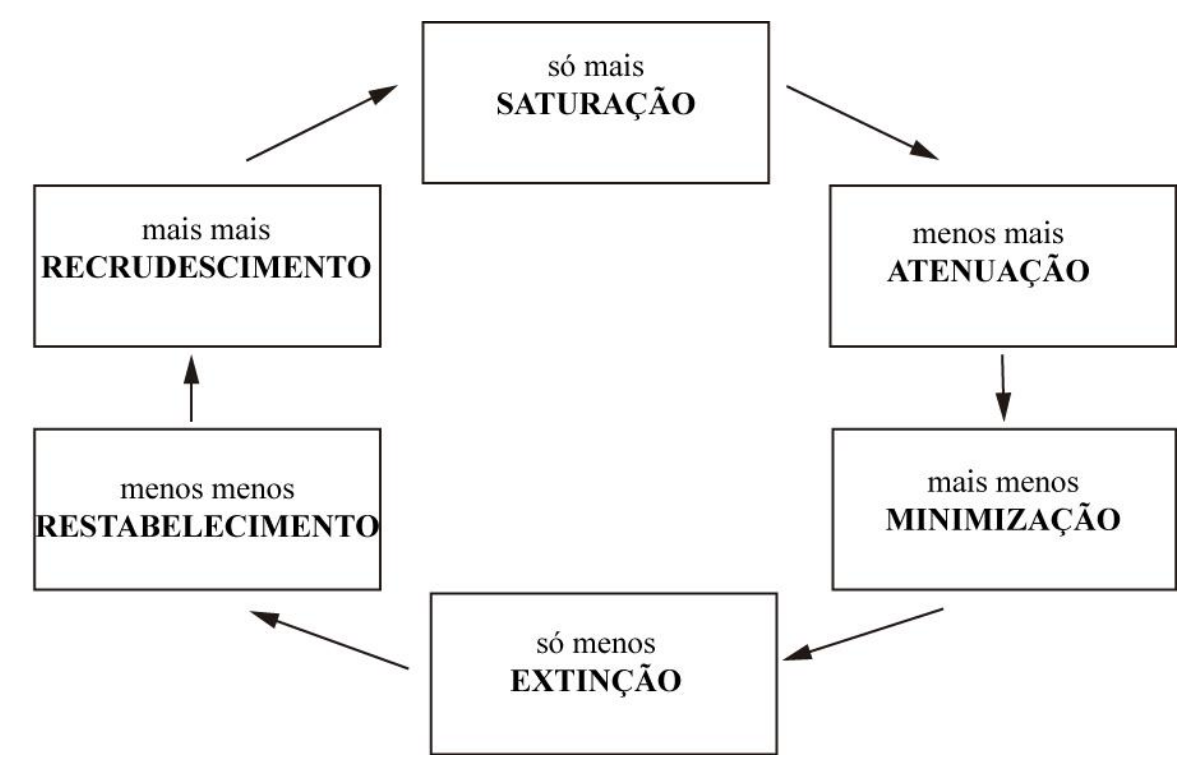

Figura 36. Quadro das direções tensivas

Utilizando dispositivos de intensidade representados pelas noções de mais e de menos e pelos movimentos de ascendência e descendência, somos capazes de, por 
exemplo, analisar de maneira mais aproximada os diferentes níveis de presença de fala e música na canção. Se elegermos a fala como parâmetro para o quadro acima, poderemos organizar a seguinte disposição de estilos ou obras cancionais.

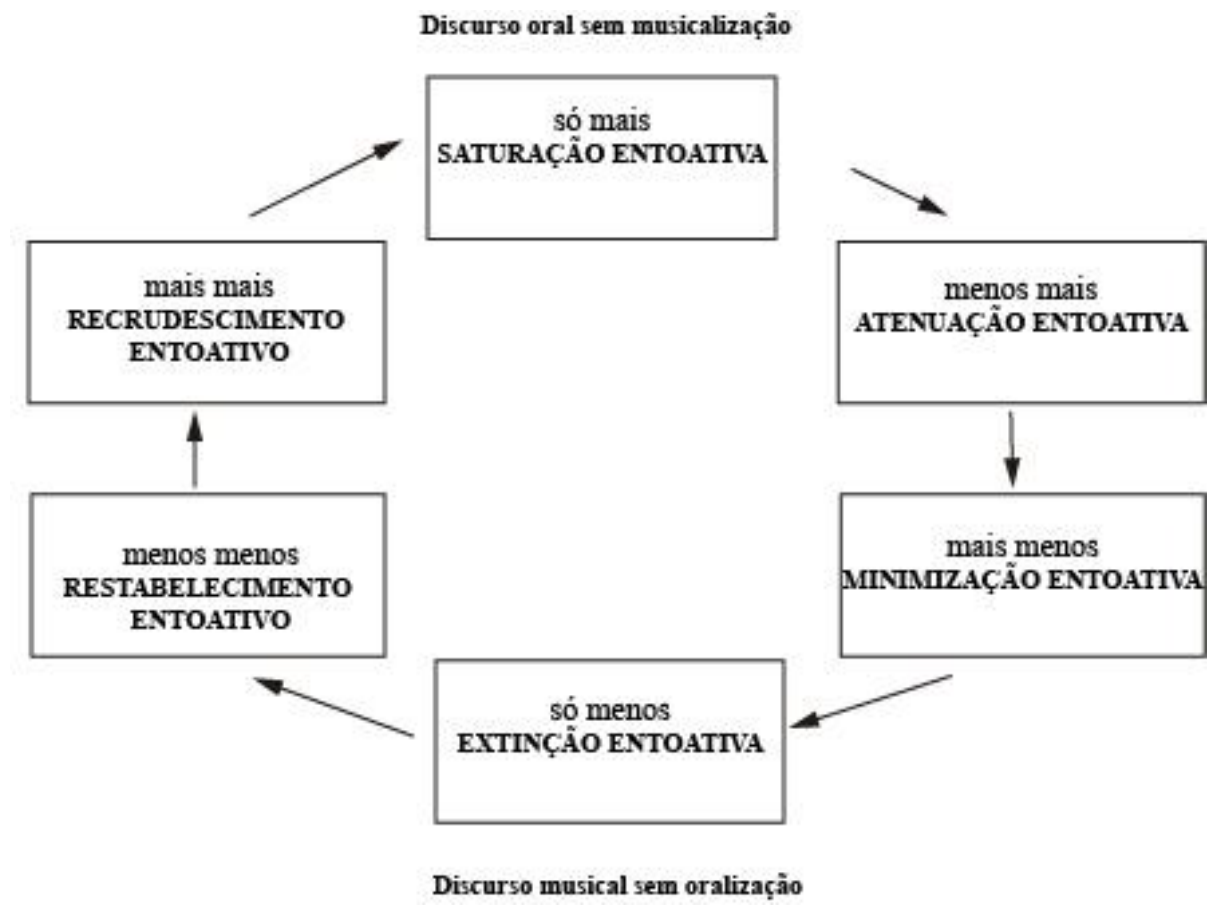

Figura 37. Quadro das direções tensivas regido pelo parâmetro da entoação

Assim, cada vez que aumentamos a quantidade de mais, seguimos na direção da saturação, cujo limite consiste em um discurso falado, sem qualquer musicalização. Por outro lado, quando diminuímos a quantidade de mais (menos mais) atenuamos a presença da fala e seguimos em direção à minimização e posteriormente à extinção da oralidade, em cujo ponto mais extremo, encontraríamos uma peça musical sem qualquer teor entoativo. Ou seja, são com esses dispositivos, entre outras questões musicais e poéticas, que os cancionistas “"temperam' suas criações” (2016:16), dosando intuitivamente a quantidade de fala e de música em suas obras e, consequentemente, fundando os seus próprios estilos de composição. Utilizando o modelo teórico acima, somos capazes de identificar de maneira mais precisa o caráter ora mais musical (como Tom Jobim), ora mais entoativo (como Mano Brown) dos cancionistas. Mais do que isso, acreditamos que o modelo explicita a especificidade do trabalho cancional, isto é, o seu mecanismo de dosagem de fala e de música. Diferentemente, o músico não se preocupa com a relação entre essas duas instâncias, mas sim com questões predominantemente sonoras. Da mesma forma, o trabalho do poeta não consiste no desenvolvimento dessa combinação 
entre o texto e a melodia, ainda que as questões sonoras sejam, sob outra perspectiva, cruciais. O cancionista é aquele cujo trabalho está voltado justamente para essa compatibilização.

Trata-se, como se pode ver, de um procedimento diferente daquele que tenta avaliar uma canção pela qualidade dos versos tomados de um ponto de vista literário ou pela qualidade da melodia sob um enfoque musical. O que o compositor nos apresenta é uma proposta de integração e não uma proposta de justaposição de linguagens paralelas. (1983: 104)

Enfim, os aspectos observados no decorrer deste capítulo nos permitem considerar a originalidade da abordagem da canção realizada por Tatit, ao desvencilhá-la das perspectivas musicais e literárias. A definição de uma atividade artística específica valoriza o trabalho do cancionista, pois entende a particularidade do seu artesanato, propondo ferramentas analíticas que nos permitem acessar suas reais questões e complexidades: as inúmeras possibilidades de combinações entre letra e música e jamais a criação isolada de uma ou de outra. Como considerar o cancionista um músico limitado ou um poeta imaturo se ele não faz música nem poesia? Trata-se, portanto, de uma postura teórica ao mesmo tempo científica, por seu rigor descritivo, e política, por estar atenta à compreensão do fenômeno como uma linguagem humana, sem enfatizar juízos culturais de valor. É possível fazer um interessante paralelo entre essa postura teórica assumida pelo autor e o surgimento da linguística moderna no início do século XX. Ao propor um estudo descritivo da língua (evitando a prescrição de uma norma a ser seguida, tão comum aos gramáticos do século XIX), a linguística permitiu a elucidação de seus fenômenos próprios, muitas vezes equivocadamente considerados "erros gramaticais" cometidos por "falantes incultos"58. A semiótica da canção, semelhantemente, propõe um olhar descritivo sobre a produção de canção, explicitando processos composicionais que, ao final, são utilizados por todos os compositores, de Mano Brown a Chico Buarque. É uma teoria mais preocupada com o detalhamento dos fenômenos cancionais do que com o estabelecimento de julgamentos estéticos, geralmente ligados a ideologias, contextos culturais etc. A nosso ver, o seu foco está em explicitar o mecanismo por meio do qual os compositores criam suas obras, isto é, apontar os diversos meios de combinação entre

\footnotetext{
${ }^{58}$ Esse assunto está inserido em um campo de estudos relativamente recente no qual se examina a questão do chamado "preconceito linguístico". Para um primeiro contato com a questão, recomendamos a leitura das seguintes obras de Marcos Bagno, importante autor da área: Preconceito linguístico - o que é, como se faz (Ed. Loyola, 2000) e A língua de Eulália: novela sociolinguística (Ed. Contexto, 2001).
} 
letra e melodia que, como vimos, podem oscilar entre os polos da música e da oralidade. Mais uma vez, então, a ideia de oscilação aparece como um princípio fundamental para a teoria.

Consequentemente, como se pode imaginar em relação ao advento de qualquer nova abordagem, a semiótica da canção, assim como a linguística moderna, gerou simultaneamente fascínio e desconforto no círculo de pesquisadores de sua área de atuação. Mesmo que brevemente, é interessante meditarmos sobre algumas das críticas mais recorrentes a ela dirigidas. A primeira delas condena uma suposta predileção dos aspectos entoativos em detrimento dos elementos musicais, como se a teoria priorizasse a origem da canção na fala. Como vimos acima, no entanto, essa avaliação não se sustenta na medida em que um dos focos principais da teoria é justamente perceber a gradação entre a música e a entoação. Supomos, no entanto, que esse frequente mal-entendido pode ser naturalmente explicado. Em primeiro lugar, acreditamos que, ao lançar suas primeiras publicações, encontrando terreno hostil à aceitação da canção como linguagem independente, diferente da música e da poesia, o autor precisou enfatizar fortemente a presença da fala na canção, como forma de mostrar a sua especificidade. Por outro lado, seguindo na mesma direção de seus trabalhos acadêmicos, a atividade artística do autor parecia afirmar a mesma ideia. Ou seja, pelas características fortemente entoativas de suas composições interpretadas pelo Grupo Rumo, é como se o autor tomasse a posição de um defensor da canção falada. Enfim, é possível que a junção de suas duas atividades (artística e intelectual) tenha suscitado o entendimento incompleto de que a canção surgiria unicamente da entoação da língua oral ou de que a melhor canção seria aquela mais próxima da fala. Contudo, como constatamos acima, fica claro que o autor desenvolveu sua reflexão no sentido de valorizar a oscilação entre a fala e a música, desde seu primeiro livro, com a presença da figurativização, de um lado, e dos processos temático e passional, de outro.

A segunda crítica comumente dirigida à semiótica da canção refere-se ao aparente abandono de questões musicais como o arranjo, a instrumentação, a harmonia etc. De pesquisadores que iniciam o estudo da semiótica da canção, é comum escutarmos frases como: "Mas a canção não é apenas melodia e letra. Eu presto mais atenção no arranjo e na música”. Realmente, como comentamos anteriormente, o ponto nevrálgico da teoria está concentrado no exame da relação entre a melodia e a letra. Afinal, como colocar o arranjo ou a harmonia como questão primordial para o estudo da canção se diversos cancionistas nunca fizeram um arranjo e muitas vezes não tocam instrumentos 
harmônicos? A nosso ver, Tatit, sem deixar de destacar a importância do arranjo e da música, o que assinala desde o seu livro de estreia (1986: 62-63), pretende somente firmar um núcleo essencial comum a todos os cancionistas. Obviamente, fruir uma canção significa ter uma experiência sonora da qual faz parte o arranjo e a mixagem do fonograma, por exemplo. Porém, o fato de o estudo centrar-se na relação entre a linha melódica e o texto verbal não impede de forma alguma a investigação desses outros aspectos sonoros. Acreditamos que, com as ferramentas concedidas pela semiótica da canção, a partir do exame da relação entre melodia e letra, podemos analisar o arranjo de determinada canção e muitas outras decorrências musicais com maior riqueza e profundidade. A letra-melodia consiste, então, em um núcleo de sentido do qual emanam ideias de arranjo, instrumentação, interpretação, videoclipe etc. Mesmo que se inicie a composição de uma canção por sua parte instrumental, por seu arranjo ou pela composição de uma melodia sem texto verbal, ainda assim, a relação entre a melodia e a sua futura letra cumprirá uma função essencial na obra. Ou seja, mesmo que a letra seja criada muitos anos depois da concepção da melodia, como no caso da canção Carinhoso, ainda assim, essa relação possuirá significações que, se ignoradas, farão com que a análise se torne exatamente idêntica à análise de uma música instrumental.

Finalmente, pudemos observar que a semiótica da canção constitui um campo ainda em desenvolvimento. Embora certas ocorrências tenham se mantido desde as suas publicações iniciais (a elasticidade melódica, os tonemas, as faixas entoativas etc.), muitas outras questões foram sendo pouco a pouco incorporadas e aprofundadas pelo autor, como, por exemplo, a análise das unidades entoativas. Em se tratando de uma teoria em permanente elaboração e, por isso, aberta a novas nuances e perspectivas, enxergamos aqui uma área muito promissora para o pesquisador interessado em canção. Ao mesmo tempo, entendemos que ela pode ser perfeitamente combinada com outras propostas analíticas, e mesmo com abordagens puramente musicais ou literárias. Isto, porque a análise musical do arranjo ou o exame literário da construção poética da letra certamente se enriquecerão quando contemplarem o estudo da relação entre a letra e a melodia proposta pelo compositor. Por outro lado, é claro, não devemos ignorar a natural dificuldade na recepção da semiótica da canção por parte dos estudiosos do assunto. A teoria apresenta, de certo modo, uma revisão radical do trabalho do compositor de canções. Como comentamos, para os estudiosos tradicionais, o bom compositor de canções é o bom músico que cria melodias ou o bom poeta que inventa letras. Assim, torna-se custoso consolidar uma teoria que não se guia pelos parâmetros literários ou 
musicais, mas sim pela relação entre texto verbal e música, relação fundadora da linguagem da canção. Além disso, por se tratar de uma abordagem específica, distinta da teoria literária, da musicologia ou da sociologia (áreas que geralmente se dedicam à canção), traz consigo uma terminologia própria que muitas vezes dificulta o acesso do pesquisador interessado ou gera nele possíveis estranhamentos por abordar questões já conhecidas ou intuídas a partir de outras denominações. Assim, há, naturalmente, uma dificuldade inicial para a difusão da semiótica da canção, já que os seus códigos não são compartilhados por grande parte dos estudiosos do assunto. Como comentamos acima, porém, acreditamos ser perfeitamente possível e fértil, o convívio entre todas essas abordagens. No capítulo seguinte, estudaremos o conceito de figurativização na semiótica geral, além de outras noções correlatas, com o intuito de compreender de modo mais aprofundado a questão da remissão à fala, bem como comentar, mesmo que brevemente, a teoria geral da qual se originou a semiótica específica da linguagem cancional. 


\section{A FigurativizaÇão NA SEMiótica GERAL}

Após discutirmos a figurativização na semiótica específica da canção (assunto mais acessível aos interessados em música popular), podemos seguir para a sua contextualização dentro da semiótica geral. Antes de entrarmos no campo da figuratividade ${ }^{59}$, no entanto, devemos situá-lo dentro do quadro geral da teoria e, para isso, precisaremos traçar um breve panorama histórico e metodológico da semiótica padrão. Acreditamos que essa exposição será proveitosa para os leitores deste trabalho, principalmente para pesquisadores de outras áreas que, ao entrarem em contato com a disciplina, frequentemente se deparam com uma terminologia própria que torna a tarefa inicialmente dificultosa. Assim, tendo em vista o fato de esta tese interessar sobretudo aos estudiosos de canção popular (que raramente possuem algum conhecimento sobre o assunto), a ocasião nos parece propícia para realizarmos uma aproximação mais cautelosa do tema ${ }^{60}$.

A título de introdução, antes de entrarmos propriamente nos assuntos deste capítulo, precisamos delinear o seu campo de estudo, bem como situar as suas principais fontes teóricas. Por se tratar de uma área relativamente recente e em constante desenvolvimento em diversas partes do mundo, a semiótica mostra-se, por vezes, exposta a alguns desentendimentos teóricos. Primeiramente, constatamos que há uma concorrência em relação ao nome "semiótica", visto que diferentes campos do conhecimento utilizam a mesma denominação. Além disso, dentro de uma corrente específica, como a semiótica francesa, por exemplo, notamos, no desenvolvimento de sua

\footnotetext{
59 Devemos diferenciar os termos "figuratividade" e "figurativização". O primeiro corresponde ao campo geral de estudo de construção das figuras e o segundo, mais específico, consiste no próprio processo de construção.

${ }^{60}$ Consideramos ser proveitoso, para o músico ou pesquisador que deseja estudar a semiótica da canção de modo mais profundo, tomar conhecimento do modelo padrão da teoria geral da qual se originou a proposta de Tatit. Cremos que, ao entrarmos em contato com os conceitos e com o método semiótico, entenderemos de maneira mais precisa e fundamentada diversas propostas do autor, não somente em relação às noções de figurativização, passionalização e tematização, mas igualmente no que se refere a outros princípios abordados por sua teoria.
} 
história, certa concomitância entre os termos "semiótica" e "semiologia", usados para denominar a mesma área de pesquisa. Devemos, então, aclarar o emprego de todas essas designações.

Num primeiro momento, podemos nos debruçar sobre as definições "semiótica" e "semiologia" diferenciando-as da "semântica", mais ligada ao estudo das significações lexicais e sua transformação ao longo do tempo (semântica histórica) ou ao exame do sentido das palavras em um sistema linguístico considerado estável num dado momento (semântica sincrônica). A semiologia e a semiótica vão além desse universo de análise proposto pela semântica, pois, mais do que investigar a palavra, a oração e o período nas línguas naturais, elas pretendem, de modo mais globalizante, estudar os significados dos discursos em diferentes linguagens, verbais ou não verbais (BERTRAND, 2003:12).

Por outro lado, a diferença entre semiologia e semiótica (termos frequentemente considerados sinônimos no campo das ciências da linguagem) nos parece mais sutil. Saussure idealizava a semiologia como uma futura "ciência geral" (da qual a linguística seria apenas uma parte) que teria por objetivo estudar o universo dos signos, para além da língua ${ }^{61}$. Essa definição de semiologia trazia consigo um caráter mais abrangente ao propor o estudo do signo em diferentes linguagens: verbais (escrita ou oral), não verbais (musical, plástica, visual, espacial, gestual etc.) e sincréticas (cinema, teatro, canção etc.). No entanto, a despeito da tentativa de se realizar uma teoria com feição mais ampla, a semiologia em geral se associou a uma concepção mais redutora de análise, estudando sistemas de signos em códigos de sinais mais informativos e referenciais (por exemplo, em códigos de trânsito e sinalizações). Diferentemente, os estudos ligados à semiótica deixam de privilegiar os signos e suas codificações para investigar o sentido suscitado por eles quando articulados em uma organização específica. Há então uma base estrutural que fundamenta o exercício semiótico: "seu objeto não é o signo, mas as relações estruturais, subjacentes e reconstruíveis, que produzem a significação" (BERTRAND, 2003: 15).

Em relação à denominação "semiótica", é preciso sublinhar a coexistência de mais de uma teoria que adota o mesmo nome. No Brasil, as duas concepções mais difundidas (e cujos objetos são, contudo, muito distintos) são a semiótica americana e a semiótica europeia ou francesa (também conhecida como "Escola de Paris"). A primeira se baseia nos estudos do lógico e filósofo Charles Sanders Peirce (1839-1914). Sumariamente,

61 “Ciência que estuda a vida dos signos no seio da vida social”" (SASSURE, 2006 :24). 
podemos dizer que ela se dedica à análise do modo de produção do signo e dos esquemas de raciocínio (dedução, indução, abdução) e à sua ligação com a realidade referencial por meio do "interpretante", o que dá suporte para uma classificação dos signos (ícone, índice, símbolo) (BERTRAND, 2003: 13). Trata-se, então, de uma semiótica mais ligada à cognição e à lógica.

De modo distinto, a origem da semiótica francesa está fundamentada principalmente em teorias da linguagem, tendo, desde o início, se dedicado ao estudo de textos orais e escritos, sobretudo literários. As elaborações teóricas de Ferdinand de Saussure (1857-1913) estão na base de sua metodologia, assim como os estudos de um de seus continuadores, Louis Hjelmslev (1899-1965), dedicados à descrição formal do plano do conteúdo das línguas. Esses dois teóricos influenciaram decisivamente a constituição de uma ciência do sentido, liderada por Algirdas Julien Greimas (1917-1992) a partir da década de 1960. Atualmente, há diversos autores que, fundamentados na teoria greimasiana, propõem novos desenvolvimentos semióticos, tais como Eric Landowski (sociossemiótica), Per Aage Brandt (semiótica cognitiva), Jacques Fontanille (semiótica visual) e Claude Zilberberg (semiótica tensiva).

A origem da semiótica europeia, no entanto, não possui apenas uma fonte linguística ${ }^{62}$. Há também uma procedência antropológica, sobretudo ligada à antropologia estrutural de Claude Lévi-Strauss (1908-2009), que valoriza os seguintes aspectos: a prática cultural do discurso que molda a expressão individual (rituais, hábitos etc.); as leis comuns a diversas culturas que orientam as formas discursivas e narrativas; e a supremacia de uma visão estrutural sobre a realidade. Além disso, a "versão binarista do estruturalismo" (ZILBERBERG, 2006: 95), associada aos linguistas Nikolay Trubetzkoy (1890-1938), Roman Jakobson (1896-1982) e André Martinet (1908-1999), embasou o trabalho de Greimas com as estruturas elementares da significação, o que estudaremos adiante no momento em que tratarmos do nível fundamental do percurso gerativo. Ainda pelo viés estruturalista, a narratologia de Vladimir Propp (1895-1970), por seu estudo dos elementos e mecanismos presentes no conto maravilhoso russo, inspirou fortemente a teoria narrativa de Greimas.

Por fim, temos igualmente uma fonte filosófica ligada à fenomenologia de Edmund Husserl (1859-1938) e Maurice Merleau-Ponty (1908-1961). Os estudos

\footnotetext{
${ }^{62}$ Sobre a origem da semiótica francesa e seu quadro de influências recomendamos a leitura do capítulo "Greimas e o paradigma semiótico", presente na obra Razão e Poética do Sentido de Claude Zilberberg (2006: 91-126).
} 
fenomenológicos localizam a significação em um espaço entre o sensível e o inteligível, “entre a ilusão e a crença partilhada, na relação reciprocamente fundadora entre sujeito sensível e objeto percebido" (BERTRAND, 2003: 17), o que se relaciona com a abordagem semiótica que relativiza o sentido, sempre suspenso e dependente do discurso que o expressa.

Nesta tese, nos dedicaremos somente à semiótica de origem francesa, pois é a partir dela que se desenvolve a semiótica da canção. Nesse momento, tentaremos delimitar melhor seu objeto e suas metodologias para que possamos, enfim, localizar e estudar o conceito de figurativização com maior propriedade, dentro de sua teoria. Discutiremos, neste capítulo, entre outras questões surgidas ao longo de nossas reflexões acerca da teoria greimasiana, quatro principais assuntos: o percurso gerativo do sentido, a figuratividade, a veridicção e a noção de isotopia. Passemos, então, para o nosso primeiro item. 


\subsection{Da manifestação concreta à estrutura abstrata: o percurso gerativo do sentido}

O modelo clássico de análise do sentido criado pela semiótica francesa, cujo alvo é, para além da palavra e da frase, o discurso, se apresenta como um trajeto que percorre diversos níveis de profundidade. Parte-se da manifestação concreta, particular e complexa de um texto específico e chega-se às suas formas de estruturação mais abstratas, gerais e elementares, comuns a muitos outros textos. Por outro lado, como modelo de base para se conceber a geração do sentido, costuma-se pensar a construção da significação de um texto a partir de um caminho inverso: parte-se das estruturas mais simples às estruturas mais complexas, como se ocorresse um enriquecimento gradativo, nível após nível, numa sucessão de patamares. Esse processo que simula a geração do sentido, das estruturas profundas às estruturas de superfície, é denominado "percurso gerativo".

O modelo padrão propõe três níveis: fundamental, narrativo e discursivo. Cada uma dessas camadas de profundidade possui um componente sintáxico (esquema relacional com regras de combinação e encadeamento dos elementos) e um componente semântico (investimentos de carga semântica, mais abstratas ou mais concretas). Nosso intuito é realizar uma breve caracterização de cada uma delas. Dessa maneira, percorrendo esses estratos de sentido, do mais abstrato ao mais concreto, acreditamos que o leitor poderá vislumbrar de modo mais preciso a função desempenhada pela figurativização no interior do sistema.

O nível mais profundo, das estruturas elementares, articula as categorias semânticas que embasam a construção dos discursos. A semântica do nível fundamental contém categorias que se estabelecem por uma oposição: /vida/ versus /morte/, /natureza/ versus /cultura/, /estaticidade/versus /dinamicidade/, /ordem/versus /desordem/ etc. Cada texto poderá ser reduzido, em seus estratos mais profundos, a termos opostos como esses, muitas vezes caracterizados como universais semânticos. Além disso, cada um desses termos também receberá uma qualificação tímica de /euforia/ (quando o termo for considerado um valor positivo) e /disforia/ (quando o termo for considerado um valor negativo). Por exemplo, em um poema no qual o eu-lírico lamenta a morte de sua amada, as categorias /vida/ e /morte/ são consideradas, respectivamente, eufórica e disfórica. Por outro lado, em um filme no qual uma personagem em estado terminal trava uma batalha judicial para obter do governo uma permissão para que a equipe médica realize uma conduta de eutanásia, a categoria /morte/ será eufórica e a categoria /vida/, disfórica. 
A sintaxe do nível fundamental contém duas operações, negação e asserção, que, quando aplicadas aos termos em oposição, delineiam a representação do chamado “quadrado semiótico". É a partir dessas operações que a significação do discurso pode ser narrativizada. Por exemplo, a suposta personagem em estado terminal que mencionamos acima poderá traçar um caminho que parte da /vida/ (quando na plenitude de suas faculdades vitais), passa pela /não-vida/ (quando hospitalizada) e chega à /morte/.

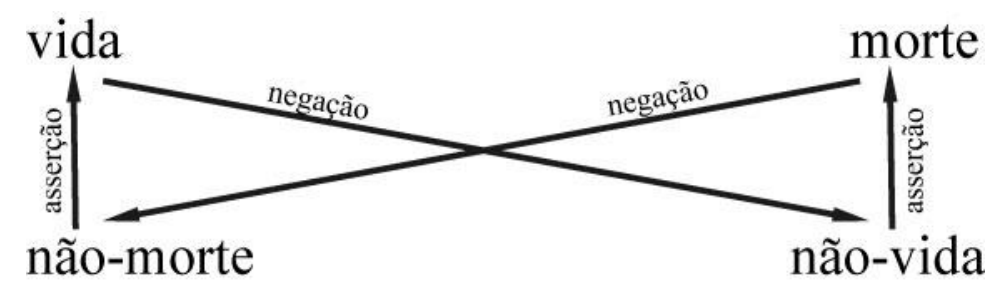

Figura 1. Quadrado semiótico articulando as categorias /vida/ versus /morte/

Nesse ponto, podemos passar para o nível narrativo, o estágio seguinte no percurso gerativo do sentido. À essa abstração máxima do nível fundamental, somaremos elementos mais concretos para formar uma estrutura que torne mais complexas essas passagens entre as categorias do quadrado semiótico.

A sintaxe narrativa contém duas espécies de enunciados elementares. Os enunciados de estado determinam uma relação de junção (conjunção ou disjunção) entre o sujeito e o objeto: o enunciado "A canção é bonita" contém um sujeito "canção" em conjunção com um objeto "beleza”. Em "Maria não é feliz”, há uma relação de disjunção entre um sujeito "Maria" e um objeto "felicidade". Diferentemente, os enunciados de fazer representam as transformações, as mudanças de um enunciado de estado a outro enunciado de estado: em "Iracema morreu" há uma transformação de um estado inicial "viva" (Iracema em conjunção com a vida) em um estado final "morta" (Iracema em disjunção com a vida).

A partir desses exemplos, constatamos a existência de uma sintaxe actancial, isto é, a presença de funções narrativas (sujeito, objeto, destinador, destinatário, antissujeito etc.), anteriores aos investimentos mais superficiais. Assim, não devemos confundir a noção de actante com a noção de personagem. Em "O carro matou Iracema", há um sujeito "carro" e um objeto "Iracema". Em "Iracema se matou", "Iracema" corresponde tanto ao sujeito como ao objeto do enunciado, desempenhando simultaneamente dois papéis narrativos. Os dois tipos de enunciado que mencionamos acima representam 
elementos narrativos mínimos. Os textos, no entanto, são estruturas muito mais complexas que organizam e combinam diversos enunciados de estado e de fazer, formando programas narrativos.

A narrativa complexa se fundamenta em uma sequência canônica formada por quatro fases: a fase da manipulação e contrato (na qual o destinador se dirige a seu destinatário para leva-lo a /querer/ ou /dever fazer/ alguma coisa), a fase da competência (na qual o sujeito que realizará a ação é provido de um /saber/ ou /poder fazer/), a fase da performance (na qual o sujeito realiza a ação, isto é, a transformação narrativa com a mudança de um estado a outro) e a fase da sanção (na qual se verifica, por meio do julgamento de um destinador julgador, se o sujeito realizou ou não sua performance).

A semântica do segundo nível do percurso gerativo estuda os valores presentes na narrativa, dividindo-os em valores modais (/querer/, /poder/, /dever/ e /saber/) e valores descritivos (que definem o que o sujeito/objeto é ou possui). É preciso enfatizar que valores descritivos como /riqueza/, /vida/ ou /prestígio/ ainda constituem elementos abstratos. O valor /riqueza/, por exemplo, pode ser concretizado de variadas formas: “dinheiro", "propriedades", "cabeças de gado" etc. Por outro lado, podemos considerar o item concreto "carro" como a representação mais superficial de valores diversos tais como /riqueza/, /posição social/, /independência/, entre outros.

O terceiro e último nível proposto pelo modelo padrão da semiótica greimasiana, o nível discursivo, será responsável por revestir com elementos ainda mais concretos as formas abstratas do nível narrativo. A sintaxe discursiva tratará de duas questões: as diferentes projeções da enunciação (o ato de produção do discurso) no enunciado (produto da enunciação) e as relações argumentativas entre o enunciador (autor implícito) e o enunciatário (leitor implícito). Na prática, ambas aparecerão combinadas, já que as projeções da enunciação no enunciado têm como objetivo final fazer com que o enunciatário acredite no discurso comunicado pelo enunciador. Ao se debruçar sobre os vestígios da enunciação no enunciado, são estudados três procedimentos discursivos: a representação dos indivíduos (actorialização), do espaço (espacialização) e do tempo (temporalização). Assim, fará parte do projeto discursivo do enunciador, ordenar esses possíveis elementos componentes (“eu” versus "ele", "aqui” versus "lá" e "agora"versus "então") para gerar efeitos de proximidade ou distanciamento, concomitância ou não-concomitância e, dessa maneira, levar seu enunciatário a crer em seu discurso. 
Por fim, é justamente no âmbito da semântica discursiva que abordaremos as questões ligadas à figuratividade, principal propósito deste capítulo. Ela tratará da transformação dos percursos narrativos em percursos temáticos e, posteriormente, de sua cobertura figurativa. Como vimos acima, no nível narrativo, temos estruturas de significação ainda abstratas: um sujeito entra em conjunção com a /riqueza/. Mas quem é esse sujeito? A conjunção com a /riqueza/ foi resultado de um "enriquecimento ilícito por prática de corrupção" ou da "obtenção de herança de um parente falecido"? A/riqueza/ é concretizada como "um milhão de dólares" ou como “imóveis em Miami”? Enfim, é a semântica discursiva que concretizará todas essas instâncias do nível narrativo dando ao discurso coerência, produzindo efeitos de realidade e assegurando, consequentemente, a relação entre o discurso e o mundo.

Nesse ponto, chegamos na localização exata da área da figuratividade dentro do modelo da semiótica francesa, constatando que esse conceito pertence a um patamar mais concreto do percurso gerativo. Pensamos ser de grande importância para o leitor a possibilidade de visualizar, mesmo que de maneira simplificada, o lugar ocupado na teoria geral por essa noção fundamental para o estudo da canção popular, bem como compreender a estruturação do modelo a partir de seus diferentes níveis de profundidade e graus de concretização.

A análise do plano discursivo que incorpora essa perspectiva do percurso gerativo nos permite entender a unicidade dos fenômenos da significação, independentemente de sua forma de expressão. Assim, um filme e um romance podem apresentar manifestações textuais distintas de uma mesma significação. Semelhantemente, duas canções podem concretizar de modos variados um mesmo conteúdo abstrato. Por exemplo, o cotejo de três pares de obras muito conhecidas, as canções Luar do sertão e Lamento sertanejo, Chega de saudade e Como vai você e La vie en rose e And I love her ${ }^{63}$, nos possibilita observar concretizações distintas de conteúdos abstratos significativamente próximos: a oposição entre campo e cidade, a disjunção amorosa (e possibilidade de conjunção futura) e a conjunção amorosa, respectivamente.

Visualizemos então o seguinte quadro que organiza os conceitos comentados acima de acordo com o patamar em que eles estão localizados no percurso gerativo:

63 Luar do sertão (João Pernambuco/Catulo da Paixão Cearence); Lamento sertanejo (Dominguinhos/Gilberto Gil); Chega de saudade (Tom Jobim/Vinicius de Moraes); Como vai você (Antônio Marcos e Mário Marcos); La vie en rose (Louis Gugliemi/Edith Piaf); And I love her (Paul McCartney). 


\begin{tabular}{|c|c|c|}
\hline $\begin{array}{c}\text { NÍVEIS DO PERCURSO } \\
\text { GERATIVO }\end{array}$ & COMPONENTE SINTÁXICO & COMPONENTE SEMÂNTICO \\
\hline NÍVEL FUNDAMENTAL & - quadrado semiótico & $\begin{array}{l}\text { - categorias semânticas } \\
\text { fundamentais } \\
\text { - qualificações semânticas: /euforia/ } \\
\text { versus /disforia/ }\end{array}$ \\
\hline NÍVEL NARRATIVO & $\begin{array}{l}\text { - enunciados de estado e enunciados } \\
\text { de fazer } \\
\text { - actantes (funções narrativas) } \\
\text { - relações de conjunção ou } \\
\text { disjunção } \\
\text { - sequência canônica: manipulação, } \\
\text { competência, performance e sanção. }\end{array}$ & $\begin{array}{l}\text { - valores inscritos nos objetos } \\
\text { - valores modais: /querer/, /dever/, } \\
\text { /saber/ e /poder/ } \\
\text { - valores descritivos } \\
\text { - paixões: qualificações modais que } \\
\text { modificam o sujeito de estado }\end{array}$ \\
\hline NÍVEL DISCURSIVO & $\begin{array}{l}\text { - projeções da enunciação no } \\
\text { enunciado: actorialização, } \\
\text { temporalização e espacialização } \\
\text { - relações entre enunciador e } \\
\text { enunciatário }\end{array}$ & - tematização e figurativização \\
\hline
\end{tabular}

Figura 2. Percurso gerativo

A semiótica greimasiana, também chamada semiótica padrão, assim organizou o seu estudo. No entanto, certos tópicos desse quadro foram mais aprofundados do que os demais, priorizando-se, sobretudo, quatro áreas de análise: no nível narrativo, a narratividade e o exame das paixões e, no nível discursivo, a questão enunciativa e a figuratividade (BERTRAND, 2003: 27). A importância da pesquisa sobre a narratividade encontra-se na explicitação das estruturas que organizam a nossa percepção do mundo como uma narrativa: a organização actancial, a composição modal do sujeito (/querer/, /dever/, /saber/, /crer/ e /poder/) e o cumprimento das fases de manipulação, competência, performance e sanção, por exemplo, nos permitem desvendar a conformação dos discursos (relatos, contos populares etc.) que fazem parte de nossa história cultural. Mais do que o exame dos textos com os quais temos contato ao longo de nossas vidas, a própria existência do ser humano parece operar por meio de processos narrativos, como se fôssemos sempre sujeitos buscando seus objetos de valor.

Todavia, a perspectiva da ação não é capaz de explicar todos os sentidos do discurso, pois, para além das fases que formam o percurso do sujeito que age, há significações presentes nos intervalos das operações narrativas que precisam ser investigadas. É essa a lacuna teórica que o estudo da dimensão passional deseja suprir. Há toda uma existência do sujeito que transforma seus estados de alma de acordo com as 
relações que ele estabelece com objetos e valores eufóricos ou disfóricos, desejados ou rejeitados. A semiótica das paixões passa a direcionar a análise para o sujeito de estado, isto é, para as significações geradas pelas qualificações modais que modificam sua conformação emocional. Observemos a letra da canção Luz Negra, de Nelson Cavaquinho.

\section{Sempre só}

Eu vivo procurando alguém

Que sofra como eu tambem

E não consigo achar ninguém

Sempre só

E a vida vai seguindo assim

Não tenho quem tem do de mim

Estou chegando ao fim

A luz negra de um destino cruel

Ilumina um teatro sem cor

Onde estou representando o papel

De palhaço do amor

Aqui, a irrealizável conquista do objeto de desejo, cuja organização modal apresenta a oposição entre o /querer/ ("Eu vivo procurando alguém") e o /não-poder/ ("E não consigo achar ninguém"), resulta em uma estrutura passional que produz o sentido de lamento ou amargura. O sujeito, numa etapa anterior da sequência canônica (manipulação e contrato), configura-se como o destinatário de um destinador (um destino cruel) que somente lhe transmite o pessimismo de uma funesta luz negra.

Já no nível discursivo, a terceira área de análise muito presente nos estudos da semiótica greimasiana, a questão enunciativa, apresenta-se como um assunto de difícil acesso para os pesquisadores. $\mathrm{O}$ delicado exame da enunciação, que tende a incorporar problemas extralinguísticos, de certa maneira, se opõe ao princípio semiótico do estudo do discurso enunciado (que exclui os elementos externos ao texto). Ainda assim, a teoria realizou desenvolvimentos importantes na esfera do sujeito da enunciação, estudando sua presença no interior do discurso (o narrador, o observador e os interlocutores) e as operações de debreagem enunciativa (projeção do eu-aqui-agora como a pessoa, o espaço e o tempo do enunciado), debreagem enunciva (projeção do ele-lá-então como a pessoa, o espaço e o tempo do enunciado) e embreagem, conceitos que examinaremos adiante. 
Desse modo, mesmo que de maneira cautelosa, a teoria também trouxe importantes contribuições para o estudo dessa matéria.

Por fim, chegamos ao quarto e último tópico que, segundo Bertrand, também possui presença marcante no desenvolvimento dos estudos semióticos. Trata-se do conceito de figuratividade, assunto fundamental para a nossa pesquisa e para o qual devemos reservar, neste capítulo, um item à parte. 


\subsection{A figuratividade}

Como ocorre com muitas teorias e modelos analíticos, certos termos e conceitos são por vezes emprestados de outras áreas do conhecimento. É o caso dessa noção cuja origem remete à diferenciação entre a arte figurativa e a arte abstrata estudada pela teoria estética. Como sabemos, a arte figurativa propõe representações formais que se assemelham às imagens do mundo: a pintura de uma paisagem, a escultura de um herói nacional etc.

Para além das artes plásticas, na semiótica, esse conceito é utilizado na análise de todos os tipos de linguagem (verbal e não-verbal) e, da mesma maneira, se refere à capacidade de criar, mesmo que parcialmente, significações próximas das percepções concretas da realidade que nos circunda. Ou seja, ele produz, no discurso, "este efeito de sentido particular que consiste em tornar sensível a realidade sensível" (BERTRAND, 2003: 154). Pensando nos textos verbais, notamos a sua presença em grande parte dos gêneros discursivos: na literatura popular, na narrativa mítica, nas fábulas, nos ditados populares etc. Presenciamos nesses tipos de textos um maior grau de concretude que os diferencia dos discursos mais abstratos como, por exemplo, os textos científicos ou filosóficos. Definemos melhor esse conceito.

A teoria semiótica denomina como "figuras" os elementos das línguas ou de outros sistemas de representação que correspondem a componentes presentes no mundo natural. A figurativização, dessa forma, se caracteriza como um investimento semântico realizado a partir da inserção de figuras, concedendo maior concretude às categorias dos níveis anteriores do percurso gerativo. Na camada antecedente, em um enunciado de estado "sujeito em disjunção com o objeto" (S U O), o sujeito e o objeto são apenas posições sintáticas, papéis narrativos, e o programa narrativo representará o processo de tentativa de conjunção desse sujeito com seu objeto de valor.

\footnotetext{
Há, entretanto, mil maneiras de contar tal história. Dir-se-á que o discurso será figurativizado no momento em que o objeto sintático $(\mathrm{O})$ receber um investimento semântico que permitirá ao enunciatário reconhecê-lo como uma figura, como um automóvel por exemplo
} (GREIMAS, 2012: 211)

Ao concretizar a relação de junção do sujeito com o objeto como "uma busca do automóvel”, as outras instâncias da narrativa também são figurativizadas, especificando 
e particularizando ainda mais um conteúdo inicialmente abstrato. Assim, o sujeito se tornará um ator ("piloto de Fórmula 1", "João", "taxista" etc.) e haverá igualmente uma cobertura semântica do tempo (“década de 1990", "atualmente", “outono" etc.) e do espaço (“Autódromo de Interlagos", “estrada de terra”, "Nova York” etc.). Esses elementos (a actorialização, a temporalização e a espacialização) podem ser, como sugerimos nos exemplos acima, mais genéricos ou mais específicos, de acordo com "o grau desejável de reprodução do real" pretendido pelo enunciador (GREIMAS, 2012: 212). As figuras “João" e "Autódromo de Interlagos", por exemplo, são mais específicas do que "taxista" e "estrada de terra", respectivamente. Além disso, é necessário sublinhar que, se, por um lado, podemos recobrir um mesmo dado abstrato com diferentes figuras, por outro, podemos igualmente ter uma mesma figura manifestando diferentes itens abstratos. A figura “cartaz", por exemplo, pode concretizar tanto o tema da publicidade quanto o tema da passeata estudantil.

Por meio da figurativização, então, o enunciador pode criar "efeitos de realidade" (BARROS, 2001: 117). Vejamos. Na semiótica, costuma-se chamar de "referente" os itens da realidade designados pelas diferentes línguas. A denominação "objeto" é considerada insatisfatória, na medida em que o novo termo também pretende abarcar "as qualidades, as ações e os acontecimentos reais" (GREIMAS, 2012: 413). Assim, "automóvel", "bondade", "dirigir" e "atropelamento de um ciclista na Av. Paulista em outubro de 2014" são todos referentes do mundo para uma dada cultura.

Similarmente, a semiótica da canção, como vimos acima, também identificou a relação entre a melodia e a letra executada pelo cantor como um referente do mundo real, por sua proximidade com a fala. Assim, a figurativização entoativa cultivada pelos cancionistas produz o que podemos denominar "ilusão enunciativa" que, ligada a um contexto mais amplo, também pode ser considerada uma espécie de "ilusão referencial". Podemos analisar esse assunto recuperando um ponto que mencionamos há pouco, quando nos referíamos ao estudo da enunciação no interior do nível discursivo: são as operações de debreagem (enunciativa e enunciva) e de embreagem.

Esses dois recursos estão ligados à questão das projeções da enunciação no enunciado, constituindo mecanismos por meio dos quais o enunciador pode simular maior ou menor distância do texto. Vejamos. A enunciação, entendida como o ato de produção do discurso, pode deixar marcas no enunciado por ela produzido ou pode igualmente ocultá-las. Por exemplo, no enunciado "Eu digo que Deus não existe”, o enunciador insere o sujeito e o ato de enunciar ("Eu digo"). Por outro lado, no enunciado "Deus não existe", 
o enunciador omite "o simulacro do ato de enunciar" (FIORIN, 2008: 55). Para construir o seu discurso o enunciador utiliza as categorias de pessoa, de espaço e de tempo, fazendo uso de dois mecanismos: a debreagem e a embreagem. Vejamos os seguintes exemplos:

Chego agora aqui em casa e não encontro o livro que você me pediu.

Benjamin chegou ontem em sua casa e não encontrou o livro que Cecília havia lhe pedido.

No primeiro exemplo, operou-se uma debreagem enunciativa projetando-se um eu-aqui-agora enquanto que no segundo caso, houve uma debreagem enunciva (elealhures-então). Esses dois tipos de debreagem resultam, então, nos discursos de primeira e terceira pessoa, produzindo efeitos de subjetividade e objetividade, respectivamente. Ambas, no entanto, possuem um propósito comum de "fazer com que as coisas ditas pareçam, de acordo com o contexto discursivo, verdadeiras” (TATIT, 2002b: 203).

Diferentemente, no processo de embreagem, há "uma suspensão das oposições de pessoa, de tempo ou de espaço" (FIORIN, 2008: 74), como forma de criar efeitos de sentido variados. Um exemplo frequentemente utilizado para ilustrar esse tipo de mecanismo é o seguinte. Um adolescente diz à sua mãe: "O seu filho vai preparar um jantar especial para você". Vemos que, aqui, emprega-se simultaneamente elementos da debreagem enunciativa (eu/tu) e da enunciva ("o seu filho").

\footnotetext{
A embreagem, em sua acepção geral, corresponde justamente ao reengate de todos esses efeitos à instância da enunciação, de modo que se conceba tanto os recursos enuncivos quanto os enunciativos como procedentes da mesma fonte. Em outras palavras, se há coisas consideradas verdadeiras, há um responsável por essa verdade. A embreagem, em sua acepção específica, corresponde a processos estritos de uso do "ele" com valor de "eu" (ex.: Edson Arantes do Nascimento tecendo elogios a Pelé). (TATIT, 2002b: 204)
}

Em Estimar canções, com o intuito de investigar a instauração da ilusão enunciativa como um efeito de sentido promovido pelo canto, Tatit recupera o conceito de embreagem. Ao contrário do que observamos no enunciado linguístico, no qual o enunciador pode ocultar o ato de enunciar, no "enunciado-canção" a enunciação do cantor está sempre ativada (TATIT, 2016: 128), isto é, a presença da voz do intérprete impede que ele se distancie de seu processo de enunciação. 
Se a letra se desenvolve em primeira pessoa, as inflexões melódicas reforçam a conexão dos enunciados com o enunciador. Este não apenas diz “eu", mas também "entoa" concomitantemente suas emoções como qualquer falante em suas locuções diárias. Se a letra relata algo em terceira pessoa, os contornos entoativos impedem que o efeito de objetividade se imponha com plenitude. Os sentimentos atribuídos a "ele" são infletidos pelas modulações vocais do intérprete, portanto, do "eu". Tudo que a letra desconecta da enunciação, a melodia se encarrega de reconectar (TATIT, 2016: 129).

Esse cruzamento entre as instâncias do "ele" e do "eu", configurando um processo similar ao mecanismo de embreagem empregado na análise de textos verbais, é o responsável pela criação da ilusão enunciativa na canção. Por meio dessa embreagem cancional o público "vincula, quase automaticamente, os conteúdos da letra ao dono da voz" (TATIT, 2016: 130). Assim, ainda que o texto retrate temas aparentemente alheios ao intérprete, "a melodia se encarrega de aproximá-los da persona do cantor", impedindo que eles "sejam focalizados de maneira neutra sem envolvimento emocional" (TATIT, 2016: 130). Isso, ao final, permite que o ouvinte se sensibilize com a canção.

Se o canto tem o poder de transformar o "ele" em "eu", uma vez que os sentimentos atribuídos à terceira pessoa são modulados na voz da primeira, a expressão direta do "eu" na letra de uma canção, algo bastante corriqueiro, aguça a reconstituição do momento enunciativo e produz no ouvinte a ilusão de que o intérprete fala de si como ser humano: a personagem cancional se confunde com a personagem do mundo. Ao identificar-se com essa personagem do mundo, o ouvinte presta solidariedade aos intérpretes acompanhando o seu sofrimento nas canções passionais ou compartilhando com eles as alegrias das canções de encontro (TATIT, 2016: 130-131).

Essa força do canto que revela a presença de um corpo sensível e liga intimamente os cancionistas às suas respectivas canções é cuidadosamente calculada pelos compositores e intérpretes com o objetivo de distanciar ou aproximar o "sujeito do canto" dos "sujeitos do conteúdo cantado" (TATIT, 2016: 133). Evidentemente, esse processo está presente em diferentes linguagens artísticas, embora certas manifestações estéticas sejam mais suscetíveis à sua influência, sobretudo quando o corpo do artista participa da constituição de sua obra. Na televisão, no cinema e no teatro, por exemplo, os espectadores costumam associar fortemente o ator à sua personagem, a ponto de gerar constrangimentos e situações inusitadas. Na história da literatura também encontramos casos em que o público estabelece uma identificação entre as figuras ficcionais e os seus 
respectivos autores, como no conhecido processo judicial movido contra o escritor francês Gustave Flaubert (1821-1880) no qual o autor era acusado de ofensa à moral e à religião pelo comportamento de sua personagem Emma Bovary, protagonista do romance Madame Bovary, inicialmente publicado em fascículos em 1856. Enfim, são elos que os leitores, espectadores e ouvintes estabelecem entre os sujeitos do mundo e os sujeitos inventados pela criação artística.

Dito isso, é necessário observar que, ainda que tenhamos essa relação referencial entre a linguagem e o mundo, cada discurso (canção, poesia, cinema, texto científico etc.) produz o seu próprio referente interno. $\mathrm{Na}$ experiência de escuta de uma canção, esse fenômeno é nítido, pois não é a língua oral real que está presente na voz dos cancionistas, mas sim uma fala construída internamente, isto é, uma fala fictícia cuja forma de relação com a entoação é aceita pelo ouvinte. Não é tarefa da semiótica analisar o referente de forma independente da experiência do enunciado, mas sim investigar a referencialização que ele constrói, isto é, os procedimentos usados pelo enunciador para fundamentar um determinado efeito de sentido de realidade, com o auxílio dos processos de ancoragem espaço-temporal e da actorialização, por exemplo (GREIMAS, 2012: 415).

De todo modo, esse processo de figurativização do discurso não deve ser entendido como algo absoluto ou estático. A oposição entre concreto e abstrato (na semiótica muitas vezes representada pela oposição entre "figura" e "tema"), longe de ser uma relação imobilizada, funciona mais como um continuum em que se passa de um universo a outro de maneira gradual: os esquemas abstratos do nível narrativo podem ser revestidos com temas e produzir um discurso temático (não-figurativo) ou podem, após esse revestimento temático, ser ainda mais concretizados com a presença de figuras, produzindo um discurso figurativo ${ }^{64}$.

Dessa maneira, na semiótica greimasiana, devemos compreender a figurativização e a tematização como graus diferentes de concretização do sentido (FIORIN, 2008: 9091). Por exemplo, um discurso no qual um sujeito busca um /saber/ pode receber pouquíssimo investimento figurativo (como em um texto científico) ou ser completamente preenchido com figuras (como em um filme de espionagem no qual um detetive procura a solução de um crime). Ou seja, o mesmo esquema narrativo da busca do /saber/ recebe graus diferentes de investimentos figurativos, com variados níveis de especificação e o uso de antropônimos, topônimos e cronônimos mais ou menos

\footnotetext{
${ }^{64}$ Mais a frente, estudaremos o conceito semiótico de tematização de modo mais detalhado.
} 
genéricos. Essa noção de figurativização como um continuum já ocupava os estudos da semiótica padrão, quando Greimas identificava dois patamares nos procedimentos de construção das figuras:

(...) o primeiro é o da figuração, ou seja, instalação das figuras semióticas (uma espécie de nível fonológico); o segundo seria o da iconização, que visa revestir exaustivamente as figuras, de forma a produzir a ilusão referencial que as transformaria em imagens do mundo (GREIMAS, 2012: 212)

A figuração representaria o processo de conversão dos temas em figuras e a iconização um recrudescimento da cobertura figurativa com maiores "investimentos particularizantes" que produzem maior efeito de realidade (GREIMAS, 2012: 251). Nesse sentido, podemos considerar que os termos opostos abstração e iconicidade constituem, na verdade, estágios variados da figurativização (BERTRAND, 2003: 208). Como forma de representar essa gradação, seguindo o esquema do percurso gerativo, preparamos a seguinte ilustração:

\begin{tabular}{|c|c|c|c|}
\hline & \multicolumn{3}{|c|}{ FIGURATIVIZAÇÃO } \\
\hline NÍVEL NARRATIVO $\rightarrow$ & $\longrightarrow$ FIGURAÇÃO & $\longrightarrow$ & ICONIZAÇÃOO \\
\hline
\end{tabular}

Figura 3. A gradualidade do figurativo

Dentro do percurso gerativo do sentido, a iconicidade seria, então, o último patamar da figurativização do discurso, isto é, o ponto mais alto da ilusão referencial de um texto ${ }^{65}$. Em um desenho, por exemplo, alguns poucos traços podem representar a imagem de uma pessoa. Não sabemos se ela é uma mulher ou um homem, um adulto ou uma criança, mas reconhecemos naquela imagem a figura de um ser humano. Essa ilustração, por um lado, poderia ter o grau de concretização dos seus traços elevado ao máximo, resultando na iconização (BERTRAND, 2003: 210). Teríamos então um retrato extremamente realista no qual a significação estaria bastante fechada: reconheceríamos a idade, o sexo, a nacionalidade ou até mesmo a própria identidade da pessoa retratada. Por outro, esse grau poderia ser reduzido ao mínimo, produzindo a abstração, quando as

\footnotetext{
65 Obviamente, como a iconicidade é o produto dos processos mobilizados por um enunciador, ela estará sempre dependente de uma concepção cultural específica de "realidade".
} 
significações estariam mais abertas. Teríamos um desenho sem qualquer elemento figurativo no qual não reconheceríamos nenhum item do mundo natural.

Portanto, para além da representação mimética de um elemento do mundo sensível (o que seria apenas uma dentre muitas possibilidades), a teoria semiótica passou a reservar o termo figurativização para esse processo gradual entre a abstração e a iconização, tendo em vista os variados graus possíveis de concretude. No caso da canção popular, na qual as figuras do mundo natural são prioritariamente as figuras de fala presentes na relação entre a melodia e a letra, poderíamos associar o conceito de iconicidade ao gênero rap, possivelmente o tipo de canção que mais intensifica a presença da linguagem oral. É interessante notar que, assim como no caso da hipotética ilustração mencionada acima, o rap também pode resultar em um efeito de hiper-realismo. $\mathrm{O}$ fato de o rapper entoar os versos de maneira muito próxima à nossa fala cotidiana problematiza a questão da verdade discursiva e gera até mesmo episódios inusitados como o conhecido caso em que letras de rap foram utilizadas por promotores como provas criminais em processos judiciais de tribunais norte-americanos (SEGRETO, 2015: 40). Nesse caso, a forte intensificação da iconização foi capaz de gerar uma postura questionável por parte dos promotores de justiça, ao defenderem um paralelismo entre o mundo construído pelo discurso e o mundo real.

Por outro lado, o entendimento da figurativização como um processo que prevê ocorrências graduais também nos permite melhor fundamentar o princípio, comentado anteriormente, no qual o cancionista, quando canta ou compõe, não realiza uma imitação da fala. Se assim o fizesse, não haveria um percurso gradativo no qual as figuras pudessem estar mais ou menos intensificadas. Portanto, não há uma simples e estanque reprodução da fala, mas sim um permanente vagar entre e a música, mais abstrata, e a entoação, mais concreta.

A discussão sobre a ideia de continuum figurativo também nos permite apreciar mais satisfatoriamente a posição da tematização dentro da teoria da semiótica greimasiana. Como vimos na figura 2 deste capítulo, no quadro que representa os três patamares do percurso gerativo, ela ocupa, juntamente com a figurativização, o componente semântico do nível discursivo. Constatamos, então, que Tatit utuliza a mesma denominação para designar dois de seus processos de compatibilização de letra e melodia. É interessante observar que ambos, figurativização e tematização, constituem procedimentos de natureza distinta para cada campo de pesquisa. Na tradição greimasiana, sua natureza é verbal. Na semiótica da canção, é melódica. Acima, já 
pudemos constatar que a noção de figurativização proposta por Greimas estabelece uma íntima relação com a figurativização da melodia cancional estudada no capítulo anterior: ambas, de certa maneira, representam a inserção de referentes do mundo no discurso, sejam eles elementos linguísticos ou elementos entoativos.

No caso da tematização, também é possível notar semelhanças e diferenças entre as aplicações do termo nas duas abordagens teóricas. Tatit certamente aproveitou o caráter abstrato de sua acepção greimasiana para construir sua noção de tematização melódica, mais ligada ao ímpeto musical e suas abstrações sonoras do que às questões entoativas, mais "concretas" do ponto de vista da compatibilização entre a letra e a melodia. Aproveitou igualmente o fato de a musicologia (e mesmo a prática musical em geral) utilizar amplamente o termo "tema" para denominar certos segmentos melódicos, mais recorrentes e destacados: o "tema" do primeiro movimento de uma sinfonia de Brahms, o "tema" sobre o qual Hermeto Paschoal improvisa em determinada faixa, o "tema" de Asa Branca etc. Tendo em vista essa coincidência lexical, a noção de tematização é, em geral, mais facilmente apreendida pelos músicos ou cancionistas que iniciam seus estudos de semiótica da canção. Afinal, ela se aproxima da conformação de um corpo rítmicomelódico que possui destaque dentro de determinada unidade, seja ela uma canção, uma peça instrumental de jazz ou uma sinfonia.

Para que possamos aprofundar nossas reflexões sobre o uso desse conceito na análise cancional é interessante, então, examinarmos de maneira mais detalhada a noção de tematização na semiótica francesa. Aqui, esse processo, mais geral e abstrato, portanto, aberto a um maior número de possibilidades semânticas, também pode ser entendido como uma atenuação da figurativização. Vejamos. Assim como o termo "figurativo" também pertence a outros campos de pesquisa, a denominação "tema" é igualmente utilizada em outras áreas do conhecimento. Nas artes plásticas, a noção de tema pode denominar, por exemplo, signos mais generalizantes da natureza como a "paisagem" e a "representação humana" ou motivos culturais como a "prosperidade" e a "esperança". Essas acepções já trazem consigo a ideia, cara à semiótica, de uma significação mais abstrata que poderá ou não ser concretizada a partir de diferentes graus e maneiras variadas (BERTRAND, 2003: 212).

Como dissemos anteriormente, em todos os textos figurativos, as figuras são o revestimento de temas que constituem, por sua vez, a cobertura de esquemas narrativos mais abstratos. Contudo, diferentemente das figuras, os temas são investimentos semânticos que não se ligam diretamente ao mundo natural, ou seja, possuem caráter mais 
conceptual, organizando e classificando elementos da realidade de um modo mais "impalpável”, como observamos, por exemplo, nos vocábulos "arrogância", "zelo", "humildade" ou "raciocinar" (FIORIN, 2008: 91).

O texto temático por excelência é aquele no qual os temas aparecem sem coberturas figurativas. O texto figurativo, ao contrário, sempre possuirá uma camada temática implícita, já que a tematização é um estágio de concretização da significação que precede a figurativização (FIORIN, 2008: 94). Contudo, ainda que possamos encontrar textos puramente temáticos, em geral, a experiência nos mostra que há sempre a presença de figuras, assim como de temas nos textos figurativos. Consequentemente, ao falarmos em textos figurativos e temáticos, estamos, na verdade, tratando de discursos "predominantemente, e não exclusivamente, figurativos e temáticos" (FIORIN, 2008: 92). Além disso, como comentamos, a noção de continuum figurativo ilustrada na figura 3 nos permite considerar a tematização como "uma redução do figurativo" (BERTRAND, 2003: 231 ${ }^{66}$. Pensemos no conteúdo temático da felicidade, por exemplo. Um hipotético conto poderia figurativizá-lo relatando a história de uma menina que, em sua festa de aniversário, ganha presentes, sorri, pula, dança e é abraçada pelos convidados. Há um desenvolvimento figurativo (que poderia ser ainda mais desenvolvido, levando à iconização) que afirma a presença desse conteúdo temático. Isto é, a felicidade, ainda que não exista no mundo natural, é capaz de condensar itens figurativos (abraços, oferendas para a aniversariante etc.).

Tendo em vista o que estudamos anteriormente sobre a semiótica da canção, podemos identificar diferenças significativas entre a presença desses conceitos na semiótica geral e a presença deles no contexto específico do estudo da linguagem cancional. Ou melhor, podemos dizer que a diferença na aplicação desses conceitos delimita, na teoria de Tatit, a própria noção de canção. Como vimos acima, segundo a teoria greimasiana, é possível haver textos unicamente temáticos, como certos exemplos científicos ou filosóficos que podem se manifestar sem a cobertura figurativa. Os textos figurativos, por sua vez, possuem sempre um nível temático subjacente. Isto é, ainda que grande parte dos textos combine tematização e figurativização, a semiótica francesa prevê a possibilidade de manifestações que trabalham exclusivamente com temas.

\footnotetext{
${ }^{66}$ Essa perspectiva nos auxilia no estudo da relação entre a melodia e a letra da canção, pois a partir dela podemos compreender a minimização da entoação em obras de maior investimento temático. Retornaremos a esse tópico nos capítulos seguintes, ao analisarmos o ajuste entre o texto linguístico e a linha melódica em três diferentes níveis: sílaba, palavra e frase. Por enquanto, nos concentraremos em alguns aspectos temáticos que poderão ser úteis nas discussões seguintes presentes neste trabalho.
} 
Diferentemente, a concepção de canção elaborada por Tatit não contempla a ocorrência de obras puramente temáticas, isto é, exclusivamente abstratas ou musicais. No seu objeto de estudo há sempre, segundo o autor, a presença de um componente musical e um componente entoativo, mesmo que um deles esteja bastante minimizado. Assim, uma obra puramente musical ou abstrata não estaria mais no domínio da canção, mas sim na esfera da música instrumental ${ }^{67}$. A semiótica da canção, portanto, realiza um recorte da área de atuação dos conceitos de tematização e figurativização estudados pela semiótica geral.

\footnotetext{
${ }^{67}$ Evidentemente, esses limites são tênues. Há obras marcadamente musicais que, ao incluírem cantores em sua formação (ainda que essas vozes executem melodias puramente instrumentais e distantes da fala), passam a veicular um componente entoativo mínimo: a simples presença de um timbre de voz já é suficiente para marcar algum teor de oralidade.
} 


\subsection{A veridicção da canção}

Voltando ao domínio da figuratividade, fundamental por sua relação com a presença da fala na canção popular, vejamos mais algumas decorrências desse conceito na semiótica geral que, por sua vez, embasam importantes discussões levantadas pela semiótica da canção. Desejamos, a princípio, nos ater à questão do "raciocínio figurativo", o que nos levará naturalmente ao assunto principal deste item, a veridicção. Segundo Bertrand, trata-se de uma forma de argumentação diferente da racionalidade científica baseada em uma estrutura lógica e dedutiva de causas e consequências. Ao contrário, "funciona por analogia direta ou, por assim dizer, lateralmente" (BERTRAND, 2003: 216). O autor exemplifica esse tipo de raciocínio ou "racionalidade figurativa" com a parábola, pequena narrativa alegórica geralmente associada a algum conteúdo moral ou religioso. A argumentação realizada por meio de processos figurativos seria aquela na qual a adesão do enunciatário se dá por meio da articulação de elementos concretos e sensíveis, sem valer-se de estratégias persuasivas ligadas ao raciocínio lógico.

A verdade que se supõe contida no discurso parabólico não pode ser compreendida, no sentido racional da palavra, ela tem de ser literalmente incorporada pelos ouvintes que a assumem e assimilam (BERTRAND, 2003: 216)

Como demonstra a semiótica da canção, essa ideia de uma argumentação figurativa, assimilada por meio de elementos sensíveis e, por isso, menos "intelectual", é extremamente pertinente na experiência do ouvinte de música popular. Na canção, a figurativização é também uma forma de argumentação que não passa pelo entendimento racional do enunciatário. Isto é, as figuras são geralmente assimiladas pelo ouvinte de maneira desapercebida. Há, portanto, tipos diferentes de adesão do enunciatário: um raciocínio científico pode persuadi-lo por meio de uma exposição dedutiva dos elementos e uma fábula apenas por meio da apresentação de figuras do mundo natural. Nesse último caso, o enunciador utiliza essas figuras para fazer-crer, isto é, fazer com que o enunciatário reconheça em seu texto "imagens do mundo" e consequentemente aceite como "verdadeiro" o seu discurso. A questão da "verdade" do discurso depende, assim, de uma articulação entre as instâncias do enunciador e do enunciatário. O "crer verdadeiro" deve estar presente nessas duas esferas da experiência comunicativa e a 
relação entre elas (que pode ser mais ou menos instável) é denominada "contrato de veridicção" (GREIMAS, 2012: 530).

Nesse sentido, pensando no que comentamos anteriormente a respeito das funções narrativas, podemos considerar, na instância da enunciação, o enunciador como um destinador-manipulador que deseja levar o destinatário (o enunciatário) a crer e a fazer para que o contrato enunciativo se concretize e a comunicação se torne eficaz (GREIMAS, 2012: 368). Contudo, a instauração e o sucesso desse contrato, isto é, a interpretação veridictória dos discursos, é sempre relativizada culturalmente. Por isso, a questão da "verdade" discursiva é cuidadosamente formulada pela semiótica não como uma representação da verdade absoluta e exterior ao texto, mas como algo construído em seu próprio interior:

\footnotetext{
Não mais se imagina que o enunciador produza discursos verdadeiros, mas discursos que produzem um efeito de sentido de "verdade": desse ponto de vista, a produção da verdade corresponde ao exercício de um fazer cognitivo particular, de um fazer parecer verdadeiro que se pode chamar, sem nenhuma nuance pejorativa, de fazer persuasivo (GREIMAS, 2012: 531)
}

Cada discurso elabora a sua própria verdade. Por isso, ela não deve ser compreendida como uma adequação direta ao referente, aos elementos do mundo natural. Diferentemente, a verdade deve ser entendida como a construção de um simulacro que depende mais da estruturação interna do discurso do que da sua correspondência com a realidade exterior.

Essa ideia liga-se ao conceito de "verossimilhança", muito empregado nos estudos literários em geral. Se por um lado a verossimilhança organiza o discurso "representando" elementos do mundo que o enunciador espera que o enunciatário reconheça, por outro, não podemos tratá-la como uma reprodução exata da realidade, mas como um artifício que realiza uma simulação cujo objetivo é fazer parecer verdadeiro (GREIMAS, 2012: 534). Além disso, esse status de verdade depende de fatores culturais e sociais: o enunciador propõe um contrato enunciativo que já prevê a maneira como o enunciatário deverá interpretar o discurso, uma vez que a interpretação da verdade discursiva depende de outros contratos veridictórios anteriores, "próprios de uma cultura, de uma formação ideológica e da concepção, por exemplo, dentro de um sistema de valores, de discurso e de seus tipos" (BARROS, 2001: 94). Assim, a criação desse simulacro por parte do 
enunciador depende tanto do seu universo cultural quanto do entendimento que possui em relação ao universo de seu enunciatário, além, é claro, do fazer interpretativo realizado por essa última instância (GREIMAS, 2012: 531).

Essa reflexão interessa particularmente ao estudo da canção popular, pois se o cancionista procura a adesão do ouvinte, o faz dialogando com todo o ambiente cultural que os circunda. Assim, entendemos que a semiótica da canção não pretende, a priori, abordar a relação da melodia com a fala como algo absoluto para o "sucesso" do contrato enunciativo. Isto é, sob o ponto de vista no qual o simulacro de verdade depende das conformações culturais de todas as partes envolvidas no processo, não podemos dizer que todo e qualquer ouvinte aceitará como "verdadeiro" o recorte figurativo proposto por determinada canção. O depósito das figuras empregadas pelo enunciador é parte integrante de uma dada cultura (FIORIN, 2008: 95). Portanto, se cada cultura figurativiza o mundo à sua maneira, a produção de suas canções também gerará figuras próprias. Por isso, para analisarmos canções em língua estrangeira (caso pretendamos examinar o sentido da relação entre a melodia e a letra de maneira mais profunda), é indubitavelmente necessário o conhecimento das figuras entoativas da língua utilizada pelo cancionista. Além disso, a simulação efetuada pelo enunciador (aquele que faz parecer verdadeiro) fomenta discursos que, se por um lado, como dissemos acima, abarcam as figuras de seu universo linguístico, por outro, não deixam de representar distorções do mundo natural que, pouco a pouco, vão sendo culturalmente aceitas.

É aqui que aparecem diversas atitudes epistêmicas coletivas, culturalmente relativizadas, concernentes à interpretação veridictória dos discursos-signos. É assim que certas sociedades exploram, por exemplo, a materialidade do significante para assinalar o caráter anagógico e verdadeiro do significado (a recitação rect tono de textos sagrados, a distorção rítmica dos esquemas de acentuação, por exemplo, insinuam a existência subjacente de uma voz outra e de um discurso verdadeiro por ela sustentado (GREIMAS, 2012: 530)

O exemplo utilizado por Greimas nos parece muito oportuno. Essa "voz outra", cuja materialidade do significante se distancia da entoação da linguagem verbal (com sua deformação rítmica e emissão sem qualquer variação de altura), é capaz de explicitar a construção culturalmente forjada dos discursos. A melodia de uma canção funciona de maneira similar. Ela não consiste na imitação da fala, mas sim em uma simulação distorcida que, ainda que não exista no mundo natural (afinal ninguém fala estabilizando 
durações, ritmos e alturas) estabelece certas ligações com nossa língua oral cotidiana. Nesse sentido a canção é também uma "voz outra" que sustenta um discurso admitido como "verdadeiro" pelos ouvintes.

Constatamos, então, que o exame mais detalhado da noção de veridicção (da verdade e da crença partilhada) pode contribuir de modo significativo para a nossa pesquisa sobre a figuratividade. Como comentamos, o discurso (seja um filme, um pronunciamento de uma autoridade, um romance, uma canção etc.) é o resultado de um acordo implícito entre as duas instâncias do processo comunicativo: o enunciador e o enunciatário. A relação entre ambos, por vezes frágil, pode ser chamada de "contrato de veridicção". Há aqui uma permanente construção ou desconstrução da confiança que permite ou impede o compartilhamento das crenças entre os dois actantes. A semiótica cria então um modelo de análise para examinar a ocorrência desse processo em cada discurso. O seu objetivo não é alcançar o valor da verdade absoluta do discurso e a sua relação com os referentes do mundo real, mas sim descrever as operações entre os sujeitos que possibilitam as diferentes formas de adesão. Isso amplia o campo de atuação do modelo para além de textos considerados referenciais, podendo ser aplicado, por exemplo, em obras da literatura fantástica ou em textos surrealistas.

\footnotetext{
As formas de ajuste entre as duas semióticas - a do mundo natural e a das manifestações discursivas das línguas naturais - são relativamente movediças e culturalmente forjadas pelo uso. Por isso, não será mais o caso de opor os textos que têm um "referente real" e os que têm um "referente fictício ou imaginário". Tentaremos de preferência distinguir as formas de discurso a partir do regime de "veridicção" - os jogos de verdade que o discurso instala em seu interior - que as caracteriza propriamente. Noutras palavras, a partir do modo de adesão que o contrato enunciativo de cada um deles propõe a seu leitor: em que ele faz crer, e como? O efeito produzido por ocasião da leitura poderá ser o de "realidade", mas também os de “irrealidade" ou "surrealidade" (BERTRAND, 2003: 161)
}

O modelo semiótico em questão é o quadrado da veridicção que, ao articular as categorias /ser/ e /parecer/, delineia os conceitos de verdade (é e parece), mentira (não é, mas parece), falsidade (não é e não parece) e segredo (é, mas não parece). Com isso, a semiótica ganha um importante instrumento com o qual é possível avaliar a forma de construção da "verdade" discursiva e a sua eficácia no processo comunicativo. 


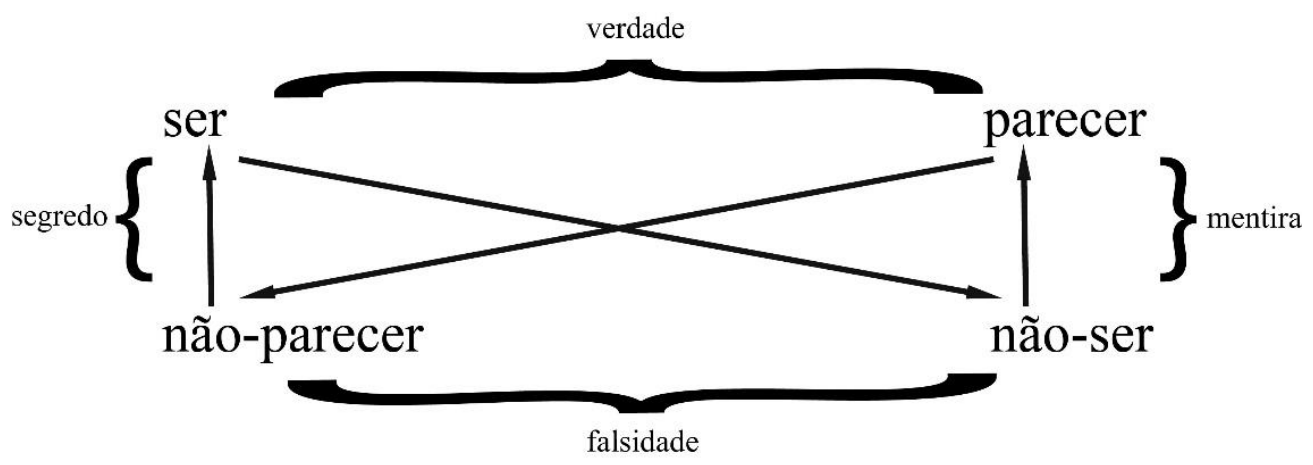

Figura 4. Quadrado da veridicção

Quando analisamos um texto concreto e a crença partilhada entre o enunciador e o enunciatário no seu processo de enunciação, constatamos a centralidade dos elementos figurativos que são apresentados à nossa percepção. No caso de uma canção fortemente entoativa, por exemplo, baseamos nossa escuta em valores orais (a ligação entre a melodia executada pelo cantor e a nossa fala cotidiana), o que supre nossa necessidade de reconhecer ali aspectos do mundo real. No entanto, pensando de uma maneira mais ampla sobre o reconhecimento desses referentes do mundo por parte dos ouvintes de canção, supomos ser possível, numa certa medida, considerar obras temáticas ou passionais como “figuras reconhecíveis" de nosso universo de escuta ${ }^{68}$. Ou seja, canções menos entoativas também poderiam ser apontadas como figuras do mundo, pois são tipos de canção que o ouvinte reconhece como possíveis a partir de sua experiência de escuta. Além disso, em obras cancionais temáticas e passionais, a interpretação do cantor também pode trazer referentes do mundo concreto para o espectador de um show, por exemplo. A interpretação vívida de um cantor para uma canção de conteúdo eufórico traz para o ouvinte algo do mundo que intuitivamente ele já conhece: um sujeito satisfeito por estar em conjunção com seu objeto de valor. Da mesma maneira, a interpretação lamuriosa de uma canção passionalizante de conteúdo disjuntivo (sobre uma perda amorosa, por exemplo) também apresenta um referente do mundo. Há aqui uma imagem visualauditiva possível de ser reconhecida pelo ouvinte, afinal, ele conhece a reação emocional de alguém que sofre por amor.

\footnotetext{
${ }^{68}$ Dizemos "numa certa medida”, pois, embora seja possível estabelecer essa relação entre construções tematizantes e passionalizantes e as figuras entoativas, não devemos abrir excessivamente o conceito de figurativização. Assim, para obtermos uma teoria eficiente do ponto de vista operacional, é necessário que tenhamos uma diferenciação mais clara entre os três procedimentos cancionais.
} 
É claro que as questões artísticas ultrapassam em muito essa redução que realizamos acima. As canções, obviamente, apresentam complexidades que vão além dessa conexão com o intérprete a partir de um referente do mundo assimilado anteriormente pelo ouvinte. No entanto, essa discussão abre a possibilidade de travarmos investigações muito interessantes acerca da recepção da canção (e das artes em geral) e de seu processo histórico.

Pensando na importância do "crer" para a relação entre o enunciador e o enunciatário e no amparo dado pelo referente, o que possibilita o reconhecimento mútuo da "verdade" do discurso, podemos considerar que o público, ao se deparar com certa obra de arte, realizará a sua fruição a partir de sua própria bagagem de referentes que acumulou ao longo de sua experiência com outras obras de arte. De certa maneira, o público confiará sempre na sua experiência estabelecida. Quando há a inserção de um elemento estético inesperado, não compartilhado entre enunciador e enunciatário, temos uma descontinuidade entre o sujeito (público) e seu objeto (obra de arte), gerando uma cisão entre ambos.

A história do homem e da arte é repleta de cisões desse tipo. Basta pensarmos nas vanguardas artísticas do século XX ou em qualquer outra renovação estética ocorrida em nossa história. De forma imprecisa, os críticos de arte geralmente referem-se à recusa inicial de um artista esteticamente inovador como uma deficiência de apreciação estética por parte do público. O artista, genial e progressista, seria incompreendido e injustiçado na recepção de sua obra. E o público, incompetente na sua avaliação. Contudo, quando nos baseamos nas ideias acima levantadas, notamos que essa relação pode ser significativamente enriquecida.

Tendo em vista os pontos apresentados pelos estudos semióticos sobre a veridicção, podemos atentar para o fato, óbvio e fundamental, de que o público só reconhece o que já conhece. Expliquemos. A conjunção entre sujeito e objeto só ocorre pois ambos formam um único ser, isto é, o objeto é parte do sujeito antes mesmo de entrarem em conjunção. Por isso a busca se dá: o sujeito busca sua parte perdida no objeto. Assim, quando reconhecemos uma obra de arte, estamos, ao mesmo tempo, nos reconhecendo enquanto indivíduos, procurando o que ali já nos pertence. Ou seja, para que novas propostas artísticas sejam aceitas pelo público, deverá haver uma assimilação mais gradual de seus elementos perturbadores.

Por exemplo, em fins do século XIX, há fatos curiosos que ficaram famosos na história do surgimento do cinema e que ilustram bem esse processo. Na primeira exibição 
pública do famoso filme L'Arrivée d'un train en gare de La Ciotat (1895) dos irmãos Louis e Auguste Lumière, no qual se vê um trem chegando à estação, os espectadores, ao se depararem com a imagem do comboio vindo em sua direção, se desesperam e abandonam a sala de projeção com medo de se chocarem com o trem. Outro fato interessante é, nesse início da história do cinema, o público não compreender e estranhar os enquadramentos que omitiam partes dos corpos das personagens, como o close. Gradualmente, com a popularização do cinema nas décadas seguintes (o que, no Brasil, ocorre a partir da década de 1910) a nova linguagem se consolida. Assim, os estranhos referentes introduzidos no início do século pelo cinema são ao logo dos anos absolutamente assimilados pelo público.

Bertrand faz uma interessante análise de Intervenção do escritor belga Henri Michaux (BERTRAND, 2003: 256-257) no qual uma personagem decide abruptamente trazer para a cidade onde morava animais totalmente desconhecidos por seus habitantes: decide "introduzir camelos". Quando o faz, o sujeito não introduz referentes estabelecidos naquela sociedade. Não há figuras identificáveis, já que os moradores do local desconhecem esse tipo de animal. Contudo, ele não deixa de difundir qualidades sensíveis aos indivíduos daquele universo e de estimular a partilha desses novos valores. Há então uma violenta surpresa inicial que vai se tornando pouco a pouco menos intensa, quando a comunidade passa a incorporar paulatinamente o referente "camelo". Bertrand destaca a articulação entre a intensidade e a extensidade nessa pequena anedota: um valor inicialmente restrito a um indivíduo e que causava espanto nos demais vai progressivamente atingindo mais indivíduos e gerando menos assombro.

A trajetória das figuras da sensibilidade e sua progressiva transferência do sujeito individual que as gerou para o sujeito coletivo que as assimilou, pode ser assim resumida: à intensidade máxima do início correspondia uma extensão mínima; inversamente, ao final do percurso, à intensidade mínima vem corresponder uma extensão máxima. Tal transfusão gradual, que associa os dois percursos em relação inversa, perturba o regime dos valores estabelecidos, suspende sua circulação e acaba substituindo-os pela nova ordem do sensível (BERTRAND, 2003: 257)

Em certa medida, esse exemplo pode ilustrar a relação que estabelecemos com as figuras do mundo: trata-se de um vínculo que não é estanque. A todo momento, quando nosso universo referencial parece estar absolutamente estabelecido, novas figuras são 
introduzidas e instigam nossa percepção. Somos, então, convidados a recriar o nosso mundo referencial.

Essa discussão, ainda no âmbito do contrato de veridicção, pode contribuir significativamente para o estudo da canção popular, no que se refere à recepção por parte do público e à carga de oralidade presente na relação entre a melodia e a letra. A nosso ver, as figuras que percebemos nas canções também estão sujeitas a esse mesmo funcionamento observado no texto de Michaux. É possível analisar essa questão a partir de duas perspectivas. Primeiramente, sob o ponto de vista da figurativização melódica, podemos pensar que os ouvintes, ao escutarem uma canção, mesmo que inconscientemente, são estimulados a reconhecer a fala dentro do canto, isto é, a identificar na voz do intérprete figuras entoativas semelhantes às de sua língua natural ${ }^{69}$. Nesse sentido, a incorporação de elementos linguísticos estranhos ao seu universo poderia abalar o contrato de veridicção fazendo romper o elo entre o público e a obra. Esse pacto, porém, tende a se manter assegurado, visto que a língua utilizada pelo cancionista é geralmente aquela já assimilada pela comunidade de falantes à qual ele pertence.

A semiótica narrativa explica esse fenômeno de maneira interessante, considerando incompleta a ideia de associar a questão da veridicção unicamente à comunicação intersubjetiva. Devemos lembrar que o enunciador e o enunciatário são actantes, isto é, funções sintáticas que podem ser concretizadas por um único ator. Dessa maneira, o cancionista, sujeito da enunciação, ao experimentar as unidades entoativas no ato de criação de sua canção, assume os dois papéis actanciais (de enunciador e de enunciatário) e intuitivamente avalia a verossimilhança entoativa da relação entre a melodia e a letra. Sozinho, sem a presença do ouvinte, ele faz crer e crê. Persuade a si mesmo de antemão, o que assegura a posterior persuasão do público. Assim, as unidades entoativas são gramaticalmente possíveis para o ouvinte na medida em que foram previamente testadas pelo compositor, ambos integrantes de um mesmo universo linguístico-cultural.

A persuasão e a interpretação, o fazer-crer e o crer-verdadeiro não são, assim, senão procedimentos sintáticos, capazes de dar conta de uma "busca interior da verdade", de uma

\footnotetext{
${ }^{69}$ Há, é claro, diversos graus de presença da entoação nas melodias de canção popular e cada ouvinte poderá reagir de maneiras distintas a essas diferentes experiências. Para certo ouvinte, o gênero rap pode surpreender pela minimização musical de sua melodia (sem os contornos melódicos que estabilizam notas de escalas do sistema tonal). Para outro, peças eruditas podem surpreender pela atonização da entoação do canto. Com o passar do tempo, como temos visto no caso do rap, as novas propostas vão sendo cada vez mais aceitas pelo público.
} 
"reflexão dialética", chamada ou não à manifestação sob forma de discursos com vocação científica, filosófica ou poética (GREIMAS, 2012: 532)

No caso do enunciador e do enunciatário constituírem atores distintos, o contrato de veridicção também estaria fundamentado no reconhecimento mútuo de figuras de fala. Mas o leitor poderia se perguntar: por que nos envolvemos com canções cantadas em línguas estrangeiras desconhecidas? Por que certas vezes assistimos a um show sem repararmos no significado das palavras cantadas pelo intérprete? Por que frequentemente a canção nos convida mais à dança do que ao entendimento intelectual? Numa segunda perspectiva de análise, podemos dizer que não há apenas um tipo de contrato de veridicção possível entre o cantor e o público. Afinal, esse acordo depende de uma comunhão cultural que pode variar significativamente. Haverá, então, experiências de escuta cujo contrato pode ser não apenas entoativo, mas também musical, coreográfico, visual etc. Certamente, quando um cantor está presente, há sempre uma carga oral mínima, mas, sem dúvida, há muitas canções cujo foco principal não é a entoação. Nesse sentido, uma coreografia, uma proposta musical ou um figurino também podem ser considerados "figuras do mundo" reconhecidas pelo público. Aqui, a veridicção estaria assegurada por meio do reconhecimento de elementos verossímeis encontrados num show ou num disco: a dança, a instrumentação, o gesto e a roupa também precisam ser referentes culturalmente compartilhados. Seriam como figuras de segunda ordem ${ }^{70}$.

Contudo, tanto as figuras entoativas quanto os outros tipos de figuras elencadas acima (musicais, visuais, coreográficas etc.) são elementos compartilhados entre o cantor e o público. E quando não há esse reconhecimento mútuo? Pois bem, os cancionistas, assim como a personagem de Michaux, também poderão "introduzir camelos" na canção. Como comentamos acima, o rap representa um bom exemplo de rompimento com os padrões estéticos de determinada comunidade de ouvintes. Inicialmente, a sua proposta de intensificação da fala gerou forte estranhamento no público cuja cultura cancional pendia mais para a esfera musical. A surpresa vinha da minimização musical proposta pelos rappers, já que o ouvinte estaria acostumado a certo padrão sonoro estabelecido (instrumentação, configurações melódico-harmônicas esperadas, tonalidade, estilo vocal

\footnotetext{
${ }^{70}$ Sabemos que estamos saindo do universo da canção propriamente dita que, segundo Luiz Tatit, centrase na relação entre a melodia e a letra. Porém, questões como essa sempre vêm à tona nas reflexões de estudiosos e músicos que entram em contato com a semiótica de canção. A nosso ver, a sua proposta teórica, ao incorporar uma visão gradual dos fenômenos, não exclui os casos de canções mais musicais (e até mesmo visuais) do que entoativas. Ainda que sempre presente, a entoação pode estar minimizada.
} 
etc.). Com o passar do tempo e com a sustentação do gênero no mercado da música comercial, o estranhamento em relação a essa característica está se diluindo pouco a pouco.

De certa forma, essa reflexão também é útil para analisarmos a recepção das obras de arte experimentais, aquelas que exploram as linguagens estéticas de maneira inusual. O caráter de subversão ligado à história das vanguardas artísticas nas diferentes épocas é resultado da inclusão, por parte dos criadores, de elementos não reconhecidos pelo público como "figuras" de seu mundo. Tomando como exemplo um movimento artístico como o Cubismo, mais de um século após o seu surgimento ${ }^{71}$, constatamos que as suas propostas, antes surpreendentes, encontram-se já perfeitamente assimiladas pelo público. Isso demonstra que a experiência estética das pessoas não se constitui como um universo fechado. Há sempre espaço para o novo. Nas artes, assim como na vida, o contrato veridictório entre enunciador e enunciatário pode se transformar ao longo do tempo. Enfim, essas são algumas reflexões que podem ser enriquecidas a partir do modelo comentado por Bertrand no fragmento acima: as figuras que percebemos podem cumprir um percurso no qual são paulatinamente transportadas de um sujeito individual (o enunciador que propõe figuras "novas") para um sujeito coletivo (o enunciatário que as percebe) que vai assimilando-as pouco a pouco até que se transformam em valores axiológicos, como "evidências ou estereótipos" (BERTRAND, 2003: 261).

São figuras novas, mas não totalmente novas. Expliquemos. Mesmo que reconheçamos o mecanismo apontado por Bertrand, algumas perguntas ainda permanecem sem respostas: Por que algumas figuras "individuais" prosperam e outras não? Isto é, por que os elementos estéticos propostos pelos primeiros rappers da Nova York dos anos 1970 foram acolhidos e difundidos pelo mercado enquanto que as obras de compositores como Arrigo Barnabé, por exemplo, não obtiveram a mesma sustentação comercial. Afinal, por que, para o mercado, algumas figuras "novas" parecem mais convincentes do que as outras?

Supomos que, em geral, as figuras mais convincentes são aquelas que encontram respaldo na comunidade de ouvintes. Sob o ponto de vista da história da arte e de uma restrita elite cultural que acompanha o seu desenvolvimento, a apropriação da técnica serialista por parte de Arrigo deveria causar pouca estranheza, na medida em que esses elementos já haviam sido lançados desde o início do século XX. No entanto, sob a

\footnotetext{
${ }^{71}$ Costuma-se localizar o marco inicial do Cubismo na data de realização da obra Les demoiselles d'Avignon (1907) de Pablo Picasso (1881-1973).
} 
perspectiva do grande público, acostumado à canção veiculada nas rádios e emissoras de televisão, a apreensão das propostas atonais do compositor dificilmente se daria.

O mercado, ao visar o lucro, somente insiste na estranheza de determinadas formas quando constata que o público pode aceitá-las com maior facilidade. É preciso que elas sejam potencialmente compartilháveis ou que venham de encontro a alguma necessidade de determinado grupo social. No caso do rap, a estranheza da neutralização musical da melodia (a emissão mais falada do MC), ao compatibilizar-se perfeitamente com o caráter de denúncia e reivindicação presente nas letras do gênero, encontrou forte receptividade nas comunidades dos bairros pobres da Nova York da década de 1970 e, posteriormente, nas periferias das grandes cidades. No Brasil, espalhando-se primeiramente por essas comunidades, desenvolveu um potencial mercado a ser explorado pela indústria musical.

De maneira similar, o gênero funk carioca, ainda que agregasse elementos estéticos inusitados (o seu canto falado e a ausência de um acompanhamento harmônico convencional), alcançou, por sua característica rítmica e dançante, grande público nos bailes do início dos anos 2000, delineando igualmente um nicho de mercado altamente lucrativo. Evidentemente, diversos fatores podem influenciar a consolidação desses gêneros na cultura. Sob o ponto de vista cancional, no entanto, podemos identificar compatibilizações entre a letra e a emissão vocal dos MC's e funkeiros que contribuem para a aceitação desses estilos. Afinal, um elo pode ser estabelecido entre o canto dos rappers e o canto no samba de breque, por exemplo, ou mesmo entre esse canto e a fala com a qual convivemos cotidianamente. Há, entre a figura já reconhecida e a nova figura proposta, uma continuidade que permite maior receptividade por parte do público e do mercado. Mais uma vez, são figuras novas, mas não totalmente novas.

Acreditamos, então, que a transformação estética é inerente às linguagens artísticas (embora certas culturas a realizem de maneira extremamente lenta, sobretudo quando a manifestação possui caráter ritualístico). No entanto, não devemos acreditar que há um caminho evolutivo natural no qual um artista ou grupo de artistas propõe um novo aspecto e o público paulatinamente o assimila. Esse discurso, muito empregado pelos artistas brasileiros nos anos 1960 e 1970, defensores de uma arte experimental de vanguarda, não nos parece abarcar toda a complexidade da questão. Trata-se de uma espécie de "crença" que coloca a transformação estética unicamente nas mãos do artista e ignora que a comunhão de valores com a sua comunidade de ouvintes tem papel chave nesse processo. É quando os artistas frequentemente se entusiasmam com a inovação de uma proposta musical enquanto que o público nem sempre se satisfaz com a mesma. 
Enfim, pudemos discutir neste item, ainda que brevemente, possíveis contribuições do exame da noção de veridicção para o nosso estudo da canção popular. Observamos, igualmente, a importância desse conceito para o campo da figuratividade na semiótica geral ${ }^{72}$. Passemos, então, para um outro aspecto da teoria greimasiana que, a nosso ver, pode suscitar interessantes reflexões acerca de nosso assunto.

72 Na semiótica, a importância da questão do "crer" é marcante até mesmo para a história do desenvolvimento das pesquisas sobre a figuratividade. Ela marca a passagem de uma visão semiótica ligada ao estruturalismo para uma visão mais recente que contempla aspectos ligados à fenomenologia. Até o início da década de 1980, o entendimento da figuratividade passava por uma definição estruturalista do conceito. As questões eram examinadas a partir de uma metodologia fundamentada numa "concepção diferencial, categorial e descontínua da significação" (BERTRAND, 2003:233). Essa primeira abordagem centrava-se na relação entre as figuras do plano da expressão do mundo natural e as figuras do plano do conteúdo da linguagem (categorias espaciais, temporais e actoriais), no contrato de veridicção (o crer compartilhado), na iconização e na tematização. A partir da segunda metade de década de 1980, com a publicação de De l'imperfection de Greimas (1987), há certo rompimento com esse tratamento estruturalista da matéria. $\mathrm{O}$ autor passa a olhar a figuratividade a partir do acontecimento da apreensão perceptiva e a sua avaliação estética. Nessa segunda abordagem, a modalização ligada ao /crer verdadeiro/ (o contrato enunciativo que permite o reconhecimento de um mundo partilhado entre enunciador e enunciatário) ganha acentuado destaque, o que demonstra um forte contato com estudos fenomenológicos. Segundo Bertrand, ao invés de se examinar a figuratividade já transformada na manifestação do discurso, "a posteridade dos efeitos de sentido produzidos e sua estruturação" (BERTRAND, 2003:235), volta-se para a própria gênese do conceito, isto é, para os processos de reconhecimento e identificação dos objetos na percepção, operações que compõem a "função figurativa" de E. Husserl, fundador da fenomenologia. 


\subsection{O conceito de isotopia}

Dando prosseguimento à nossa investigação das formulações semióticas que podem suscitar relações com a esfera da figuratividade, também devemos tratar da importante noção de isotopia, conceito que pode enriquecer a análise de diversos aspectos ligados ao tema de nossa pesquisa. Assim como outros termos semióticos tratados anteriormente, essa designação também pertence a uma outra área do conhecimento. $\mathrm{Na}$ química, se refere ao estado ou qualidade dos isótopos, átomos de um elemento químico cujos núcleos possuem o mesmo número atômico, mas massas atômicas diferentes. $\mathrm{Na}$ tabela periódica (quadro que organiza os elementos químicos de acordo com suas propriedades), os isótopos estão posicionados num mesmo local. Por isso, são denominados com o termo grego iso-topos (“mesmo lugar").

Na semiótica, o conceito de isotopia é lançado por Greimas na obra Semântica estrutural (1966). As isotopias verificadas ao longo de um discurso, que também o direcionam para um mesmo "lugar semântico", proporcionam coerência ao texto permitindo uma leitura uniforme, tornando-o claro, compreensível. Elas garantem o desenvolvimento do sentido, gerando uma sensação de continuidade das significações. Vejamos.

Quando examinamos os lexemas presentes em um enunciado, podemos depreender, a partir da relação estabelecida entre eles, um classema comum. Isso tornase possível na medida em que cada lexema é portador de um conjunto de traços semânticos (os seus sememas). Um classema se estabelece quando há uma coincidência entre os traços semânticos de dois ou mais lexemas. Por exemplo, no português brasileiro, o lexema "manga" abrange, além do semema "parte do vestuário que cobre o braço", outros sememas como "fruta da mangueira" ou "filtro afunilado para filtrar líquidos". Esse é o seu conjunto de traços semânticos. É a articulação entre os lexemas e seus sememas ativados durante o texto que marcará as leituras isotópicas possíveis. Nos enunciados "a manga estragou depois que caiu no chão e bateu em uma pedra do terreiro" e "a manga rasgou depois que ele caiu no chão e bateu o braço em uma pedra do terreiro" alguns lexemas cumprem a função de desencadeadores de isotopia e permitem a compreensão de um ou de outro caminho semântico. No segundo enunciado, os elementos "rasgou" e "braço", por exemplo, tendem a conduzir nossa compreensão para a isotopia do vestuário: a manga da camisa ficou esfarrapada. No primeiro, o verbo "estragar", comumente associado ao apodrecimento de alimentos, além da ausência de traços 
humanos ("ele" e "braço" do segundo enunciado), nos leva a realizar uma leitura isotópica ligada a natureza: a fruta caiu da mangueira e se rompeu.

Essas diferentes possibilidades de leituras são possíveis graças à especificidade polissemêmica dos lexemas. Contudo, observamos que, ainda que tenhamos diversas leituras possíveis para um determinado texto, elas não são infinitas, pois a quantidade de sememas, mesmo que variável, é limitada a um certo número de possibilidades. O lexema "manga" não possui uma porção infinita de sememas ${ }^{73}$.

Esse fenômeno linguístico tão específico está na base do que entendemos como um trabalho de crítica de arte responsável: quando os estudiosos entendem a plurissignificação das obras, as suas diversas possibilidades de interpretação, mas reconhecem que nem toda leitura é possível. A noção de isotopia nos auxilia a encontrar os diversos planos de leituras dos textos (se ele abarcar mais de um) e compreender a maneira como são construídos certos discursos pluri-isotópicos. A canção "Cálice" (Gilberto Gil / Chico Buarque), por exemplo, ilustra de maneira mais explícita essa possibilidade de sentidos múltiplos do texto.

Cálice

Pai, afasta de mim esse cálice

Pai, afasta de mim esse cálice

Pai, afasta de mim esse cálice

De vinho tinto de sangue

Como beber dessa bebida amarga

Tragar a dor, engolir a labuta

Mesmo calada a boca, resta o peito

Silêncio na cidade não se escuta

De que me vale ser filho da santa

Melhor seria ser filho da outra

Outra realidade menos morta

Tanta mentira, tanta força bruta

Como é difícil acordar calado

Se na calada da noite eu me dano

Quero lançar um grito desumano

${ }^{73}$ Sobre a questão da isotopia, recomendamos a leitura da análise da letra da canção $O$ cio da terra (Milton Nascimento/Chico Buarque) realizada por Tatit em Análise semiótica através das letras (2001: 83). 
Que é uma maneira de ser escutado

Esse silêncio todo me atordoa

Atordoado eu permaneço atento

$\mathrm{Na}$ arquibancada pra a qualquer momento

Ver emergir o monstro da lagoa

De muito gorda a porca já não anda

De muito usada a faca já não corta

Como é difícil, pai, abrir a porta

Essa palavra presa na garganta

Esse pileque homérico no mundo

De que adianta ter boa vontade

Mesmo calado o peito, resta a cuca

Dos bêbados do centro da cidade

Talvez o mundo não seja pequeno

Nem seja a vida um fato consumado

Quero inventar o meu próprio pecado

Quero morrer do meu próprio veneno

Quero perder de vez tua cabeça

Minha cabeça perder teu juízo

Quero cheirar fumaça de óleo diesel

Me embriagar até que alguém me esqueça

$\mathrm{Na}$ canção acima, observamos a presença de várias leituras isotópicas possíveis. Na isotopia da bebida temos os lexemas ou enunciados "cálice", "vinho tinto de sangue", "beber", "bebida", "tragar", “engolir", "pileque”, "bêbados", "veneno", "óleo diesel” e "embriagar". Na isotopia do silenciamento temos "calada a boca", "silêncio na cidade não se escuta", "acordar calado", "grito desumano", "ser escutado", "silêncio todo me atordoa", "palavra presa na garganta" e "mesmo calado o peito". Na isotopia da opressão, muito próxima da leitura do silenciamento, temos "afasta de mim", "bebida amarga", “dor", "labuta", "calada a boca", "realidade morta", "mentira", "força bruta", "me dano", "silêncio todo me atordoa", "monstro da lagoa", "palavra presa na garganta" e "calado o peito". $\mathrm{Na}$ isotopia religiosa do cristianismo temos "pai", "cálice", "vinho tinto de sangue", "filho da santa", "boa vontade" e "pecado". É justamente o entralaçamento dessas isotopias que valoriza a semelhança sonora de "cálice" e "cale-se", elemento central da canção. Não houvesse o plano isotópico do silenciamento da voz presente nas 
estrofes que sucedem o refrão, ainda que mantivéssemos a isotopia da opressão, o entendimento auditivo do substantivo "cálice" como o imperativo do verbo "calar-se" seria significativamente minimizado. Nesse sentido, as figuras de impedimento da voz elencadas acima, ao explicitarem tal equivalência, fazem com que o tema da opressão seja ainda mais intensificado. Por outro lado, a isotopia religiosa colabora para o sentimento de injustiça causado por essa opressão, já que sugere uma correspondência entre a angústia vivida pelo eu-lírico da canção e os sofrimentos de Jesus Cristo nos momentos que antecederam seu julgamento e crucificação ${ }^{74}$. O termo que dá título à canção, que auditivamente pode ser tanto o substantivo quanto o verbo, é denominado pela semiótica como um conector de isotopia, isto é, um elemento que liga as várias leituras isotópicas do discurso (nesse caso, a isotopia da bebida e a isotopia do silenciamento). Os termos relacionados ao abafamento da palavra ("calada a boca", "grito desumano" etc.) se apresentam na letra após os termos ligados à isotopia da bebida. Por isso, são considerados desencadeadores de isotopia, ou seja, novos elementos que despontam no discurso e que nos obrigam a refazer a sua leitura e a interpretá-lo sob um novo ponto de vista.

Sobre a equivalência sonora entre "cálice" e "cale-se" outra característica nos chama a atenção. Primeiramente, podemos dizer que, por se tratar de uma canção (cuja relação com o público se dá, em geral, pela audição do canto e não pela leitura da letra), a presença desse conector de isotopia torna-se ainda mais interessante. Aqui, o ouvinte estaria mais propício a dubiedade dos sentidos. Um hipotético leitor desses primeiros versos identificaria o vocábulo escrito "cálice" e o entenderia por meio da isotopia da bebida. Diferentemente, o ouvinte, sem visualizar a sua grafia, estaria mais sujeito à pluralidade das possibilidades isotópicas ali presentes. Nesse sentido, esse termo conector é ainda mais dúbio quando escutado em uma canção e não quando lido em um poema, por exemplo. Aqui, então, a questão da oralidade exerce uma função crucial. Mais interessante ainda é a maneira como esse fenômeno repercute na interpretação e no arranjo da versão da obra gravada no LP Chico Buarque de 1978. Por um lado, em relação à entoação do elemento conector, há diferenças sutis entre a interpretação dos cantores Chico Buarque e Milton Nascimento (que enfatizam mais o entendimento do vocábulo “cálice") e as vozes do coro que irrompem no final da canção e cuja entoação (mais curta, incisiva e desconectada da frase linguística "Pai, afasta de mim") valoriza

\footnotetext{
${ }^{74}$ Como se sabe, a canção Cálice transformou-se em um símbolo da luta contra a violenta Ditadura Militar instaurada no Brasil entre os anos de 1964 e 1985.
} 
prioritariamente a compreensão do verbo "calar-se". Essa nova maneira de entoar realizada pelo coro pode então ser considerada um desencadeador de isotopia, já que consiste em uma nova maneira de dizer a mesma sequência fônica, nos levando a rever a leitura inicial da obra e colaborando para o entendimento da palavra "cálice" como "calese". Outro desencadeador que nos conduz para a leitura isotópica do silenciamento é o arranjo instrumental que, ao final da obra, apresenta momentos de pausa na medida em que o coro entoa a expressão "cale-se".
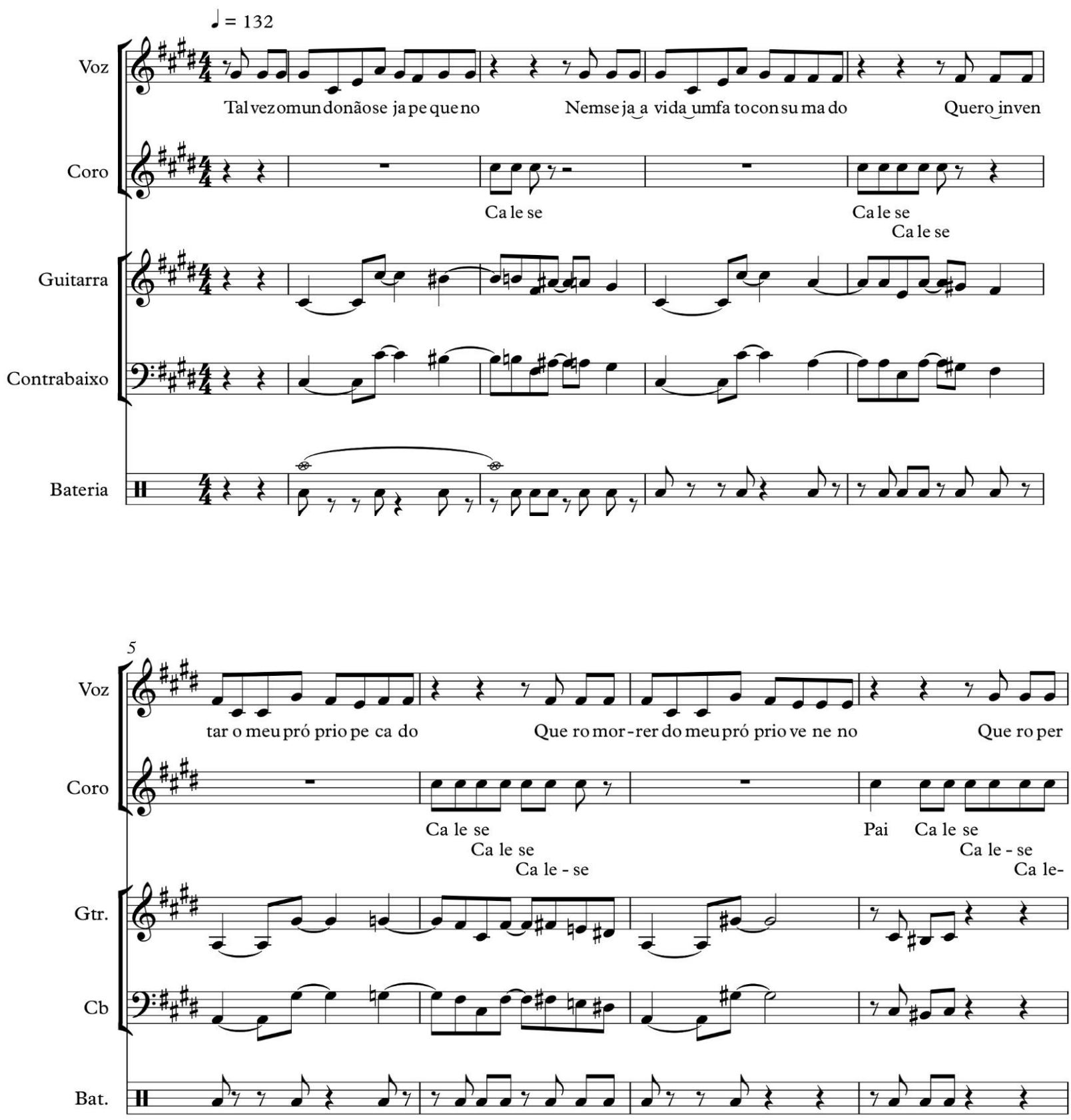

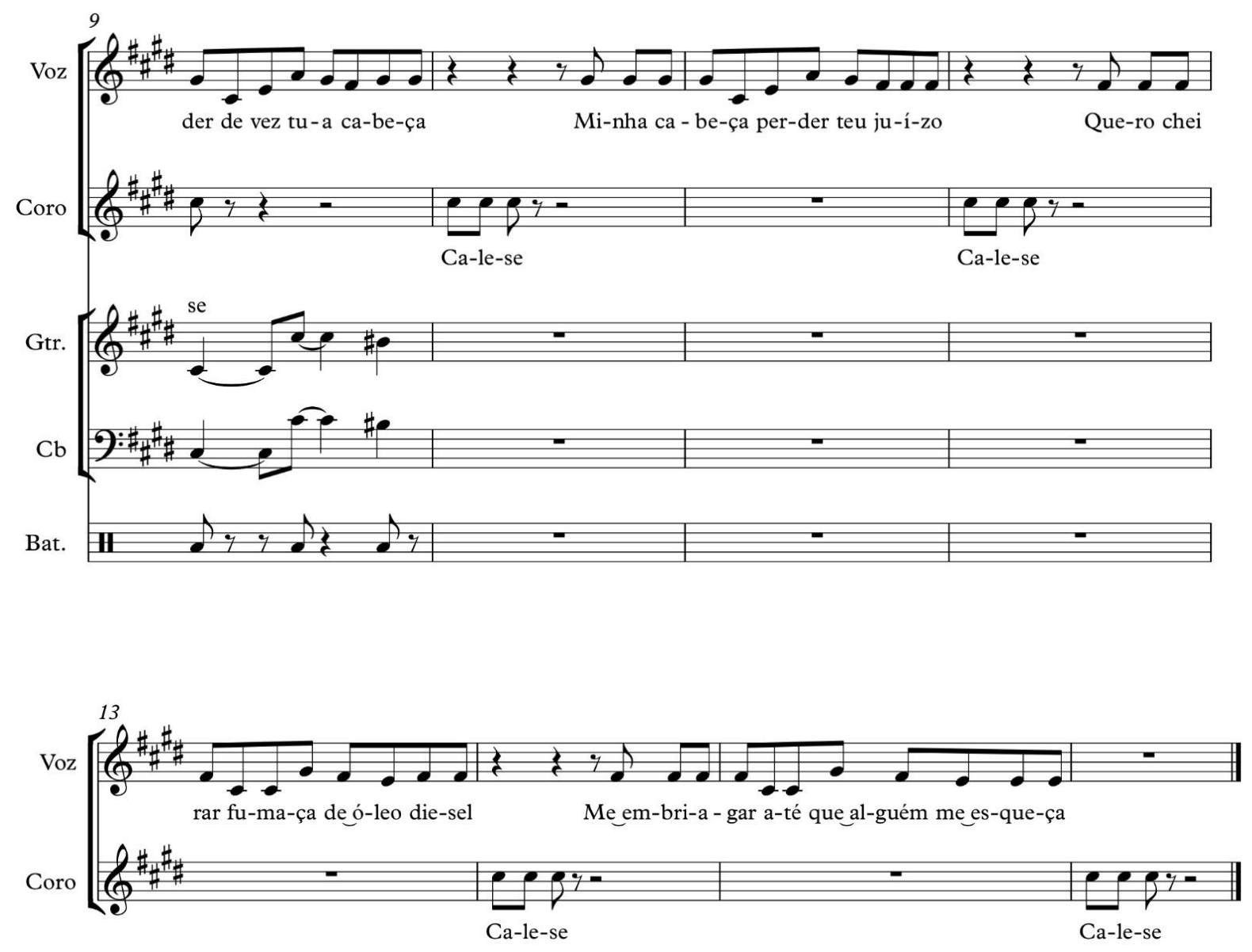

Figura 5. Arranjo da canção Cálice (Gilberto Gil/Chico Buarque) gravada no LP Chico Buarque (1978)

No fragmento acima, observamos que, a partir do compasso 10 até o final, as frases da bateria, do contrabaixo e da guitarra são omitidas como se o acompanhamento instrumental, assim como o sujeito, fosse bruscamente emudecido. Significativamente, a canção finaliza com o coro "cale-se" no compasso 16. De forma muito interessante, podemos considerar o primeiro caso (o coro) como um desencadeador de isotopia entoativa e a segunda ocorrência (a supressão instrumental do arranjo) como um desencadeador puramente musical.

De acordo com as unidades semânticas que são repetidas no discurso, a semiótica define dois tipos de isotopia: a temática e a figurativa. A primeira consiste na repetição de categorias sêmicas abstratas que constituem um mesmo percurso temático. É por meio da isotopia temática que somos capazes de reconhecer o "tema" dos discursos: uma canção que trata da opressão, um romance que retrata a infância, um filme que aborda a criação artística etc. A isotopia figurativa, por sua vez, permite a coerência no 
encadeamento das figuras presentes no discurso por meio da redundância de traços figurativos, formando um percurso único, "uma imagem organizada e completa de realidade" (BARROS, 2001: 125). Ao entrarmos em contato com a letra de uma canção, por exemplo, nossa experiência com a linguagem seleciona, entre as várias possibilidades semânticas de cada palavra, aquelas que podem ser combinadas com as virtualidades de sentido das figuras que estão mais próximas. Esses jogos de associações vão formando as isotopias figurativas.

(...) a passagem de uma frase à que lhe sucede imediatamente e assim por diante até o fim do texto, só pode ser percebida como um continuum semântico se postularmos uma isotopia comum que tece uma ligação entre cada figura, pela recorrência de uma categoria significante (ou de uma rede de categorias no decorrer do desenvolvimento discursivo) (BERTRAND, 2003: 38)

Assim, essa associação entre as figuras, ainda que possa ocorrer livremente, em geral se faz por meio de um universo cultural específico, uma vez que "lançada uma primeira figura, essa exige apenas algumas, com exclusão de outras" (GREIMAS: 2012: 213). A figura "bola de futebol", por exemplo, no final do século XIX, mantinha proximidade com figuras diferentes das que estamos acostumados a ver atualmente, mais de cem anos após a chegada desse jogo esportivo no Brasil. Se hoje essa figura estaria acompanhada de outras como "estádio", "multidão", "altos rendimentos", "brigas" e "festa popular", nos primeiros anos de sua prática em território nacional motivaria figuras como "clubes privados", "participantes escassos", "esporte britânico" e "divertimento elitizado". De acordo com a época, com a classe social ou com qualquer outra variante cultural, uma figura pode suscitar associações isotópicas distintas.

Dos encadeamentos isotópicos decorre também a definição das relações metafóricas e metonímicas. As duas figuras de linguagem, como se sabe, não constituem a mera permutação de um vocábulo por outro, mas sim, uma nova perspectiva de leitura motivada pelo contexto (FIORIN, 2008: 118). Se há uma convergência dos traços semânticos, temos uma metáfora. Por exemplo, a aproximação dos termos "sol” e "diamante", "janela" e "ferida" ou "manhã" e "infância" mobiliza a intersecção das marcas de sentido /brilho/, /abertura/ e /incoação/, respectivamente. São traços sêmicos comuns a ambos os vocábulos. Se há uma relação de contiguidade, temos uma metonímia. $\mathrm{Na}$ história da canção brasileira, por exemplo, é comum os letristas se referirem ao 
instrumento musical "violão" como "pinho". A relação metonímica se justifica pelo fato de o violão fazer parte do conjunto de objetos produzidos com o tipo de madeira pinho.

Após essas observações iniciais a respeito da noção de isotopia, pensamos que, para esta pesquisa, a mais rica contribuição que a análise desse conceito poderá propiciar é o seu exame a partir do material primordial do cancionista, isto é, a relação entre a melodia e a letra, formadora das chamadas unidades entoativas. Primeiramente, devemos observar que isso acarreta uma alteração de perspectiva, já que, até o momento, a ideia de isotopia estava mais ligada ao plano do conteúdo. Como aponta Greimas, a semiótica passa a abarcar, sobretudo com os estudos de François Rastier, a análise das relações isotópicas ligadas ao plano da expressão.

(...) nada impede que se transfira o conceito de isotopia, elaborado e mantido até aqui no nível do conteúdo, para o plano da expressão: assim, o discurso poético poderia ser concebido, do ponto de vista do significante sob a forma de uma projeção de feixes fêmicos isotópicos, em que se reconheceriam simetrias e alternâncias, consonâncias e dissonâncias, e, finalmente, transformações significativas de conjuntos sonoros. (GREIMAS, 2012: 278)

Greimas destaca que, sob essa nova perspectiva estudada por Rastier, a isotopia passa a ser definida como a reiteração de "unidades linguísticas" que podem estar vinculadas tanto ao plano do conteúdo quanto ao plano da expressão (GREIMAS, 2012: 278). Observamos que, seja no âmbito do significado ou do significante, a noção de continuum semântico, isto é, o elo entre as figuras a partir da repetição de uma categoria de significado, se mantém. Resta-nos então examinar como esse conceito se aplica à relação entre a melodia e a letra na canção. Haveria uma isotopia das unidades entoativas? Acreditamos que sim. Supomos que, na canção, uma figura de fala se torna gramaticalmente reconhecível para o ouvinte no momento em que estabelece relação com outras figuras presentes em seu entorno imediato. Assim, uma frase com tonema ascendente e outra subsequente com tonema descendente, por posicionarem-se lado a lado, também contribuem para a seleção, dentre as várias virtualidades de sentido que abrigam, de significados inter-relacionados. Sob esse ângulo, uma frase asseverativa é tanto mais assertiva quanto maior a contundência da frase interrogativa que a antecede. Para examinar essa questão separamos os exemplos abaixo. No primeiro, apresentamos a letra e melodia do refrão da canção Ladeira da Preguiça. Nas figuras seguintes, alteramos 
a sua letra para investigar a permanência ou a transformação do sentido de suas unidades entoativas.

Essa ladeira

Que ladeira é essa?

Essa é a ladeira da preguiça

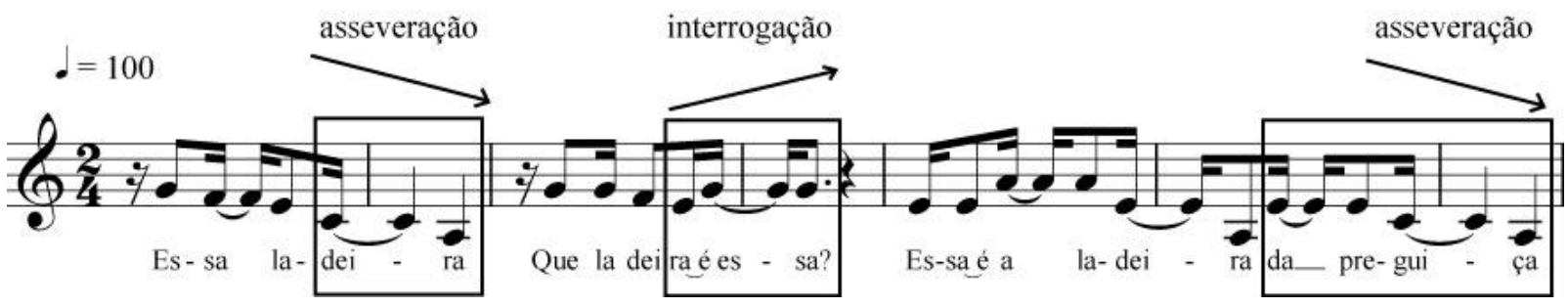

Figura 6. Ladeira da Preguiça (Gilberto Gil)

Essa ladeira

Que ladeira linda

Essa é a ladeira da preguiça

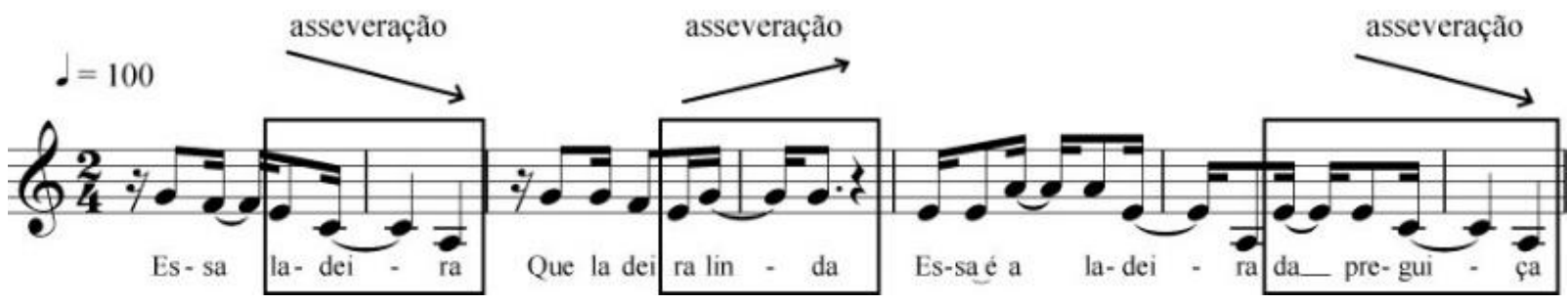

Figura 7. Alteração da letra e do sentido das unidades entoativas em Ladeira da Preguiça (Gilberto Gil)

Quem é você?

Ô, quem é você?

De onde você vem? Quem é você?

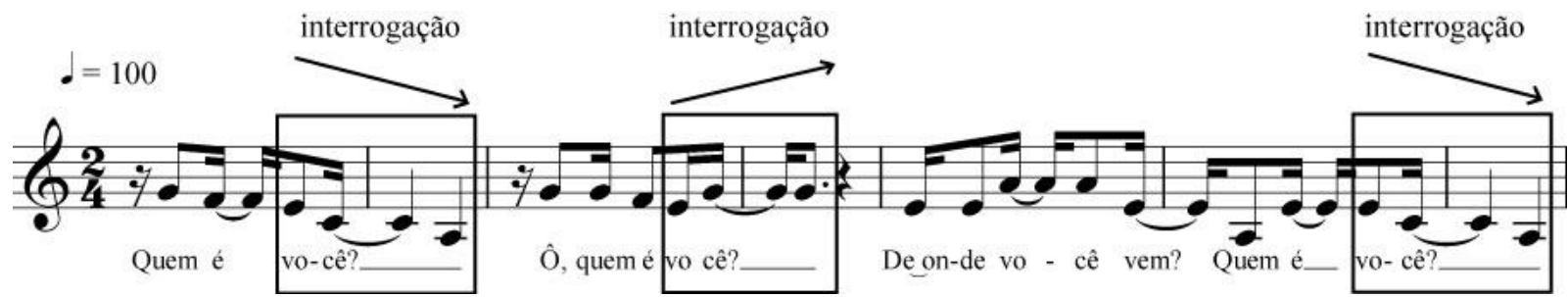

Figura 8. Alteração da letra e do sentido das unidades entoativas em Ladeira da Preguiça (Gilberto Gil)

Notamos que, na figura 6, o sentido afirmativo da terminação de frase que ocupa os compassos 6 e 7 ("Essa é a ladeira da preguiça") relaciona-se com seu entorno, sendo valorizado pela terminação interrogativa da frase anterior "Que ladeira é essa?" (compassos 3 e 4). A partir do significado do texto linguístico que recorta cada uma das 
frases, determinadas virtualidades presentes nas curvas melódicas são ativadas em detrimento de outras. Ou seja, o recorte da letra vai selecionando os traços semânticos já contidos nos perfis melódicos, em suas ascendências e descendências. Como ilustra a figura 7, a permutação da frase com sentido de indagação “Que ladeira é essa?” por outra com sentido de afirmação ("Que ladeira linda”) gera uma alteração da carga semântica da curva melódica absolutamente aceitável do ponto de vista entoativo. Nesse caso, teríamos três frases afirmativas em sequência: "Essa ladeira", "Que ladeira linda" e "Essa é a ladeira da preguiça”. Na figura 8 , substituímos a letra original por frases exclusivamente interrogativas: “Quem é você?”, “Ô, quem é você?”, “De onde você vem?” e “Quem é você?". Com isso, constatamos que os perfis melódicos descendentes, que na versão original da canção possuem sentido asseverativo, exibem agora um sentido de indagação latente, anteriormente minimizado. Parece-nos, dessa maneira, que o modo como a letra vai selecionando os traços semânticos contidos nessas curvas musicais é muito semelhante ao modo como se dá a leitura isotópica de um texto escrito: cada unidade linguística possui diversos sentidos latentes, culturalmente forjados, prontos para serem selecionados e apresentados em um texto concreto.

É interessante notar que as configurações melódicas, ainda que apresentem múltiplas possibilidades virtuais de sentido (ao serem recobertas com diferentes letras como mostramos nas figuras acima), podem ser culturalmente mais compatíveis com determinadas frases linguísticas em detrimento de outras. O perfil melódico ascendente, por exemplo, ainda que seja capaz de suscitar significações distintas, tem na interrogação (ou na não-afirmação) a sua mais forte tendência. Na língua oral há a mesma condição. Os vocábulos do português brasileiro, embora carreguem diversos significados latentes, também possuem uma disposição maior para certa significação: a palavra "manga", da qual falamos anteriormente, além dos significados mais usuais "parte do vestuário" e "fruto da mangueira", também comporta outros potenciais sentidos como "chaminé de lampião", "mangueira de bomba", "chocalho grande", “ajuntamento", entre outros. A tendência do falante do português brasileiro é, no entanto, selecionar os dois primeiros traços semânticos e não os demais. Nesse sentido, o texto que opta pelas acepções menos difundidas de "manga", assim como a canção que escolhe um caminho entoativo diferente daquele que estabelece o tonema ascendente como interrogativo, estará se distanciando em algum grau do que o público espera reconhecer, ainda que essas escolhas sejam perfeitamente possíveis. 
De todo modo, via de regra, o discurso apresenta uma construção interna que naturalmente propicia a coerência e a seleção dos traços semânticos desejados pelo enunciador. O leitor ou o ouvinte serão guiados pelo contexto discursivo, ligado à própria cultura do enunciatário, o que os ajudará a eleger uma leitura em conformidade com o que o autor intencionava exprimir.

(...) um lógico conclui a introdução de sua obra indicando que se contentou até então em apresentar "a ossatura de seu raciocínio". Leitor algum, é óbvio, imaginaria concretamente a organização de um esqueleto. Os elementos figurativos, embora presentes, estão de alguma forma suspensos. Seria muito diferente se ele continuasse dizendo: "passemos agora à carne e aos músculos". Rompendo a isotopia abstrata de seu discurso (cujo termo regente é "raciocínio"), ele transformaria assim a figuratividade enfraquecida e virtualizada que se tece na abstração em figuratividade saliente, de caráter icônico, e perturbaria um pouco as expectativas do leitor... (BERTRAND, 2003: 208)

O leitor, tendo consciência de que está lendo um texto eminentemente científico, faz com que as significações abstratas permaneçam ao longo do enunciado e, consequentemente, compreende a expressão "ossatura do raciocínio" como "estrutura do raciocínio”. O leitor legitima a metáfora usada pelo cientista, isto é, a relação sêmica entre "esqueleto humano" e "organização de uma teoria", pois ambos suscitam os traços semânticos "estrutura", "sustentação", "eixo" etc. Nessa perspectiva, falar em "carne e músculos" seria tentar inserir traços semânticos presentes em "ossatura" que estavam minimizados pelo contexto abstrato do discurso científico, o que desestabilizaria a leitura do texto. Tentaremos, nos capítulos seguintes, constatar se, na canção, encontramos fenômenos similares. Afinal, uma questão nos instiga: no interior de uma obra fortemente temática, um trecho oral repentino (instável musicalmente), pode perturbar as expectativas do ouvinte assim como a expressão "carne e músculos” perturbaria a leitura do texto do cientista exemplificado por Bertrand? Essa questão nos acompanhará adiante quando, por exemplo, em nossos testes de reescrita, efetuarmos modificações nos padrões melódicos de certas canções para, amenizando deslocamentos no nível da sílaba, da palavra ou da frase, verificarmos os diferentes resultados de sentido ${ }^{75}$.

Por fim, antes de encerrarmos este capítulo, desejamos discutir um apontamento frequentemente realizado por estudiosos de outros campos do conhecimento a respeito da

\footnotetext{
${ }^{75}$ Nos capítulos seguintes, por vezes, para realizar tal abrandamento, utilizaremos o recurso da elasticidade melódica, perturbando a regularidade do padrão musical vigente.
} 
abordagem semiótica do texto. Essa discussão, aliás, nos ajudará a explicitar uma das razões pelas quais adotamos a semiótica da canção e a semiótica geral em nossas análises (sem desconsiderar as importantes colaborações já consolidadas pelas outras áreas de estudo). Vejamos. A noção de isotopia comentada há pouco, ao fundamentar-se na relação entre os elementos internos de um discurso, ilustra claramente um importante princípio para os semioticistas e que está ligado às frequentes críticas dirigidas à teoria: o princípio da imanência.

A autonomia da linguística - justificável pela especificidade de seu objeto, afirmada com insistência por Saussure - foi retomada por Hjelmslev sob a forma do princípio de imanência: sendo a forma (ou a língua no sentido saussuriano) o objeto da linguística, qualquer recurso aos fatos extralinguísticos deve ser excluído por ser prejudicial à homogeneidade da descrição (GREIMAS, 2012: 255)

As críticas dirigidas à semiótica geralmente se relacionam a essa tendência do princípio da imanência de se descartar da análise os elementos extradiscursivos e de entender o texto como um sistema fechado de relações. Como destaca Bertrand, há um questionamento da teoria (uma espécie de "censura ao formalismo") pela ausência da instância da enunciação (2003: 30). Essa falta geraria uma cisão entre sujeito e discurso, abduzindo o texto de sua realidade histórica e ignorando as condições de sua produção e recepção. Conforme o autor, no entanto, a noção de imanência não produz esse distanciamento histórico apontado pela crítica. É preciso examinar o princípio semiótico da imanência de modo mais aprofundado para observarmos que a teoria, sob essa perspectiva, também nos conduz a reflexões de caráter social e psicológico.

Parece-nos que descobrir estruturas imanentes nas formas é também dotar-se dos meios de reconhecer as convenções que o uso pouco a pouco estabeleceu, sedimentadas em estruturas e construídas com regras implícitas. Essas convenções moldam as expectativas dos leitores. Elas asseguram, para além do sistema da língua em si, a previsibilidade do conteúdo, as hipóteses e inferências da leitura. As estruturas assim compreendidas deveriam estar também relacionadas com o sujeito, mas elas fazem parte agora de uma enunciação enfraquecida, do murmúrio impessoal dos discursos que milhões de falas engendram, retomadas e repisadas: a fraseologia, as expressões fixas, os estereótipos, esses blocos pré-fabricados e prémoldados de discursos atestam na superfície a impessoalidade da enunciação (BERTRAND, 2003:31) 
Por outro lado, como também comenta o autor, se o princípio da imanência permite a identificação dessa sedimentação resultante de um padrão enunciativo culturalmente determinado, por outro, possibilita igualmente o reconhecimento das ocorrências inovadoras, “enunciações singulares” (BERTRAND, 2003: 31) que propõem novas configurações discursivas. A semiótica nos auxilia a perceber que essas originais fisionomias, inéditas e destoantes no momento de seu surgimento, possivelmente serão incorporadas na "regularidade das esquematizações" (BERTRAND, 2003: 31).

Acostumamo-nos a observar, no decorrer da história da canção popular, essa recorrente aparição de formas inovadoras e individuais que, inicialmente refutadas por camadas consideráveis de ouvintes, passam a abarcar a coletividade e a se oficializar. A bossa-nova, o tropicalismo e o rap são exemplos notáveis de manifestações musicais que, se ao aparecerem produziram certo estranhamento e indicaram um rompimento com o padrão cancional vigente, paulatinamente se tornaram cada vez mais estabelecidas e incorporadas ao universo de escuta. Assim, trabalhar o texto considerando prioritariamente os seus elementos internos em detrimento dos fatos extradiscursivos, divisando conteúdos sedimentados e conteúdos inovadores, é também compreendê-lo historicamente.

\footnotetext{
Vista dessa maneira, a abordagem sincrônica das estruturas não contradiz nem a abordagem diacrônica da história, nem a abordagem pragmática da leitura: ao contrário, ela oferece mesmo a possibilidade de uma história das poéticas, ou de uma história cultural das formas, apreendidas sobre um outro regime de duração que não o de uma cronologia de obras e de movimentos literários (BERTRAND, 2003:31)
}

Certamente, o estudo dos elementos internos de uma obra pode estabelecer relações com circunstâncias extratextuais de diversas maneiras. No caso do rap, ao analisarmos a forma da canção e seus componentes intrínsecos, somos capazes de avaliar aspectos de seu contexto histórico: por exemplo, o fato de a proximidade da melodia do canto com a fala ser significativamente propícia à veiculação de suas mensagens contestatórias (SEGRETO, 2015:17). Enfim, ao passarmos nesse momento para a próxima parte da pesquisa, na qual analisaremos a figurativização em diversos níveis composicionais da canção, desejamos sublinhar que o exame imanente das obras não deverá impedir a constante reflexão acerca de seu contexto de escuta e de seu posicionamento histórico e social. Ao contrário, deverá embasá-lo. 
O intuito desta primeira seção de nossa tese, formada pelos três primeiros capítulos, foi, assim como sugere o modelo do percurso gerativo, propor a apreciação de um conteúdo a partir da sua estratificação em camadas (no caso do modelo padrão, patamares que se sucedem do mais abstrato ao mais concreto). Percorrendo um caminho inverso, como mencionamos em nossa introdução, nosso ponto de partida constituiu uma manifestação mais concreta do tema: os indícios históricos da presença da fala em diversos movimentos artísticos ligados à música erudita ou popular comentados no capítulo inicial. Em seguida, no segundo capítulo, pudemos acompanhar o modo pelo qual a semiótica da canção tratou essa influência da língua oral na composição de canções. É como se, ao propor um conjunto de conceitos e ferramentas analíticas, a teoria desenvolvida por Tatit concedesse um grau maior de abstração para o exame de nosso assunto. Por fim, neste terceiro capítulo, embasados pela semiótica geral (e não pela semiótica específica da linguagem cancional) constatamos como a entoação na canção pode se relacionar com noções mais amplas como, por exemplo, a referencialização no mundo natural, a veridicção etc. Ao organizarmos dessa maneira os capítulos iniciais, nosso objetivo foi, então, não somente apresentar a pesquisa de uma maneira mais convidativa (sobretudo para o leitor interessado em canção, mas alheio ao aparato teórico da semiótica), mas igualmente traçar um caminho que pouco a pouco conceitualizasse e aprofundasse algo que nos parece um dado sensorial relevante: a cada vez que ouvimos uma canção, nossa experiência com a linguagem oral, entre outras muitas experiências, é ativada. Passemos, nesse momento, à parte analítica de nossa tese, seção igualmente dividida em patamares de investigação (sílaba, palavra e frase). 


\section{PARTE II}

ORALIZAÇÃO LINEAR E ORALIZAÇÃO NÃO-LINEAR 
Ao longo dos últimos três capítulos, ao estudarmos a questão da relação entre o canto e a língua oral e examinarmos de modo detalhado o processo da figurativização (ou oralização) proposto pela semiótica da canção, pudemos observar um importante pensamento teórico: a oscilação cancional entre as tendências ligadas à linguagem oral e os padrões estabelecidos pela música. Nos dedicamos à essa questão oscilatória não somente apresentando exemplos de obras e compositores pertencentes à história da música popular e erudita (assunto de nosso capítulo inicial "O canto e a fala"), mas também a partir da abordagem proposta por Tatit que identifica o permanente vagar entre duas tendências fundamentais da canção: a força entoativa e a forma musical. O fenômeno cancional poderia, então, ser tratado como uma contínua flutuação entre um canto mais oral e um canto mais musical, sendo que ambos os processos (oralização e musicalização) estão sempre atuando de maneira simultânea. Para representar esse pensamento proposto pela semiótica de Tatit, formulação que até mesmo delimita a própria linguagem da canção (diferenciando-a da linguagem musical ou verbal nas quais não há a necessidade da atuação concomitante dos dois processos citados acima), elaboramos a seguinte ilustração:

\section{oralização}

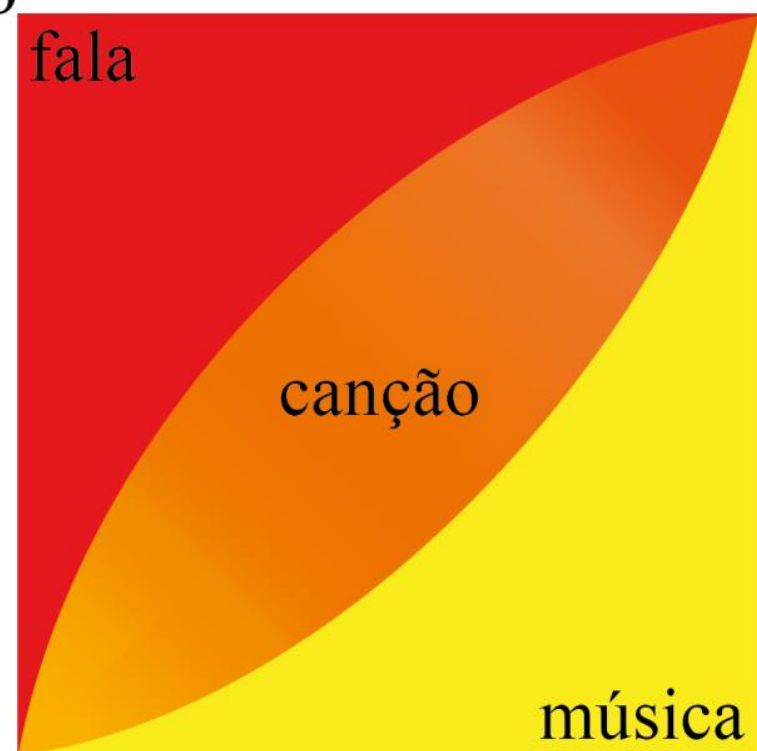

musicalização

Figura 1. A atuação simultânea dos processos de musicalização e oralização na canção

A figura acima nos auxilia a demonstrar como a semiótica da canção entende a presença simultânea desses dois processos. Primeiramente, utilizamos duas cores primárias, o vermelho para oralização e o amarelo para musicalização. Essas tonalidades, 
quando misturadas, produzem a cor laranja. A canção pode ser representada pela coloração laranja, pois jamais se confunde com a fala ou com a música, sendo sempre uma espécie de mistura dos dois componentes. Como vimos anteriormente, o compositor de canções, quando combina unidades verbais e unidades melódicas, cria modos de dizer que não devem ser confundidos com a língua oral nem com a música pura, ainda que estabeleçam relações com ambas. Da mesma forma, o laranja constitui uma terceira coloração que surge da junção das duas cores primárias selecionadas acima.

Em segundo lugar, podemos traçar linhas horizontais para definir certos "estados de canção". Cada linha selecionada delimitará uma quantidade maior ou menor de música e de fala. Jamais, entretanto, observaremos a ausência completa de um desses dois componentes. Na figura abaixo, traçamos uma linha que pretende ilustrar a presença de ambos no caso do rap, gênero no qual a presença da língua oral se destaca. Poderíamos continuar em direção ao limite extremo superior encontrando uma obra com uma presença quase absoluta da fala e uma quantidade mínima de música. Ainda assim, no entanto, o componente musical permanece ativo. O mesmo ocorre com uma linha horizontal traçada no limite inferior da figura (a música muito proeminente e a fala quase ausente). A ocorrência desses casos extremos é rara, mas existe.

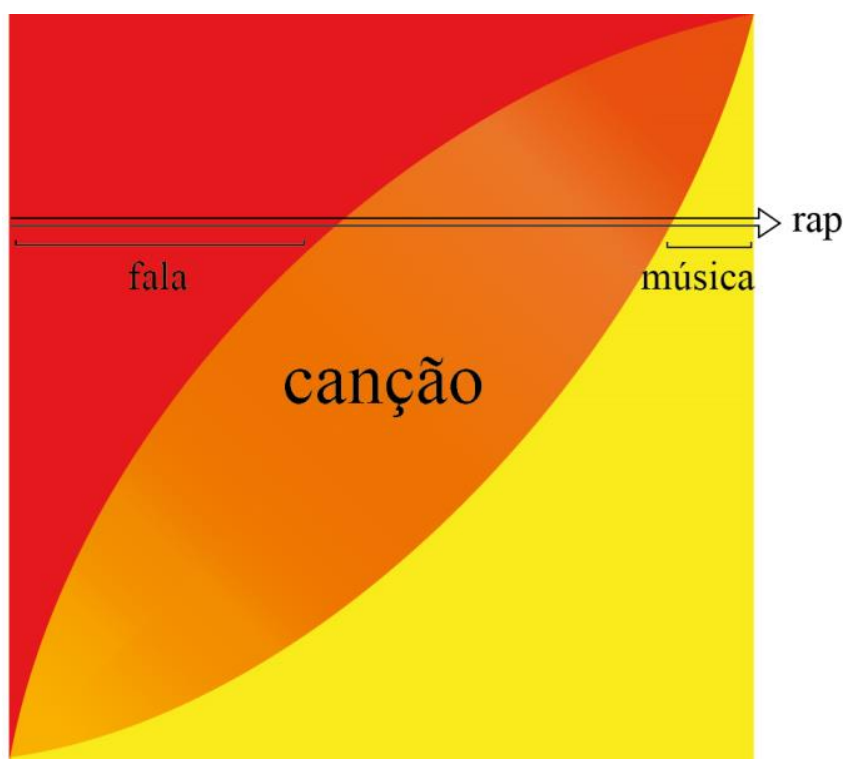

Figura 2. A representação de um "estado de canção"

A forma que representa a canção, preenchida com a cor laranja, é uma espécie de elipse distorcida. Aproveitamos o fato de essa forma tornar-se mais estreita nas pontas 
para representar a menor ocorrência das "canções extremas", isto é, das obras que trabalham com quantidades ínfimas de algum dos dois componentes. Por outro lado, o fato de ela ser mais larga na região central nos indica que a maioria das canções atua combinando quantidades mais equilibradas de fala e de música.

Por fim, a coloração alaranjada que preenche a elipse sofre uma gradação, do meio para as pontas. No extremo superior, há uma gradação para um laranja mais avermelhado, indicando a maior presença da fala. No extremo inferior, uma transição para um laranja amarelado, assinalando uma presença maior da música. No entanto, ainda que tenhamos essas mudanças progressivas na tonalidade, podemos dizer que a cor que preenche a elipse é sempre o laranja, isto é, jamais se confunde com o vermelho ou com o amarelo. Por conseguinte, a linguagem cancional não deve ser compreendida como imitação da fala, por exemplo.

Enfim, acreditamos que a ilustração acima seja útil para ressaltarmos a ideia de que não existe canção sem a atuação simultânea dos dois processos. Como vimos anteriormente, a presença exclusiva da oralização ou da musicalização não constitui a linguagem da canção, já que, nesses casos hipotéticos, observaríamos somente a linguagem verbal ou musical, isoladas. Mais do que isso, a ilustração nos auxilia a compreender de modo mais objetivo os limites da linguagem cancional. Trata-se da mesma questão que discutimos no capítulo "A oscilação entre a força entoativa e a forma musical", quando, opondo força e forma, situamos a canção em um permanente vagar entre os dois polos.

Nos capítulos seguintes, dando prosseguimento às reflexões conceituais que realizamos na parte inicial de nossa tese (sobretudo quando estudamos a teoria da semiótica da canção), analisaremos diversos exemplos a partir dos quais desejamos propor uma nova reflexão teórica, para além dessa questão ligada à oscilação. Os casos analisados a seguir nos permitirão examinar o processo figurativo de modo mais aprofundado, detalhando esses diferentes tipos de ocorrências a partir da criação de subcategorias para a noção de figurativização. Expliquemos. Como vimos, na canção, todas as vezes que o letrista recorta uma melodia ou o melodista recobre uma letra eles estão propondo um modo de dizer. A esse processo cancional de união entre unidades verbais e unidades melódicas que instituem modos de dizer chamamos "figurativização" ou "oralização". Nesse procedimento de junção, fatalmente teremos resultados mais próximos ou mais distantes do que estamos acostumados a presenciar em nossa experiência cotidiana com a linguagem oral. Entretanto, tanto as proposições mais usuais 
quanto as menos usuais fazem parte desse processo cancional. Assim, é como se as canções já nascessem automaticamente figurativas. Se há canção, há figurativização e, por conseguinte, há encaixes mais ou menos próximos da língua oral.

Podemos entender a canção como a criação de prosódias plausíveis. É evidente que a plausibilidade desses modos de dizer depende de um consenso social, mas, como constatamos no decorrer de nossa pesquisa, esse acordo é bastante maleável. Uma vez que a maioria das ocorrências é pontual, o ouvinte pode admitir pausas no interior das frases, deslocamentos silábicos, ênfases em palavras menos importantes da oração e até mesmo soluções que chegam a prejudicar a inteligibilidade da letra (o que pode ultrapassar levemente os limites desse consenso). Por serem passageiras, essas ocorrências não quebram o contrato oral entre o artista e o público. Portanto, as propostas figurativas dos autores, mais ou menos comuns, sempre se beneficiam da elasticidade consensual da nossa cultura entoativa.

Com isso, definindo a figurativização como um processo que inevitavelmente engloba modos de dizer mais ou menos usuais, estamos nos prevenindo do estabelecimento de relações inadequadas entre esse conceito e a língua oral, evitando o seu engessamento na ideia de que a canção deve respeitar (ou imitar) as leis linguísticas da fala. De modo distinto, devemos entendê-lo como um processo que funda a canção a partir das propostas originais de cada autor e não como uma simples mimetização da língua oral. A canção não é a fala, assim como o quadro figurativo e bidimensional de um artista plástico que pinta um autorretrato não é o próprio artista. Em vista disso, por exemplo, não devemos descrever uma canção como "mais figurativa" ou "menos figurativa" (como sinônimo de "mais próxima" ou "menos próxima" da língua oral), visto que todas as canções constituem propostas figurativas inventadas pelo autor. $\mathrm{O}$ cancionista, a princípio, não segue e nem deseja realizar os contornos entoativos que experenciamos na fala (ainda que isso ocorra eventualmente). Ele apenas fabrica contornos inéditos que se convertem em novos modos de dizer um determinado texto linguístico, sem jamais serem idênticos às inflexões de uma fala específica: assim como na pintura (ou mesmo na escultura cuja tridimensionalidade se aproxima um pouco mais de nossa experiência com a imagem de uma pessoa no mundo real), o cancionista jamais reproduzirá a realidade ${ }^{76}$. O campo da figurativização, ilustrado por todos os exemplos que selecionamos para nossa pesquisa, é bem mais vasto que isso.

\footnotetext{
${ }^{76}$ No seu caso, jamais criará o mesmo modo de dizer que encontramos na língua oral.
} 
A partir do exame de variadas obras de nosso cancioneiro, constatamos que muitas canções não confluem integralmente para uma solução oral usual e que, por vezes, notamos uma quebra de expectativa que não chega, porém, a invalidar a apreensão geral das unidades entoativas. Esses comportamentos desviantes não são "melhores" ou "piores" que o pleno consenso prosódico, apenas indicam que o cancionista dispõe de uma ampla margem de soluções figurativas que confirmam ou modificam nossas expectativas orais. Podemos considerar, então, na linguagem da canção, duas novas subcategorias: a figurativização/oralização linear, quando constatamos modos de dizer mais usuais, e a figurativização/oralização não-linear, quando detectamos um tipo de oralização menos esperado ou direto (ainda que ele configure uma figura entoativa fabricada pela composição e aceita na nossa cultura). No segundo caso, portanto, temos encaixes também consensuais, mas não tão diretamente ${ }^{77}$.

Assim, dentro dessa abrangente elasticidade, todas as criações de unidades entoativas constituem figurativizações (modos de dizer) que adquirem, em relação à linguagem oral, feição ora mais regular, ora mais inusitada. Ora mais usual, ora mais inusual. Ora mais convergente, ora mais divergente. Ora mais básica, ora mais propositiva. Ainda que essa terminologia não seja satisfatória, acreditamos que ela ajuda a libertar o termo "figurativização" para definir toda relação entre melodia e letra criada pelos compositores, independentemente de sua aproximação ou afastamento do padrão da fala. Observamos, então, o vasto campo figurativo por onde circulam as obras e suas infinitas nuances:

FIGURATIVIZAÇÃO

NÃO-LINEAR

modo de dizer

mais distante

da língua oral
FIGURATIVIZAÇÃO LINEAR

modo de dizer mais próximo da língua oral

\section{CANÇÃO}

Figura 3. O campo gradativo da figurativização na canção

\footnotetext{
77 Os termos "linear" e "não-linear" foram sugeridos pelo próprio Luiz Tatit, como forma de abarcar os diferentes tipos de exemplos cancionais, todos fundados na figurativização, mas com modos de dizer oralmente distintos.
} 
Pelo fato de as canções sempre envolverem melodia e letra, só artificialmente teremos casos que negligenciam por completo a figurativização (talvez no domínio erudito ou semierudito). Afinal, como vimos, todas as criações cancionais são ligadas a esse processo. Os elementos de musicalização, cujo estudo não corresponde ao tema central de nossa tese, atuam simultaneamente, em paralelo, em todas as situações figurativas previstas na ilustração acima. Na figurativização linear, é fácil depreendermos a colaboração das cadências tonais e suspensões melódicas na constituição dos tonemas prosódicos (asseverações, perguntas, hesitações etc.), por exemplo. Na figurativização não-linear, por outro lado, constataremos configurações musicais que resultam em propostas orais menos consensuais. É como se a musicalização na canção fosse, além de um procedimento de estabilização sonora, um "ninho" de propostas onde nascem unidades melódicas às vezes arredias à língua oral mais corrente. Ela pode, portanto, favorecer saídas figurativas mais ou menos esperadas.

A continuação do trajeto em direção à não-linearidade, no limite, poderia “explodir” a figurativização. No repertório da música vocal erudita contemporânea, por exemplo, encontramos peças nas quais não há encaixes entoativos ou modos de dizer como aqueles que observamos na canção popular, o que exigiria, sem dúvida, outras ferramentas analíticas (diferentes das cancionais) ${ }^{78}$. Via de regra, no entanto, o que encontramos são criações com propostas de inflexão que apresentam "desvios" pontuais que não comprometem a figurativização geral da obra. Além disso, como veremos adiante, diversos casos estudados nesta tese (nos quais observaremos esses desvios nos níveis silábico, lexical e frasal) constituem, do mesmo modo, conformações figurativas não-lineares que representam uma maneira especial de dizer a letra. Há, ao mesmo tempo, um desvio do padrão e o surgimento de aspectos inventivos. Nesse sentido, poderíamos associar a figurativização não-linear às questões ligadas à "renovação", à "proposição", à "inventividade" (ainda que nem sempre essas soluções produzam de fato algum avanço na linguagem).

Enfim, essa reflexão nos auxilia a compreender a relação das canções com a oralização como uma determinação que independe da vontade do cancionista. Só há uma maneira de não existir oralização na canção: se o cancionista não criar a letra para a sua

\footnotetext{
${ }^{78}$ Como já comentamos nesta pesquisa, a peça para voz solo que integra as Sequências de Luciano Berio é um bom exemplo desse tipo de composição. Nesse caso, adotaríamos, sobretudo, procedimentos de análise musical.
} 
melodia. Se ele o fizer, teremos sempre uma proposta de figurativização mais linear ou menos linear, como constataremos nas canções aqui analisadas.

Para melhor compreendermos esses diferentes tipos de oralização (linear ou nãolinear), podemos estabelecer uma interessante relação entre essa questão entoativa na canção e fenômenos ligados à língua oral estudados pela linguística. Trata-se do campo de estudo que se dedica aos casos de variação linguística, uma característica universal das línguas naturais. Os exemplos de variação linguística são “detectáveis no léxico, na fonética, na morfologia e na sintaxe do português brasileiro" e explicados "com base na localização geográfica dos falantes e em aspectos sociais, tais como escolaridade do falante e formalidade e informalidade da situação de fala" (BELINE, 2012: 125-126). No caso da língua oral, podemos dizer que há, de um lado, uma norma padrão que consiste em um "ideal de língua", em uma "abstração" (BAGNO: 2001, 159) e, de outro, “em termos de realidade linguística e social, a massa de variedades reais, concretas, como se encontram na sociedade.” (BAGNO: 2001, 161). Há, então, na língua falada, uma ampla gama de possibilidades de execução dessa língua idealizada identificada com a norma culta.

No português brasileiro, se tomarmos o caso da pronúncia do -r em final de sílaba (em uma palavra como "porta", por exemplo), constataremos que a sua emissão abstrata se realiza na língua como uma variável linguística, ou seja, um conjunto de duas ou mais variantes. Os paulistanos, por exemplo, pronunciam o -r como vibrante simples (o chamado flap paulistano). Os falantes da cidade do Rio de Janeiro, por sua vez, o fazem com uma emissão distinta (o aspirado carioca). Há ainda a pronúncia do falar caipira que apresenta o $-\mathrm{r}$ retroflexo. Para a sociolinguística variacionista, esses três casos correspondem a variantes linguísticas que constituem uma variável, pois todas elas "são diferentes formas linguísticas que veiculam um mesmo sentido" (BELINE, 2012: 122). Assim, o mesmo fonema $/ \mathrm{r} /$ pode ser realizado na língua com diversas configurações sonoras, como no exemplo do vocábulo "porta". Ainda que suas realizações sejam distintas, todas elas são perfeitamente aceitas pelos falantes do português brasileiro. Um paulistano não terá problemas para compreender a palavra "porta" dita por um falante carioca. Há aqui, portanto, uma mudança fonética sem mudança fonológica. O signo não se altera. 
Observamos um fenômeno equivalente nas diferentes formas de pronunciarmos, no português brasileiro, o vocábulo "mesmo"79. Há, aqui, diversas variantes possíveis: "mexmo" (carioca), "mesmo" (paulistano), "mermo" (carioca) e ainda a possível supressão do som no final da sílaba em "memo" (falantes de diversas regiões em uma situação informal de fala). Todas essas variantes remetem ao mesmo signo cuja transcrição fonológica é /'meSmo/. Para a linguística, portanto, os fonemas constituem essa abstração de tudo o que é variável foneticamente numa língua, constituindo algo invariável e único. Assim, ainda que um falante carioca pronuncie o som aspirado ['mezmu] e um falante paulistano o emita com a consoante fricativa ['mezmu], isto é, ainda que os sons [3] e [z] sejam distintos, o fonema é exatamente o mesmo (/S/). Os fonemas possuem, portanto, um aspecto mais abstrato do que os fones (os sons produzidos na fala), constituindo uma espécie de imagem mental dessas unidades sonoras. Enfim, podemos dizer que todas essas variantes fonéticas elencadas acima se remetem a um mesmo fonema abstrato que constitui uma abstração consensual dos falantes.

As subcategorias figurativas propostas acima, isto é, as oralizações lineares e nãolineares podem ser abordadas a partir da mesma perspectiva. É como se a relação entre a fonética e a fonologia se repetisse na entoação da canção. Um recorte frasal menos esperado, por exemplo, quando uma unidade verbal se divide em duas unidades melódicas ${ }^{80}$, pode ser considerado uma espécie de "variante entoativa" que forma, juntamente com outras variantes, um conjunto de possibilidades plausíveis de emissão dessa mesma unidade verbal. Ou seja, há aqui uma variável entoativa constituída por múltiplas materializações de uma curva abstrata. A diferença entre o campo da fonologia e o campo da canção está, é evidente, na dimensão artística deste último. Muitas vezes, as soluções inventivas de entoações não-lineares cumprem funções estéticas. Diferentemente, as variantes fonéticas resultam, como já mencionamos, de hábitos regionais, influências migratórias, escolaridade, dentre outros fatores.

Enfim, visto que nenhuma canção imita os contornos da fala, mas sim, os recria, podemos dizer que os compositores produzem diversas realizações (manifestações) de uma entoação abstrata aceita pelos ouvintes (falantes da língua sobre a qual ela é composta). Há uma síntese consensual da curva que está sendo cantada. Essa síntese é produzida apenas na mente do público, com base na gramática da língua internalizada

\footnotetext{
79 Esse interessante exemplo, conveniente para demonstrar a relação entre a fonética e a fonologia e a entoação na canção, foi sugerido por Luiz Tatit.

${ }^{80}$ Estudaremos diversos casos como esse adiante.
} 
pelos indivíduos. Assim, esse contorno entoativo está em nossa cabeça (em virtude do consenso), mas não pode se fixar em um desenho concreto. Não há, pois, um padrão.

A entoação abstrata formada por todas as execuções possíveis de uma frase, por exemplo, pode ser considerada uma espécie de matriz entoativa. Há, portanto, diferentes formas de consumar o mesmo texto verbal e todas elas são possíveis, ou melhor, consensuais, remetendo a uma configuração conceptual. Assim como no caso do "fonema", temos aqui, igualmente, uma imagem mental que as abarca. É justamente por essa razão que, nos capítulos seguintes, realizaremos a atividade de reescritura de diversos trechos de obras. Alterando a melodia ou a letra de algumas canções, como uma espécie de experimentação entoativa, poderemos explicitar o funcionamento do processo de oralização na canção, evidenciando as diversas propostas possíveis para uma mesma entoação abstrata.

Desse modo, nesta segunda parte de nossa tese, além de considerarmos a oscilação entre os processos de oralização e musicalização, observaremos igualmente essa interessante questão da existência de oralizações mais lineares ou menos lineares, entendendo que no processo de combinação entre texto verbal e música, pode haver múltiplas variantes, todas aceitas pelo consenso cancional. 


\section{A SSLABA}

Neste capítulo, por meio da análise de fragmentos de diversas obras e da prática de composição de letra e melodia (a partir da recriação de alguns desses exemplos), desejamos observar questões ligadas à acentuação silábica nas letras de canção. Examinaremos igualmente alguns exemplos retirados de estudos que abordaram esse assunto, mesmo não sendo o foco principal de seus autores. São eles os livros Ensaio sobre a música brasileira de Mário de Andrade, Feitiço decente: transformações do samba no Rio de Janeiro (1917-1933) de Carlos Sandroni e Bim bom - A contradição sem conflitos de João Gilberto de Walter Garcia. A partir desse material, analisaremos de que maneira os parâmetros musicais intensidade, duração e altura podem influenciar nas mudanças de acentuação silábica.

Antes de tudo, como já comentamos anteriormente, devemos lembrar que a experiência de escuta de uma canção ocorre a partir de parâmetros de plausibilidade preestabelecidos pela cultura. É incomum, por exemplo, encontrarmos no universo da canção popular comercial obras que não apresentam unidades entoativas plausíveis, pois, como vimos, é parte essencial do trabalho do cancionista a valorização da naturalidade oral. De forma lúdica e intuitiva, o intérprete convence o ouvinte de que a situação retratada na letra está sendo vivida naquele exato instante. Por isso, a naturalidade da fala exerce uma função especial na canção, embora encontremos no interior de uma mesma obra trechos que apresentam maior ou menor consenso entoativo. No caso do assunto de nosso capítulo, supomos que a naturalidade oral esteja ligada a uma coincidência entre os pontos de destaque da melodia e as sílabas tônicas dos vocábulos. Quando há uma confluência entre eles, torna-se mais espontânea a apreensão por parte dos ouvintes. Analisemos esse fenômeno de maneira mais detida.

Há algo curioso em relação à acentuação silábica, pois, em geral, trata-se do único parâmetro a partir do qual músicos, cancionistas ou estudiosos não familiarizados com a 
linguagem da canção propriamente dita ${ }^{81}$ costumam avaliar a boa ou má adequação entre o texto verbal e a linha melódica. Ela consiste, então, em um dos poucos aspectos de fato cancionais (visto que articula simultaneamente letra e melodia) observados até mesmo por ouvintes não especializados. Assim, um desvio na acentuação silábica logo chamalhes a atenção para o que denominam um "erro de prosódia". A prosódia, definida segundo o Dicionário Aurélio da Língua Portuguesa (FERREIRA, 1988) como "pronúncia regular das palavras, com a devida acentuação" ou como "a parte da gramática que estuda as pronúncias das palavras", estabelece, então, um paralelo entre a emissão do cantor e o que estamos acostumados a vivenciar em nossa linguagem oral cotidiana. Neste capítulo, no entanto, como forma de destacar a sílaba como o elemento mínimo da composição, adotaremos, para examinar esse fenômeno, ao invés de "prosódia", a expressão "acentuação silábica".

Antes de partirmos para a análise, uma ressalva. Como veremos adiante, não é aconselhável reduzirmos o encaixe entre a música e a letra somente ao aspecto silábico. Em geral, costuma-se considerar como criações bem resolvidas apenas aquelas em que as suas acentuações são respeitadas. Essa visão, ainda que represente um mínimo de interesse entoativo por parte dos consumidores de canção (já que há uma vontade de reconhecer as palavras da forma como as escutamos em nosso cotidiano $^{82}$ ), inadequadamente isola esses elementos mínimos do todo, examinando a acentuação silábica sem considerar os demais níveis composicionais da canção.

Nesse sentido, acreditamos que os fenômenos ordinariamente chamados de "erros de prosódia" possuem um alcance mais pontual e dificilmente comprometem a concepção geral do compositor. Isto é, os ouvintes, ao entrarem em contato com as unidades entoativas de uma canção, podem aceitar construções que desprezam o acento tônico de certas palavras se o projeto global realizado pelo cancionista apresentar um tratamento entoativo plausível. Supomos que esses casos se tornam menos relevantes quando inseridos no contexto maior de uma obra, pois o efeito entoativo de uma canção ultrapassa o cuidado mais pontual com a acentuação silábica do texto. Dito isso, é por esse elemento mínimo, a sílaba, que iniciaremos nossa análise.

\footnotetext{
${ }^{81}$ Entendida aqui, sob a perspectiva da semiótica da canção, como a relação entre a melodia e a letra.

${ }^{82}$ Como estudamos anteriormente, se o público não reconhecer as palavras cantadas da forma como ele as reconhece em seu cotidiano, o vínculo entoativo se fragiliza.
} 


\subsection{A alteração da acentuação silábica pela intensidade}

Mário de Andrade, em seu Ensaio sobre a música brasileira (1928), interessado no estudo da música popular folclórica como forma de sustentar uma arte nacional erudita, comenta certas construções rítmicas encontradas em canções brasileiras. Primeiramente, destaca a diferença entre a execução da obra e a sua versão impressa em partitura, apontando que a capacidade de invenção rítmica do cantador não comparece nas transcrições melódicas dos músicos contratados pelas editoras. Em contraposição à música europeia, observa a valorização da fala e da dicção de cada cantor na configuração sonora das obras nacionais:

De fato, qualquer cantiga está sujeita a um tal ou qual ad libitum rítmico devido as próprias condições da dicção. Porém essas fatalidades da dicção relativamente a música europeia são de deveras fatalidades, não tem valor específico pra invenção nem efeito da peça. (...) Mas o mesmo não se dá com as danças cariocas e grande número de peças nordestinas. Porquê nestas zonas os cantadores se aproveitando dos valores prosódicos da fala brasileira tiram dela elementos específicos essenciais e imprescindíveis de ritmo musical. E de melodia também. Os maxixes impressos de Sinhô são no geral banalidades melódicas. Executados, são peças soberbas, a melodia se transfigurando ao ritmo novo. (ANDRADE, 1972: 23)

E mais adiante:

Ora, esses processos de rítmica oratória, desprovidas de valores de tempo musical contrastavam com a música portuguesa afeiçoada ao mensuralismo tradicional europeu. Se deu pois na música brasileira um conflito entre a rítmica diretamente musical dos portugueses e a prosódica das músicas ameríndias, também constante nos africanos aqui. E a gente pode mesmo afirmar que uma rítmica mais livre, sem medição isolada musical era mais da nossa tendência, como provam tantos documentos já perfeitamente brasileiros que exponho em seguida a este Ensaio. Muitos dos cocos, desafios, martelos, toadas, embora se sujeitando à quadratura melódica, funcionam como verdadeiros recitativos (ANDRADE, 1972: 31)

A partir da leitura desses dois fragmentos, podemos constatar que o autor já intuía os elementos próprios da canção, independentemente da linguagem musical, percebendo que os seus compositores se apoiam na maneira de dizer para estabilizar ritmicamente o canto. Assim, assinala a diferença significativa entre as melodias que escutava na voz dos cantadores e a escrita em partitura realizada por músicos de seu tempo. É o que observa 
ao comparar as duas versões da canção Pinião, obra que ficou conhecida na gravação de 1927 do grupo Turunas da Mauriceia.

Pinião, pinião, pinião

Oi pinto correu com medo do gavião

Por isso mesmo sabiá cantou

E bateu asa e voou

E foi comer melão!

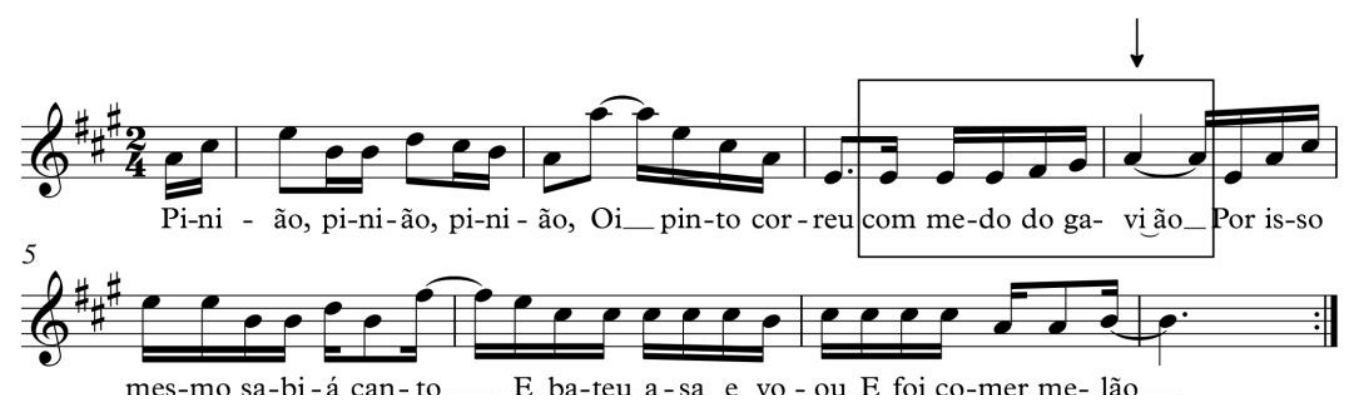

Figura 1. Versão impressa de Pinião (Augusto Calheiros e Luperce Miranda) pela Ed. Wehrs e Cia

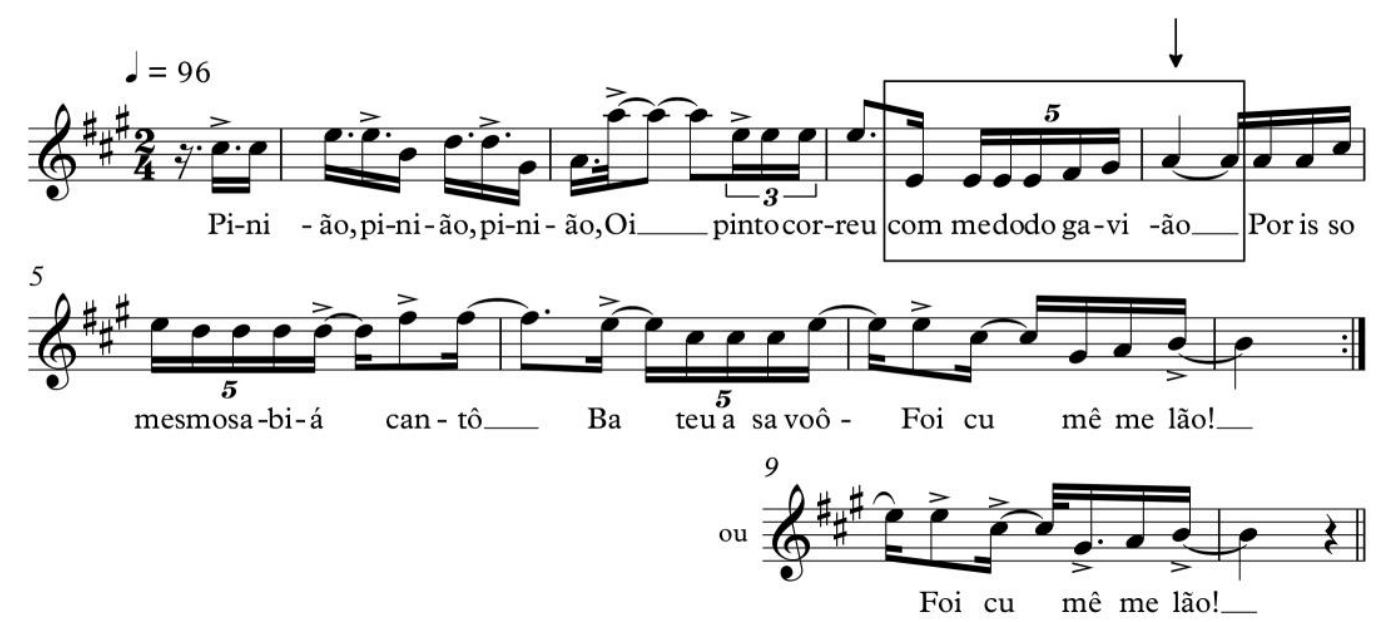

Figura 2. Análise prosódica da versão popular de Pinião (transcrição realizada por Mário de Andrade)

Na versão impressa, mais regular e binária, a palavra "gavião" (compassos 3 e 4) é dita de modo menos natural do que na versão transcrita pelo autor, pois o acento forte da melodia coincide com a sílaba átona "vi”. Na segunda figura, na qual observamos menor regularidade rítmica pela presença de figuras pontuadas e quiálteras, a sua sílaba tônica "ão" coincide com o acento melódico. Ou seja, ao adequar a melodia à maneira de falar a letra, o cantor realiza pequenas alterações para que os acentos fortes do texto linguístico coincidam com os acentos musicais da linha vocal. Dessa maneira, consegue evitar essa possível fragilidade entoativa. Ao mesmo tempo, no entanto, há, segundo a 
transcrição de Mário, palavras que são emitidas de modo menos entoativo, com ênfases em sílabas átonas ("cantou" e "bateu" nos compassos 5 e 6, respectivamente), o que, dessa vez, expõe as intenções mais musicais do intérprete. Vejamos outro interessante exemplo apresentado pelo autor, a segunda parte do coco Olê Lioné, canção tradicional do Rio Grande do Norte.

Da Baía me mandaram

Uma camisa bordada

$\mathrm{Na}$ abertura da camisa

Tinha o nome da safada

Lioné!

Olê, Lioné! Cadê Lianô?

Que eu tava na varanda

Quando a morena passou

Lioné!
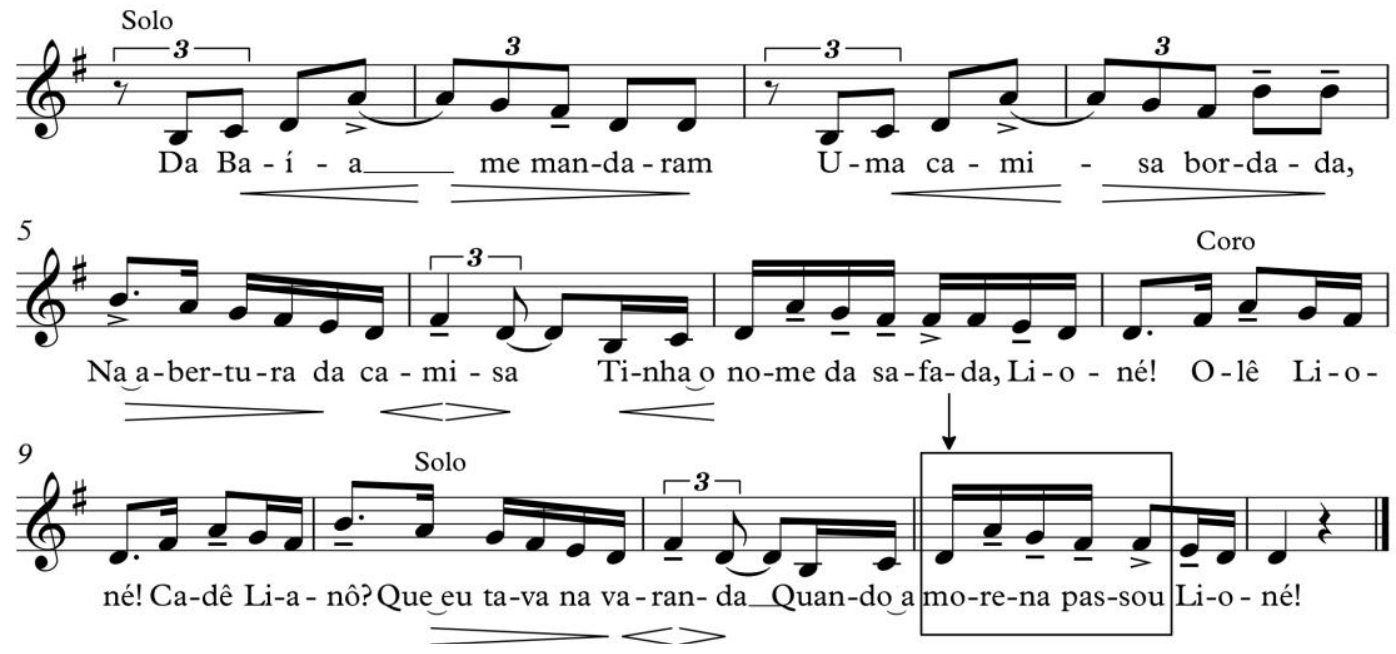

Figura 3. Acentuação silábica em Olê Lioné (anônimo)

Destacamos acima o segmento no qual observamos um deslocamento na acentuação do vocábulo. No penúltimo compasso, para a frase verbal "quando a morena passou", podemos estabelecer diferentes maneiras de executar a palavra "morena". Primeiramente, como vemos grafado na partitura, a forma musical produz um deslocamento de acento que enfatiza a sílaba átona "mo" ("quando a morena passou”), ao posicioná-la na cabeça do tempo forte do compasso. Contudo, como veremos ao longo deste capítulo, ainda que a forma musical não favoreça a emissão natural do vocábulo, é possível realizar pequenos rearranjos acentuais que amenizam (ainda que não resolvam) 
o desvio entoativo: o cantador, sem grande dificuldade, pode enfatizar a sílaba tônica "re" ("quando a morena passou"), mesmo que ela não esteja coincidindo com o acento forte da melodia musical. Nesse caso, é por meio de um acréscimo de intensidade que o cantor consegue preservar a acentuação natural da palavra, caminhando para uma oralização mais linear. As duas formas de acentuação são frequentes nas canções populares em geral. Se o cantor acentuar a sílaba átona (como está grafado na figura acima) provavelmente estará favorecendo o caráter tematizante da canção. Se, por outro lado, acentuar a sílaba tônica da palavra "morena", estará restabelecendo a oralidade do canto. Evidentemente, não há forma mais ou menos correta, mas sim interesses mais musicais ou mais entoativos. Mário de Andrade já havia notado essa questão, colocando-a em termos de um embate entre o canto estrófico (mais apegado à música) e o recitativo (mais ligado à fala).

É pela adição de tempos, talequal fizeram os gregos na maravilhosa criação rítmica deles, e não por subdivisão que nem fizeram os europeus ocidentais com o compasso, o cantador vai seguindo livremente, inventando movimentos essencialmente melódicos (alguns antiprosodicos até) sem nenhum dos elementos dinamogênicos da síncopa e só aparentemente sincopados, até que num certo ponto (no geral fim da estrofe ou refrão) coincide de novo com o metro (no sentido grego da palavra) que pra ele não provém duma teorização mas é de essência puramente fisiológica. Coreográfica até. São movimentos livres determinados pela fadiga. São movimentos livres desenvolvidos pela fadiga. São movimentos livres específicos da moleza da prosódia brasileira. São movimentos livres não acentuados. São movimentos livres acentuados por fantasia musical, virtuosidade pura ou precisão prosódica. Nada tem com o conceito tradicional da sincopa e com o efeito contratempado dela. Criam um compromisso sutil entre o recitativo e o canto estrófico. São movimentos livres que se tornaram específicos da música nacional. (ANDRADE, 1972: 36)

É como se em Olê Lioné tivéssemos um desenho musical preestabelecido (como no caso do canto estrófico) e essa propensão entoativa (o compromisso com o recitativo citado pelo autor) desvirtuasse o seu padrão. Enfim, esses exemplos recolhidos por Mário de Andrade apresentam deslocamentos acentuais gerados pelo fator intensidade, quando uma sutil descontinuidade entoativa é causada pelo desencontro entre os acentos de linha melódica e os acentos naturais das palavras da língua.

Podemos encontrar exemplos como esse em outras publicações, ainda que o objetivo analítico de seus autores não seja a questão da acentuação silábica. Em Feitiço decente: transformações do samba no Rio de Janeiro (1917-1933), Carlos Sandroni 
estuda as transformações sofridas pelo samba carioca na virada dos anos 1930 a partir da presença de certos elementos musicais, sobretudo as fórmulas rítmicas do acompanhamento. Essas configurações definem dois padrões rítmicos distintos: o tresillo, característico em obras das décadas de 1910 e 1920, e o paradigma do Estácio, padrão rítmico do samba a partir de 1930. Mesmo que seu interesse principal não seja a relação entre a melodia e a letra, o autor examina de que forma a melodia da voz contribuiu para a consolidação de novos paradigmas rítmicos do gênero, o que pode auxiliar nossas investigações sobre a sílaba. Sandroni nos apresenta exemplos muito interessantes, nos quais podemos examinar alguns desvios de acentuação ${ }^{83}$. Nos três exemplos a seguir, constatamos que o desvio em relação ao acento tônico dos vocábulos, assim como nos fragmentos analisados acima, se dá pelo fato de o ponto de maior intensidade da linha melódica coincidir com pontos átonos do texto linguístico.

Não venha com seus carinhos

Minha reza atrapalhar

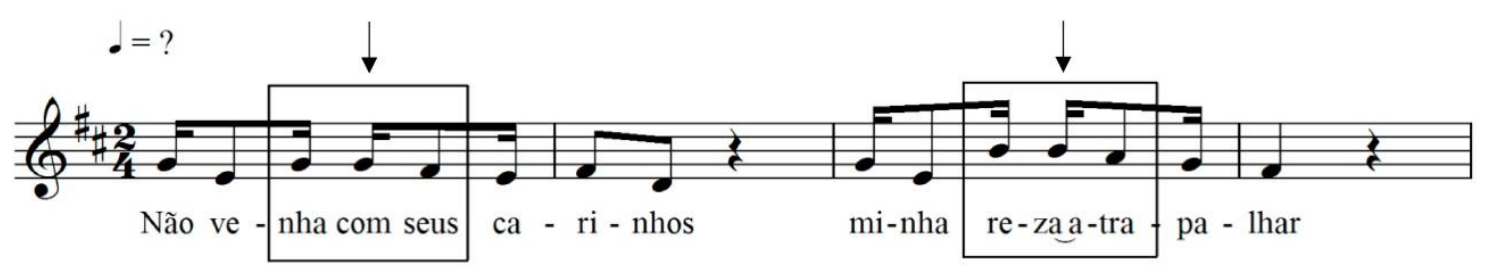

Figura 4. Acentuação silábica em Lundu das beatas (1862) (J. da Silva Ramos) (SANDRONI, 2012: 62)

Trabalhar só obrigado

Por gosto ninguém vai lá

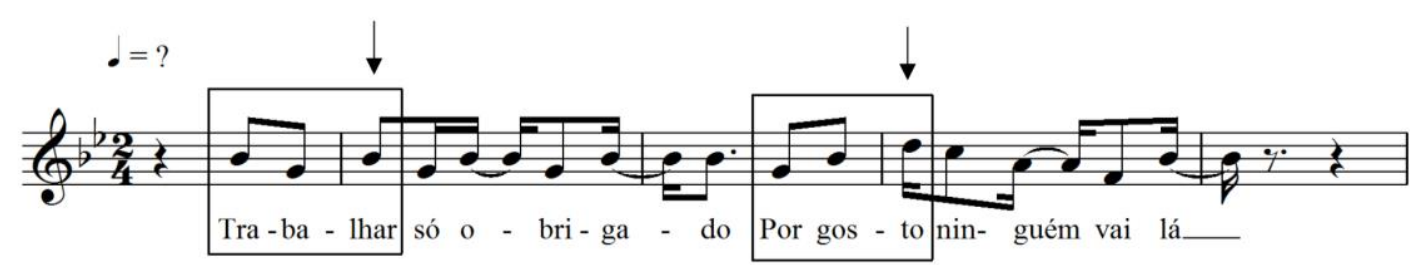

Figura 5. A acentuação silábica em $O$ que será de mim (Ismael Silva/Nilton Bastos/Francisco Alves) (SANDRONI, 2012: 207)

Toma cuidado que o luar já se foi, ai

Que o luar já se foi, ai

Que o luar já se foi

83 Infelizmente, o autor não especificou a indicação metronômica dos andamentos dos fonogramas transcritos, o que prejudica um pouco a análise da acentuação silábica. 


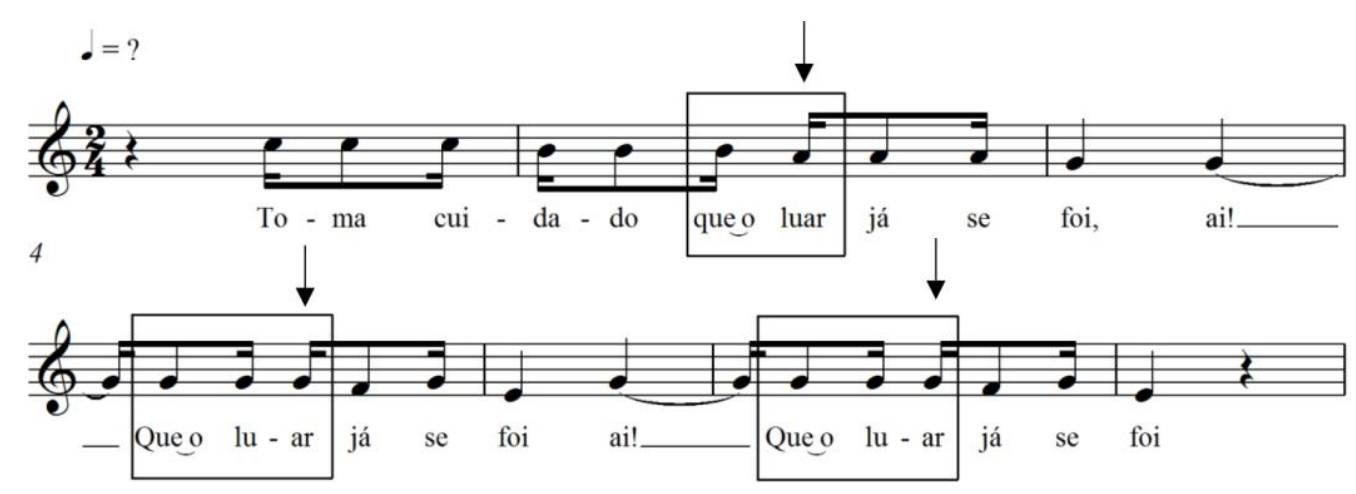

Figura 6. A acentuação silábica em Quem são eles? (Sinhô) (SANDRONI, 2012: 197)

Nas figuras 4 e 5, notamos a repetição de um mesmo motivo rítmico-melódico. O primeiro trecho destacado nos dois exemplos apresenta uma coincidência acentual entre a letra e a melodia. No entanto, na repetição do motivo, verificamos um deslocamento em relação à palavra "reza" (figura 4) e "gosto" (figura 5) ${ }^{84}$. Em Quem são eles (figura 6), observamos um fenômeno interessante. Há um deslocamento do acento tônico de "luar" no primeiro trecho destacado. Esse desvio, também causado pelo fator intensidade, enfatiza a sua sílaba átona "lu". Além disso, notamos uma elisão vocálica com a sílaba seguinte que prejudica ainda mais a sua naturalidade entoativa. Entretanto, na medida em que, logo em seguida, a mesma frase (“Que o luar já se foi”) é repetida duas vezes (dessa vez com o acento preservado), temos a impressão de que essa repetição anula o efeito descontínuo observado no primeiro destaque, já que ela reitera para o ouvinte o mesmo vocábulo com a acentuação oral "esperada", amenizando a oralização não-linear anterior. Assim, no momento em que o segmento com acento deslocado volta a se repetir, já não representa para o ouvinte uma descontinuidade tão marcante. Abordaremos esse tipo de fenômeno mais à frente, no item dedicado ao estudo dos diversos tipos de abrandamento dos desvios acentuais.

Neste capítulo, pretendemos demonstrar que a intensidade, aspecto mais saliente nos exemplos apresentados por Mário de Andrade e Carlos Sandroni, pode ser considerada o fator mais determinante para o deslocamento da acentuação silábica nas letras de canção. É realmente numerosa a quantidade de casos de desvio acentual gerados por esse parâmetro musical em canções pertencentes aos mais variados gêneros e

\footnotetext{
${ }^{84} \mathrm{Em}$ Lundu das beatas, como forma de amenizar esse desvio, o cantor poderia até mesmo acentuar a sílaba "re", mesmo quando colocada em tempo fraco do compasso. Em O que será de mim, não obstante o deslocamento verificado em "gosto", a maior duração da sílaba tônica "gos" em relação à sílaba átona "to" favorece a emissão natural do vocábulo. Se a duração da sua última sílaba fosse alargada, certamente a prosódia se tornaria ainda mais prejudicada.
} 
compositores, da canção erudita ao rap. Nesse sentido, após a observação dos exemplos citados pelos dois autores, trechos de canções muito pouco conhecidas pelo grande público, desejamos destacar a ocorrência desse mesmo tipo de desvio silábico em obras mais difundidas na tradição da canção popular comercial brasileira. Posteriormente, no entanto, retomaremos diversos aspectos sugeridos pelos exemplos analisados por ambos os estudiosos, tais como a possibilidade de abrandamento do desvio acentual por meio da interpretação do cantor, a atenuação do deslocamento por meio da reiteração de elementos, a elisão de vogais, a simultaneidade dos parâmetros intensidade, duração e altura etc. Por ora, concentremo-nos em exemplos de deslocamento silábico gerados predominantemente pela intensidade. Encontramos, pois bem, no refrão da conhecida canção Panis et Circenses de Caetano Veloso e Gilberto Gil, um desvio que incide sobre um verso muitas vezes repetido pelos intérpretes ao longo da obra. A preservação do acento natural da palavra, no entanto, não é observada em nenhuma das repetições do estribilho:

Mas as pessoas da sala de jantar

Essas pessoas da sala de jantar

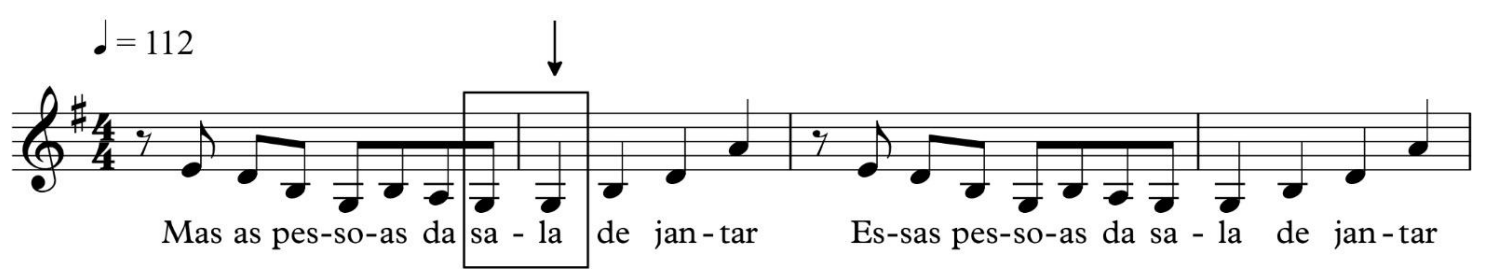

Figura 7. O deslocamento silábico na canção Panis et Circenses (Gilberto Gil/Caetano Veloso)

Essa configuração rítmico-melódica que não favorece a prosódia do texto pode até mesmo desvirtuar o sentido linguístico da frase. Nesses casos, é comum que o ouvinte tente estabelecer uma nova conexão a partir de outros vocábulos sonoramente próximos. Aqui, é possível que o público perceba a seguinte frase: "Mas as pessoas da salada e jantar", permutando "sala de jantar" por "salada e jantar", tendo em vista a ênfase de intensidade sobre a sílaba átona de "sala". A insistência do deslocamento acentual é tão marcante (na medida em que esse verso se repete muitas vezes no decorrer da canção) que, no trecho final do fonograma original, ouvimos a voz de um homem falando a frase “me passa a salada pra mim por favor", explicitando a consciência do desvio acentual e, possivelmente, um aproveitamento estético do mesmo (algo como uma depredação irreverente da palavra "sala" como forma de atingir as pessoas que, segundo a letra, 
ocupavam-se em nascer e morrer, mas não em viver). Se reescrevêssemos a melodia desse trecho, alterando sobretudo a sua configuração rítmica, produziríamos uma oralização mais linear, ao preservarmos a acentuação natural do vocábulo.

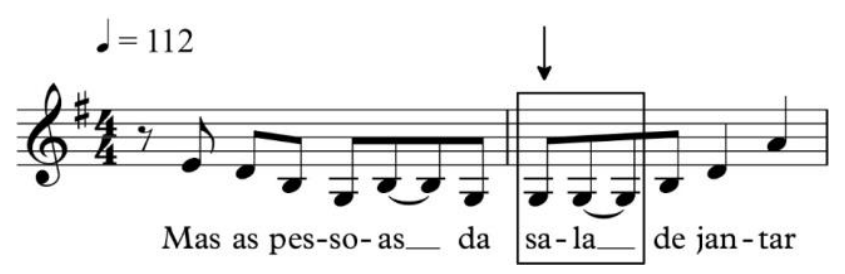

Figura 8. Reescrita da canção Panis et Circenses

Evidentemente, essa alteração corrompe o padrão rítmico-melódico que vinha sendo explorado desde o início da canção, cujo teor tematizante é estimado pelos compositores. Observamos, no entanto, o quanto o fator intensidade influencia na readequação do acento: não obstante a permanência da duração mais alongada da nota que incide sobre a sílaba átona de "sala", na figura acima, o deslocamento é anulado ao posicionarmos a sílaba tônica do vocábulo na cabeça do tempo forte do compasso.

Seguindo nessa mesma direção, podemos observar um conhecido exemplo de cantiga popular cuja letra apresenta desvios acentuais. Na canção folclórica Atirei o pau no gato, o vocábulo "berro" sofre, com o perdão da redundância, um gritante deslocamento silábico.

Atirei o pau no gato

Mas o gato não morreu

Dona Chica admirou-se

Do berro do berro que ele deu

Miau

$d=112$

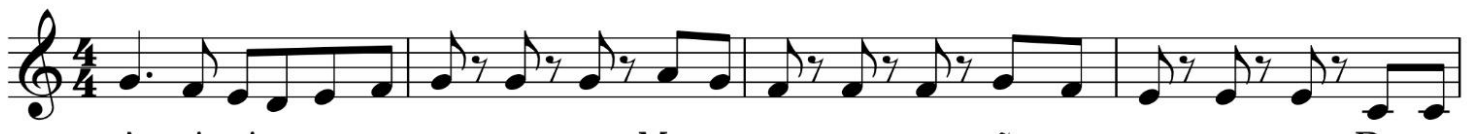

A - ti-rei o pau no ga - to to Maso ga - to to não mor-reu reu reu Do-na

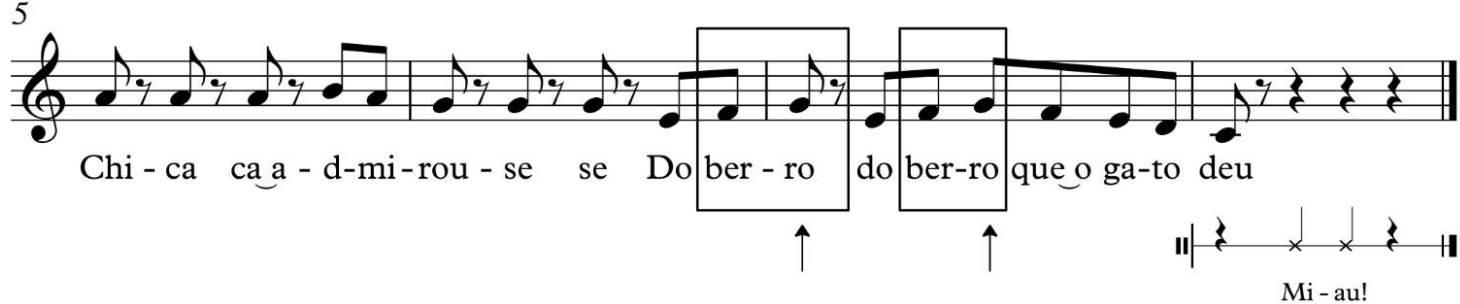

Figura 9. O deslocamento silábico em Atirei o pau no gato (anônimo) 
Mais uma vez, o fator intensidade é determinante para a alteração do acento silábico. As duas notas Sol que recaem sobre a cabeça do primeiro e do terceiro tempo do compasso 7 incidem sobre a sílaba átona da palavra 'berro'. Temos aqui um caso claro de uma figurativização menos esperada ou não-linear (deslocamento que, aliás, combina com a proposta lúdica da obra). Como forma de investigar outras possibilidades de encaixe que possam enfatizar a sílaba tônica do vocábulo, realizamos abaixo uma recriação da letra da canção.

Atirei o pau no gato

Mas o gato não morreu

Dona Chica admirou-se

Com o berro, com o berro que ele deu, miau

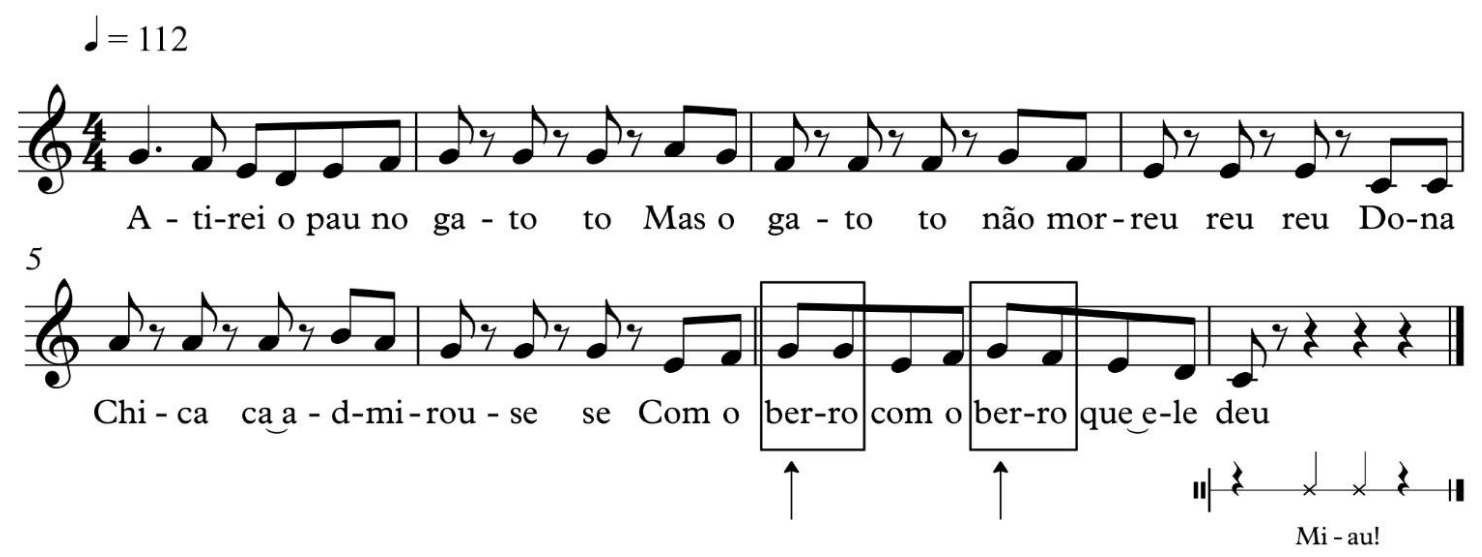

Figura 10. Recriação da letra da cantiga Atirei o pau no gato

No registro culto da língua, a regência do verbo "admirar" (quando ele é usado em sua forma pronominal "admirar-se" e possui complemento), prevê o uso da preposição "de". Assim, a frase "Dona Chica admirou-se do berro que o gato deu", com o uso do vocábulo "do" (contração da preposição "de" com o artigo "o") se adequa perfeitamente à norma culta. Na recriação que realizamos acima, substituímos o mesmo verso pela frase "com o berro que ele deu" que, recoberta pela linha melódica modificada de modo sutil, faz com que o vocábulo "berro" deixe de sofrer deslocamento silábico. Dessa maneira, utilizamos um registro mais coloquial da língua no qual o verbo "admirar-se" pode aceitar o uso da preposição "com”, o que nos parece soar de modo familiar: "Ele admirou-se com o talento daquele músico". Contudo, caso não quiséssemos utilizar o verbo admirar-se sem a regência prevista pela norma culta, poderíamos substituí-lo pelo verbo "assustarse", já que a frase "Dona Chica assustou-se com o berro" respeita a regência verbal 
prevista pelo português padrão. Enfim, temos aqui uma cantiga que, curiosamente (tendo em vista sua fortíssima penetração na cultura oral), utiliza um registro de língua distante do coloquial: o uso da forma pronominal, combinada com essa linha melódica específica, se afasta do registro falado do português brasileiro. Nesse sentido, é possível que o ouvinte, no lugar da frase original, tenha uma compreensão equivocada da letra, algo como "Dona Chica de Mirô cê cê", na medida em que há uma elisão entre a última vogal de "chica" e a primeira de "admirou-se".

Como comentamos anteriormente, esses desajustes acentuais estão presentes em obras de cancionistas pertencentes aos mais variados estilos. Abaixo, selecionamos outros cinco exemplos como forma de ilustrar essa diversidade, todos contendo desvios causados pelo parâmetro da intensidade.

Misture bem essa química

Pronto, eis um novo detento

Lamentos no corredor, na cela, no pátio

Ao redor do campo

Em todos os cantos

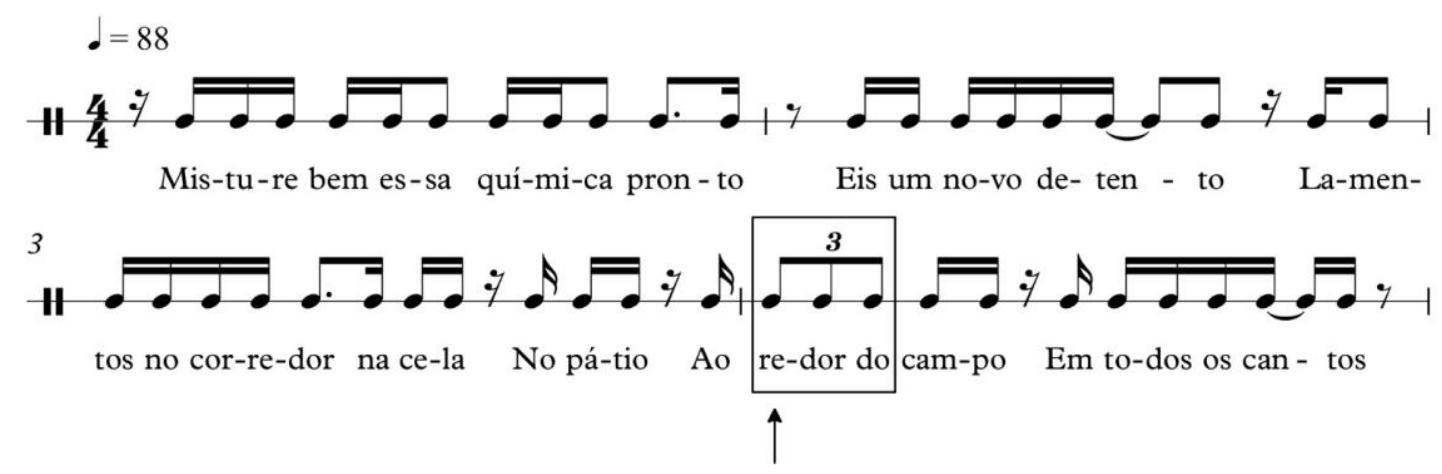

Figura 11. Deslocamento silábico em Diário de um detento (Mano Brown/Jocenir)

Nossos destinos foram traçados na maternidade

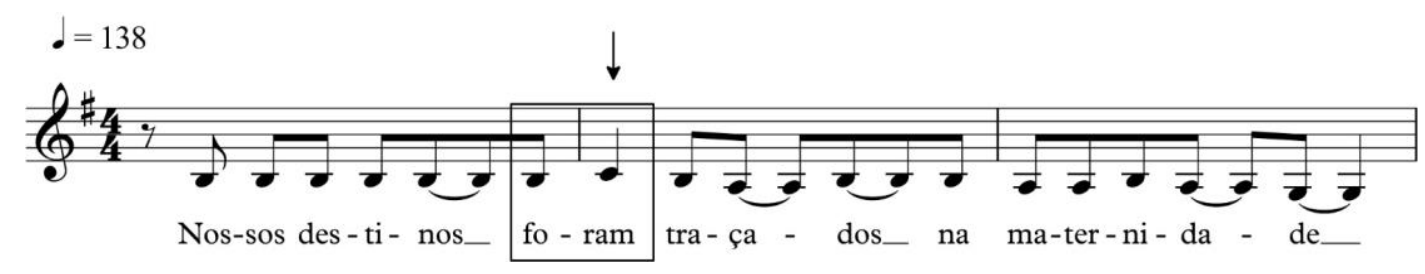

Figura 12. Deslocamento silábico em Exagerado (Cazuza/Ezequiel Neves/Leoni)

Sábado na balada

A galera começou a dançar 
E passou a menina mais linda

Tomei coragem e comecei a falar
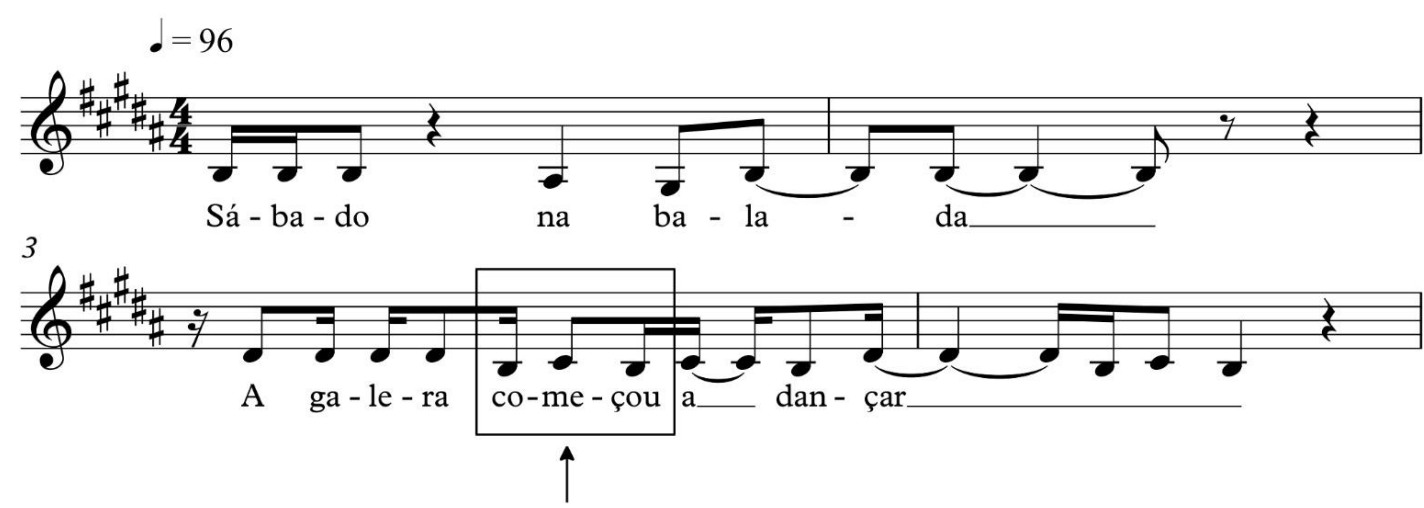

Figura 13. O deslocamento silábico em Ai se eu te pego (Antonio Dyggs/Sharon Acioly/Karine Vinagre/Amanda Cruz/Aline Medeiros)

Tu és muié pra homem nenhum

Botar defeito

Por isso sastifeito

Com você vou dançar

$$
\cdot=152
$$

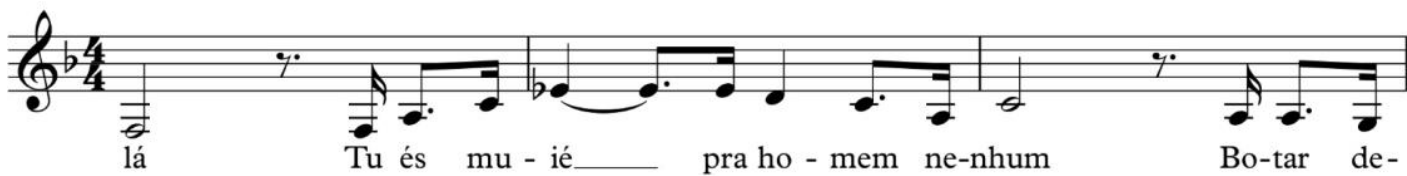

4

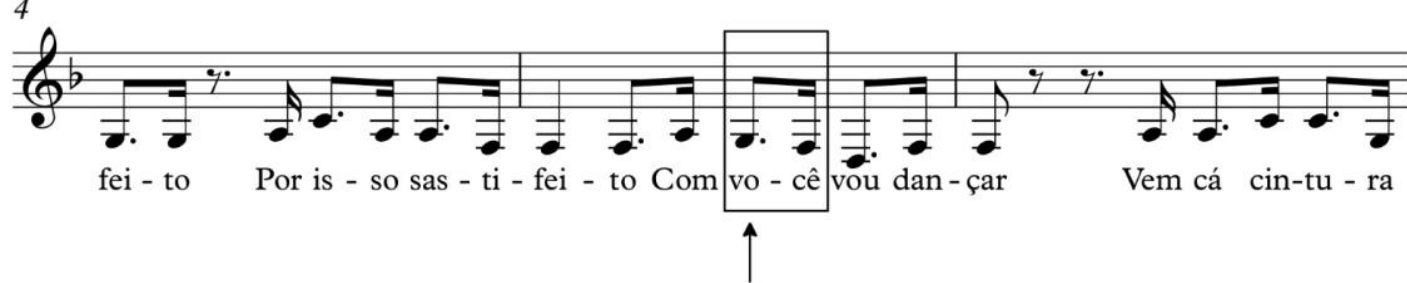

Figura 14. Deslocamento silábico em Cintura Fina (Luiz Gonzaga/Zé Dantas)

Um dia surgiu, brilhante

Entre as nuvens, flutuante

Um enorme zepelim

Pairou sobre os edifícios

Abriu dois mil orifícios

Com dois mil canhões assim 


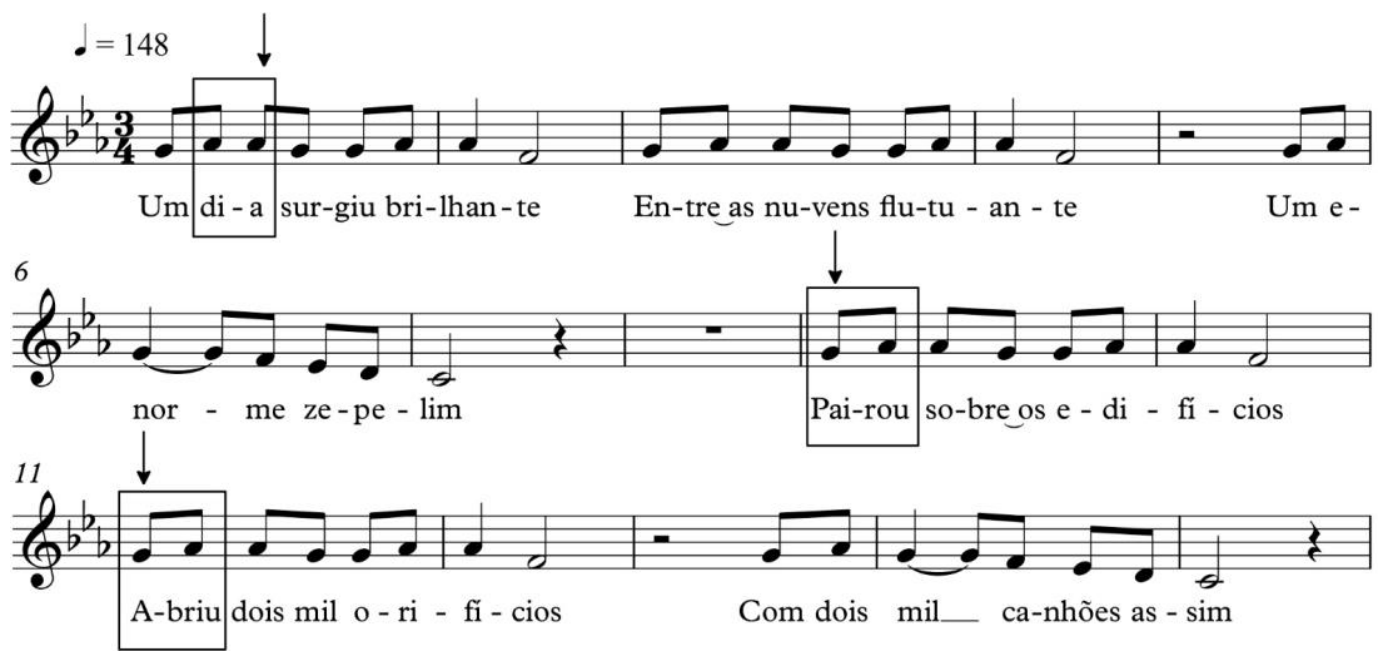

Figura 15. Deslocamento silábico em Geni e o Zepelim (Chico Buarque)

Em todas essas figuras observamos um desencontro entre os pontos de ênfase da melodia (as notas que recaem sobre as partes fortes dos tempos dos compassos) e os pontos de ênfase dos vocábulos (suas sílabas tônicas). Para enriquecer a análise desses exemplos, é necessário observar como a teoria musical explica a questão das ênfases por intensidade, diferenciando o termo "acento" da expressão "acento métrico". Poderíamos definir "acento" como "uma intensidade maior atribuída a determinada nota de um desenho, frase ou período musical" (MED, 1996: 141). Ao grafarmos uma composição musical em uma partitura, poderíamos utilizar um sinal de acento (>) sobre determinada nota para indicar ao intérprete que a mesma deve ser enfatizada. É justamente o que Mário de Andrade utilizou para destacar as notas que, segundo o autor, os intérpretes da canção folclórica Pinião (figura 2 deste capítulo) enfatizavam no canto (e cujo realce não estava grafado nas partituras publicadas pelas editoras). O acento métrico, por sua vez, não é indicado na partitura, sendo "constituído pelas acentuações fortes e fracas dos tempos dos compassos" (MED, 1996: 141). Indicamos nas ilustrações abaixo a disposição dos tempos fortes $(\mathrm{F})$, meio-fortes $(\mathrm{mF})$ e fracos (f) nos compassos binário, ternário e quaternário ${ }^{85}$ :

\footnotetext{
85 Não apresentamos exemplos de compassos de cinco ou sete tempos, pois, além de serem menos frequentes nas melodias de canção popular, correspondem à soma dos compassos binário, ternário e quaternário. O compasso de cinco tempos, por exemplo, pode ser entendido como a junção de um compasso binário com um ternário $(2+3)$ ou de um compasso ternário com um compasso binário $(3+2)$.
} 


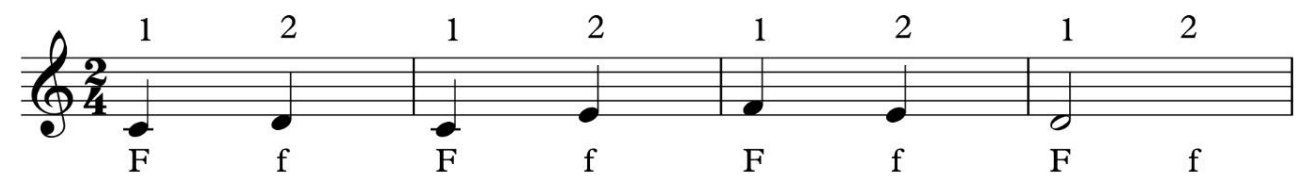

Figura 16. Acento métrico no compasso binário

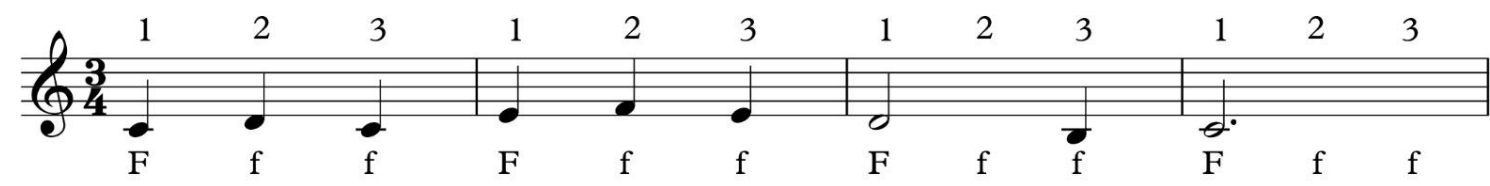

Figura 17. Acento métrico no compasso ternário

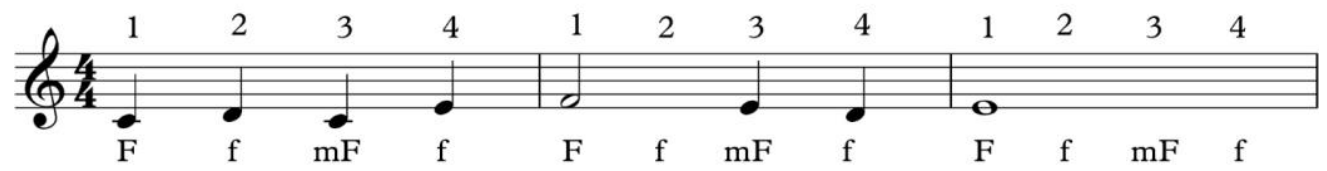

Figura 18. Acento métrico no compasso quaternário

Observamos que o acento métrico padrão determina que o primeiro tempo de todos os compassos é forte e os demais fracos, com exceção do compasso quaternário, no qual o terceiro tempo é meio-forte $(\mathrm{mF})$. Cada tempo, por sua vez, pode ser dividido em "partes de tempo, as quais seguem as mesmas regras das acentuações dos tempos de compasso" (MED, 1996: 142). Assim, a primeira parte de cada tempo é sempre forte e a segunda, fraca. No caso da divisão do tempo em quatro partes, aplica-se a mesma configuração do compasso quaternário ( $\mathrm{F}$ - f - mF - f).

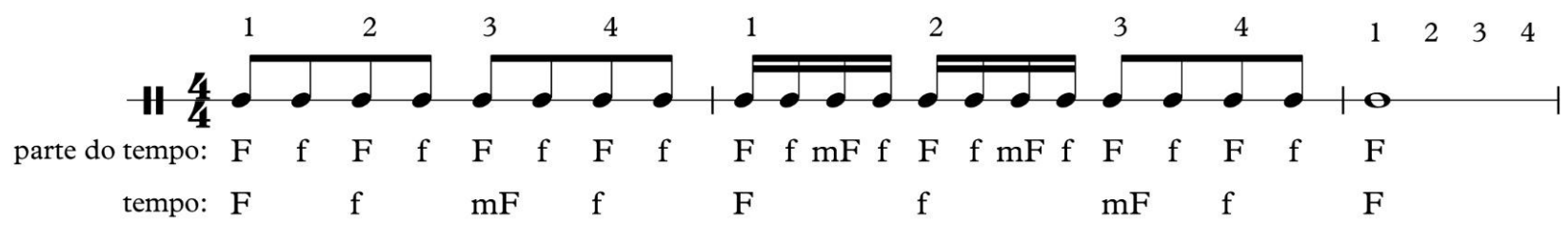

Figura 19. A divisão de cada tempo em partes de tempo no compasso simples

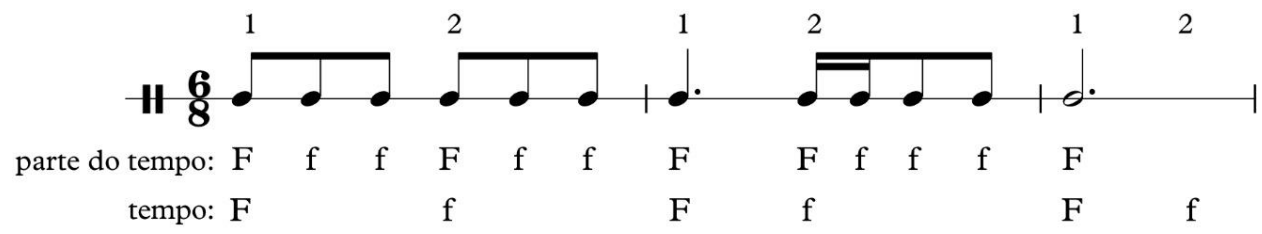

Figura 20. A divisão de cada tempo em partes de tempo no compasso composto 
Os acentos dos tempos do compasso são denominados "acentos principais" e os acentos das partes dos tempos são chamados de "acentos secundários". A importância dos acentos secundários depende do andamento da canção: "no andamento lento se destacam, mas no andamento rápido às vezes até desaparecem” (MED, 1996: 143). Evidentemente, diferentes gêneros musicais ou propostas estéticas mais experimentais, com suas construções rítmicas específicas, poderão acentuar notas não previstas pelo acento métrico. Deverão, para isso, utilizar o sinal de acento (>) ou mesmo fórmulas de compasso irregulares. Nesses casos, do mesmo modo, deveremos analisar a relação entre as acentuações do texto e as acentuações musicais propostas pela melodia. Voltando aos nossos exemplos, vejamos como essas questões do acento métrico atuam sobre a configuração dos deslocamentos silábicos.

Nas canções Diário de um Detento e Exagerado, as sílabas átonas das palavras "redor" e "foram" coincidem justamente com o primeiro tempo do compasso quaternário (o mais forte dos tempos nessa configuração métrica), resultando em uma oralização mais incomum. Em Ai se eu te pego e em Cintura Fina, as sílabas átonas de "começou" e "você" recaem sobre o terceiro tempo do compasso quaternário que, como vimos acima, consiste em ponto meio-forte $(\mathrm{mF})$ da melodia. Em Geni e o Zepelim, por sua vez, temos um compasso ternário cuja acentuação permanece enfatizando o primeiro tempo do compasso, fator que contribui para o deslocamento acentual das palavras "pairou" e “abriu" nos compassos 9 e 11, respectivamente. A questão mais interessante nesse exemplo, no entanto, refere-se ao deslocamento silábico que incide sobre o vocábulo "dia", no primeiro compasso. Aqui, podemos observar como o acento secundário pode tornar-se protagonista: a sílaba átona "a" recai sobre a parte forte de um tempo fraco, isto é, sobre a cabeça do segundo tempo do compasso. Como sua sílaba tônica é menos valorizada do que ela (já que está localizada na parte fraca do tempo), sentimos o deslocamento silábico da letra. Poderíamos reescrever esse exemplo alterando levemente a melodia para evitarmos os desvios acentuais: 


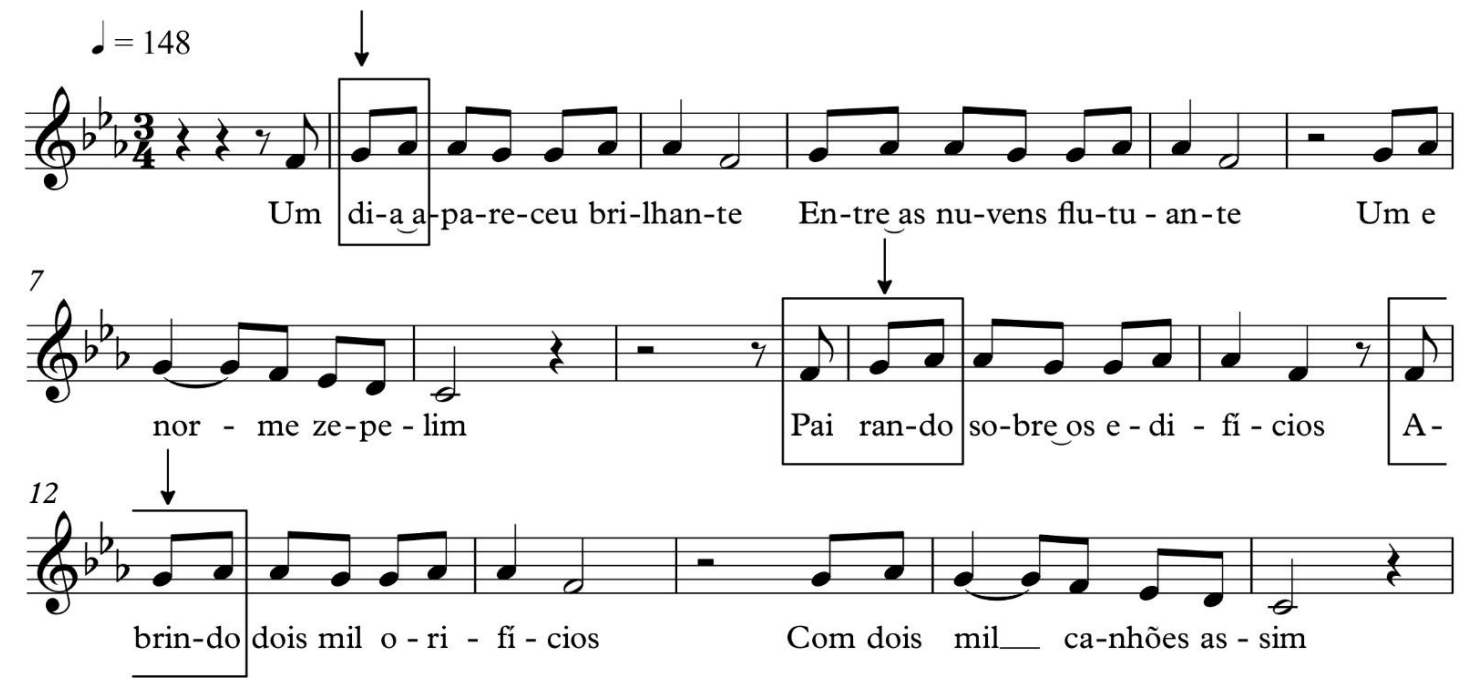

Figura 21. Reescrita de Geni e o Zepelim para evitar o deslocamento silábico.

Modificamos a letra original substituindo os versos "Um dia surgiu brilhante", "Pairou sobre os edifícios" e "Abriu dois mil orifícios" (nos quais destacamos desvios de acento silábico) por, respectivamente, "Um dia apareceu brilhante", "Pairando sobre os edifícios" e "Abrindo dois mil orifícios". Para isso, acomodamos a melodia inserindo a nota Fá natural antes de cada frase e, por consequência, transformamos o ritmo originalmente tético do início dos versos (que principiavam no primeiro tempo dos compassos 2, 10 e 12) em um ritmo anacrústico ${ }^{86}$. Essa modificação do trecho propõe, então, um tipo de oralização mais comum ou linear.

Por fim, antes de passarmos para a análise da alteração silábica por meio do parâmetro duração, gostaríamos de apresentar três últimos exemplos nos quais o fator intensidade, deslocando o acento natural dos vocábulos, por vezes impede a compreensão do texto pelo ouvinte ou mesmo sugere a presença de um outro vocábulo, diferente daquele originalmente selecionado pelo compositor.

Deixa balançar a maré

E a poeira assentar no chão

Deixa a praça virar um salão

Que o malandro é o barão da ralé

\footnotetext{
${ }^{86} \mathrm{O}$ termo musical anacruse vem do grego Anakrousis. Na Grécia Antiga, "designava uma ou mais sílabas que se encontravam no início de certos versos líricos antes da sílaba acentuada" (MED, 1996: 148). Na música, correspondem às figuras de duração que antecedem o compasso inicial da peça. São notas menos destacadas que têm a função de direcionar o início da melodia para a sua primeira nota mais acentuada. Aqui, adotamos o termo de um modo mais livre, utilizando-o não somente para o trecho inicial da melodia.
} 

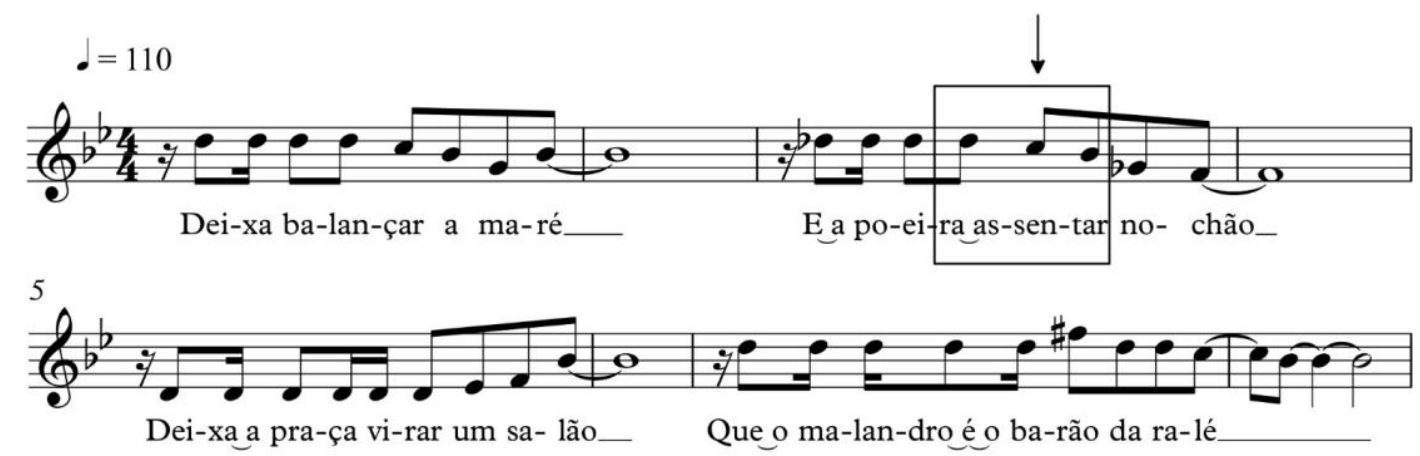

Figura 22. Deslocamento silábico em A Volta do Malandro (Chico Buarque)

Ela pode rodopiar

E mudar de figura

A paloma do seu mirar

Virar miúra

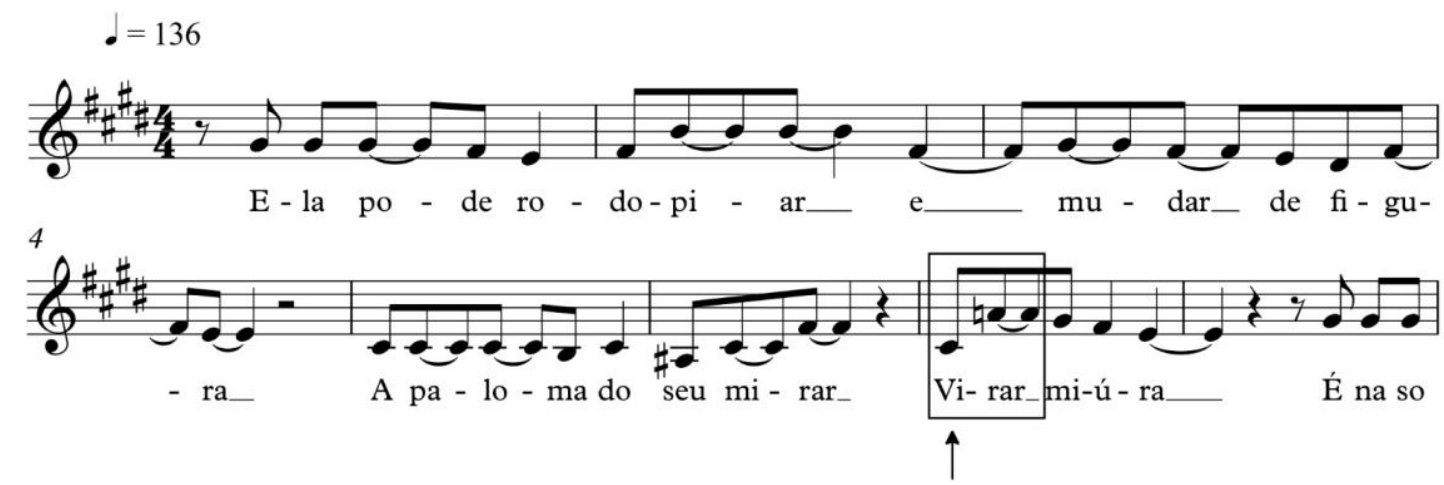

Figura 23. Deslocamento silábico em Tanto Amar (Chico Buarque).

Será que me põe de castigo

Será que ele me estende a mão

Será que o pai dança comigo ou não?

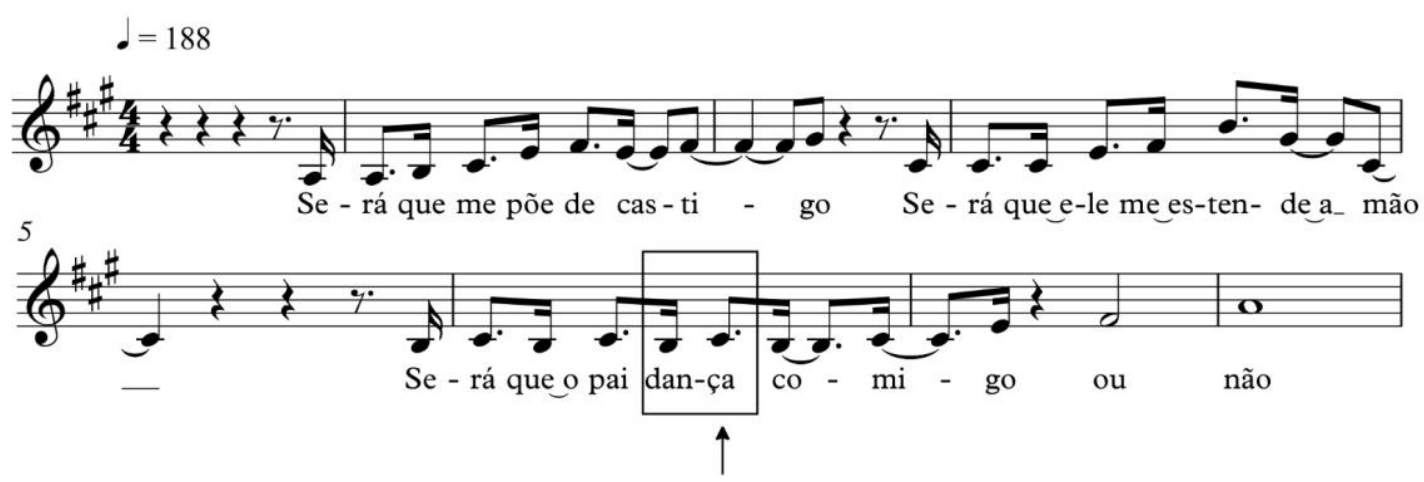

Figura 24. Deslocamento silábico em Ai, se eles me pegam agora (Chico Buarque). 
São exemplos interessantes nos quais outros fatores, além da questão central da intensidade, colaboram para que o ouvinte não compreenda o texto linguístico almejado pelo cancionista, semelhantemente ao que observamos na canção Panis et Circenses. Em A Volta do Malandro, a sílaba átona ("-sen”) da palavra "assentar" recai sobre um tempo meio-forte do compasso quaternário ${ }^{87}$. No entanto, além desse desvio, notamos a ocorrência de uma elisão vocálica entre a última sílaba da palavra que precede "assentar" e a sua sílaba inicial: "poeira_assentar". Por isso, tendemos a compreender a palavra "senta" (verbo "sentar" conjugado no presente, na terceira pessoa do singular): "E a poeira senta no chão".

Em Tanto Amar, a sílaba átona da palavra "virar" é acentuada pelo primeiro tempo (forte) do compasso quaternário, fazendo com que compreendamos o mesmo verbo no presente, conjugado na terceira pessoa do singular ("ela vira miúra"), e não no infinitivo. Ocorre que o cancionista, além do desvio acentual, utiliza uma forma linguística que dificulta o entendimento originalmente desejado. Fazendo uso de um tipo de elipse ${ }^{88}$, por meio do qual omite um termo que já havia aparecido na estrofe (a supressão da palavra "pode"), o sentido do verso "A paloma do seu mirar (pode) virar miúra" levemente se perde. Além disso, o fato de o significado das palavras "paloma" (pomba) e "miúra" (touro bravo) não ser tão comum no registro oral da língua com certeza contribui para um leve enfraquecimento referencial dessa passagem.

No final da canção $A i$, se eles me pegam agora acreditamos haver uma ocorrência similar por meio da qual o ouvinte é levado a compreender a frase "será que vai dançar comigo" ao invés do verso originalmente concebido pelo compositor ("será que o pai dança comigo"). No compasso 6 da sua respectiva figura, observamos a presença de um deslocamento acentual no vocábulo "dança" que passa a soar como um verbo no infinitivo: “dançar”. É possível que, ao percebermos o verbo no infinitivo, imediatamente façamos uma substituição da palavra "pai” pela palavra "vai", motivados não apenas pela proximidade sonora entre os dois vocábulos, mas também pela forte recorrência da segunda ao longo da obra. De fato, no decorrer da letra da canção há diversas frases que propõem a mesma estrutura linguística da locução verbal com o verbo ir: "será que vai ficar sentida", "será que vai me dar razão", "será que vai passar carão" e "será que vai morrer de inveja ou não". Desse modo, o ouvinte pode ser conduzido a um entendimento

\footnotetext{
87 Poderíamos grafar a mesma melodia em compasso binário. Nesse caso, a sílaba átona da palavra "assentar" coincidiria com o primeiro tempo do compasso (tempo forte).

${ }^{88}$ Trata-se da figura de linguagem de sintaxe denominada zeugma.
} 
equivocado do verso, ainda que esse entendimento possa ser combinado com o sentido geral da letra da canção.

Neste item, pudemos analisar diversos exemplos de deslocamento silábico motivados pela intensidade, alguns mais sutis e outros cuja veemência, aliada a certos fatores linguísticos, pode até mesmo fazer com que o ouvinte não compreenda o sentido do texto inicialmente planejado pelo cancionista. Passemos, então, ao estudo da alteração da acentuação silábica provocada pelo parâmetro duração. 


\subsection{A alteração da acentuação silábica pela duração}

Quando nos dedicamos ao exame dos casos de deslocamento silábico por meio do parâmetro duração, constatamos que, além de serem bem menos numerosos (se comparados aos exemplos ligados ao fator intensidade), em geral aparecem associados aos outros dois parâmetros. Assim, dificilmente encontraremos uma ocorrência na qual apenas a duração influencie a acentuação dos vocábulos, sem a presença da altura e, sobretudo, da intensidade. Não obstante, há em nosso cancioneiro certas canções em que esse fenômeno se dá. Analisemos a canção Wave do compositor Tom Jobim.

\section{Vou te contar}

Os olhos já não podem ver

Coisas que só o coração pode entender

Fundamental é mesmo o amor

É impossível ser feliz sozinho

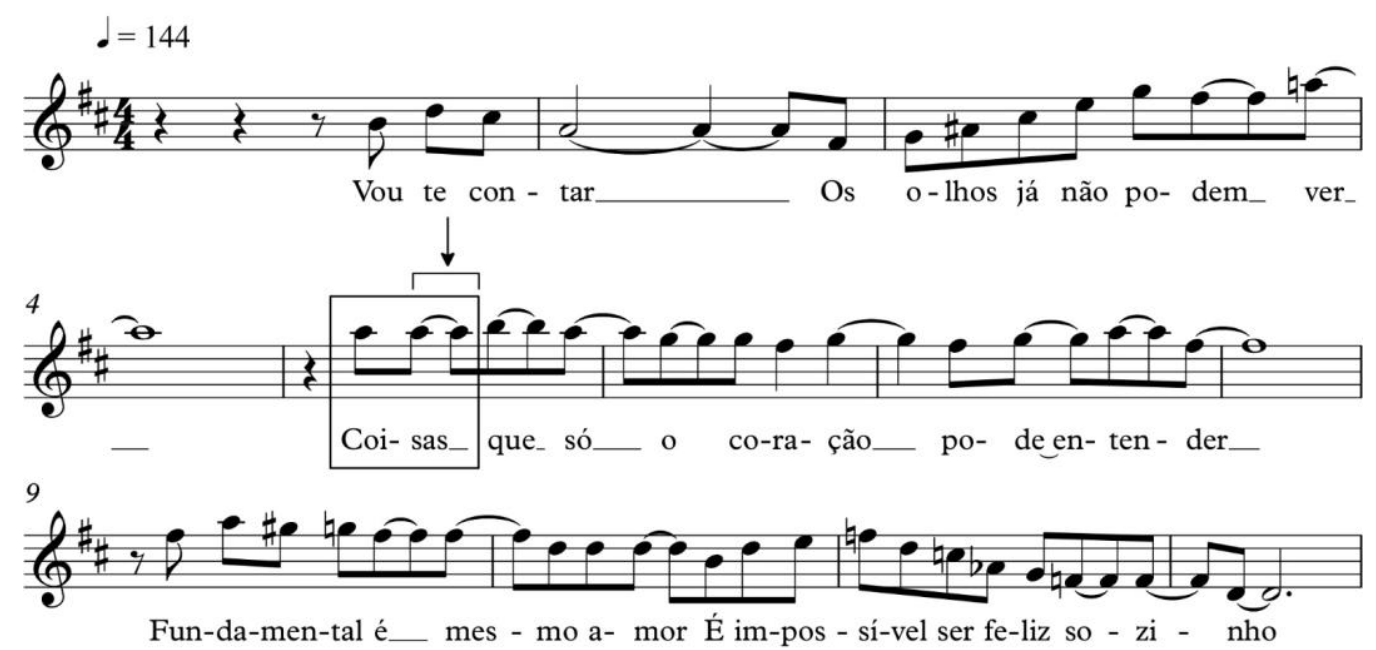

Figura 25. Deslocamento silábico em Wave (Tom Jobim)

Acreditamos que esse é um exemplo que ilustra muito bem a possibilidade de haver a influência suprema da duração em um caso de deslocamento silábico. Analisando a partitura acima, constatamos que os outros dois parâmetros, altura e intensidade, encontram-se de certa forma neutralizados no que se refere às causas do desvio que ocorre na palavra "coisas". Em relação ao primeiro aspecto, não há saltos intervalares, já que a nota que incide sobre o vocábulo anterior (“ver”) mantém-se a mesma. Além disso, todas as sílabas de "coisas" situam-se na mesma nota (Lá natural). O parâmetro intensidade, do mesmo modo, também não exerce influência sobre o deslocamento de acento na 
medida em que a sílaba tônica de "coisas" coincide com a parte forte do tempo. Assim, acreditamos que o fator duração age aqui de maneira soberana: a sílaba átona "sas", com seu intervalo de tempo estendido em duas colcheias é mais enfatizada do que a sílaba tônica “coi”. No refrão de Tarde em Itapoã, percebemos algo similar:

É bom

Passar uma tarde em Itapuã

Ao sol que arde em Itapuã

Ouvindo o mar de Itapuã

Falar de amor em Itapuã

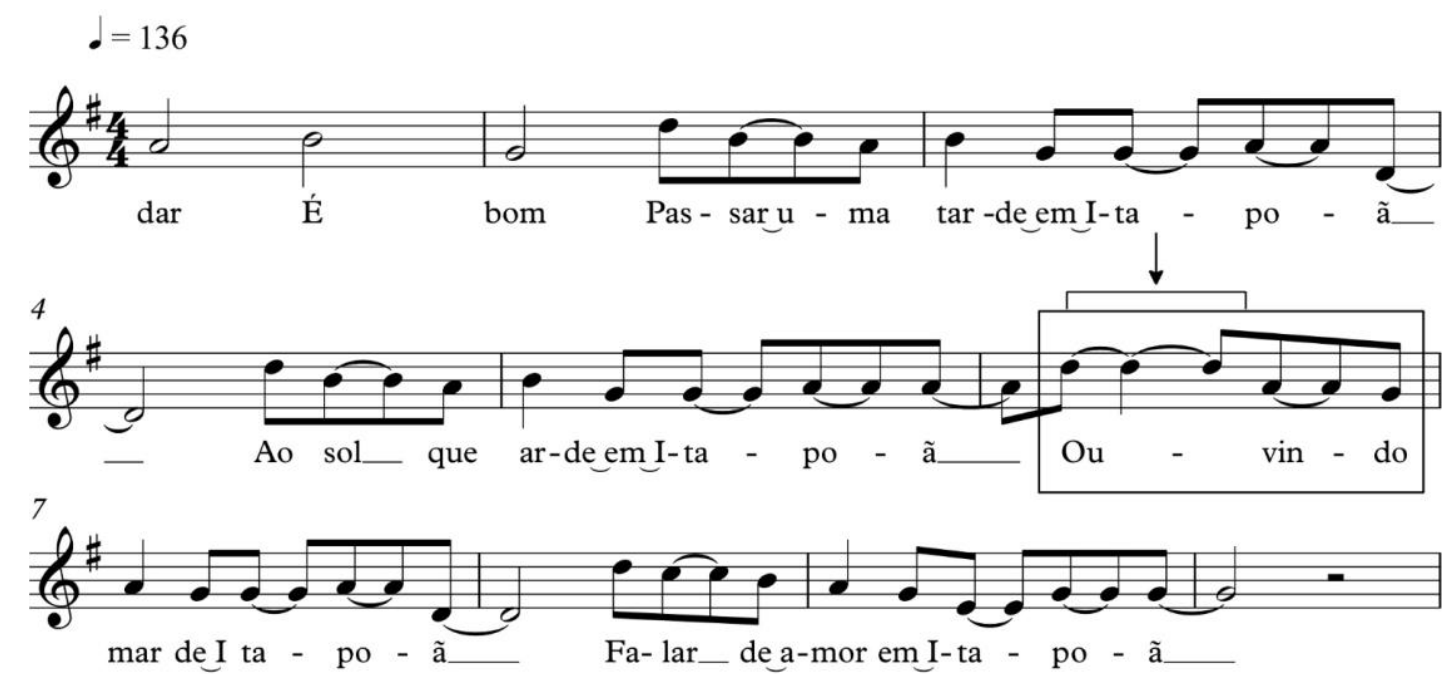

Figura 26. Deslocamento silábico em Tarde em Itapoã (Toquinho/Vinicius de Moraes)

Nesse exemplo, a sílaba átona "ou" da palavra ouvindo é entoada com uma duração muito mais alongada, durando quatro colcheias (em contraposição às duas colcheias que recobrem a sílaba tônica "vin", além da sílaba final "do" que dura apenas uma colcheia). Observamos, então, mais um exemplo em que a duração prepondera sobre os demais fatores, ainda que não possamos deixar de considerar a participação do parâmetro altura, por exemplo (a sílaba átona mais alongada é cantada com a nota mais aguda da tessitura e é alcançada e abandonada por meio de um salto intervalar (Lá-RéLá).

O desvio de acentuação silábica por intermédio da duração, no entanto, geralmente vem acompanhado pela ação dos outros fatores musicais. Abaixo, selecionamos quatro exemplos de conhecidas canções nas quais a intensidade se alia à duração em casos de deslocamento de acento. São elas as canções Eu te amo (Tom 
Jobim/Chico Buarque), Jesus Cristo (Roberto Carlos/Erasmo Carlos), Meia lua inteira (Caetano Veloso) e Esquadros (Adriana Calcanhoto).

Se entornaste a nossa sorte pelo chão

Se na bagunça do teu coração

Meu sangue errou de veia e se perdeu

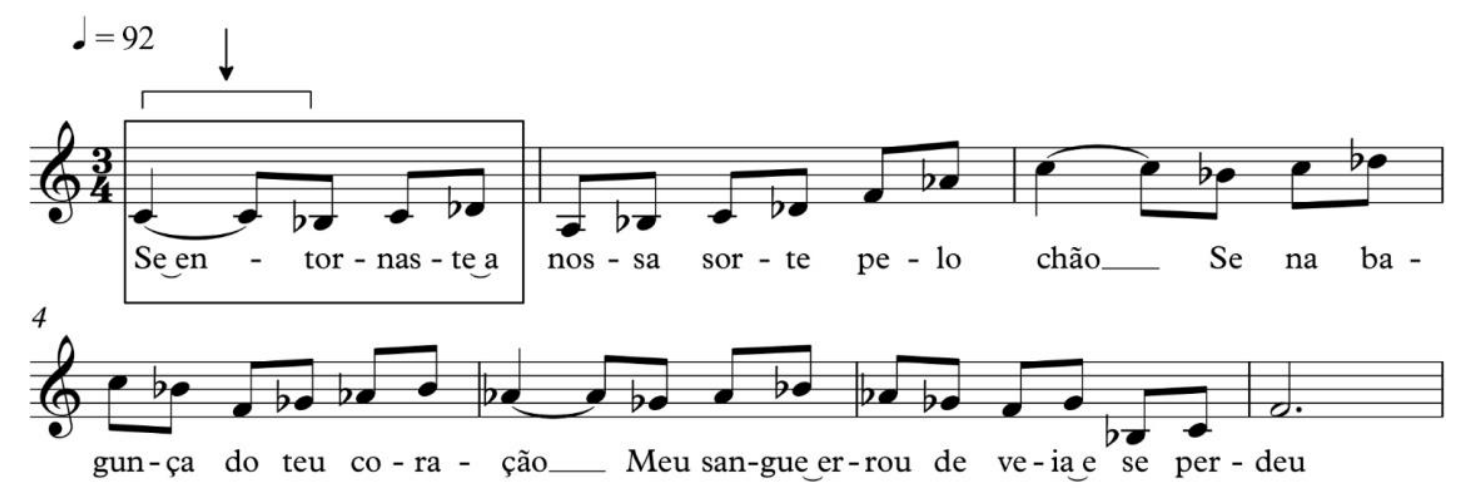

Figura 27. Deslocamento silábico em Eu te amo (Tom Jobim/Chico Buarque)

Jesus Cristo, Jesus Cristo

Jesus Cristo, eu estou aqui

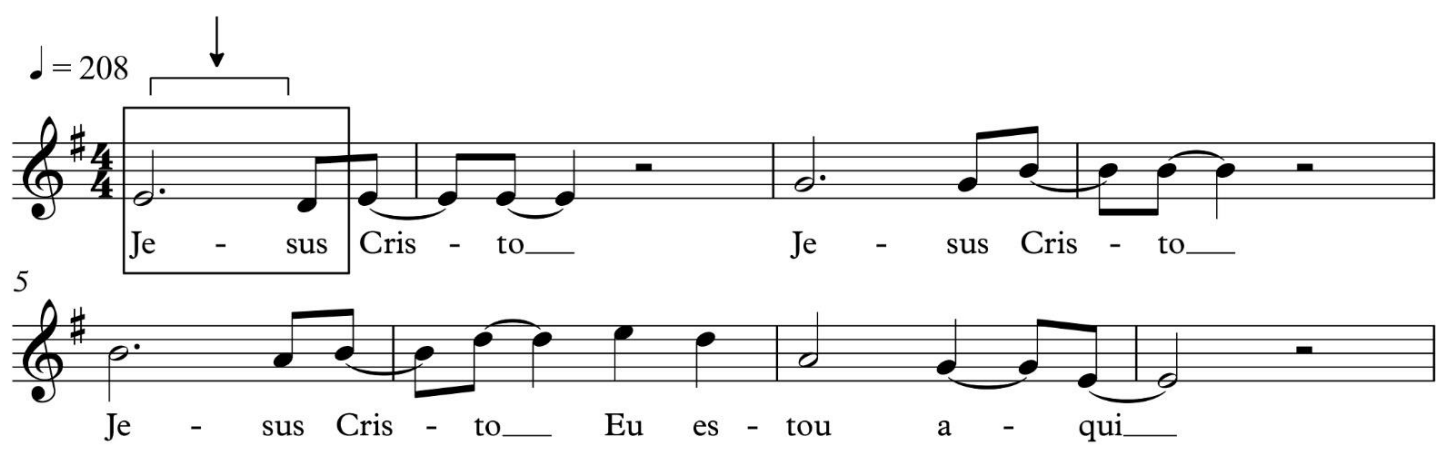

Figura 28. Deslocamento silábico em Jesus Cristo (Roberto Carlos/Erasmo Carlos)

São dim, dão, dão, São Bento

Grande homem de movimento

Martelo do tribunal

Sumiu na mata adentro

Foi pego sem documento

Terreiro regional 


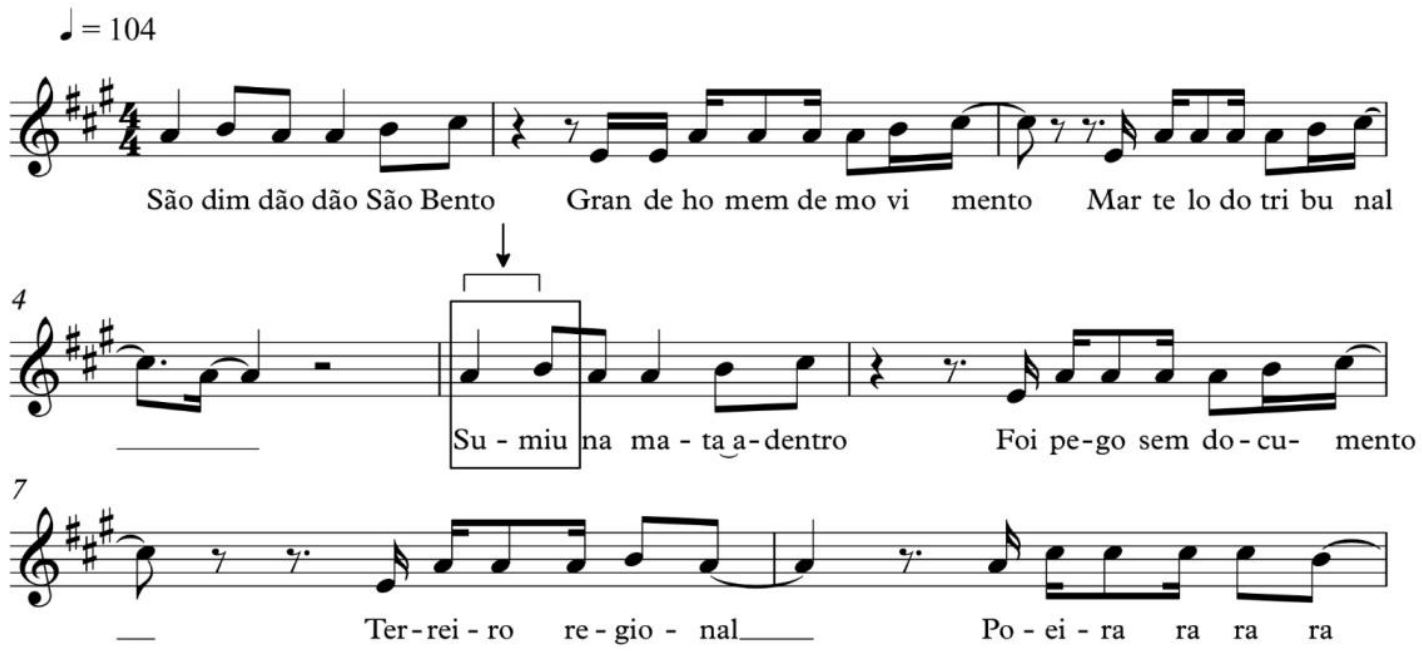

Figura 29. Deslocamento silábico em Meia Lua Inteira (Caetano Veloso)

Eu ando pelo mundo

Prestando atenção em cores

Que eu não sei o nome

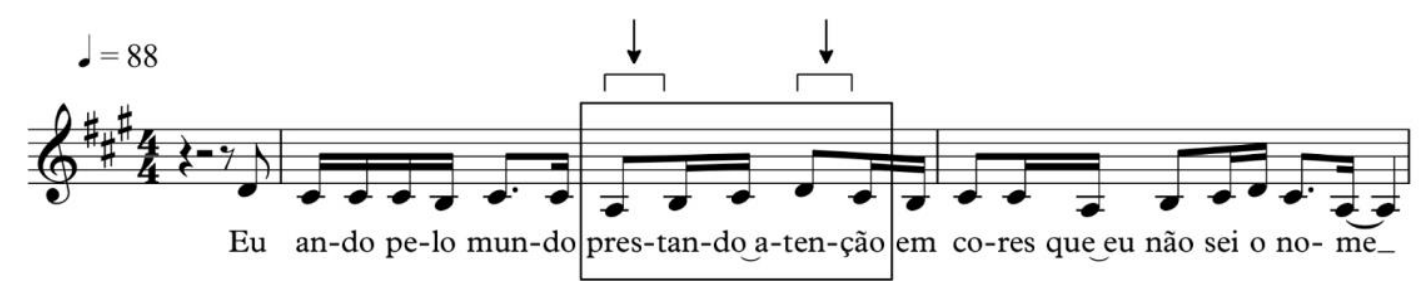

Figura 30. Deslocamento silábico em Esquadros (Adriana Calcanhoto)

Em todos esses exemplos, notamos que o alongamento das sílabas átonas é complementado pela coincidência com o tempo forte do compasso (em Eu te amo, Jesus Cristo e Meia lua inteira elas recaem sobre o primeiro tempo) ou com a parte forte de um tempo fraco (caso da palavra "atenção" em Esquadros). Julgamos, contudo, que nessas canções o fator duração é sensivelmente mais decisivo. Poderíamos até mesmo reescrever alguns desses fragmentos para investigar a real importância de cada um desses parâmetros musicais. Nas figuras abaixo, realizamos sutis alterações nas melodias que recobrem as palavras que sofrem deslocamento acentual nas canções Eu te amo e Jesus Cristo. 


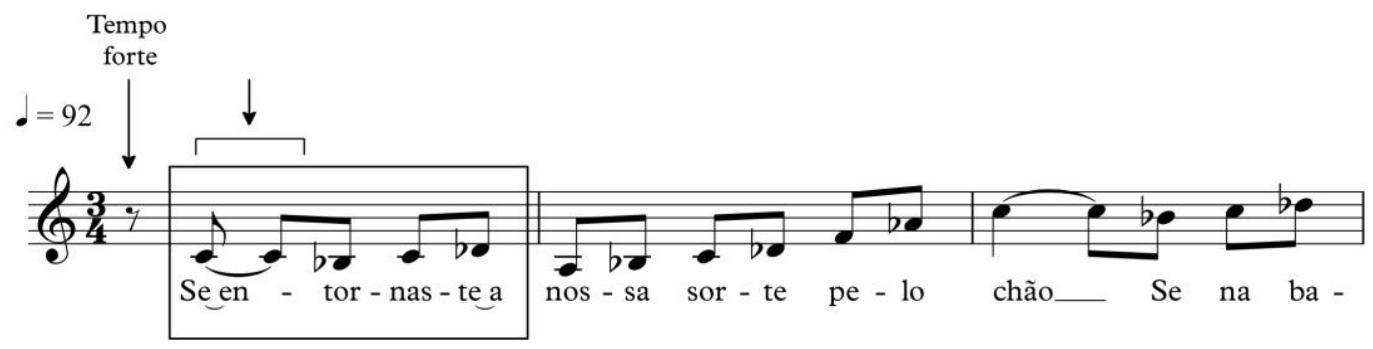

Figura 31. Reescrita de Eu te amo

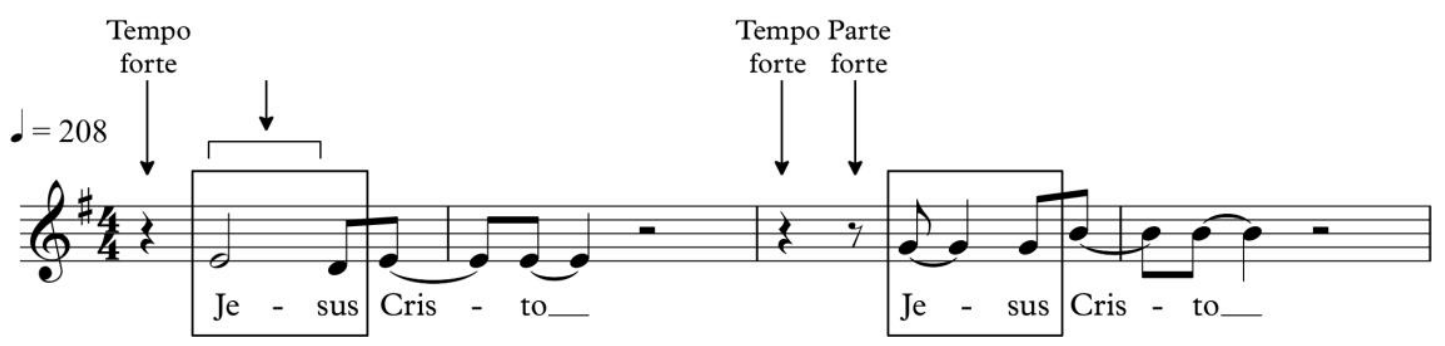

Figura 32. Reescrita de Jesus Cristo

Em ambos os exemplos, atrasamos o início de cada verso para que a primeira sílaba das palavras "entornaste" e "Jesus", sílabas átonas, deixassem de coincidir com o tempo forte do compasso (primeiro tempo) ou com a parte forte do segundo tempo (terceiro compasso da segunda figura). Preservamos, no entanto, a maior duração de suas respectivas notas, mantendo-as mais longas do que as sílabas subsequentes. Com isso, tentamos senão neutralizar, ao menos abrandar a influência do parâmetro intensidade ${ }^{89}$. Verificamos, então, que, mesmo com as alterações, o deslocamento silábico dessas palavras permanece.

É interessante reconhecer as especificidades de cada exemplo e o modo como o ouvinte passa a se relacionar intelectualmente com cada uma das letras, buscando, de modo intuitivo, referências linguísticas próximas de sua escuta. Em Eu te amo, a estranheza gerada pelo deslocamento silábico em "Se entornaste a nossa sorte pelo chão" pode fazer com que o ouvinte compreenda a frase de maneira diferente. Algo como "Sim, tornaste a nossa sorte pelo chão". Na canção de Roberto Carlos e Erasmo Carlos, por sua vez, devemos observar que a forte presença cultural do nome Jesus Cristo atua no sentido de abrandar a percepção do deslocamento silábico e a possível não compreensão do vocábulo, além do fato de o mesmo ser repetido diversas vezes ao longo da obra ${ }^{90}$.

\footnotetext{
${ }^{89}$ É possível que ainda tenhamos a sensação da ação do fator intensidade na medida em que estamos analisando palavras que iniciam versos e estrofes.

${ }^{90}$ Nessa canção notamos algo ainda mais curioso: a nota que recobre a última sílaba do nome "Jesus Cristo" é mais aguda do que as demais (sobretudo no compasso 6 da figura 28). Esse fenômeno, contudo, pode
} 
Em Feitiço Decente, Sandroni apresenta exemplos nos quais encontramos desvios acentuais causados pela duração. Selecionamos um deles, quando esse parâmetro influi no deslocamento silábico nos vocábulos "tornar" e "fazer" (SANDRONI, 2012: 194).

Tomara que tu apanhes

Pra não tornar fazer isso

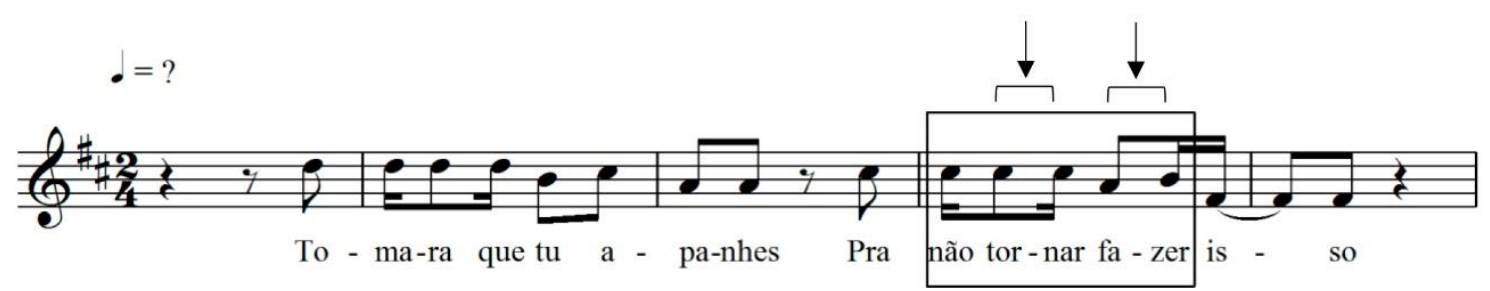

Figura 33. Terceira parte da canção Pelo telefone (Donga/Mauro de Almeida)

A primeira frase transcrita ("Tomara que tu apanhes") apresenta uma oralização mais linear do que a frase seguinte. Quando se repete o motivo melódico com novo recorte textual, há um deslocamento dos acentos tônicos das palavras "tornar" e "fazer". Em ambos os vocábulos, a sílaba átona possui duração maior do que a tônica. No primeiro, a sílaba tônica "nar" (1 semicolcheia) dura menos que "tor" (2 semicolcheias). No segundo, a sílaba "zer" apresenta um intervalo temporal mais curto do que a sílaba átona "fa" que, por isso, é enfatizada ${ }^{91}$.

Em Bim bom - A contradição sem conflitos de João Gilberto, Walter Garcia faz uma abordagem predominantemente musical da questão da acentuação. $\mathrm{O}$ autor examina os aspectos rítmicos do acompanhamento realizado ao violão nas canções do gênero bossa-nova e conclui que seu padrão rítmico segue o princípio da regularidade (nas notas graves) e da não-regularidade (nas notas mais agudas dos acordes) (GARCIA, 1999: 6869). Esses princípios, segundo Garcia, também norteiam a melodia do canto, situada entre a fala e a música, assim como pontuou Mário de Andrade em relação à tensão entre o recitativo e o canto estrófico.

O canto-falado de João Gilberto, ao se equilibrar no fio entre a origem e o desaparecimento do próprio ato de cantar, concilia o ritmo da fala - ditado pelo encadeamento das ideias que devem ser compreendidas intelectualmente pelo ouvinte - e o ritmo da música - criado por

configurar um gesto oral plausível na medida em que, na fala, é comum destacarmos a última sílaba de um nome em uma situação de chamamento (ainda que a palavra não seja uma oxítona).

${ }^{91}$ Notamos que a sílaba átona de "fazer" é também enfatizada pelo parâmetro intensidade, na medida em que ela recai justamente sobre a parte forte do segundo tempo do compasso. 
estímulos psicossomáticos para atingir o corpo da assistência, e emitido em dissociação combinada com a sua batida. (GARCIA, 1999: 126)

Como já constatamos anteriormente, o caráter entoativo do canto praticado por João Gilberto é um tópico muito recorrente nas análises de suas obras. Há até mesmo depoimentos do próprio artista que tornam explícita essa tendência ao canto mais ligado à fala.

Outra coisa com que eu não concordava era as mudanças que os cantores faziam em algumas palavras, fazendo o acento do ritmo cair em cima delas para criar um balanço maior. Eu acho que as palavras devem ser pronunciadas da forma mais natural possível, como se estivesse conversando. Qualquer mudança acaba alterando o que o letrista quis dizer com seus versos. (GARCIA, 1999: 128) ${ }^{92}$

Após situar o canto de João Gilberto nesse entrecruzamento entre a fala e a música, Garcia analisa a relação entre a voz, o violão e a acentuação do texto linguístico em Bim bom, examinando os jogos de fase e defasagem entre o canto e o instrumento acompanhador. Nesse momento, interessa-nos, sobretudo, a sua análise da segunda parte da canção.

É só isso meu baião

E não tem mais nada não

O meu coração pediu assim, só
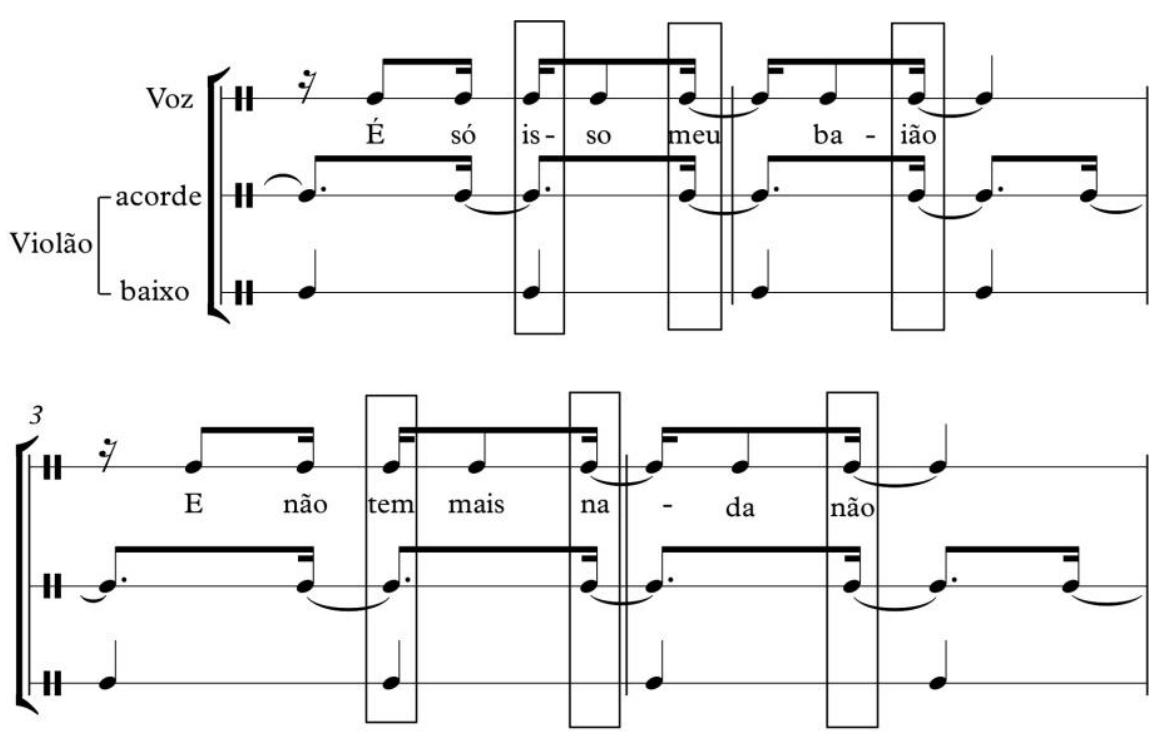

${ }^{2}$ In: SOUZA, Tárik de. \& ANDREATO, Elifas. "Entrevista: João Gilberto". Rostos e gostos da música popular brasileira. Porto Alegre: L\&PM, 1979. Pp. 49-56 (publicada na revista Veja de 12/05/71). 

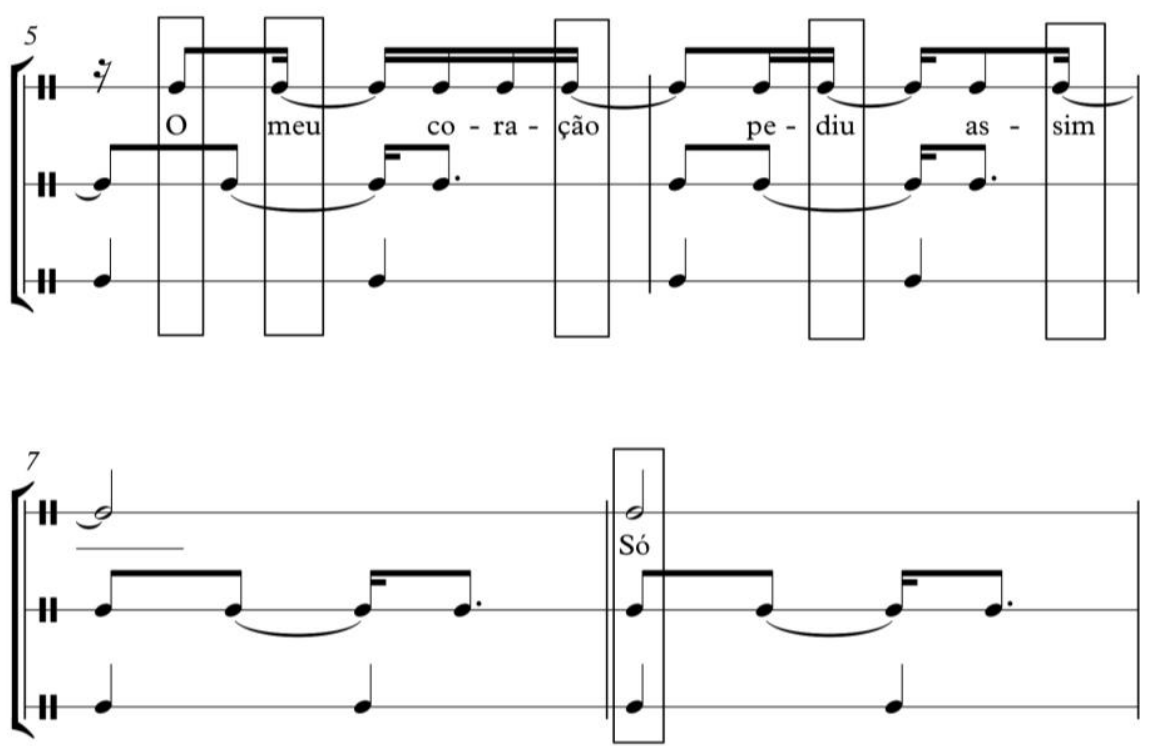

Figura 34. Bim bom (João Gilberto)

$\mathrm{O}$ autor analisa detalhadamente as coincidências entre os ataques do violão e os da voz (GARCIA, 1999: 142). Destaca que, nessa parte da canção, os dois primeiros versos apresentam o mesmo motivo melódico, com a mesma medida (redondilha maior) e acentos (na terceira, quinta e sétima sílabas). Como indicamos na figura acima, podemos verificar que os acentos da letra coincidem com os ataques instrumentais (ora com os baixos, ora com as notas mais agudas do acorde). Garcia observa a forte tensão entre o violão e o canto que encontramos no terceiro verso ("O meu coração pediu assim”), no qual nenhuma sílaba tônica coincide com os ataques do acompanhamento. Após esse trecho de maior instabilidade, no quarto verso ("Só"), há novamente uma coincidência entre a voz e o instrumento. Trata-se do mesmo fenômeno que verificamos nos exemplos de Mário de Andrade: a alternância de trechos em que a melodia apresenta um motivo mais regular (ligado ao padrão rítmico do acompanhamento) e de trechos em que a voz valoriza a entoação e abandona as balizas rítmicas estabelecidas pelo gênero. Aqui, no entanto, nos interessa assinalar que a frase musical que recobre o terceiro verso (compassos 5 e 6), ainda que possua maior instabilidade musical conforme a análise do autor, não apresenta desvios de acentuação silábica. A nosso ver, o motivo para a manutenção do acento natural deve-se ao fato de as sílabas tônicas de "coração", "pediu" e "assim" serem enfatizadas pelo alongamento da duração de suas respectivas notas. De fato, podemos observar na figura abaixo que a frase "O meu coração pediu assim" apresenta uma configuração rítmica diferente do padrão repetido pelas frases anteriores: 


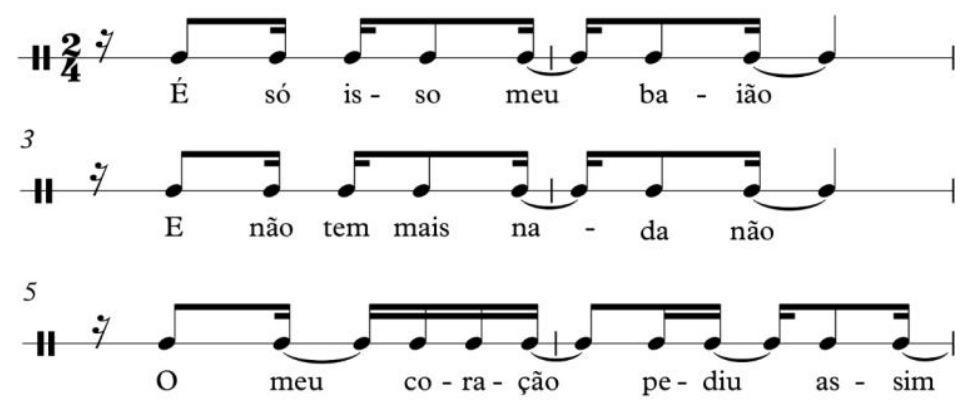

Figura 35. A diferença entre as configurações rítmicas das frases em Bim bom

Observando de maneira mais atenta, é curioso notar que a terceira frase dessa figura poderia, no entanto, ser cantada com o mesmo padrão rítmico que vinha sendo desenhado pelo cancionista. Teríamos, então, a seguinte configuração:

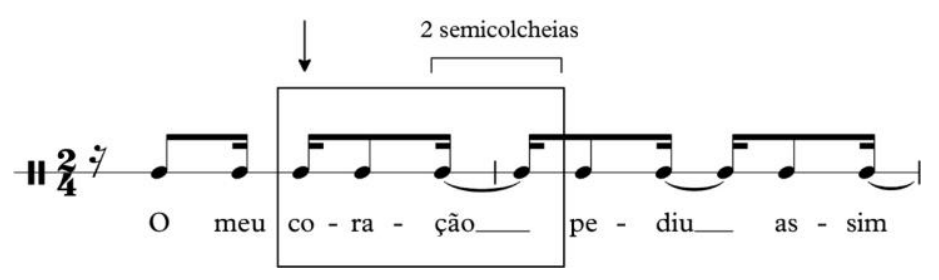

Figura 36. Manutenção do padrão rítmico para a frase "O meu coração pediu assim” em Bim Bom

Como destacamos acima, caso esse padrão fosse mantido pelo cantor, ainda que não houvesse desvios relevantes na acentuação natural dos vocábulos, a palavra "coração" teria sua sílaba átona "co" recaindo sobre a parte forte do segundo tempo do compasso. Como veremos abaixo, ao realizar a alteração rítmica da frase, o compositor, além de evitar essa coincidência entre a sílaba átona e o acento métrico, permite que a sílaba tônica da palavra "coração" seja sutilmente alongada (três semicolcheias ao invés de duas).

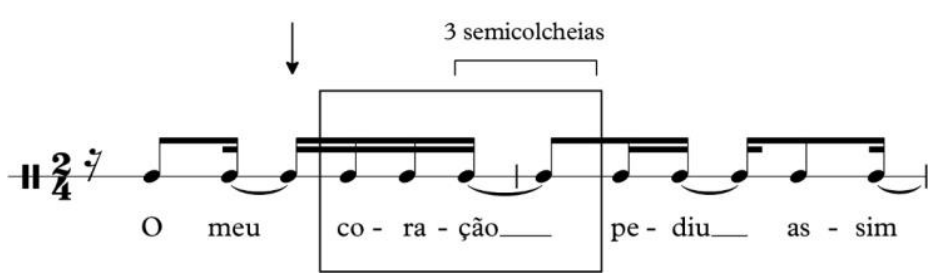

Figura 37. Configuração rítmica proposta por João Gilberto 
De maneira curiosa, voltando aos exemplos apresentados por Carlos Sandroni em Feitiço Decente, encontramos um caso similar que apresenta justamente a palavra "coração" no mesmo contexto melódico analisado acima. Trata-se da obra Modinha $n^{o}$ 17, presente no manuscrito Modinhas do Brazil, documento anônimo do final do século XVIII, cujas peças, no entanto, são atribuídas à Domingos Caldas Barbosa (SANDRONI, 2012: 51$)^{93}$.

Eu nasci sem coração

Quem ama que culpa tem?

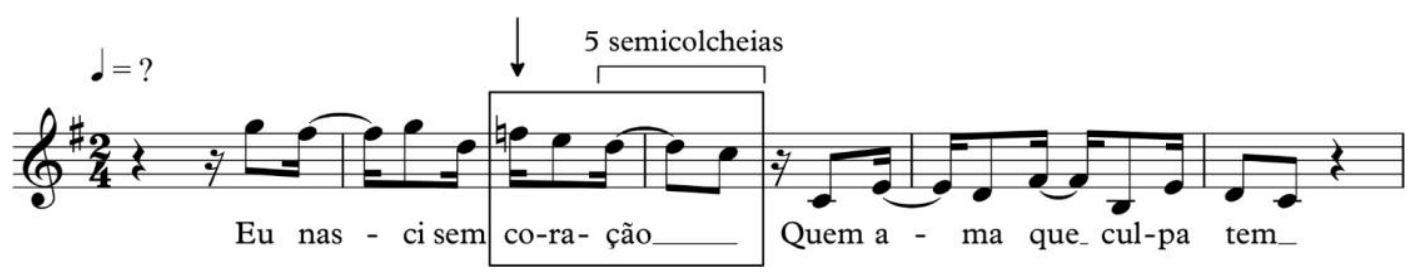

Figura 38. Deslocamento da acentuação silábica por meio da duração em Modinha $n^{\circ} 17$ (anônimo)

É muito interessante a comparação entre a Modinha $n^{\circ} 17$ e a figura 36, na qual experimentamos repetir o padrão rítmico dos versos iniciais de Bim Bom para a frase "O meu coração pediu assim”. Nesse caso, teríamos a mesma subdivisão rítmica para a palavra "coração", com sua primeira sílaba átona coincidindo com a parte forte do segundo tempo do compasso. Na Modinha, contudo, a sua sílaba tônica é ainda mais alongada: se contarmos o melisma entre as notas Ré e Dó temos ao todo uma duração de cinco semicolcheias. Aqui, podemos constatar a significativa importância do parâmetro duração para a questão prosódica na medida em que a pronúncia do vocábulo "coração" nos parece mais plausível pelo prolongamento de sua última sílaba. Além disso, contribui para a amenização do deslocamento acentual o fato de a palavra se situar em final de frase. Examinemos esse fenômeno de maneira mais detida a partir dos exemplos seguintes.

Primeiro era vertigem

Como em qualquer paixão

Era só fechar os olhos

E deixar o corpo ir no ritmo

${ }^{93}$ O manuscrito (Ms. 1596) compõe o acervo da Biblioteca da Ajuda em Lisboa 


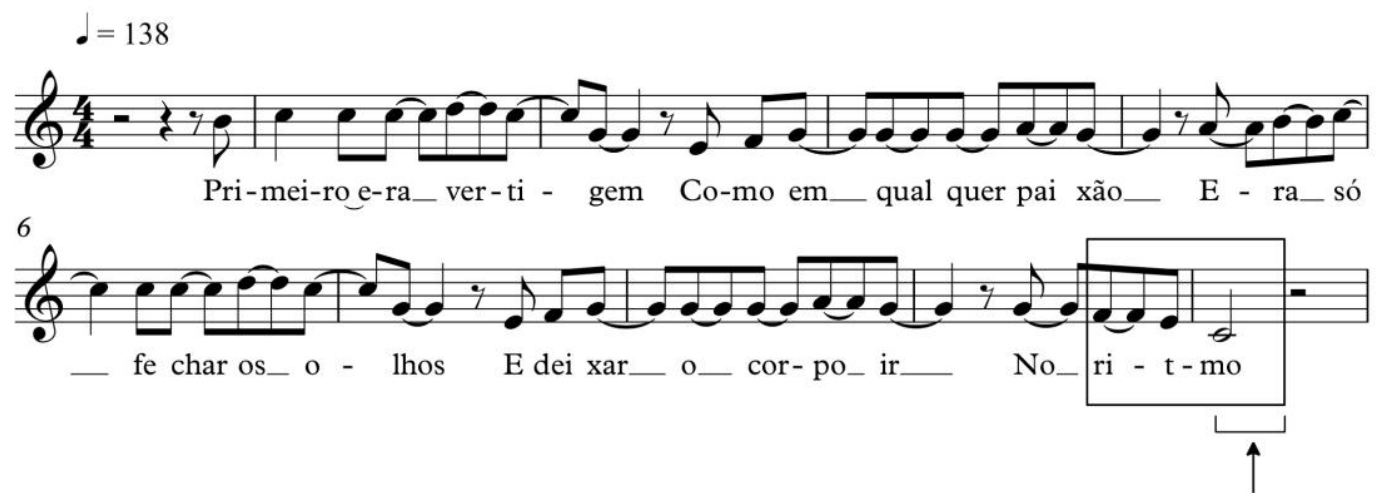

Figura 39. Deslocamento da acentuação silábica em Casa (O Eterno Retorno) (Lulu Santos)

Faltava abandonar a velha escola

Tomar o mundo feito Coca-Cola

Fazer da minha vida sempre

O meu passeio público

E ao mesmo tempo fazer dela

O meu caminho só, único

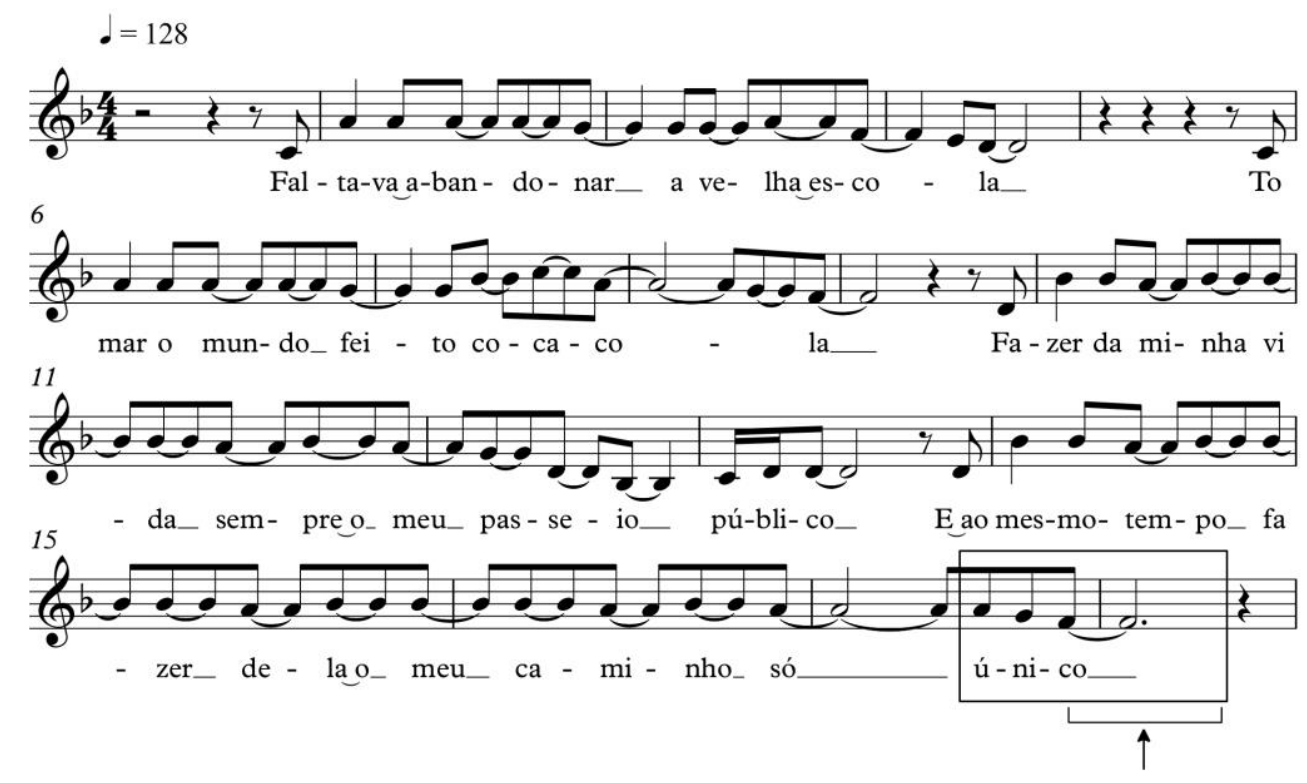

Figura 40. Deslocamento da acentuação silábica em $O$ último romântico (Sergio Almeida/Antonio Cicero/Lulu Santos)

Quem não é Recôncavo e nem pode ser reconvexo

Figura 41. Deslocamento da acentuação silábica em Reconvexo (Caetano Veloso) 
Ao analisarmos as figuras acima, desejamos demonstrar que as palavras "ritmo" (em Casa), "único" (em O último romântico) e "reconvexo" (em Reconvexo) sofrem desvio acentual pelo fato de as suas respectivas sílabas finais (sílabas átonas) terem a sua duração prolongada. Mesmo em Reconvexo, na qual a referida palavra possui a sua sílaba tônica ("ve") recaindo sobre a parte forte do segundo tempo do compasso, não escutamos o vocábulo de maneira natural ${ }^{94}$. Porém, mais do que indicar o desvio por meio da duração, esses exemplos podem nos sugerir a existência de um interessante e sutil fenômeno: palavras colocadas no final de um segmento melódico podem ter sua última sílaba "virtualmente alongada". Vejamos os exemplos seguintes.

$\mathrm{Na}$ fronteira de um oásis

Meu coração em paz, se abalou

É surpresa demais que trazes

'Inda bem que eu sou Flamengo

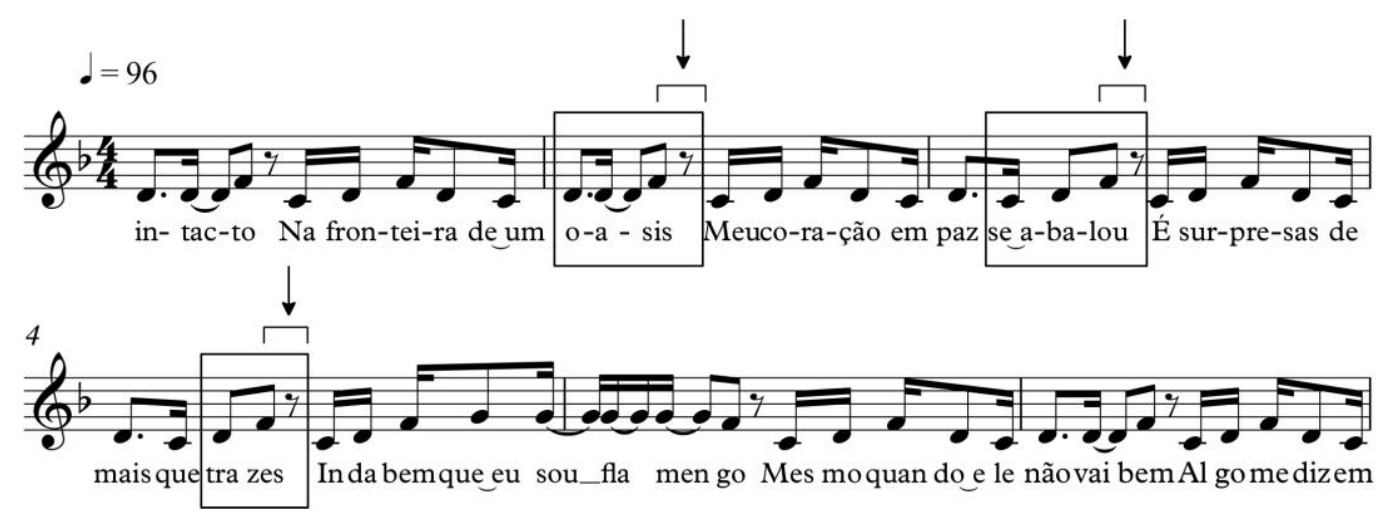

Figura 42. Deslocamento da acentuação silábica em Boa noite (Djavan)

Nessa canção, observamos três ocorrências distintas. A palavra "oásis" sofre deslocamento na medida em que sua primeira sílaba átona recai sobre o primeiro tempo forte do compasso. Também podemos pensar no mesmo tipo de desvio para o vocábulo "abalou", no qual sua sílaba átona "ba" recai sobre a parte forte do segundo tempo. A palavra "trazes" (cuja sílaba tônica recai sobre a parte forte do tempo) deveria, então, não sofrer deslocamento acentual. Entretanto, sentimos uma ênfase sutil na sua sílaba final, não apenas pela questão do salto intervalar, mas pela sua localização no final de uma unidade melódica. É como se sentíssemos uma maior duração dessa sílaba pelo fato de ela ser sucedida por uma pausa. Parece-nos que ela permanece ressoando em nossa

\footnotetext{
${ }^{94}$ Colabora para isso o fato de a sua primeira sílaba "re" (igualmente átona) cair sobre o ponto mais forte do compasso (primeiro tempo).
} 
percepção, virtualmente alongada. Acreditamos que é justamente por essa razão que a palavra "oásis" possui, além da primeira sílaba átona acentuada, a sua última sílaba também enfatizada. Além disso, é também por esse mesmo motivo que o vocábulo "abalou", a princípio corrompido em sua prosódia, passa a ser entoado de maneira mais natural, como se o deslocamento fosse corrigido: a sua sílaba final, tônica, ainda que recaia sobre a parte fraca do segundo tempo, é claramente acentuada por localizar-se no fim da frase melódica. Pensamos, desse modo, que o fenômeno do alongamento virtual da sílaba final possui papel importante na maneira como percebemos esses trechos de melodia e letra. Aqui, o fator altura, ainda que possua certa influência, nos parece menos relevante. Abaixo, para neutralizá-lo e comprovar que a ênfase na última sílaba do verso permanece, alteramos as notas finais dos respectivos vocábulos, eliminando os saltos intervalares encontrados na versão original da canção.

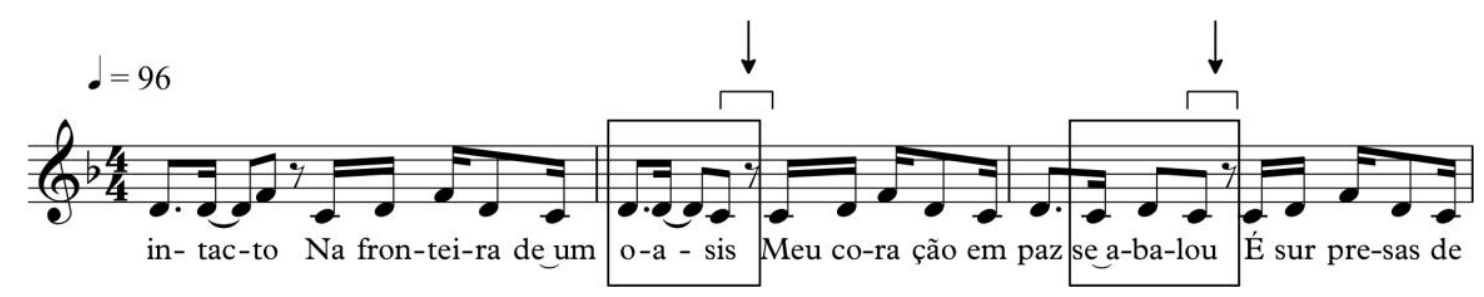

Figura 43. Alteração da altura das notas finais das palavras "oásis" e "abalou" em Boa noite

Alteramos as notas finais das palavras “oásis" e "abalou” para a nota Dó (um intervalo de $4 \mathrm{~J}$ abaixo em relação à nota original) e ainda assim sentimos certa ênfase que, se por um lado, prejudica a prosódia da primeira, por outro, faz com que a segunda seja cantada de maneira mais entoativa. Essa espécie de "correção" pode ser encontrada em outros exemplos. Em seguida, observamos dois trechos de canções cujos desvios acentuais causados pela duração alongada de sílabas átonas são, ao final, entoados de maneira mais natural, abrandando o estranhamento desse desvio por meio da ênfase dada às sílabas tônicas finais.

\section{Não desespere}

Quando a vida fere, fere

E nenhum mágico interferirá

Se a vida fere

Com a sensação do brilho

De repente a gente brilhará 


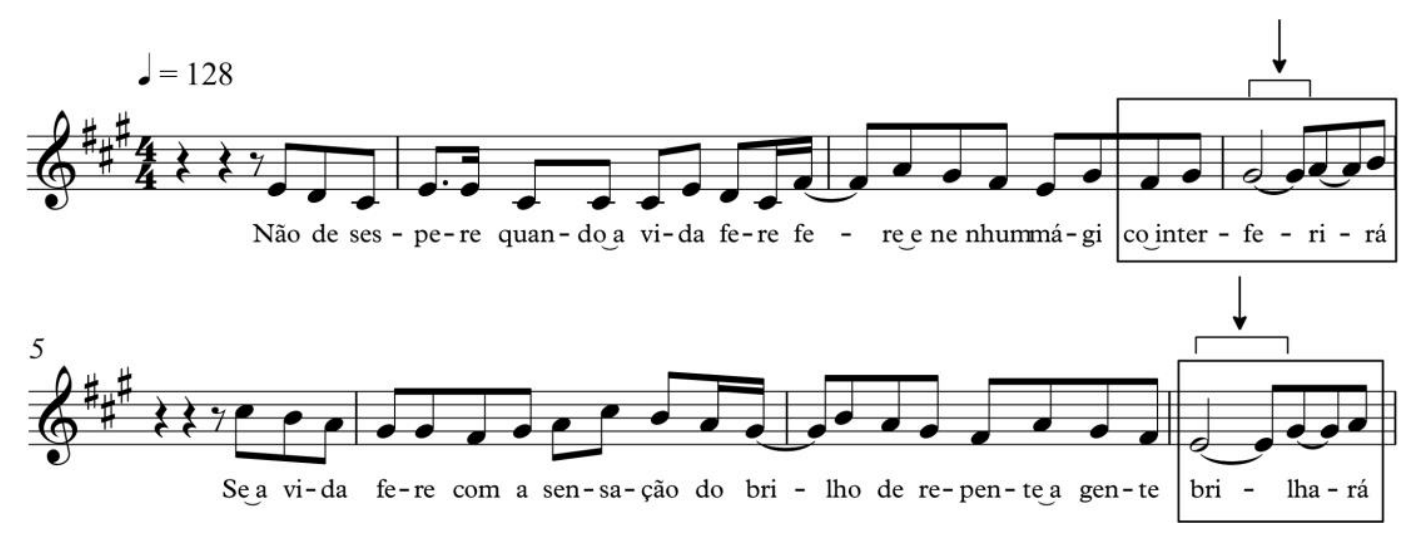

Figura 44. A duração virtual da sílaba final em Realce (Gilberto Gil)

O amor se deixa surpreender

Enquanto a noite vem nos envolver

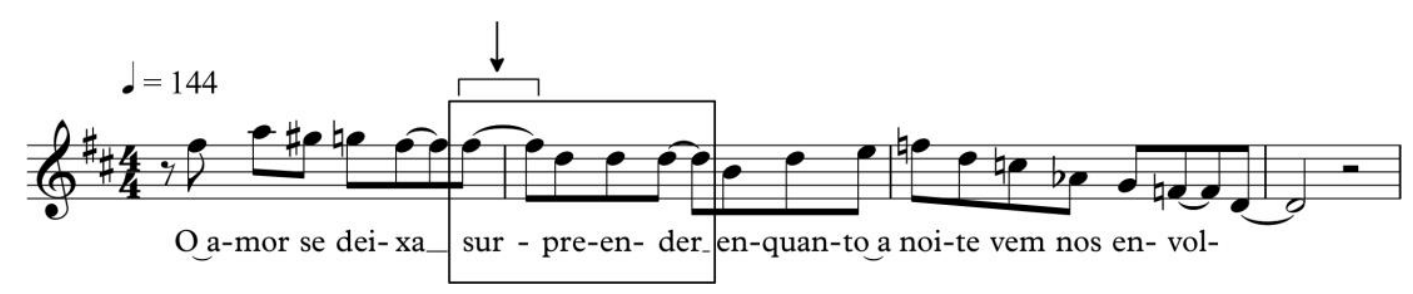

Figura 45. A duração virtual da sílaba final em Wave (Tom Jobim)

Nas figuras acima, as três palavras oxítonas destacadas "interferirá", "brilhará" e "surpreender" possuem sílabas átonas acentuadas por meio do parâmetro duração, respectivamente as sílabas "fe", "bri” e sur". No entanto, por localizarem-se no final de segmentos melódicos, observamos certo abrandamento do deslocamento silábico. É interessante notar a sutil diferença entre ambas as canções. Em Realce, há, entre os segmentos em questão, um tempo de pausa considerável (os dois tempos e meio de pausa do compasso 5, por exemplo). Parece-nos que esse tempo permite que o ouvinte possa refazer ou corrigir mentalmente o desvio acentual anterior. Em Wave, por sua vez, não encontramos pausa entre o final da unidade que termina com o vocábulo "surpreender" e o começo da seguinte. Mesmo assim, é possível perceber a separação entre ambas. Por conseguinte, a sua sílaba tônica final “der” é sensivelmente valorizada. Passemos para o estudo do próximo parâmetro sonoro responsável pelas alterações acentuais no nível da sílaba. 


\subsection{A alteração da acentuação silábica pela altura}

O terceiro e último parâmetro musical que acreditamos influir no deslocamento silábico, a altura, embora não seja o fator mais recorrente (os casos relacionados à intensidade e à duração são com certeza mais numerosos), pode ainda assim representar a principal causa de um desvio acentual. Em grande parte dos casos, contudo, ele atua conjuntamente com os dois outros fatores. Vejamos alguns exemplos:

E a gente canta

E a gente dança

E a gente não se cansa

De ser criança

A gente brinca

Na nossa velha infância

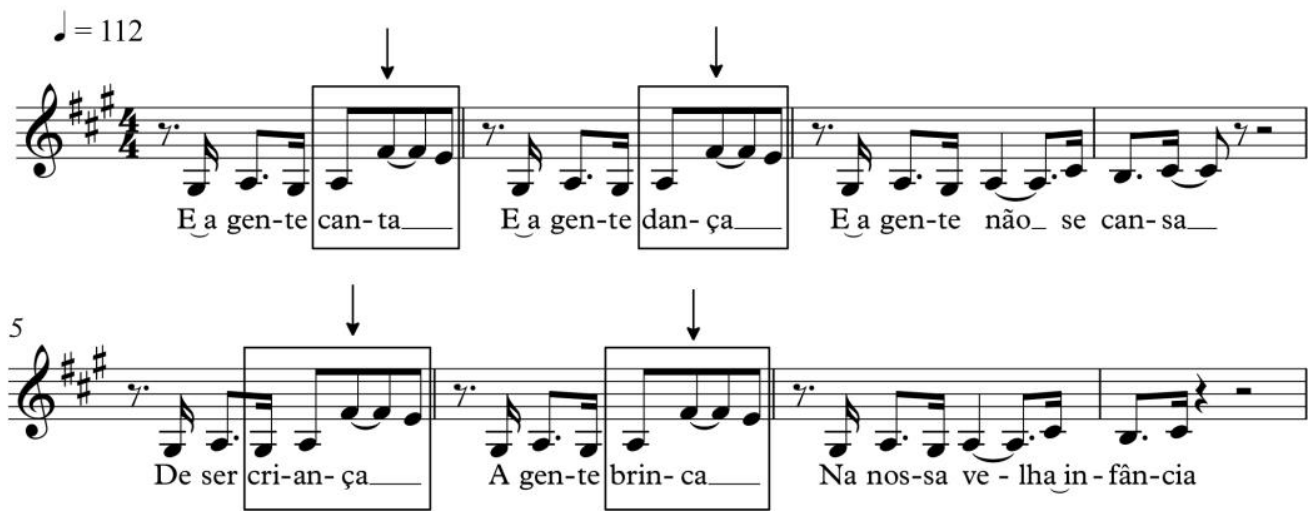

Figura 46. Deslocamento silábico em Velha infância (Carlinhos Brown/Marisa Monte/Arnaldo Antunes/Pedro Baby/Davi Moraes)

Nesse exemplo, observamos quatro palavras paroxítonas cujas sílabas finais, portanto átonas, são alcançadas por meio de um salto intervalar de sexta maior (de Lá natural para Fá\#). Os vocábulos "canta", "dança", "criança" e "brinca" sofrem, desse modo, deslocamento silábico, mesmo que suas sílabas tônicas coincidam com a parte forte do terceiro tempo do compasso ${ }^{95}$. Esses desvios fazem com que o ouvinte não capte o sentido dos versos de maneira totalmente imediata. Parece-nos que ocorre uma leve hesitação entre o entendimento do verbo no presente ("canta", "dança" etc.) e o verbo no infinitivo ("cantar", “dançar" etc.). Aproveitando esse fenômeno, para as unidades

\footnotetext{
${ }^{95}$ Essas sílabas finais também possuem duração mais alongada, mas acreditamos que o fator altura atua de maneira mais decisiva.
} 
entoativas que terminam com esse salto, poderíamos propor um recorte textual levemente distinto, resultando em uma figurativização mais linear. Para os primeiros dois segmentos, por exemplo, poderíamos substituir as frases linguísticas por uma forma com o infinitivo do verbo principal antecedido pela preposição $a$, para indicar uma ação durativa no presente: "E a gente a cantar" e "E a gente a dançar". Com isso, o acento tônico da letra passaria a combinar com o acento da melodia (gerado, a nosso ver, sobretudo pelo fator altura).

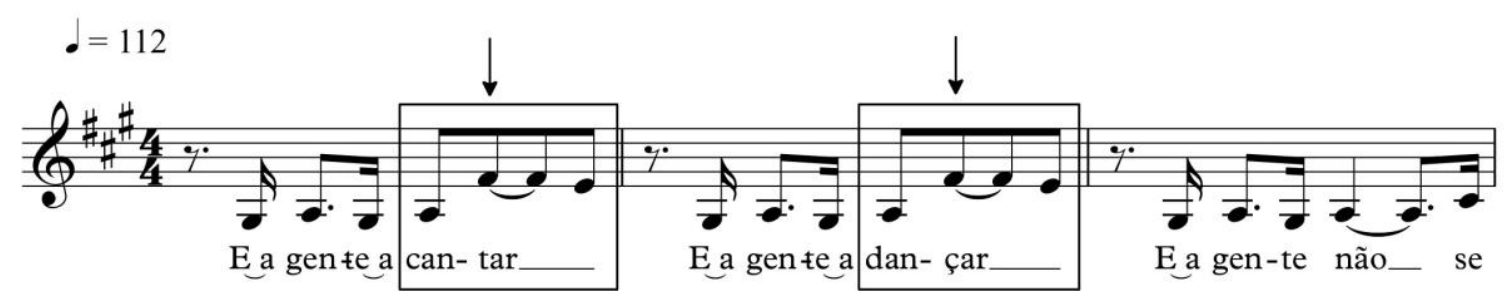

Figura 47. Reescrita de duas unidades entoativas de Velha infância

Essa solução, contudo, afasta-se levemente do registro de fala do português brasileiro. Ainda que seja perfeitamente plausível em nossa língua, essa forma é, sem dúvida, mais comum no português europeu. Começamos, então, a perceber a importância do parâmetro altura para os casos de deslocamento silábico. As notas agudas, de acordo com o intervalo que as separam das demais, podem enfatizar as suas respectivas sílabas. Com o devido cuidado e atenção aos demais parâmetros, poderíamos dizer que o aumento da frequência vem acompanhado de um aumento na acentuação. Examinemos as conhecidas canções Desafinado (Tom Jobim/Newton Mendonça) e $O$ bêbado e a equilibrista (João Bosco/Aldir Blanc). Notamos nelas algo semelhante: um salto intervalar entre a primeira sílaba, átona, e a segunda, nas palavras "musical” e "azar".

Se você insiste em classificar

Meu comportamento de antimusical

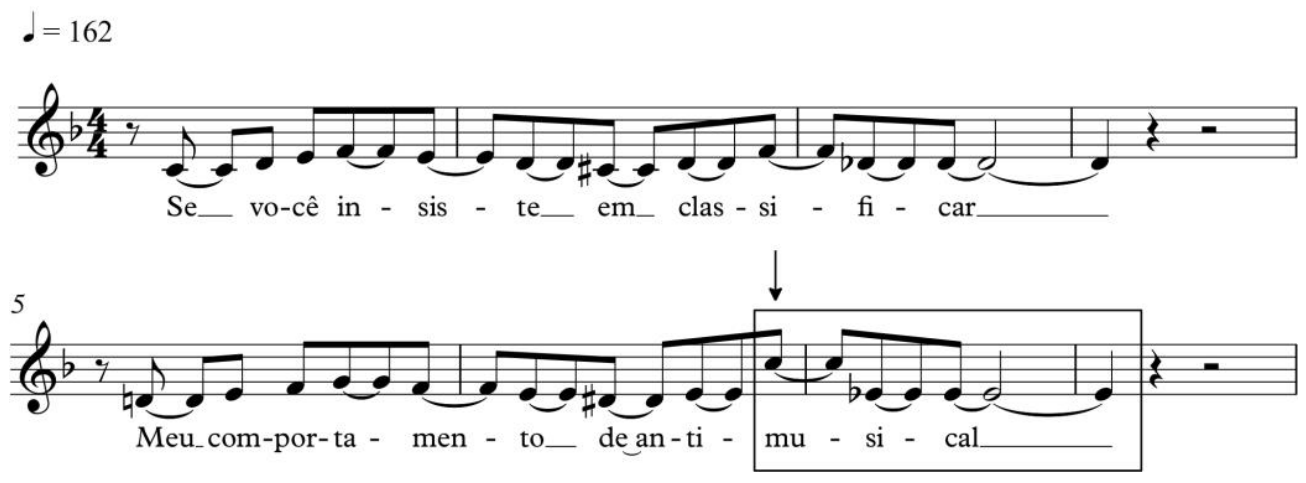

Figura 48. Deslocamento silábico em Desafinado (Tom Jobim/Newton Mendonça) 
Azar

A esperança equilibrista

Sabe que o show de todo artista

Tem que continuar
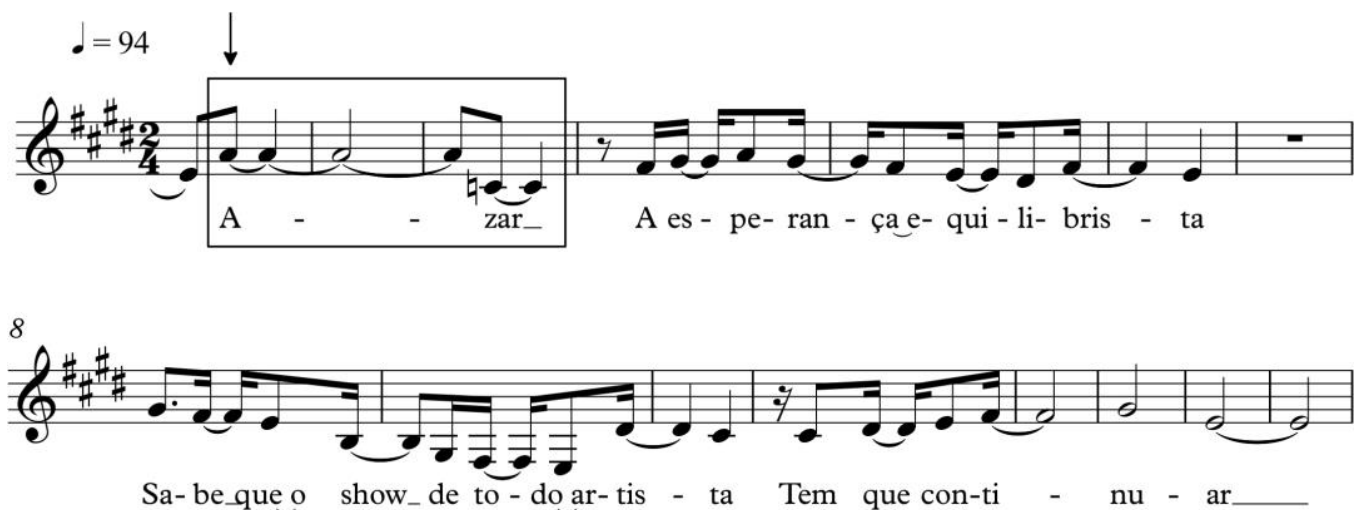

Figura 49. Deslocamento silábico em O bêbado e a equilibrista (João Bosco/Aldir Blanc)

É interessante notar que os dois exemplos apresentam exatamente o mesmo intervalo de sexta maior observado na canção Velha infância, de modo descendente, no entanto. Em Desafinado, o fator altura parece ser o agente mais relevante no leve deslocamento acentual que observamos no vocábulo "musical", na medida em que a duração das sílabas átonas é de duas colcheias ("mu" e "si") e a da sílaba tônica é de sete colcheias ("cal"). Além disso, acreditamos que a intensidade está, de certo modo, neutralizada pelo fato de as notas não coincidirem com pontos métricos fortes do compasso. A ênfase na primeira sílaba do vocábulo "musical” se dá, portanto, pelos saltos intervalares entre as notas Mi natural, Dó e Mi bemol, entre os compassos 6 e 7. Diferentemente, em $O$ bêbado e a equilibrista, o fator altura (o salto descendente entre as notas Lá natural e Dó natural na palavra “azar”) 96 divide espaço com o parâmetro duração, já que a sílaba átona desse vocábulo dura oito colcheias em oposição às três colcheias da sílaba tônica. A intensidade, do mesmo modo, apresenta-se anulada pela não coincidência das sílabas com os tempos fortes. Por fim, examinemos um último exemplo, um trecho da canção Feitiço da Vila de Vadico e Noel Rosa

Que faz dançar os galhos do arvoredo

E faz a lua nascer mais cedo

\footnotetext{
${ }^{96}$ Além do fato de haver um salto ascendente entre a nota anterior à sílaba átona de "azar" (de Mi natural para Lá natural) no início do primeiro compasso.
} 


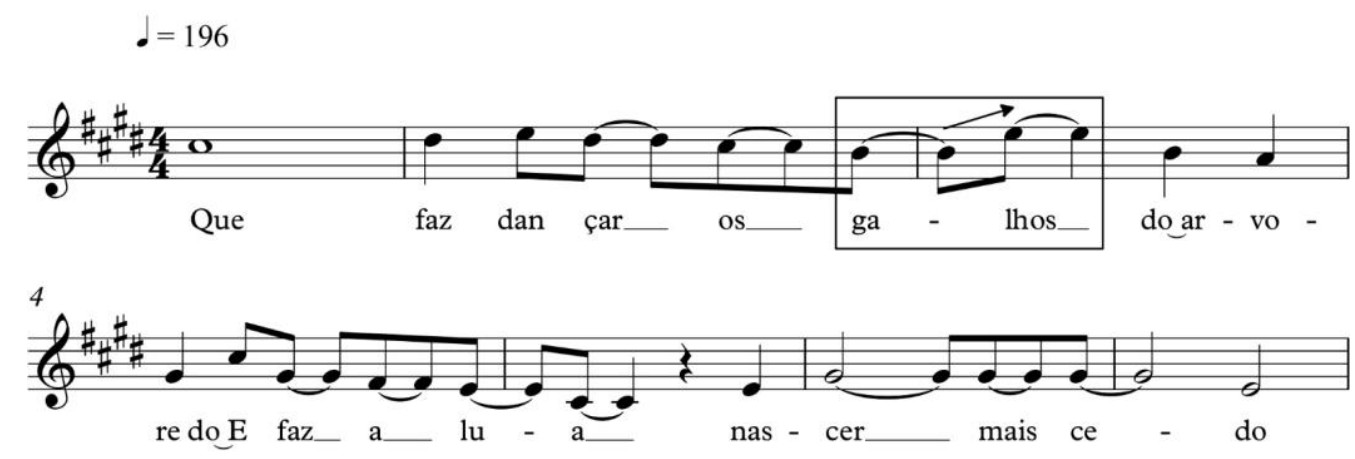

Figura 50. Deslocamento de acento em Feitiço da Vila (Vadico/Noel Rosa)

Como observamos na figura acima, a palavra "galhos" sofre deslocamento silábico devido à ênfase da melodia sobre a nota Mi natural do terceiro compasso (a nota mais aguda do fragmento). Coincidindo com a sua sílaba átona ("lhos"), esse salto intervalar faz com que a emissão do vocábulo seja realizada com menor naturalidade entoativa. Não obstante, outro aspecto nos chama a atenção. A palavra "galhos" encontrase justamente no limite entre duas unidades melódicas. No nosso capítulo sobre a figurativização na semiótica da canção, quando observamos a análise dessa mesma obra realizada por Tatit, pudemos verificar que o trecho musical abaixo, ao ser segmentado por cinco unidades entoativas, passava a apresentar um resultado mais natural do ponto de vista entoativo. Isto é, naquele caso, as cinco unidades melódicas que indicamos na próxima figura coincidiam exatamente com cinco unidades entoativas: "Mas, / tenho que dizer, / modéstia à parte, / meus senhores, / eu sou da Vila". Aqui, de modo diferente, uma única frase linguística (“que faz dançar os galhos do arvoredo") ocupa três segmentos melódicos.

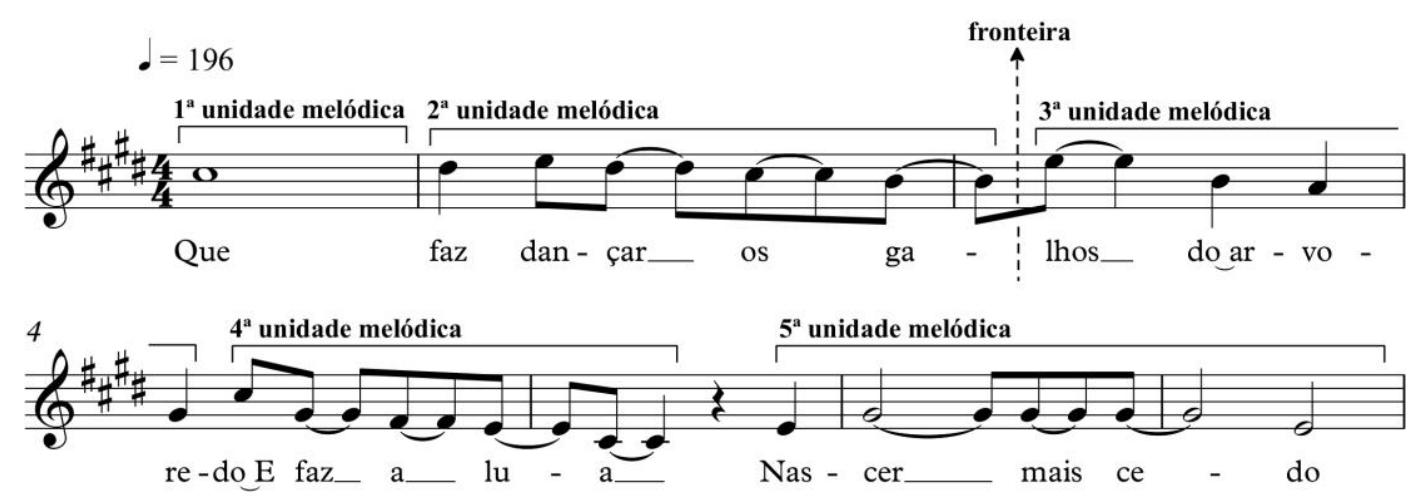

Figura 51. A localização da palavra "galhos" na fronteira entre duas unidades melódicas 
Pois bem, como verificamos acima, a primeira sílaba de "galhos" localiza-se no final da segunda unidade melódica, enquanto a sílaba seguinte encontra-se no início da próxima unidade. Estudaremos essa questão de maneira mais aprofundada em um capítulo posterior dedicado à frase. Já conseguimos, no entanto, observar que a acentuação silábica pode ser influenciada por outras instâncias composicionais. Aqui, a separação da palavra entre dois segmentos melódicos distintos reforça, a nosso ver, o seu deslocamento acentual. 


\subsection{A simultaneidade dos três parâmetros}

Evidentemente, ainda que possamos analisar casos de deslocamento de acentuação silábica considerando os seus fatores de maneira isolada, é bastante comum esse tipo de desvio ocorrer por meio da influência simultânea dos três parâmetros. Assim, por vezes, a intensidade, a duração e a altura determinam conjuntamente regiões fortes da melodia que podem não coincidir com pontos tônicos da letra. Podemos retomar um exemplo apresentado por Carlos Sandroni, uma modinha atribuída a Caldas Barbosa, presente no mesmo manuscrito do século XVIII mencionado anteriormente, Modinhas do Brazil (SANDRONI, 2012: 50):

Você se esquiva de mim

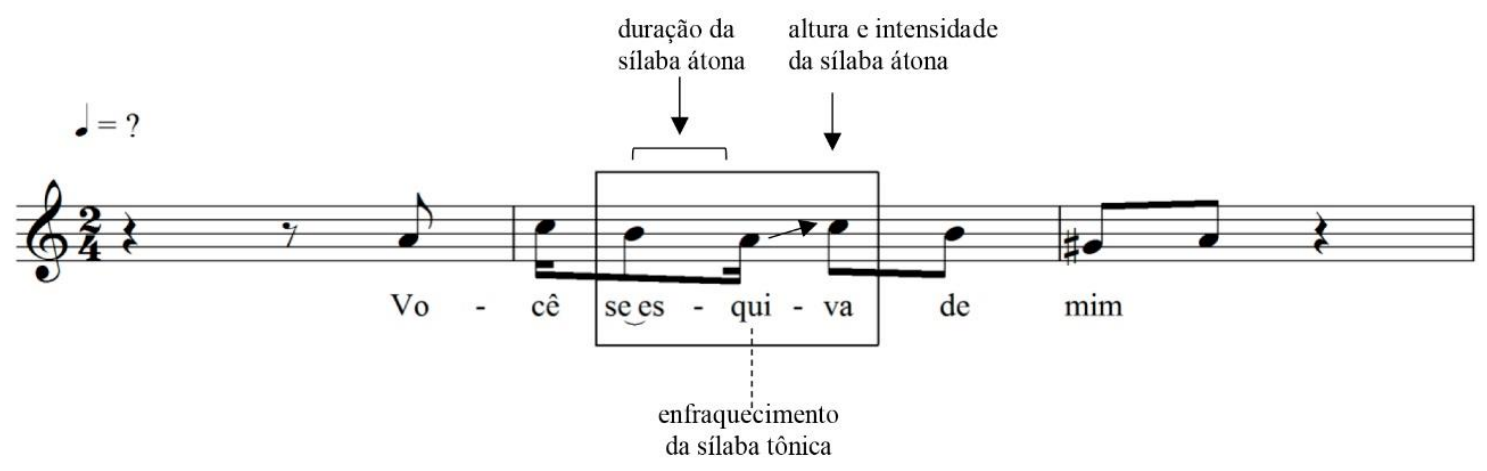

Figura 52. A influência dos três parâmetros em Modinha nº 1 (anônimo)

Nessa canção, notamos que a entoação da palavra “esquiva” não se dá de maneira natural. Em primeiro lugar, a sua sílaba tônica "qui" está localizada em uma parte fraca da melodia (a quarta semicolcheia do primeiro tempo do compasso). Por outro lado, apresenta uma duração menor do que as outras sílabas do vocábulo: as sílabas átonas "es" e "va" duram duas semicolcheias ao passo que a sílaba tônica dura somente uma. Por fim, há um pequeno salto intervalar de $3^{\mathrm{a}} \mathrm{m}$ (Lá - Dó) que enfatiza ainda mais o acento da sílaba átona "va", prejudicando sensivelmente a naturalidade entoativa do trecho. Assim, percebemos que os três parâmetros (intensidade, duração e altura) estão atuando de maneira simultânea. Na canção Realce, de Gilberto Gil, assinalamos dois vocábulos em que o mesmo fenômeno se dá.

Realce, realce

Quanto mais purpurina melhor

Realce, realce 
Com a cor-do-veludo,

Com amor, com tudo

De real teor de beleza

Realce, realce, realce, realce

Realce, realce, realce, realce

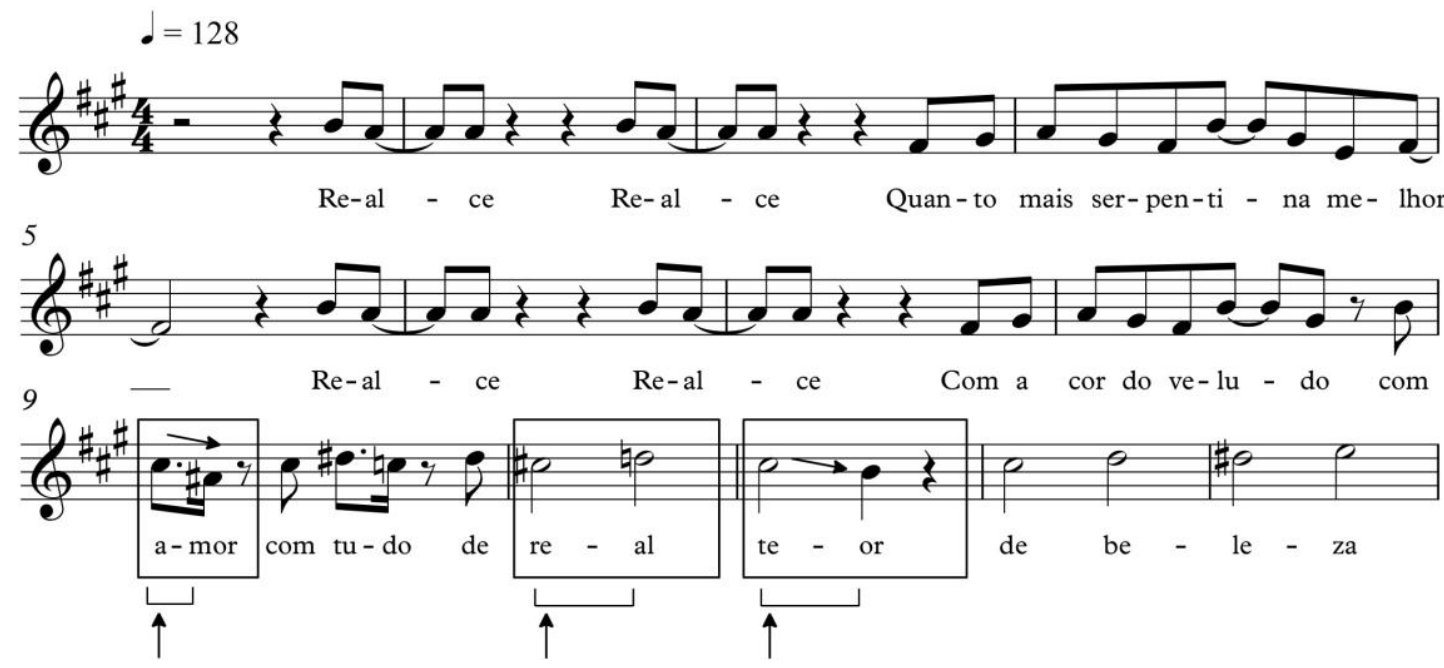

Figura 53. A influência dos três parâmetros em Realce (Gilberto Gil)

As palavras "amor" e "teor", ambas dissílabas e oxítonas, sofrem deslocamentos silábicos similares. Suas respectivas sílabas átonas "a" e "te" são inconvenientemente acentuadas pela intensidade (pela sua localização na parte forte do primeiro tempo do compasso), pela duração (elas duram, respectivamente, o triplo e o dobro da duração das sílabas tônicas subsequentes) e, por fim, pela altura (ambas recaem sobre notas mais agudas estabelecendo intervalos descendentes entre a primeira sílaba, átona, e a segunda, tônica). O mesmo ocorre com a palavra "você" em Noite dos Mascarados:

Deixa o dia raiar, que hoje eu sou

Da maneira que você me quer

O que você pedir eu lhe dou

Seja você quem for

Seja o que Deus quiser 


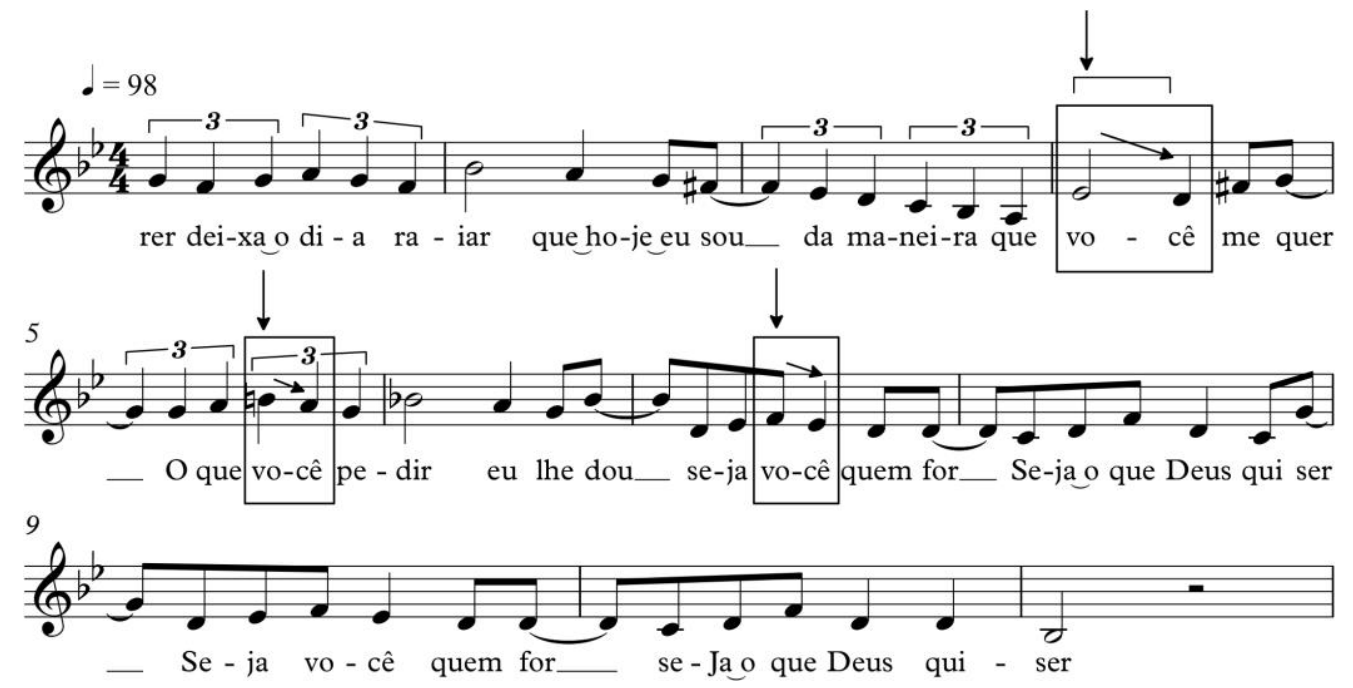

.Figura 54. A influência dos três parâmetros em Noite dos Mascarados (Chico Buarque)

Na primeira ocorrência do vocábulo observamos a influência dos três parâmetros no desvio prosódico. A sílaba átona de "você" recai sobre o primeiro tempo do compasso, com duração e altura superiores às da sílaba tônica "cê". Quando a palavra volta a se repetir, no entanto, o fator duração deixa de ser relevante. Podemos examinar igualmente, exemplos nos quais há um interessante jogo de forças entre os três fatores. Vejamos os trechos destacados das canções Será e De onde vem a calma, obras que se tornaram conhecidas nas interpretações dos grupos brasileiros Legião Urbana e Los Hermanos, respectivamente.

Será só imaginação?

Será que nada vai acontecer?

Será que é tudo isso em vão?

Será que vamos conseguir vencer?

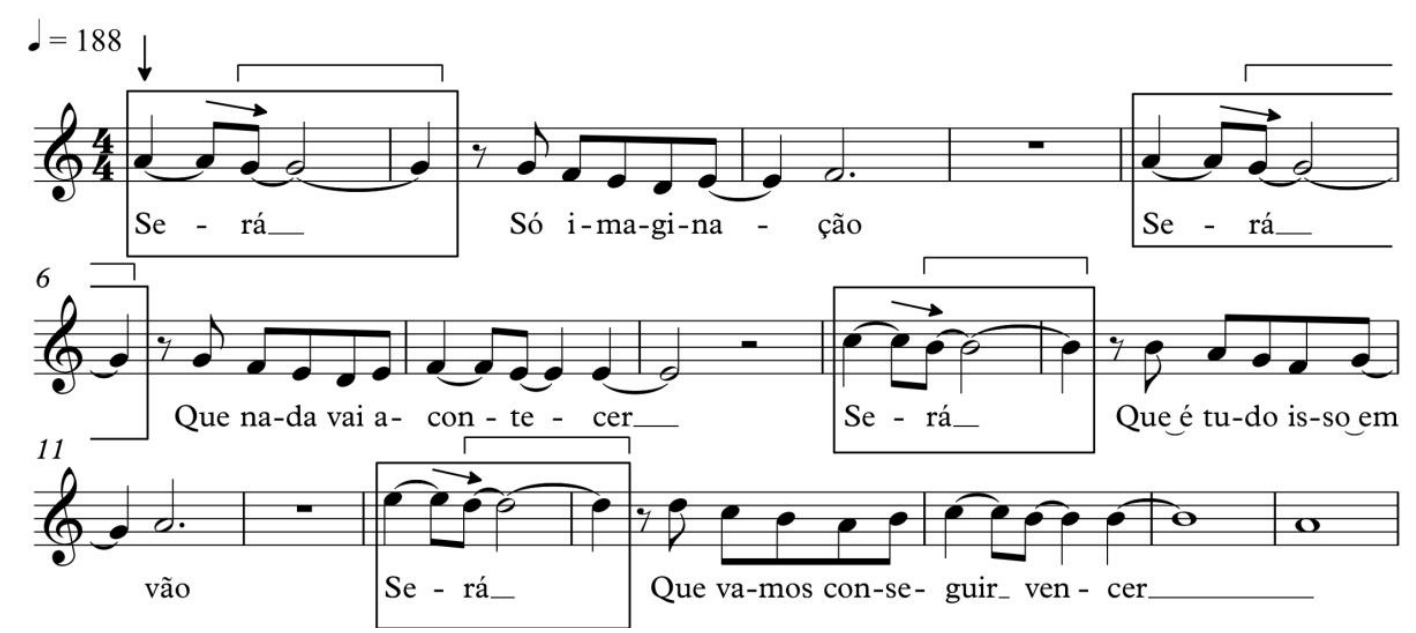

Figura 55. Deslocamento de acento em Será (Dado Villa-Lobos/Marcelo Bonfá/Renato Russo) 
Como não entende de ser valente?

Ele não sabe ser mais viril

Ele não sabe não, viu?

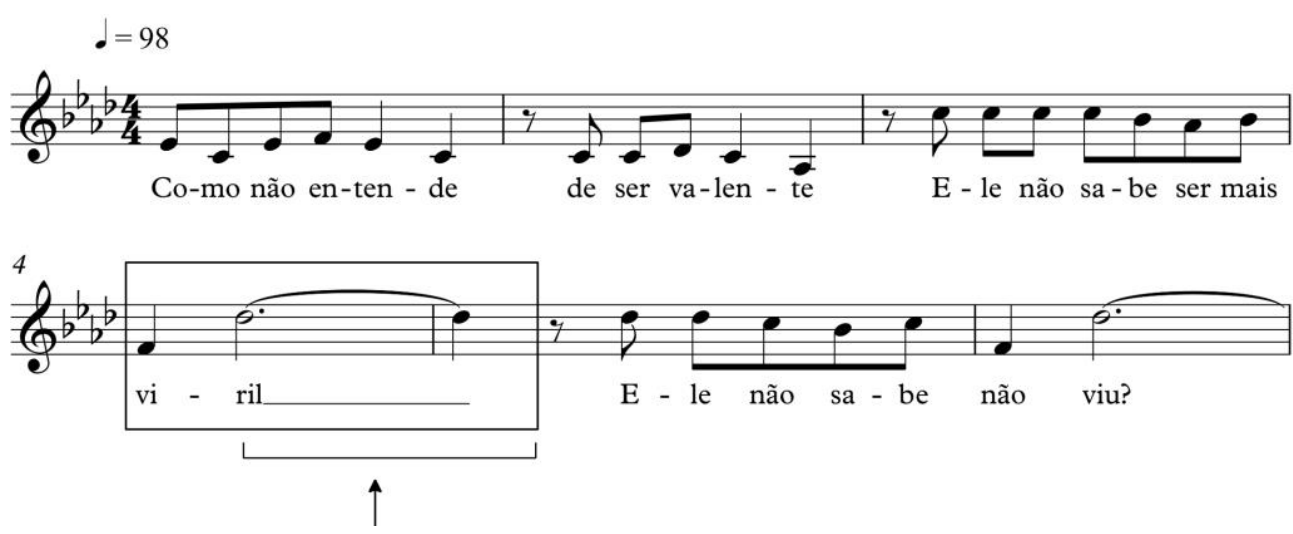

Figura 56. Deslocamento de acento em De onde vem a calma (Marcelo Camelo)

Ao observarmos a maneira como o cantor entoa as palavras "será" e "viril" percebemos algo curioso. As sílabas tônicas de ambos os vocábulos são, de certa forma, valorizadas pela duração muito alongada das notas. Em De onde vem a calma, além da duração, a altura também age no mesmo sentido. Contudo, ainda que tenhamos essa valorização, os desvios prosódicos desses vocábulos permanecem. Parece-nos, então, que o fator intensidade, além de mais recorrente do que os demais, também prepondera sobre eles. A sílaba tônica de "viril" dura quatro vezes mais e é atingida por meio de um salto amplo de $6^{\mathrm{a}}$ menor em relação à sua sílaba átona. Entretanto, o ponto de acento predominante continua sendo aquele gerado pela intensidade. Se esse fator, por um lado, pode provocar deslocamentos acentuais, subjugando os demais fatores, por outro, pode evitar ou abrandar certos desvios prosódicos causados pelos mesmos. Nos três exemplos seguintes, a coincidência da sílaba tônica com um ponto métrico forte do compasso abranda as ênfases produzidas pela altura e pela duração. Vejamos.

Nas favelas, no senado, sujeira pra todo lado

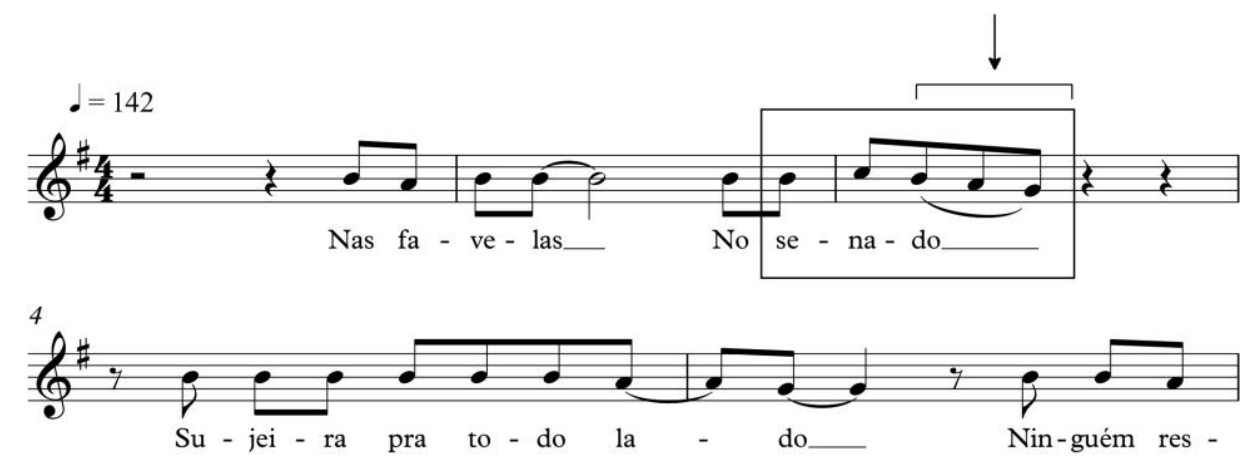

Figura 57. A preponderância da intensidade em Que país é esse? (Renato Russo) 
$\mathrm{O}$ acaso vai me proteger

Enquanto eu andar distraído
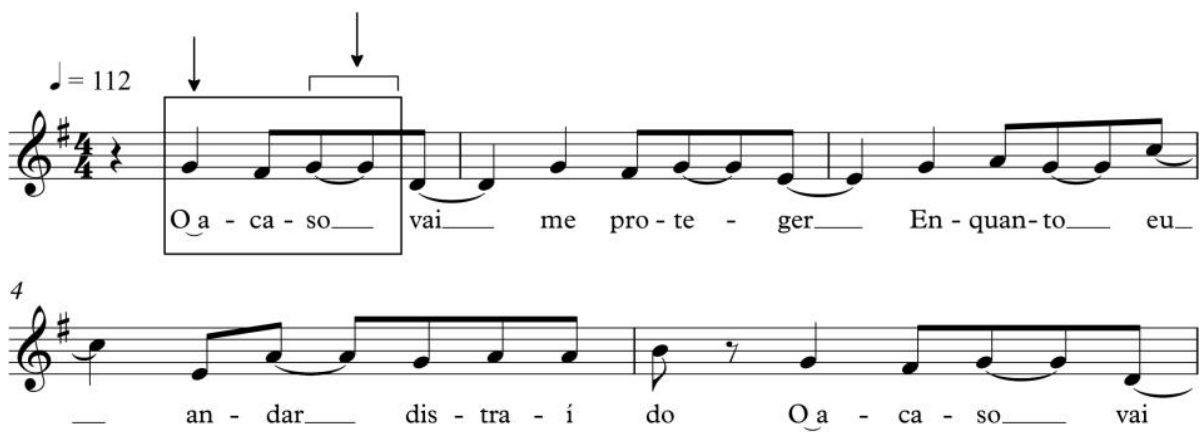

Figura 58. A preponderância da intensidade em Epitáfio (Sérgio Britto)

Até mesmo a asa branca

Bateu asas do sertão

Então eu disse, adeus Rosinha

Guarda contigo meu coração

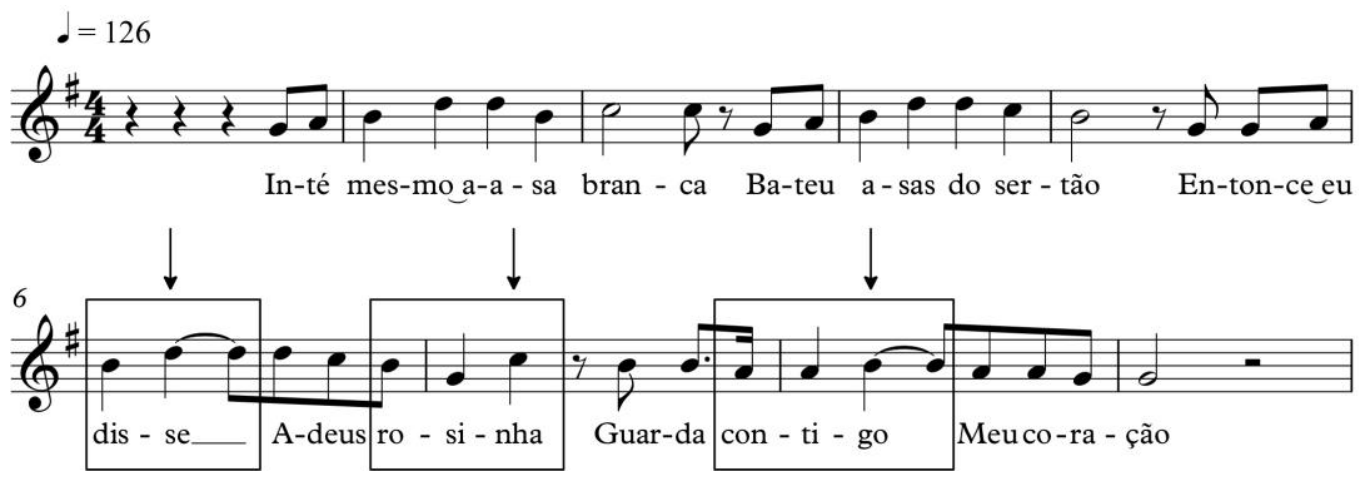

Figura 59. A preponderância da intensidade em Asa Branca (Luiz Gonzaga/Humberto Teixeira)

Nos três casos acima, em todas as palavras destacadas, observamos uma ênfase nas sílabas pós-tônicas. Em "senado", assinalamos um prolongamento da última sílaba átona por meio de um melisma descendente constituído pelas notas Si-Lá-Sol. Em "acaso", as duas sílabas átonas duram o dobro da sílaba tônica e a primeira também é enfatizada na medida em que está localizada na parte forte do segundo tempo do compasso $^{97}$. No terceiro exemplo, as últimas sílabas das palavras "disse", "Rosinha" e "contigo" são alcançadas por meio de pequenos saltos intervalares e, no primeiro e no terceiro caso, possuem duração mais alongada do que a tônica. Todavia, essas ênfases não chegam de fato a comprometer a naturalidade na emissão dos vocábulos, que ainda

\footnotetext{
${ }^{97}$ A sílaba tônica "ca" está também meio tom abaixo em relação às demais.
} 
nos parece plausível ${ }^{98}$. Isso porque as suas respectivas sílabas tônicas coincidem justamente com partes fortes da métrica do compasso. Esses exemplos podem nos indicar, mais uma vez, que a intensidade prevalece sobre os outros parâmetros musicais.

Aprofundando um pouco mais a questão da intensidade e voltando ao que observamos no início deste capítulo acerca do acento métrico dos diferentes tipos de compasso (binário, ternário, quaternário etc.), desejamos examinar um interessante fenômeno. São casos em que a nota emitida pelo cantor constitui uma síncopa para o tempo forte ou meio forte. A sua respectiva sílaba localiza-se, então, antes do acento métrico do primeiro ou do terceiro tempo num compasso quaternário, por exemplo. Analisemos os seguintes fragmentos:

De terno branco e chapéu de palha

Vou me apresentar à minha nova parceira

Já mandei subir o piano pra Mangueira

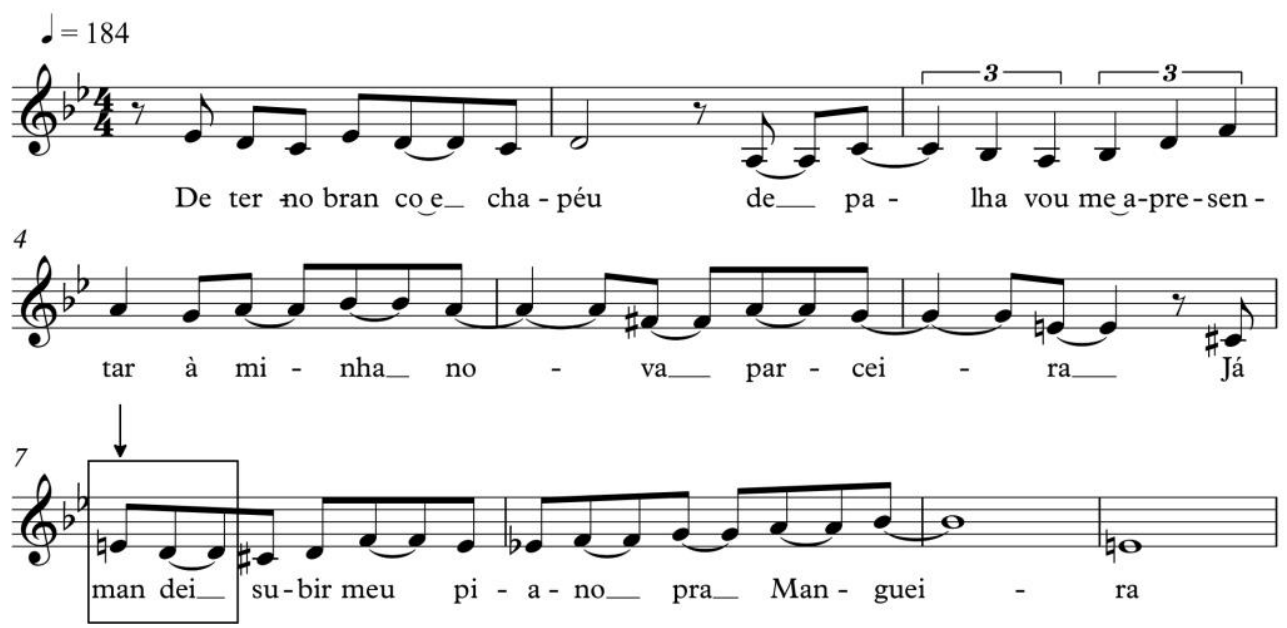

Figura 60. O fator intensidade em Piano na Mangueira (Tom Jobim/Chico Buarque) na versão cantada por Chico Buarque

É conhecido o episódio em que o compositor Tom Jobim se mostrou descontente com um detalhe da letra apresentada por seu parceiro Chico Buarque. Na primeira figura, constatamos que o incômodo de Jobim se deve ao fato de a palavra "mandei" sofrer deslocamento silábico gerado pelo fator intensidade: sua primeira sílaba, átona, coincide

\footnotetext{
${ }^{98}$ Essa plausibilidade decorre ainda de um encaixe confluente entre todo o trecho melódico descendente (que decai gradativamente apoiando-se nas notas que destacamos na figura 59: ré, dó e si) e a frase linguística de teor asseverativo: "Então eu disse / adeus Rosinha / guarda contigo meu coração". Nesse sentido, segundo a teoria de Tatit, essas elevações das sílabas átonas podem exprimir os sucessivos adiamentos da afirmação final e servem justamente para deixá-la mais contundente.
} 
com o tempo mais forte do compasso, um caso típico já estudado anteriormente. Interessanos, contudo, observar a maneira pela qual o compositor reescreveu o mesmo trecho, numa tentativa de corrigir o desvio acentual.

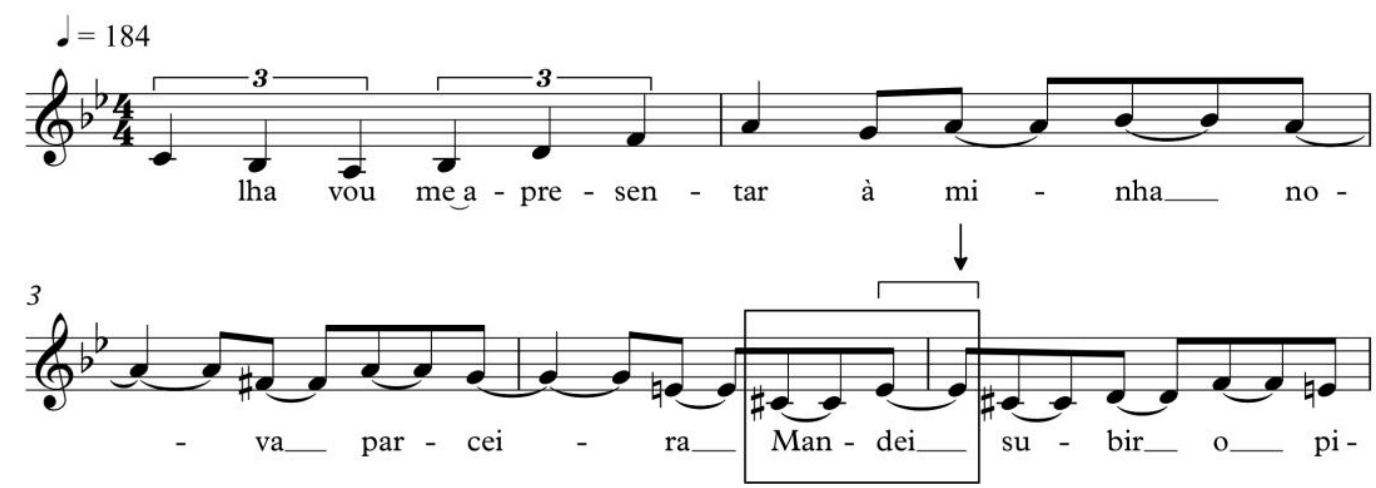

Figura 61. O fator intensidade em Piano na Mangueira na versão cantada por Tom Jobim

Tom Jobim, ao alterar a letra de Piano na Mangueira, seguindo o caráter melódico sincopado de toda a obra (e também uma característica do gênero no qual a canção está inserida), não posicionou a sílaba tônica do vocábulo "mandei” exatamente na parte forte do tempo do compasso, colocando-a numa síncopa para o primeiro tempo. É interessante notar que essa sutil alteração já foi suficiente para produzir uma oralização mais linear. Esse caso nos sugere a existência de uma possível força exercida pelos tempos fortes e meio-fortes do compasso sobre as sílabas colocadas em síncopas que os antecedem. Os dois exemplos a seguir podem contribuir para nossa investigação:

Dinheiro não lhe emprestei

Favores nunca lhe fiz

Não alimentei o seu gênio ruim

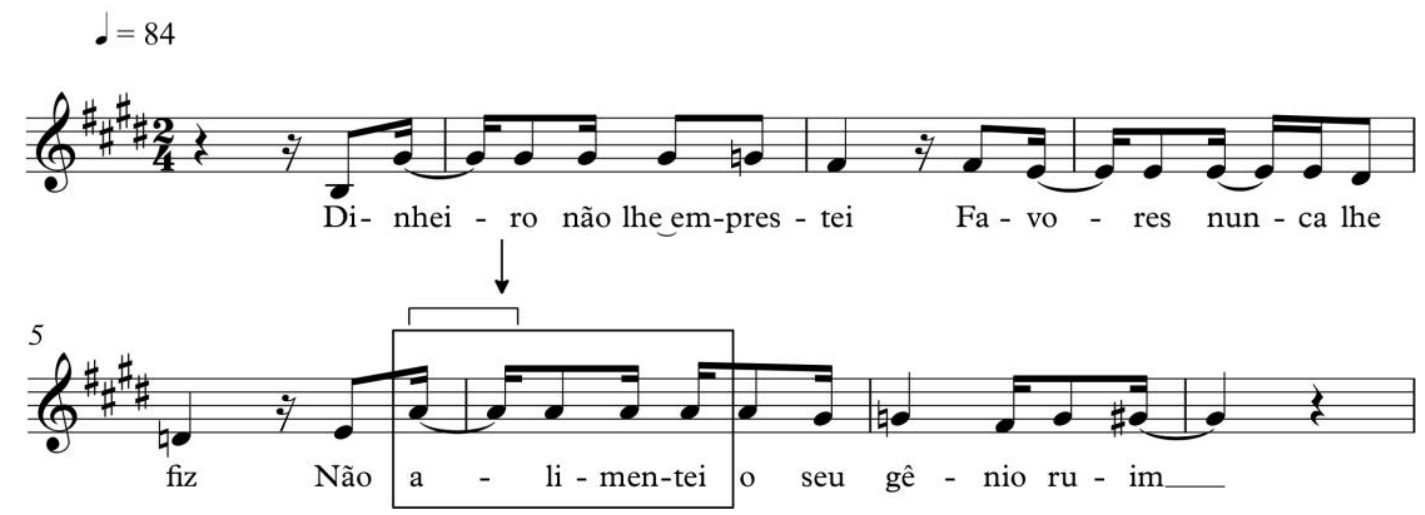

Figura 62. O fator intensidade em Injuriado (Chico Buarque) 
Meu amor, você me dá sorte

Meu amor, você me dá sorte

Meu amor, você me dá sorte de cara

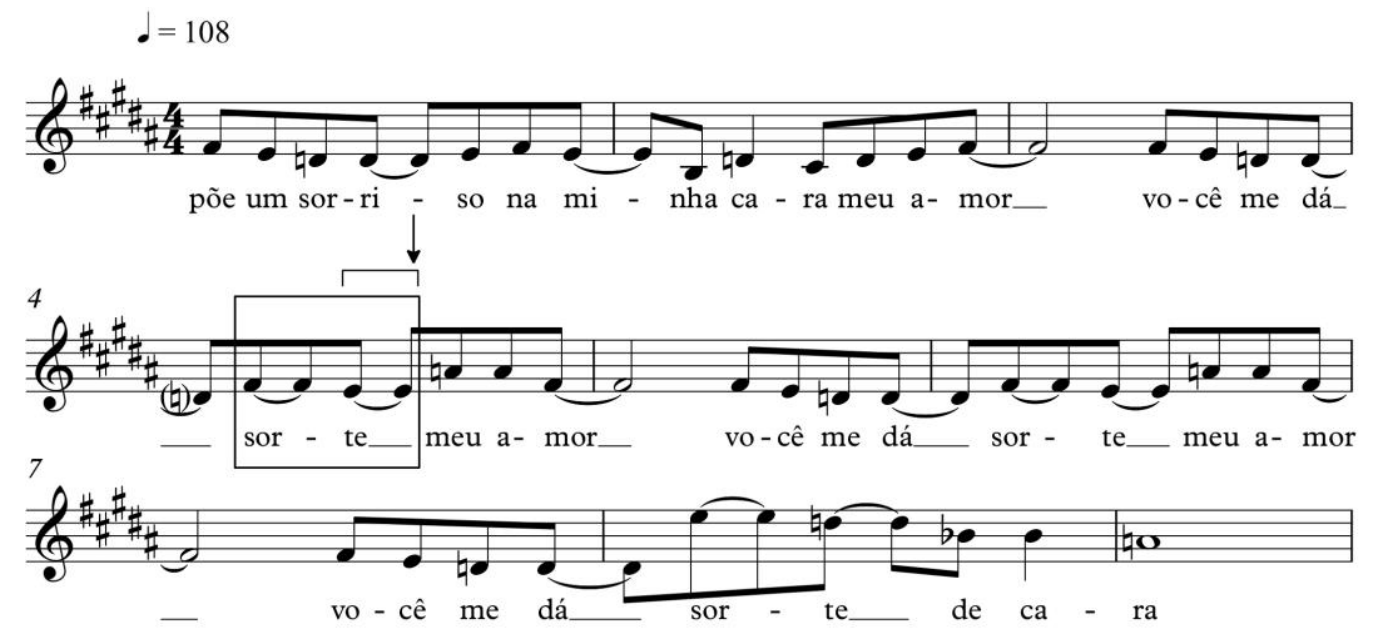

Figura 63. O fator intensidade em Sorte (Celso Fonseca/Ronaldo Bastos)

Nessas canções, as palavras "alimentei" e "sorte" possuem sílabas átonas enfatizadas por essa força exercida pelos tempos fortes do compasso. Em Injuriado, a primeira sílaba do vocábulo destacado está numa síncopa para o primeiro tempo do compasso 6, conforme nos mostra a figura acima. O desvio se dá de maneira muito sutil, dado que a sua sílaba tônica recai sobre a cabeça de um tempo meio-forte. Em Sorte, a síncopa que acompanha a sílaba átona dessa palavra antecede o terceiro tempo. Em ambos os exemplos, sílabas fracas são levemente realçadas uma vez que elas ocupam um espaço temporal que, na métrica do compasso, contém inflexões mais pronunciadas (o acento do primeiro e do terceiro tempo) $)^{99}$.

Por fim, é interessante sublinhar que a determinação das forças exercidas pelos tempos acentuados do compasso não se resume a um padrão rígido ao qual toda e qualquer melodia está sujeita. Afinal, uma mesma composição musical pode ser grafada de diversas maneiras. Por exemplo, podemos escrever o início da melodia de Sítio do PicaPau Amarelo em compasso quaternário ou binário, ou mesmo dobrando o valor das figuras de duração. Quando a grafamos em quatro tempos verificamos as seguintes configurações:

\footnotetext{
${ }^{99}$ Evidentemente, diversos fatores podem agir de maneira conjunta. Nesse sentido, podemos retomar um exemplo visto acima, a canção Wave de Tom Jobim (figura 25), quando investigávamos deslocamentos gerados apenas pelo parâmetro duração. Podemos, então, relativizar nossa análise, posto que a sílaba átona de "coisas" ocupa uma síncopa para o tempo meio-forte do compasso.
} 
Marmelada de banana

Bananada de goiaba

Goiabada de marmelo

Sítio do Pica-Pau amarelo

Sítio do Pica-Pau amarelo

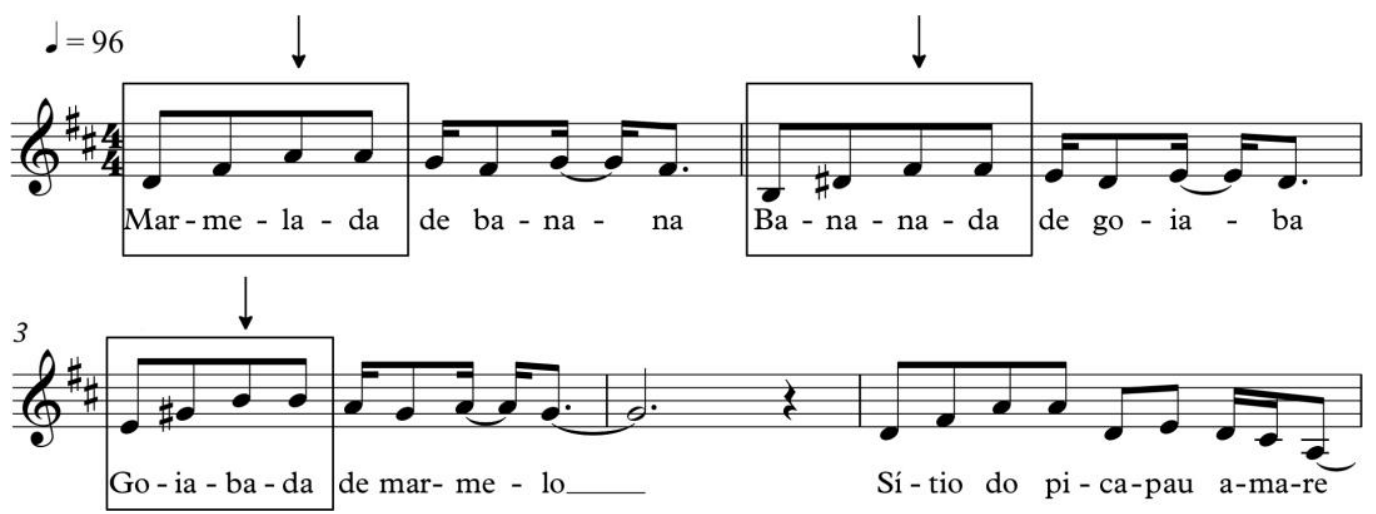

Figura 64. Sítio do Pica-Pau Amarelo (Gilberto Gil) em compasso quaternário

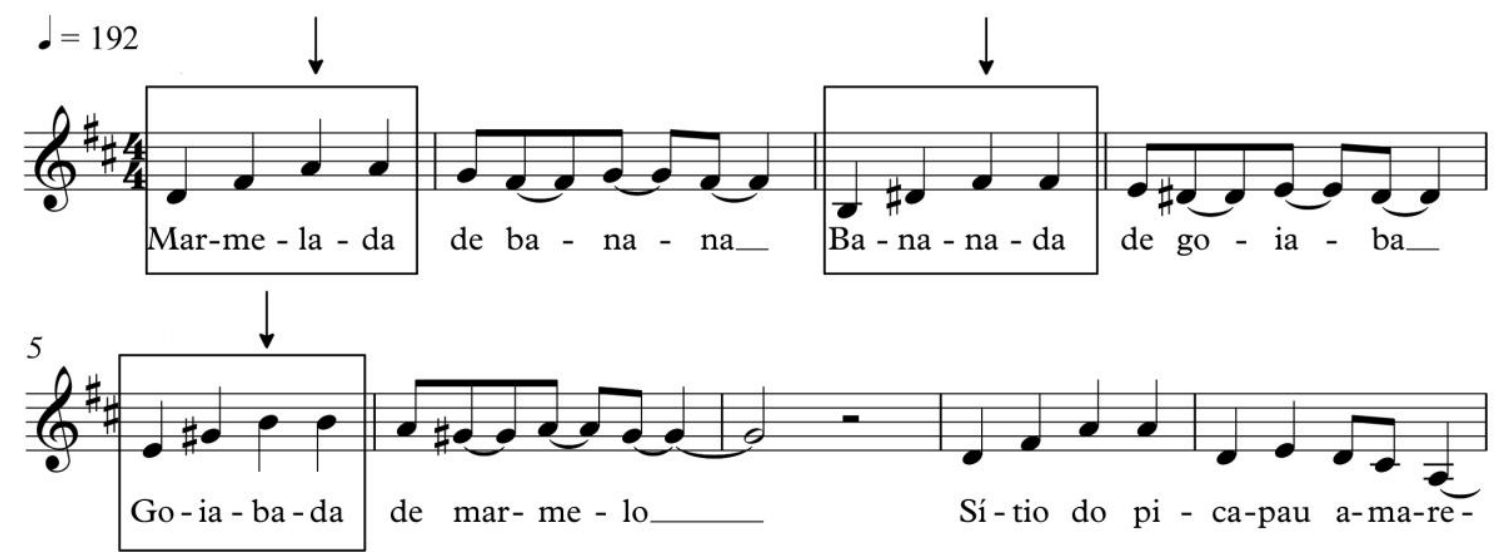

Figura 65. Sítio do Pica-Pau Amarelo em compasso quaternário com as figuras de duração dobradas

Nas duas maneiras de grafar em compasso quaternário (dobrando a velocidade da pulsação da primeira para a segunda), as sílabas tônicas dos vocábulos "marmelada", "bananada" e "goiabada" coincidem com partes fortes dos tempos. Na primeira figura, com a cabeça do segundo tempo e, na seguinte, com a cabeça do terceiro. Quando transcrevemos para compasso binário essa compatibilidade se mantém. 


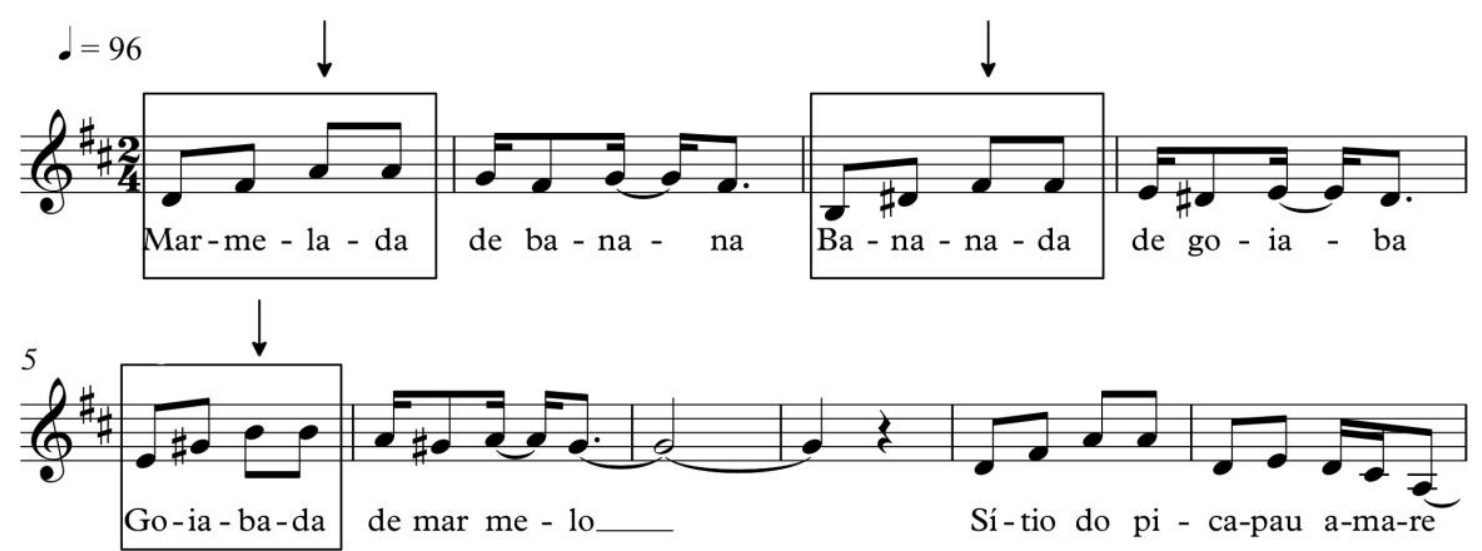

Figura 66. Sítio do Pica-Pau Amarelo em compasso binário

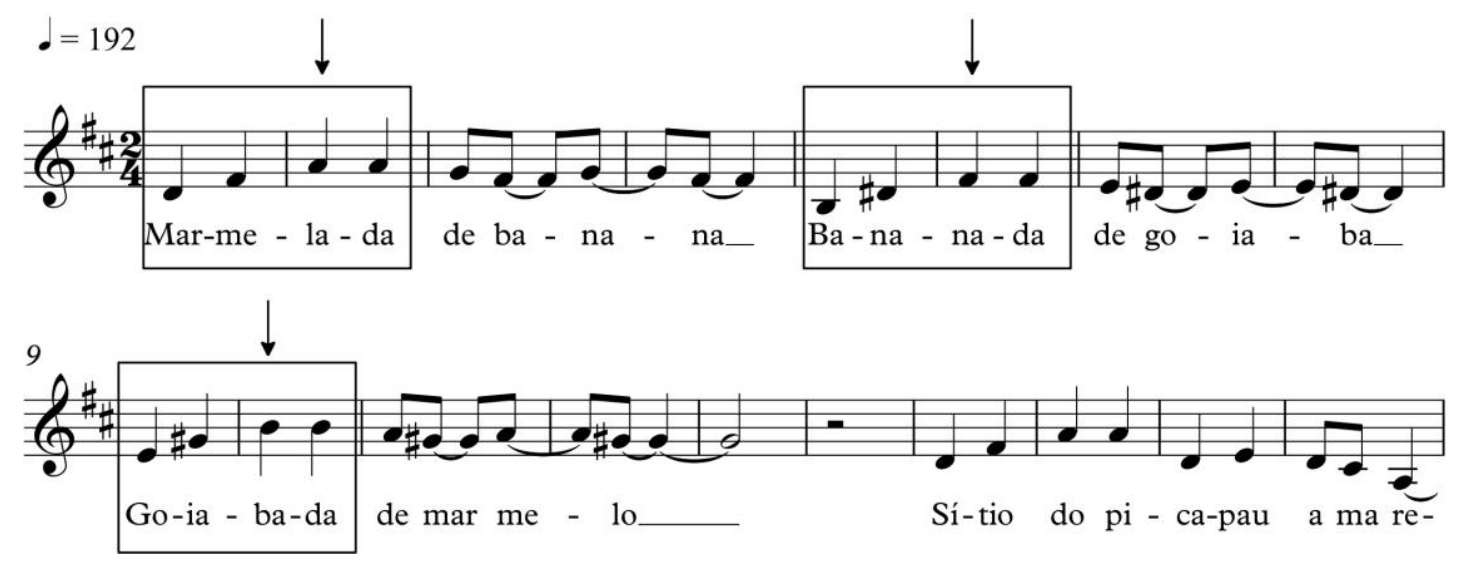

Figura 67. Sítio do Pica-Pau Amarelo em compasso binário com as figuras de duração dobradas

Como vemos acima, as sílabas tônicas coincidem, na primeira figura, com a parte forte do segundo tempo e, na seguinte, com o primeiro tempo do compasso. Naturalmente, essas diferentes configurações métricas podem suscitar propostas musicais variadas, visto que diversos elementos do arranjo instrumental, por exemplo, podem se guiar pela métrica do compasso. Não analisaremos essas diferentes musicalidades. Nosso intuito é somente observar como se acomodam os acentos melódicos e linguísticos. Ao experimentarmos diferentes maneiras de grafar essa mesma linha melódica, notamos que as sílabas tônicas sempre coincidem com tempos fortes, meio-fortes ou com partes fortes dos tempos. Parece-nos, então, que, independentemente da fórmula de compasso adotada pelo editor da partitura, o que realmente importa é percebermos que há uma alternância entre pontos fortes e pontos fracos. O fato de a sílaba tônica de um vocábulo poder encontrar a parte forte de um tempo ou, em outro tipo de grafia, coincidir com a parte meio-forte de uma subdivisão do pulso em quatro semicolcheias, por exemplo, não parece tão relevante para nossa investigação sobre o deslocamento silábico. 


\subsection{O abrandamento dos desvios acentuais}

Vimos, até aqui, diferentes tipos de oralização (mais esperados ou menos esperados) com diversos casos de deslocamento silábico, gerados por diferentes parâmetros musicais. Chama-nos a atenção, no entanto, o fato de alguns desses exemplos não serem percebidos pelos ouvintes (ou não lhes causarem maiores incômodos), como se os seus desvios acentuais fossem de alguma maneira abrandados. Interessa-nos, então, analisar as diferentes formas de atenuação dessas transgressões prosódicas, tentando encontrar os seus possíveis fatores. Acreditamos que um deles pode ser vislumbrado nas figuras abaixo. Vejamos.

Um dia ele chegou tão diferente

Do seu jeito de sempre chegar

Olhou-a de um jeito muito mais quente

Do que sempre costumava olhar
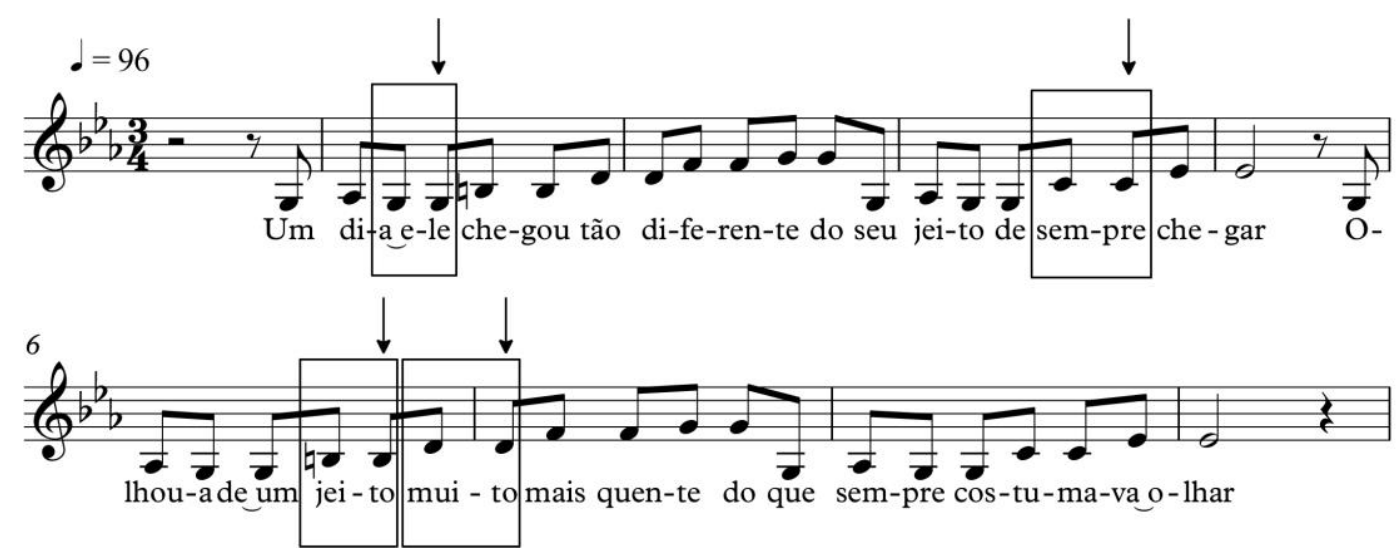

Figura 68. O abrandamento do deslocamento silábico em Valsinha (Vinicius de Moraes/Chico Buarque)

Este luar cá da cidade tão escuro

Não tem aquela saudade do luar lá do sertão

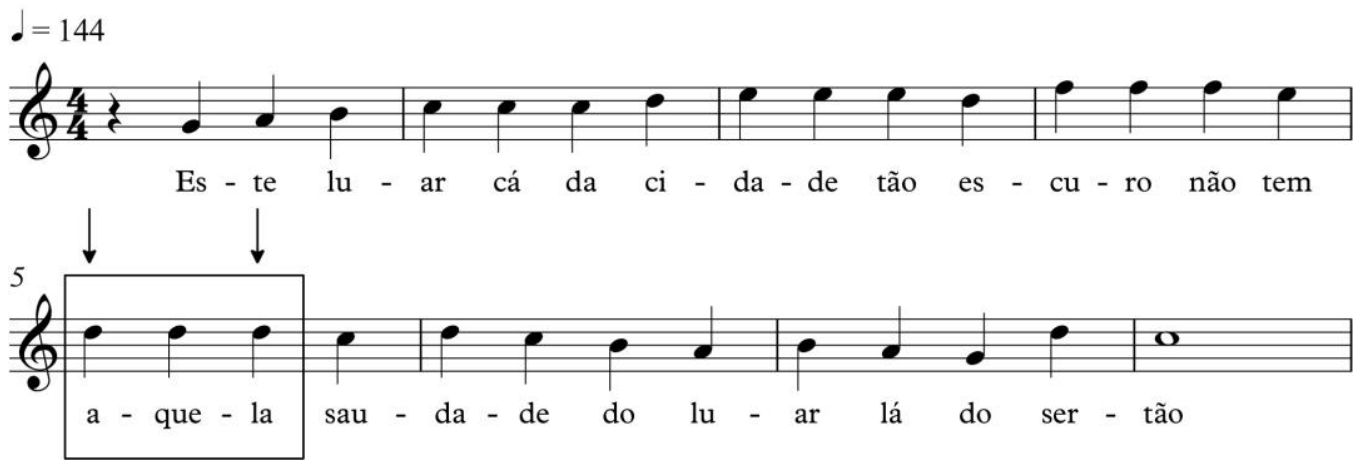

Figura 69. O abrandamento do deslocamento silábico em Luar do Sertão (João Pernambuco/Catulo da Paixão Cearense) 
Ô, marinheiro, marinheiro

Ô, quem te ensinou a nadar

Ou foi o tombo do navio

Ou foi o balanço do mar

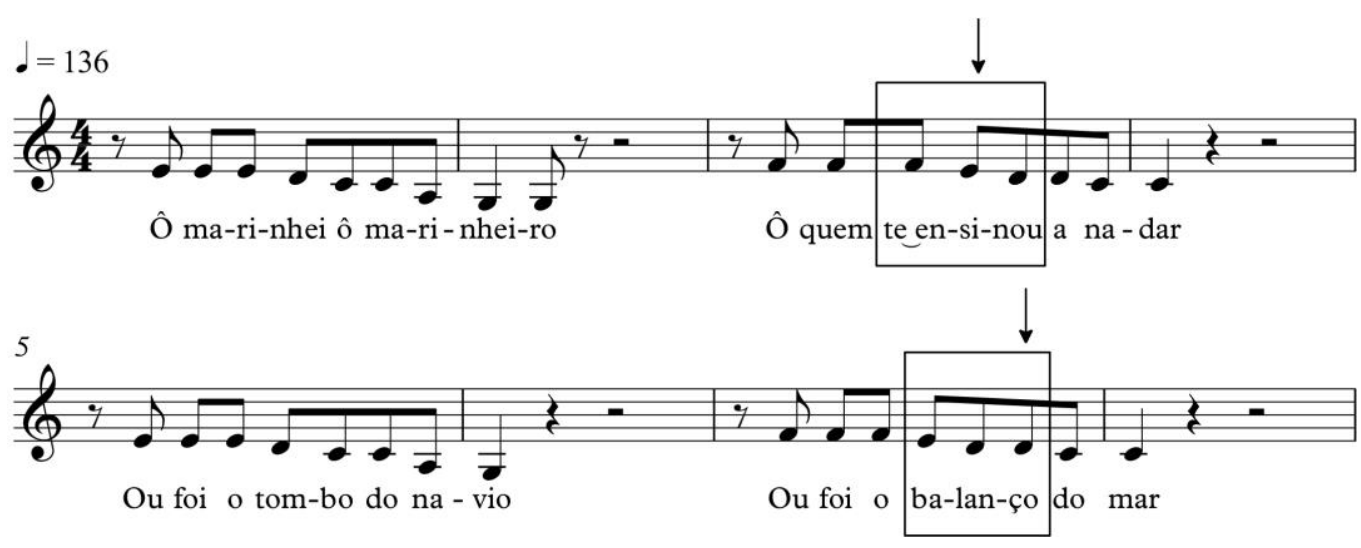

Figura 70. O abrandamento do deslocamento silábico em Marinheiro só (anônimo)

Nos três fragmentos acima, destacamos deslocamentos acentuais gerados pelo fator intensidade. As sílabas átonas dos vocábulos assinalados coincidem com partes fortes dos tempos do compasso. Entretanto, diferentemente de outros exemplos vistos no decorrer deste capítulo, cremos que esses desvios são menos percebidos pelos ouvintes. Esse fenômeno, supomos, deve-se ao fato de essas propostas prosódicas inesperadas estarem inseridas em frases melódicas contínuas, isto é, compostas por figuras de duração de mesmo valor. É como se em Valsinha e em Marinheiro Só, por exemplo, a emissão incomum dos vocábulos gerada pela acentuação melódica perdesse o seu efeito de estranhamento por se dar no meio de uma sequência de notas regulares, como um contínuo de colcheias que ao nivelar o aspecto durativo, atenua possíveis arestas. De modo similar, em Luar do Sertão, a sucessão regular de vinte e sete semínimas parece suavizar o desvio que encontramos no meio da frase, sobre a palavra "aquela".

Retomando um exemplo já apresentado anteriormente, o coco Olê Lioné (anônimo) analisado por Mário de Andrade, verificamos a ocorrência de algo equivalente. $\mathrm{Na}$ figura abaixo, supomos que o fato de o vocábulo "morena" estar inserido no interior de uma frase mais ampla cujas sílabas são emitidas com notas de igual valor de duração contribui para que a pronúncia do vocábulo não seja percebida de modo tão antinatural. Se essa mesma palavra fosse cantada de modo isolado, possivelmente o estranhamento entoativo gerado nos ouvintes se intensificaria. Assim, acreditamos que esse 
deslocamento de acento se torna menos perceptível quando o escutamos dentro desse contínuo de semicolcheias:

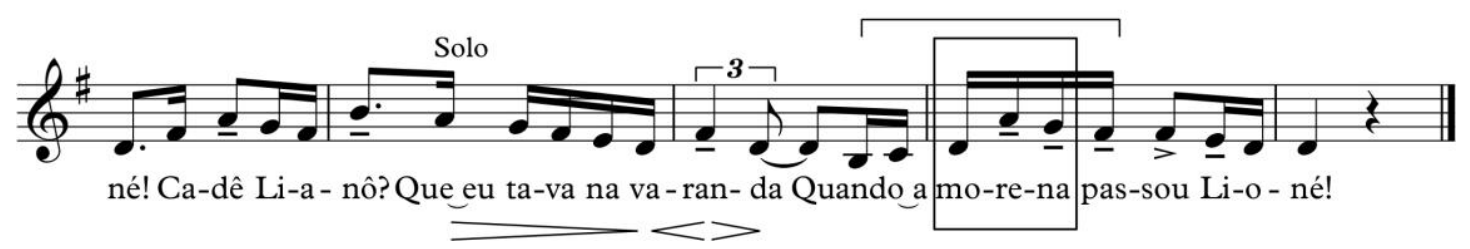

Figura 71. Fluxo de notas com duração equivalente amenizando o desvio da acentuação silábica

O fluxo regular de semicolcheias proposto pela frase musical acima possivelmente se assemelha a maneiras de emissão que escutamos cotidianamente na língua oral. É quando, em um conjunto de palavras emitidas pelo falante, os acentos de algumas delas são amenizados em favor do realce de vocábulos que são mais determinantes para o sentido da sentença (nesse caso, o termo "passou") ${ }^{100}$. Analisaremos esse aspecto no capítulo seguinte, dedicado ao nível da palavra. Outro autor que tangencia a mesma questão é Thiago Pinheiro no texto "Quem canta deveria ser como quem reza", já citado anteriormente. Ao estudar o fraseado do canto de João Gilberto, tece um interessante comentário a respeito do deslocamento silábico presente em uma das frases da canção Desafinado, sem, contudo, destacar a ideia do contínuo de notas de igual duração.

\begin{abstract}
A respeito da relação entre letra e métrica, é necessário fazer uma reflexão antes de seguirmos em frente para formulações de outras questões. Conforme verificamos nas transcrições, por vezes é a parte "fraca" - e não a "acentuada"- das palavras que coincide com os pulsos fundamentais, sem ênfase, mas bem na "cabeça" do tempo, digamos assim. Por exemplo, no primeiro chorus da gravação de 1994 e 2000, a sílaba "nas" de "apenas", na frase "Eu possuo apenas o que Deus me deu", cai no primeiro tempo do compasso. No entanto, como não existe ênfase no canto, a coincidência não prejudica a prosódia (PINHEIRO, 2012: 421-422)
\end{abstract}

Quando o autor aponta a preservação da prosódia por meio da falta de uma "ênfase no canto", toca num ponto muito pertinente ligado às possibilidades do intérprete de rearranjar os parâmetros sonoros para tornar a frase mais ou menos entoativa. Sendo mais preciso, no entanto, e com auxílio da transcrição abaixo, também utilizada por Pinheiro ${ }^{101}$,

\footnotetext{
${ }^{100}$ Devemos notar que o fator altura cumpre igualmente um papel importante para o abrandamento do deslocamento acentual em Olê Lioné na medida que a sílaba tônica de "morena" recai sobre uma nota mais aguda da melodia (nota Lá natural), alcançada por meio de um salto intervalar.

${ }^{101}$ Acrescentamos a indicação metronômica do andamento que estava faltando na ilustração utilizada pelo autor.
} 
poderíamos dizer que há fatores ligados à duração e à altura que favorecem esse abrandamento do desvio acentual. Vejamos.

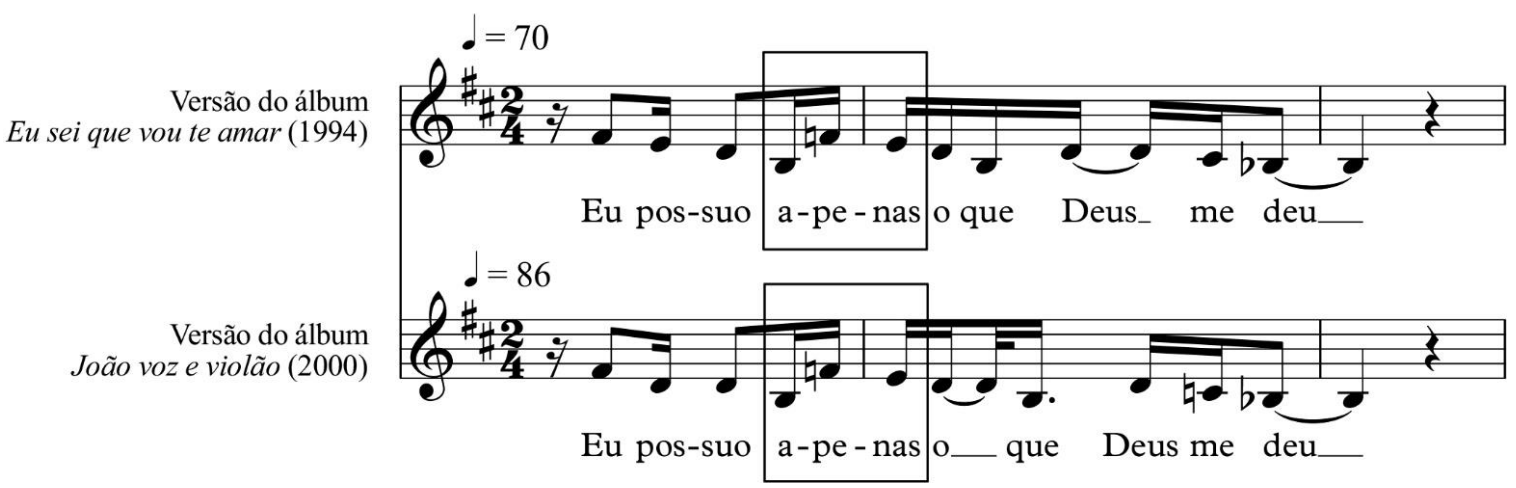

Figura 72. A acentuação silábica na canção Desafinado (Tom Jobim/Newton Mendonça)

A primeira nota do segundo compasso recobre justamente a sílaba átona "nas" da palavra "apenas". No entanto, observamos que aqui, mais uma vez, o vocábulo com acentuação deslocada está inserido em uma frase musical mais ampla, constituída por uma sequência de notas curtas de igual duração (no caso da versão de 1994) e de duração ligeiramente variável (na versão de 2000). Tendo em vista o aumento do andamento (de setenta para oitenta e seis batimentos por minuto), parece-nos que a variação observada na segunda versão não é tão relevante. Por outro lado, sob a perspectiva do trabalho com as alturas, o fato de a sílaba tônica da palavra "apenas" coincidir com a nota mais aguda da melodia (Fá natural), atingida por meio de um salto intervalar de quinta diminuta (da nota Si para a nota Fá), faz com que o desvio de acentuação provocado pelo fator intensidade seja significativamente abrandado. Assim, embora as diversas possibilidades de emissão por parte do cantor possam eliminar essa "ênfase no canto" (para que a acentuação do texto verbal se torne mais natural), há fatores composicionais ligados ao arranjo das durações e das alturas, anteriores à interpretação, que influenciam de maneira decisiva em casos como esse.

Outros fenômenos ligados à composição podem igualmente abrandar possíveis coincidências entre pontos fortes da melodia e sílabas átonas da letra. Há casos em que o desvio acentual é atenuado devido à elisão vocálica entre a sílaba átona indevidamente acentuada e a primeira sílaba da palavra seguinte. Vejamos os seguintes exemplos. 
Quando eu estou aqui

Eu vivo esse momento lindo

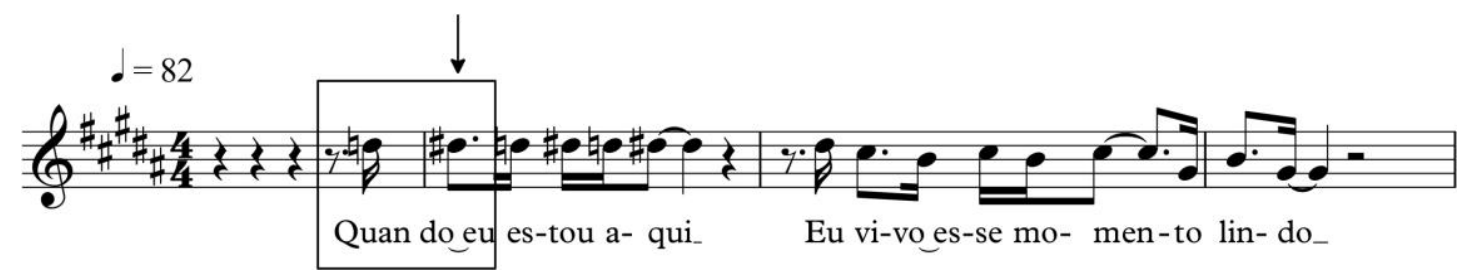

Figura 73. O abrandamento do deslocamento silábico em Emoções (Roberto Carlos/Erasmo Carlos)

Com seus mesmos tristes velhos fatos

Que num álbum de retrato

Eu teimo em colecionar

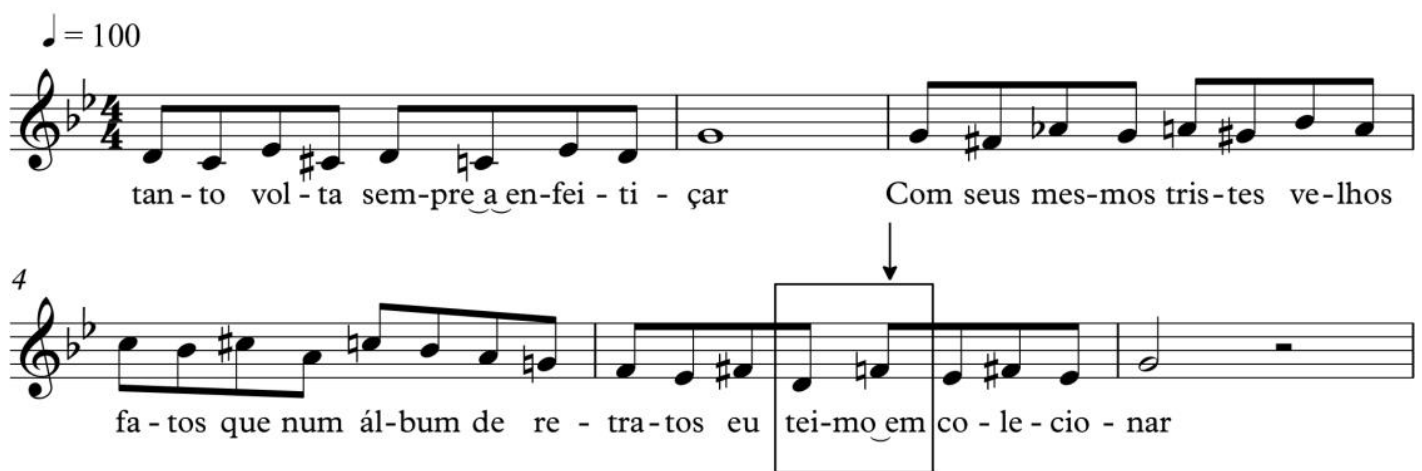

Figura 74. O abrandamento do deslocamento silábico em Retrato em Branco e Preto (Tom Jobim/Chico Buarque)

Ela pensa em casamento

E eu nunca mais fui à escola

Sem lenço e sem documento

Eu vou
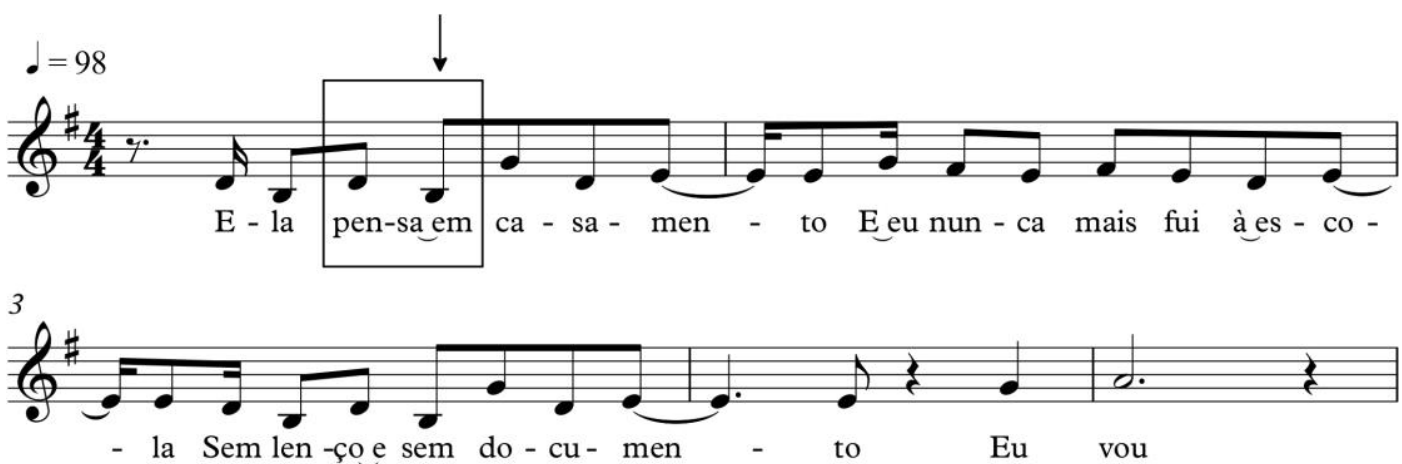

Figura 75. O abrandamento do deslocamento silábico em Alegria, alegria (Caetano Veloso)

Quando a luz dos olhos meus

E a luz dos olhos teus 
Resolvem se encontrar

Ai, que bom que isso é, meu Deus

Que frio que me dá

O encontro desse olhar

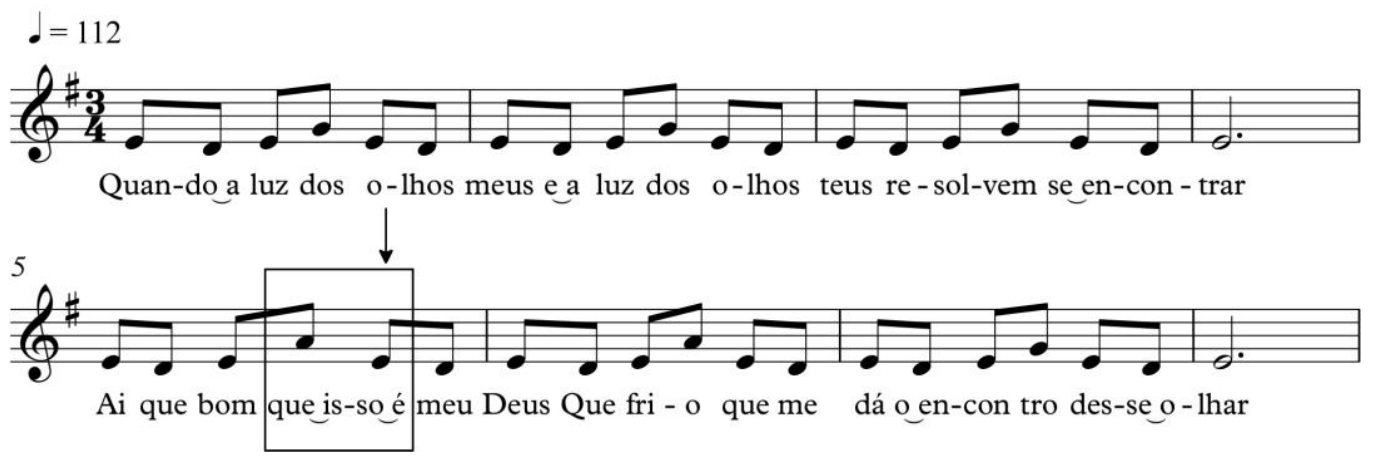

Figura 76. O abrandamento do deslocamento silábico em Pela luz dos olhos teus (Vinicius de Moraes)

Nas figuras acima, as palavras "quando", "teimo", "pensa" e "isso", todas paroxítonas, possuem suas sílabas átonas finais acentuadas. Entretanto, essas sílabas formam uma elisão vocálica com as palavras monossilábicas seguintes, respectivamente, “eu”, “em”, “em” e "é”. Parece-nos que essa junção, com a colocação dos monossílabos em pontos fortes do compasso, faz com que nossa atenção se volte a eles e, em consequência, colabora para que os desvios acentuais das palavras precedentes sejam menos perceptíveis. É como se o cancionista, de modo intuitivo, abrandasse o deslize prosódico mediante o destaque da palavra seguinte e a valorização da continuidade da frase. Naturalmente, o desvio pode nem chegar a ser percebido pelo compositor dado que a sua atenção está voltada para outras regiões de sentido. O deslocamento, no entanto, está lá. $\mathrm{Na}$ canção Emoções, por exemplo, se eliminássemos a palavra "eu”, o perceberíamos de maneira muito mais evidente. Nesse caso, o resultado do encaixe entre a letra e a melodia poderia incomodar o cancionista, mas ainda seria aceito pelo consenso linguístico internalizado pelos falantes. $\mathrm{Na}$ nossa experimentação entoativa abaixo, estamos, então, propondo uma oralização não-linear, um modo de dizer mais distante da fala.

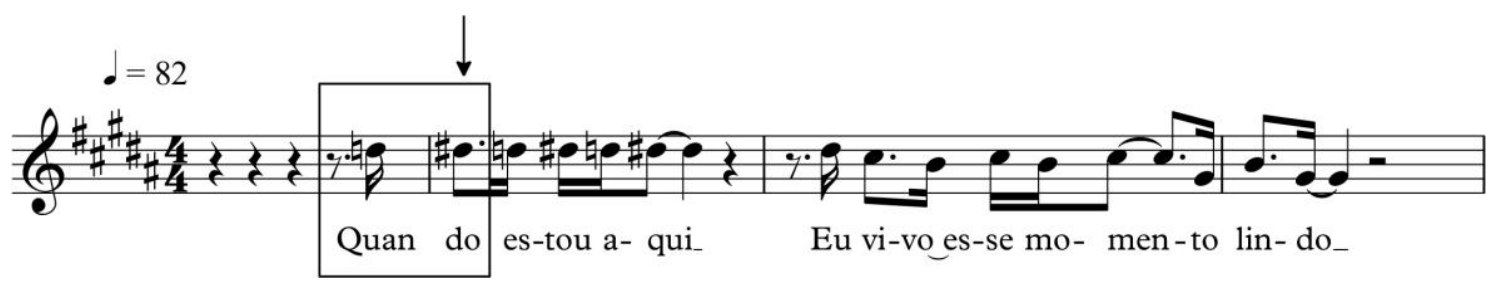

Figura 77. Reescrita da canção Emoções com a proposta de uma oralização não-linear 
Ao eliminarmos o vocábulo "eu", contudo, podemos facilmente alterar a posição da palavra "quando" com o intuito de evitar o seu desvio acentual. O resultado deste segundo teste entoativo é, portanto, um tipo de oralização mais linear.

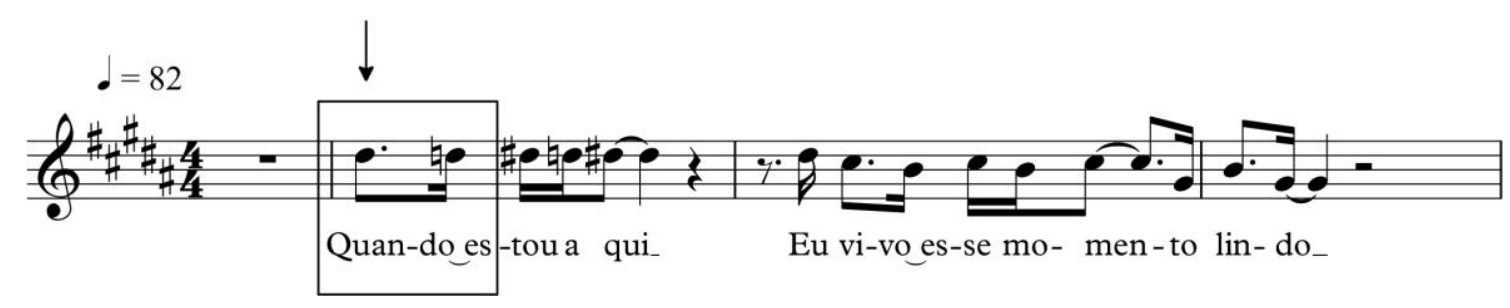

Figura 78. Reescrita da canção Emoções com a eliminação do deslocamento silábico

Essa nova compatibilização entre a letra e a melodia elimina o deslocamento silábico trazido pela versão original, ainda que nosso teste entoativo substitua a ênfase concedida ao vocábulo "eu" por uma valorização da palavra "quando". O sentido alterase de maneira muito sutil. Cabe ao compositor fazer a escolha entre a ênfase em determinados pontos da frase (os quais ele intuitivamente considera importantes) e possíveis desvios prosódicos. Se a solução original, não obstante o desvio, se apresenta entoativamente plausível, então, o cancionista pode optar pela valorização da palavra “eu”. É o caso dessa canção. Na repetição do mesmo trecho melódico, após uma parte instrumental, observamos uma nova proposta de letra que suprime o deslocamento silábico inicial. O relevo sobre a palavra “eu”, no entanto, permanece.

Mas eu estou aqui

Vivendo esse momento lindo"

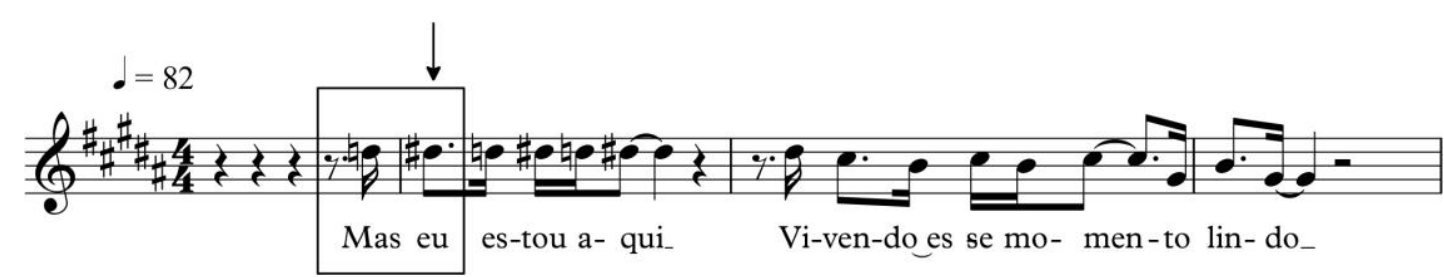

Figura 79. Repetição da melodia com uma nova letra na segunda parte de Emoções

É interessante observarmos o quanto a valorização melódica de determinadas palavras da frase linguística faz com que desvios em palavras menos relevantes sejam menos percebidos. Abordaremos esse mesmo assunto no capítulo seguinte, dedicado à palavra. Por ora, no entanto, desejamos somente sublinhar um caso muito similar que 
está, curiosamente, presente no mesmo exemplo. No trecho inicial de Emoções, a segunda unidade entoativa apresenta a seguinte configuração:

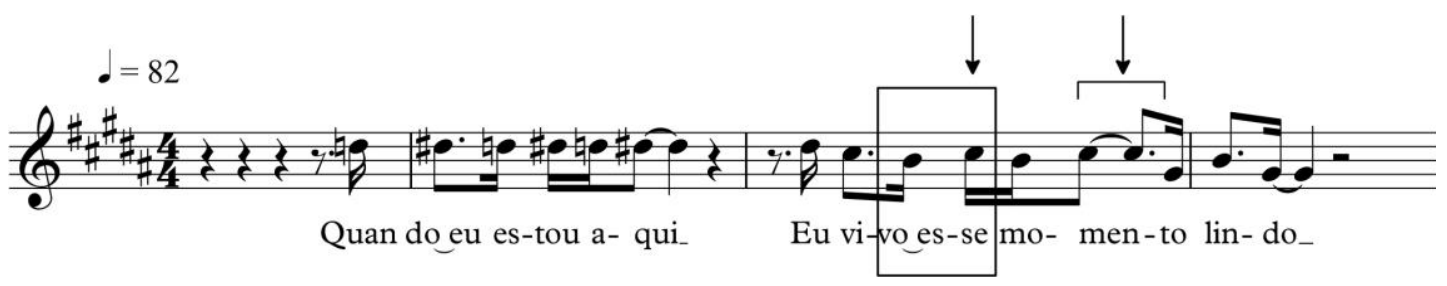

Figura 80. O deslocamento silábico na segunda unidade entoativa da canção Emoções

De modo muito semelhante, a palavra "esse" possui sua sílaba átona enfatizada pelo fator intensidade, por sua coincidência com a parte forte do segundo tempo do compasso. Todavia, ao escutarmos o trecho, dificilmente percebemos o deslocamento, visto que a frase melódico-linguística tende a valorizar a palavra "momento". Nesse sentido, a duração mais alongada de sua sílaba tônica, como assinalamos na figura acima, marca muito bem esse realce.

Durante a fruição de uma canção na qual encontramos deslocamentos silábicos, outras questões composicionais podem influir na percepção desses desvios por parte do público. Em seguida, selecionamos quatro exemplos nos quais as palavras que sofrem deslocamento são apresentadas anteriormente na letra com suas prosódias preservadas. Assim, é como se a primeira aparição da palavra, cantada de modo usual, atenuasse a sua reaparição com desvio, assegurando uma maior plausibilidade entoativa.

Podem me prender, podem me bater

Podem até deixar-me sem comer

Que eu não mudo de opinião.

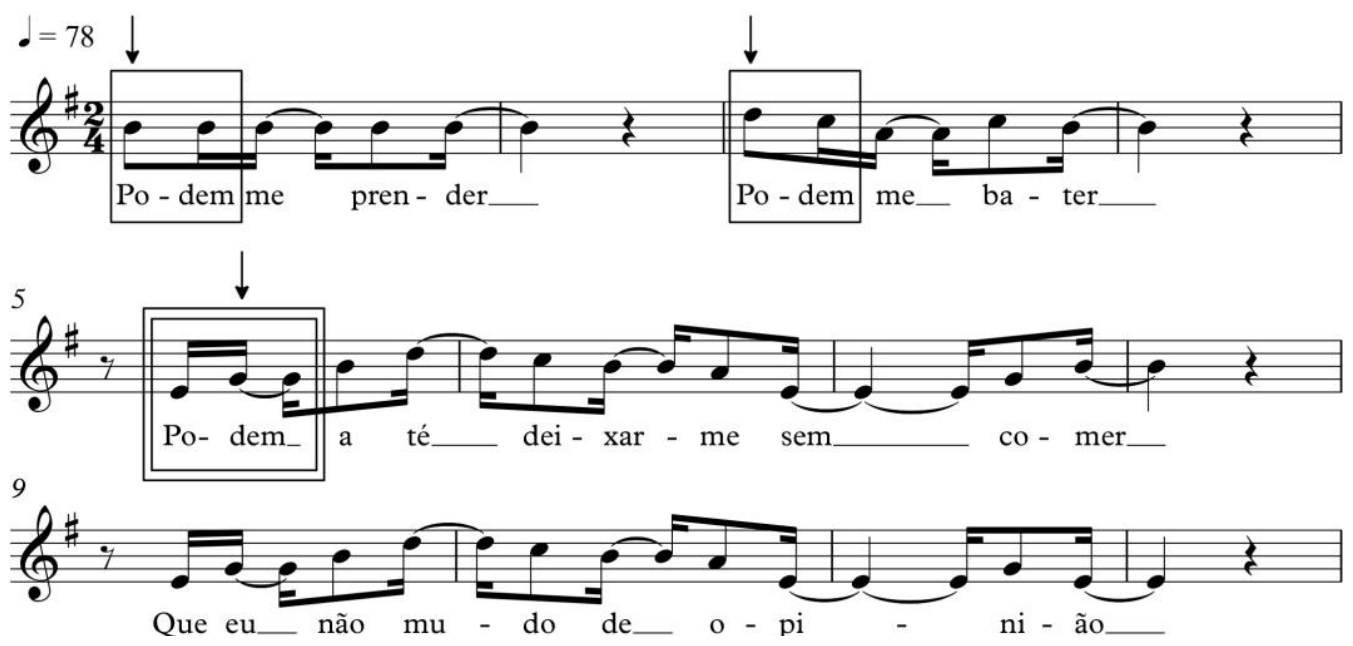

Figura 81. O abrandamento do deslocamento silábico em Opinião (Zé Kéti) 
O que será, que será?

Que andam suspirando pelas alcovas

Que andam sussurrando em versos e trovas

Que andam combinando no breu das tocas

Que anda nas cabeças, anda nas bocas

Que andam acendendo velas nos becos
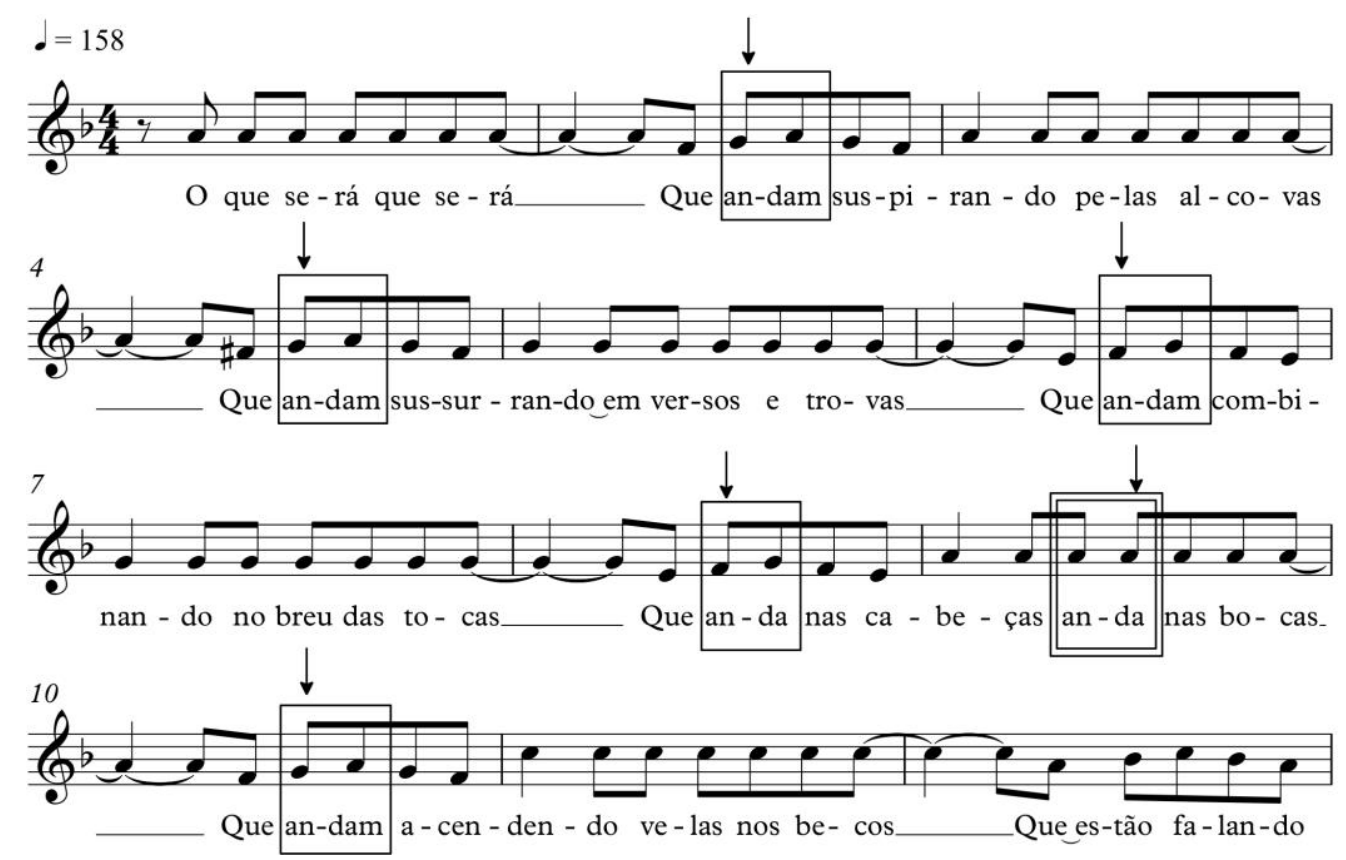

Figura 82. O abrandamento do deslocamento silábico em O Que Será (Chico Buarque)

Vinha nego humilhado

Vinha morto-vivo

Vinha flagelado

De tudo que é lado

Vinha um bom motivo pra te esfolar

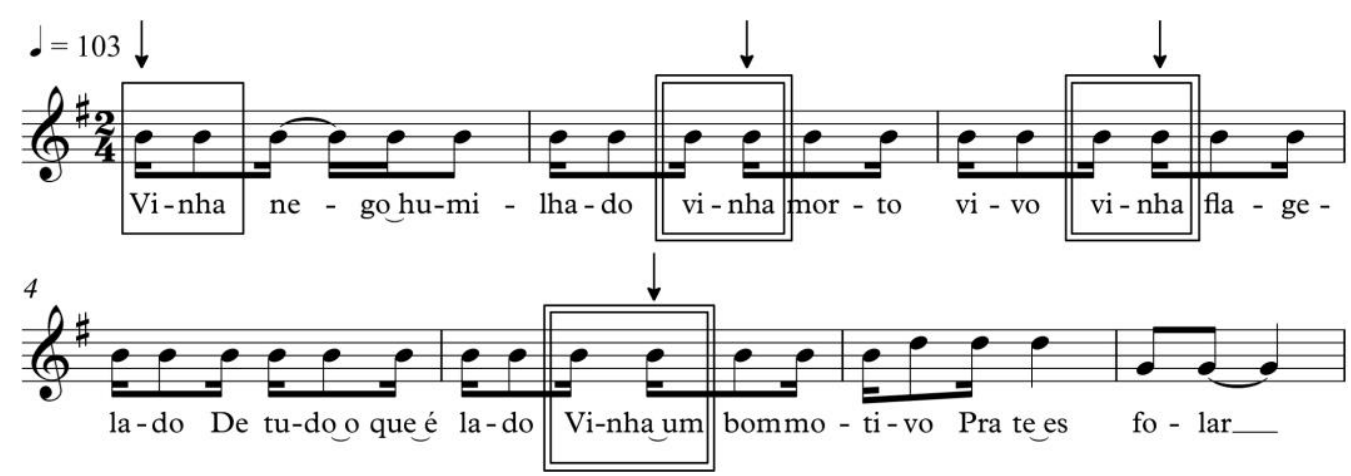

Figura 83. O abrandamento do deslocamento silábico em Não sonho mais (Chico Buarque)

O meu amor

Tem um jeito manso que é só seu 
E que me deixa louca

Quando me beija a boca

A minha pele toda fica arrepiada

E me beija com calma e fundo até minh'alma

Se sentir beijada

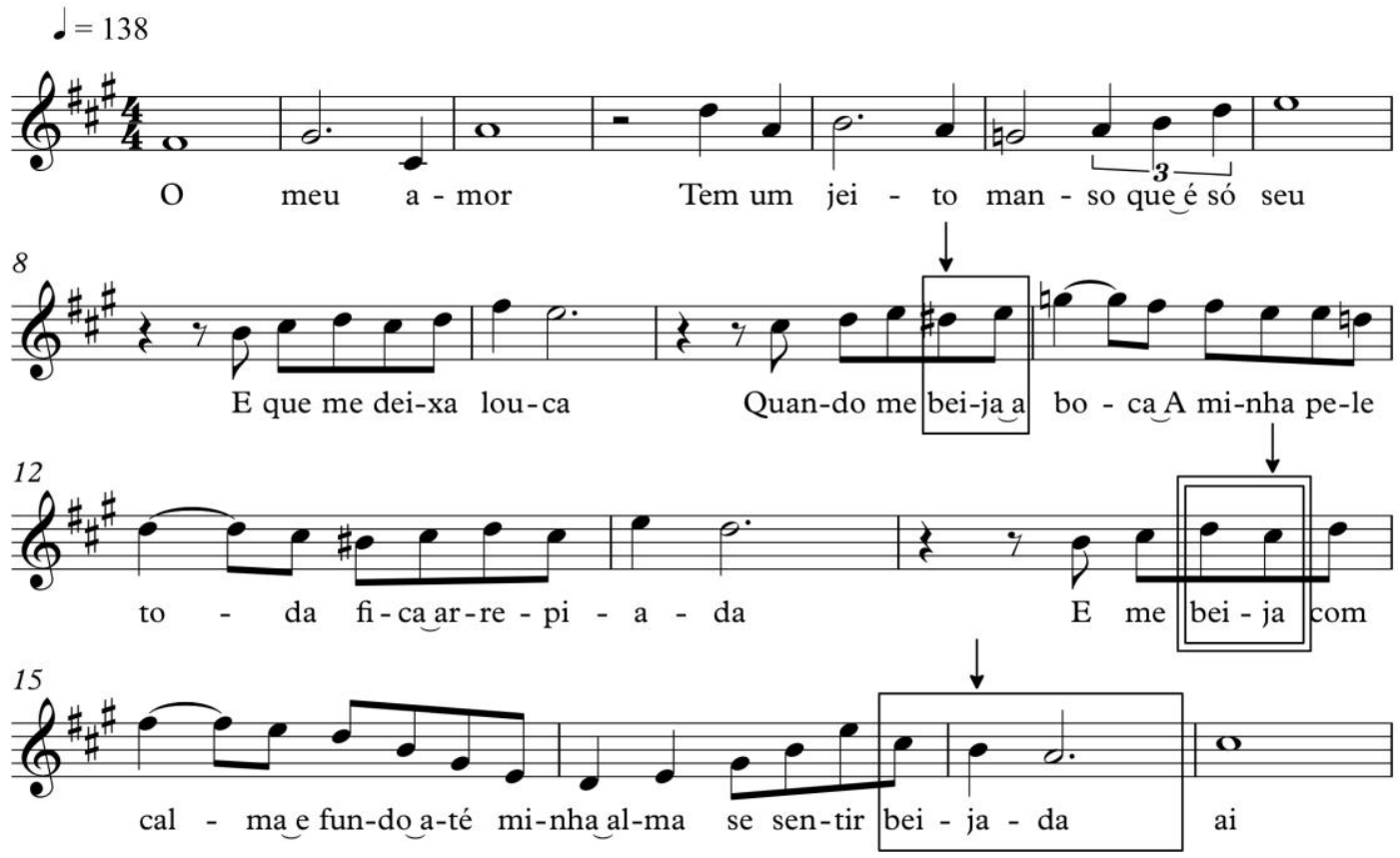

Figura 84. O abrandamento do deslocamento silábico em O Меи Amor (Chico Buarque)

Nas canções Opinião, O Que Será e $O$ Meu Amor, as palavras que sofrem deslocamento silábico ("podem", "andam/anda" e "beija") são previamente cantadas de maneira natural. Em $O$ Que Será, por exemplo, o verbo "andar" é quatro vezes entoado sem desvio acentual antes de o escutarmos com sua prosódia deslocada. Em todos esses fragmentos observamos o mesmo fenômeno: a anterioridade e a reiteração da palavra perfeitamente acentuada amenizam a percepção do desvio posterior. Há certa previsibilidade que assegura o seu entendimento. Em Não Sonho Mais, observamos que basta apenas uma ocorrência entoativamente intacta do vocábulo "vinha" para que os demais, todos com desvio, não causem estranhamentos significativos.

Nesse sentido, tendo em vista o peso da intuição linguística dos ouvintes e cancionistas, podemos considerar uma outra forma de abrandamento desses desvios acentuais. Trata-se de uma natural propensão de, sempre que ouvimos qualquer texto oral, nos guiarmos pela gramaticalidade da língua. Expliquemos. Inconscientemente, em nossa experiência com a língua falada e, por conseguinte, ao escutarmos uma canção, buscamos reconhecer as palavras e as estruturas linguísticas já internalizadas. Por isso, muitas vezes, 
certos deslocamentos acentuais tornam-se imperceptíveis ou, pelo menos, não chegam a prejudicar o entendimento dos vocábulos em que eles se encontram. É justamente isso o que garante a ampla elasticidade do consenso entoativo e a possibilidade de existência de oralizações não-lineares. Analisemos os seguintes exemplos:

Enquanto os homens exercem seus podres poderes

Morrer e matar de fome de raiva e de sede

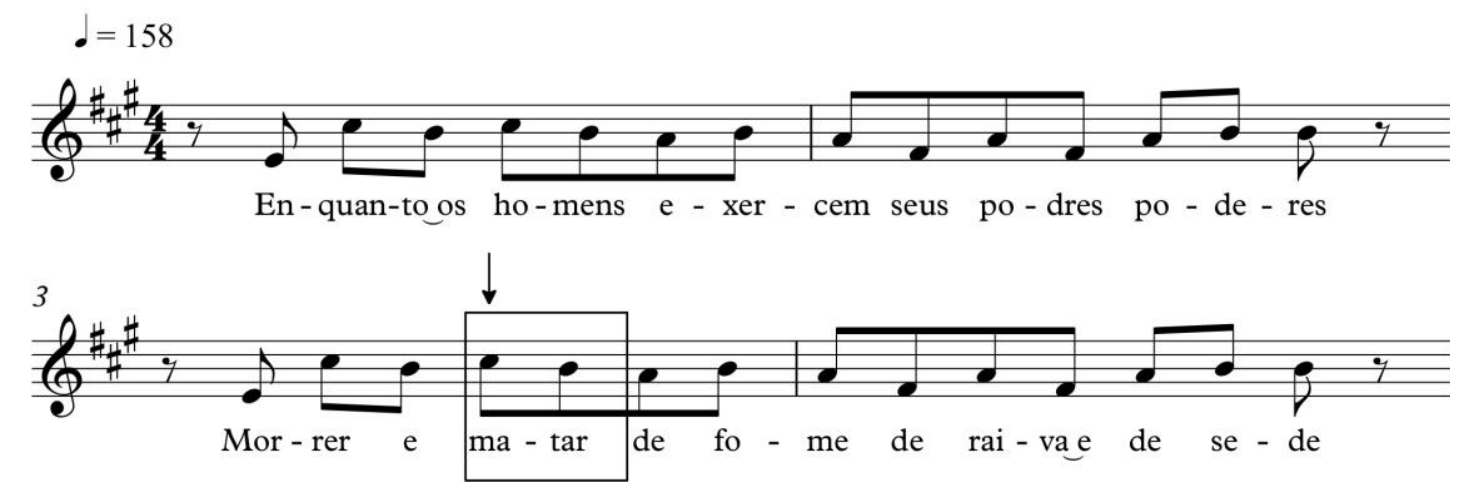

Figura 85. O abrandamento do deslocamento silábico em Podres poderes (Caetano Veloso)

No terceiro compasso de Podres Poderes, a palavra "matar" tem sua emissão natural prejudicada visto que sua sílaba átona coincide com a parte forte do terceiro tempo do compasso (tempo meio-forte) e com uma nota mais aguda em relação à sílaba seguinte. O vocábulo poderia se tornar incompreensível para o ouvinte ou, então, soar como o mesmo verbo conjugado no presente, na terceira pessoa do singular: "mata". No entanto, a força da expressão linguística "matar e morrer" (invertida aqui pelo compositor) facilita a apreensão do verbo no infinitivo e, de certa forma, oculta o seu deslocamento silábico. Em Roda Viva, encontramos algo similar.

A gente quer ter voz ativa

No nosso destino mandar

Mas eis que chega a roda-viva

E carrega o destino pra lá 

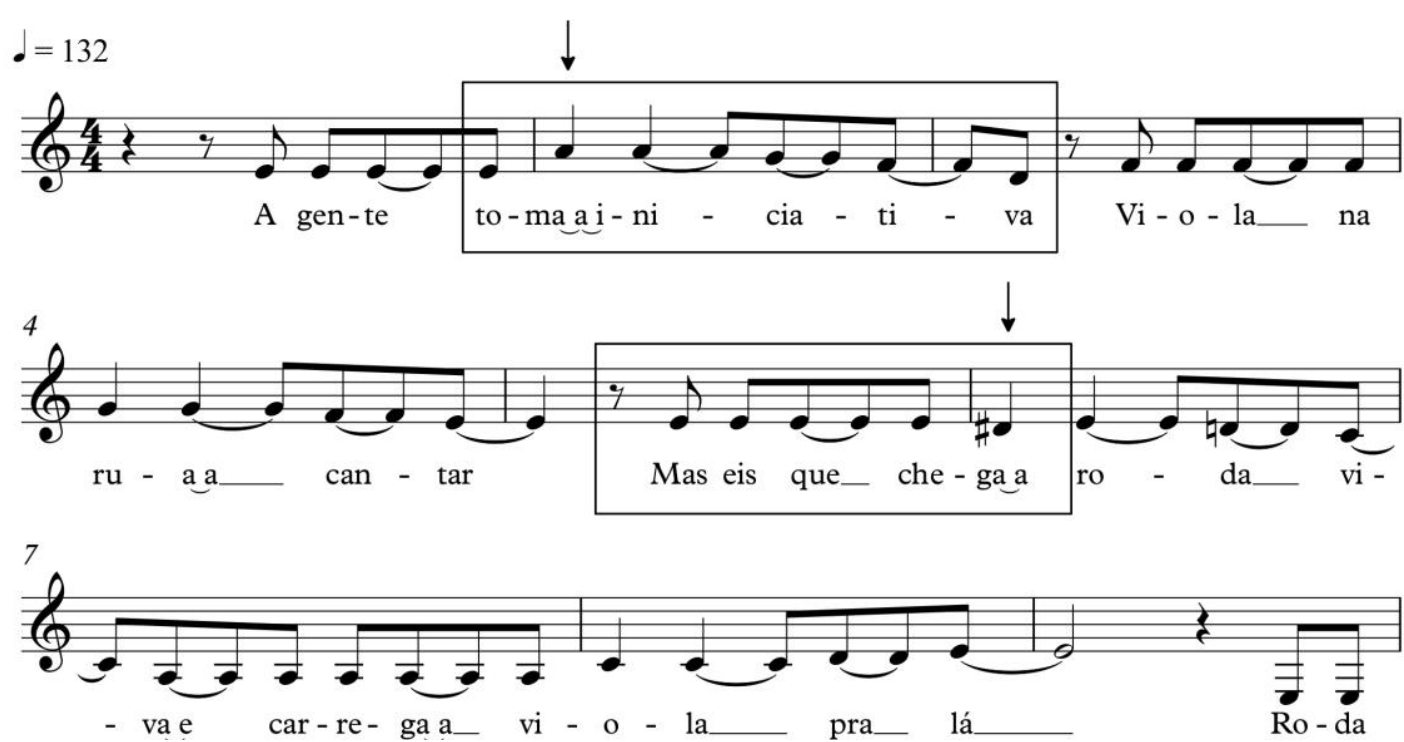

Figura 86. O abrandamento do deslocamento silábico em Roda Viva (Chico Buarque)

Semelhantemente, nessa canção, os vocábulos "toma" e "chega" são acentuados em suas sílabas finais, átonas, o que poderia sugerir a presença dos verbos no infinitivo ("tomar" e "chegar") ou mesmo impedir a sua exata compreensão. Porém, uma vez que eles estão inseridos em expressões linguísticas usuais (como a expressão "tomar a iniciativa"), o seu entendimento torna-se mais imediato. Por outro lado, a canção apresenta predominantemente os verbos no presente: "Tem dias que a gente se sente", "A gente quer ter voz ativa", “A gente vai contra a corrente” etc. Essa configuração temporal que perpassa toda a obra também contribui para que o ouvinte tenha pleno entendimento dessas partes de letra assinaladas acima. O mesmo notamos na canção Primeiros Erros.

Meu corpo viraria sol

Minha mente viraria ar

Mas só chove, chove

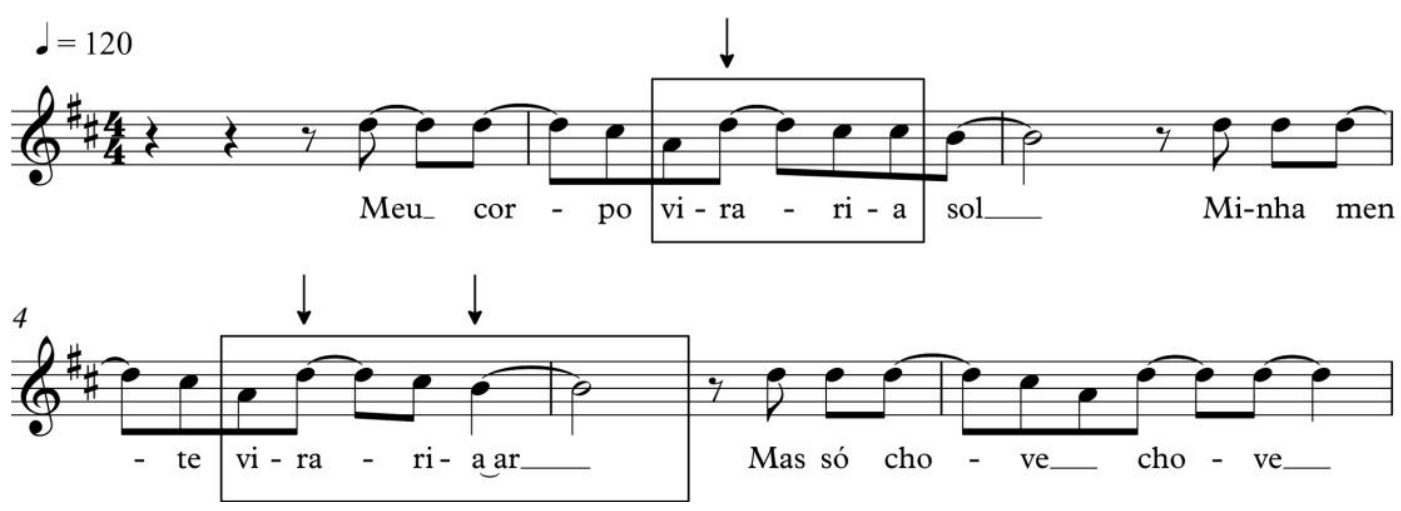

Figura 87. O abrandamento do deslocamento silábico em Primeiros erros (Kiko Zambianchi) 
Nesse caso, a palavra "viraria" (no modo condicional) possui a sílaba átona "ra" acentuada de modo inusual pelo fator altura e duração. Entretanto, não havendo outras possibilidades linguísticas para se apoiar, o ouvinte é naturalmente levado a entender o que o cancionista pretendeu exprimir. Afinal, o trecho destacado faz parte do contexto mais amplo de uma afirmação condicionada: "Se um dia eu pudesse ver meu passado inteiro (...), meu corpo viraria sol”. Assim, evidentemente, a letra como um todo, e não apenas seus trechos mais pontuais, são determinantes para a apreensão do sentido do texto verbal de cada obra. De modo curioso, no segundo verso ("minha mente viraria ar"), é difícil captarmos o vocábulo "ar". Tendo em vista a elisão vocálica com a sílaba precedente, essa palavra parece constituir um prolongamento do som da última sílaba de "viraria". Mais uma vez, o contexto geral da letra atua de forma determinante, agora, para desvirtuar a proposta original do compositor. $\mathrm{Na}$ estrofe anterior, observamos a presença dos seguintes versos: "Se o meu corpo virasse sol" e "Se a minha mente virasse sol". Pois bem, quando o ouvinte escuta a sequência da letra (a parte transcrita na figura acima), ele pode ser levado a um entendimento equivocado da mesma: a frase "minha mente viraria ar" lhe parece, então, "minha mente viraria (sol)", como se o sentido trazido pela estrofe anterior fosse reiterado ("se a mente virasse sol") e o vocábulo "sol" estivesse oculto (na medida em que "ar" soa como alongamento vocálico de "viraria").

Por fim, uma última forma de atenuação dos desvios prosódicos consiste na possibilidade de o intérprete readequar a entoação da letra, realizando pequenas acomodações rítmicas ou mesmo acentuando notas que a métrica do compasso não previa. O cantor, sem dúvida, possui a capacidade de "entoativizar" ou "desentoativizar" a canção por meio de diversos procedimentos. Ele adapta os encaixes entre a letra e a melodia para remodelar as oralizações, tornando-as entoativamente mais comuns ou incomuns. Nos atentaremos, aqui, às adaptações no nível da sílaba. Vejamos o seguinte exemplo.

\section{Petrolina, Juazeiro}

Juazeiro, Petrolina

Todas as duas eu acho uma coisa linda

Eu gosto de Juazeiro

E adoro Petrolina 


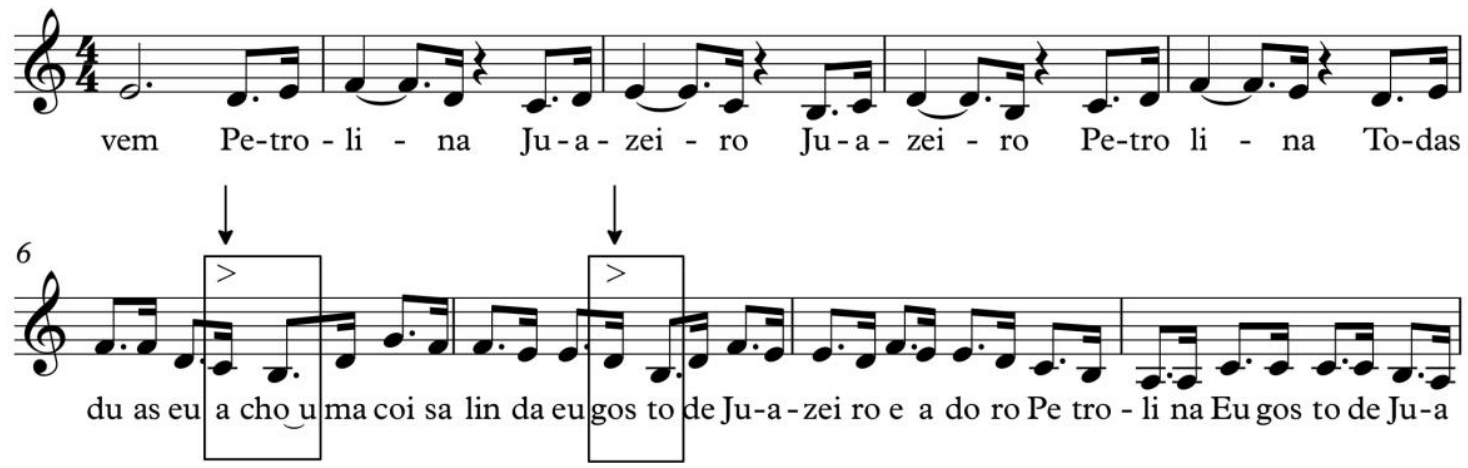

Figura 88. O abrandamento do deslocamento silábico em Petrolina, Juazeiro (Jorge de Altinho)

Nessa canção, o intérprete acentua as palavras assinaladas de forma natural, mesmo que as suas respectivas sílabas tônicas coincidam com tempos fracos do compasso: a prosódia natural dos vocábulos "acho" e "gosto" é valorizada pelo cantor por meio de um acento de intensidade nas suas sílabas tônicas. O mesmo ocorre com a canção Cajuína, de Caetano Veloso.

Existirmos: a que será que se destina?

Pois quando tu me deste a rosa pequenina

Vi que és um homem lindo e que se acaso a sina

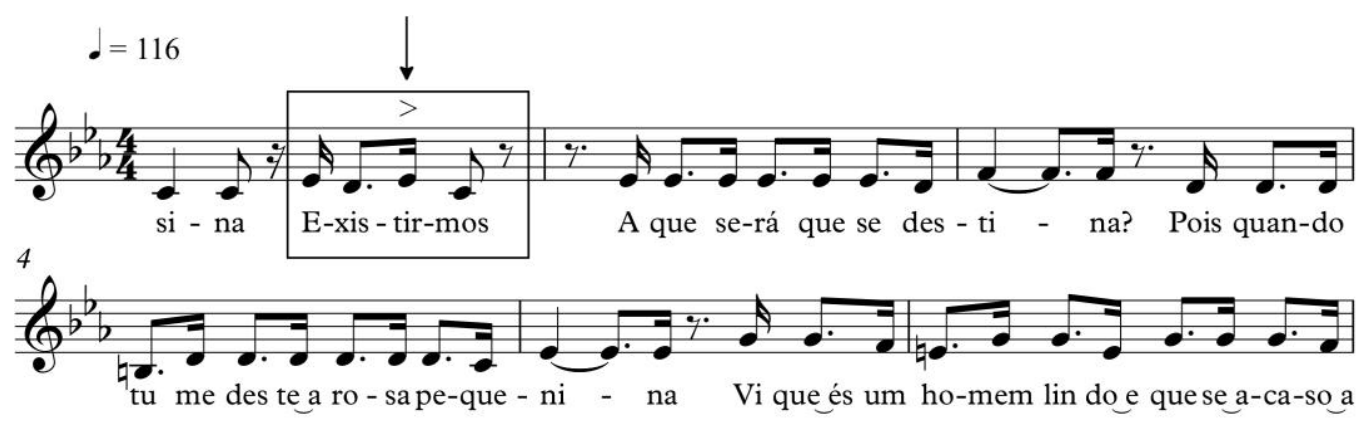

Figura 89. O abrandamento do deslocamento silábico em Cajuína (Caetano Veloso)

Similarmente ao que observamos na canção Petrolina, Juazeiro, a sílaba tônica da palavra destacada encontra-se numa parte fraca da métrica do compasso (a quarta semicolcheia do terceiro tempo, nesse caso). O intérprete, contudo, a acentua para garantir uma oralização mais linear do canto ${ }^{102}$. Podemos constatar esse mesmo fenômeno em

${ }^{102}$ É preciso notar que, em ambos os exemplos, a nota que coincide com a sílaba tônica, ainda que recaia em tempo fraco, é mais aguda do que a nota seguinte, o que favorece a possibilidade de readaptação prosódica. 
alterações do padrão melódico realizadas pelo cantor, em um jogo de forças entre a fala e a música. Em Funeral de um Lavrador, por exemplo, percebemos uma nítida diferença entre a emissão do cantor e a emissão do coro.

É uma cova grande

Pra teu pouco defunto

Mas estarás mais ancho que estavas no mundo

Estarás mais ancho que estavas no mundo

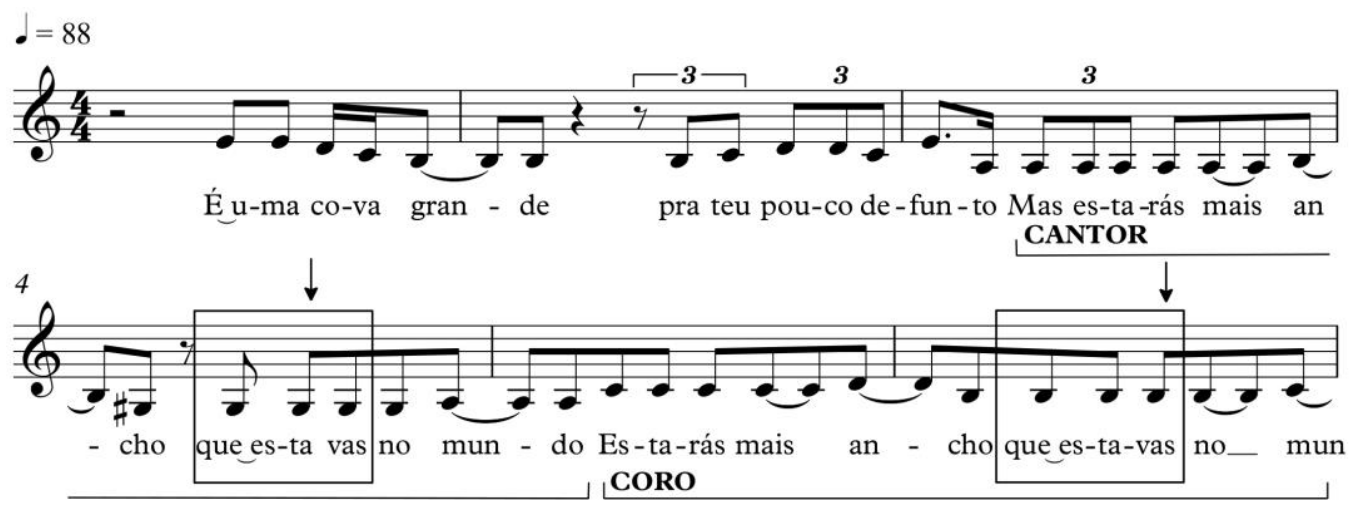

Figura 90. O abrandamento do deslocamento silábico em Funeral de um lavrador (Chico Buarque)

Ao longo dessa canção, o coro sempre repete o último verso da estrofe entoada pelo cantor. É notável a diferença entre as duas interpretações. O coro, mais propenso à tematização, é mais regular e não subverte o padrão rítmico da melodia, favorecendo, como vemos na figura acima, o desvio acentual na palavra "estavas". O cantor, ao contrário, ao propor um canto mais oral, altera o padrão melódico para acomodar as acentuações naturais da letra. Notamos, aqui, a significativa importância do intérprete, responsável, muitas vezes, por tornar a canção mais ou menos entoativa.

Antes de partirmos para o próximo item, acreditamos ser proveitoso para nossa análise da atenuação dos deslocamentos silábicos certos aspectos já tratados pelos linguistas ou gramáticos que se dedicaram ao estudo da fonética da língua portuguesa ${ }^{103}$. São questões que, a nosso ver, aprofundam a reflexão sobre o encaixe da melodia com a

\footnotetext{
${ }^{103}$ Ao longo da parte analítica de nossa tese, como forma de enriquecer o exame dos exemplos, também faremos uso de questões estudadas pela gramática normativa. Ainda que a linguística tenha abandonado a perspectiva proposta pelas gramáticas escolares, acreditamos que, ao operarmos com noções bem mais conhecidas que as veiculadas pela linguística moderna, poderemos tornar nosso trabalho mais acessível aos pesquisadores de outras áreas.
} 
letra no nível da sílaba. O primeiro ponto sobre o qual gostaríamos de nos debruçar é a oposição entre o chamado acento principal e o acento secundário. Geralmente, as palavras de menores dimensões possuem uma única sílaba tônica na qual se apoiam as demais sílabas átonas. É o caso dos vocábulos "canção", "música”, "acorde” etc. Certas palavras, no entanto, sobretudo as derivadas, contêm, além da sílaba tônica, uma ou mais sílabas que são pronunciadas de modo mais forte do que as outras sílabas átonas. São as chamadas "subtônicas" (CUNHA, 2017: 71). Assim, consideramos como principal o acento que coincide com a sílaba tônica e secundário aquele que recai sobre a subtônica.

$\mathrm{O}$ advérbio descabeladamente, por exemplo, constituindo uma paroxítona, apresenta o seu acento principal na penúltima sílaba ("men”). Entretanto, os demais segmentos que formam o vocábulo não são todos equitativamente átonos. A sílaba "la", sem dúvida menos intensa do que a sílaba tônica "men", é, contudo, mais forte do que as demais. Isso deve-se ao fato de esse vocábulo ser derivado do adjetivo descabelado, no qual a mesma sílaba ("la") é acentuada. Temos, portanto, em descabeladamente, o acento principal em "men" e o acento secundário em "la". Analisemos a ocorrência desse mesmo vocábulo em Uma Canção Inédita, de Edu Lobo e Chico Buarque.

Se outro amor surgir um dia

A valsa perde o ar

Definha

Mas se você descabeladamente me esperar

Sozinha no breu

$\cdot=132$

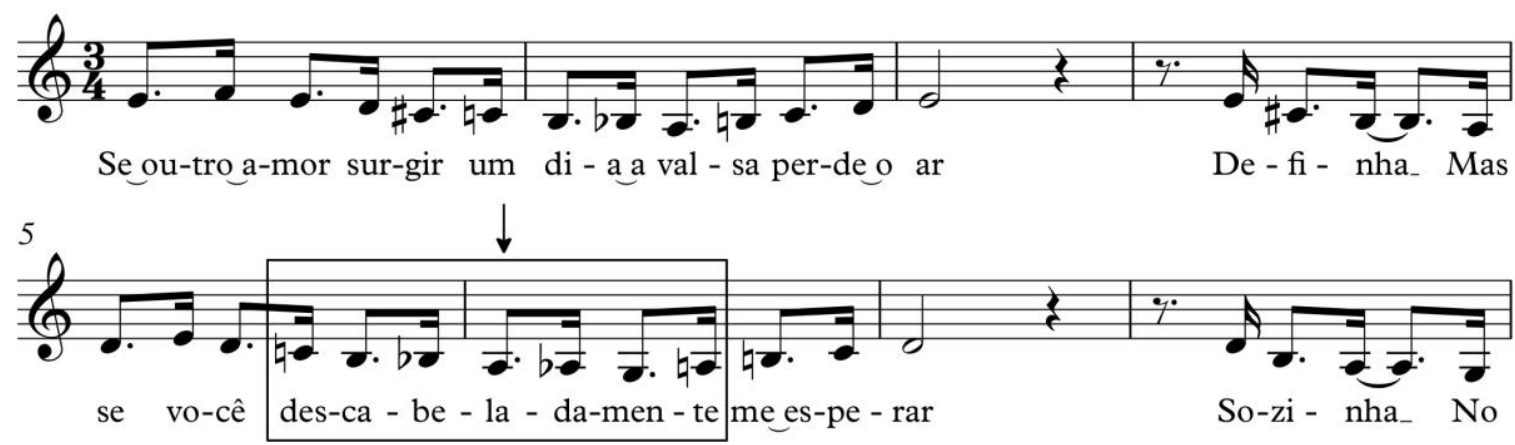

Figura 91. Acento principal e acento secundário em Uma Canção Inédita (Edu Lobo/Chico Buarque)

Consideramos o fragmento acima um bom exemplo de um abrandamento do deslocamento silábico resultante desse fenômeno linguístico dos acentos principais e secundários em palavras derivadas. Aqui, a sílaba subtônica de "descabeladamente" recai 
sobre o acento métrico mais forte do compasso (primeiro tempo) e a sílaba tônica sobre a parte forte de um tempo fraco (segundo tempo). Assim, um caso que poderia representar um possível desvio prosódico não chega a incomodar o ouvinte, uma vez que a sílaba não tônica acentuada pela melodia é justamente a sílaba tônica da palavra primitiva "descabelado".

Outro conceito interessante para nossa reflexão acerca do desvio silábico é a noção de grupo acentual ou grupo de intensidade (CUNHA, 2017: 72). Vejamos. No fluxo da língua falada, em geral, os vocábulos se conectam sonoramente formando segmentos maiores, as frases. Essa cadeia sonora, muitas vezes formada por várias palavras, passa a apresentar um único acento tônico principal e, por conseguinte, a reduzir a importância dos acentos principais de outros vocábulos que a compõem. Constituem, então, um grupo acentual. Retomando o exemplo da canção Emoções, podemos analisá-lo sob uma nova perspectiva.

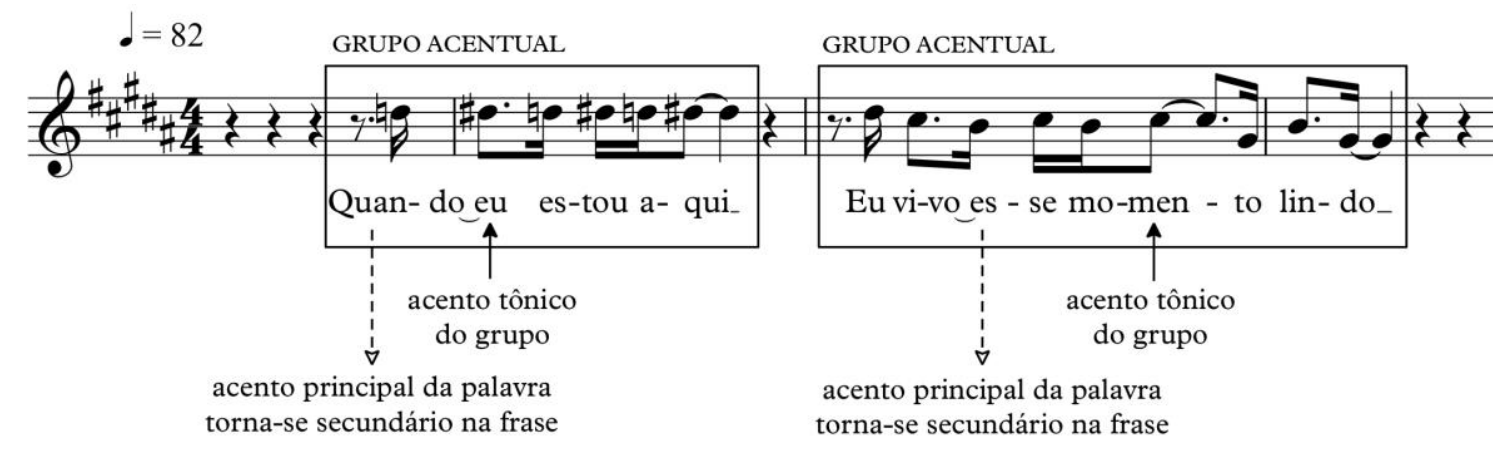

Figura 92. Grupos acentuais na canção Emoções

Observamos acima dois grupos acentuais, conjuntos que, aliás, coincidem com a noção de unidade entoativa proposta por Tatit. São eles "quando eu estou aqui" e "eu vivo esse momento lindo". Analisemos o primeiro. Composto por quatro vocábulos, ele pode ser realizado sonoramente na fala com uma ênfase no pronome pessoal da primeira pessoa “eu”. É o que propõe a melodia dessa canção, visto que a palavra coincide com o tempo mais forte do compasso. Assim, o pronome monossilábico torna-se o ponto de destaque do seu grupo acentual e, em consequência, enfraquece as sílabas tônicas dos demais vocábulos. A desvitalização da sílaba tônica de "quando", causada pela direcionalidade dada à palavra "eu", se aproxima, portanto, de um fenômeno comum em nossa língua oral. Isso colabora para que o ouvinte, ainda que perceba racionalmente o deslocamento acentual, aceite como plausível essa combinação de letra e melodia. Vemos esse mesmo 
fenômeno se repetir no grupo acentual seguinte. A sílaba tônica de "esse" é enfraquecida pela carga de intensidade depositada sobre a sílaba tônica de "momento".

Por fim, é interessante refletirmos sobre o chamado acento de insistência que se divide em dois tipos: o acento afetivo e o acento intelectual. É quando, na fala, uma palavra recebe uma acentuação diferente daquela oferecida pelos acentos principais e secundários, "para realçá-la em determinado contexto, quer impregnando-a de afetividade (emoção), quer dando ênfase à ideia que expressa" (CUNHA, 2017: 73). Quando, por exemplo, enunciamos o nome composto "Jesus Cristo", sem uma intenção emocional específica, a sua pronúncia apresenta uma acentuação sobre a sílaba "cris" (ao lhe conceder maior intensidade, altura ou duração do que as demais). Esse nome, no entanto, ao ser emitido em um momento em que estamos tomados por determinada emoção, também pode ser acentuado em sua primeira sílaba “je”, que passa a rivalizar com a sílaba tônica "cris" (“Jesus Cristo!"). Verificamos, então, a presença simultânea de dois acentos, praticamente equivalentes. É a expressão fonética desse sentimento. Na canção homônima, de Roberto Carlos e Erasmo Carlos, já analisada acima, encontramos esse mesmo deslocamento acentual. Durante a apreensão da obra por parte do ouvinte (que inconscientemente relaciona a língua da fala com a língua da canção), esse desvio pode significar um acento afetivo.

Jesus Cristo, Jesus Cristo

Jesus Cristo, eu estou aqui

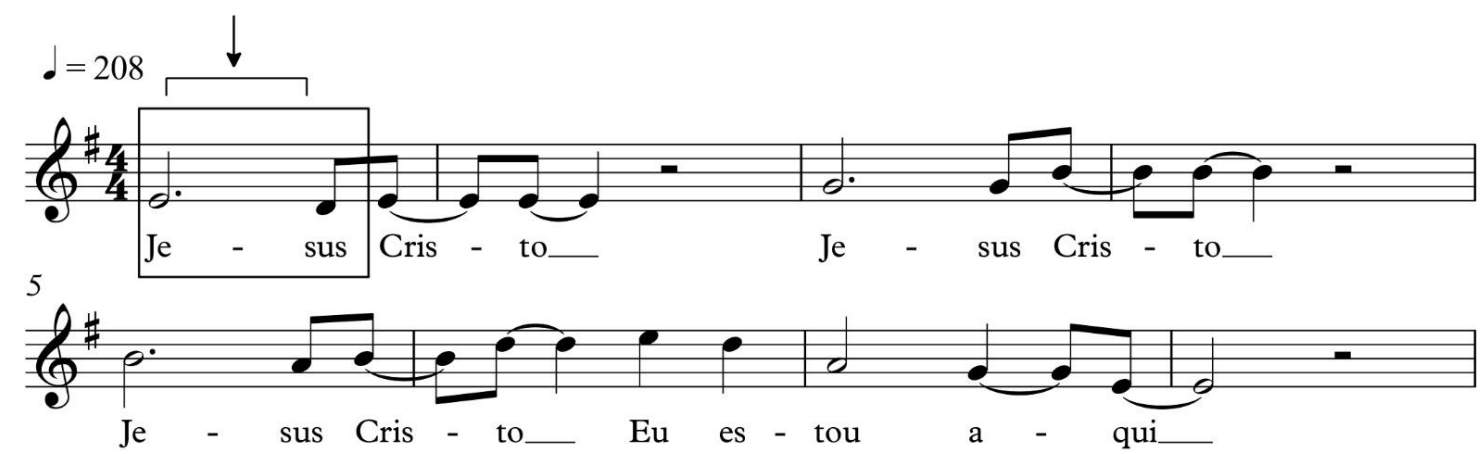

Figura 93. O acento afetivo em Jesus Cristo (Roberto Carlos/Erasmo Carlos)

O acento afetivo, nesse caso, pode representar mais uma razão pela qual esse trecho da canção permanece plausível, ainda que contenha o deslocamento silábico. Uma emoção particular é impressa na entoação da palavra. Diferentemente, o acento intelectual 
pode realçar uma sílaba átona de um determinado vocábulo não para transmitir um sentimento, mas para valorizar uma ideia, como "um recurso eficaz de que dispomos para valorizar uma noção, para defini-la, para caracterizá-la, geralmente contrastando-a com outra" (CUNHA, 2017: 74). Podemos encontrar algo próximo desse fenômeno em duas canções já examinadas neste capítulo, Desafinado e Será, nos quais as palavras "musical” e "será" são inesperadamente acentuadas em suas sílabas iniciais, átonas. Vejamos.

Se você insiste em classificar

Meu comportamento de antimusical

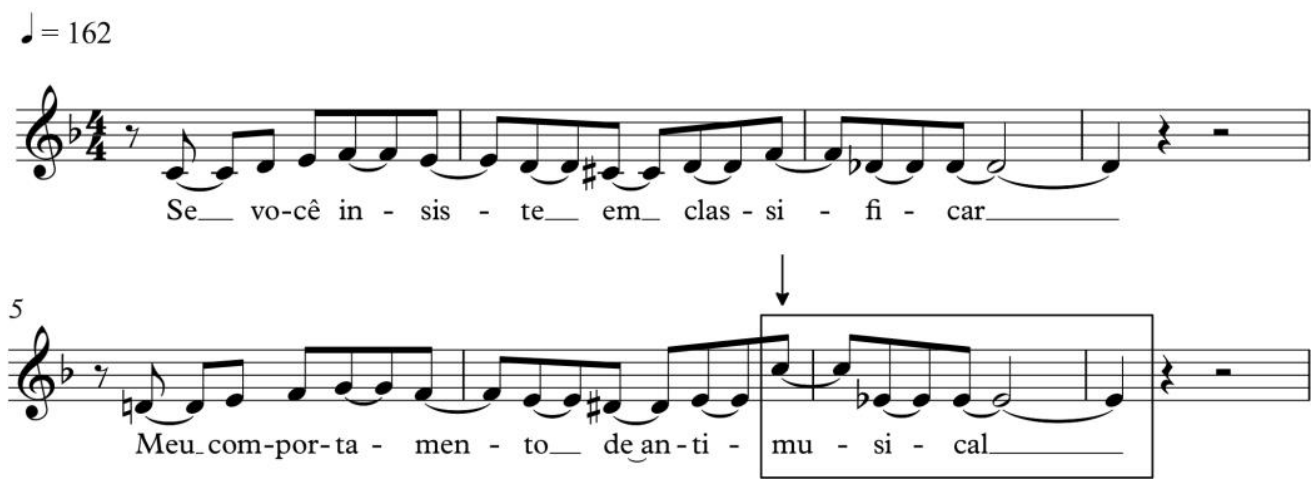

Figura 94. O acento intelectual em Desafinado (Tom Jobim/Newton Mendonça)

Em uma situação conversacional comum, a expressão "antimusical” seria naturalmente acentuada em sua última sílaba "cal". Ao enfatizar o primeiro segmento do vocábulo "musical", no entanto, o cantor acaba dando um especial relevo à essa palavra, como em situações possíveis de fala nas quais o enunciador quer deixar claro para o enunciatário que ele está falando de um "comportamento antimusical" e não "anticancional" ou "antinatural". Ainda que esse sentido de "destaque" ou "diferenciação" não seja abarcado pela canção, mesmo assim, o deslocamento acentual verificado acima, sendo possível na língua oral (no caso de um acento de insistência), torna-se menos incômodo para o ouvinte. Em Será, exemplo já analisado neste capítulo, observamos outro possível acento de insistência.

Será só imaginação?

Será que nada vai acontecer?

Será que é tudo isso em vão?

Será que vamos conseguir vencer? 


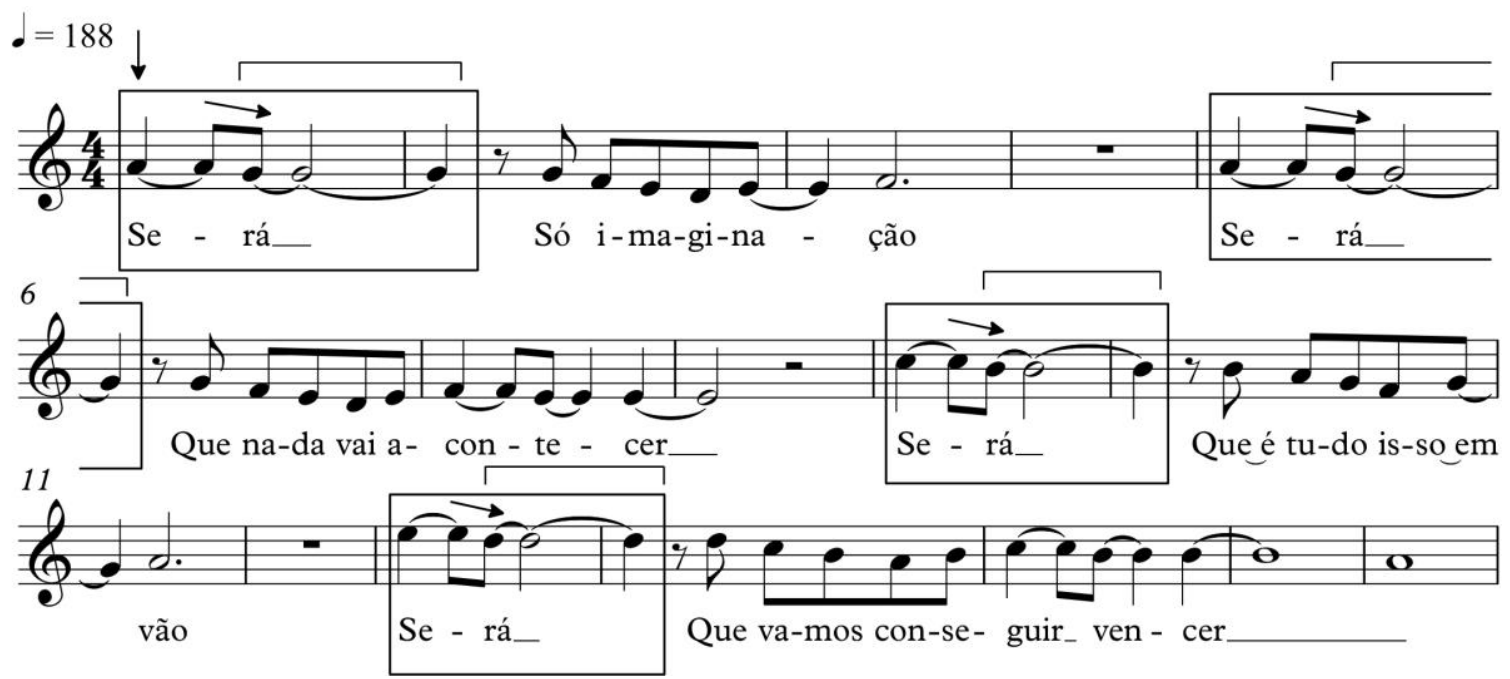

Figura 95. O acento de insistência em Será

Mais uma vez, notamos um vocábulo inesperadamente acentuado em sua primeira sílaba (átona). Algo que pode sugerir um possível acento de insistência (intelectual) no qual um interlocutor intensifica ainda mais a sua dúvida: "Será só imaginação? Não é possível... será?”. Enfim, nosso intuito, nesse momento, é demonstrar que certos deslocamentos silábicos também estão presentes na língua oral, ainda que em ocasiões específicas, e, por isso, podem ser considerados plausíveis pelos ouvintes. 


\section{6 $O$ aproveitamento artístico do deslocamento acentual}

Seguindo nosso propósito de tornar mais complexa a reflexão acerca dos deslocamentos silábicos, devemos observar que os exemplos analisados anteriormente (nos quais o cancionista, consciente ou inconscientemente, produz oralizações lineares e não-lineares) podem ser considerados soluções artísticas originais. Ou seja, os desvios acentuais também podem sugerir interessantes expressividades poéticas. Neste item, selecionamos casos mais explícitos desse aproveitamento artístico. Em Palco, de Gilberto Gil, por exemplo, encontramos um desvio sobre a palavra "bumbum". Examinemos de modo mais detido.

Subo nesse palco,

Minha alma cheira a talco como bumbum de bebê

De bebê

(...)

Vale quanto pesa

Pra quem preza o louco bumbum do tambor

Do tambor
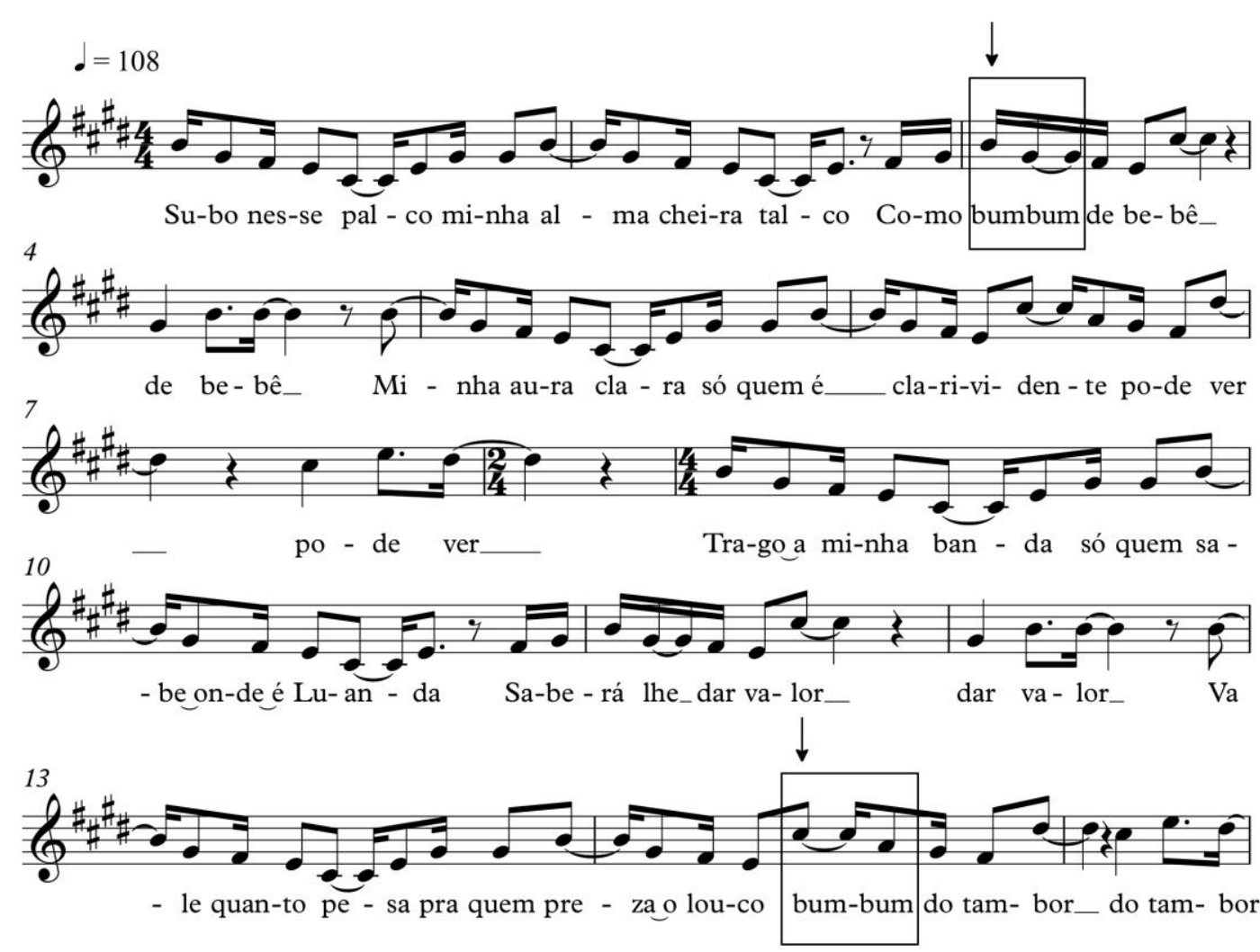

Figura 96. O aproveitamento artístico do deslocamento silábico em Palco (Gilberto Gil) 
Nessa canção, há um evidente desvio de acentuação silábica. A palavra destacada, oxítona, tem sua sílaba átona enfatizada pelo fator intensidade, visto que coincide com o primeiro tempo do compasso. Há, então, certa perda de naturalidade entoativa na emissão da frase "como bumbum de bebê". Todavia, com a continuação da letra, percebemos o aproveitamento artístico desse deslocamento acentual, na medida em que o compositor explora o mesmo vocábulo para ilustrar, como uma onomatopeia, o som da percussão na pele do tambor. Nesse caso, há uma interessante aproximação entre o "bumbum do bebê" e o "bumbum do tambor", ambos valorizando a mesma ideia de uma experiência repleta de frescor. Do mesmo compositor, analisemos um trecho da canção Esotérico.

Não adianta nem me abandonar

Nem ficar tão apaixonada, que nada

Que não sabe nadar

Que morre afogada por mim
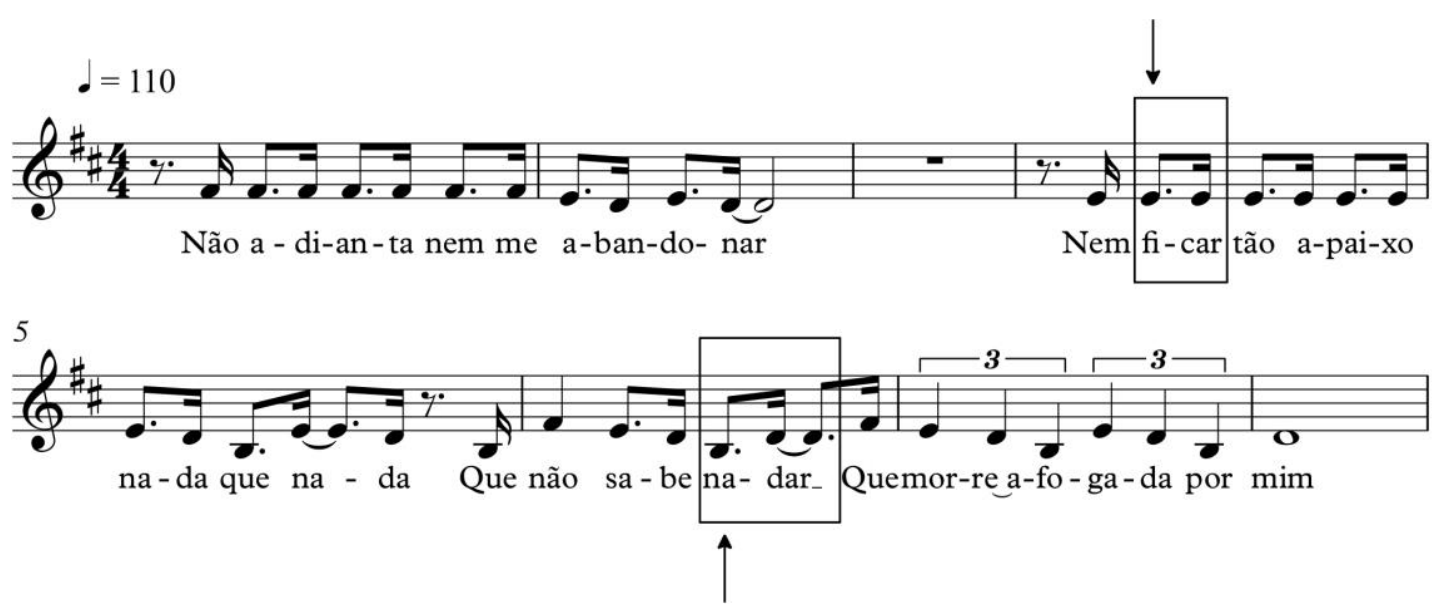

Figura 97. O aproveitamento artístico do deslocamento silábico em Esotérico (Gilberto Gil)

Desejamos nos ater ao segundo deslocamento destacado na figura cima. A sílaba átona da palavra "nadar" é enfatizada pelo acento métrico do compasso, ao recair sobre a parte forte do terceiro tempo. Com essa configuração melódica, o ouvinte se divide entre a apreensão do verbo no infinitivo ("nadar") e o entendimento do substantivo masculino "nada". Assim, de modo muito interessante, o cancionista aproveita o aparecimento da sequência fônica "nada" em "apaixonada", "que nada" e "que não sabe nada(r)"104 para realizar uma relação metafórica entre o afogamento por não saber nadar e a submissão do interlocutor ao eu-lírico da letra. Em Refazenda, do mesmo compositor, temos outro caso

${ }^{104}$ E até mesmo a repetição dos fonemas [n] e [d] de "nada" no vocábulo "abandonar" 
de deslocamento acentual por meio da intensidade que resulta em uma solução estética curiosa.

Enquanto o tempo não trouxer teu abacate

Amanhecerá tomate e anoitecerá mamão

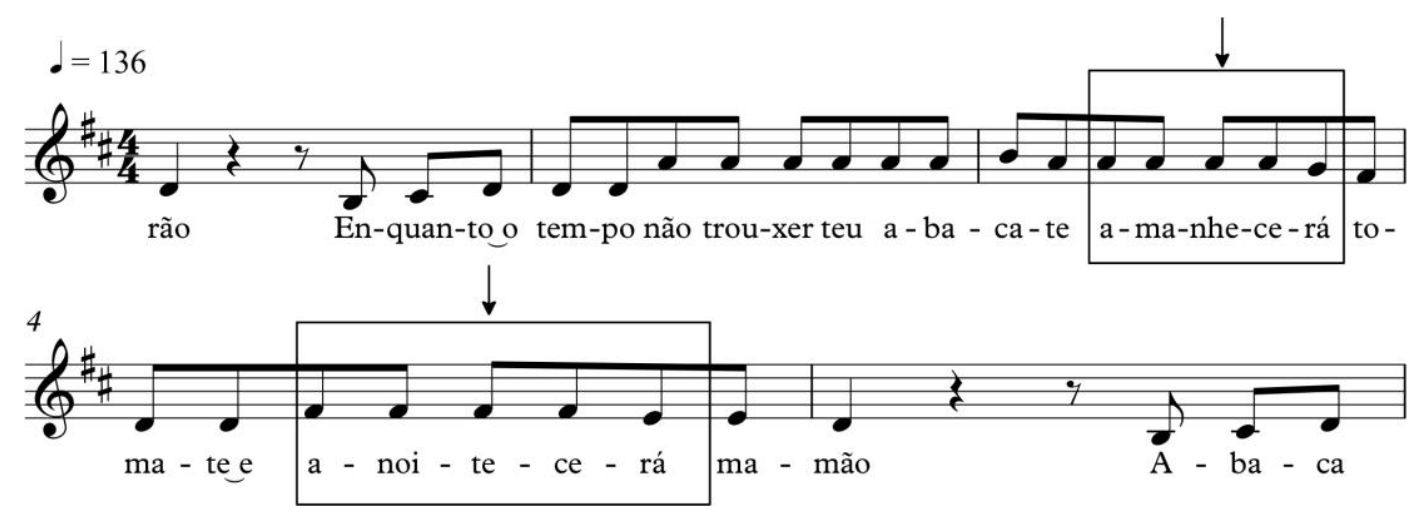

Figura 98. O aproveitamento artístico do deslocamento silábico em Refazenda (Gilberto Gil)

Considerando os vocábulos “amanhecerá” e “anoitecerá”, verificamos que há uma ênfase melódica a princípio indesejada sobre as suas sílabas átonas, embora os segmentos tônicos de ambos recaiam sobre a parte forte do quarto tempo ${ }^{105}$. Essa configuração rítmica, combinada com a letra (linguisticamente inusitada para os padrões da língua falada), resulta em um entendimento ambíguo do texto, pela semelhança sonora entre a frase original "amanhecerá tomate" e algo como "amanhã será tomate". Isto é, a acentuação da sílaba "nhe" e a estranheza do uso do verbo no futuro nesse contexto faz o ouvinte titubear entre essas duas possibilidades linguísticas. Ao cancionista, muitas vezes, essa ambiguidade parece constituir uma solução estética interessante. Em Qualquer Coisa, de Caetano Veloso, encontramos algo similar.

Não se avexe não, baião de dois

Deixe de manha, deixe de manha

Pois, sem essa aranha, sem essa aranha, sem essa aranha

Nem a sanha arranha o carro

Nem o sarro arranha a Espanha

Meça tamanha, meça tamanha

Esse papo seu já tá de manhã

105 Colabora ainda para que o desvio apontado inicialmente não seja tão contundente o fato de a frase consistir em uma sequência de notas de mesma duração. 

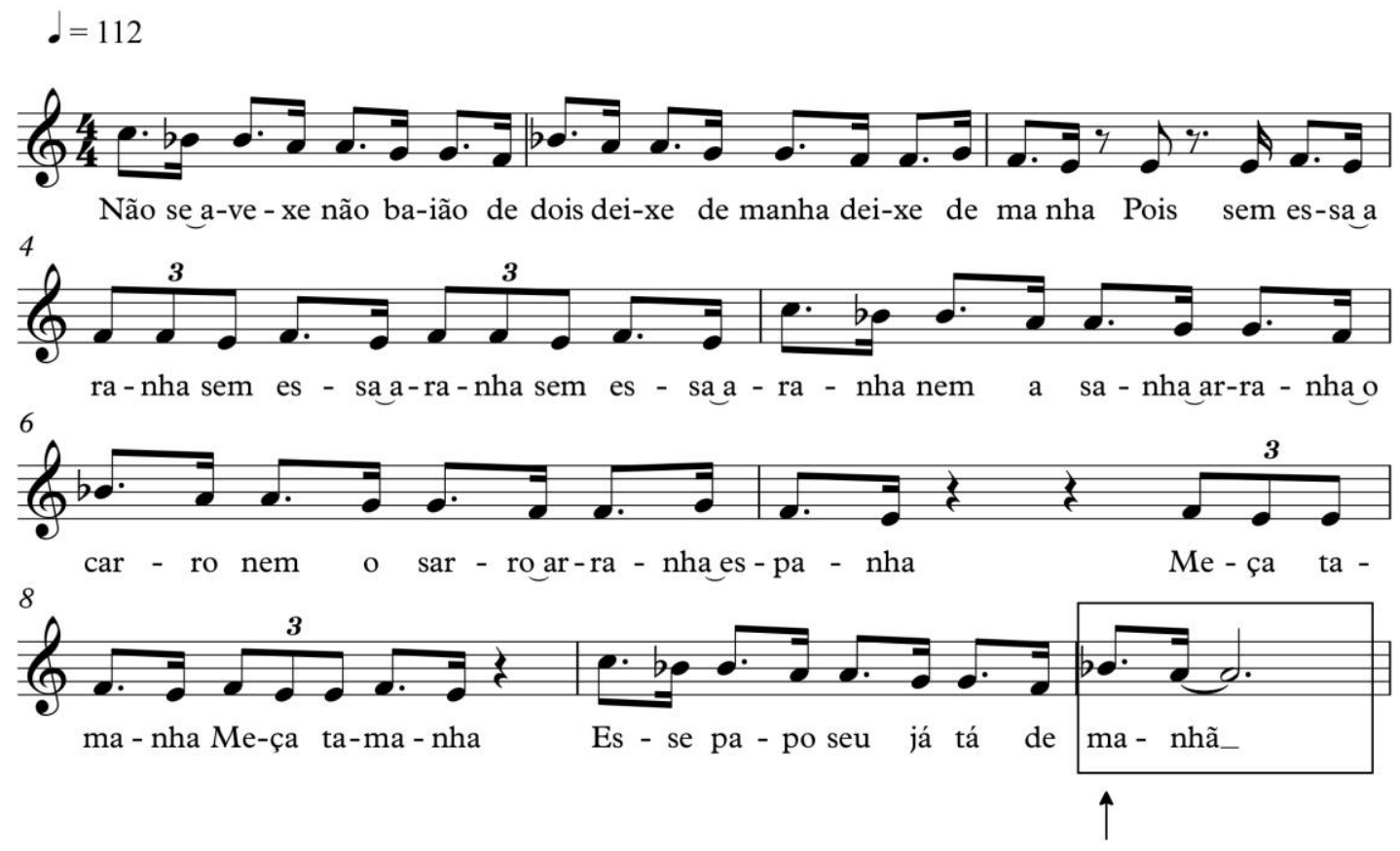

Figura 99. O aproveitamento artístico do deslocamento silábico em Qualquer coisa (Caetano Veloso)

Nesse exemplo, o cancionista aproveita a existência do deslocamento acentual que detectamos na palavra "manhã" (cuja primeira sílaba, átona, recai sobre o tempo forte do compasso 10) para sugerir uma nova menção ao vocábulo "manha" (que já havia aparecido diversas vezes na letra em "deixe de manha, deixa de manha" e, implicitamente, em "meça tamanha, meça tamanha"). Acreditamos que, graças à essa ambiguidade, o compositor consegue atingir significações poéticas diversas e simultâneas. Nesse sentido, a frase "esse papo seu já tá de manhã/manha" sugere tanto a duração cansativa da conversa quanto o seu conteúdo manhoso, causador de aborrecimento. Enfim, analisamos exemplos nos quais constatamos que os deslocamentos silábicos não apenas produzem uma possível quebra da expectativa oral, mas igualmente participam da proposta artística da canção. 


\subsection{O conflito entre o padrão melódico e a naturalidade oral}

Muitos exemplos de deslocamento silábico analisados ao longo deste capítulo foram gerados por uma incompatibilidade entre os acentos tônicos do texto verbal e os acentos preestabelecidos pela melodia. Trata-se, evidentemente, do mesmo embate entre a tematização melódica (com padrões musicais mais rígidos) e os ímpetos orais que desvirtuam os modelos sonoros reiterativos. É o caso do chamado canto estrófico, sobre o qual já discorremos anteriormente, que, por sua inflexibilidade, por vezes leva o compositor a cometer desvios prosódicos na letra, em favor da integridade da música. É também o caso da adaptação da letra ao gênero. Sandroni, ao transcrever as melodias dos sambas sobre os quais se debruçou, percebeu que as frases melódicas executadas pela voz eram baseadas no padrão rítmico do chamado "paradigma do Estácio". São momentos em que a divisão temporal da articulação silábica explicita a clave rítmica do gênero e ajuda em sua caracterização.

\footnotetext{
Essa ideia de uma correspondência entre uma fórmula rítmica de acompanhamento e a articulação rítmica do canto foi sugerida em primeiro lugar por Alejo Carpentier, quando afirmou que '...o ritmo das claves, como inteligentemente notou Emilio Grenet, é o único que pode ajustar-se sempre, sem variantes, a todos os tipos de melodias cubanas, constituindo portanto uma espécie de constante escancional'. Assim, do mesmo modo que as melodias cubanas seriam construídas na fôrma do ritmo feito pela clave, as melodias de certos sambas seriam construídas na do ritmo do tamborim. (SANDRONI, 2012: 204)
}

Assim, diferentes claves rítmicas sugerem diferentes recortes melódicos e, consequentemente, influenciam na acomodação acentual do texto linguístico. Nos exemplos abaixo, notamos que uma mesma canção pode aceitar divisões rítmicas distintas, sem desrespeitar a prosódia. São diferentes versões para a canção Se Você Jurar de Ismael Silva. A primeira, interpretada por Francisco Alves e Mário Reis. A segunda, pelo próprio compositor (SANDRONI, 2012: 210).

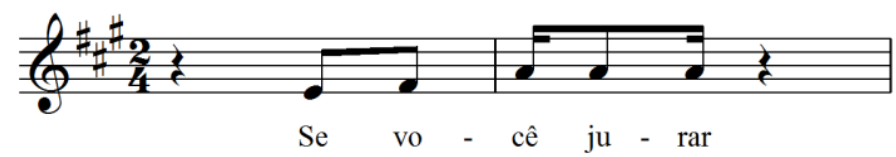

Figura 100. Se você jurar (Ismael Silva) na versão de Francisco Alves e Mário Reis 


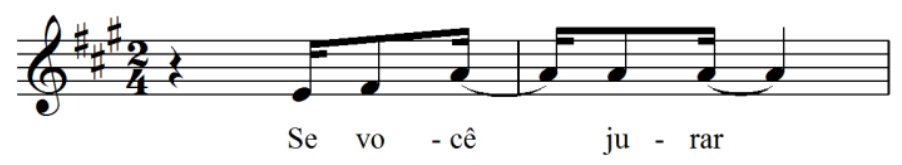

Figura 101. Se você jurar na versão de Ismael Silva

Muitas vezes, ao tentar manter o padrão rítmico do gênero o cancionista opta (mesmo que intuitivamente) por desrespeitar a acentuação natural da letra. Em Se você jurar, no entanto, percebemos que é perfeitamente possível conciliar a base rítmica com a preservação da prosódia. Em outros casos, no entanto, essa conciliação torna-se dificultosa. É o que ocorre, por exemplo, na conhecida canção Tem gato na tuba, "onde, para não quebrar a acentuação melódica, pois se tratava de marcha carnavalesca, os autores modificaram o acento linguístico: 'melodia' passou a ser 'melódia"” (TATIT, 1986: 11). As exigências musicais do gênero passam a constituir uma certa classe de canções ou estilos cancionais, "onde a inteligibilidade melódica antecede a inteligibilidade linguística" (TATIT, 1986: 12). No exemplo seguinte, de modo semelhante, o desejo de manter rigorosamente o padrão rítmico da melodia acaba por produzir um resultado mais distante em relação à entoação da fala.

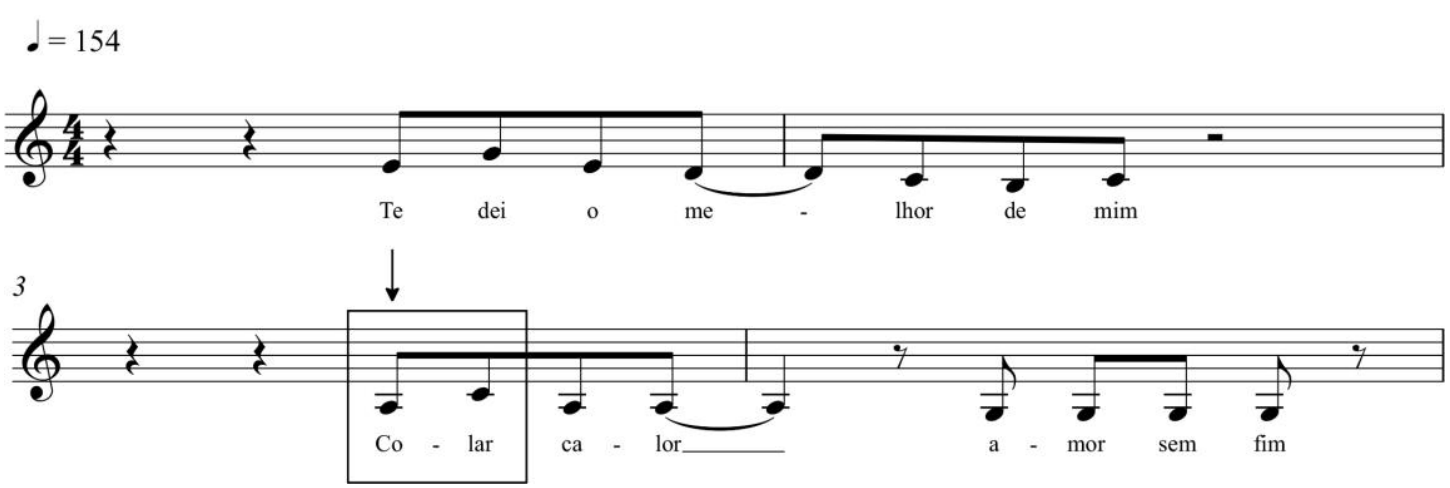

Figura 102. O conflito entre o padrão melódico e a letra em Meu amigo Enock (Zeca Baleiro)

Destacamos o vocábulo "colar" no terceiro compasso da figura acima. O modo como ele é cantado, com andamento relativamente acelerado e com o tempo forte da melodia recaindo sobre a sua sílaba átona, torna-se distante da maneira como o entoaríamos numa situação normal de fala, constituindo uma oralização não-linear. $\mathrm{O}$ ouvinte, ainda que aceite essa entoação, pode estranhar a sua construção ou até mesmo não compreender o sentido do texto. Há, em Meu Amigo Enock, aspectos que estudamos no decorrer deste capítulo. Percebemos, por exemplo, que o encaixe entre as inflexões da 
letra e os tempos fortes da melodia não diz respeito apenas ao acento, mas também à duração das notas ou sílabas. Vejamos. A emissão da palavra "colar" soa de forma inusitada. No entanto, o vocábulo seguinte, "calor" (cuja sílaba tônica também não coincide com a acentuação melódica), parece-nos mais natural. Isso se deve ao fato de que a sua sílaba tônica ("lor”), ainda que não coincida com o acento forte da melodia, tem sua duração alongada. Esse aumento, além da pausa subsequente do canto (o que igualmente favorece a compreensão do vocábulo), faz com que a palavra soe de modo mais habitual.

Da mesma forma, no primeiro verso, quando o cantor alonga a sílaba "me" da palavra "melhor", observamos um distanciamento em relação ao seu modo de dizer usual. Entretanto, no contexto geral da frase, somos capazes de captar o seu sentido e aceitar como plausível a emissão desse vocábulo. É como se a expressão “dar o melhor de si”, muito arraigada na língua, já parecesse, a priori, suficientemente reconhecível ao ouvinte, mesmo que algum de seus componentes seja cantado de maneira deslocada.

No caso do verso "Colar, calor", no entanto, constatamos maior dificuldade em compreender o seu sentido. Isto porque a junção dessas duas palavras é menos comum na fala cotidiana. Como vimos antes, na fala, raramente fazemos construções linguísticas que chamem atenção para o significante. Não obstante, como exercício investigativo, podemos reescrever esse trecho e propor duas novas versões para a letra, substituindo a palavra "colar" ou a palavra "calor" por "colo". Assim, mantemos a mesma isotopia do afago ou do cuidado do eu-lírico em relação à sua bem-amada, sem prejuízo da sonoridade do verso.

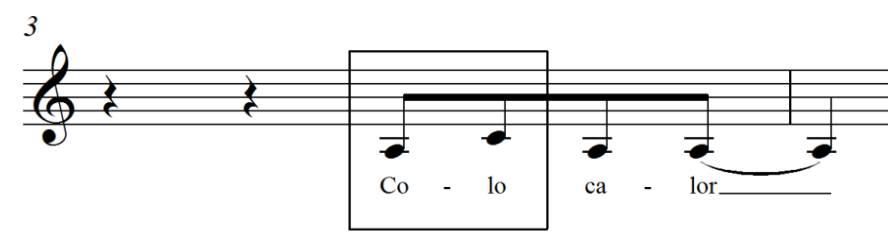

Figura 103. Substituição de "colar" por "colo" em Meu amigo Enock

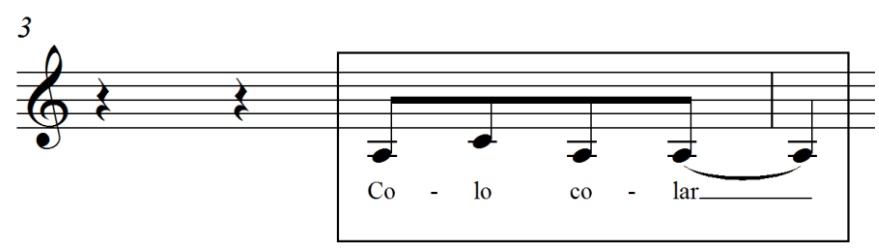

Figura 104. Substituição de "calor" por "colo" Meu amigo Enock 
Ao substituirmos "colar" ou "calor" pela palavra "colo", preservamos a figura de linguagem da paronomásia (emprego de vocábulos sonoramente semelhantes) desejada pelo compositor e, ao mesmo tempo, favorecemos uma proximidade maior com a entoação natural das palavras na língua oral. Essa alteração proporciona mais naturalidade para o modo de dizer do cantor, pois elimina uma ocorrência linguística estranha aos ouvidos dos falantes da língua portuguesa.

Esse jogo entre os elementos reconhecíveis e os elementos inusitados é, aliás, algo relevante para nosso estudo da figurativização na canção. Para o exame dessa questão prosódica, por exemplo, consideramos interessante aplicar as noções de espera e surpresa formuladas pelo poeta Paul Valéry (TATIT, 1997: 54-55). Trata-se de uma maneira de interpretar a experiência do sujeito em seu contato com os acontecimentos inesperados ou programados. Na perspectiva do sujeito, a surpresa estaria identificada com "o que (já) é não é (ainda)": o fato já está no mundo real, mas ainda não existe para o indivíduo, por isso o surpreende. A espera, por sua vez, identifica-se com “o que não é (ainda) (já) é”: o fato ainda não existe na realidade, mas já se configura na mente do sujeito que espera por ele.

\footnotetext{
Note-se que ambas as noções (a surpresa e a espera), mesmo em suas disposições extremas, pressupõem um certo equilíbrio das funções de sujeito e de objeto. Se este for rápido demais, a ponto de ultrapassar a esfera daquilo que conhecemos como surpresa, acaba perdendo seus contornos de identificação e, consequentemente, o objeto escapa do sujeito. (TATIT, 1997:
} 54)

Acreditamos que a relação entre melodia e letra pode trazer para o ouvinte fenômenos mais ou menos previsíveis em relação à nossa experiência com a fala cotidiana. Observamos trechos de canções em que as construções linguísticas sendo mais inusitadas não favorecem o entendimento imediato por parte do público. O exemplo acima, de Zeca Baleiro, de certa maneira, apresenta um nível maior de imprevisibilidade na medida em que conjuga duas palavras distantes semanticamente ("colar" e "calor") e encerra, além disso, um significativo deslocamento silábico. Portanto, a surpresa gerada por esse tipo de conformação cancional simboliza a nossa dificuldade de apreensão imediata do fragmento. Seguindo a reflexão de Tatit a partir das ideias de Valéry, é como se o objeto escapasse um pouco do sujeito. Voltando à nossa análise do conflito entre o 
padrão melódico e a entoação natural da letra, observemos a canção Expresso 2222, do compositor Gilberto Gil.

Segundo quem já andou no Expresso

Lá pelo ano 2000 fica a tal

Estação final do percurso-vida

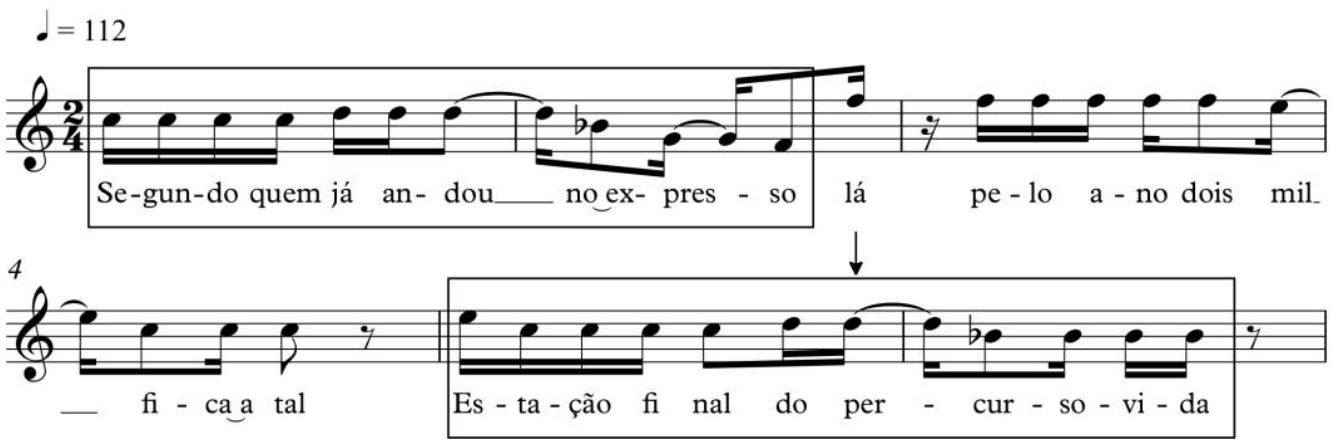

Figura 105. Expresso 2222 (Gilberto Gil)

No pentagrama inferior, destacamos o deslocamento acentual que incide sobre a palavra "percurso" (que forma a expressão "percurso-vida"). Trata-se do único momento da canção em que o ouvinte tem dificuldade de compreensão direta da letra. Podemos constatar que esse trecho repete, ainda que de modo menos estrito, o mesmo padrão melódico da frase inicial "Segundo quem já andou no expresso". Ao propor uma nova letra para essa mesma configuração rítmico-melódica, o cancionista opta por manter certas características musicais em detrimento da emissão usual do texto verbal: a sílaba tônica do vocábulo "percurso" não coincide com nenhum acento métrico enquanto a sua primeira sílaba, átona, parece estar sob a influência de força do primeiro tempo do compasso (como nos casos examinados acima nos quais a nota emitida pelo cantor constitui uma síncopa para o tempo forte ou meio forte). Por outro lado, supomos que, além do fator sonoro ligado à intensidade, também colabora para a dificuldade de apreensão desse trecho a surpresa que a expressão inusitada "percurso-vida" produz no público. É como se fosse necessário desacelerar a emissão dessa frase (alterando, portanto, o padrão melódico) para que o seu sentido pudesse ser capturado mais facilmente pelo ouvinte.

Outro aspecto relevante para o exame da questão prosódica é a chamada dessemantização, noção sobre a qual já comentamos anteriormente. Esse conceito semiótico nos ajuda a compreender certo tipo de experiência vivida pelo ouvinte de canção popular: 
Dessemantização é a perda de certos conteúdos parciais em benefício do significado global de uma unidade discursiva mais ampla. Longe de ser apenas linguística (por exemplo: "matar o tempo"), a dessemantização é um fenômeno semiótico muito geral: "dar nó na gravata", por exemplo, é o significado de um processo gestual complexo em que os enunciados que o constituem se encontram dessemantizados (GREIMAS, 2012: 131)

Nos momentos em que os deslocamentos acentuais não permitem a compreensão de certas palavras notamos pontos mínimos de dessemantização. Nesse caso, em geral, o interesse do ouvinte se volta para questões mais musicais do que linguísticas. Em nossa experiência de escuta, podemos nos deparar com canções cujas letras não compreendemos ou que entendemos apenas parcialmente. No caso de canções em língua estrangeira, esse fato é ainda mais evidente, mas em canções brasileiras também constatamos esse mesmo tipo de ocorrência. Há determinados trechos de certas canções dos quais jamais chegamos a compreender a letra. Há, igualmente, casos em que certas estrofes são mais lembradas do que outras. Trata-se de um fenômeno muito interessante, pois essas canções de forma alguma são menos apreciadas do que outras que não apresentam esses trechos dessemantizados. Assim, podemos supor que o foco do ouvinte muda de acordo com as suas diferentes experiências de escuta. $\mathrm{O}$ fato de a letra não ser bem compreendida pelo público faz com que a sua atenção se volte naturalmente para o aspecto musical, por exemplo. É evidente que ninguém deixa de gostar de uma canção por isso. A experiência, contudo, já não é mais a mesma.

Isso nos conduz, no entanto, a uma interessante investigação sobre a questão figurativa da canção, nosso assunto principal nesta tese. Se, por um lado, na grande maioria dos casos, o deslocamento da acentuação silábica não chega a impedir de fato a compreensão efetiva do texto, por outro, ele faz com que o trecho linguístico não seja captado de maneira direta. Supomos, então, haver uma gradação no modo de apreensão do ouvinte: uma alternância entre momentos em que o ouvinte apreende a letra de um modo muito direto e instantâneo (quando a acentuação natural das palavras e da frase está totalmente preservada) e momentos em que o ouvinte capta o texto de um modo mais truncado ou vago. Essa é, talvez, a principal contribuição que podemos oferecer a partir de nossas análises e, por isso, voltaremos a esse ponto em diversos momentos desta pesquisa: não se trata de avaliar se os versos de uma canção estão "certos" ou "errados", se eles são "melhores" ou "piores", mas sim de observar a interessante questão da 
gradação na percepção do público, como um pêndulo entre uma assimilação imediata do conteúdo e uma percepção menos linguística do mesmo trecho. O problema, aqui, muda de feição, sendo mais enriquecedor percebermos as nuances nos níveis de instantaneidade da recepção da mensagem linguística. No caso de um desvio acentual, o ouvinte pode até compreender a palavra e, por conseguinte, a mensagem. Porém, a sua percepção é significativamente alterada ou, talvez, atrasada. É como se as palavras demorassem mais para serem captadas ou tivessem o seu sentido mais usual (aquele que atingimos por meio da fala) enfraquecido. A canção Biscate, de Chico Buarque, nos parece um bom exemplo.

Sirvo seu pitéu na cama

E nada dele comer, ai

Telefone, é voz de dama

Se penteia pra atender

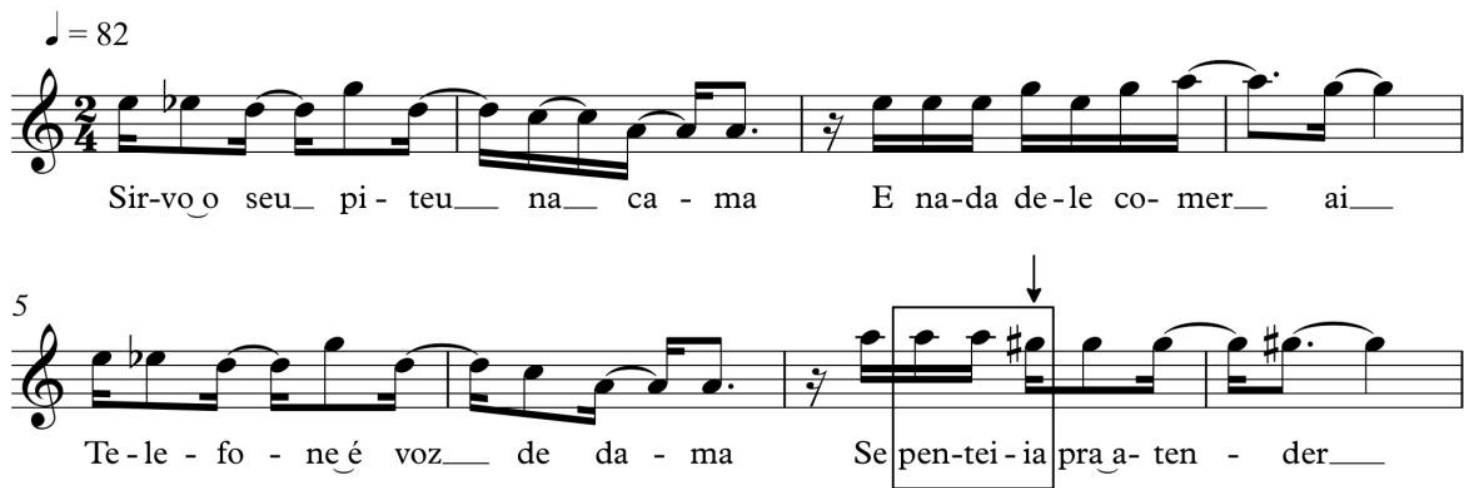

Figura 106. Biscate (Chico Buarque)

O deslocamento silábico indicado na figura acima não é capaz de impedir totalmente a compreensão da frase "se penteia pra atender". No entanto, a nosso ver, sua assimilação é mais lenta e débil. É como se o cancionista, ao se distanciar de uma emissão mais direta, despotencializasse a sentença linguística. Algo como "perder a piada": ao corromper a prosódia do vocábulo "penteia", tornando-o intelectualmente menos acessível, o compositor deixa de enfatizar uma palavra essencial para o sentido brincalhão de seu verso. Na canção, portanto, pode haver uma possível eficácia combinatória entre a melodia e a letra que permite o entendimento mais imediato e pleno do conteúdo do texto verbal. Abaixo, reescrevemos o mesmo fragmento para investigar a possibilidade de uma solução mais direta para o mesmo exemplo. 


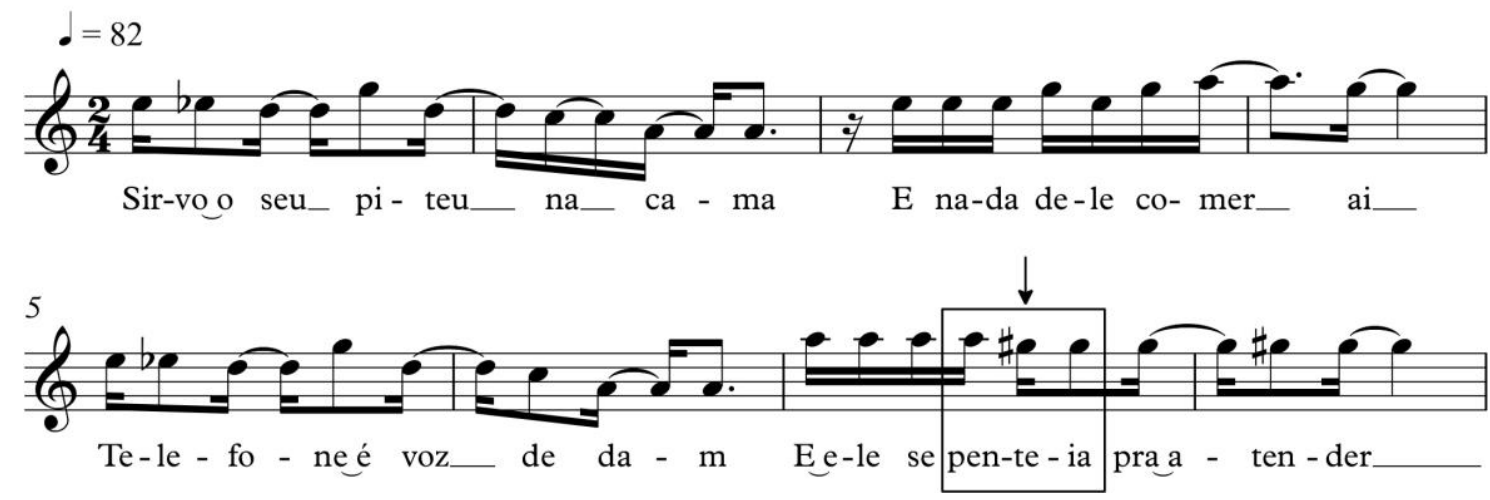

Figura 107. Reescrita de Biscate

$\mathrm{Na}$ figura acima, realizamos uma pequena alteração rítmica na frase e acrescentamos uma conjunção e um pronome (“E ele se penteia...”) de modo que a sílaba tônica do vocábulo destacado coincida com uma parte forte do tempo do compasso. Com isso, acreditamos que o conteúdo da frase linguística passa a ser assimilado de maneira mais imediata, mantendo a atenção do ouvinte mais apegada ao texto.

Nesse tipo de discussão estão, talvez, possíveis respostas para questões intrigantes no universo da canção popular. Afinal, por que algumas estrofes e versos são mais destacados linguisticamente do que outros? Por que certas passagens são mais lembradas pelo público? Quando a apreensão é mais imediata e natural, a canção é mais apreciada pelo ouvinte? O cancionista deveria, então, buscar somente esse tipo de construção mais direta? Parte dessas indagações pode ser respondida com algumas análises realizadas aqui. As duas últimas, no entanto, merecem uma possível ressalva, posto que a atividade criativa do cancionista jamais deve ser tratada de modo reducionista. Expliquemos. A canção congrega uma simultaneidade de forças distintas (forças musicais e forças poéticas, por exemplo) e o próprio processo composicional por vezes leva o compositor a optar por soluções menos orais. É justamente pelo fato de a canção, ainda que possua sua especificidade, incorporar linguagens adjacentes como a música e a poesia que a compatibilização figurativa entre a letra e a melodia se torna complexa. O cancionista naturalmente cria oralizações lineares e não-lineares e ambas despertam interesse artístico. O intuito de nosso trabalho é se debruçar sobre essa complexidade.

Enfim, no decorrer deste capítulo, pudemos constatar que os deslocamentos acentuais das letras de canção ocorrem a partir de variados parâmetros musicais: intensidade (quando os ataques mais fortes ou mais fracos da linha melódica geram pontos 
de destaque no texto linguístico), duração (quando os intervalos temporais enfatizam as sílabas) e altura (quando saltos intervalares colaboram para a acentuação silábica). Pudemos verificar igualmente a maior quantidade de casos de desvio ocorridos pelo fator intensidade e a sua maior preponderância sobre os dois outros parâmetros. Observamos ainda que, nos casos de variação acentual, frequentemente, o que está em jogo é a oposição entre um caráter melódico mais entoativo e um sonoramente mais formalizado. Isto é, há um embate entre as leis entoativas e as leis musicais, tudo realizado pelo compositor/intérprete de maneira intuitiva. O cancionista, de maneira natural, aciona toda a sua experiência com a língua oral ao mesmo tempo em que coloca em prática toda a sua vivência musical. Passemos, nesse momento, ao nível seguinte do encaixe entre a letra e a melodia: a palavra. 


\section{APLLAVRA}

Estudaremos, a partir desse momento, o que consideramos representar o segundo nível dos elementos entoativos significativos para a composição de canção (tendo em vista nossa perspectiva de trabalho com os diferentes tamanhos das unidades linguísticas). Entre a sílaba e a frase, ocupemo-nos agora da palavra. De fato, de um modo geral, podemos defini-la como uma unidade linguística maior do que a sílaba e menor do que a frase, ainda que os estudos linguísticos proponham outros níveis e formas de classificação mais acuradas. Nesta pesquisa, por exemplo, optamos por não tratar os conceitos de fonema e morfema (unidades significativas mínimas) de um modo aprofundado. Constituem, no entanto, noções que podem enriquecer análises futuras, sobretudo quando pensamos no segundo conceito. Comentando-o brevemente, o vocábulo "músicas" é composto pelo morfema "música" (que pode ser usado como palavra isolada ou formar outras palavras como musicalidade, musical etc.) e pelo morfema "s" (forma plural que está no final de muitos vocábulos, mas que não pode ser usada como palavra autônoma). Imaginamos, por exemplo, o quanto esse conceito pode participar do estudo dos acentos principais e secundários em palavras derivadas (assunto que vimos no capítulo anterior). Por ora, no entanto, não acreditamos ser muito proveitoso trabalhar com essas questões. Para a análise da presença da língua oral na percepção de uma canção por parte do ouvinte, supomos que a sílaba, a palavra e a frase são os níveis de significação mais pertinentes.

Como averiguamos no capítulo precedente, percebemos, em uma frase, sílabas acentuadas e sílabas inacentuadas e nossa percepção desse fenômeno decorre dos variados graus das características físicas do som (intensidade, duração e altura) ${ }^{106}$. Vimos também que, em geral, "esses elementos estão intimamente associados" e que a questão do acento tônico está ligada à simultaneidade desses fatores, "com predominância da

\footnotetext{
${ }^{106}$ Optamos por não abordar o timbre nesta pesquisa.
} 
intensidade, do tom e da quantidade" (CUNHA, 2017: 68) ${ }^{107}$. Pois bem, o nosso intuito, nesse momento, é investigar a existência de um possível acento tônico da frase. Isto é, desejamos observar se, dentro de uma sentença formada por diversas palavras, podemos localizar vocábulos mais acentuados e vocábulos menos acentuados.

Pensando na análise silábica estudada no capítulo anterior, é como se pudéssemos falar sobre a presença de "palavras tônicas" e "palavras átonas". Muitas indagações interessantes podem decorrer dessa perspectiva: Havendo, na frase linguística, uma palavra nuclear, a melodia da canção geralmente a destaca? Quais são os níveis de plausibilidade entoativa observados em combinações de melodia e letra que enfatizam palavras átonas? Além disso, entre os parâmetros sonoros citados acima, quais são os mais decisivos na acentuação de um vocábulo? Nosso campo de estudo, nesse momento, passa a observar os exemplos cancionais de uma maneira menos pontual, visto que deveremos estar atentos à direcionalidade da frase como um todo, identificando os seus pontos de destaque.

A nossa reflexão sobre a palavra vem ao encontro do assunto que estávamos discutindo ao final do capítulo anterior, tópico que acreditamos ser crucial para a investigação de como o ouvinte percebe e assimila as combinações entre letra e melodia. Há uma espécie de mistério sobre o qual gostaríamos de nos debruçar. O que, afinal, determina a produção de certos encaixes entre língua e música que transmitem de modo mais direto a mensagem verbal? Há, nesse sentido, um determinado equilíbrio entre a letra e a linha melódica? Delimitando melhor essa última indagação, queremos observar se há um modo pelo qual o ouvinte é capaz de captar o texto verbal e o texto musical de maneira simultânea e imediata. Ou seja, quando sua atenção não se divide e não prioriza a melodia em detrimento da letra, por exemplo.

Supomos que há, nas canções, uma permanente oscilação entre momentos nos quais notamos um encontro equilibrado entre melodia e letra (quando o conteúdo da mensagem verbal nos chega de modo mais instantâneo) e momentos em que as forças poéticas (a busca por aliterações e metáforas etc.) e as forças musicais (a priorização de aspectos melódicos, harmônicos etc.) provocam expressões estéticas distintas. Suspeitamos que, na verdade, essa oscilação, é parte intrínseca do trabalho artístico do

\footnotetext{
107 Assim como descreve o autor, não acreditamos que o timbre, por ele definido como a presença de "sons mais abertos ou sons mais fechados" (CUNHA, 2017: 68), possua uma função tão determinante nos fenômenos de deslocamento acentual observados nas obras. Possui, certamente, no entanto, grande importância em outras esferas de significação da canção, o que pretendemos estudar em pesquisas futuras.
} 
cancionista. O seu ofício, então, seria justamente esse embate entre uma prática específica (a relação entre a melodia e a letra e a presença crucial da fala) e outras práticas que procedem das suas linguagens adjacentes (a música e a poesia, sobretudo). Ao combinar todas essas forças, o cancionista produz um material único que, se algumas vezes, distancia-se da fala, em outras ocasiões, esvazia a obra de música e de poesia.

Pois bem, voltando ao propósito deste capítulo, comecemos a delimitar melhor o nosso assunto e a observar como o nível da palavra pode nos ajudar a responder algumas das indagações acima. A conhecida canção Pelo telefone, cuja a autoria é hoje atribuída aos compositores Donga e Mauro de Almeida, possui, como se sabe, diversas versões e gravações. Analisando duas versões diferentes da letra para o mesmo trecho melódico, podemos observar algumas questões ligadas à ênfase dos vocábulos na frase.

Ai, ai, ai

É deixar mágoas pra trás, ô rapaz

Ai, ai, ai

Deixa as mágoas para trás, ô rapaz

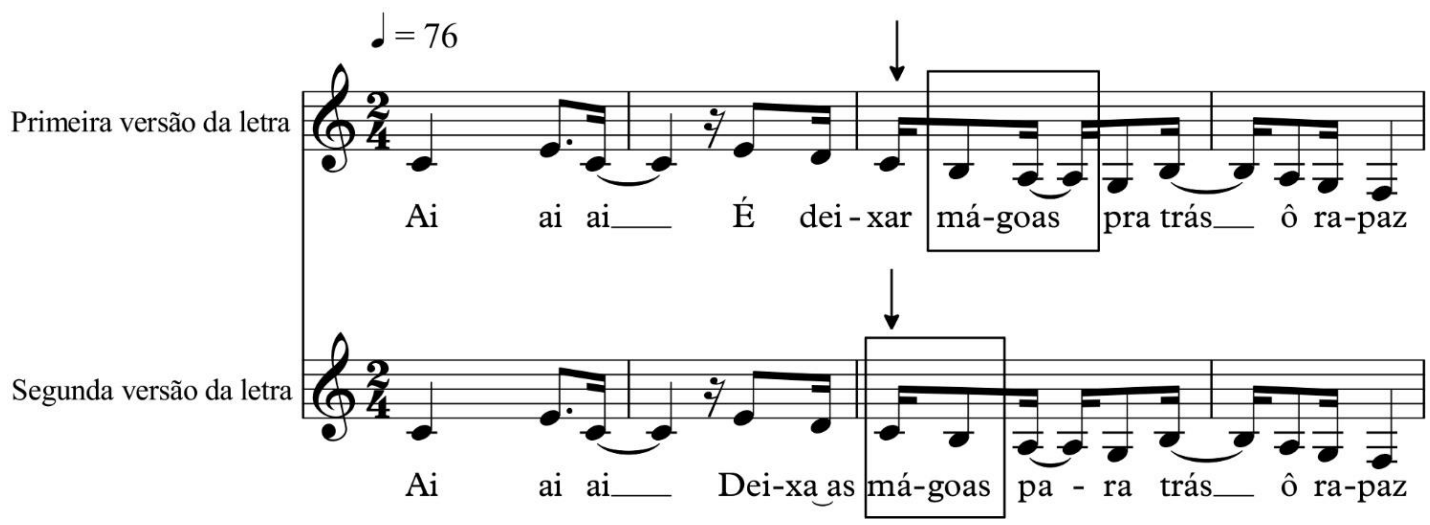

Figura 1. A ênfase na palavra em Pelo Telefone (Donga/Mauro de Almeida)

Na primeira versão da letra, Sandroni destaca que "por causa da melodia, a palavra 'mágoas' aqui é pronunciada 'maguás"” (SANDRONI, 2012: 127). De fato, observamos que a sílaba átona desse vocábulo está localizada em uma síncopa que ocupa a parte forte do segundo tempo do compasso. Notamos, então, a presença daquela força exercida pelos acentos métricos da melodia, assunto sobre o qual comentamos no capítulo precedente. Diferentemente, no segundo exemplo, a inversão dos vocábulos faz com que a frase linguística se acomode na linha melódica de uma maneira mais natural do ponto de vista entoativo. 
Entretanto, ao examinarmos esse exemplo, algo nos sugere que essa maior naturalidade obtida pela segunda versão da letra não é resultado somente do encaixe no nível da sílaba. Acreditamos que, ao antecipar a aparição do vocábulo "mágoas", posicionando a sua sílaba tônica no primeiro tempo do compasso, o cancionista valoriza, dentro da frase, uma palavra central para o sentido da sentença. A nosso ver, a segunda variante corrige, mais do que um deslocamento silábico, um deslocamento lexical. É como se pudéssemos falar sobre a tonicidade de unidades maiores, as palavras "tônicas" e "átonas" citadas acima. Isso nos leva a supor que podemos encontrar canções nas quais as sílabas que compõem uma unidade entoativa estão adequadamente acentuadas, mas, mesmo assim, sentimos uma estranheza na sua emissão (sintoma de um tipo de oralização menos linear): é quando o ponto forte da melodia não coincide com a palavra mais forte da frase. Examinemos esse fenômeno de maneira mais detida. 


\subsection{O campo de força exercido pela palavra núcleo}

A entoação, isto é, a configuração melódica definida pela voz de um falante ao pronunciar palavras, orações e períodos, possui, na língua oral, uma especial importância. Ela exerce uma função linguística significativa em nosso idioma, posto que diferentes curvas melódicas que recobrem mensagens foneticamente idênticas "podem ser interpretadas de maneira distinta pelos usuários de uma mesma língua" (CUNHA, 2017: 182). Ela realiza, então, essa função distintiva entre frases como "Ele está bem" (frase declarativa) e "Ele está bem?" (frase interrogativa). Além disso, a entoação é a responsável pelo teor emotivo das expressões linguísticas. Segundo Cunha, ao tratar do que denomina "entoação oracional", o parâmetro sonoro mais relevante para as suas modulações emocionais que encontramos na fala é a altura. O tom da voz de um falante pode agradar ou desagradar o seu interlocutor e somos capazes de reconhecer rapidamente se as suas frases possuem poucas ou muitas inflexões. No primeiro caso, identificamos uma entoação monótona ou tediosa, ou seja, que possui um só tom. No segundo caso, um discurso expressivo, com "variedade de tons e sua adequação ao pensamento" (CUNHA, 2017: 182).

A variação de altura que encontramos na língua oral, no entanto, não se dá de modo aleatório. As ascendências e descendências ocorrem, de acordo com o tipo de oração, em pontos determinados da frase. Para examinar esse assunto, é proveitoso utilizarmos as noções de grupo acentual e grupo fônico (CUNHA, 2017: 182). A primeira refere-se aos pequenos fragmentos de frase que se apoiam em um acento tônico principal. A seguir, por exemplo, podemos identificar cinco grupos acentuais: "O chefe / da polícia / pelo telefone / manda / me avisar". O artigo "o", as preposições "da" e "pelo" e o pronome "me" passam a orbitar em torno dos acentos das palavras "chefe", "polícia, "telefone" e "avisar", respectivamente.

O segundo conceito nos possibilita encontrar unidades maiores, formadas por um ou diversos grupos acentuais. Os grupos fônicos são delimitados por pausas que podem ser lógicas (aquelas que devem ser respeitadas para que o significado do texto não seja alterado), expressivas (por meio da qual o locutor pode enfatizar determinado vocábulo ou ponto específico do texto) e respiratórias (determinadas pela inspiração do locutor). No verso da canção Pelo Telefone, citado acima, as pausas nos ajudam a encontrar três grupos fônicos: "O chefe da polícia, // pelo telefone, // manda me avisar". Retomando um assunto que tratamos no capítulo anterior, podemos observar uma coincidência entre a 
noção de grupo fônico e o que chamamos de unidade melódica. De fato, segundo Cunha (2017: 182), podemos "considerar o grupo fônico o equivalente da unidade melódica", compreendida como "o segmento mínimo de um enunciado com sentido próprio e com forma musical determinada". É interessante observar, no verso da canção, como os vocábulos "polícia", "telefone" e o grupo acentual "me avisar" são destacados pelo perfil da melodia, em cada um dos três grupos fônicos. Todos se encontram em pontos mais agudos de cada unidade melódica, ao mesmo tempo em que perfazem uma descendência mais ampla que coincide com o caráter afirmativo da frase.

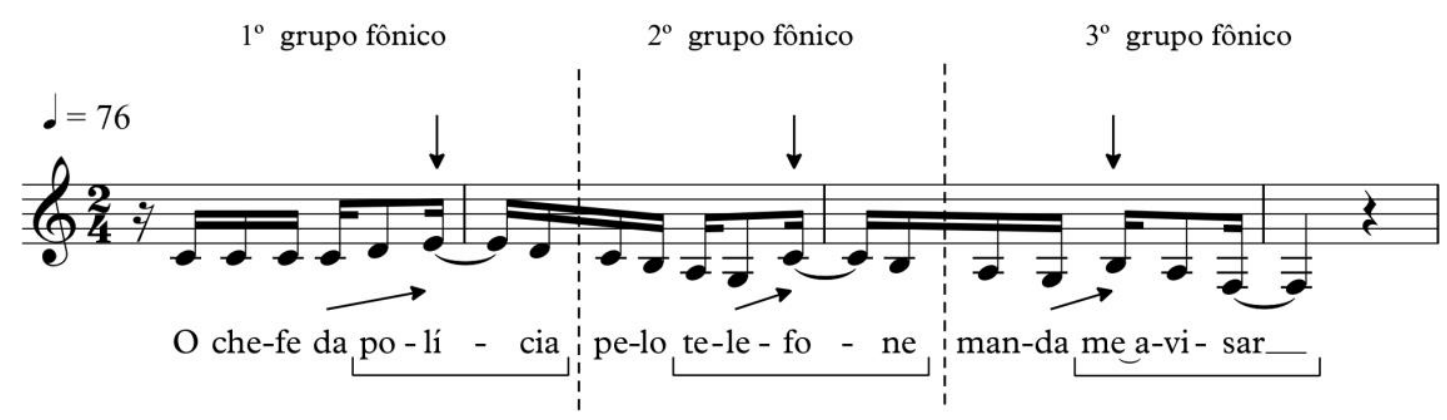

Figura 2. Os grupos fônicos em Pelo Telefone (Donga/Mauro de Almeida)

Pois bem, pensando no perfil melódico das frases, examinemos orações formadas por um único grupo fônico. Veremos que cada tipo de oração (declarativa, interrogativa ou exclamativa) pode apresentar diferentes contornos tonais. $\mathrm{Na}$ oração seguinte, exemplo apresentado por Cunha (2017:183), observamos que as sílabas tônicas das palavras principais estão posicionadas nas frequências mais agudas da curva entoativa.

\begin{tabular}{|c|c|c|l|l|l|l|l|l|}
\hline & & LU & & & GA & & TAR & \\
\hline & & & NOS & CHE & & RAM & & \\
\hline & A & & & & & & & \\
\hline OS & & & & & & & & \\
\hline & & & & & & & & DE \\
\hline
\end{tabular}

Figura 3. A curva tonal da oração declarativa

De fato, os acentos das palavras "alunos", "chegaram" e "tarde" são valorizados nos pontos mais agudos do perfil. Esse exemplo corresponde ao que examinamos no capítulo sobre a figurativização na semiótica da canção quando estudamos a definição das três fases entoativas da enunciação proposta por Navarro Tomás. Há um momento inicial ascendente que atinge um ponto culminante na primeira sílaba tônica ("alunos"). Em seguida, com algumas ondulações, o meio da frase permanece no nível de frequência 
alcançado na primeira ascendência. Por fim, o término da curva apresenta uma descendência acentuada atingindo o ponto mais grave na sílaba final (o tonema asseverativo estudado anteriormente). Eis o perfil sonoro da oração declarativa. Aqui, interessa-nos, mais do que a questão do tonema, examinarmos a parte medial da frase e os seus pontos de destaque. No exemplo abaixo, retirado da canção Geni e o Zepelim, observamos uma curva melódica muito semelhante à apresentada acima.

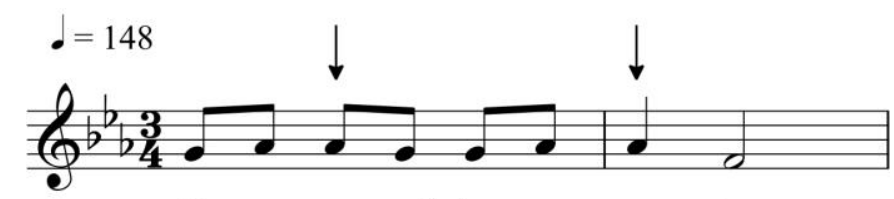

O seu cor-poé dos er - ran - tes

Figura 4. A curva tonal da oração declarativa em Geni e o Zepelim (Chico Buarque)

Do mesmo modo, as palavras "corpo" e "errantes" são mais destacadas pelo fato de as suas respectivas sílabas tônicas coincidirem com os pontos mais agudos da melodia e com posições fortes da métrica do compasso. O segundo vocábulo é ainda mais destacado por ter a sua sílaba forte acentuada no primeiro tempo do segundo compasso e apresentada com maior duração. Comparando esse trecho de Geni e o zepelim com o enunciado apresentado na figura 3 , constatamos que os perfis das frases são bastante semelhantes: uma ascendência inicial menos enfática do que a descendência final e a permanência na frequência aguda atingida pela primeira ascendência.

Em relação à oração interrogativa, há uma diferença de perfil entre aquelas que são iniciadas por pronomes (quem, o que, qual e quanto) ou advérbios interrogativos (quando, onde, como e por que) e aquelas que não apresentam esses elementos linguísticos. Comecemos pela segunda, transformando a frase analisada acima em uma pergunta: “os alunos chegaram tarde?”.

\begin{tabular}{|c|c|c|c|c|c|c|c|c|}
\hline & & & & & & & TAR & \\
\hline & & & & & GA & & & \\
\hline & & & & & & RAM & & \\
\hline & & & & CHE & & & & $\overline{\mathrm{DE}}$ \\
\hline & & LU & & & & & & \\
\hline & & & NOS & & & & & \\
\hline & A & & & & & & & \\
\hline OS & & & & & & & & \\
\hline
\end{tabular}

Figura 5. A curva tonal da oração interrogativa não iniciada por pronome ou advérbio interrogativo 
Geralmente, a resposta que esperamos após esse tipo de interrogação é sempre categórica: sim ou não. Podemos observar diferenças claras entre as orações declarativa e interrogativa. Em primeiro lugar, sendo um dado que a figura acima não é capaz de representar, visto que não delimitamos valores exatos para os patamares de frequência, devemos ressaltar que o nível tonal geral de cada oração é bem contrastante: na declarativa a região de frequência é média e baixa, na interrogativa é alta ou altíssima. Em seguida, notamos que a maior ascendência da oração interrogativa, com uma elevação muito acentuada da voz na última sílaba tônica (alcançando o ponto mais agudo do trecho), contrasta com a descendência observada na oração declarativa e com o seu campo de frequências mais restrito.

Ainda que óbvio, é muito interessante atentarmos para o fato de que uma mesma frase linguística ("os alunos chegaram tarde"), ao ser recoberta por diferentes curvas melódicas, passa a apresentar caracteres marcadamente distintos. Assim, a curva tonal é, nesse caso, a única responsável pela criação do sentido afirmativo ou indagativo da oração, o que nos possibilita concluir que "a entoação apresenta inequívoco valor funcional em nossa língua" (CUNHA, 2017: 185). Quando nos deparamos com as frases linguísticas propostas pelas canções, podemos encontrar fenômenos semelhantes, como nessa sequência de orações interrogativas que perfaz uma curva tonal muito análoga ao perfil observado na figura anterior.

\section{Olha}

Será que ela é moça?

Será que ela é triste?

Será que é o contrário?

Será que é pintura?

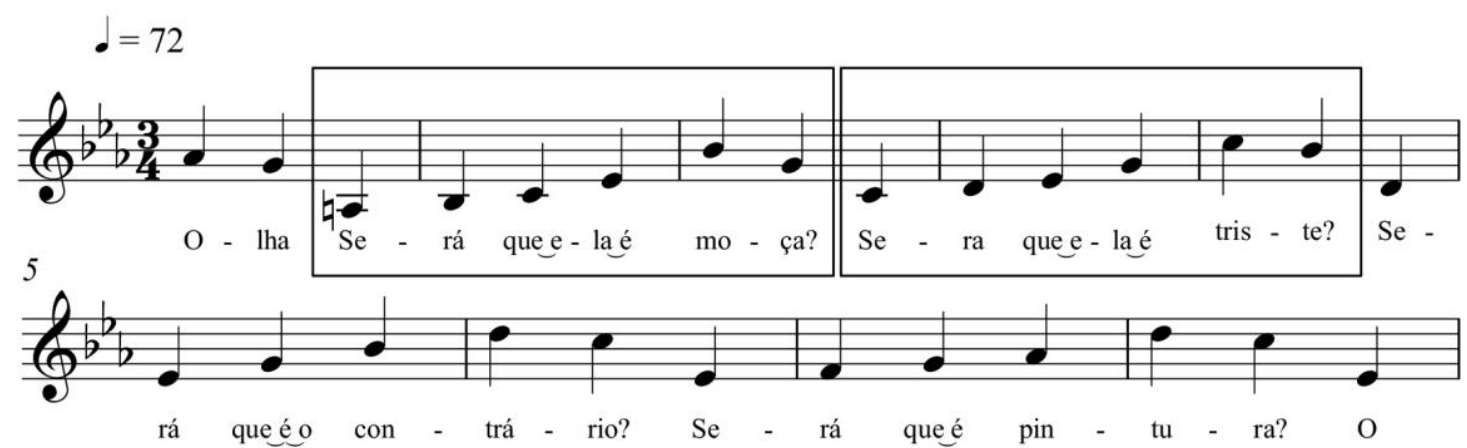

Figura 6. A curva tonal da oração interrogativa em Beatriz (Edu Lobo e Chico Buarque) 
Nas orações interrogativas iniciadas por pronome ou advérbio interrogativo a curva tonal se dá de modo muito distinto. Observemos a figura abaixo que representa os contornos de frequência da frase "como soube disto?".

\begin{tabular}{|l|l|l|l|l|l|}
\hline CO & & SOU & & & \\
\hline & MO & & BE & & \\
\hline & & & & DIS & \\
\hline & & & & & TO \\
\hline
\end{tabular}

Figura 7. A curva tonal da oração interrogativa iniciada por pronome ou advérbio interrogativo.

Nesse tipo de oração interrogativa, a entrada da frase localiza-se em um nível tonal muito elevado. Em geral, há uma elevação brusca em direção à sílaba tônica do pronome ou do advérbio que inicia o segmento e confere o sentido interrogativo da oração. No exemplo acima, posto que a sílaba tônica do advérbio "como" é justamente a primeira do vocábulo, essa elevação brusca de um ponto mais grave a um ponto mais agudo não ocorre (o que poderia ser observado com o advérbio por que, por exemplo). Após esse início em frequência elevada, a curva melódica perfaz uma descendência gradual e mais acentuada do que o caimento que notamos nas frases declarativas. Observando a ocorrência desse tipo de oração nas canções, podemos analisar o seguinte exemplo:

Como vai você?

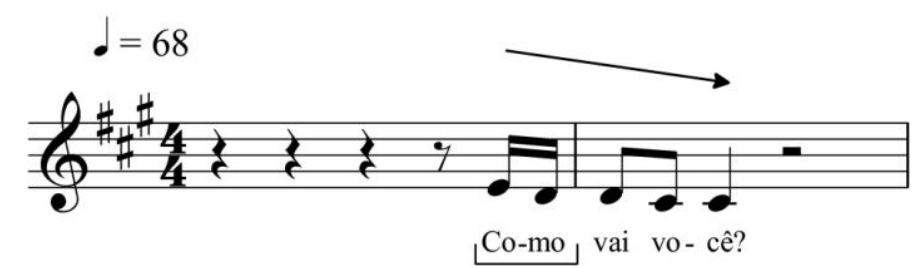

Figura 8. A curva tonal da oração interrogativa iniciada por advérbio interrogativo em Como vai você? (Antônio Marcos/Mário Marcos)

Do mesmo modo, em Como vai você?, a sílaba tônica do advérbio "como" localiza-se na nota mais aguda do segmento descendente. A alteração de frequência é bem sutil, na medida em que a frase se desenrola por meio de graus conjuntos (Mi-Ré-Dó), 
mas essa configuração já é suficiente para destacar o advérbio interrogativo e produzir o sentido indagativo da oração.

Ambas as orações, "Os alunos chegaram tarde?" e "Como soube disto?", constituem interrogações diretas. Caso transformássemos a segunda oração em uma interrogação indireta, por exemplo, com a frase "Diga-me como soube disto", a sua curva tonal passaria a ser muito semelhante à da oração interrogativa iniciada por advérbio. Observaríamos, então, um ataque em nível alto (Diga-me) e um declínio progressivo da melodia até o término do segmento. O patamar de frequência geral da frase, no entanto, seria mais grave do que o da interrogação direta.

As orações interrogativas iniciadas por advérbio ou pronome, ao posicionarem esses termos em pontos de destaque sonoro, explicitam o fenômeno entoativo sobre o qual gostaríamos de nos debruçar neste capítulo: o realce de determinados vocábulos em detrimento de outros. Certas variações, é claro, são perfeitamente plausíveis e poderão enriquecer a nossa abordagem. Tatit, em A Canção: Eficácia e Encanto, ao analisar a curva melódica em casos de interrogação seleciona um exemplo muito próximo ao fragmento que utilizamos acima, mas com perfil tonal diverso. Trata-se da canção Como vaes você? de Ary Barroso. Nela, a curva melódica que recobre a frase "Como vaes você?”, verso similar à letra do nosso último exemplo, destaca o verbo ir (conjugado na segunda pessoa do presente do indicativo, mas sem a grafia habitual "vais") e não o advérbio interrogativo "como".

No caso da interrogação, o processo também se desenvolve na esteira do discurso coloquial. A melodia sempre se eleva exatamente no termo sobre o qual incide a pergunta (...) No ex. 85 , o cerne da questão incide sobre "estar indo" ou "estar passando" bem ou mal. Daí o acento sobre "vaes" (TATIT, 1986: 43-44)

Esse fenômeno de destaque dos vocábulos que possuem um peso semântico maior na significação de uma frase é incorporado pela canção desde os tempos mais remotos. Voltando às peças pertencentes ao início da música ocidental, o chamado cantochão (ou canto gregoriano) ao qual nos dedicamos no início desta tese, observamos que os compositores possuíam essa mesma preocupação ao ressaltarem termos linguísticos relevantes por meio da altura.

Na maioria dos casos a linha melódica tem a forma de um arco: começa em baixo, eleva-se até um ponto mais alto, onde permanece por algum tempo, e volta a descer no final da frase. 
(...) Configuração melódica menos frequente, característica das frases que começam por uma palavra excepcionalmente importante, é a que se inicia com uma nota aguda, descendo depois gradualmente até o fim. (GROUT \& PALISCA, 2007:61)

Por último, na oração exclamativa, as características da curva melódica dependerão de muitos fatores, "especialmente do grau e da natureza da emoção de quem fala” (CUNHA, 2017: 187). Essa carga emocional é então a responsável pela alteração dos parâmetros sonoros (altura, duração, intensidade e timbre) em palavras monossilábicas (“Oh!”, “Ah!”, “Sim!” etc.) ou polissilábicas (“Maravilha!”, “Conseguimos!” etc.), nas quais a ênfase pode recair na sílaba que possui o acento de insistência (assunto tratado no capítulo anterior) ou na que possui o acento natural do vocábulo. A questão da oração exclamativa nos interessa de modo particular pelo fato de ela explicitar mais fortemente, no interior de uma frase, a presença de palavras com maior ou menor conteúdo expressivo.

\footnotetext{
Maior variedade em matizes de entoação encontramos, naturalmente, nas frases exclamativas constituídas de duas ou mais palavras. A curva melódica dependerá sempre da posição da palavra de maior conteúdo expressivo, porque é sobre a sua sílaba acentuada que irão incidir o tom agudo, a intensidade mais forte e a maior duração. Como a sílaba forte da palavra de maior valor expressivo pode ocupar a posição inicial, medial ou final da oração, três soluções devem ser consideradas (...) (CUNHA, 2017: 188)
}

O autor ilustra, então, cada uma das três possibilidades entoativas ligadas à oração exclamativa. Na primeira, observamos a sílaba inicial enfatizada no agudo e, em seguida, uma entoação descendente: "Deus me livre e guarde!". Na segunda, quando o vocábulo de maior valor expressivo ocupa posição final, a oração vem acompanhada de uma entoação ascendente em direção à sua sílaba tônica: "Você é meu grande amor!". Quando a posição da palavra mais expressiva é no centro da oração, a curva tonal traça um perfil ascendente até a sua sílaba forte e descendente depois dela: "Sai da frente, rapaz!".

Como veremos ao longo deste capítulo, a reflexão acerca das variadas possibilidades de ênfase sonora dos vocábulos de maior valor expressivo nos diferentes tipos de oração nos auxiliará no exame da combinação entre a melodia e a letra da canção, agora no nível da palavra. Assim como estudamos a maior ou a menor ênfase melódica sobre a sílaba tônica que compõe um vocábulo, analisaremos o maior ou o menor destaque musical sobre a palavra tônica que compõe uma frase. É como se pudéssemos estabelecer 
uma correspondência entre a estrutura de ênfases e abrandamentos que constatamos na configuração sonora de um vocábulo e a estrutura que encontramos na entoação de uma frase: "Enfim a entoação reflete e expressa nossos pensamentos e sentimentos. Se o acento é a 'alma da palavra', devemos considerá-la a 'alma da oração'” (CUNHA, 2017: 189).

O cancionista, de modo intuitivo, além de se preocupar com a "alma da palavra", evitando desvios de acentuação que comprometam o seu projeto entoativo no nível da sílaba, também está atento às coincidências entre os pontos de destaque da frase melódica e os vocábulos de maior valor expressivo. Voltando ao nosso primeiro exemplo, a canção Pelo Telefone, apresentamos abaixo uma ilustração com as indicações do que acreditamos ser os pontos fortes da frase, ainda sem a presença da letra.

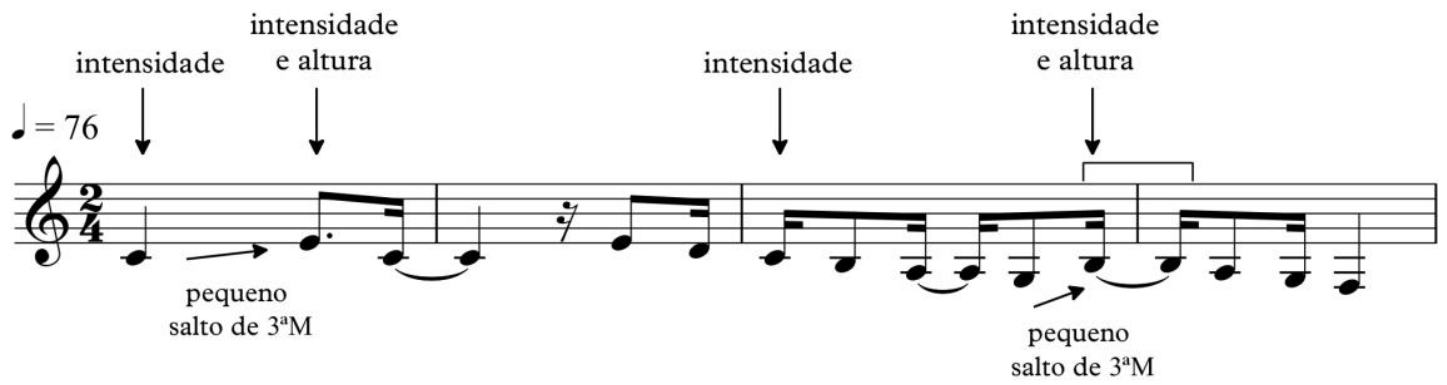

Figura 9. Os pontos fortes na melodia de Pelo Telefone

É importante sublinhar que a definição dos pontos de apoio das frases melódicas é uma parte importante do trabalho do cancionista. Cantarolando a melodia transcrita acima, o compositor poderia identificar posições destacadas pela intensidade (caso dos tempos fortes dos compassos 1 e 3 ) e pela altura e intensidade (quando temos os pequenos saltos intervalares de $3^{\mathrm{a}}$ maior, conforme indicamos na figura). Amparando-se na sua experiência cotidiana com a língua oral, o cancionista tentará acomodar as regiões de destaque da frase linguística aos pontos sonoros mais enfáticos da melodia. Na versão da letra apresentada a seguir, acreditamos que a combinação entre texto e música apresenta um resultado satisfatório do ponto de vista da naturalidade oral. 


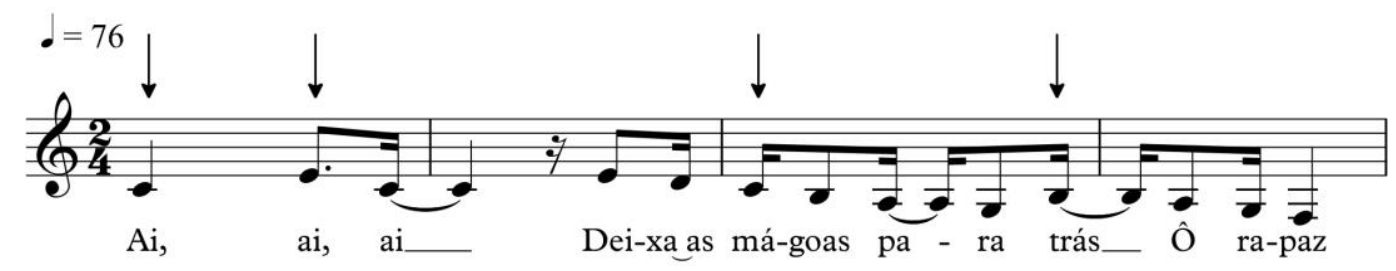

Figura 10. O recorte da letra e sua relação com os pontos fortes na melodia de Pelo Telefone

A sequência formada pelas palavras monossilábicas (“Ai, ai, ai”) recebe uma ênfase coerente com o seu valor expressivo de exclamação. Além disso, os vocábulos "mágoa" e "trás", núcleos de sentido da frase linguística são também convenientemente destacados pela linha melódica. Parece-nos, então, que a melodia, quando apresenta certa direcionalidade acentual (demarcada pela métrica do compasso ou por uma ascendência de frequência combinada a essa métrica, entre outros fatores), exige cuidado especial com o arranjo dos elementos linguísticos que a recortarão. Quando há coincidência entre as regiões de destaque de ambos, a mensagem transmitida pela letra parece chegar de modo mais direto ao ouvinte.

Já não tenho dedos pra contar

De quantos barrancos despenquei

E quantas pedras me atiraram

Ou quantas atirei

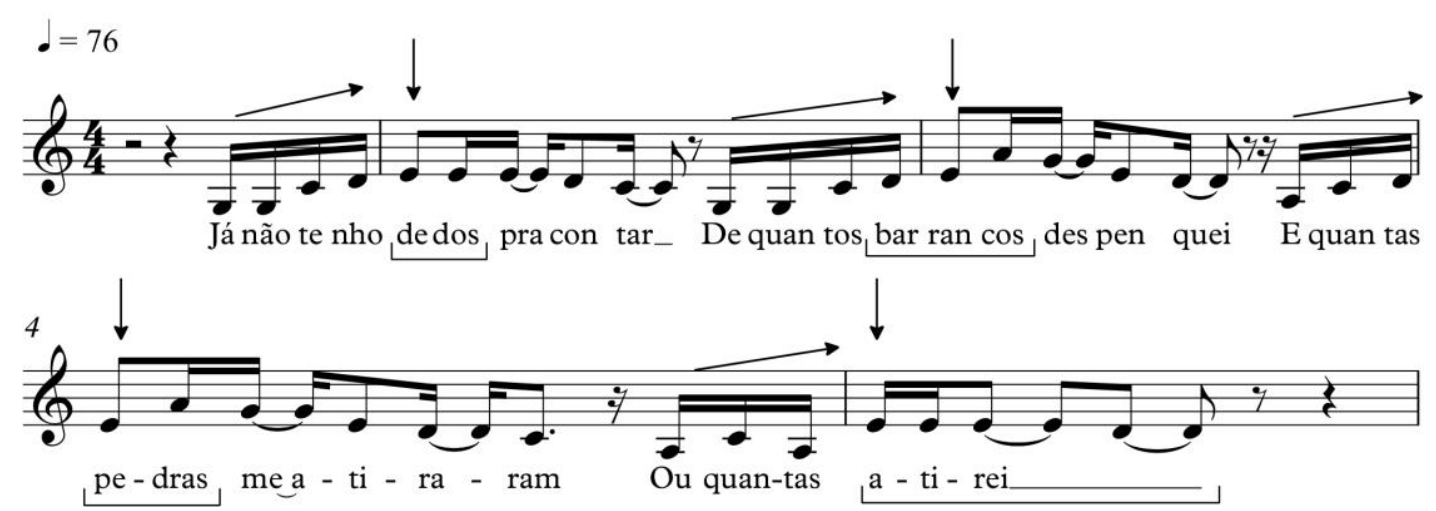

Figura 11. A acentuação lexical em Tudo Bem (Lulu Santos)

Os pontos de ênfase melódica localizados sobre as palavras "dedos", "barrancos" e "pedras", vocábulos nucleares dentro de suas respectivas orações, são atingidos por meio de uma sequência de notas curtas ascendentes que levam diretamente para o acento métrico mais forte do compasso. Na música, como já comentamos, chamamos de 
anacruse o conjunto de notas que precedem o primeiro tempo do compasso inicial de uma peça. Aqui, é como se tivéssemos quatro anacruses que se direcionam para o tempo forte inicial de cada compasso, como um campo de força exercido pela nota mi (cujas ocorrências estão destacadas com setas na figura acima). Nesse caso, no nível da palavra, a letra satisfaz perfeitamente as exigências acentuais da melodia.

Outros exemplos interessantes para o exame da combinação entre letra e melodia a partir desse jogo de forças entre os pontos de destaque de cada uma dessas esferas, são aqueles em que encontramos palavras compostas ou expressões formadas por mais de um termo. Dois substantivos como "samba" e "enredo", por exemplo, podem se unir para formar o substantivo composto "samba-enredo". Nesse caso, a ênfase entoativa concentra-se na sílaba tônica do segundo termo. O acento da palavra "samba", em consequência, perde força em prol da ênfase da palavra principal da expressão. Na gramática da língua portuguesa esse assunto é estudado por meio do conceito de próclise, quando observamos a presença de um vocábulo átono subordinado a um vocábulo seguinte cujo acento tônico prevalece sobre o anterior. São exemplos de próclise, como vimos anteriormente, os artigos e preposições monossilábicos que formam com a palavra seguinte um todo fonético apoiando-se em seus acentos tônicos ("O Francisco", "do Francisco" etc.). Mas não apenas os monossílabos. Casos proclíticos como "Senhor Francisco" apresentam o mesmo fenômeno. O primeiro termo perde o seu acento tônico em prol da ênfase no segundo componente e pode até mesmo sofrer contrações significativas: "Senhor Francisco" transforma-se, então, em "Seu Francisco". Do mesmo modo, na canção, expressões como "querer bem", "rubro-negro", "norte-americano" e "São Paulo", nas quais o primeiro termo se subordina ao acento tônico do termo seguinte, devem ser combinadas com uma linha melódica que favoreça essa conformação acentual peculiar. Vejamos a ocorrência desses exemplos em obras de nosso cancioneiro.

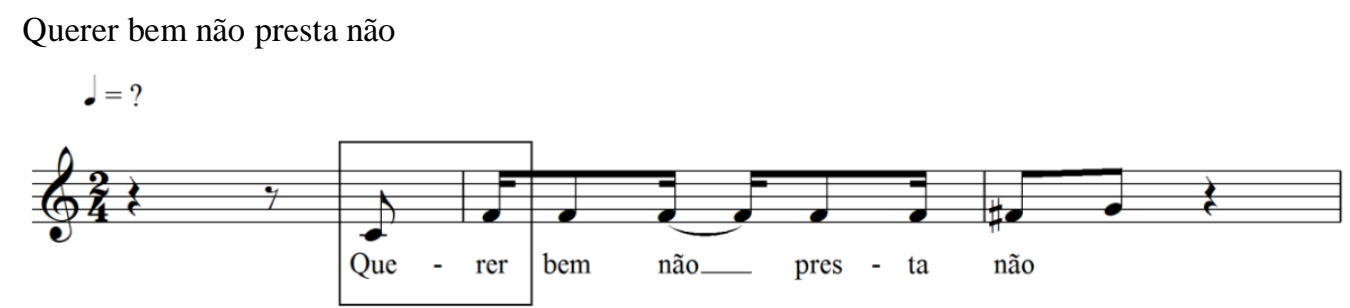

Figura 12. Deslocamento da acentuação lexical em Modinha (Domingos Caldas Barbosa) 
Examinemos a presença da expressão "querer bem" nessa modinha atribuída ao compositor Domingos Caldas Barbosa, obra que também compõe os manuscritos Modinhas do Brazil, documento anônimo do século XVIII ${ }^{108}$. Sob o ponto de vista da acentuação silábica, não parece haver desvios prosódicos significativos: a sílaba tônica do vocábulo "querer" coincide justamente com o tempo forte do segundo compasso (ainda que a sua sílaba átona "que" possua certo destaque tendo em vista a duração mais alongada). No entanto, pensando nos pontos de destaque no nível da palavra, há um significativo estranhamento entoativo, a nosso ver, decorrente da indivisibilidade da expressão linguística "querer bem". Isto é, quando a reproduzimos na língua oral, acentuamos o segmento "bem", como se emitíssemos uma única palavra oxítona “quererbem". Em consequência, quando a melodia acentua a sílaba "rer", sentimos um desvio prosódico na emissão desse todo fonético. O mesmo ocorre com os adjetivos compostos "rubro-negro" e "norte-americano" nas canções de Djavan e Caetano Veloso, respectivamente.

Mesmo quando ele não vai bem

Algo me diz em rubro-negro

Que o sofrimento leva além

Não existe amor sem medo

Boa noite

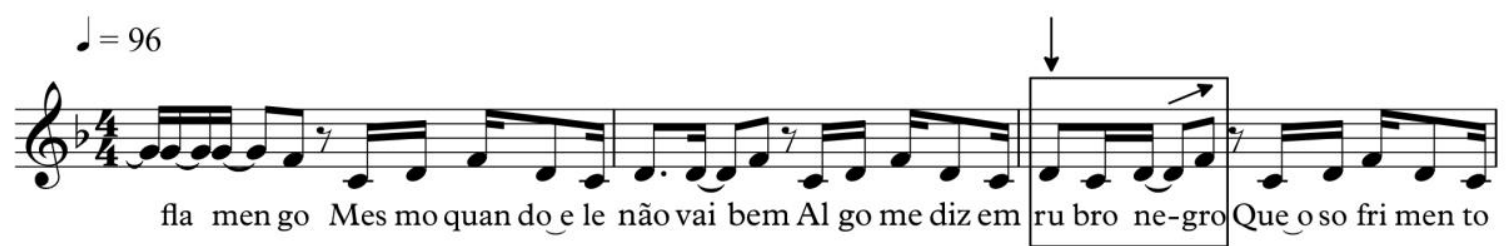

Figura 13. Deslocamento da acentuação lexical em Boa Noite (Djavan)

Eu sou um preto norte-americano forte

Com brinco de ouro na orelha

108 Como já dissemos, Carlos Sandroni não identifica de modo preciso a numeração dessa modinha (SANDRONI, 2012: 51). 


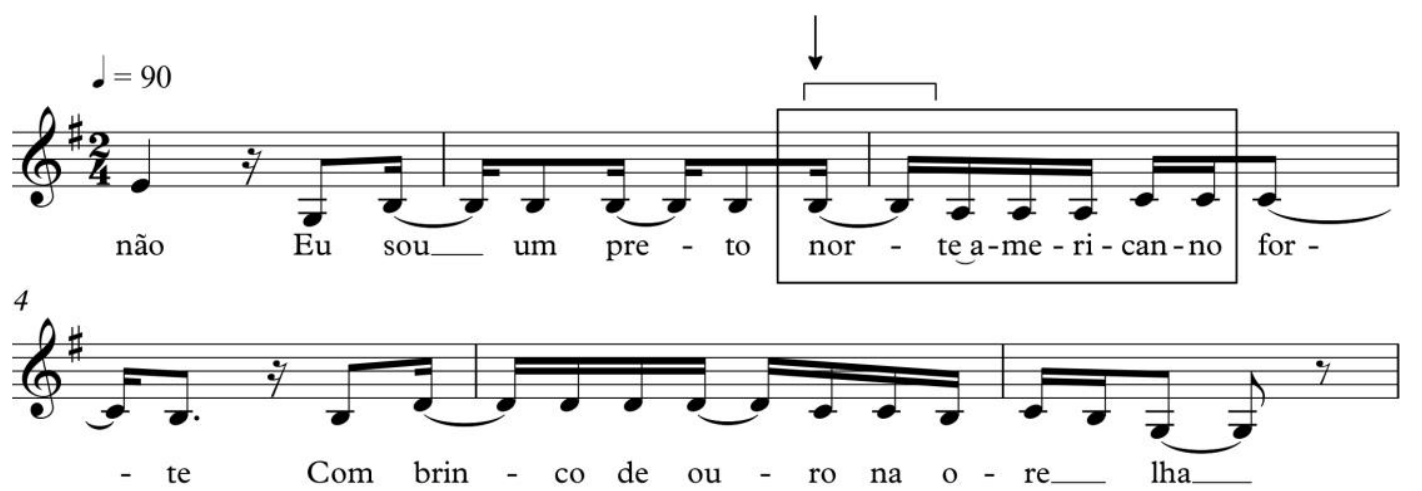

Figura 14. Deslocamento da acentuação lexical em Reconvexo (Caetano Veloso)

No primeiro exemplo, o corpo fonético formado pelas palavras "rubro" e "negro" é mais comumente entoado na língua oral com o acento no segundo vocábulo. Em Boa Noite, no entanto, a ênfase recai sobre a sílaba tônica da palavra "rubro", no primeiro tempo forte do terceiro compasso. Além disso, nesse exemplo, há também uma acentuação da sílaba átona de "negro" na medida em que temos um pequeno salto intervalar de $3^{\mathrm{a}}$ menor realçando a sílaba "gro". O segundo exemplo, Reconvexo, apresenta um fenômeno ainda mais interessante. Nele, as acentuações silábicas de todos os vocábulos que compõem a frase "Eu sou um preto norte-americano forte" estão intactas. Contudo, ao passarmos para o exame no nível da palavra, assunto deste capítulo, notamos um desvio acentual que enfatiza, no adjetivo composto "norte-americano", mais o primeiro do que o segundo vocábulo. Esse exemplo é significativo uma vez que explicita o fato de o problema entoativo encontrar-se no nível da palavra e não no da sílaba. Expliquemos. Na língua oral, ao falarmos essa expressão, é mais comum enfatizarmos o vocábulo "americano", visto que o acento tônico de "norte", seguindo o fenômeno proclítico, tende a se subordinar ao acento do termo seguinte. Nessa canção, diferentemente, o compositor prioriza o interessante efeito sonoro do desenho melódico (que propõe as síncopes nos tempos fortes do compasso) em detrimento da emissão mais oral da letra. Examinemos os próximos dois exemplos.

\section{Lá, em Vila Isabel}

Quem é bacharel

Não tem medo de bamba

São Paulo dá café

Minas dá leite

E a Vila Isabel dá samba 

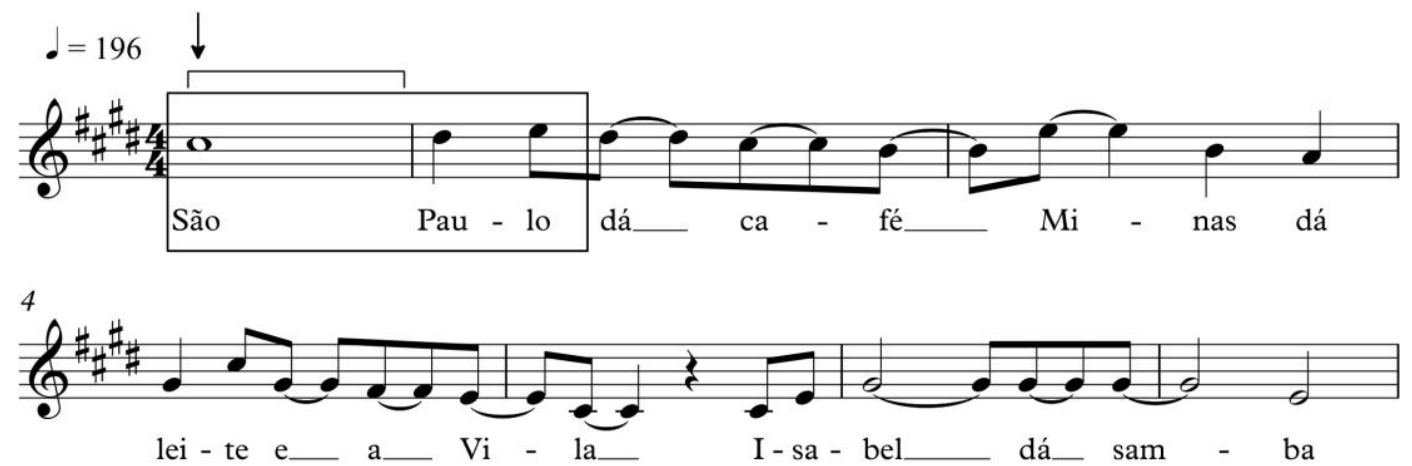

Figura 15. Deslocamento da acentuação lexical em Feitiço da Vila (Vadico/Noel Rosa)

Essa desmesura de paixão

É loucura de coração

Minha Foz do Iguaçu

Polo Sul, meu azul

Luz do sentimento nu

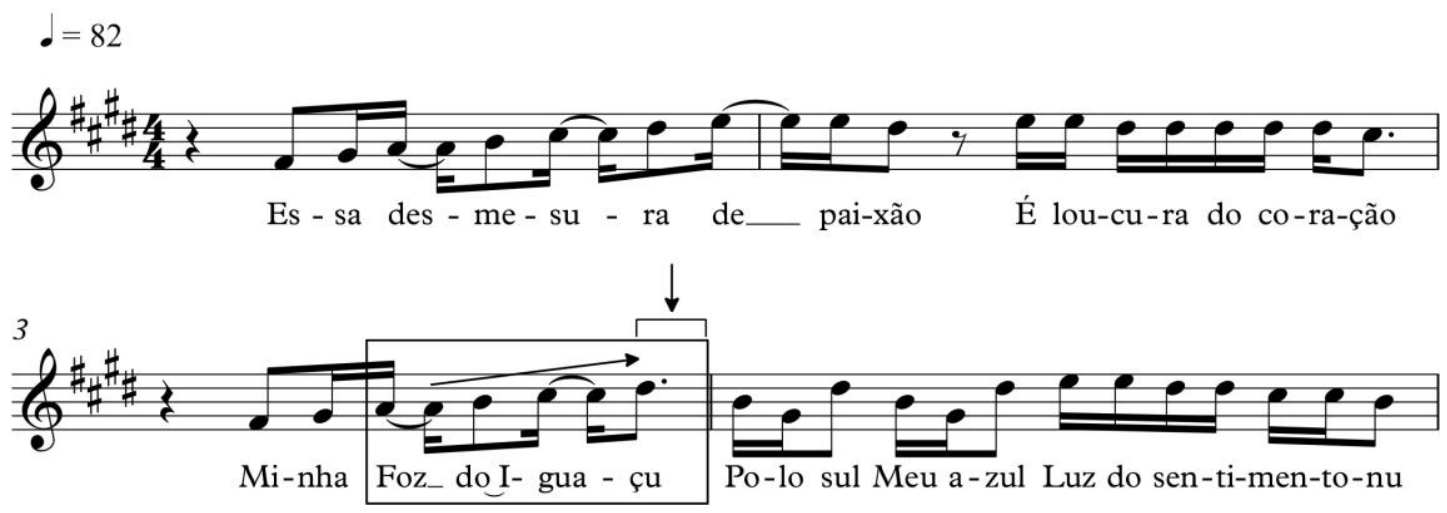

Figura 16. A acentuação lexical em Linha do Equador (Djavan/Caetano Veloso)

Em Feitiço da Vila, a emissão do substantivo próprio composto "São Paulo" parece constituir uma oralização não-linear. Ainda que a sílaba tônica do segundo termo seja convenientemente acentuada, observamos a concessão de uma ênfase excessiva ao primeiro vocábulo "São". A melodia o acentua no primeiro tempo forte do compasso e lhe concede uma duração longuíssima (a semibreve do primeiro compasso). Nesse caso, esse realce inusual gera um evidente desmembramento da expressão "São Paulo". Há um demasiado afastamento dos dois termos que, na língua falada, são emitidos como um único corpo fonético.

Em contraposição, na canção Linha do Equador, podemos observar uma entoação mais falada do substantivo "Foz do Iguaçu”. A sílaba tônica do segundo termo, “çu”, é o 
ponto culminante de uma melodia ascendente formada por graus conjuntos (Fá\#-Sol\#Lá-Si-Dó\#-Ré\#) e apresenta uma duração mais alongada do que as notas precedentes. Evidentemente, como estudamos na parte inicial desta tese, a entoação na canção jamais corresponderá à fala de modo fiel, na medida em que ela trabalha em conjunto com as questões melódicas propostas pelo cancionista. Pois bem, o trecho destacado de Linha do Equador é um bom exemplo dessa complexa conjugação entre a língua e a música. Assim, se por um lado, o segundo termo é convenientemente acentuado, por outro, acreditamos que a palavra inicial "foz" apresenta-se mais apagada do que o desejável. Isto é, na fala, sem alterar a proeminência do acento no vocábulo "Iguaçu", o termo "foz" recebe também uma certa ênfase. Na melodia dessa canção, no entanto, sua presença é por demais mitigada. 


\subsection{A alteração da acentuação lexical}

O que observamos acima nos permite, de certo modo, pensar em um possível fenômeno de deslocamento da "acentuação lexical" no interior da frase, assim como estudamos o desvio de acentuação silábica no interior da palavra. É quando a linha melódica e seus pontos de destaque coincidem com os acentos silábicos da letra, mas enfatizam vocábulos secundários da oração. São oralizações não-lineares ligadas ao nível da palavra. Trata-se, provavelmente, de um evento muito mais sutil e menos frequente do que a questão silábica. Contudo, cremos que esse tipo de análise contribui de maneira significativa para a discussão que empreendemos ao final do capítulo anterior acerca do mistério do encaixe natural entre a letra e a melodia, mistério que acreditamos tornar-se menos obscuro após essas análises. Passemos, nesse momento, ao estudo de outras conhecidas canções.

\section{Longe da felicidade}

E todas as suas luzes

Te desejo como ao ar

Mais que tudo

És manhã na natureza das flores

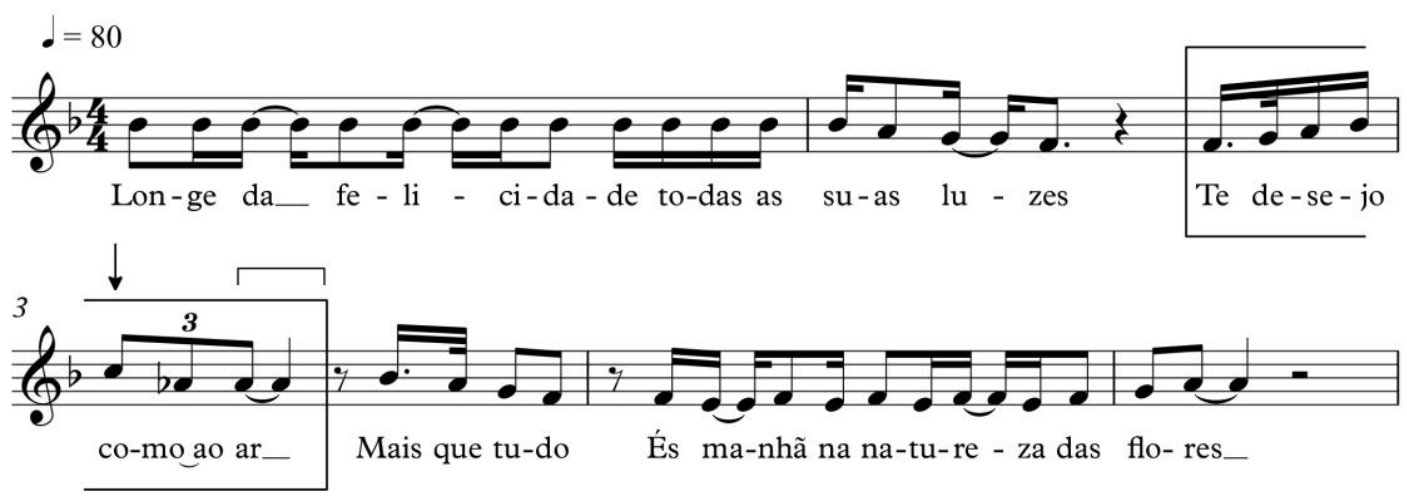

Figura 17. Deslocamento da acentuação lexical em Nem um Dia (Djavan)

Percebemos claramente que na frase destacada acima "Te desejo como ao ar" não há qualquer deslocamento em relação às acentuações silábicas. No nível da palavra, no entanto, a ênfase usual deveria recair sobre a palavra "ar" e não sobre a conjunção comparativa "como" (cuja sílaba tônica coincide com o tempo forte do terceiro compasso, além de ser também a culminância de frequência de uma linha melódica ascendente). A palavra "ar", após essa ênfase direcionada ao vocábulo "como" fica por demais apagada no contexto sonoro da frase. Esses destaques lexicais, assim como as acentuações 
silábicas analisadas no capítulo precedente, também podem ser gerados pela predominância de um só parâmetro sonoro ou pela ação simultânea de todos eles. Nos dois exemplos seguintes, acreditamos que a melodia realça de modo incomum vocábulos linguisticamente periféricos por meio da intensidade. Vejamos.

Um dia surgiu, brilhante

Entre as nuvens, flutuante

Um enorme zepelim

Pairou sobre os edifícios

Abriu dois mil orifícios

Com dois mil canhões assim
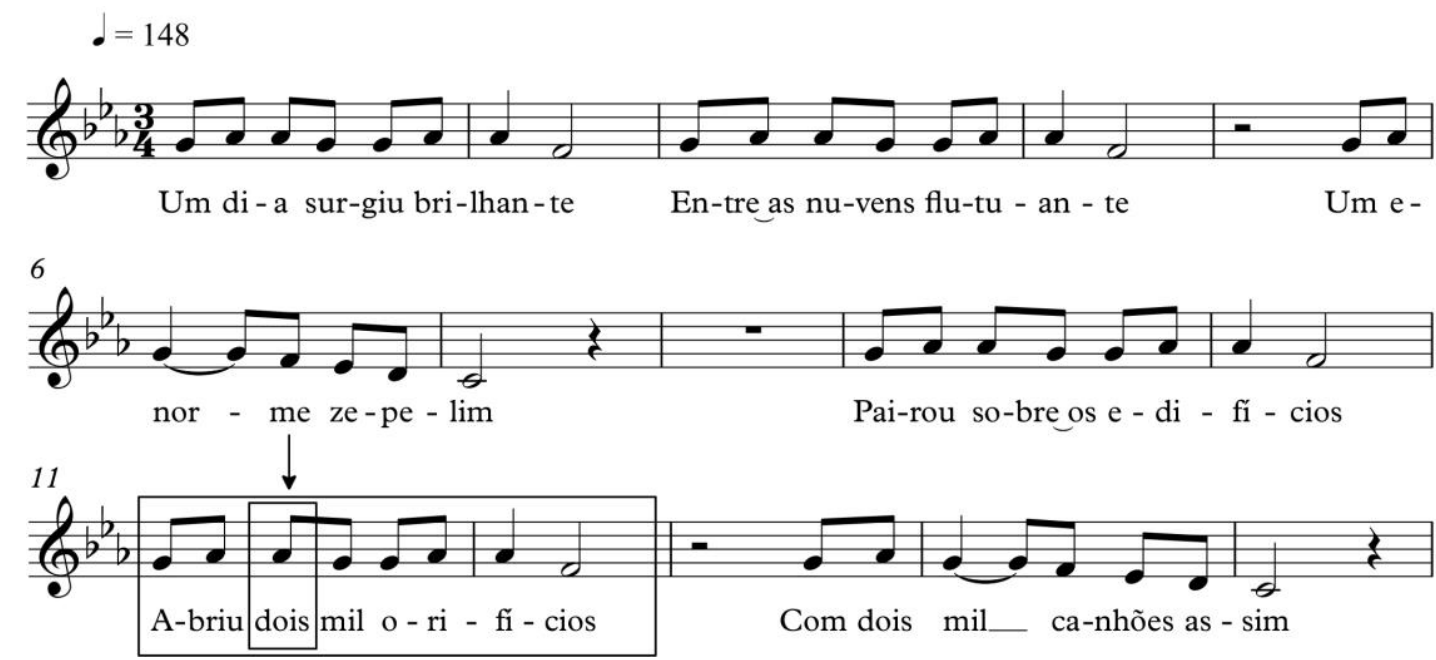

Figura 18. Deslocamento da acentuação lexical em Geni e o Zepelim (Chico Buarque)

Quando você for convidado pra subir no adro

Da fundação casa de Jorge Amado

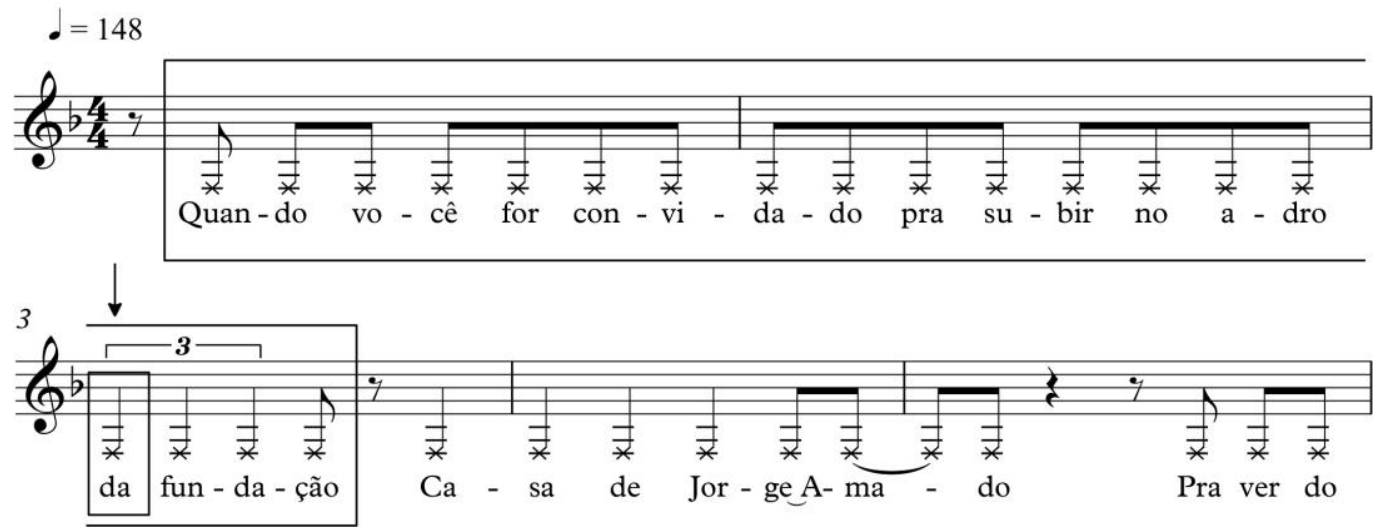

Figura 19. Deslocamento da acentuação lexical em Haiti (Gilberto Gil/Caetano Veloso) 
Em Geni e o Zepelim, a melodia que recobre a frase verbal "Abriu dois mil orifícios" além de gerar um desvio silábico na palavra “abriu” (já mencionado no capítulo anterior), enfatizando a sua sílaba átona, produz igualmente, no nível lexical, uma oralização inesperada ao realçar a palavra "dois", posicionando-a na parte forte do segundo tempo do compasso. Nesse momento, independentemente das questões estéticas pretendidas pelo compositor, desejamos somente identificar uma construção entoativa incomum e notar que ela decorre do fato de esse vocábulo fazer parte de um corpo fonético maior, “dois mil”, no qual o segundo termo é o que possui acento preponderante. Em Haiti, a linha melódica, dessa vez com o parâmetro altura de certa forma neutralizado, também enfatiza um vocábulo secundário da oração. Aqui, ouvimos maior destaque sobre a preposição "da" (que recai sobre o tempo forte do compasso) do que sobre o termo principal "fundação", o que contribui para que o trecho seja realizado de modo menos usual. No próximo exemplo, além da intensidade, outros parâmetros contribuem para a alteração da acentuação lexical.

Vai trabalhar, vagabundo

Vai trabalhar, criatura

Deus permite a todo mundo uma loucura

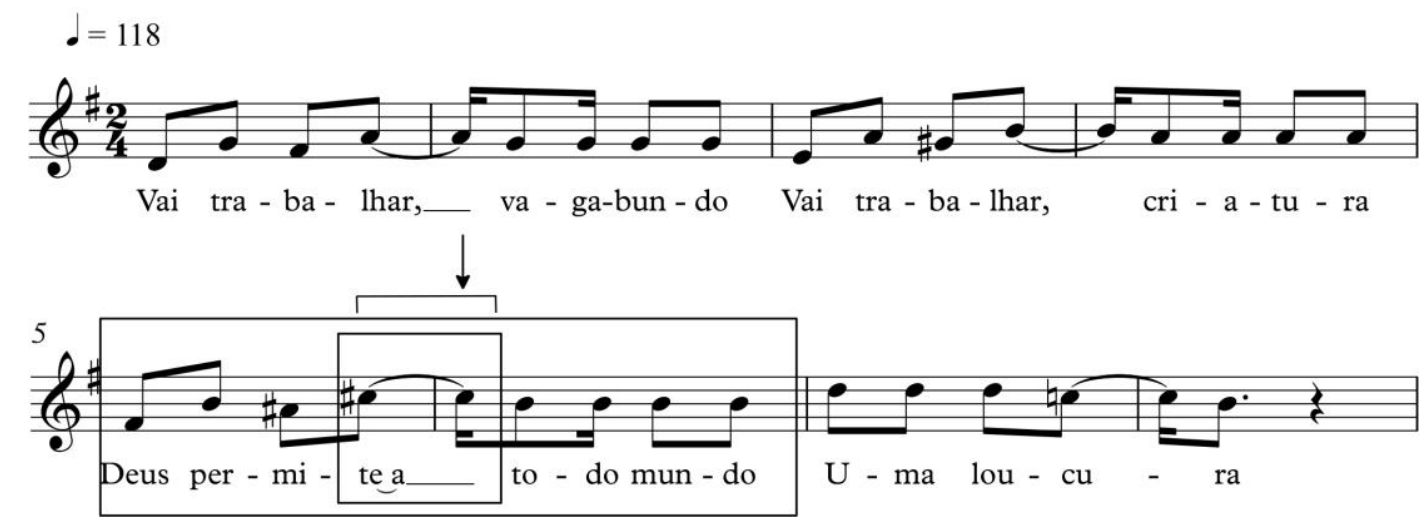

Figura 20. Deslocamento da acentuação lexical em Vai trabalhar, Vagabundo (Chico Buarque)

As primeiras frases dessa canção firmam para o ouvinte um desenho melódico que enfatiza a quarta nota da sequência, o que se compatibiliza com os versos "Vai trabalhar, vagabundo" e "Vai trabalhar, criatura". Essa ênfase é ao mesmo tempo produzida pela altura, pela duração e pela intensidade: a quarta nota de cada unidade melódica é sempre a mais aguda do trecho, dura mais do que as demais (uma colcheia pontuada) e ocupa o espaço da síncope para o primeiro tempo forte do compasso. Desse modo, quando 
ouvimos o terceiro verso da estrofe ("Deus permite a todo mundo"), sentimos uma ênfase incomum sobre preposição "a" que coincide justamente com a quarta nota da frase. Não sendo um vocábulo nuclear da oração, essa combinação entre letra e melodia configura um tipo de figurativização não-linear e, ao mesmo tempo, preserva o seu aspecto tematizante, ao manter o perfil rítmico-melódico intacto ${ }^{109}$. No exemplo seguinte, o deslocamento lexical deve-se à intensidade e à duração, com certa neutralidade do parâmetro altura.

\section{Diz-lhe numa prece}

Que ela regresse

Porque eu não posso mais sofrer

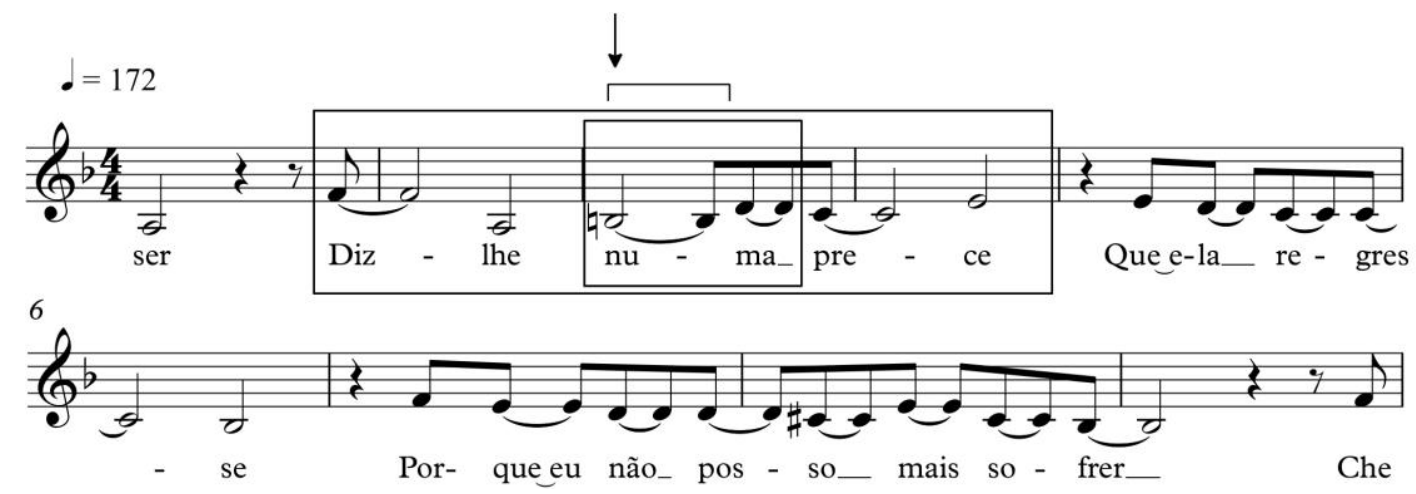

Figura 21. Deslocamento da acentuação lexical em Chega de Saudade (Tom Jobim/Vinicius de Moraes)

A oração "Diz-lhe numa prece", na língua falada, em geral, recebe destaque nos vocábulos "diz" e "prece". A palavra "numa", contração entre a preposição "em" e o artigo indefinido "uma", possui um papel acentual secundário, juntando-se ao termo seguinte e formando o corpo fonético "numa prece", no qual predomina o acento do segundo vocábulo. Na canção acima, no entanto, a sílaba tônica de "numa" recebe significativo relevo por meio da intensidade (tempo forte do terceiro compasso) e da duração (uma mínima ligada à uma colcheia). O fato de as palavras principais "diz" e "prece" também receberem destaque impede que o estranhamento oral produzido pela ênfase em "numa" seja excessivo. Todavia, quando transformamos a melodia ou a letra alterando alguns desses parâmetros sonoros, observamos o quanto a passagem poderia aumentar o seu teor de oralidade (e, como natural consequência, diminuir a sua característica musical reiterativa).

\footnotetext{
109 Além disso, acreditamos que a elisão entre a última sílaba de "permite" e a preposição "a" contribui ainda mais para a perturbação oral do trecho.
} 


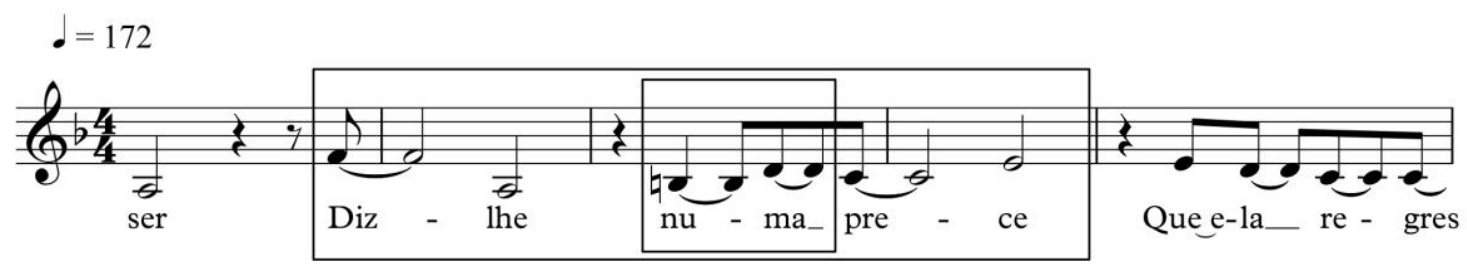

Figura 22. Alteração melódica em Chega de Saudade (Tom Jobim/Vinicius de Moraes)

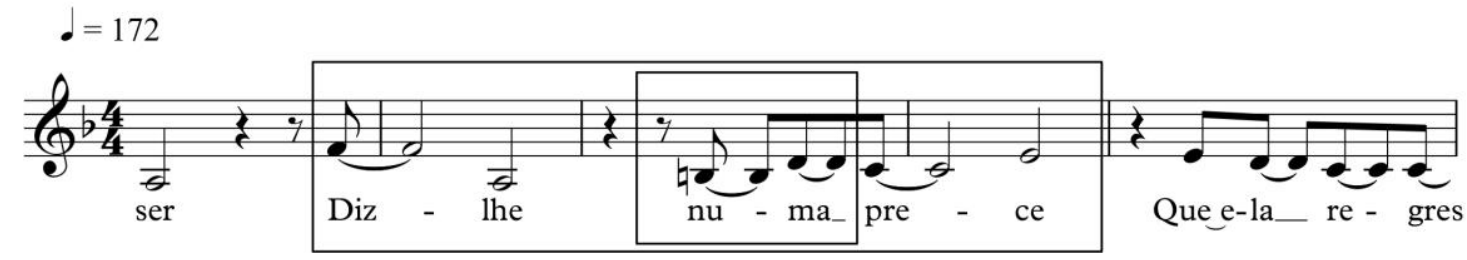

Figura 23. Alteração melódica em Chega de Saudade (Tom Jobim/Vinicius de Moraes)

Nas duas figuras acima, preservamos a letra original da canção e reposicionamos o ataque da palavra "numa" para que ele não coincidisse com o tempo forte do compasso $^{110}$. Na primeira ilustração, atrasamos a sua ocorrência em uma unidade de tempo. Na segunda, em uma unidade e meia, o que nos parece uma solução mais próxima da oralidade, uma vez que o vocábulo "numa" perderia ainda mais destaque em favor da palavra principal "prece”. Essas alterações, contudo, provocam a modificação de um padrão melódico que parece ser caro aos compositores, visto que esse motivo se repete muitas vezes ao longo da canção. São as três primeiras notas destacadas abaixo.

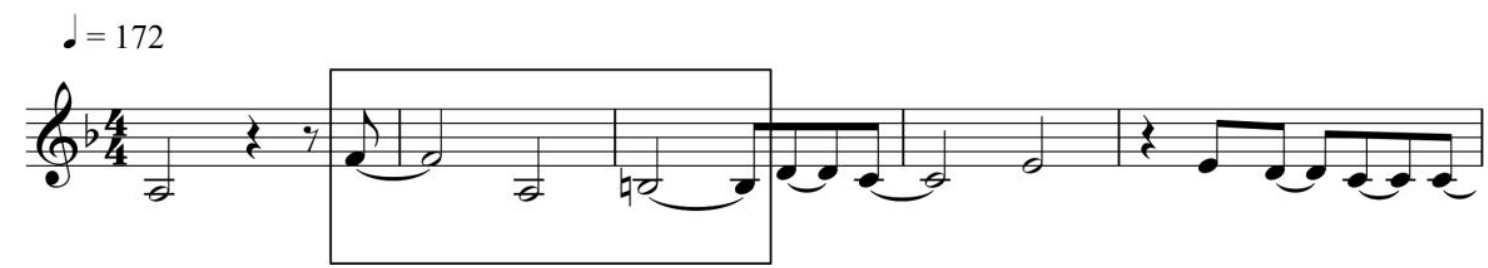

Figura 24. O motivo melódico inicial em Chega de Saudade (Tom Jobim/Vinicius de Moraes)

Esse motivo recobre diversas versões de letra nessa canção. Os versos "Vai, minha tristeza", "Diz-lhe numa prece", "Chega de saudade" e "Dentro dos meus braços" recaem sobre essa mesma configuração rítmico-melódica (as notas podem se alterar, mas a

\footnotetext{
110 Assim como comentamos anteriormente, esses testes nos quais fazemos alterações linguísticas ou melódicas são recursos técnicos por meio dos quais podemos avaliar as variações possíveis de sentido no contexto cancional. Isso não significa que os compositores, ao adotarem essas mudanças, serão mais exitosos em sua atividade. Proposições de modos de dizer mais ou menos usuais apenas delineiam características composicionais distintas e, por isso, dentro da teoria, não devem se ligar a valores ideológicos.
} 
duração e o perfil são semelhantes). Nesse sentido, pensando em preservar esse padrão sonoro, poderíamos propor algumas alterações linguísticas com modificações melódicas muito sutis.

Vai e diz numa prece

Que ela regresse

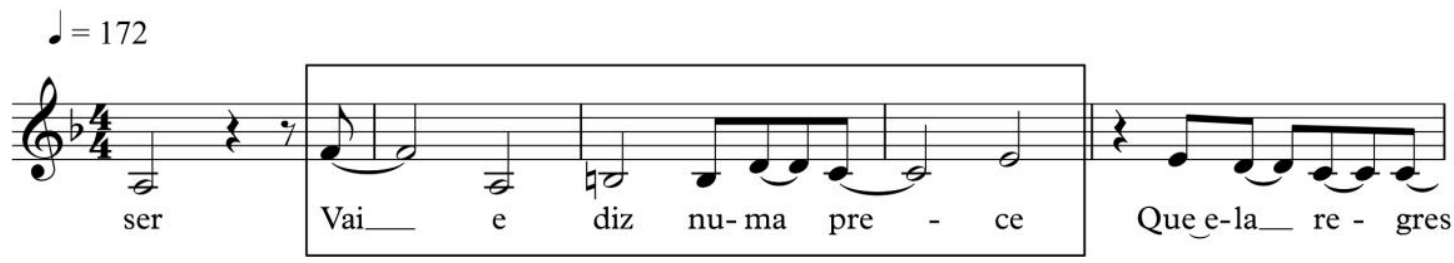

Figura 25. Alteração da letra e da melodia em Chega de Saudade (Tom Jobim/Vinicius de Moraes)

Aproveitando a presença do verbo ir no início da letra da canção ("Vai, minha tristeza"), poderíamos reiterá-lo na sequência com o verso "Vai e diz numa prece". Assim, com uma alteração melódica quase imperceptível (o desligamento entre a mínima Si natural e a colcheia seguinte), conseguimos fazer com que a ênfase recaia sobre vocábulos linguisticamente mais relevantes, nesse caso, as palavras “vai", “diz" e "prece”. O vocábulo secundário "numa", desse modo, deixa de ganhar um realce inadequado. Por fim, poderíamos experimentar uma alteração mais acentuada na letra e na melodia, explorando o fenômeno da elasticidade melódica, já estudado no início desta tese.

Diz que eu peço numa prece

Que ela regresse

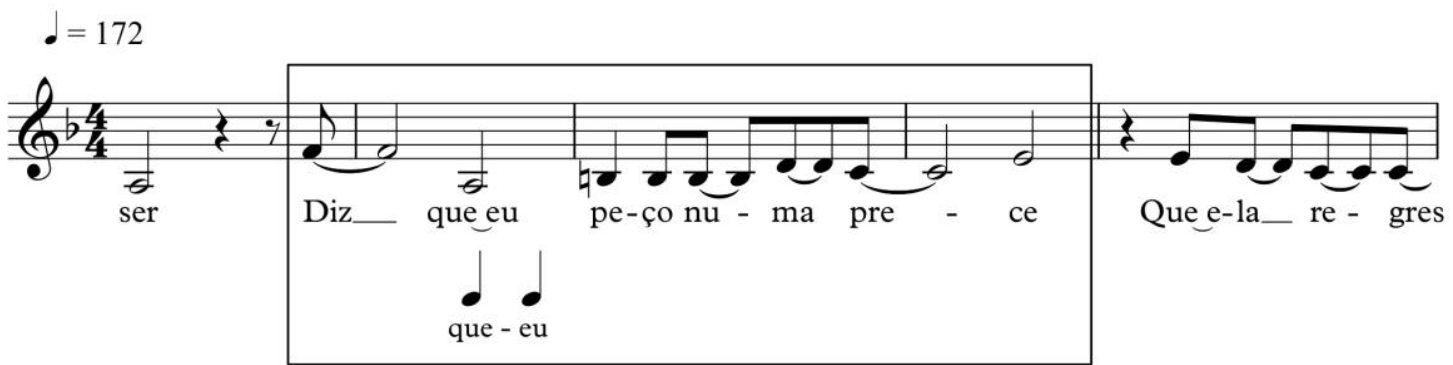

Figura 26. Alteração da letra e da melodia em Chega de Saudade (Tom Jobim/Vinicius de Moraes)

$\mathrm{Na}$ ilustração acima, transformamos a figura longa que iniciava o terceiro compasso, dividindo-a em figuras mais curtas. Mantivemos, no entanto, a sua altura em Si natural. Com isso, aumentando o número de notas, conseguimos encaixar uma maior 
quantidade de sílabas, seguindo o mesmo propósito de tornar a frase mais próxima da linguagem oral ao retirar destaque do vocábulo secundário "numa". Assim, o mesmo trecho melódico se flexibiliza para acomodar um segmento linguístico mais amplo "peço numa prece" onde havia somente a expressão "numa prece". 


\subsection{Aprofundando a questão dos monossílabos}

Os vocábulos monossilábicos possuem especial interesse para o assunto de nosso capítulo. Devemos investigar a função e o peso acentual que eles exercem na entoação da língua oral e, em seguida, cotejar essas características com a sua presença nas letras de canção. Acreditamos que os casos em que encontramos deslocamentos lexicais em palavras de uma só sílaba são mais frequentes do que aqueles ligados aos vocábulos de maior corpo. Segundo a gramática da língua portuguesa, podemos classificar os monossílabos em átonos ou tônicos, de acordo com a intensidade com que eles são pronunciados. Examinemos cada um deles.

Seguindo a mesma lógica que observamos no fenômeno linguístico do grupo acentual (conforme tratado anteriormente), no qual acentos de palavras secundárias são anulados em favor do acento de um termo principal, podemos definir os monossílabos átonos como aqueles que, com emissão muito enfraquecida, passam a depender do apoio do acento tônico de uma palavra contígua (CUNHA, 2017: 69). É como se os monossílabos átonos fossem apenas uma sílaba do termo seguinte, formando com ele um só corpo sonoro. Não possuem, então, autonomia fonética ou semântica, uma vez que seu significado depende igualmente dos demais elementos da frase. São eles os artigos definidos (a, o, as, os), os artigos indefinidos (um, uns), as preposições (de, em, a, com, sem, por, sob), as contrações de preposições com artigos (da, do, na, no, à, ao, num), as conjunções (mas, e, ou, se, nem, que), os pronomes pessoais oblíquos (me, te, se, o, a, lhe, nos, vos, os, as, lhes) e suas associações (mo, to, lho), o pronome relativo (que) e as formas de tratamento (são, dom, frei, seu).

Os monossílabos tônicos, por sua vez, são pronunciados de modo mais forte e por isso não dependem do acento tônico de vocábulos vizinhos. Podemos dizer que, ao contrário dos átonos, eles são fonética e semanticamente autônomos, possuindo significado próprio mesmo quando isolados do contexto da frase. Como veremos em seguida, podem pertencer a diversas classes gramaticais e ser acentuados ou não acentuados. São eles substantivos (dor, fé, flor, mar, céu, mal, pó, sol, mês, mão), adjetivos (má, mau, só), advérbios (mal, já, cá, lá), pronomes pessoais (eu, tu, nós), pronomes possessivos (meu, teu, seu), pronomes pessoais oblíquos (mim, ti) e verbos (vou, pôr, dói, dá, dê).

Ao entendermos as diferenças entre os monossílabos átonos e tônicos na língua oral, podemos avaliar de modo mais preciso a ocorrência desses vocábulos nas canções. 
O compositor, ao compatibilizar a melodia com o texto verbal, estará sujeito, então, às diferentes gradações entoativas, a depender da maneira como tratar o acento de intensidade desses vocábulos. Comecemos avaliando a presença dos monossílabos átonos. Nesse primeiro exemplo, do ponto de vista do registro oral, notamos a acentuação inesperada sobre o artigo definido "a".

E a linda mulata

Com rendas do Alentejo

De quem numa bravata

Arrebato um beijo

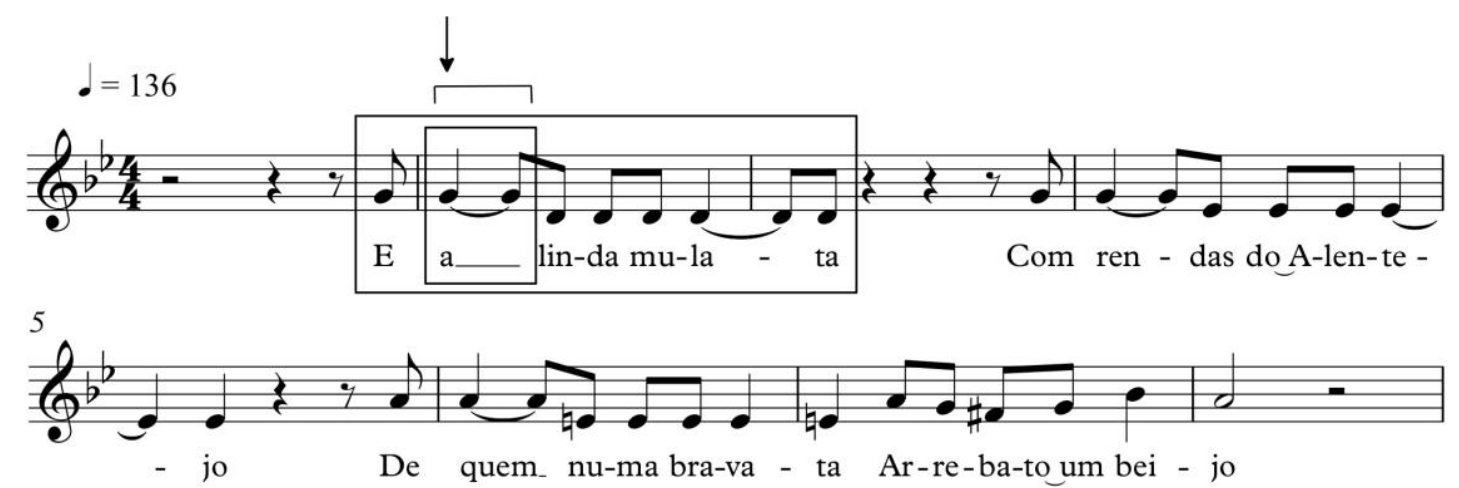

Figura 27. Acentuação de monossílabo átono em Fado tropical (Chico Buarque/Ruy Guerra)

Na língua oral, não costumamos acentuar o artigo definido. Como comentamos acima, ele não possui autonomia fonética e, por isso, tenderíamos a apagar a sua presença ligando-o ao acento da palavra seguinte: "E a linda". A relação entre a melodia e a letra proposta em Fado Tropical, no entanto, enfatiza esse vocábulo, posicionando-o sobre o tempo forte do compasso e alongando significativamente a sua duração. No exemplo abaixo, $A B C$ do Sertão, os cancionistas apresentam algo similar, mas dessa vez enfatizando o artigo indefinido "um".

Lá no meu sertão

Pros caboclo lê

Têm que aprender um outro ABC

O jota é ji,

O ele é lê

O esse é si

Mas o erre tem nome de rê 


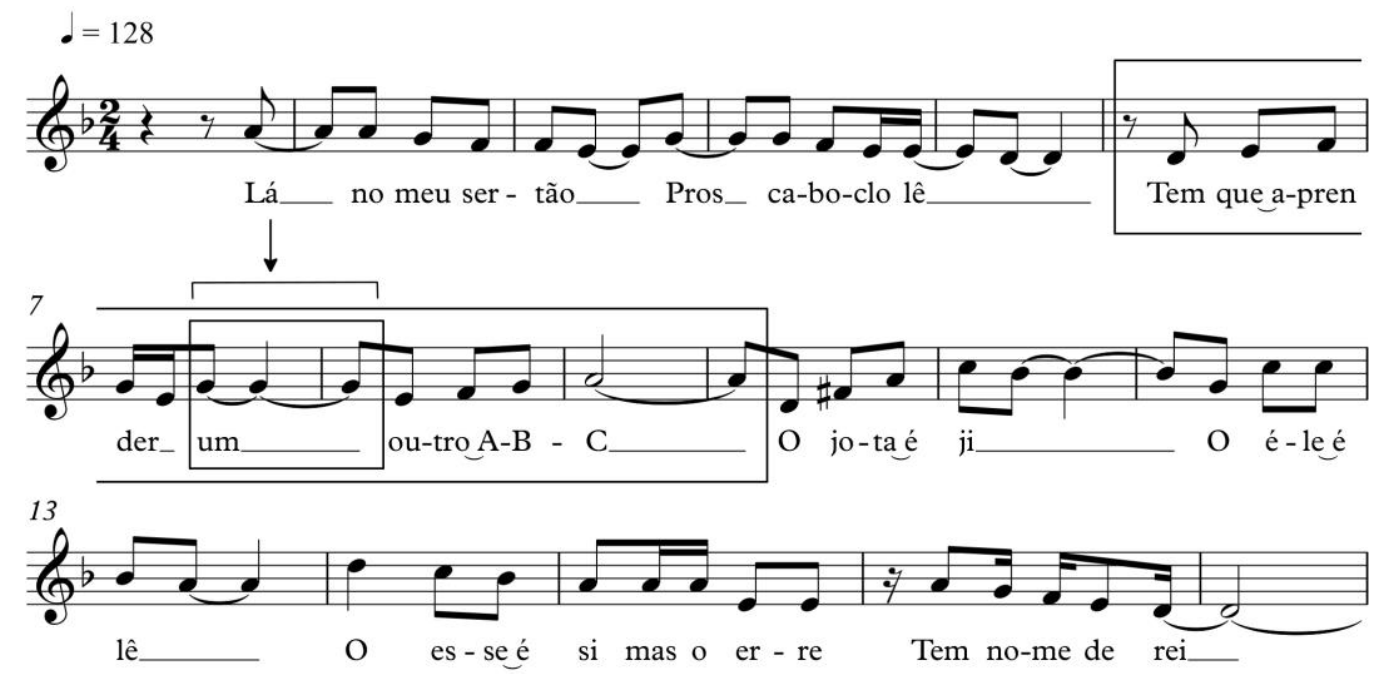

Figura 28. Acentuação de monossílabo átono em $A B C$ do sertão (Luiz Gonzaga/Zé Dantas)

Nesse exemplo, por meio do parâmetro sonoro da duração, o monossílabo átono "um" é bastante destacado. Recaindo sobre um som representado por três notas ligadas (colcheia, semínima e colcheia), ele praticamente ocupa o espaço integral de um compasso. Assim, sob o ponto de vista oral, não há dúvida de que esse encaixe entre letra e melodia apresenta uma figurativização menos linear. Afinal, na língua falada, nossa tendência natural seria enfatizar o pronome indefinido "outro" e não o artigo "um" ("Têm que aprender um outro $\mathrm{ABC}$ "). Outra classe gramatical que possui monossílabos átonos por vezes acentuados pelos cancionistas é a preposição. Observemos a forma como a melodia de Cada Macaco no seu Galho, do compositor Riachão, recobre o vocábulo “em".

Xô xuá

Cada macaco no seu galho

Xô xuá

Eu não me canso de falar

Xô xuá

O meu galho é na Bahia

Xô xuá

O seu é em outro lugar 


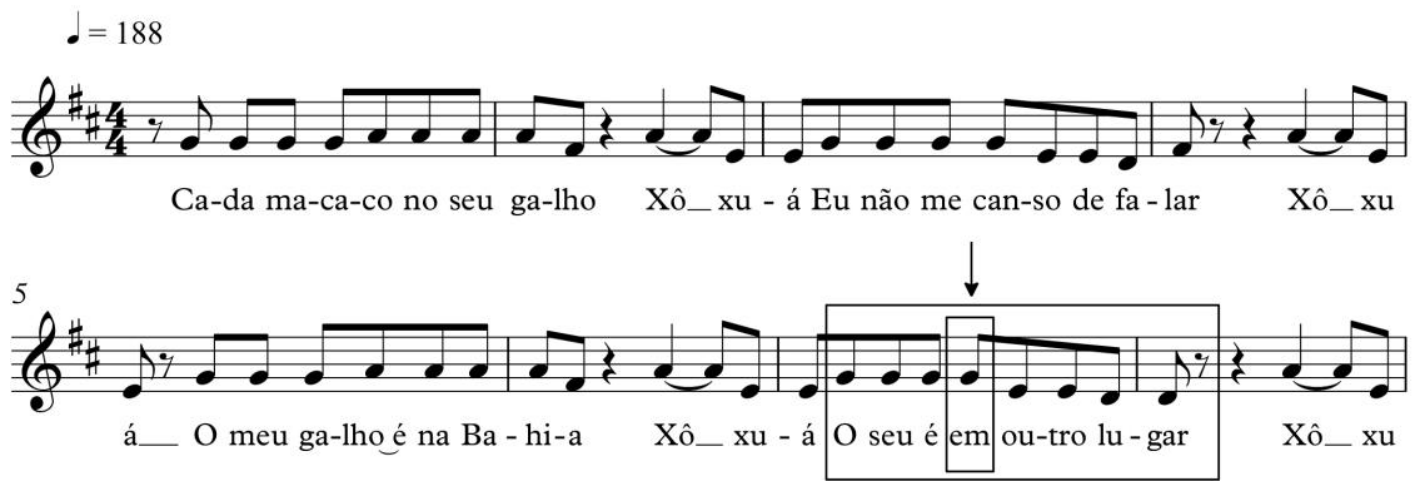

Figura 29. Acentuação de monossílabo átono em Cada macaco no seu galho (Riachão)

Na língua falada, a entoação mais usual é aquela na qual o pronome indefinido "outro" ou o substantivo "lugar" são mais enfatizados. Quando essa frase verbal encontra a linha melódica acima, no entanto, a preposição "em" é destacada demasiadamente por recair na cabeça do terceiro tempo (meio-forte) e na nota mais aguda da sua unidade melódica (conjunto de notas que destacamos na figura). Colabora para o enfraquecimento entoativo do trecho o fato de o pronome "outro" ter sua acentuação silábica prejudicada (sua sílaba tônica recai sobre a parte fraca do terceiro tempo). Abaixo, a canção Assum Preto apresenta algo similar, dessa vez acentuando a preposição "por".

Talvez por ignorança

Ou maldade das pior

Furaro os óio do Assum Preto

Pra ele assim, ai, cantar melhor
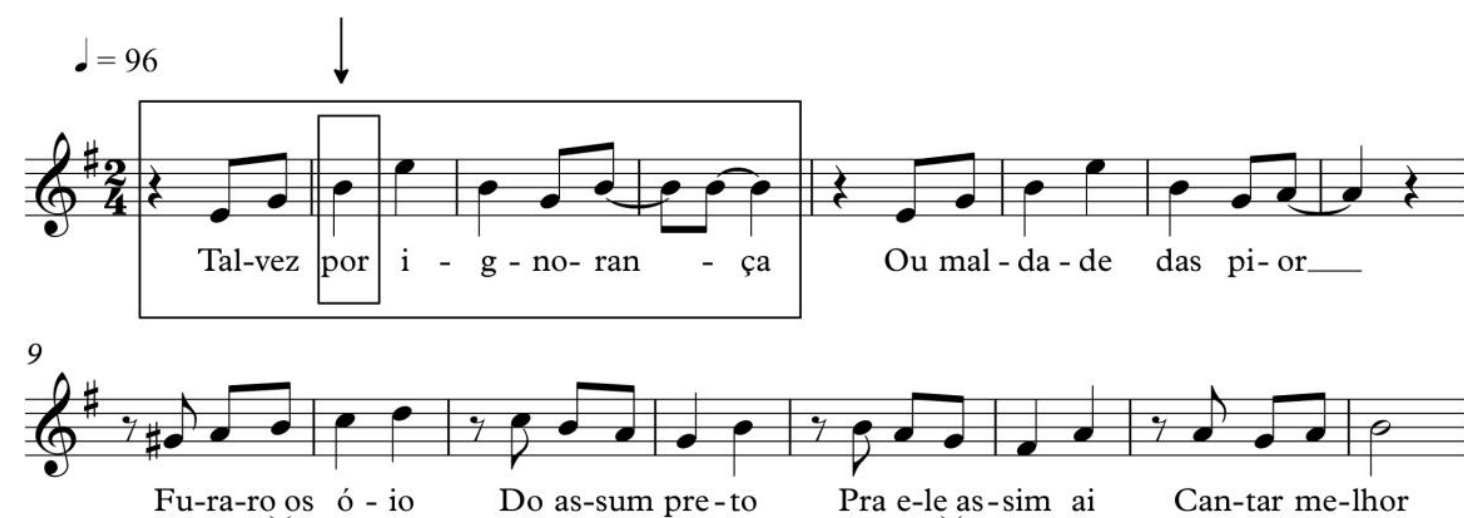

Figura 30. Acentuação de monossílabo átono em Assum Preto (Luiz Gonzaga/Humberto Teixeira)

Nessa canção, quando observamos os diferentes versos que recortam a mesma unidade melódica destacada acima (ou a seguinte, que apresenta perfil similar), 
constatamos que a nota assinalada com a seta (ponto de forte ênfase da melodia) geralmente recai sobre palavras menos periféricas da oração: "Tudo em vorta é só beleza", "Sol de abril e a mata em frô", "Assum preto veve sorto", "Mas não pode avoar". Isso ocorre na medida em que as sílabas tônicas dos vocábulos frisados coincidem com o tempo forte do compasso e constituem o ponto de chegada do início anacrústico (as duas notas iniciais possuem a função de levar o ouvinte para a nota que indicamos com a seta). Desse modo, quando a mesma linha melódica encontra a frase verbal "Talvez por ignorança”, é a preposição “por”, termo secundário da oração, que recebe esse realce sonoro. É como se o cancionista acostumasse o ouvinte a escutar o ponto de apoio (musical e linguístico) na terceira nota da melodia gerando, então, um sutil estranhamento entoativo quando um monossílabo átono é ali posicionado. Em nosso cancioneiro, supomos que o exemplo mais recorrente de acentuação de preposição é, no entanto, aquele ligado ao monossílabo "de".

Será que me põe de castigo

Será que ele me estende a mão

Será que o pai dança comigo ou não?

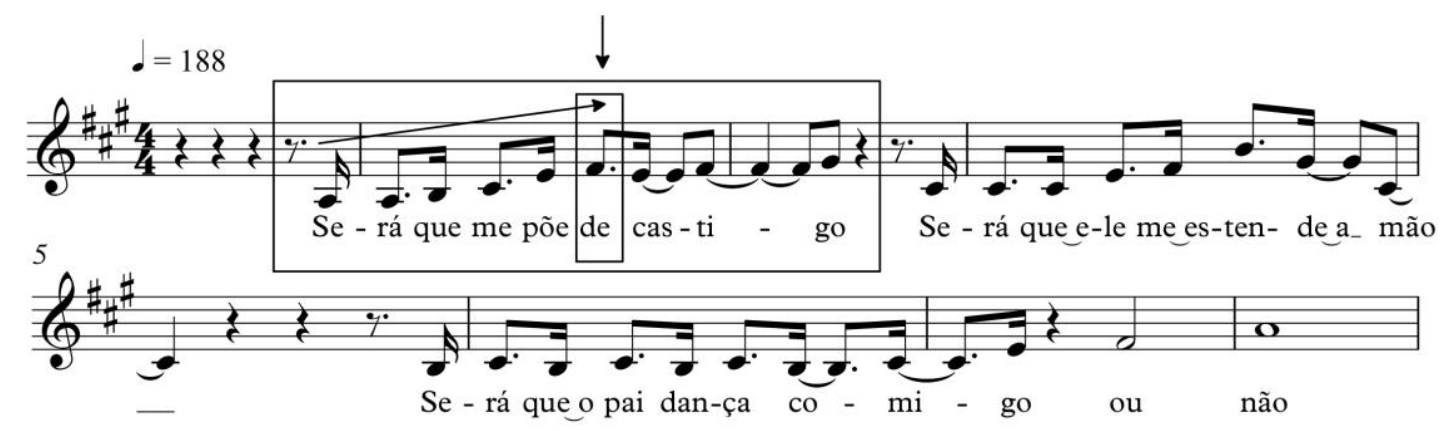

Figura 31. Acentuação de monossílabo átono em Ai, se eles me pegam agora (Chico Buarque)

Existirá

Em todo porto tremulará

A velha bandeira da vida

Acenderá

Todo farol iluminará

Uma ponta de esperança 


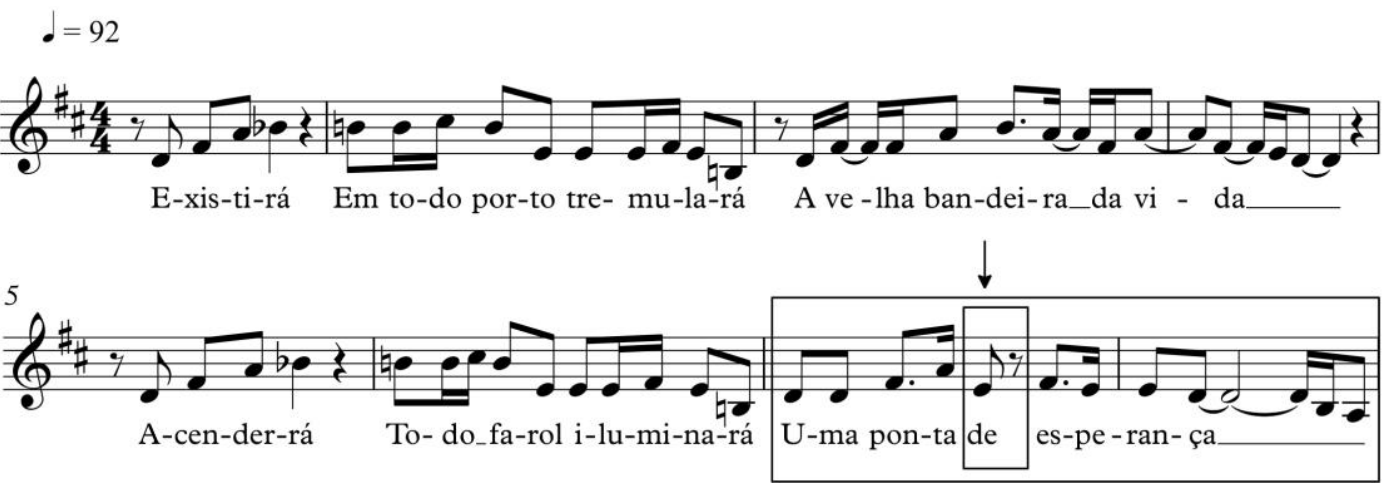

Figura 32. Acentuação de monossílabo átono em A cura (Lulu Santos)

Futucando bem

Todo mundo tem piolho

Ou tem cheiro de creolina

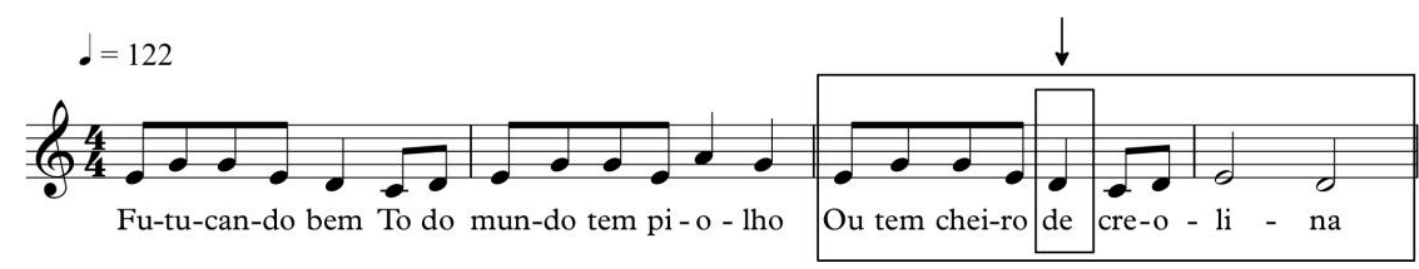

Figura 33. Acentuação de monossílabo átono em Ciranda da Bailarina (Edu Lobo/Chico Buarque)

Curiosamente, nos três exemplos acima, o monossílabo átono "de" recai sobre o terceiro tempo do compasso quaternário (tempo meio-forte) e ganha um relevo entoativo incompatível com o seu menor valor linguístico. Em Ai, se eles me pegam agora, por exemplo, a preposição “de” é mais realçada do que o verbo "põe”. Além do parâmetro intensidade, outros fatores também influenciam no deslocamento de acentuação lexical desses fragmentos. No primeiro, a preposição "de" é um ponto culminante do início ascendente da melodia. Em A Cura, além da intensidade, notamos a presença de uma pausa após o monossílabo, o que lhe confere ainda mais destaque, visto que o desconecta em relação à continuação da frase linguística. Em Ciranda da Bailarina, por sua vez, é o parâmetro duração que atua fazendo com que a preposição destacada dure o dobro das notas anteriores.

Poderíamos reescrever a melodia do primeiro exemplo para amenizar o desvio sobre o vocábulo "de". Sem alterar a letra da canção, conseguiríamos aumentar a duração da palavra "põe", ligando-a com a nota seguinte e deslocando o monossílabo átono "de" para a parte mais fraca do terceiro tempo do compasso. Assim, com uma leve alteração 
no padrão melódico (o que, por outro lado, pode representar uma mudança significativa, tendo em vista o caráter tematizante da obra), é possível atenuar o desvio oral do trecho:

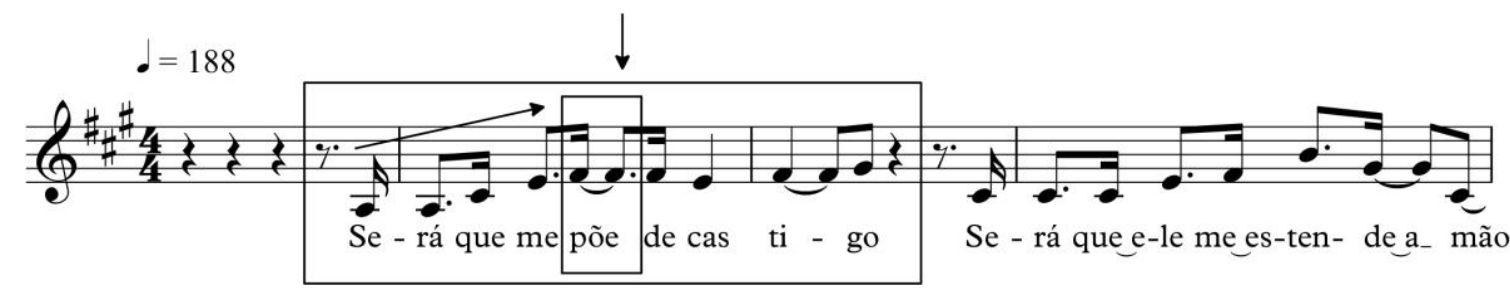

Figura 34. Reescrita de Ai, se eles me pegam agora (Chico Buarque)

São também comuns os exemplos de canções que apresentam a contração da preposição "de" com os artigos definidos "o" e "a" acentuada de modo inusual. Examinemos os pontos melódicos em que recaem os monossílabos átonos "da" e "do" nas canções Águas de março e Falando de Amor, ambas do compositor Tom Jobim.

É o vento ventando, é o fim da ladeira

É a viga, é o vão, festa da cumeeira

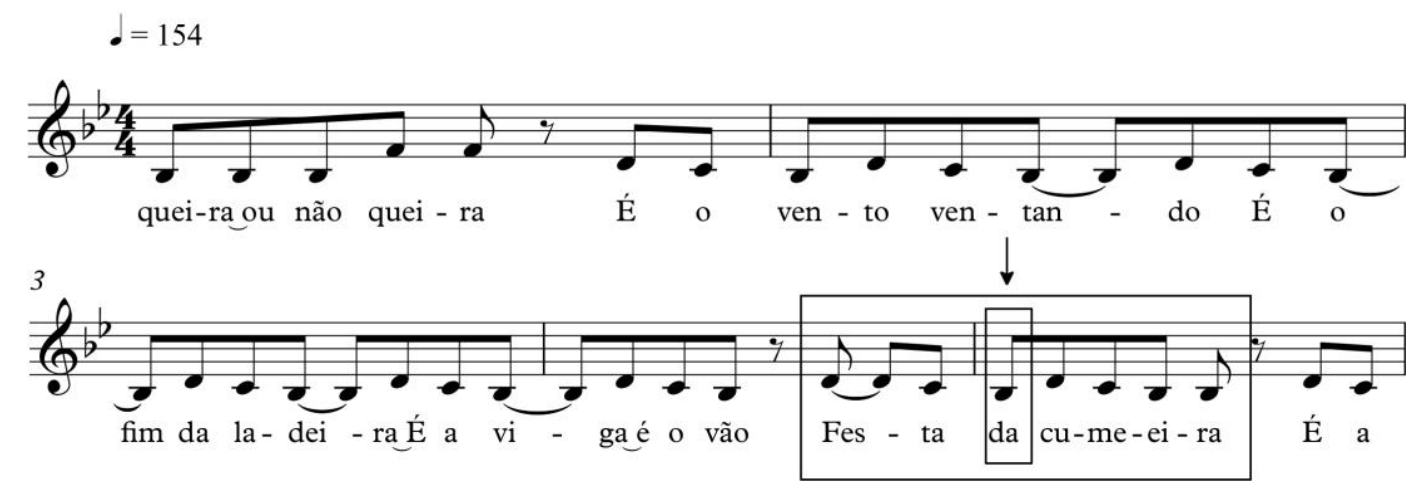

Figura 35. Acentuação de monossílabo átono em Águas de março (Tom Jobim)

Quando passas, tão bonita

Nessa rua banhada de sol

Minha alma segue aflita

E eu me esqueço até do futebol

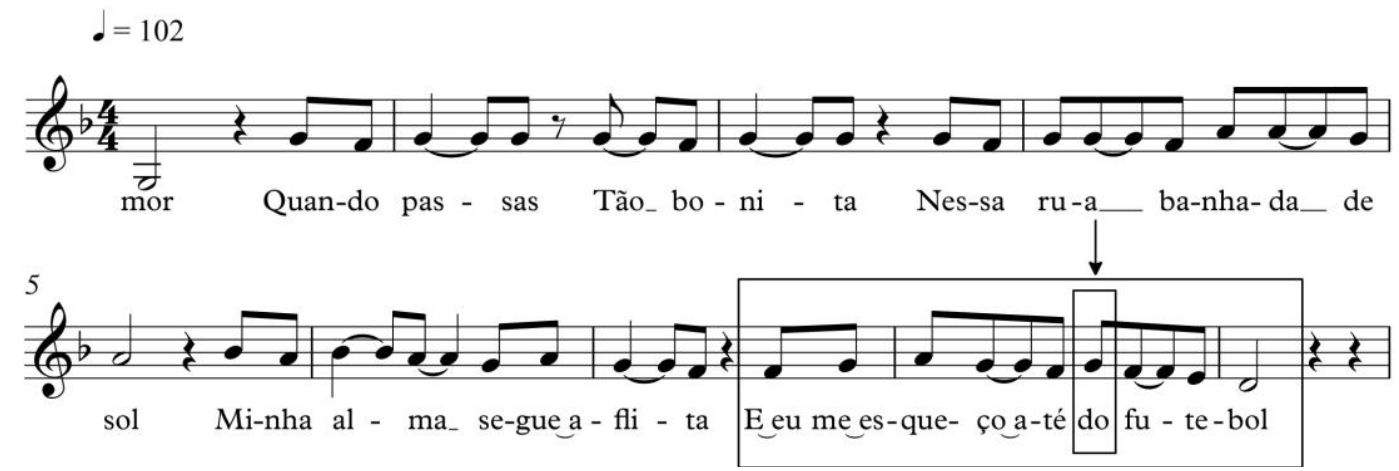

Figura 36. Acentuação de monossílabo átono em Falando de amor (Tom Jobim) 
Nas figuras acima, as preposições "da" e "do" coincidem, respectivamente, com as partes fortes do primeiro e do terceiro tempo do compasso e destacam-se mais do que as palavras nucleares "cumeeira", na primeira figura, e "até" ou "futebol", na segunda. Águas de março, conhecida por seu grande sucesso internacional (obra que está entre as dez canções mais executadas no século XX), possui inúmeras versões, com diferentes intérpretes e em diferentes línguas. É curioso, então, notarmos as diferenças entre a versão transcrita acima (cantada por João Gilberto em álbum de 1973) e outras interpretações da mesma obra. Podemos compará-la com a versão de Elis Regina e Tom Jobim (que abranda a emissão da preposição "da" e enfatiza a primeira sílaba da palavra "cumeeira") ou mesmo com a transcrição em partitura que encontramos no site do compositor (realizada pelo arranjador Claus Ogerman). Nesse caso, como constatamos abaixo, o mesmo monossílabo é também acentuado.

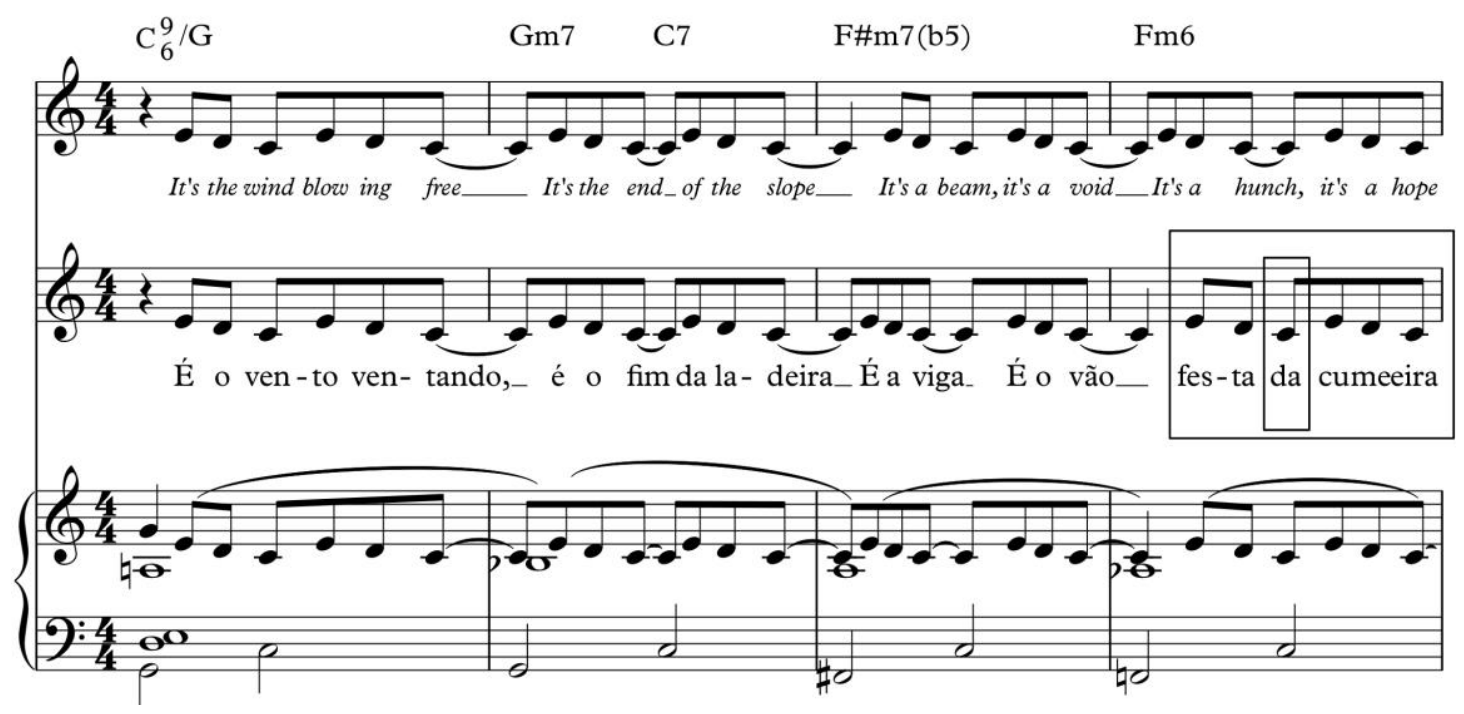

Figura 37. Deslocamento lexical na partitura do arranjo de Águas de Março realizado por Claus Ogerman

Por fim, ainda analisando a ocorrência de ênfase melódica sobre monossílabos átonos, podemos examinar a classe gramatical dos pronomes. Os dois exemplos seguintes, as canções Se de Djavan e Tanto Amar de Chico Buarque, apresentam os pronomes pessoais "te" e "me" sutilmente realçados pelo parâmetro intensidade, no primeiro, e pela duração e intensidade no segundo. Vejamos.

Sei lá o que te dá, não quer meu calor

São Jorge, por favor, me empresta o dragão

Mais fácil aprender japonês em braile

Do que você decidir se dá ou não 


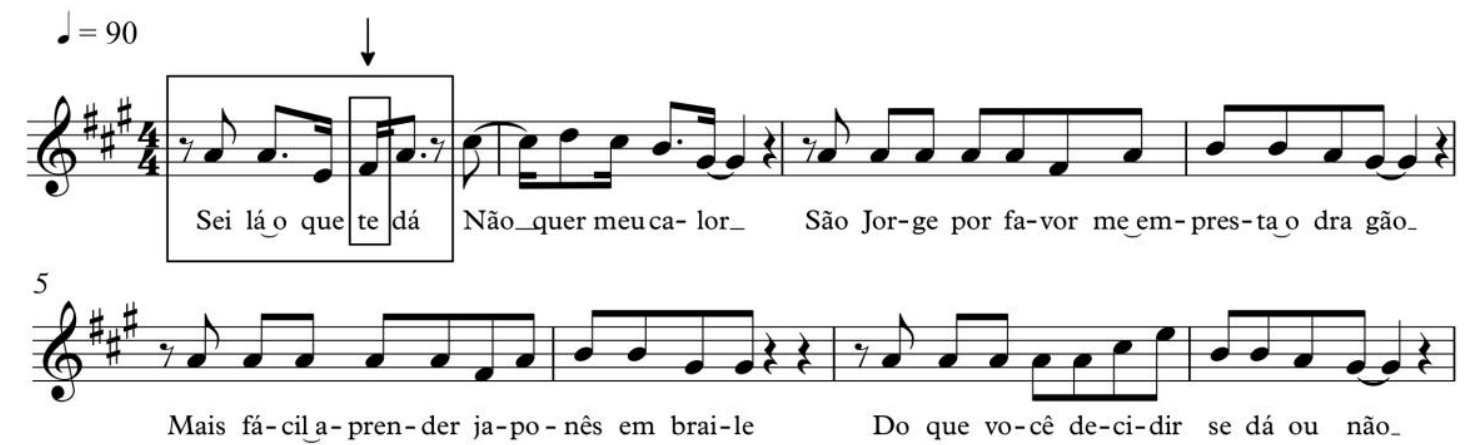

Figura 38. Acentuação de monossílabo átono em Se (Djavan)

É na soma do seu olhar

Que eu vou me conhecer inteiro

Se nasci pra enfrentar o mar

Ou faroleiro

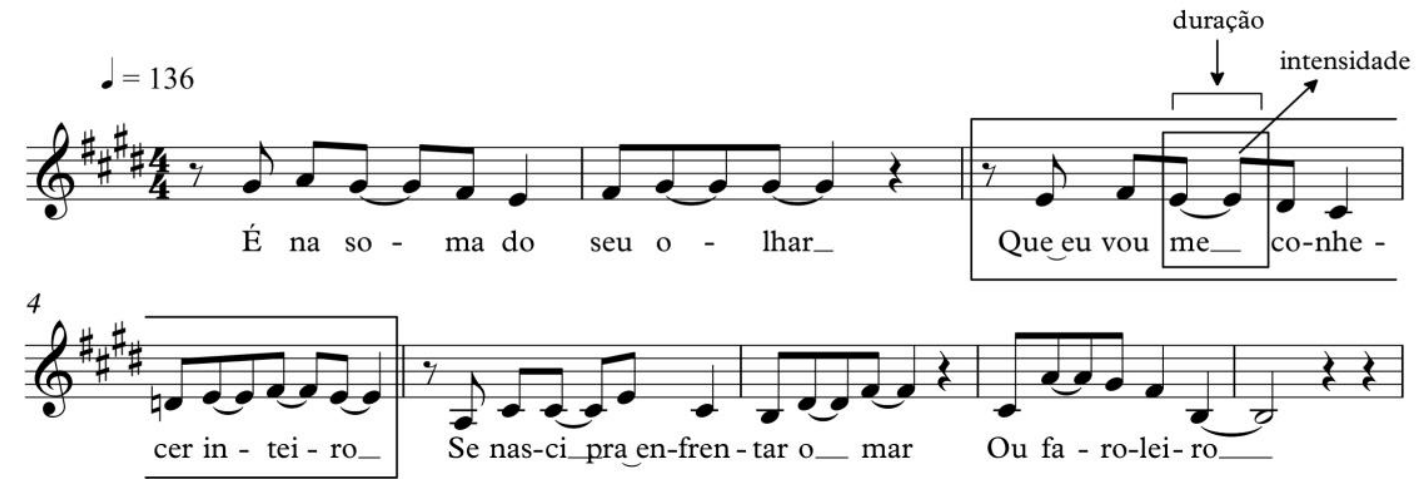

Figura 39. Acentuação de monossílabo átono em Tanto amar (Chico Buarque)

Em Tanto Amar, a linha melodia se caracteriza por uma síncopa entre o segundo e o terceiro tempo, conforme podemos notar nos compassos 1, 3 e 5 da ilustração acima. Quando o compositor encaixa esse padrão melódico nas frases verbais “É na soma do seu olhar" e "Se nasci pra enfrentar o mar", não sentimos nenhum desvio acentual, uma vez que a ênfase sonora recai justamente sobre as sílabas tônicas de "soma" e "nasci". Examinando o verso "Que eu vou me conhecer inteiro", no entanto, verificamos que esse ponto de destaque coincide com o pronome pessoal "me", monossílabo átono que, na fala, corresponderia a um agregado sonoro do vocábulo seguinte: "me conhecer". Na canção de Djavan, é muito mais sutil o realce sobre o pronome pessoal "te" que, na língua oral, via de regra, está sonoramente subordinado ao acento da palavra seguinte: "te dá". Curiosamente, constatamos aqui a justaposição de um monossílabo átono e um tônico, o que nos permite avaliar o quanto nossa intuição linguística clama pela acentuação do segundo. Em Se, devemos pontuar que, pela duração e altura mais elevada do vocábulo 
"dá", o acento de intensidade sobre o pronome "te" é, sem dúvida, abrandado. Nesse momento, então, podemos passar ao exame dos monossílabos tônicos. Vejamos o exemplo seguinte.

No sábado então, às duas horas

Todo o povo sem demora foi lá só para assistir

$$
\cdot=178
$$

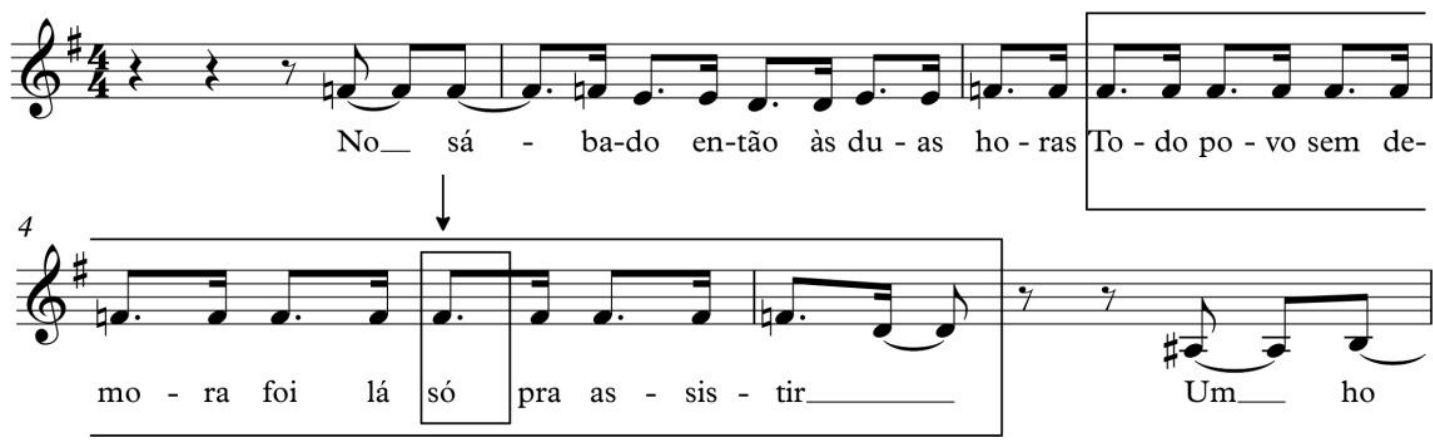

Figura 40. Acentuação de monossílabo tônico em Faroeste Caboclo (Renato Russo)

A passagem assinalada apresenta três monossílabos tônicos consecutivos: o verbo "foi" e os advérbios "lá" e "só". Tendo em vista que a melodia acima se configura como uma sucessão de ataques fortes e fracos (colcheia pontuada na cabeça do tempo e semicolcheia), essa junção de três monossílabos "fortes" em sequência torna complexo o encaixe entoativo entre a letra e a melodia. Isto é, ao juntarmos os três vocábulos, fatalmente algum desvio acentual será cometido. Assim, em Faroeste Caboclo, acreditamos que o posicionamento do advérbio "lá" na parte fraca da pulsação resulta em uma entoação menos usual, pois, na língua oral, costumamos enfatizá-lo ao dizermos a expressão "foi lá". Nesse exemplo, portanto, cremos que a singularidade verbal decorra mais da atenuação do vocábulo "lá" do que da ênfase no verbo que o antecede. Podemos reescrever esse mesmo trecho com uma formulação linguística levemente distinta, tentando enfatizar a emissão desse advérbio.

No sábado então, às duas horas

Todo povo sem demora foi pra lá só pra assistir 


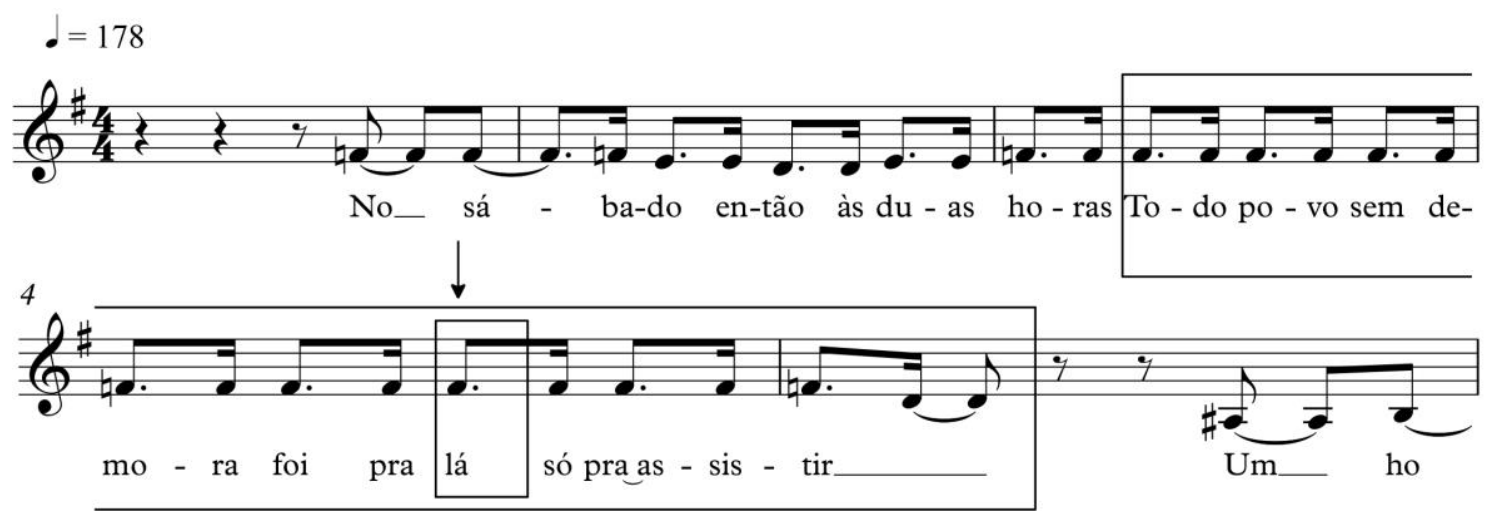

Figura 41. Recriação da letra para acomodação de monossílabo tônico em Faroeste Caboclo

Aproveitando a possibilidade de realizarmos uma elisão vocálica entre a preposição "pra" e o verbo "assistir" e, com isso, obtendo espaço para encaixar mais uma sílaba na melodia, conseguimos inserir uma preposição entre os monossílabos "foi" e "lá", deslocando o segundo para a parte forte do terceiro tempo do compasso: "foi pra lá". Nesse caso, priorizaríamos o advérbio "lá" em detrimento de "só" que, por sua vez, passaria a ocupar um ponto fraco da linha melódica. Esse último tenderia, então, a ser incorporado pelo campo de força exercido pelo acento de "assistir", o que nos parece plausível. Essa experimentação, contudo, nos indica o quanto que uma alteração melódica ou linguística, ao corrigir certo deslocamento, pode provocar um novo desvio. Indica-nos, também, o quanto que uma leve modificação pode alterar de modo substancial a nossa assimilação da mensagem linguística. Comparando as duas figuras acima, constatamos a diferença significativa entre acentuar o advérbio "só" ou o "lá". Passemos ao exame dos pronomes possessivos, considerados igualmente monossílabos tônicos.

Varo a noite sem cochilar, aflito

Amanheço imitando o seu grito

Me aproximo rondando a sua toca

$\mathrm{E}$ ao me ver você me provoca 


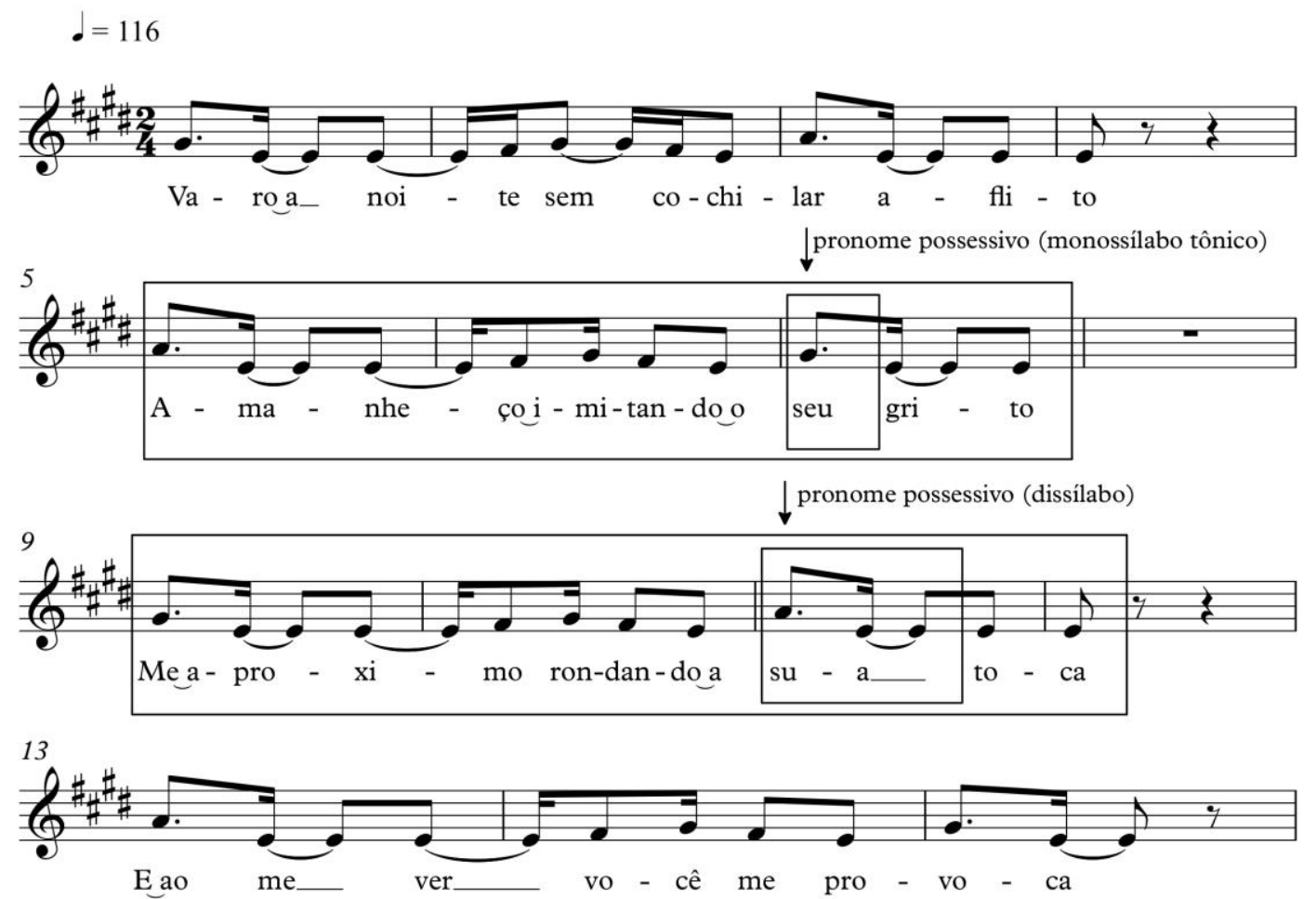

Figura 42. Acentuação de monossílabo tônico em Caçada (Chico Buarque)

A partir da análise de Caçada, podemos observar um interessante jogo de forças entre os vocábulos da oração. Acreditamos que os monossílabos tônicos que recebem certo destaque sonoro podem gerar, a depender do contexto frásico, dois resultados entoativos distintos: às vezes, uma perda oral e, às vezes, apenas uma leve mudança semântica, sem um maior distanciamento em relação à língua falada (diferentemente dos átonos que, enfatizados pela melodia, costumam causar forte estranhamento em relação à naturalidade entoativa). Assim, por um lado, os monossílabos tônicos, quando inseridos em determinados contextos linguísticos, devem seguir o mesmo fenômeno de anulação de seus respectivos acentos em favor dos acentos das palavras vizinhas, formando com elas um só corpo fonético ("seu grito"). Por outro lado, o pronome pode ser ressaltado por meio do mesmo fenômeno do acento de insistência estudado no capítulo anterior. É o que supomos ocorrer nessa canção de Chico Buarque, quando a linha melódica realça, no sétimo compasso, o pronome possessivo "seu" e não o substantivo "grito", concedendo maior autonomia fonética a esse monossílabo e reduzindo a importância da palavra seguinte $^{111}$. Aqui, o enunciador, consciente ou inconscientemente, dá mais evidência ao dono do "grito" e da "toca", como em um acento intelectual de insistência: "Imitei o seu

${ }^{111}$ Destacamos também a presença do pronome possessivo "sua”, vocábulo dissílabo sobre o qual podemos aplicar o mesmo raciocínio. 
grito, e não o grito deles”. Esse novo sentido linguístico, no entanto, precisa estar coerente com o restante da letra da canção. Caso contrário, essa mudança acentual poderá gerar um modo de dizer pouco usual do ponto de vista da oralidade. O exemplo seguinte, a canção Os Cegos do Castelo de Nando Reis, consiste em um caso interessante de não acentuação de um monossílabo tônico.

Eu não quero mais mentir

Usar espinhos que só causam dor

Eu não enxergo mais o inferno que me atraiu

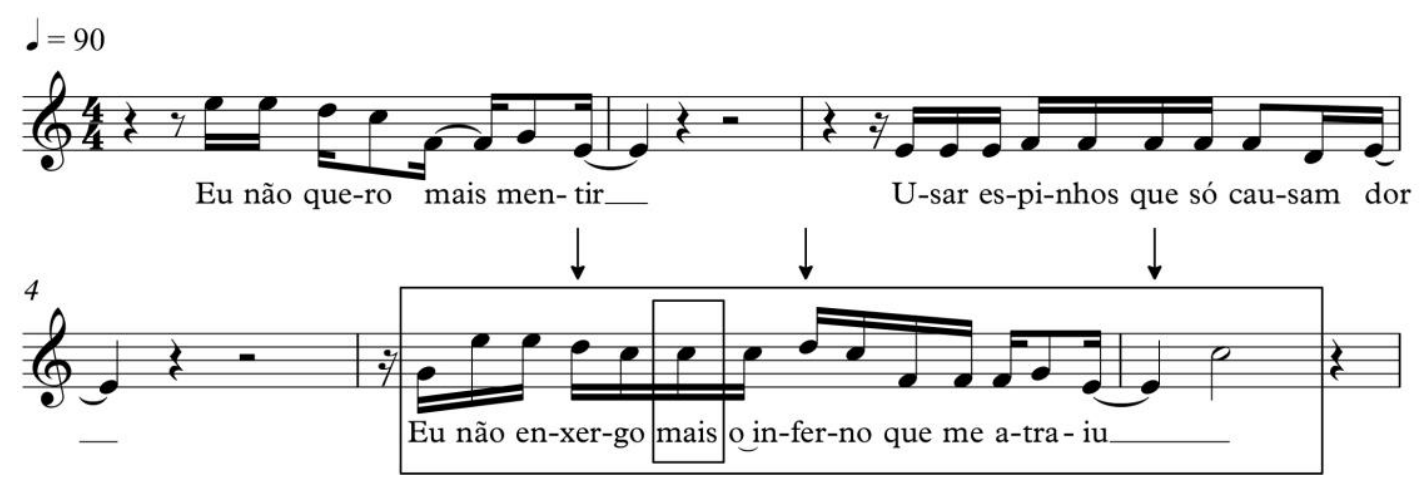

Figura 43. Acentuação de monossílabo tônico em Os cegos do castelo (Nando Reis)

$\mathrm{Na}$ figura acima, marcamos com setas os pontos fortes da linha melódica. Coincidem com eles as sílabas tônicas dos vocábulos "enxergo", "inferno" e "atraiu". No entanto, examinando a passagem como um todo ("Eu não enxergo mais o inferno que me atraiu"), notamos que o advérbio "mais", naturalmente mais acentuado na língua oral, coincide com um ponto muito fraco da melodia. É até mesmo possível que esse vocábulo, não sendo enfatizado pela linha melódica, seja apreendido pelo ouvinte como a conjunção "mas" (monossílabo átono). Nesse caso, acreditamos que a oralização resultante dessa combinação de melodia e letra se apresenta de modo menos linear.

Por fim, analisando ainda a questão dos monossílabos tônicos e átonos, gostaríamos de examinar um último exemplo. Trata-se da canção Só chamei porque te amo, uma versão em português de Gilberto Gil para a obra I just called to say I love you, do compositor e cantor estadunidense Stevie Wonder.

Só chamei porque te amo

Só chamei porque é grande a paixão 


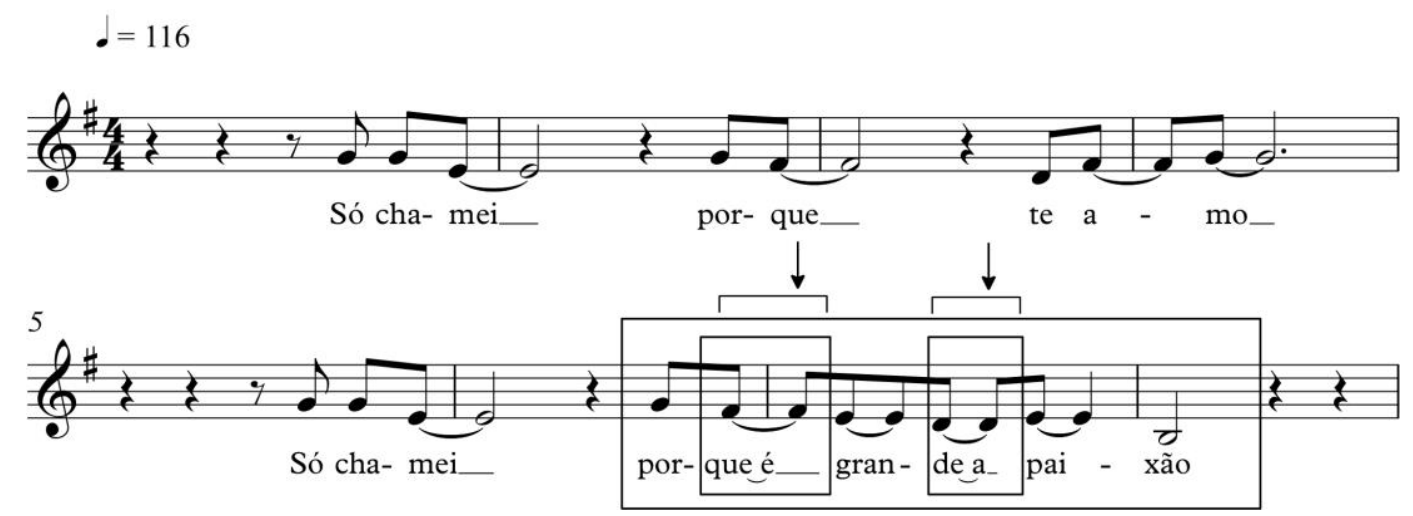

Figura 44. Acentuação de monossílabo tônico e átono em Só chamei porque te amo (Stevie Wonder/ versão de Gilberto Gil)

Assinalamos na figura acima, dois pontos fortes propostos pela linha melódica, ambos ligados ao parâmetro intensidade (por coincidirem com as síncopas para o primeiro e para o terceiro tempo, forte e meio forte, respectivamente). Sobre esses pontos estão o monossílabo tônico "é” (verbo) e o monossílabo átono "a” (artigo). Contudo, se pensarmos na emissão dessa frase na língua oral, é provável que façamos a acentuação sobre o adjetivo "grande" ("porque é grande a paixão"), fazendo com que os monossílabos "é" e "a" sejam apenas agregados sonoros das palavras "grande" e "paixão". Assim, desejamos demonstrar que o enfraquecimento entoativo desse trecho se deve não apenas à acentuação melódica sobre esses monossílabos, mas, sobretudo, pela não acentuação da palavra núcleo "grande". Podemos verificar igualmente que a estranheza oral gerada pelo primeiro ponto é menor do que a produzida pelo segundo não só pelo fato de o monossílabo “é” ser tônico. A síncopa para o terceiro tempo do compasso, além de enfatizar o artigo "a", o faz destacando a sílaba átona do vocábulo "grande" por meio de uma elisão: "grande_a". Essa ocorrência desestabiliza ainda mais a naturalidade verbal da passagem.

Tratando-se de uma versão para a língua portuguesa de uma canção norteamericana, torna-se muito interessante a avaliação da composição original. Ao analisarmos a versão de Stevie Wonder, percebemos que os mesmos pontos de apoio preenchidos por Gilberto Gil com vocábulos secundários coincidem com elementos linguisticamente nucleares.

I just called to say I love you

I just called to say how much I care 


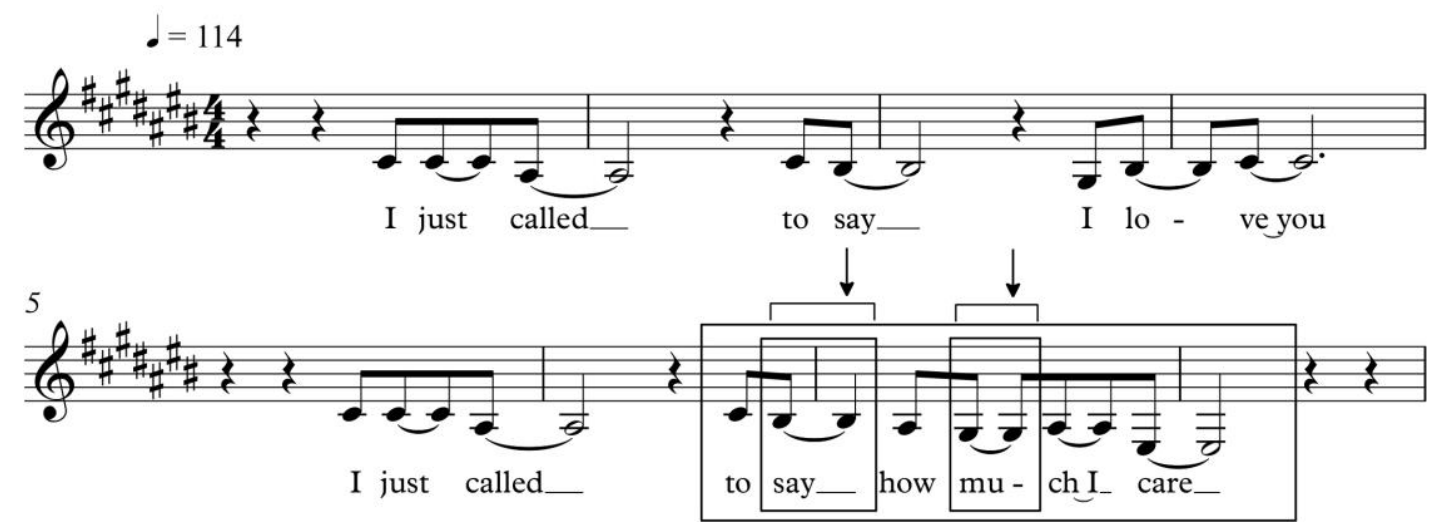

Figura 45. Acentuação lexical em I just called to say I love you (Stevie Wonder)

Nessa versão, as palavras nucleares "say" e "much" são enfatizadas ao coincidirem com as regiões fortes da melodia, como já havíamos destacado na figura anterior. Os vocábulos "to" e "how" são, assim, os seus respectivos agregados sonoros, formando com eles os corpos fonéticos "to say" e "how much". Comparando as duas versões, podemos dizer que o trecho aqui analisado é oralmente mais comum na canção original do que na obra criada pelo compositor brasileiro. Obviamente, a recriação da letra em outro idioma não constitui uma tarefa fácil, visto que o cancionista, em geral, deseja preservar a melodia original e se adequar ao tema ou mesmo à sonoridade das palavras. Podemos realizar uma experimentação entoativa atenuando o desencontro entre os pontos de apoio da melodia e os da letra. Abaixo, alteramos o segundo verso para que as palavras centrais sejam enfatizadas pela linha melódica.

\section{Só chamei porque te amo}

Só te amei na chama da paixão

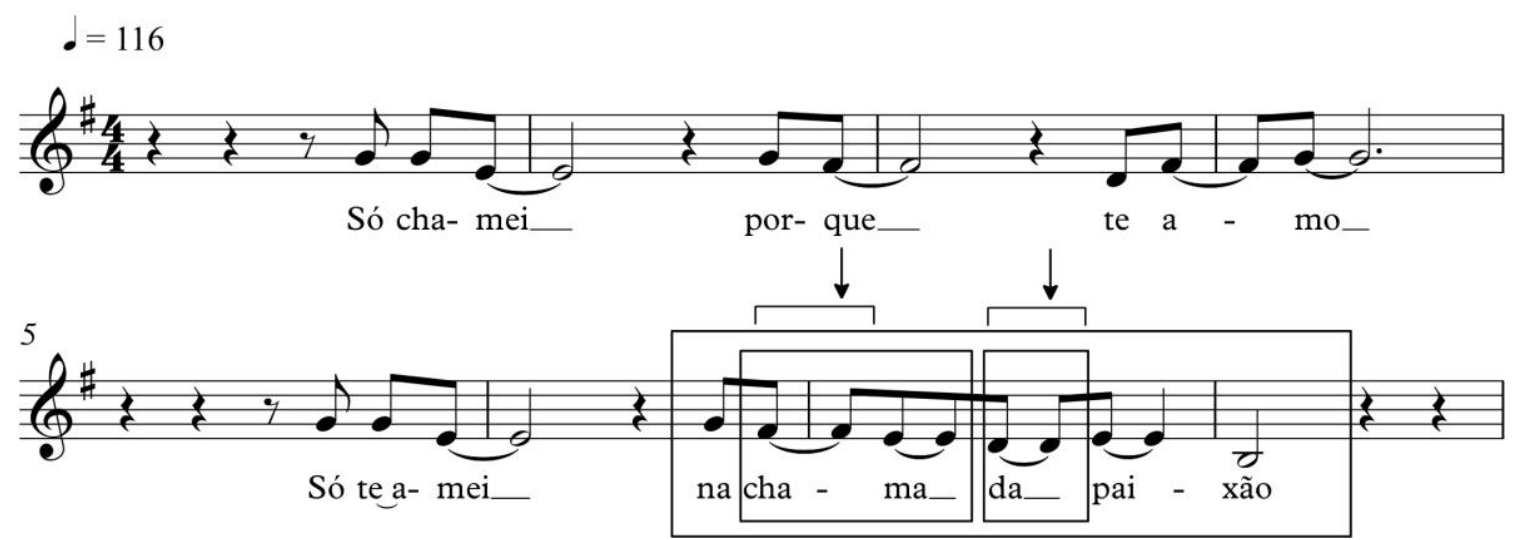

Figura 46. Reescrita da letra de Só chamei porque te amo (Stevie Wonder/ versão de Gilberto Gil) 
Os vocábulos "chama" e "paixão" se apresentam devidamente acentuados. O primeiro pela síncopa para o primeiro tempo do compasso. O segundo, pelo acento de intensidade do primeiro tempo do compasso seguinte (que coincide com a sílaba tônica de "paixão"). A nosso ver, nessa nova proposta, ainda que a preposição "da" (monossílabo átono) possua destaque, encontramos uma oralização mais comum. Notamos, então, que observar as combinações de melodia e letra de uma canção estrangeira e de sua versão para o português é um exercício bastante rico para o analista que pretende examinar a questão da acentuação lexical.

Além disso, a partir da análise acima, conseguimos verificar que, sob a perspectiva da figurativização, o trabalho realizado pelos cancionistas é estritamente o mesmo, independentemente de sua língua natural. O seu idioma possui um repertório de configurações entoativas mais ou menos consensuais, nos quais alguns vocábulos podem ser mais ressaltados do que outros. A compatibilização da melodia com a letra, nesse sentido, é também a conciliação entre esses realces verbais preestabelecidos e os destaques sonoros propostos pela música. Por isso, o cancionista que se aventura na composição em língua estrangeira deve dominá-la de modo profundo, conhecendo não apenas a língua escrita, mas sobretudo as suas nuances entoativas, isto é, as suas palavras átonas e tônicas (aquelas que devem se submeter sonoramente às palavras vizinhas e aquelas que devem ser de fato ressaltadas).

Constatamos, nesse sentido, mais uma prova de que o letrista e o poeta não exercem a mesma atividade artística. Isto é, para escrever um poema em idioma estrangeiro, sobretudo se a regularidade métrica não é um valor estético caro ao escritor, não é necessário adquirir um grau tão grande de conhecimento entoativo, o que é absolutamente imprescindível ao compositor de canções. É evidente que os poetas conhecem a língua com que trabalham de um modo profundo. A questão entoativa, porém, não possui para ele, nem para o seu leitor, a mesma centralidade que observamos no universo cancional. 


\subsection{O abrandamento dos desvios no nível lexical}

No capítulo anterior, estudamos diversos casos nos quais o deslocamento da acentuação silábica era amenizado mediante algum fator musical, sobretudo pelo fato de a palavra com desvio prosódico estar inserida em uma frase ritmicamente regular, isto é, formada por notas de igual duração. Quando passamos para o nível da palavra, podemos reconhecer casos em que o mesmo fenômeno se dá. Na figura abaixo, transcrevemos um pequeno trecho da canção Casa do compositor Lulu Santos. Observemos como a preposição “em”, monossílabo átono, coincide com a síncopa para o primeiro tempo do quarto compasso.

Primeiro era vertigem

Como em qualquer paixão

Era só fechar os olhos

E deixar o corpo ir

No ritmo

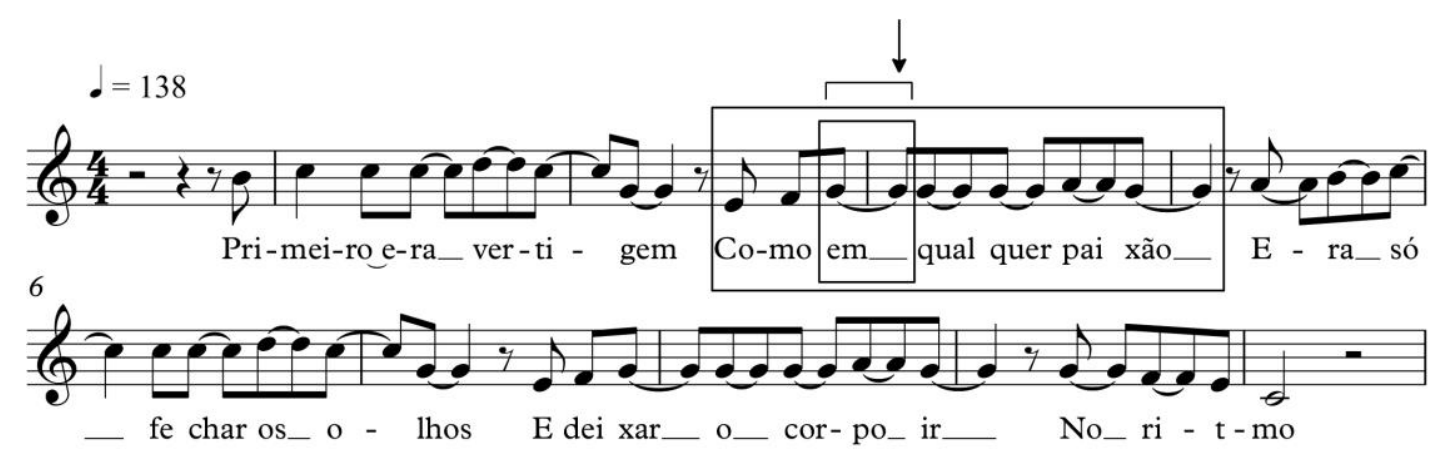

Figura 47. Acentuação de monossílabo tônico em Casa (Lulu Santos)

Há, sem dúvida, uma ênfase inesperada sobre a preposição “em”. Na fala, a maneira mais natural de entoar essa frase verbal destacaria apenas as palavras "qualquer" ou "paixão". Contudo, o fato de o monossílabo recair sobre essa região forte da melodia tende a ser neutralizado pelas características musicais do segmento destacado. Sob o ponto de vista da duração, notamos uma uniformidade rítmica formada pela sequência de síncopas de duas colcheias ligadas. Sob o ponto de vista da altura, a frase se mantém praticamente na mesma nota (Sol natural). Essa equivalência na altura e na duração, a nosso ver, minimiza o que estamos chamando de deslocamento lexical. Isto é, a linha melódica, conquanto acentue a preposição “em", não deixa de colocar em realce as palavras que são linguisticamente nucleares: as sílabas tônicas de "qualquer" e "paixão" 
possuem duração e altura equivalente em relação à nota que recobre o monossílabo. Além disso, ambas também estão ocupando o espaço da síncopa para os tempos meio forte e forte ("qualquer" no terceiro tempo do quarto compasso e "paixão" no primeiro tempo do compasso seguinte). Desse modo, tendo em vista tal abrandamento, o trecho se torna entoativamente plausível para o ouvinte. Algo similar ocorre na canção Baião de Luiz Gonzaga e Humberto Teixeira. Vejamos.

Eu já cantei no Pará

Toquei sanfona em Belém

Cantei lá no Ceará

E sei o que me convém

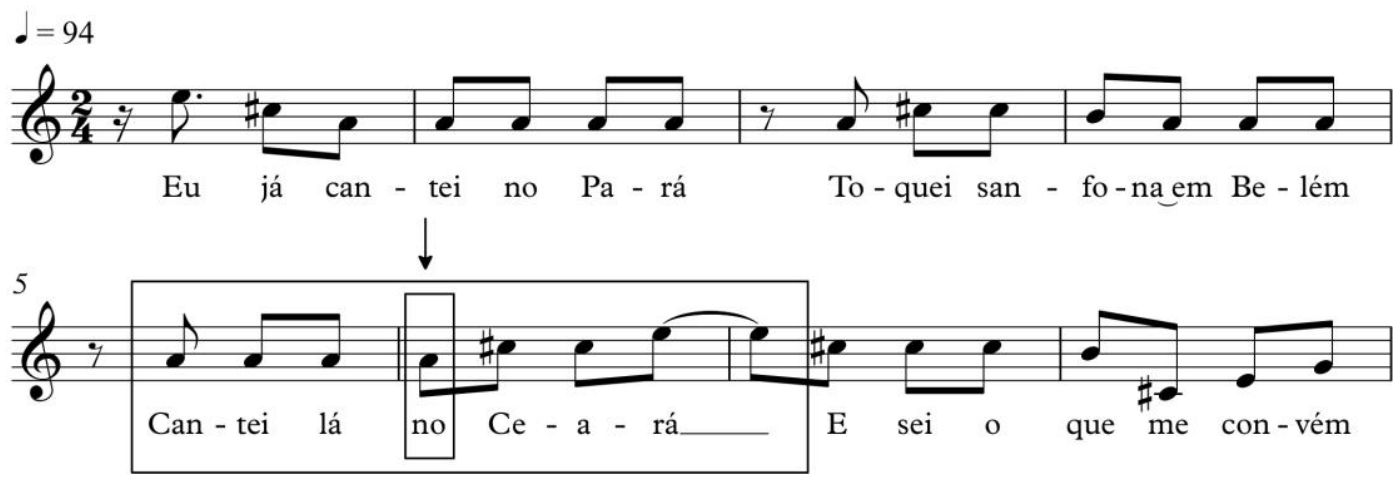

Figura 48. A acentuação lexical em Baião (Luiz Gonzaga/Humberto Teixeira)

$\mathrm{Na}$ frase destacada acima, não percebemos nenhum deslocamento silábico. $\mathrm{O}$ desvio, apontado na ilustração com uma seta, se dá no nível da palavra, por meio da ênfase em monossílabo átono (a preposição com artigo "no" que coincide com o primeiro tempo forte do sexto compasso). Quando mentalizamos a entoação que realizaríamos na língua oral, constatamos que nossa ênfase se concentraria nos vocábulos "lá" e "Ceará", sobretudo no segundo, se pensarmos no contexto linguístico de toda a estrofe que elenca lugares diversos: Pará, Belém e Ceará. Assim, nesse contexto, não seria entoativamente apropriado ressaltarmos o vocábulo "cantei”, por exemplo (o que numa outra situação conversacional poderia ser perfeitamente plausível: "Eu cantei no Ceará, eu não toquei, eu apenas cantei"). Portanto, considerando "Ceará" como o vocábulo nuclear dessa oração e verificando que ele recebe um forte destaque musical, notamos a razão de a ênfase sobre o monossílabo "no" ser de certa maneira amortecida. De fato, a melodia que acompanha o vocábulo "Ceará" possui perfil ascendente e a nota que coincide com a sua sílaba tônica é a mais aguda e a mais longa da estrofe, além de ocupar a síncopa para o 
tempo forte do compasso seguinte. Enfim, acreditamos que, na canção ou na fala, quando a ênfase está sendo direcionada para uma palavra núcleo, certos vocábulos periféricos que a antecedem podem ser ressaltados sem prejuízo da naturalidade entoativa.

O adequado realce da palavra na frase pode abrandar não somente acentuações inadequadas de outros vocábulos, mas também atenuar desvios no nível da sílaba. Aliás, é possível constatar a pertinência do estudo do nível da palavra quando observamos que certos deslocamentos silábicos não são percebidos pelo ouvinte quando o vocábulo núcleo está bem enfatizado. Esse fenômeno também ocorre na língua oral, quando realizamos desvios silábicos sutis com o intuito de enfatizar palavras mais nucleares. $\mathrm{O}$ desvio de acentuação em palavras secundárias não é notado, posto que toda a atenção está voltada para o núcleo semântico da frase. Há, é claro, uma gradação no nível de plausibilidade entoativa das canções que apresentam esse fenômeno. Analisemos alguns exemplos.

Faço lelê de fubá

Faço pitu no dendê

Sirvo seu pitéu na cama

E nada dele comer, ai

Telefone, é voz de dama

Se penteia pra atender
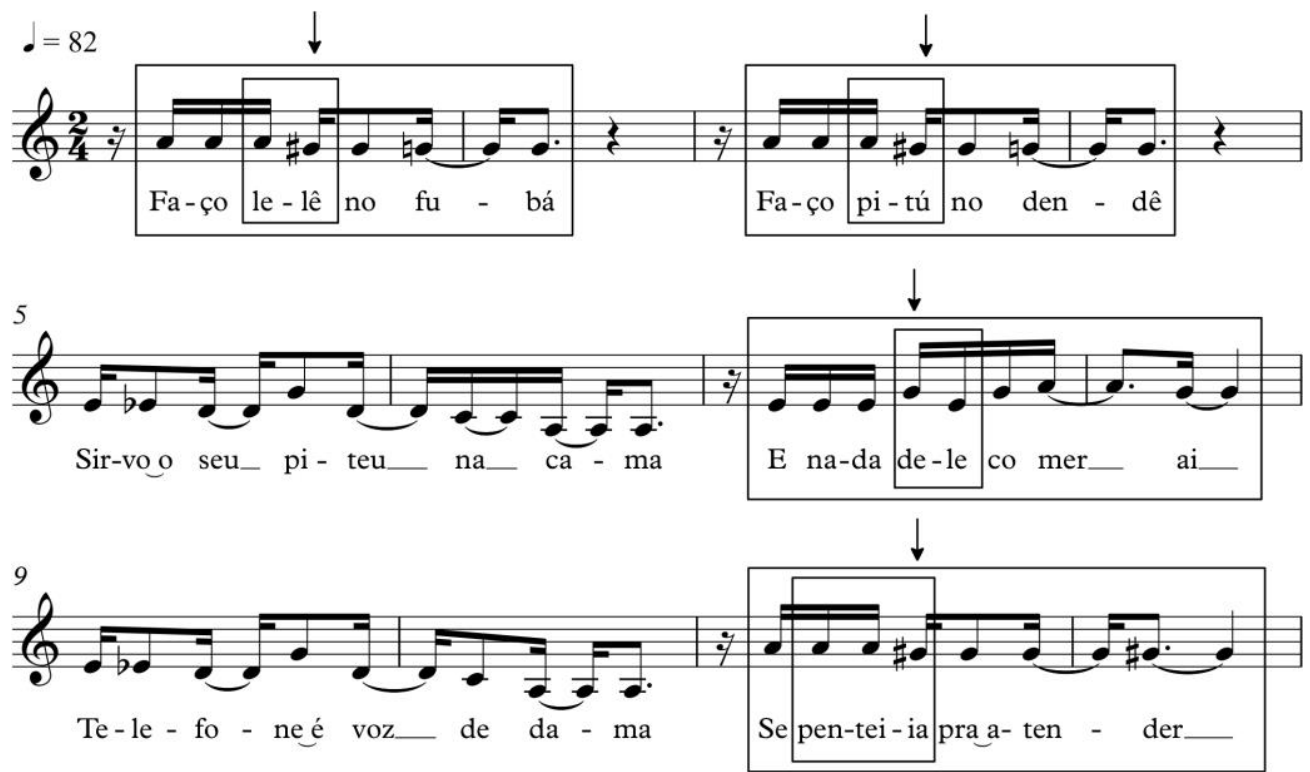

Figura 49. Abrandamento do desvio de acentuação lexical em Biscate (Chico Buarque) 
Em Biscate, desejamos chamar a atenção para o padrão rítmico-melódico que se repete nas frases destacadas acima. Tendo em vista a presença da pausa na parte forte do tempo inicial dos compassos 1,3,7 e 11, o primeiro ponto de apoio forte da frase coincide com a cabeça do segundo tempo do compasso, após a sequência de três semicolcheias. É justamente o ponto que encontra as sílabas tônicas dos vocábulos "lelê", "pitú" e "dele" e a sílaba átona do vocábulo "penteia" (conforme analisamos no final do capítulo precedente). Concentrando nossa análise nos dois primeiros segmentos destacados, desejamos observar que a emissão do vocábulo "faço" que inicia ambas as orações, ainda que seja realizada com deslocamento silábico (visto que sua sílaba átona recai na parte meio forte do primeiro tempo), não causa grande estranhamento no ouvinte. Acreditamos que a suavização de seu deslocamento acentual é gerada pelo fato de o núcleo de suas respectivas frases ("lelê" e "pitú") estarem claramente acentuados. Como se o desvio silábico anterior fosse abrandado pela esperada ênfase seguinte. Algo similar ocorre na canção Cintura Fina, de Luiz Gonzaga e Zé Dantas.

Minha morena, venha pra cá

Pra dançar xote, se deita em meu cangote

E pode cochilar

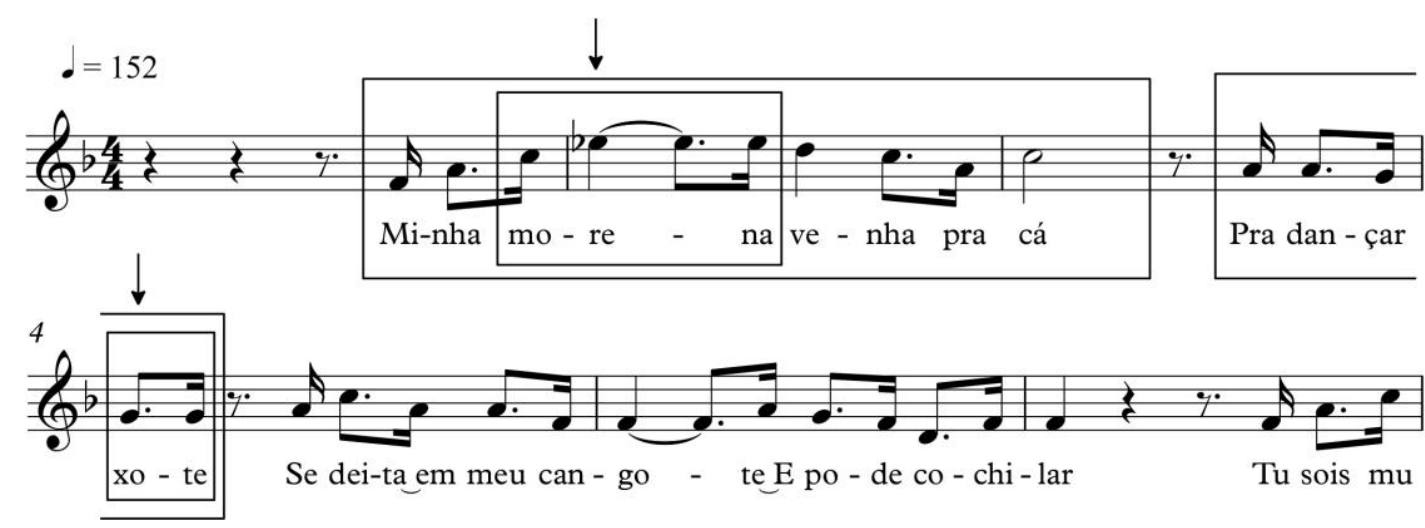

Figura 50. Abrandamento do desvio de acentuação lexical em Cintura Fina (Luiz Gonzaga/Zé Dantas)

Os vocábulos “minha" e "dançar", ainda que sofram deslocamento silábico (suas sílabas átonas se localizam na parte forte do quarto tempo do compasso), não chegam a comprometer a naturalidade entoativa das frases. Isso porque elas compõem um corpo fonético mais amplo, cuja palavra central está bem enfatizada. Assim, "minha" faz parte do segmento "minha morena" no qual o segundo vocábulo ganha destaque por meio da altura, da intensidade e da duração. Do mesmo modo, "pra dançar xote" consiste em um 
todo fonético, cujo termo nuclear "xote" recebe o apoio adequado. É como se o ouvinte não notasse o desvio da palavra secundária quando o vocábulo principal mantém intacta sua entoação natural.

Sei que alguém vai sentar junto

Você vai puxar assunto

Discutindo futebol

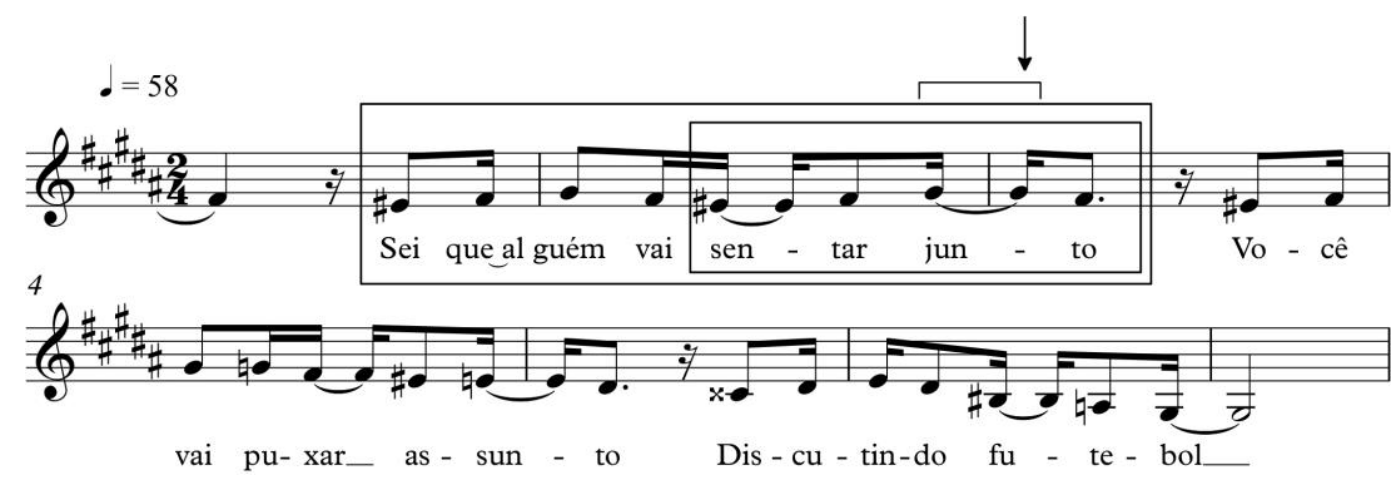

Figura 51. A acentuação lexical em Com açúcar, com afeto (Chico Buarque)

Em Com açúcar, com afeto, de maneira semelhante, o deslocamento silábico da palavra "sentar" (cuja sílaba átona recai sobre o espaço da síncopa para a parte forte do segundo tempo) é pouco percebido pelo ouvinte. Ela forma com os seus termos contíguos o grupo acentual "vai sentar junto", no qual o destaque melódico sobre o advérbio "junto" (como assinalamos na figura acima) atenua o desvio silábico anterior. Esse tipo de investigação, a nosso ver, é fundamental para a análise mais detalhada da compatibilização entre a letra e a melodia de uma canção. Acreditamos que, ao observarmos esses encaixes de maneira profunda, poderemos melhor avaliar a formação de suas unidades entoativas, detectando os seus diferentes tipos de oralização, lineares e não-lineares. 


\subsection{A desconformidade entre a palavra escrita e a palavra cantada}

Vislumbramos que o trabalho artístico do cancionista, centrado na junção entre uma letra e uma melodia, difere substancialmente do artesanato poético, por exemplo, quando pensamos sobre as complexidades advindas da compatibilização entre o texto verbal e o texto musical. Pouco importa a letra escrita de uma canção, posto que a ênfase que podemos sugerir na sua leitura pode ou não coincidir com a ênfase proposta pela melodia que a recobre. A canção, desse modo, só existe por meio do canto que conjuga a música e a língua de modo simultâneo. Ela só existe para o ouvinte e não para o leitor. Essa questão, ainda que óbvia, está no centro de um interessante fenômeno: quando a letra idealizada pelo cancionista não se concretiza ao ser combinada com a linha melódica. Vejamos o exemplo seguinte:

A mãe morre de medo de barata

O pai vive com medo de ladrão

Jogaram inseticida pela casa

Botaram cadeado no portão
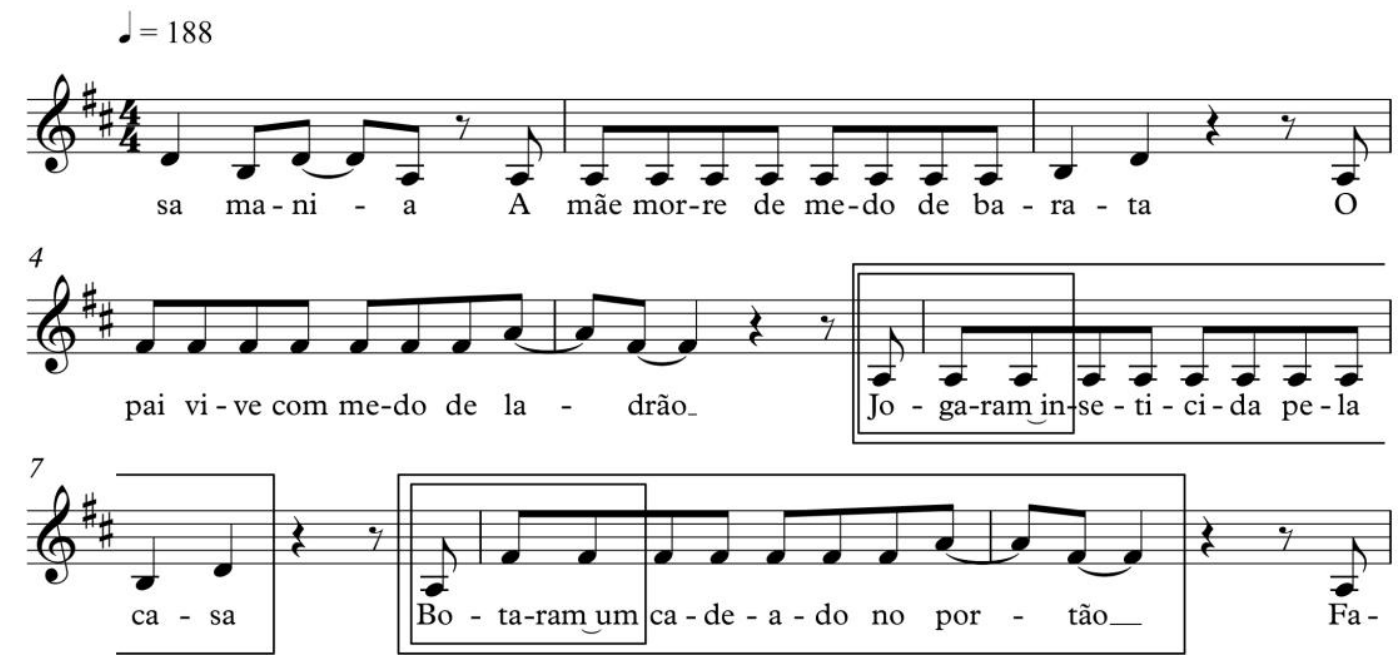

Figura 52. A palavra escrita e a palavra cantada em Família (Tony Bellotto/Arnaldo Antunes)

Quando escutamos a combinação entre a letra e a melodia da canção Família, não conseguimos captar perfeitamente o tempo verbal das palavras "jogaram" e "botaram". Ainda que o texto linguístico proponha o pretérito perfeito na terceira pessoa do plural, é possível que o ouvinte os apreenda no infinitivo: "jogar inseticida" (ou "jogar o inseticida") e "botar um cadeado" (ou "botar o cadeado"). Ocorre que o encaixe empreendido pelos cancionistas gerou um fenômeno de difícil escuta: um encontro entre 
as vogais finais das palavras "jogaram" e "botaram" e as iniciais dos vocábulos "inseticida" e "um". Os vocábulos selecionados pelos autores, tendo em vista as elisões entre essas vogais nasais (“jogaram_inseticida" e "botaram_um”), ao contrário do que pretendiam, não se concretizam na canção, apenas na letra escrita. Em Luiza, de Tom Jobim, há igualmente uma diferença entre o que ouvimos e o que lemos.

Rua, espada nua

Boia no céu imensa e amarela

Tão redonda a lua

Como flutua

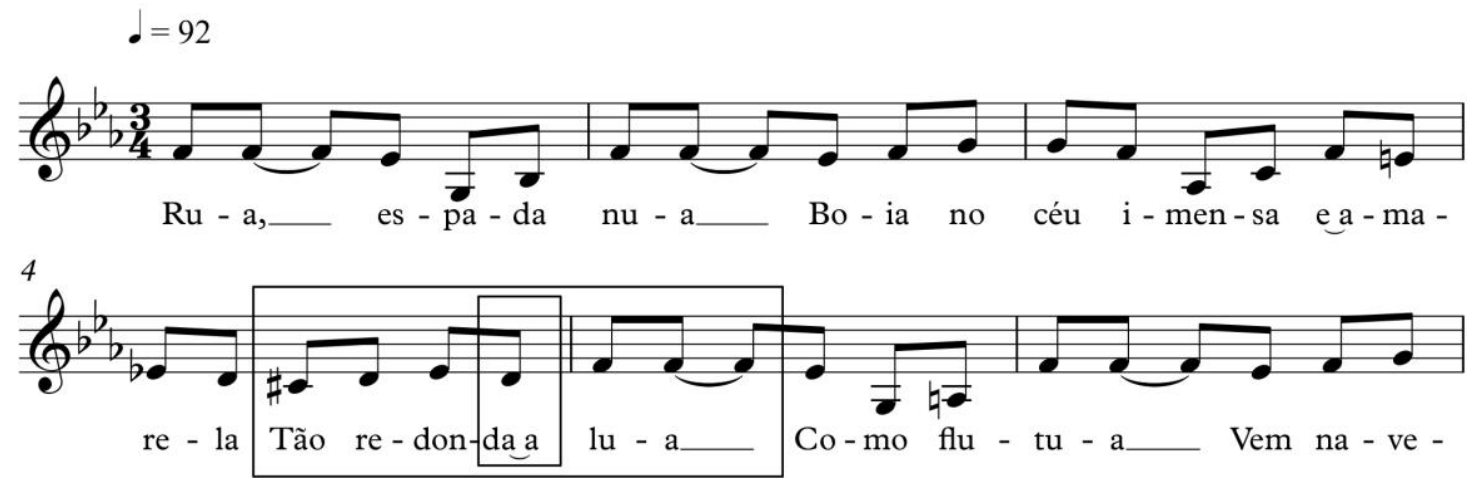

Figura 53. A palavra escrita e a palavra cantada em Luiza (Tom Jobim)

Nessa canção, a elisão entre a vogal final de "redonda" e o artigo "a" faz o segundo praticamente desaparecer na escuta. O seu desaparecimento, no entanto, não prejudica o entendimento linguístico por parte do ouvinte, visto que, nesse caso, a presença ou a ausência do artigo não altera de maneira significativa o sentido da oração. Algo similar ocorre com os dois próximos exemplos, as canções Cegos do Castelo, de Nando Reis, e Chiclete com banana de Gordurinha e Almira Castilho.

Dos cegos do castelo

Me despeço e vou

A pé até encontrar

Um caminho, o lugar

Pro que eu sou 


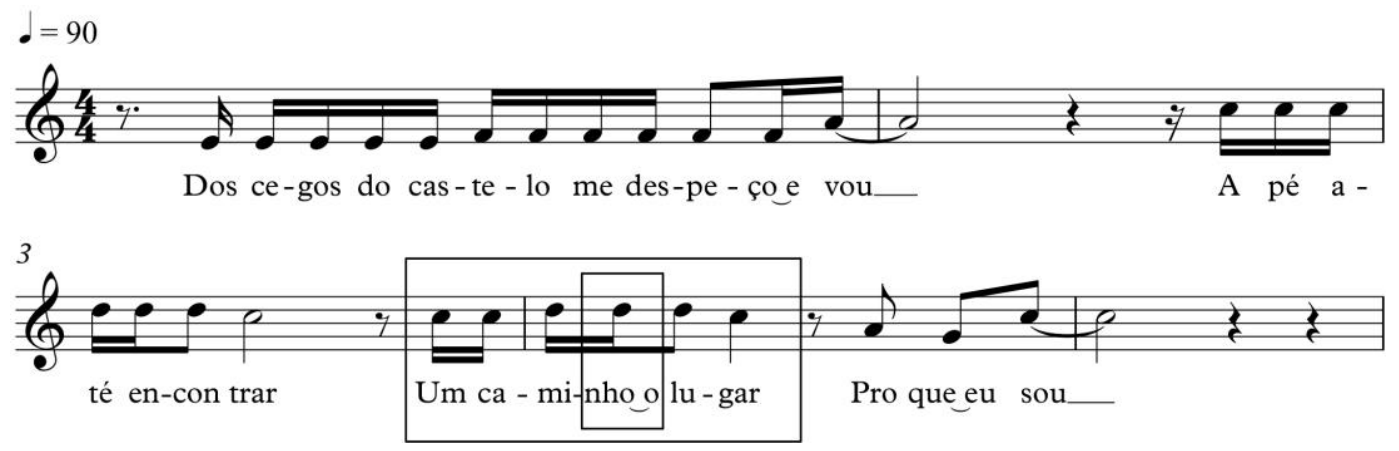

Figura 54. A palavra escrita e a palavra cantada em Cegos do castelo (Nando Reis)

Chicletes eu misturo com banana

E o meu samba vai ficar assim

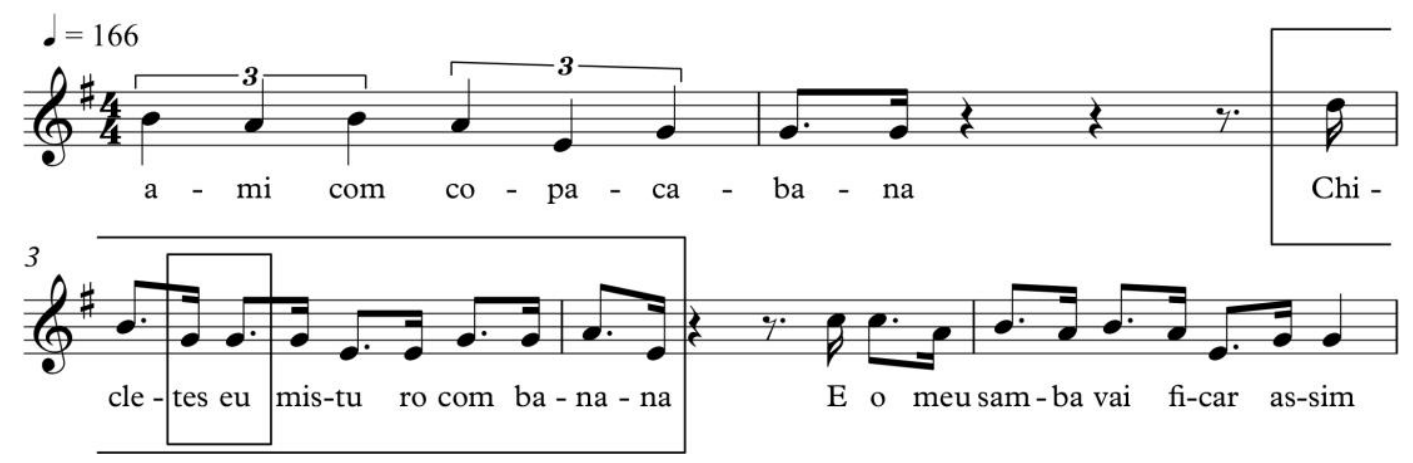

Figura 55. A palavra escrita e a palavra cantada em Chiclete com banana (Gordurinha/Almira Castilho)

Em Cegos do Castelo, o verso "um caminho, o lugar" recebe uma melodia que torna a apreensão do ouvinte um pouco ambígua em relação ao uso dos artigos indefinido “um” e definido “o". É possível que apreendamos “um lugar" ao invés de "o lugar”. Isso se deve, a nosso ver, pelo encontro vocálico entre a terminação da palavra "caminho" (com a presença da nasalidade de sua sílaba "nho") e o artigo "o", bem como pela ocorrência anterior do artigo indefinido "um" em "um caminho". Assim, a reiteração do som nasal também contribui para uma compreensão equivocada da letra.

Em Chiclete com banana, por sua vez, a depender do andamento da canção (mais ou menos acelerado), torna-se mais difícil a entoação da letra do modo como ela foi concebida pelos compositores. O verso "Chicletes eu misturo com banana", recoberto por essa linha melódica, pode ser apreendida pelo ouvinte como "Chiclete se eu misturo com banana". A junção sonora entre a desinência nominal de número (o plural -s) na palavra “chicletes" e o pronome pessoal "eu” faz surgir, na escuta, uma palavra não prevista pelos cancionistas: a conjunção "se”. Mais uma vez, em ambos os exemplos, esse descompasso 
entre a letra escrita e a letra cantada não chega a perturbar a naturalidade entoativa e nem altera de maneira relevante o sentido proposto pelo texto linguístico original. Há casos, no entanto, que podem gerar certo grau de estranhamento. Analisemos o exemplo seguinte:

Mas o baião tem um quê

Que as outras danças não têm

Quem quiser é só dizer

Pois eu com satisfação

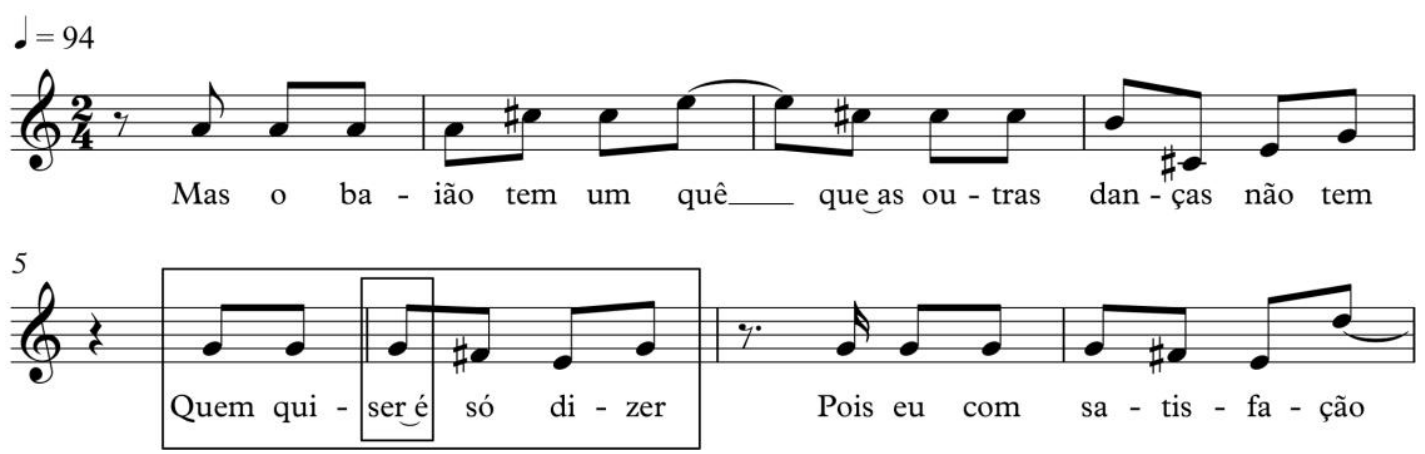

Figura 56. A palavra escrita e a palavra cantada em Baião (Luiz Gonzaga/Humberto Teixeira)

Em Baião, o encontro vocálico entre a sílaba final de "quiser"112 e a palavra "é" praticamente elimina, no canto, o segundo vocábulo. Assim, apenas pela escuta, captamos o seguinte verso: “Quem quiser só dizer”. O sentido linguístico da letra original (algo como: "quem quiser dizer, diga") transforma-se, então, numa frase como "quem quiser apenas dizer". O significado se altera mais fortemente, nesse caso, ainda que não perturbe de modo significativo a plausibilidade entoativa da canção. Afinal, o processo cancional que guia a obra, a tematização, coloca o ouvinte em outra chave de escuta.

$112 \mathrm{O}$ falante do português brasileiro não costuma pronunciar a desinência que indica o infinitivo do verbo. O vocábulo "quiser" passa então a ser pronunciado "quisé". 


\subsection{O léxico e os seus diferentes níveis de referencialidade}

O assunto específico deste capítulo, a palavra, pode contribuir para a nossa análise proporcionando outros tipos de reflexão, para além da questão da ênfase melódica em palavras tônicas ou átonas. A palavra, por si só, como uma unidade linguística dotada de significado, também pode sugerir sentidos mais ou menos usuais, conforme a comunidade linguística do ouvinte. Por outro lado, a linha melódica pode atenuar ou enfatizar os seus níveis de oralidade. Assim, desejamos observar que o uso de expressões linguísticas mais ou menos incomuns, o que a princípio não possui relação com a combinação entre a letra e a melodia, pode ser abordado a partir de uma perspectiva cancional e não literária.

A utilização de vocábulos inusitados (algo que depende da perspectiva do ouvinte, obviamente) é uma prática presente em toda a história da canção brasileira. Isso porque os cancionistas costumam trazer para as suas obras as características próprias de sua comunidade linguística. São gírias, arcaísmos, siglas, neologismos ou mesmos construções verbais pouco usuais na língua oral que muitas vezes não chegam a ser compreendidas pelo ouvinte que não partilha de seu universo linguístico. Além disso, por vezes, ao valorizar certas sonoridades da letra ou determinadas questões poéticas, o cancionista também produz expressões ou versos pouco cotidianos.

Em nosso cancioneiro, por exemplo, identificamos compositores, intérpretes e até mesmo movimentos musicais que estimam a presença de uma linguagem que acreditam ser mais requintada, pela reunião de construções verbais raras. São as letras rebuscadas que conhecemos por meio do repertório das modinhas, sambas-canções e outros gêneros praticados por cancionistas de variadas épocas. São os estilos linguisticamente empolados dos versos de Catulo da Paixão Cearense, da canção Rosa (Pixinguinha/Otávio de Souza) ou mesmo do nosso Hino Nacional Brasileiro. Tatit associa esse repertório ao que denomina "estilo semierudito", caracterizado pela "linguagem empolada e melodias que lembram árias europeias do século XIX, ainda que simplificadas e reduzidas no tamanho" (TATIT, 2002: 32). Segundo o autor, esse estilo algo parnasiano reinava na canção brasileira do início do século XX, quando se deu uma espécie de virada entoativa e uma "nova letra" começou a ser praticada pelos nossos cancionistas:

Não tanto a letra-poema, típica das modinhas, ou a letra cômico-maliciosa dos lundus, mas a letra do falante nativo, aquela que já nasce acompanhada pela entoação correspondente. Sem nunca deixar de lado o lirismo ou mesmo a comicidade que já reinavam no período 
oitocentista, a nova letra, que só se consolidou nos anos 1920 com Sinhô, substituiu o compromisso poético pelo compromisso com a própria melodia, ou seja, o importante passou a ser a adequação entre o que era dito e a maneira (entoativa) de dizer, bem mais que o valor intrínseco da letra como poema escrito ou declamado (TATIT, 2004: 71)

Ao longo do século XX, no entanto, embora essa "letra-poema" tenha caído cada vez mais em desuso, encontramos em diversos momentos, compositores que continuaram cultivando-a, ainda que em menor grau. A canção Aquarela do Brasil, composta em 1939 por Ary Barroso e que alcançaria grande sucesso popular a partir dos anos 1940, apresenta em sua letra diversos termos muito distantes da linguagem coloquial, como, por exemplo, o uso do adjetivo "merencório" para caracterizar a luz da lua como melancólica:

Deixa cantar de novo o trovador

À merencória luz da lua

Toda canção do meu amor

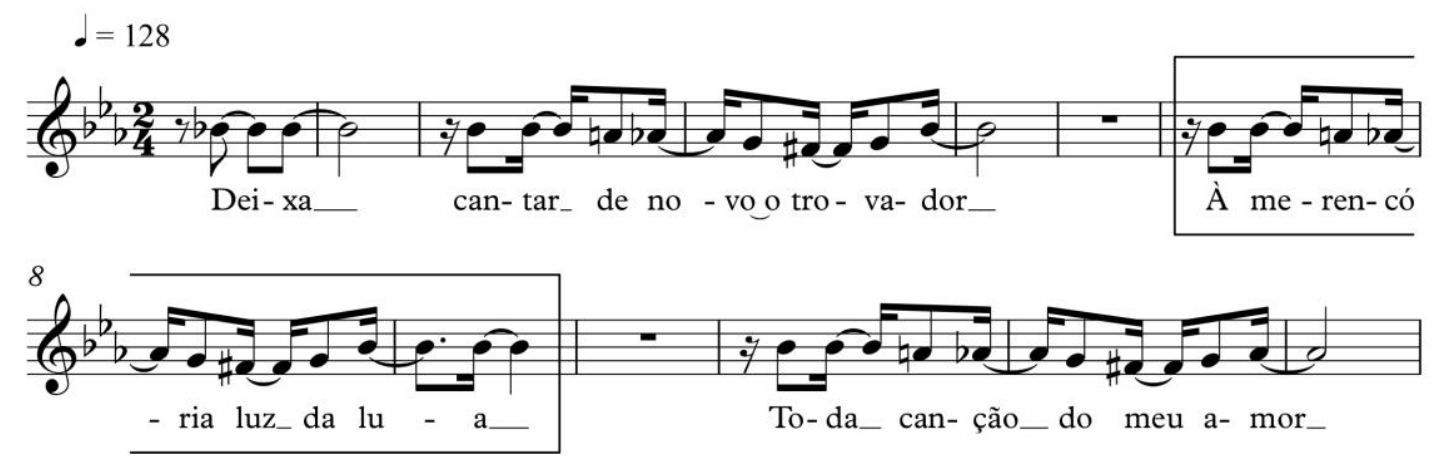

Figura 57. O léxico com menor referencialidade em Aquarela do Brasil (Ary Barroso)

O uso de um vocábulo raro e a inversão sintática que posiciona esse adjetivo antes do nome ("merencória luz" ao invés de "luz merencória") podem ser consideradas, portanto, amostras desse estilo afeito aos eruditismos poéticos oriundos do final do século XIX e que, à época, já havia sido problematizado pela produção dos autores da poesia moderna. É interessante observar que essa tendência de valorização da letra "como poema escrito ou declamado", o que, consequentemente, pode colocar a questão da naturalidade entoativa em segundo plano, se faz presente até mesmo na atualidade, sendo ainda uma das tendências de nossa canção. Trata-se de um movimento natural exercido por certos cancionistas mais afeitos à poesia que tendem a incorporar seus recursos linguísticos à letra de suas obras. Desejamos assinalar que, por serem linguagens adjacentes à canção, tanto a poesia quanto a música poderão aparecer de forma mais proeminente na obra de certos artistas (mesmo que em menor número, na medida em que a grande parte dos 
compositores não possui qualquer compromisso com a evolução estética da poesia escrita ou da música erudita ou instrumental popular). Podemos, nesse sentido, destacar certas letras de Caetano Veloso e Walter Franco ou certas melodias e arranjos de Arrigo Barnabé. Trata-se, afinal, do mesmo movimento de experimentar na canção a inclusão de elementos de uma arte socialmente consagrada: parnasianismos ou concretismos, no universo cancional, fazem parte de uma mesma tendência. Ao cabo, elas “desentoativizam" a canção em prol de interessantes buscas por outras expressões estéticas $^{113}$. Voltando aos nossos exemplos, encontramos igualmente uma construção sintática típica do registro escrito da língua em Corcovado, canção composta por Tom Jobim em 1960.

Da janela vê-se o Corcovado

O Redentor que lindo

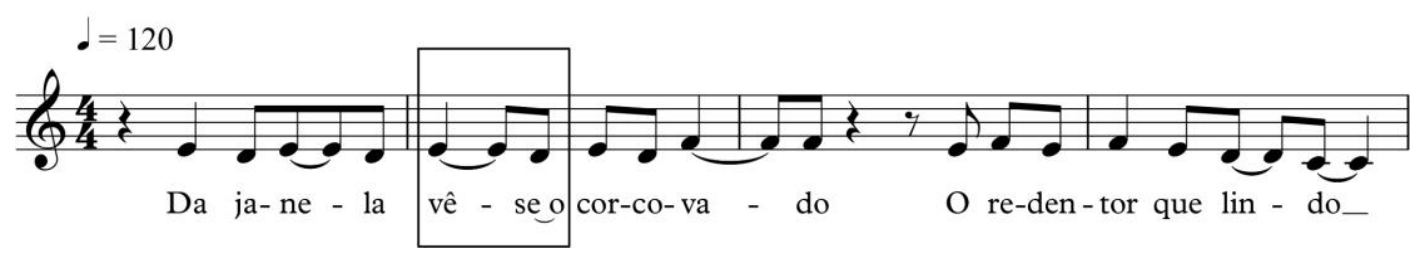

Figura 58. O léxico com menor referencialidade em Corcovado (Tom Jobim)

Nesse caso, notamos o uso da ênclise na conjugação do verbo pronominal "verse", algo que não utilizamos no registro oral do português brasileiro: "vê-se o corcovado". Desse modo, uma frase como "Da janela se vê o corcovado" parece soar um pouco mais familiar aos nossos ouvidos. Não obstante, acreditamos que esse verso poderia ser ainda mais "entoativizado" caso excluíssemos o uso do verbo pronominal.

Da janela eu vejo o Corcovado

O Redentor que lindo

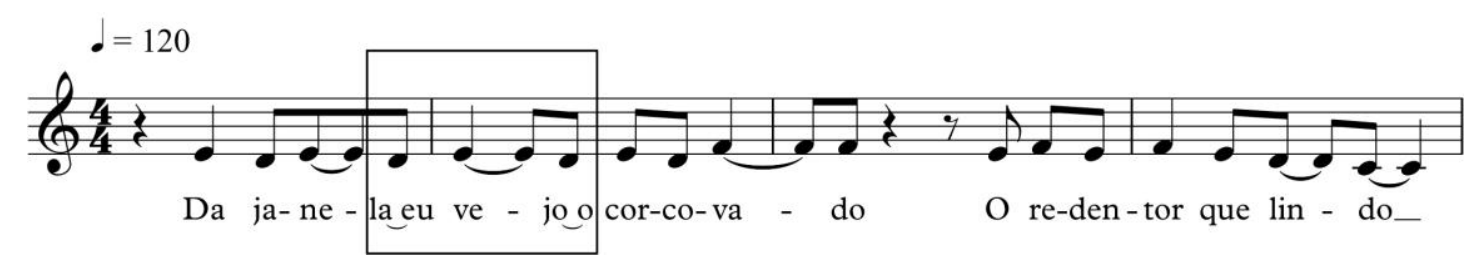

Figura 59. Reescrita da letra de Corcovado (Tom Jobim)

113 Devemos entender esse processo de um modo absolutamente técnico, jamais ideológico. Assim, “desentoativizar" a relação entre a melodia e a letra não deve ser considerado um procedimento condenável ou equivocado, mas sim uma característica composicional. Os cancionistas que incluem a poesia e a música experimental em suas obras trazem, com suas propostas estéticas incomuns, ricas contribuições para linguagem da canção. 
Ao propormos a alteração do verso para "Da janela eu vejo o Corcovado", sem dúvida, o tornamos mais próximo da língua falada, o que, acrescido da introdução do sujeito "eu", se adequa muito bem à tendência de despojamento e proximidade característica da bossa nova. Nessa canção, no entanto, nossa alteração, ainda que mais oral, poderia destoar da intenção estética do cancionista que parece querer agrupar imagens poéticas mais estáticas: "Um cantinho, um violão", "Este amor, uma canção", "Muita calma pra pensar" etc. Nesse sentido, o uso do verbo "vê-se" ao invés de "eu vejo" contribui para essa ideia de imobilidade da cena retratada (ao ocultar o sujeito da ação). O cancionista, então, precisa constantemente optar entre a inserção de certas expressões linguísticas (por vezes menos comuns) e a fluência entoativa da frase. As suas opções, no decorrer da sua produção, irão formar o seu estilo cancional. A canção $O$ sol nascerá, de Cartola e Elton Medeiros, composta em 1961 e lançada apenas na década de 1970, também apresenta uma ocorrência interessante, dessa vez articulando a escolha lexical com a linha melódica.

Finda a tempestade

O sol nascerá

Finda esta saudade

Hei de ter outro alguém para amar

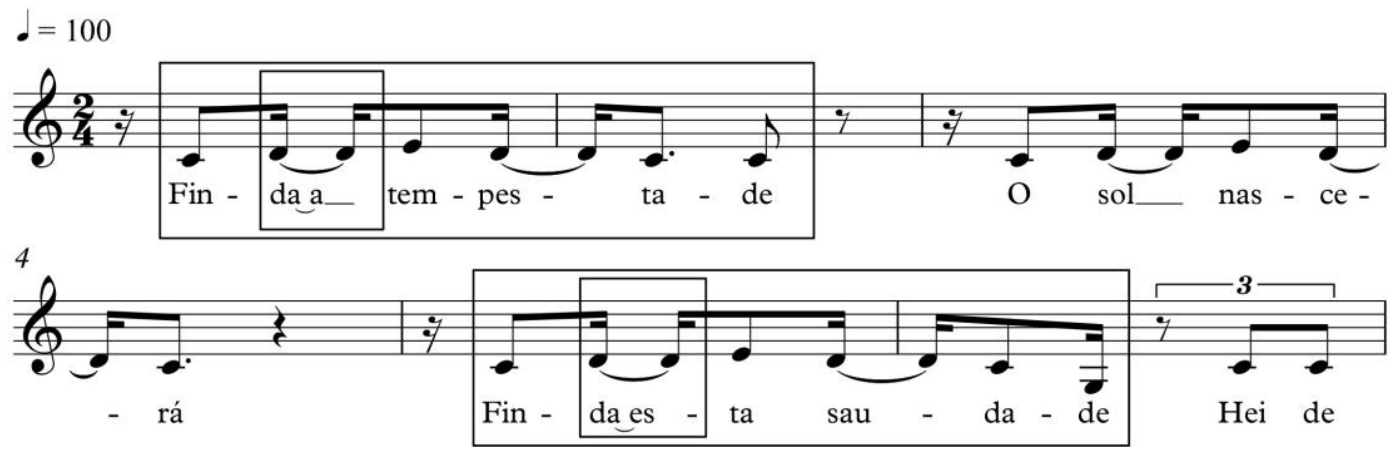

Figura 60. O léxico com menor referencialidade em $O$ sol nascerá (Cartola/Elton Medeiros)

Exemplo curioso, a letra dessa canção apresenta uma expressão linguística pouco utilizada na língua oral. Trata-se da utilização do verbo "findar" em "Finda a tempestade" e "Finda esta saudade", conjugado no presente do indicativo. A nossa intuição linguística, aliada à conformação musical da melodia, contudo, faz com que escutemos algo como "fim da tempestade" e "fim desta saudade". Ou seja, esse fenômeno é causado não apenas pela pouca recorrência do verbo "findar" na fala, mas também pelo fato de que as linhas melódicas que recobrem esses versos promovem uma elisão vocálica entre ele e o artigo 
"a" ("finda_a") ou o pronome demonstrativo "esta" ("finda_esta"). Esses dois fatores fazem com que o ouvinte, apoiando-se imediatamente na sua experiência linguística cotidiana, apreenda antes "fim da tempestade" do que "finda a tempestade".

Parece-nos, então, que o cancionista, quando deseja incorporar um termo ou construção linguística menos usual, deve redobrar a sua atenção sobre a melodia que o recobrirá, caso a relação com a língua falada seja um valor estético por ele cultivado. Nesse sentido, podemos supor que se o compositor, por uma tendência mais poética do que cancional, desfavorece à remissão à oralidade, certas formulações verbais podem não ser efetivamente realizadas na escuta. Essa é, afinal, a prova de que a canção só acontece no momento de sua execução, por meio da união entre a letra e a melodia. Todavia, há, é claro, como vimos acima, exemplos nos quais essa questão da referencialidade dos termos adotados pelos autores não é influenciada pela configuração melódica. Examinemos os seguintes trechos das canções Morena de Angola, de Chico Buarque, A filha da Chiquita Bacana, de Caetano Veloso e Sina, de Djavan.

Morena de Angola que leva o chocalho amarrado na canela

Morena, bichinha danada, minha camarada do MPLA

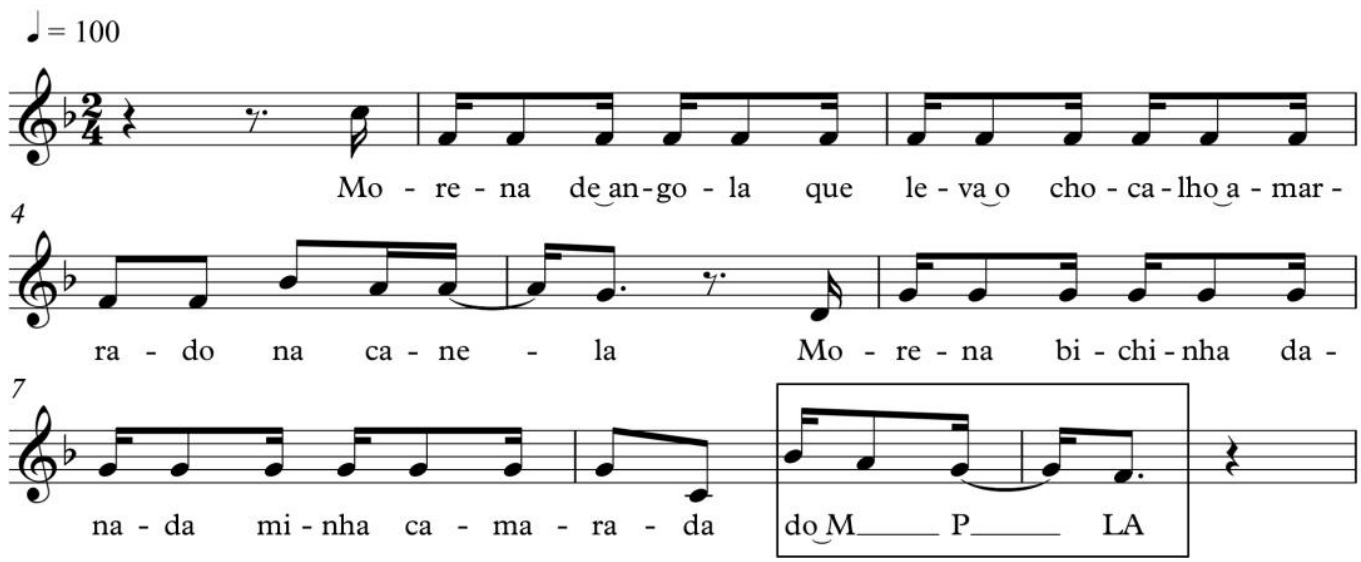

Figura 61. O léxico com menor referencialidade em Morena de Angola (Chico Buarque)

E a quadrilha toda grita

Iê, iê, îe

Viva a filha da Chiquita

Iê,iê, iê

Entrei pra "Women's Liberation Front" 


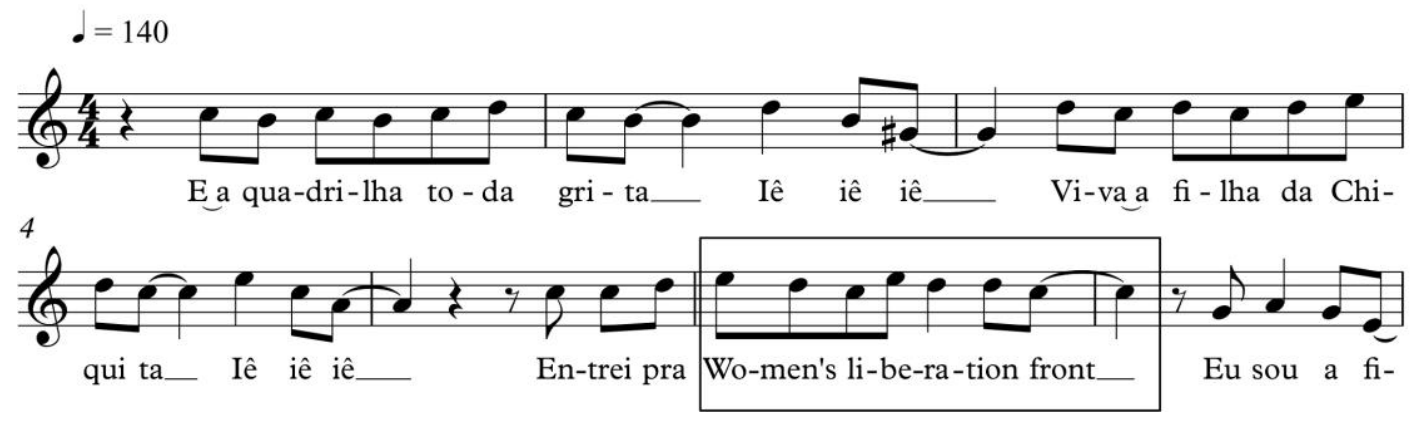

Figura 62. O léxico com menor referencialidade em A filha da Chiquita Bacana (Caetano Veloso)

O luar, estrela do mar

O sol e o dom

Quiçá, um dia, a fúria desse front virá

Lapidar o sonho até gerar o som

Como querer Caetanear o que há de bom

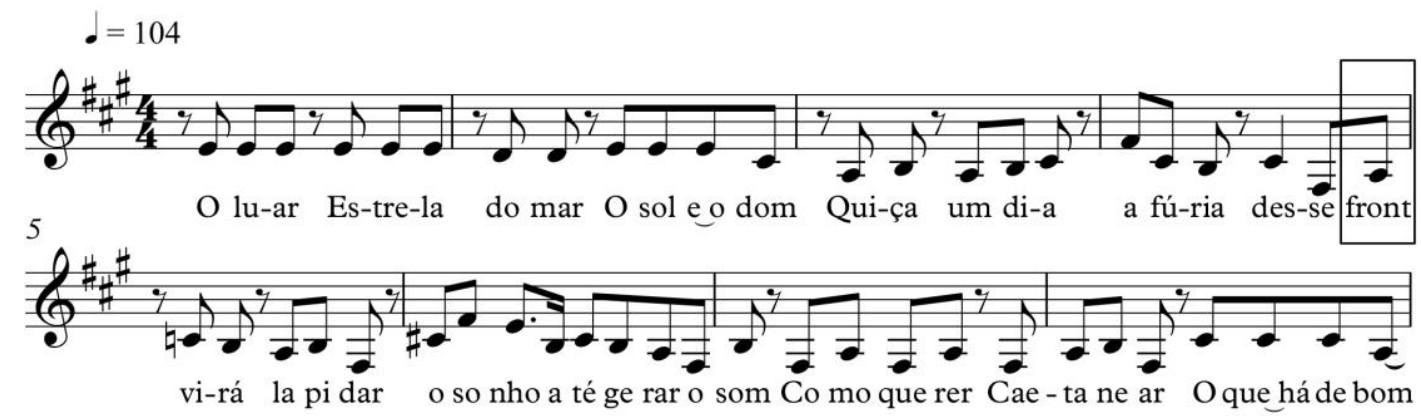

Figura 63. O léxico com menor referencialidade em Sina (Djavan)

Nesses fragmentos, encontramos a ocorrência de termos cujo significado não é facilmente compreendido pela maioria dos falantes do português brasileiro. Em Morena de Angola, por exemplo, o uso da sigla "MPLA" (designando o Movimento Popular de Libertação de Angola) mais corrente no noticiário da época em que a canção foi lançada ${ }^{114}$, hoje não possui a mesma penetração cultural, como se a canção fosse se "desreferencializando" com o passar do tempo, na medida em que a sigla vai caindo em desuso. Há, aqui, uma questão histórica e social, o que nos indica, mais uma vez, a relatividade da questão da plausibilidade oral, dependente da comunidade linguística na qual cada canção se insere.

O uso dos anglicismos nas canções de Caetano Veloso e Djavan seguem na mesma direção. Além da questão histórico-temporal ligada à expressão "Women's Liberation

\footnotetext{
${ }^{114}$ A canção foi lançada por Clara Nunes em 1980. O Movimento Popular de Libertação de Angola governa o país desde 1975, quando transformou-se em um partido político após a Guerra de Independência (19611974).
} 
Front”, menção ao movimento feminista Women's Liberation Movement surgido no final dos anos 1960, é a presença da língua inglesa que, de acordo com a comunidade linguística de cada falante, pode "desreferencializar" a canção. Em Sina, de Djavan, o mesmo termo "front" é utilizado agora de modo autônomo, como vocábulo isolado, o que também pode dificultar a sua apreensão. Notamos aqui, os naturais conflitos entre a cultura linguística do cancionista e a do público ouvinte, geralmente mais heterogênea. Nessa mesma direção, podemos analisar exemplos nos quais as expressões verbais usadas pelo compositor não configuram termos históricos de épocas passadas e nem mesmo correspondem a estrangeirismos, mas ainda assim geram certo estranhamento entoativo. São, a nosso ver, invenções linguísticas ou poéticas do cancionista, construções verbais que se distanciam de nossa linguagem cotidiana. Vejamos.

Segue o seco sem sacar que o caminho é seco

Sem sacar que o espinho é seco

Sem sacar que seco

É o Ser Sol

Sem sacar que algum espinho seco secará

E a água que sacar será um tiro seco

E secará

O seu destino seca

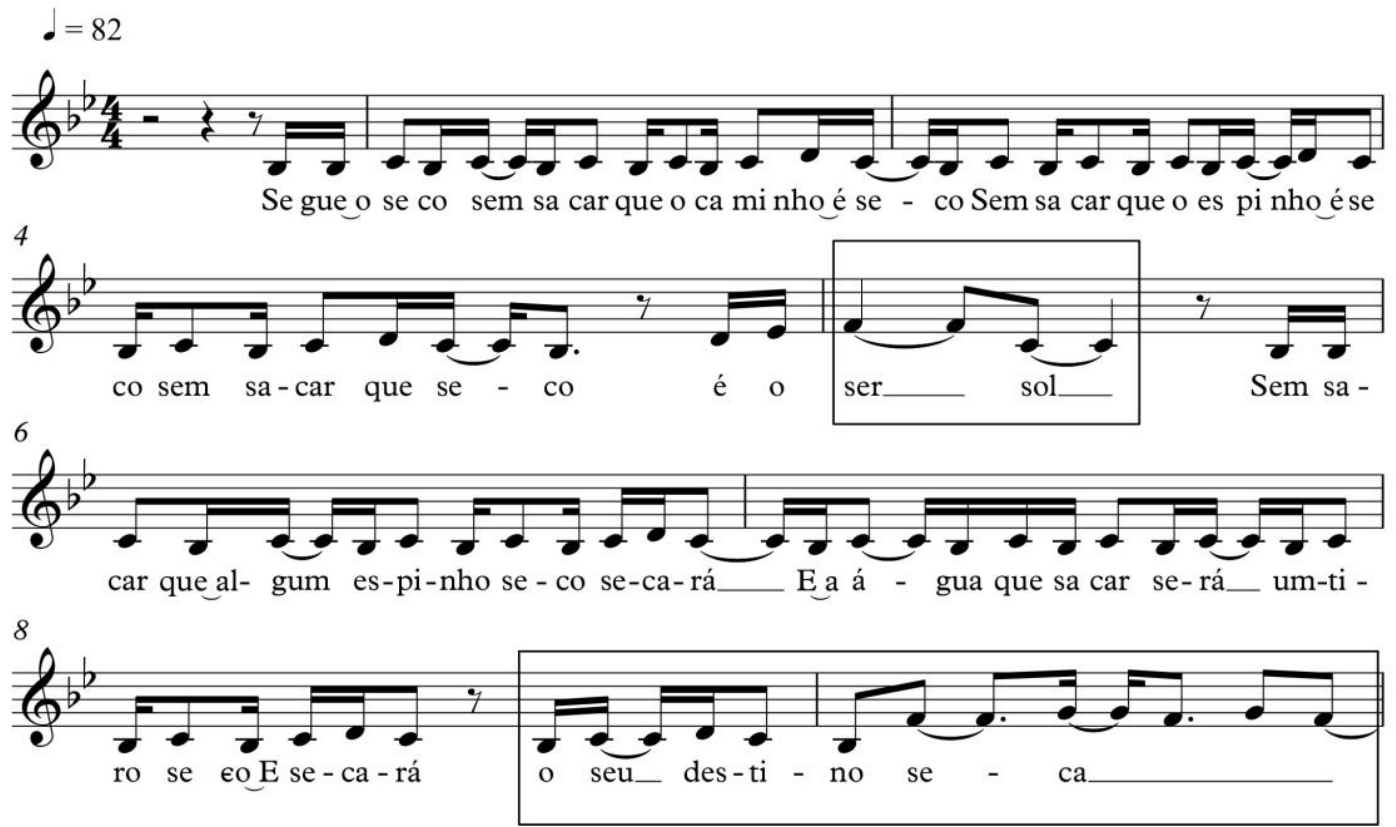

Figura 64. O léxico com menor referencialidade em Segue o seco (Carlinhos Brown) 
Ela é pró na arte

De pentelhar e aziar

É campeã do mundo

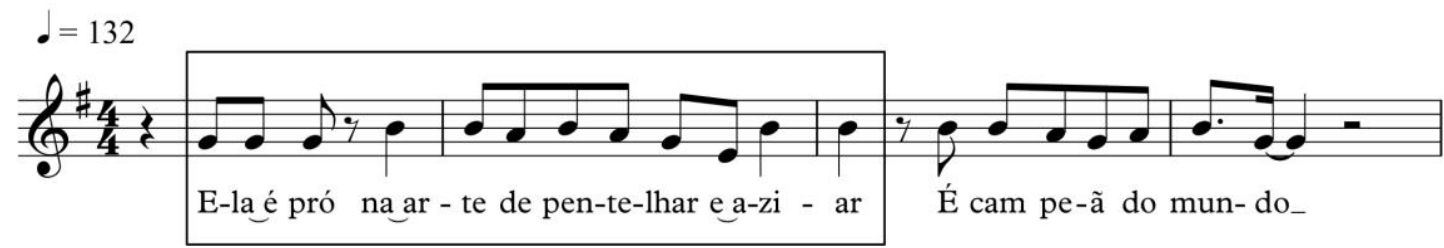

Figura 65. O léxico com menor referencialidade em Mulher de fases (Rodolfo Abrantes/Digão)

Em Segue o seco, constatamos duas expressões linguísticas incomuns utilizadas pelo cancionista: "ser-sol" e "destino-seca". No segundo caso, no entanto, o estranhamento oral aumenta na medida em que a sílaba átona de "seca" é bastante enfatizada pela melodia: ela recai sobre as alturas mais agudas do fragmento e coincide com um longo melisma entre as notas Fá e Sol. Esse destaque pode, além de dificultar a compreensão da expressão originalmente pensada pelo compositor, sugerir $\mathrm{o}$ entendimento de outro vocábulo, algo como "o seu destino secará", tamanha a ênfase na sílaba final do segmento.

Em Mulher de Fases, da mesma maneira, a letra propõe uma expressão linguística incomum. Trata-se do neologismo "aziar", verbo que o cancionista derivou do substantivo "azia" e que, inserida nesse contexto musical (cuja melodia, além de possuir andamento acelerado, também produz uma elisão problemática entre a conjunção "e" e a primeira sílaba do vocábulo), dificilmente será compreendida pelo ouvinte. Nos exemplos seguintes, Feijoada Completa e Fato consumado, observamos, da mesma forma, o uso de expressões verbais pouco usuais.

Mulher, você vai gostar

Tô levando uns amigos pra conversar

Eles vão com uma fome

Que nem me contem

Eles vão com uma sede de anteontem. 


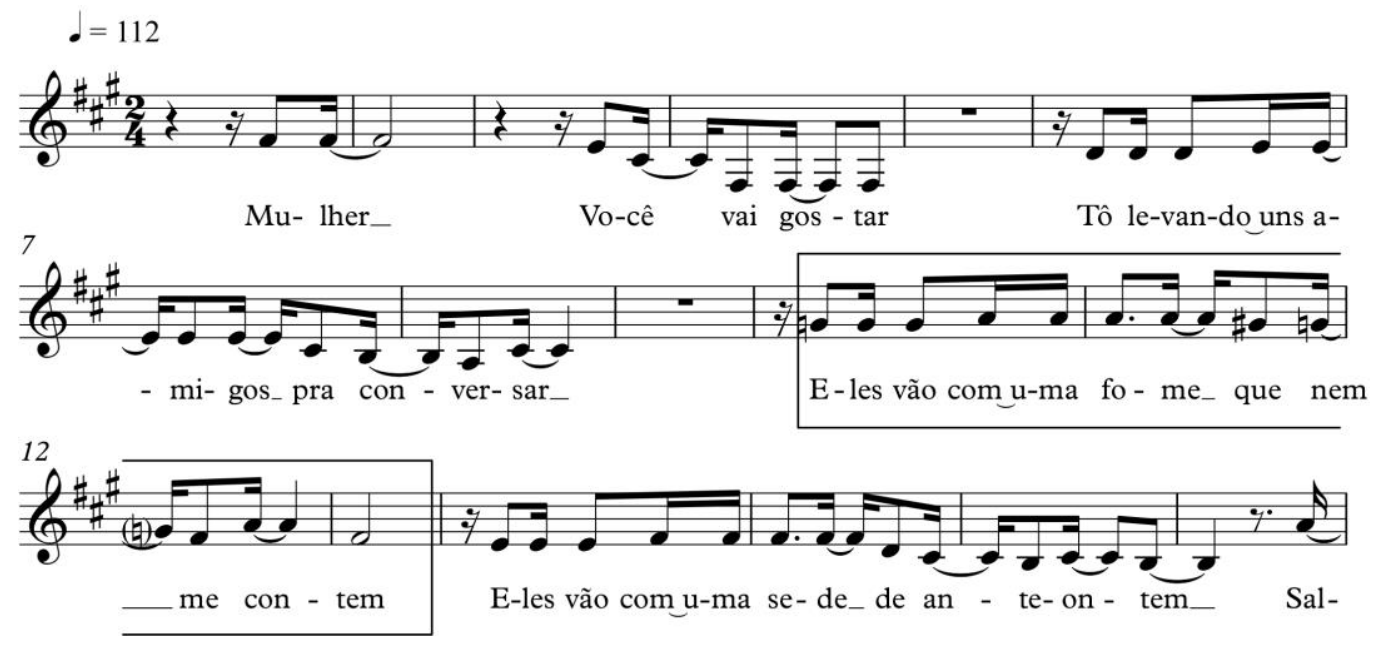

Figura 66. O léxico com menor referencialidade em Feijoada completa (Chico Buarque)

Se toda hora é hora

De dar decisão

Eu falo agora

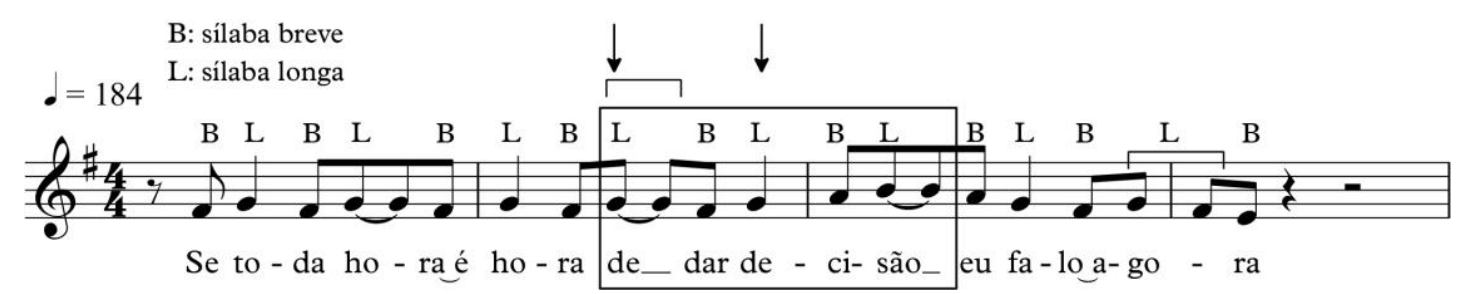

Figura 67. O léxico com menor referencialidade em Fato consumado (Djavan)

Na canção de Chico Buarque, há na letra a transformação de uma construção linguística habitual na língua oral. Trata-se do verso "Eles vão com uma fome que nem me contem" que, a nosso ver, propõe uma alteração da expressão "que eu nem te conto" (algo como "você nem imagina a fome que eu estou"). Essa expressão, no entanto, mais usada na primeira pessoa do singular, torna-se quase irreconhecível quando assim transformada pelo cancionista.

Em Fato consumado, de Djavan, observamos algo ainda mais interessante. Além do uso de uma expressão incomum ao final da frase "Se toda hora é hora de dar decisão" (ao invés das sentenças mais usuais "Se toda hora é hora de decidir" ou "de tomar decisão", por exemplo), a combinação da linha melódica com o texto verbal dificulta ainda mais o entendimento da letra. A ênfase da melodia, que na frase proposta pelo autor, deveria recair sobre o verbo "dar", coincide com a preposição "de" e com a primeira sílaba (átona) do vocábulo "decisão". "Dar" situa-se, como vemos na figura acima, em um ponto muito fraco da métrica do compasso, além de ser cantado meio tom abaixo em 
relação às suas notas vizinhas. Assim, constatamos que o cancionista, ao propor uma linha melódica que alterna repetidamente entre sílabas breves (B) e longas (L), optou por não compatibilizar essa conformação musical com as exigências entoativas do texto.

Aqui, constatamos, mais uma vez, o quanto a combinação entre a melodia e a letra é crucial para a realização entoativa dos segmentos verbais idealizados pelo compositor. Sobretudo ao criar elementos linguísticos menos usuais, como já dissemos, o cancionista pode buscar uma entoação que favoreça a compreensão dos mesmos, caso a apreensão verbal seja algo importante para ele naquele instante. A referencialidade entoativa pode também se concentrar na questão das gírias e variantes linguísticas, como na canção $D e$ repente, Califórnia, de Lulu Santos e Nelson Motta, lançada em 1982.

Eu dou a volta, pulo o muro

Mergulho no escuro

Sarto de banda

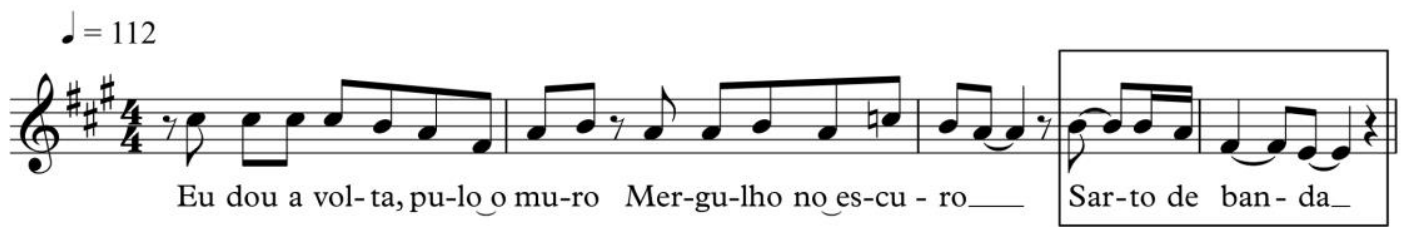

Figura 68. O léxico com menor referencialidade em De repente, Califórnia (Nelson Motta/Lulu Santos)

A expressão idiomática "sarto de banda" ou "salto de banda", cujo significado é "desistir" ou "abandonar", é um bom de exemplo de uma gíria menos utilizada na atualidade pelas comunidades linguísticas do português brasileiro. Ao usar a rotacização do "l" em "r", pronunciando-o com o fonema [R], consoante vibrante velar múltipla (CUNHA, 2017: 59), característico do português do Rio de Janeiro, o compositor acaba tornando a assimilação dessa expressão ainda mais dificultosa, sobretudo para os falantes que não a utilizam ${ }^{115}$. Nesse exemplo, contudo, é somente o uso do léxico e não a relação entre a melodia e a letra o que determina esse estranhamento entoativo. Na figura seguinte, ao contrário, observamos que a melodia exerce um papel mais decisivo:

E destes dias tão estranhos

Fica a poeira se escondendo pelos cantos

${ }^{115}$ Evidentemente, a presença das palavras isoladas "salto" e "de banda" ("de lado") na língua portuguesa pode auxiliar o ouvinte a intuitivamente conjecturar o significado da expressão idiomática em questão. 

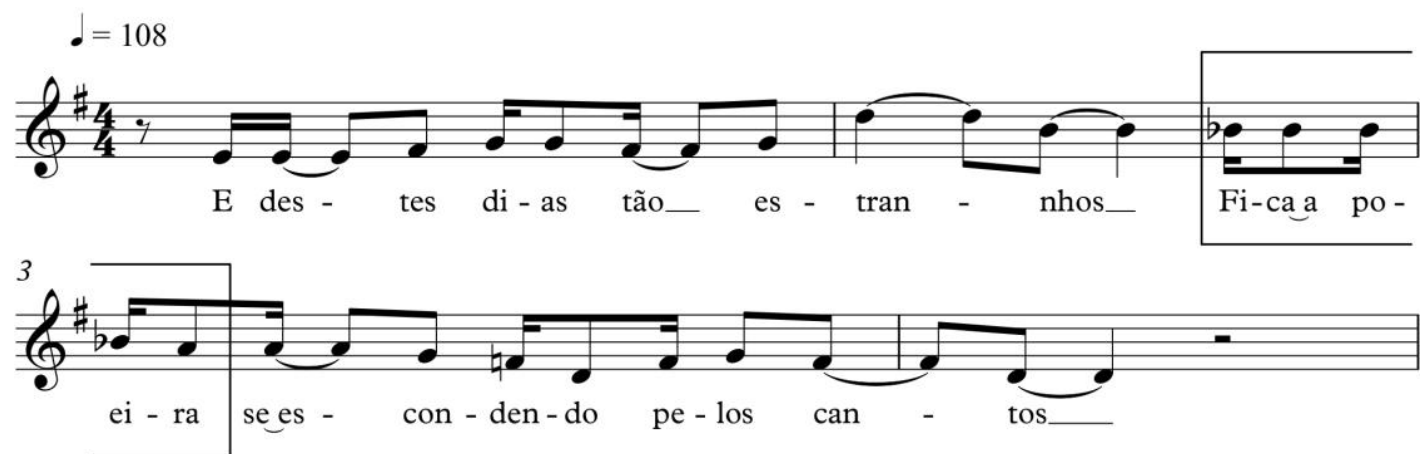

Figura 69. Cacófato em Teatro dos vampiros (Renato Russo/Dado Villa-Lobos/Marcelo Bonfá)

O cacófato "capoeira" que escutamos no início da frase linguística "Fica a poeira se escondendo pelos cantos" é gerado não somente pela escolha lexical e ordem dos vocábulos na oração. A configuração rítmica da melodia produz uma elisão vocálica entre a última sílaba de "fica" e o artigo feminino "a" e isso contribui de modo decisivo para a audição inconveniente da palavra "capoeira". O ouvinte poderia ser levado a escutar um verso algo esdrúxulo como "Vi capoeira se escondendo pelos cantos", considerando a proximidade entre os sons fricativos [f] e [v]. Trata-se, é claro, de um exemplo inusitado, mas de grande importância para nosso estudo, uma vez que demonstra que o resultado expressivo das escolhas lexicais do cancionista também dependerá das suas escolhas melódicas. 


\section{7 $O$ aproveitamento artístico da alteração da acentuação lexical}

No capítulo anterior, dedicado ao estudo da sílaba, comentamos sobre o fato de os deslocamentos de acentuação silábica integrarem as soluções artísticas dos compositores. O mesmo se dá com a palavra. O cancionista pode, até mesmo na interpretação, alterar a ênfase melódica e encontrar propostas entoativas diversas. Ao relacionar melodia e letra, ele se depara com soluções sonoras ou linguísticas inusitadas, mas que o agradam, como se pretensos "erros entoativos" pudessem gerar "acertos artísticos". Evidentemente, como vimos antes, não há, nesse processo, acertos nem erros. São ocorrências previstas pelo processo de figurativização melódica, composto por oralizações lineares e não-lineares. Examinaremos alguns casos mais didáticos nesse item. Comecemos com um exemplo ligado às múltiplas possibilidades entoativas em uma mesma obra. Comparemos duas diferentes versões da canção Sampa, de Caetano Veloso, uma interpretada pelo próprio compositor e a outra pelo cantor João Gilberto.

Alguma coisa acontece no meu coração

Que só quando cruza a Ipiranga e a avenida São João

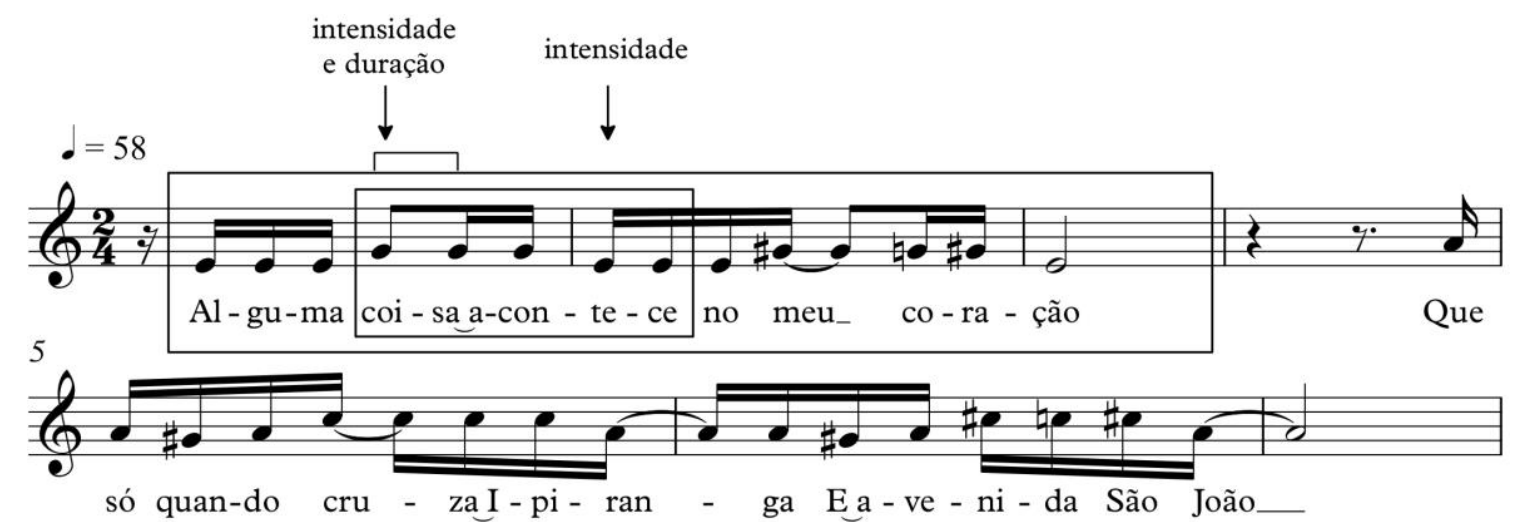

Figura 70. A acentuação lexical em Sampa (Caetano Veloso) interpretada pelo próprio compositor

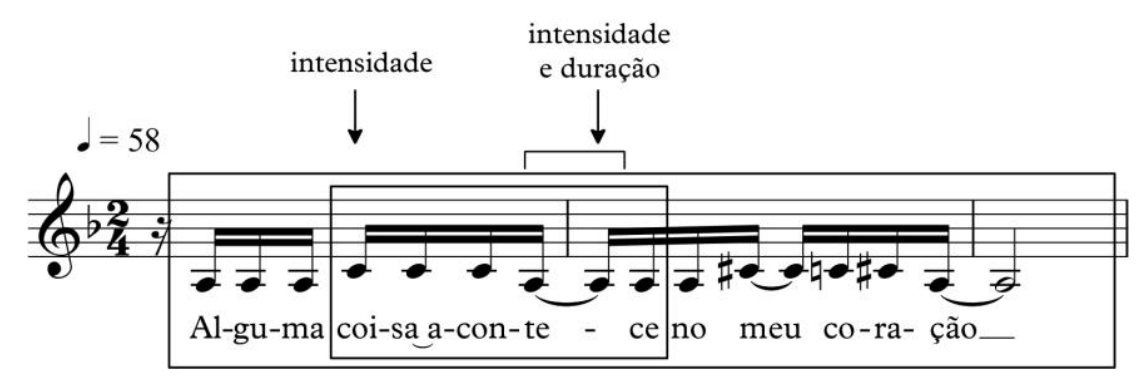

Figura 71. A acentuação lexical em Sampa (Caetano Veloso) interpretada por João Gilberto 
Quando comparamos essas duas versões, observamos que, em ambas as propostas rítmico-melódicas para a mesma frase linguística "Alguma coisa acontece no meu coração", as acentuações silábicas estão perfeitamente preservadas. No nível da palavra, contudo, notamos um curioso acontecimento. Examinando a expressão "alguma coisa acontece", verificamos que, na versão cantada por Caetano Veloso, há uma ênfase maior sobre a palavra "coisa" (intensidade e duração) do que sobre o vocábulo "acontece" (acentuado apenas pela duração) ${ }^{116}$. De modo inverso, João Gilberto, ao entoar o mesmo trecho, ressalta mais fortemente essa segunda palavra e não a primeira: a sílaba tônica de "acontece" coincide com a síncopa para o primeiro tempo forte do compasso seguinte, além de possuir duração mais alongada.

Cotejando esses dois exemplos, constatamos que o fenômeno da alteração de acentuação lexical não está ligado apenas às perturbações orais causadas pela acentuação de palavras átonas ou secundárias. Ele também consiste no mecanismo que permite realçar ora um vocábulo, ora outro, produzindo diferentes proposições entoativas, todas plausíveis. Nesse sentido, Caetano Veloso e João Gilberto aproveitaram a possibilidade oferecida pela língua de enfatizar o substantivo feminino "coisa" ou o verbo "acontecer". No primeiro caso, temos a valorização do próprio fenômeno ou daquilo que acontece no coração do sujeito. No segundo, ressalta-se um pouco mais a ação do acontecimento. Trata-se, portanto, de diferentes resultados artísticos ainda circunscritos ao campo entoativo. Há, diferentemente, casos em que observamos a presença de um verdadeiro desvio na acentuação lexical que, se por um lado, "desentoativiza" a canção, por outro, propõe determinado resultado estético caro ao compositor. Na canção Expresso 2222, de Gilberto Gil, notamos uma ocorrência interessante.

Dizem que tem muita gente de agora

Se adiantando

Partindo pra lá

Pra dois mil e um

E dois e tempo afora

Até onde essa estrada do tempo vai dar

Do tempo vai dar

Do tempo vai dar,

Menina, do tempo vai

116 Entendemos o vocábulo "alguma" somente como um agregado sonoro do grupo acentual "alguma coisa”, sendo o segundo vocábulo o núcleo desse corpo fonético. 


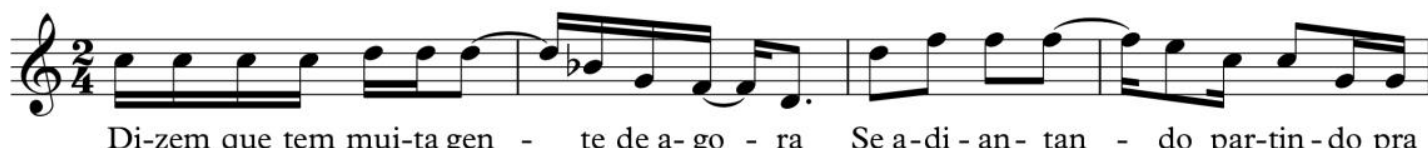
5
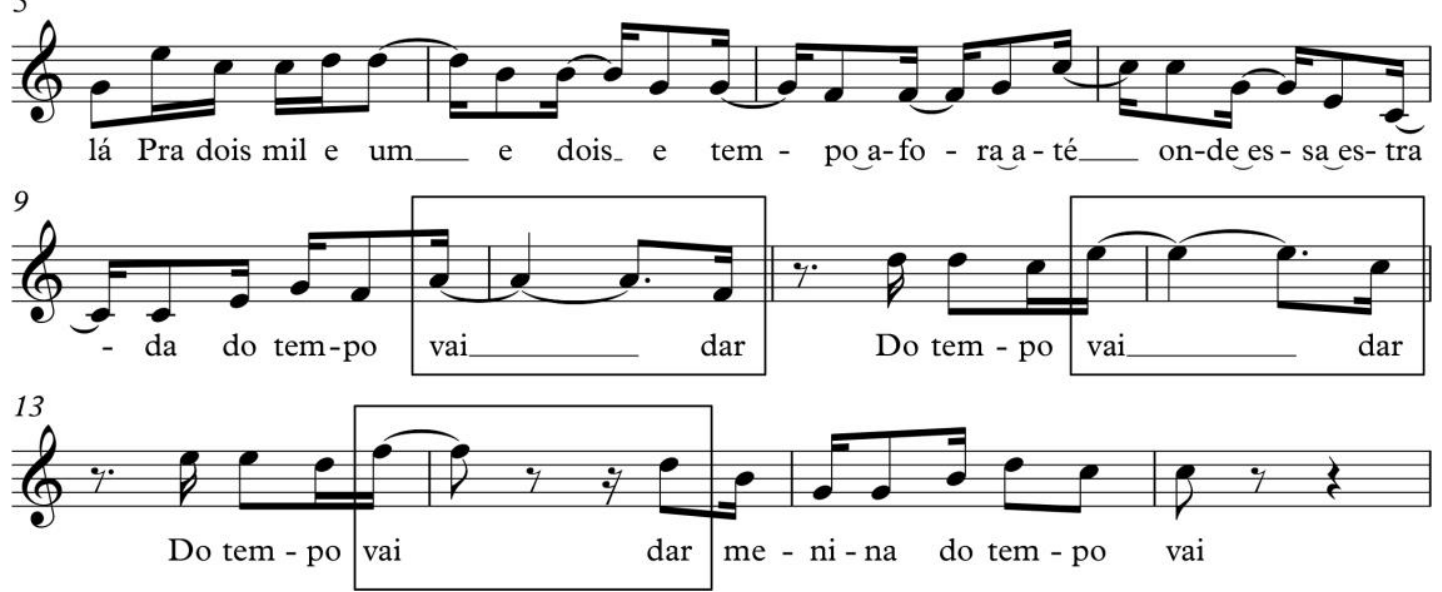

Figura 72. O aproveitamento artístico do deslocamento lexical em Expresso 2222 (Gilberto Gil)

Examinando os últimos dois termos da frase "até onde essa estrada do tempo vai dar", notamos que, na língua falada, costumamos concebê-los como um único corpo fonético ("vai dar"), ressaltando o segundo vocábulo e não o primeiro. A linha melódica proposta por Gilberto Gil, no entanto, realça a palavra "vai" e praticamente anula a presença do verbo “dar”, núcleo do grupo acentual. O primeiro termo é cantado com durações longuíssimas (se comparadas às durações das demais notas da estrofe) e atinge progressivamente alturas cada vez mais agudas (um percurso ascendente que passa pelas notas Lá, Mi e Fá). O vocábulo “dar”, em contraposição, sempre colocado em alturas mais graves, coincide com pontos muito fracos da métrica do compasso (são semicolcheias que não se localizam em partes fortes ou meio fortes do compasso ou dos tempos que o compõem).

Todavia, apesar desse estranhamento oral gerado pela combinação entre melodia e letra, o cancionista produz um resultado estético bastante interessante ao enfatizar o verbo "vai" e repetir igualmente a palavra "tempo". De fato, quando passamos por esse trecho da canção, a expressão que soa e ressoa em nossa escuta é, sem dúvida, a expressão “tempo vai". Enfatizando esses dois vocábulos e quase suprimindo a palavra "dar"117, o

\footnotetext{
117 No compasso 13, a unidade entoativa chega até mesmo a dispensar a presença do vocábulo "dar" deslocando-o para o segmento seguinte.
} 
cancionista passa a valorizar antes a ideia do próprio percurso do tempo do que a ideia de uma conclusão a ser alcançada ao final da "estrada" referida na letra.

Casos como esse que explicitam que as oralizações não lineares são construções artísticas incorporadas pelos compositores, nos fazem refletir sobre o próprio processo criativo do cancionista. A nosso ver, para além de tentarmos desvendar a intenção artística do criador, isto é, se ele produziu certa combinação entre letra e melodia de forma consciente ou inconsciente, importa-nos o resultado concreto que chegará aos ouvidos do público. Nesse sentido, é possível que Gilberto Gil, ao compor a canção examinada acima, tenha alcançado esse resultado final por meio de uma experimentação despreocupada. É como se, ao testar combinações, a própria canção fosse sugerindo caminhos, como se ela produzisse a si mesma. O cancionista, desse modo, vai descobrindo suas soluções combinatórias no interior do processo criativo, à medida que a melodia e a letra vão apresentando os seus respectivos limites e características. Assim, ao conceber a frase verbal "até onde essa estrada do tempo vai dar" e conjugá-la com a melodia, é provável que o encontro da nota longa com o vocábulo "vai" tenha agradado por demais ao compositor. Essa combinação passa, então, a dominar a sua atenção e a relegar a um segundo plano o fato de a palavra “dar" estar oralmente mal posicionada. É esse processo que faz da canção um modo de dizer especial. Examinando o exemplo seguinte, a canção Adivinha o quê, de Lulu Santos, podemos realizar uma reflexão similar.

Meu bem, meu bem

Será que você

Não vê não

Não houve nada

Só o passado rondando minha porta

Feito alma penada

$d=118$

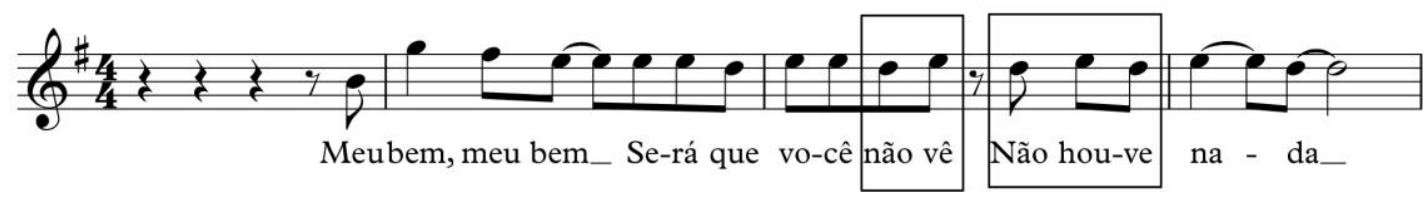

Figura 73. O aproveitamento artístico de léxico com menor referencialidade em Adivinha o quê (Lulu Santos)

Nesse exemplo, o compositor utiliza um vocábulo, senão incomum, certamente menos utilizado no registro oral do português brasileiro. Aqui, no entanto, o uso do verbo 
"haver", no sentido de "acontecer" ou "ocorrer", apresenta uma coincidência sonora com a conjugação do verbo "ouvir" no presente do indicativo. São as palavras homófonas "houve" e "ouve". O contexto da frase verbal na qual o termo ambíguo está inserido permite, então, as duas leituras. A expressão que o antecede "você não vê", destacando o sentido da visão, nos leva naturalmente a trazer o sentido da audição: "você não vê e não ouve nada". Por outro lado, é também possível apreender o verbo haver, sobretudo após a escuta da sequência da letra: "não houve nada, só o passado rondando minha porta...". De modo similar ao que comentamos a respeito de Expresso 2222, de Gilberto Gil, não nos interessa saber se Lulu Santos planejou essa ambiguidade linguística de modo consciente. A canção, autônoma, ao chegar aos ouvidos do público, suscitará neles a avaliação imediata e intuitiva do que é linguisticamente gramatical ou agramatical, plausível ou não plausível.

Pudemos verificar, ao longo desse capítulo, que a palavra representa, de fato, um segundo nível de análise da combinação entre a melodia e a letra a partir da perspectiva figurativa. Afinal, examinamos diversos exemplos nos quais as acentuações silábicas estão perfeitamente preservadas, mas, ainda assim, observa-se uma oralização inesperada. Vimos que, em geral, isso ocorre quando uma palavra secundária recebe mais realce melódico do que um termo nuclear. Evidentemente, na fala, uma frase como "Enquanto os homens exercem seus podres poderes" pode ser acentuada de diversas maneiras, de acordo com o seu contexto conversacional. Ainda que enfatizássemos de modo natural e mais ou menos equivalente os vocábulos "homens", "exercem" e "podres poderes", poderíamos, por meio de um acento de insistência (afetivo ou intelectual), destacar um em detrimento do outro, ou mesmo ressaltar termos secundários. Por exemplo, é possível realçar o artigo "os", deixando claro para o nosso interlocutor que estamos falando de vários homens e não apenas de um só indivíduo. Também poderíamos acentuar o pronome "seus" para enfatizar que os "podres poderes" pertencem a eles e não a outros sujeitos. Na canção, no entanto, essas diferentes ênfases necessitam de um contexto linguístico próprio para que não gerem um maior estranhamento oral. Como vimos acima, a acentuação melódica de monossílabos átonos, em geral, consiste em uma perda da relação entoativa entre o cantor e o público, ainda que essa perda possa ser prontamente compensada por outros ganhos estéticos.

Enfim, constatamos, no decorrer desse estudo, que a palavra constitui, de fato, um patamar de análise distinto do nível silábico ou frasal. Examinamos diversos tópicos ligados a esse estágio linguístico. Primeiramente, analisando as coincidências entre os 
pontos de destaque da frase melódica e os vocábulos de maior valor expressivo (momento em que as noções de grupo acentual e grupo fônico nos foram bastante úteis), delineamos uma espécie de campo de força exercido pelas palavras nucleares do enunciado. Passamos por numerosos exemplos nos quais observamos questões ligadas ao que denominamos "acentuação lexical”, quando tivemos a oportunidade de estudar de modo mais detalhado os monossílabos átonos e tônicos. Analisamos casos mais específicos nos quais identificamos uma possível desconformidade entre a palavra escrita e a palavra cantada, isto é, quando a letra inicialmente idealizada pelo cancionista não se concretiza após a combinação com a sua linha melódica. Estudamos igualmente exemplos de léxicos com variados graus de referencialidade. Verificamos como esse assunto pode ser abordado a partir de um ponto de vista rigorosamente cancional, diferente da perspectiva literária ${ }^{118}$. Assim, percebemos que a menor referencialidade de certos vocábulos pode ser enfatizada ou abrandada de acordo com a melodia que o recobre. Finalmente, assim como fizemos em relação ao capítulo dedicado ao nível silábico, discutimos o abrandamento e o aproveitamento artístico das alterações ligadas à configuração lexical. Passemos, então, para o capítulo seguinte, dedicado à frase.

\footnotetext{
$118 \mathrm{O}$ esforço de tratar esses aspectos composicionais a partir da perspectiva específica da canção nos é extremamente caro. No nosso entendimento, essa postura teórica é essencial para o nosso intuito de, futuramente, organizar um curso de criação de canção (conforme comentamos na introdução desta tese). Para isso, acreditamos que os elementos do artesanato cancional devem estar muito bem delineados.
} 


\section{A FRASE}

Neste terceiro e último capítulo analítico de nossa tese, estudaremos uma unidade de significação mais ampla do que a sílaba e a palavra. A frase linguística, entendida como "um enunciado de sentido completo, a unidade mínima de comunicação" (CUNHA, 2017:133), transmite maior conteúdo semântico do que os níveis anteriores e, por isso, possui uma especial importância para o estudo da figurativização melódica. Liga-se, nesse sentido, à constituição das chamadas unidades entoativas estudadas pela semiótica da canção. Examinaremos, então, entre outras questões, os variados graus de proximidade com a fala alcançados pelos diferentes recortes verbais da melodia, bem como as questões ligadas ao abrandamento e ao aproveitamento artístico dos fenômenos que ocorrem no nível da frase.

Uma frase pode ser formada por apenas um vocábulo (“Inacreditável!" ou "Silêncio!") ou pode ser composta por várias palavras, com ou sem a presença de um verbo: "Que saudade ingrata" (Doze Anos, Chico Buarque), sem verbo, e "Todo dia ela faz tudo sempre igual" (Cotidiano, Chico Buarque), com verbo. Na língua oral, assim como na canção, a frase está sempre associada a uma entoação, isto é, a uma melodia que, como vimos nos capítulos anteriores, pode definir o seu sentido como terminativo, suspensivo, hesitante etc. Nas frases que possuem verbo, a entoação e a pausa subsequente auxiliam na definição do desfecho do enunciado, como na afirmação seguida de pausa do conhecido verso "Você era a mais bonita das cabrochas dessa ala" (Quem te Viu, Quem te Vê, Chico Buarque). Por outro lado, para as frases que não possuem verbo, a melodia entoativa torna-se indispensável para a percepção do seu sentido. Assim, unidades como “Atenção!" e "Que maravilha!” necessitam desse complemento sonoro para poder expressar o seu valor gramatical. Além disso, na fala ou no palco, elas podem ser acompanhadas por gestos faciais e corporais ou mesmo pelo contexto da enunciação, de acordo com as suas necessidades expressivas.

Interessa-nos, nesse momento, comentar, mesmo que brevemente, a definição de frase em contraposição às noções de oração e período, estudadas pela gramática da língua 
portuguesa. Cremos que essas distinções nos auxiliarão no estudo desse encontro complexo entre as unidades verbais e as unidades melódicas na canção. Frase, oração e período são, desse modo, três diferentes maneiras de definir os enunciados linguísticos. A primeira, como vimos acima, corresponde a qualquer enunciado com sentido completo, não sendo necessário para isso a presença de um verbo. A frase é, por isso, uma noção de enunciado mais totalizante, englobando as unidades identificadas com os outros dois conceitos.

A oração, por sua vez, consiste em um enunciado linguístico em que há, obrigatoriamente, a presença de um verbo ou de uma locução verbal, ainda que esses termos estejam apenas subentendidos. Assim, uma frase pode conter uma ou mais orações, de acordo com a quantidade de verbos do enunciado. São frases formadas por apenas uma oração os seguintes casos: "Hoje o céu está tão lindo" (Primavera, Tim Maia), constituída por apenas um verbo e "Podem me prender" (Opinião, Zé Kéti), composta pela locução verbal "poder prender". Consequentemente, são exemplos de frases com mais de uma oração os enunciados que trazem a presença de mais de um verbo: "Levanta, / sacode a poeira / e dá a volta por cima" (Volta por cima, Paulo Vanzolini) e "Chegou, / sorriu, / venceu, / depois chorou” (Brigas nunca mais, Tom Jobim e Vinicius de Moraes).

Passando ao conceito seguinte, consideramos o período como um enunciado linguístico organizado em uma ou mais orações. Quando constituído por apenas uma oração, é classificado como simples: "O monumento é de papel crepom e prata" (Tropicália, Caetano Veloso) e "Aqui na terra estão jogando futebol” (Meu caro amigo, Francis Hime e Chico Buarque). Quando formado de duas ou mais orações é chamado de composto: "Você olha tudo e nada lhe faz ficar contente" (Debaixo dos Caracóis dos seus Cabelos, Roberto Carlos e Erasmo Carlos). Ao final de cada período, seja ele simples ou composto, há sempre uma pausa bem demarcada que contribui para uma sensação de completude e "que se marca na escrita com ponto, ponto de exclamação, ponto de interrogação, reticências e, algumas vezes, com dois pontos" (CUNHA, 2017: 136). Portanto, como o leitor já pode presumir, um dos objetivos de nossa análise neste capítulo será avaliar como as unidades entoativas de determinadas canções organizaram esses enunciados linguísticos de modo a fortalecer ou a enfraquecer esse sentido de completude.

Estudando a constituição da oração de uma maneira mais detida, também podemos definir princípios que fundamentarão as nossas análises da frase na canção. Um deles é avaliar como se dá o arranjo dos dois termos essenciais que formam a oração, o sujeito e 
o predicado. Em "A paz invadiu o meu coração" ( poderíamos estudar a maneira como a melodia organiza a disposição do sujeito "A paz" e do predicado "invadiu o meu coração", separando-os levemente. Especificando ainda mais nosso comentário acerca dos termos da oração, devemos também tratar das noções de sintagma nominal e sintagma verbal, unidades cujos núcleos são um substantivo ou um verbo, respectivamente. Pensemos na oração "Um grande amor tem sempre um triste fim" (Pierrot Apaixonado, Heitor dos Prazeres e Noel Rosa). Observamos aqui, coincidindo com o sujeito, o sintagma nominal "um grande amor", uma vez que o substantivo "amor" corresponde ao seu núcleo. Da mesma forma, coincidindo com o predicado, temos o sintagma verbal "tem sempre um triste fim" formado pelos termos “tem" (verbo) “sempre" (modificador) "um triste fim" (sintagma nominal). Aprofundando um pouco mais a descrição dos elementos da oração, podemos decompor os dois sintagmas nominais em determinantes ("um" e "um"), modificadores ("grande" e "triste") e substantivos ("amor" e "fim"). Com isso, podemos visualizar a seguinte estrutura de organização oracional:

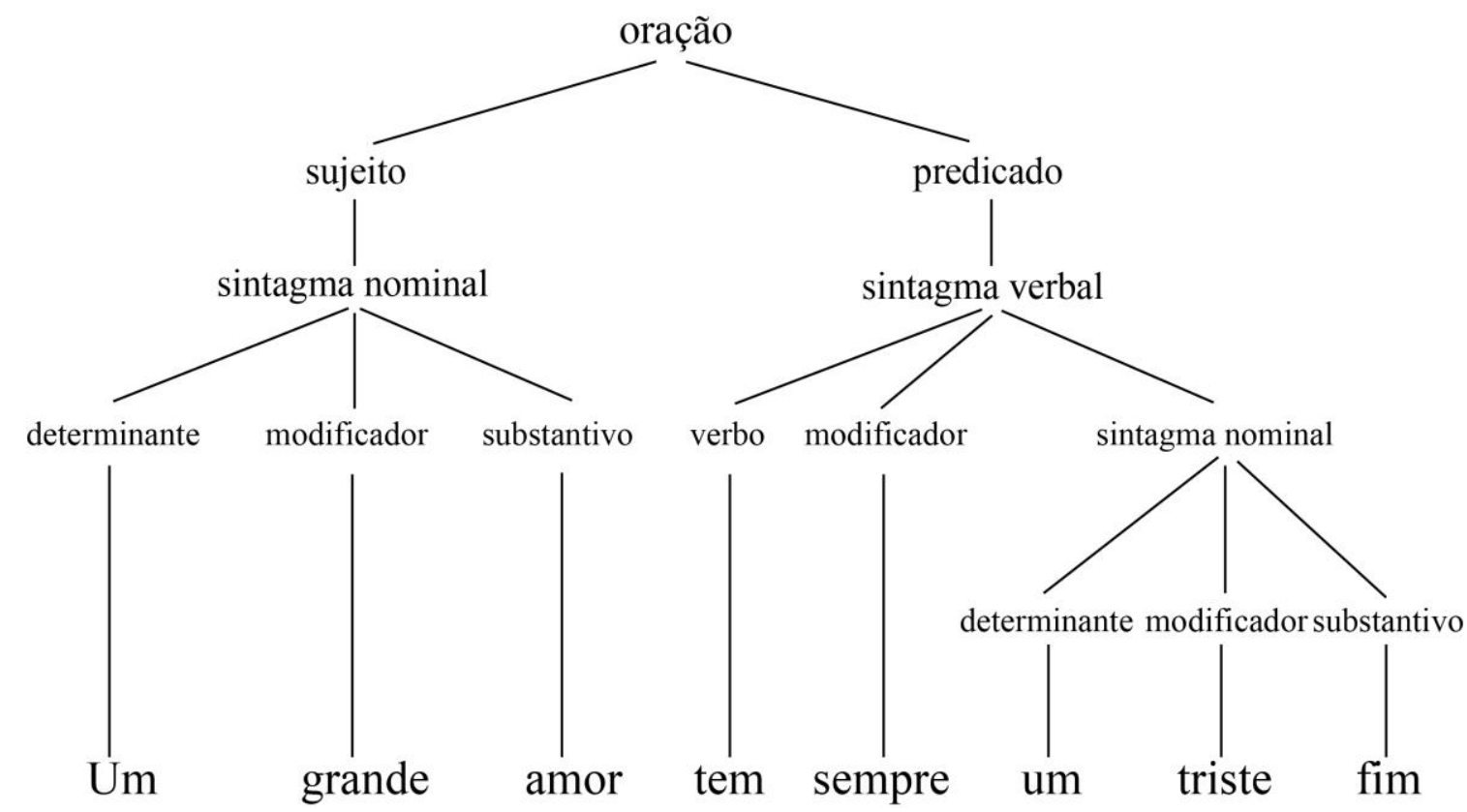

Figura 1. Os termos essenciais da oração

Tendo em vista que, ao compor, o cancionista produz encontros e desencontros entre as unidades melódicas e as unidades linguísticas, a esquematização acima poderá nos ajudar a perceber os diferentes pontos da unidade verbal em que os supostos cortes melódicos poderão ocorrer e, consequentemente, qual o nível de valorização ou 
desvalorização oral gerado por cada uma dessas cisões. Assim, veremos que, nos exemplos de canção selecionados para este capítulo, cortes distintos da frase verbal produzirão diferentes tipos de modos de dizer, isto é, oralizações lineares e não-lineares.

O exame da frase, uma unidade linguística de maior amplitude e dotada de maior significação, ao abarcar os níveis anteriores da palavra e da sílaba, proporciona uma análise mais complexa da relação entre a melodia e a letra. Talvez, por essa razão, esteve mais presente nos estudos empreendidos pela semiótica da canção. Aliás, em torno da frase, pairam diversos conceitos ou recursos figurativos explorados por Tatit: os tonemas constituem a sua terminação, carregada de significado; a elasticidade melódica corresponde à possibilidade de sua ampliação ou redução, guiadas pela tendência oral; a faixa entoativa delimita o campo restrito de suas alturas; e as unidades entoativas, por fim, são estabelecidas a partir de um constante diálogo entre a frase musical e a frase verbal. Comecemos, então, nosso estudo da frase na canção recuperando, ainda que brevemente, o recurso figurativo da unidade entoativa. 


\subsection{As unidades entoativas e seus diferentes graus de proximidade com a fala}

A unidade entoativa, conceito ligado à gênese da canção na medida em que representa a própria junção entre o texto verbal e o texto musical, constitui um importante recurso criativo para o cancionista ao proporcionar variadas maneiras de recortar uma melodia com a letra. Isso porque cada uma das unidades melódicas (que, em seu conjunto, formam a melodia de uma canção) pode receber uma ou diversas unidades verbais, além de poder abarcar somente uma parte da frase linguística. Ao serem recortadas pela letra, passam a constituir as chamadas unidades entoativas. Nesse sentido, por meio da análise desse recurso, poderemos observar os variados tipos de oralização oferecidos por esses diferentes recortes.

Em Estimar Canções, Tatit ilustra muito bem a constituição das unidades entoativas a partir da canção Ainda é Cedo, do grupo brasileiro Legião Urbana (TATIT, 2016: 106-107). O autor compara os dois diferentes recortes linguísticos do mesmo trecho melódico, em momentos distintos da obra. Como vemos na figura seguinte, há duas unidades melódicas que, em sua primeira aparição, coincidem com as duas unidades entoativas destacadas abaixo.

Ela também estava perdida

E por isso se agarrava a mim também

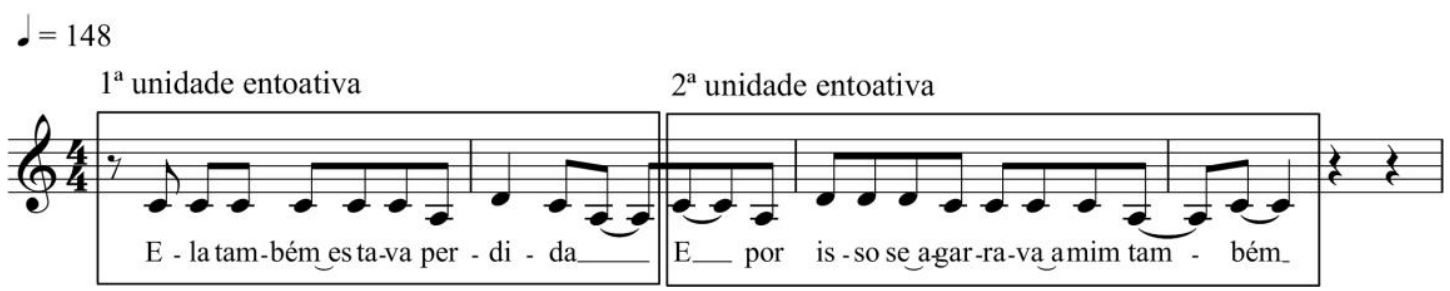

Figura 2. Duas unidades entoativas em Ainda é Cedo (Dado Villa-Lobos/Marcelo Bonfá/Renato Russo/Ico Ouro Preto)

Na repetição do mesmo trecho, no entanto, os cancionistas propõem um recorte linguístico distinto, ao apresentarem, para cada uma das unidades melódicas, duas unidades verbais:

Ela falou:

Você tem medo 
Aí eu disse:

Quem tem medo é você

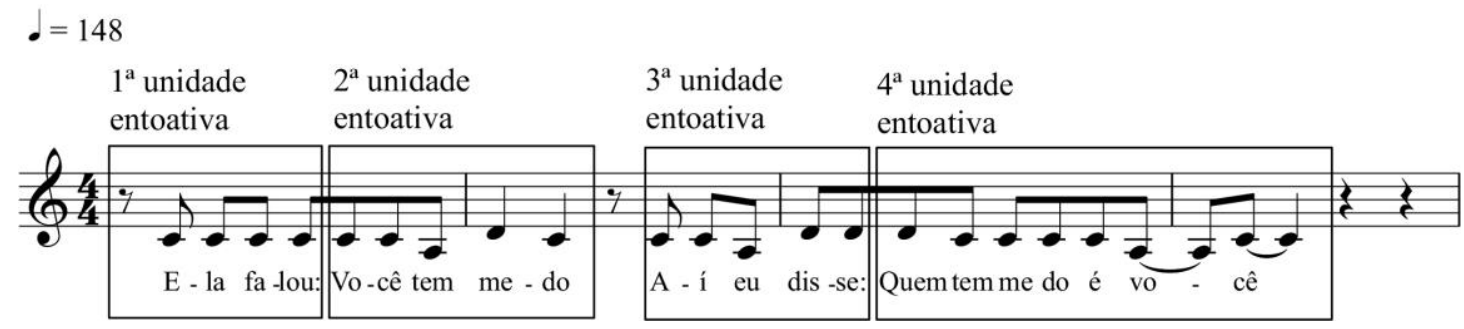

Figura 3. Quatro unidades entoativas em Ainda é Cedo (Dado Villa-Lobos/Marcelo Bonfá/Renato Russo/Ico Ouro Preto)

Grande parte dos cancionistas, de modo intuitivo e amparado pela sua experiência com a língua oral, testa os diferentes recortes linguísticos para determinada melodia e avalia a sua plausibilidade entoativa. É como se, involuntariamente, o letrista fizesse a si mesmo algumas indagações. Que tipo de frase linguística combina com essa frase musical? Quantas unidades verbais podem ser entoadas nessa unidade melódica? Essas são algumas das preocupações que habitam o inconsciente do compositor no momento de sua criação.

Como constatamos no exemplo acima, esse tipo de experimentação combinatória constitui um dos espaços de criatividade próprios da linguagem cancional, visto que está fundamentado na relação entre melodia e letra e não em aspectos poéticos ou musicais. Entretanto, se, por um lado, a conformação das unidades entoativas pode ser considerada uma ferramenta criativa para o cancionista, por outro, ela também pode constituir um valioso parâmetro a partir do qual podemos medir os diferentes graus de proximidade com a fala alcançados por determinada canção. Retomando o exemplo de Feitiço da Vila, já analisado no item dedicado às unidades entoativas presente no capítulo sobre a figurativização na semiótica da canção, podemos notar que, nessa obra, alguns recortes verbais são mais ou menos usuais do que outros. Comparemos as duas estrofes abaixo.

Sol,

Pelo amor de Deus

Não venha agora

Que as morenas

Vão logo embora 


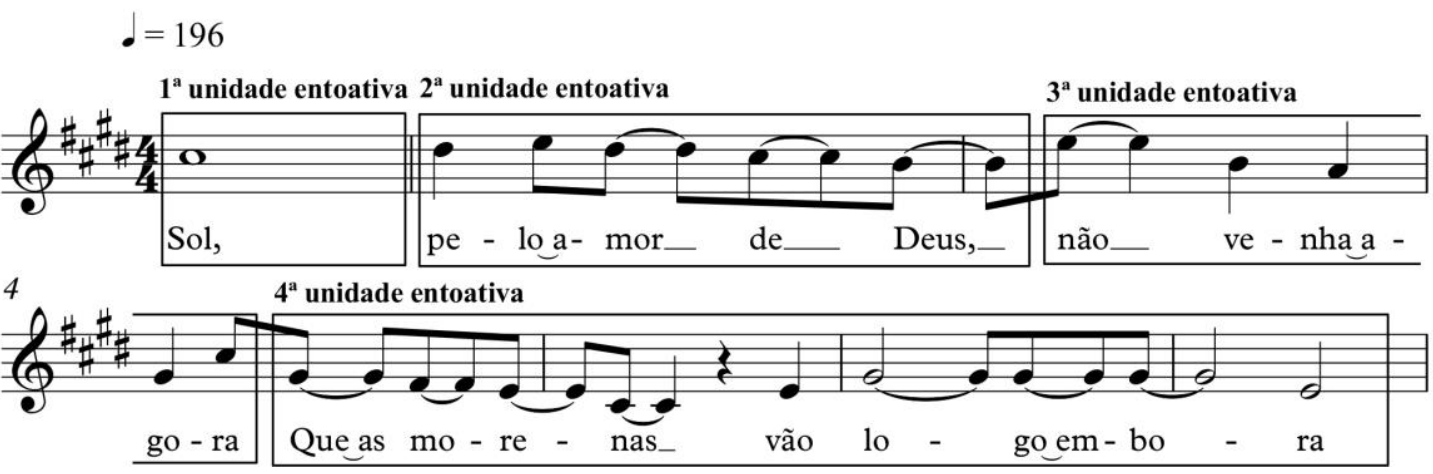

Figura 4. Quatro unidades entoativas em Feitiço da Vila (Vadico/Noel Rosa)

Mas tenho que dizer

Modéstia à parte

Meus senhores

Eu sou da Vila
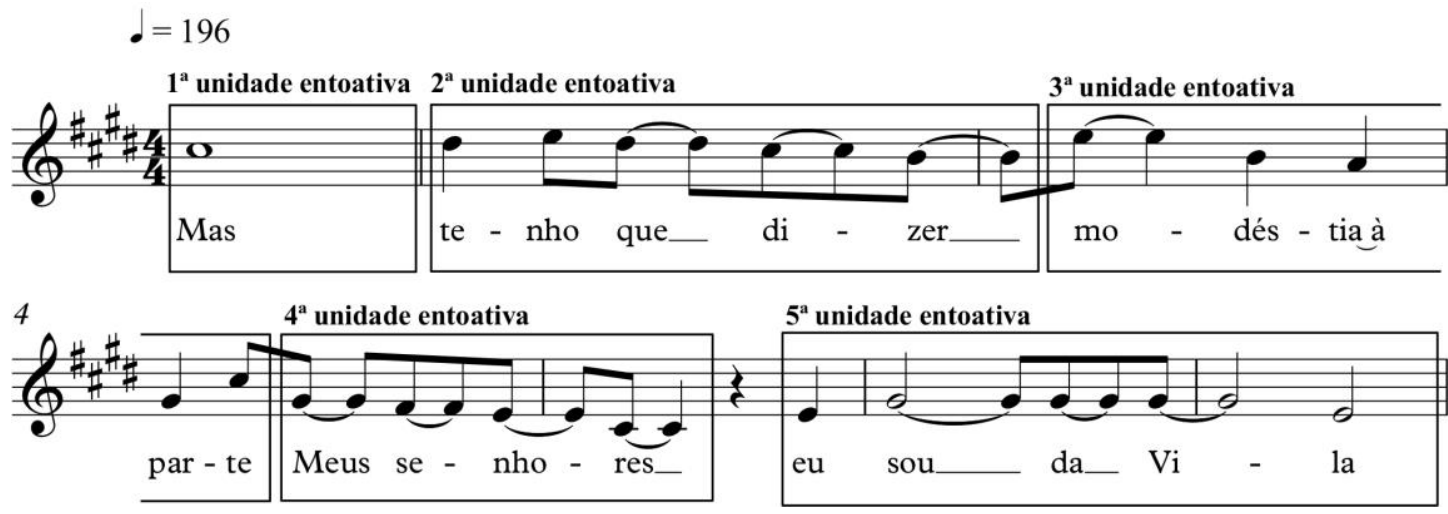

Figura 5. Cinco unidades entoativas em Feitiço da Vila (Vadico/Noel Rosa)

Observamos que nenhuma das duas estrofes acima faz coincidir exatamente todas as unidades melódicas com as unidades verbais. Concentremo-nos, contudo, nos seus segmentos finais. Se resgatarmos a ilustração na qual dividimos as unidades melódicas dessa estrofe de Feitiço da Vila, veremos que, ao final da estrofe, há duas unidades bem separadas por meio de uma pausa (o $4^{\circ}$ e o $5^{\circ}$ segmento destacados na figura abaixo):

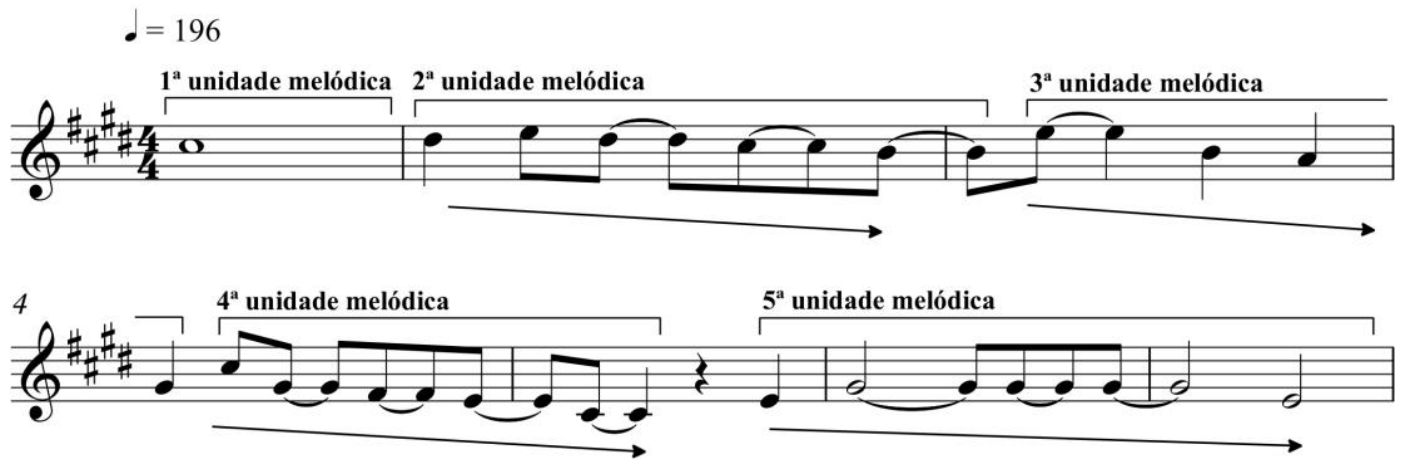

Figura 6. Divisão das unidades melódicas em Feitiço da Vila (Vadico/Noel Rosa) 
Comparando os seus dois recortes linguísticos, cremos que esse trecho musical, ao receber o texto "meus senhores, / eu sou da Vila" resulta em uma construção mais usual do que o mesmo trecho recortado pela letra "que as morenas / vão logo embora". No primeiro, as duas unidades verbais coincidem com as duas unidades melódicas. No segundo, a unidade linguística é levemente desmembrada. Essas constantes perturbações e reequilíbrios orais, como vemos, podem ocorrer dentro de uma mesma canção, uma vez que o cancionista pode propor diferentes recortes textuais para estrofes melodicamente idênticas. É o caso dos dois fragmentos seguintes extraídos da canção Geração CocaCola, do grupo Legião Urbana.

Quando nascemos fomos programados

A receber o que vocês

Nos empurraram com os enlatados

Dos U.S.A., de nove às seis

Desde pequenos nós comemos lixo

Comercial e industrial

Mas agora chegou nossa vez

Vamos cuspir de volta o lixo em cima de vocês

$$
\downarrow=196
$$

$1^{\mathrm{a}}$ estrofe
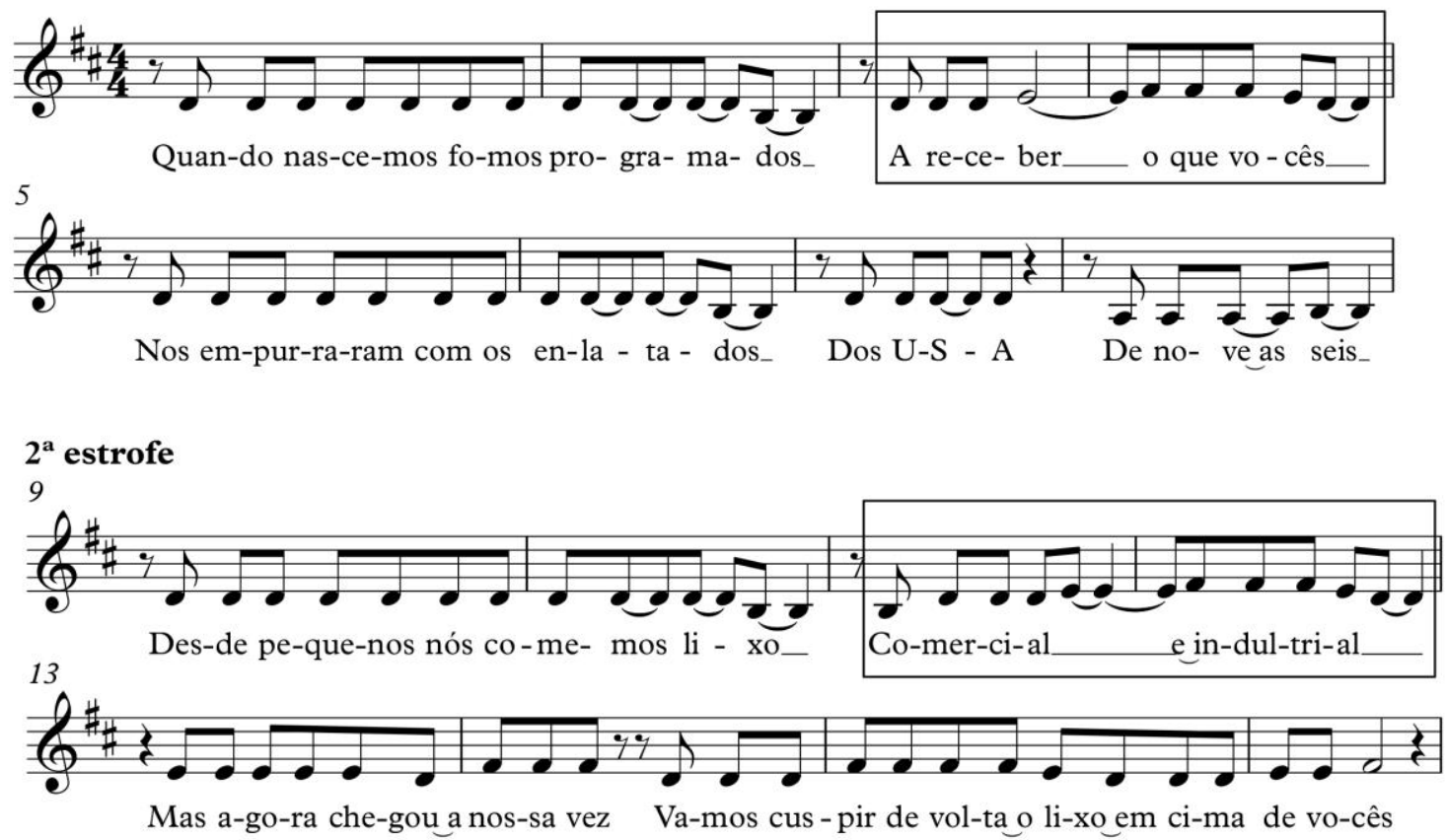

Figura 7. Duas propostas de recorte linguístico da mesma melodia em Geração Coca-Cola (Renato Russo) 
Esse exemplo é útil para avaliarmos, mesmo que ainda superficialmente, como a segunda estrofe da canção, ao contrário da primeira, não possui a mesma perturbação entoativa ligada ao recorte no nível da frase. Isso porque a sua unidade assinalada acima coincide com os complementos do substantivo "lixo" ("comercial e industrial"), sem, contudo, promover uma cisão mais radical como a que observamos entre "programados" e "a receber". Possui, nesse sentido, uma maior fluência linguística. Temos, então, numa mesma obra, trechos com diferentes tipos de oralização. Podemos, com isso, começar a observar quais são os casos de compatibilização mais ou menos usuais, delineando uma espécie de campo gradativo por onde circulam os modos de dizer criados pelos cancionistas. É o que trabalharemos no item seguinte, tentando aprofundar essa questão. 


\subsection{Encontros e desencontros entre a frase verbal e a frase melódica}

Ao compor uma canção, relacionando intuitivamente a melodia e a letra, uma diversidade muito grande de preocupações estéticas pode guiar o cancionista e, muitas vezes, fazê-lo incorporar certos desvios entoativos em prol de algumas descobertas expressivas. Uma rima, uma palavra que coincide com determinadas notas da melodia, uma progressão harmônica, uma marcação rítmica que valoriza um momento crucial da letra, entre muitas outras questões, pode dissipar a presença de algumas descontinuidades orais em sua canção. Além disso, o projeto entoativo global da obra, via de regra, satisfaz o compositor e o faz relevar alguns encaixes pontuais distantes da fala. Nesse caso, no entanto, a apreensão do ouvinte também se modifica, visto que o elo entre o público e o cantor, ainda que por um breve momento, deixa de ser estabelecido por meio do aspecto oral.

Mais uma vez, sob a perspectiva figurativa, interessa-nos vislumbrar o espaço gradativo que abarca fenômenos cancionais mais próximos ou mais distantes da língua falada (similarmente ao que investigamos no nível da sílaba e da palavra). Assim, adotando uma postura analítica mais descritiva do que prescritiva, desejamos observar como se dão os variados graus de presença da fala no patamar seguinte: a frase. De nossas reflexões iniciais, surgem diversas indagações. Havendo um corte na unidade verbal, em que locais da frase essa cisão pode se tornar mais ou menos usual? Isto é, entre quais termos da oração a segmentação pode ser realizada sem maior prejuízo entoativo? Há alguma influência da duração da pausa que divide a unidade linguística? Se a pausa for maior, maior será a perda de teor de fala? Quais fatores musicais podem influenciar nesse fenômeno? Por exemplo, se as duas unidades melódicas que desmembram a frase verbal são muito distintas (o que dificulta o estabelecimento do elo entre ambas por parte do ouvinte), menor será o grau de oralidade? Enfim, neste capítulo, guiados por essas questões, desejamos abordar a maneira como o cancionista organiza as frases verbais dentro de perfis melódicos específicos. Primeiramente, observemos as seguintes construções linguísticas, retiradas da canção Construção, de Chico Buarque.

\footnotetext{
a) Sentou pra [PAUSA] descansar como se fosse um príncipe

b) Sentou pra descansar como se [PAUSA] fosse um príncipe

c) Sentou pra descansar [PAUSA] como se fosse um príncipe
} 
Inserimos, em certos pontos da frase, algumas pausas. É nítido o maior grau de estranhamento gerado pelas sentenças A e B quando as comparamos à frase C. Em uma situação normal de conversação, dificilmente um falante do português brasileiro insere pausas como as que indicamos nas duas primeiras sentenças. Na nossa experiência cotidiana com a língua, nos acostumamos com um modo mais contínuo de dizer uma frase afirmativa como essa. Acreditamos que fenômenos semelhantes podem ocorrer na relação entre a melodia e a letra em todo tipo de canção. Vejamos um primeiro exemplo.

Eu não sei por quanto tempo eu

Tenho ainda que esperar

Quantas vezes eu até chorei

Pois não pude suportar

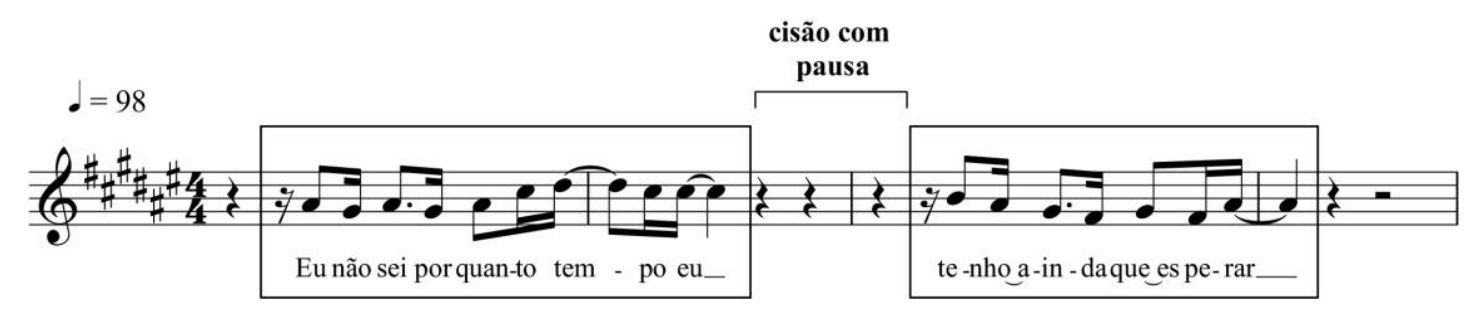

Figura 8. Cisão entre sujeito e verbo em Eu te amo, te amo, te amo (Roberto Carlos/Erasmo Carlos)

Nessa canção, constatamos um corte em uma frase verbal formada por duas orações, constituindo um período composto: "Eu não sei por quanto tempo" e "eu tenho ainda que esperar". A cisão ocorre entre o sujeito e o verbo da segunda oração. Ainda que não seja o sujeito da oração principal e que o ouvinte, após a escuta do primeiro segmento, já tenha a percepção de um enunciado com um certo sentido linguístico, ainda assim, essa segmentação produz uma significativa perturbação oral. Ao mesmo tempo, a composição gera, no público, o aumento da expectativa pela conclusão da frase (que finaliza, melódica e linguisticamente, no segmento seguinte). De modo bem sutil, no entanto, poderíamos experimentar posicionar o corte que interrompe o enunciado antes do sujeito da segunda oração, obtendo uma oralização mais comum:

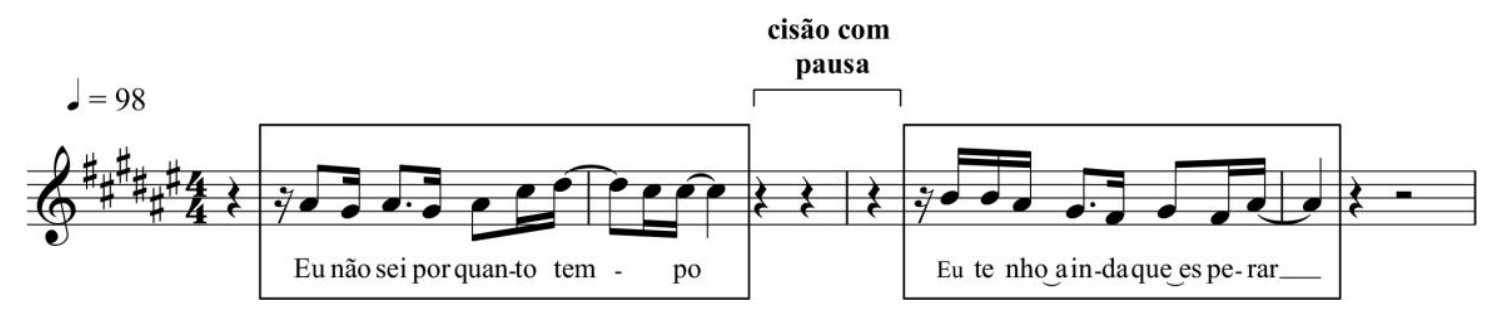

Figura 9. Reescrita de Eu te amo, te amo, te amo (Roberto Carlos/Erasmo Carlos) 
Ao reposicionarmos o vocábulo "eu", transportando-o do final da primeira unidade para o início da segunda e inserindo uma semicolcheia a mais no terceiro compasso, eliminamos a ruptura entre o sujeito e o verbo da segunda oração. Agora, a cisão incide sobre o limite entre as duas orações, o que parece abrandar o caráter menos entoativo da versão original. Essa transformação, no entanto, representa uma mudança no padrão melódico da canção, posto que as duas unidades melódicas iniciavam, no segundo tempo do compasso, com as mesmas figuras de duração: pausa de semicolcheia, colcheia e semicolcheia. Nossa experimentação, utilizando o recurso da elasticidade melódica, possibilitou a inserção de uma nota a mais no início do segundo segmento, diminuindo, ainda que discretamente, o caráter tematizante do trecho.

No encontro entre letra e melodia, durante o processo de formação das unidades entoativas, interrupções podem ocorrer entre diferentes termos da oração: entre o sujeito e o predicado, entre o determinante (artigo definido e indefinido) e o substantivo, entre o substantivo e o seu complemento nominal etc. Ao nos debruçarmos sobre os exemplos cancionais, percebemos, no entanto, uma maior ocorrência dos casos em que a segmentação ocorre entre o verbo e o seu complemento, nos diferentes tipos de predicado. Antes de apresentarmos as canções, observemos brevemente como a gramática da língua portuguesa organiza o estudo do predicado verbal, aquele que possui, como núcleo, um verbo transitivo ou intransitivo.

Os verbos intransitivos são aqueles a partir dos quais apreendemos um significado integral, acabado, sem a necessidade da presença de um objeto direto ou indireto para completar o seu sentido. Nesses casos, o sentido da ação não transita para um complemento, pois está “integralmente contida na forma verbal” (CUNHA, 2017: 149). Um enunciado como "Ela partiu e nunca mais voltou" (Ela Partiu, Tim Maia e Beto Cajueiro), por exemplo, apresenta formas verbais que não precisam de termos que concluam o seu significado, visto que "partir" e voltar" constituem verbos intransitivos.

Os verbos transitivos, por sua vez, possuem significação incompleta e por isso requerem complementação, uma vez que a ação do verbo deve ser transmitida para outros elementos da oração. Podem ser classificados em transitivos diretos, quando a ação verbal é propagada a outros componentes linguísticos sem a presença de preposição, isto é, quando o segmento da oração que completa o seu sentido é um objeto direto: "Eu vi muitos homens brigando, ouvi seus gritos" (Força Estranha, Caetano Veloso) apresenta dois verbos transitivos diretos, "ver" e "ouvir". São chamados de transitivos indiretos quando expressam uma ação que é transmitida indiretamente para outros itens da oração, 
mediante uma preposição. Em "Como a abelha necessita de uma flor, eu preciso de você e desse amor" (Eu Preciso de Você, Roberto Carlos e Erasmo Carlos), a regência dos verbos "necessitar" e "precisar", ambos complementados por objeto indireto, exige a preposição “de". Por fim, os verbos transitivos diretos e indiretos são simultaneamente acompanhados de um objeto direto e um indireto. Em "Tira as mãos de mim, põe as mãos em mim" (Tira as mãos de mim, Chico Buarque e Ruy Guerra), os verbos "tirar" e "pôr" exigem ao mesmo tempo o objeto direto "as mãos" e os objetos indiretos "de mim" e "em mim". É evidente que, ao analisarmos os diversos exemplos cancionais nos quais há uma segmentação da frase linguística pela frase melódica justamente após o verbo, a questão da transitividade terá significativa importância. Sem dúvida, ela influenciará na percepção mais ou menos habitual de cada fenômeno por parte do ouvinte. Analisemos o exemplo abaixo.

Ela me disse: - Eu não sei

Mais o que eu sinto por você

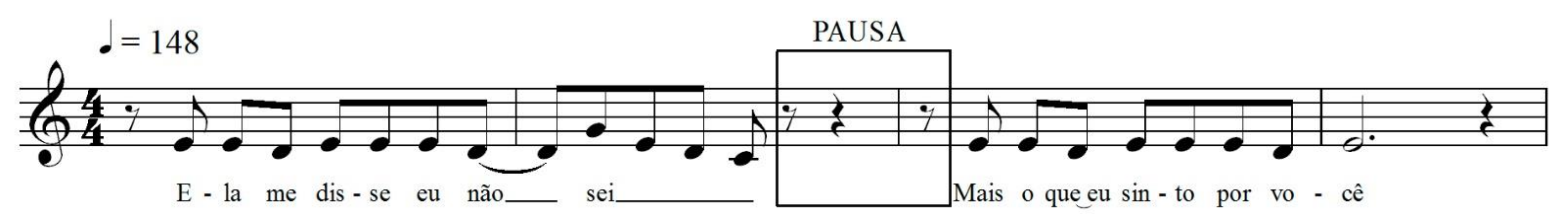

Figura 10. A unidade melódica e a unidade linguística em Ainda é cedo (Renato Russo/Dado VillaLobos/Marcelo Bonfá)

O verbo saber, na acepção de "ter consciência de algo", é transitivo direto. Nesse trecho da canção Ainda é cedo, a pausa que divide a frase "eu não sei mais o que eu sinto por você”, separando o verbo de seu complemento, diminui o caráter entoativo do canto, uma vez que, na língua falada, esse tipo de separação é muito raro. É interessante observar, no entanto, que, caso não houvesse na sentença o advérbio "mais", a segmentação da frase poderia causar menor estranhamento: "eu não sei / o que eu sinto por você". Isto é, pelo fato de, no registro falado do português brasileiro, os vocábulos "mas" e "mais" serem sonoramente equivalentes, fica ainda mais comprometida a compreensão imediata do trecho por parte do ouvinte, que pode confundir o advérbio de intensidade ("mais") com a conjunção adversativa (“mas”), no início do segundo verso. Nesse caso, é como se o corte empregado pelo cancionista, inserindo uma pausa após o verbo, desse a impressão do uso de "saber" como intransitivo, algo possível, a depender do contexto linguístico, na acepção "ter conhecimento de". Para especularmos algumas 
nuances figurativas, podemos experimentar sutis alterações no encaixe da melodia com a letra.

Ela me disse: Eu não sei mais

O que eu sinto por você

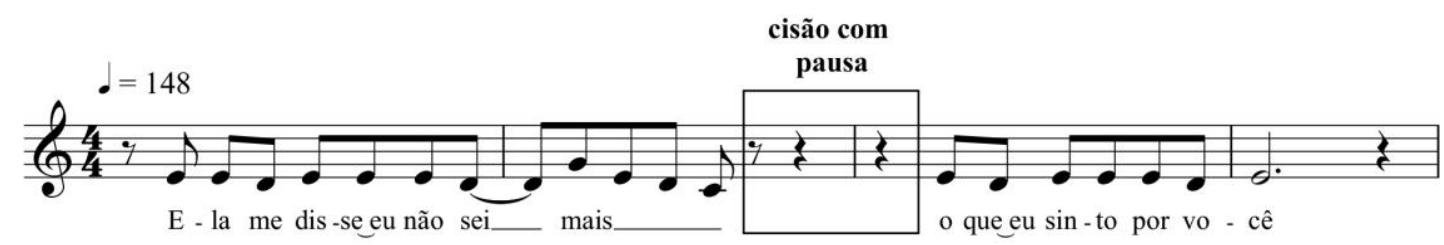

Figura 11. Primeira reescrita de Ainda é cedo (Renato Russo/Dado Villa-Lobos/Marcelo Bonfá)

Em um primeiro teste, deslocamos o advérbio "mais" que iniciava a segunda unidade melódica para o final do primeiro segmento. Com isso, diminuímos a possibilidade de o ouvinte confundi-lo com a conjunção adversativa "mas". Outra maneira de solucionar essa questão consiste em substituirmos o vocábulo "mais" pelo advérbio "já”. Desse modo, mantemos o mesmo significado linguístico, mas evitamos a coincidência fônica comentada acima.

Ela me disse eu já não sei

O que eu sinto por você

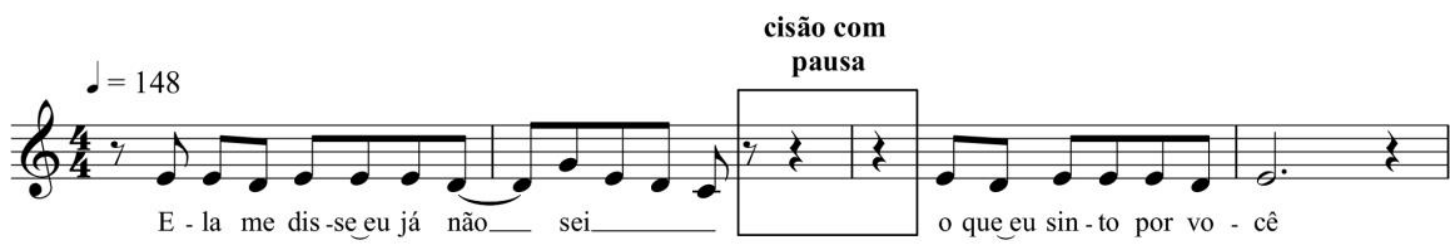

Figura 12. Segunda reescrita de Ainda é cedo (Renato Russo/Dado Villa-Lobos/Marcelo Bonfá)

Na proposta acima, acreditamos que o conteúdo linguístico inicialmente desejado pelo compositor permanece intacto. Contudo, em virtude da transitividade do verbo "saber", isto é, da sua necessidade de complementação, a significativa duração da pausa que divide os dois segmentos ainda torna a passagem oralmente menos comum. No teste seguinte, utilizando mais uma vez o recurso figurativo da elasticidade melódica, experimentamos diminuir o espaço que os separa repetindo, no início do segundo verso, a expressão "não sei”, que finalizava o primeiro. 
Ela me disse eu não sei

Não sei o que que eu sinto por você

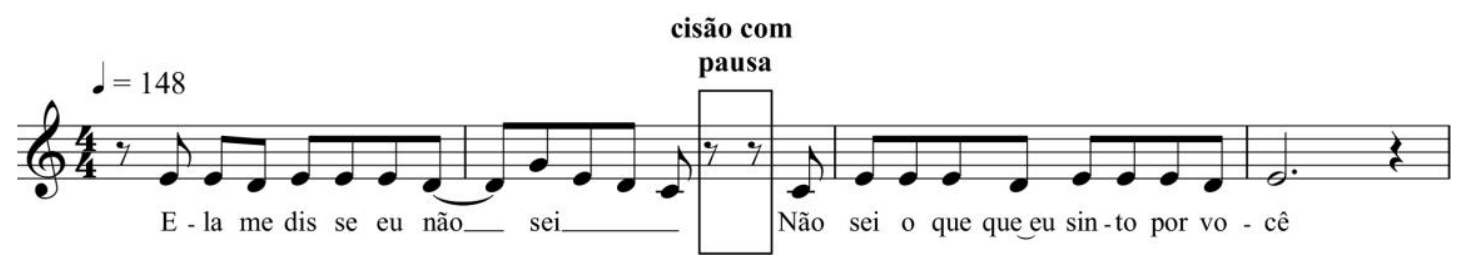

Figura 13. Terceira reescrita de Ainda é cedo (Renato Russo/Dado Villa-Lobos/Marcelo Bonfá)

Ao abreviarmos a pausa e repetirmos o termo linguístico que concluía a unidade anterior, recuperamos o seu sentido e amenizamos a quebra da unidade verbal. Com tal procedimento, é possível até mesmo resgatar o advérbio "mais" que, ao invés de ser posicionado no início do segmento, passa a ocupar o interior da unidade linguística, sem qualquer possibilidade de ambiguidade em relação ao seu homófono "mas"119.

Ela me disse eu não sei

Não sei mais o que que eu sinto por você

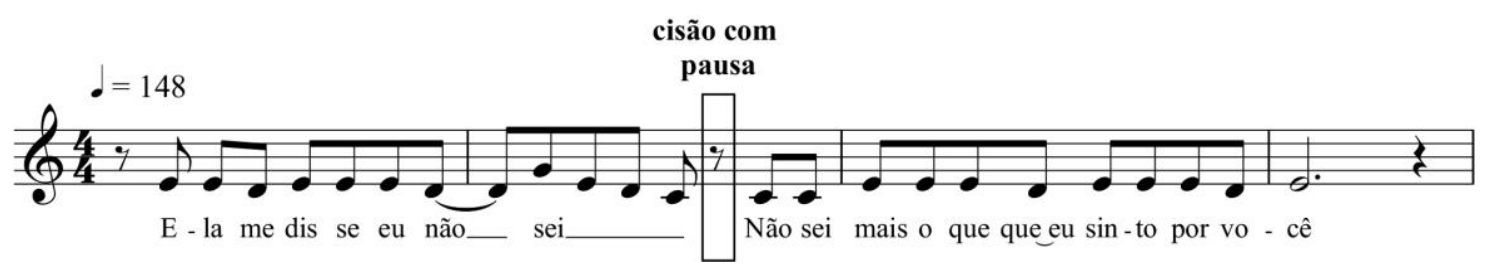

Figura 14. Quarta reescrita de Ainda é cedo (Renato Russo/Dado Villa-Lobos/Marcelo Bonfá)

$\mathrm{Na}$ figura acima, reduzimos ainda mais a separação entre as duas unidades melódicas, uma vez que elas abarcam uma só unidade verbal. Assim, com a diminuição dessa cisão (representada agora apenas pela pausa de colcheia destacada na ilustração) e com a retomada dos vocábulos "não sei”, acreditamos que a apreensão do fragmento se torna consideravelmente menos inesperada. $\mathrm{O}$ ouvinte, nesse caso, tomaria contato com uma oralização mais linear e, por isso, sua experiência estética com essa passagem poderia se conectar um pouco mais às questões orais. Como se a balança se reequilibrasse, entre a musicalização e a oralização. Vejamos os dois exemplos seguintes.

\footnotetext{
${ }^{119}$ Como dissemos acima, a homofonia pode ocorrer no registro oral do português brasileiro.
} 
Quis evitar teus olhos

Mas não pude reagir

Fico à vontade então

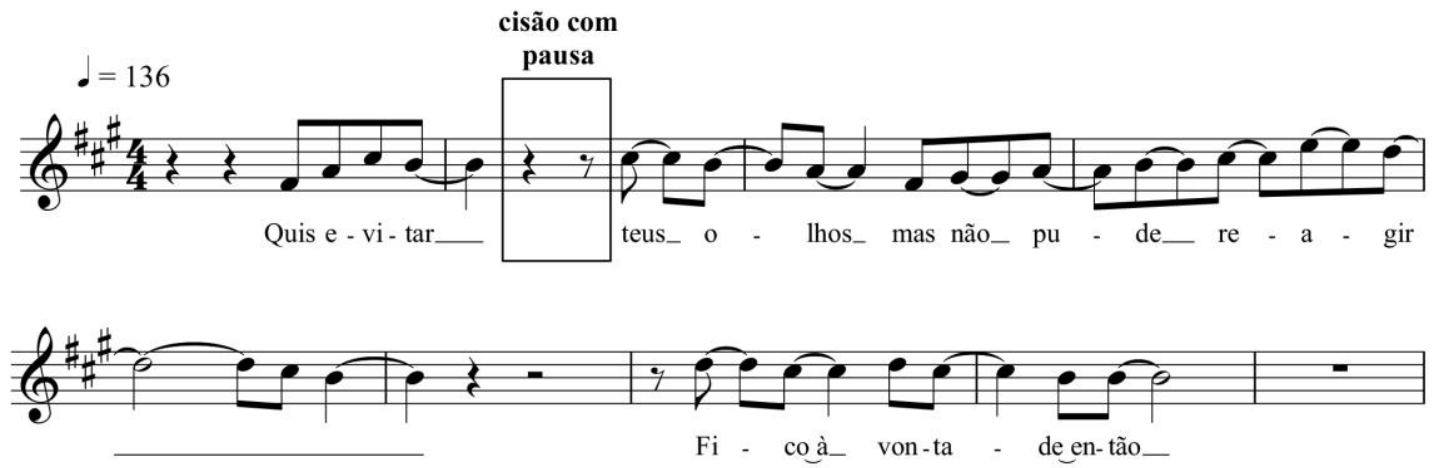

Figura 15. A unidade melódica e a unidade linguística em Um certo alguém (Lulu Santos/Ronaldo Bastos)

E te farei, vaidoso, supor

Que és o maior e que me possuis

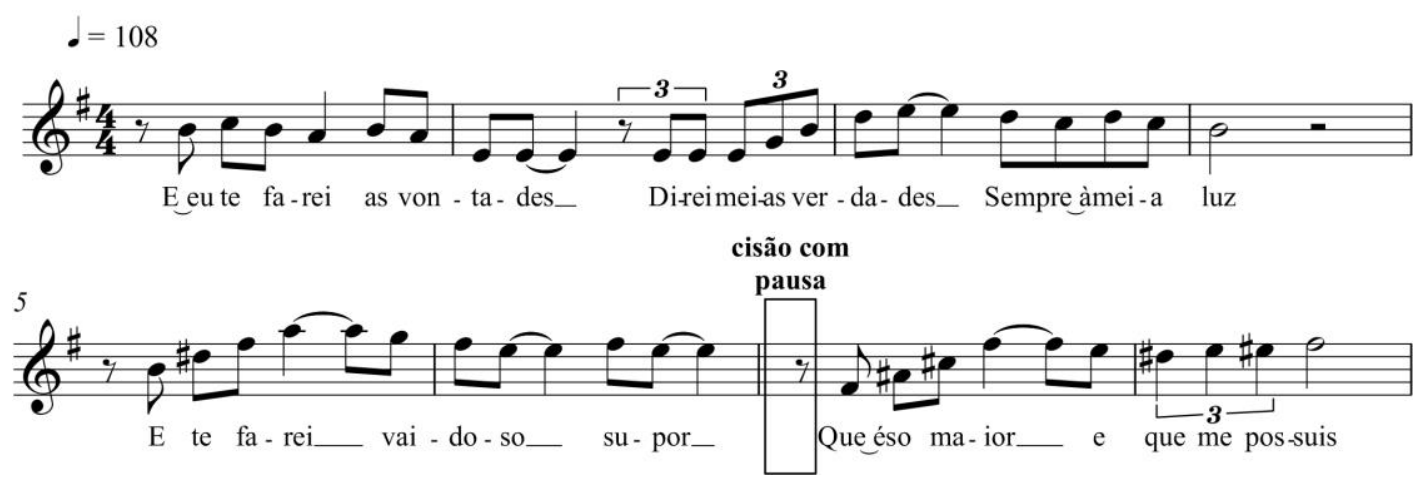

Figura 16. A unidade melódica e a unidade linguística em Folhetim (Chico Buarque)

Nas duas canções acima, observamos a interrupção da frase linguística após os verbos transitivos diretos "evitar" e "supor", ambos combinados a verbos auxiliares e constituintes de locuções verbais ("querer evitar" e "fazer supor"). O fato de aparecerem dentro de uma expressão verbal composta não elimina, no entanto, o seu caráter transitivo. Tanto "evitar" quanto "supor", por exigirem seus respectivos complementos, geram certa redução da oralidade ao aparecerem ao final da unidade melódica (mesmo que, musicalmente, não tenhamos ainda a resolução de suas tensões melódicas e harmônicas). Em Folhetim, acreditamos que um fenômeno pode agravar ainda mais essa provável perda oral: na frase verbal em questão, a palavra "vaidoso" aparece destacada entre vírgulas, com valor de aposto. A frase musical, contudo, não reitera, a nosso ver, essa mesma estrutura de modo satisfatório. Tendo em vista esse sutil desencaixe entre a letra e a 
melodia, é como se o ouvinte fosse direcionado a uma escuta que não parece ser aquela a princípio almejada pelo cancionista. Escuta, desse modo, a expressão "E te farei vaidoso" ao invés de "E te farei supor". Em seguida, observamos outros dois exemplos de canções que apresentam uma cisão da unidade linguística, ambos após o verbo “dar”.

Pedro não sabe mas talvez no fundo

Espere alguma coisa mais linda que o mundo

Maior do que o mar, mas prá que sonhar se dá

O desespero de esperar demais

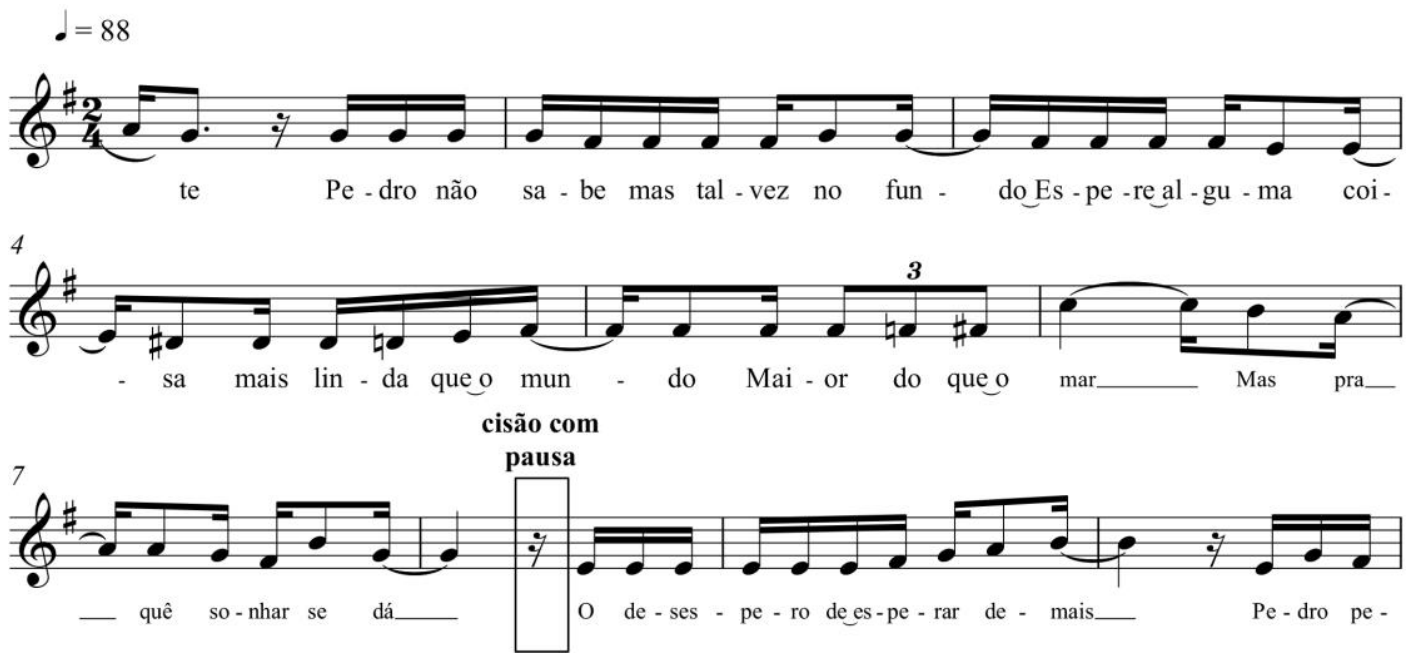

Figura 17. A unidade melódica e a unidade linguística em Pedro Pedreiro (Chico Buarque)

O que faremos do Rio

Quando enriquecendo passarmos a dar

As cartas as coordenadas de um mundo melhor

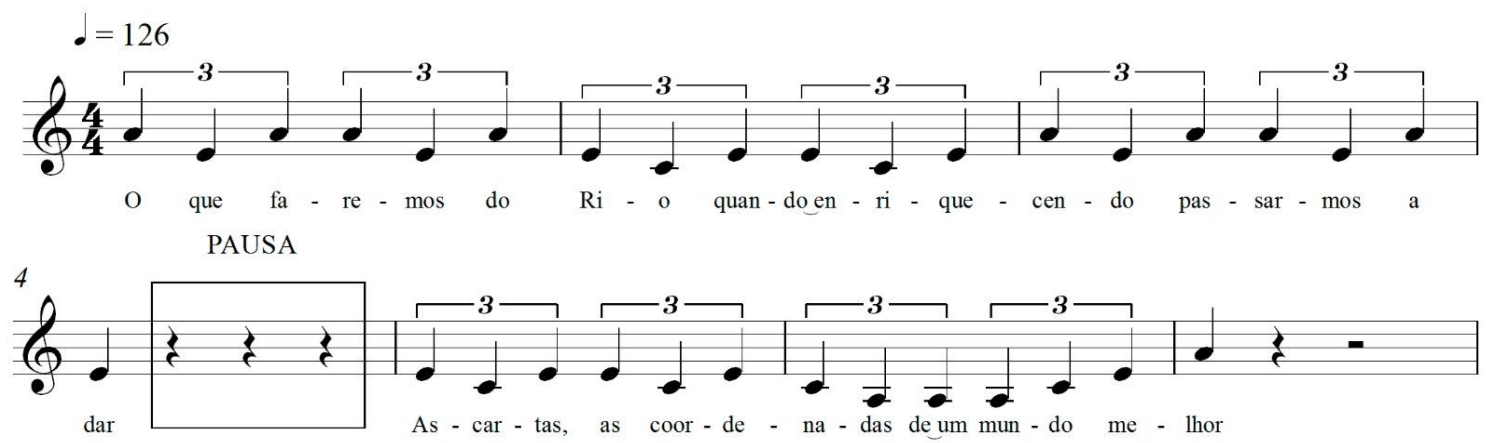

Figura 18. A unidade melódica e a unidade linguística em Falso Leblon (Caetano Veloso)

Em Pedro Pedreiro e Falso Leblon, o verbo dar (que assume, em ambas as ocorrências, a sua forma transitiva) aparece posicionado no final das unidades melódicas correspondendo aos segmentos linguísticos "mas pra que sonhar se dá" e "O que faremos 
do Rio quando enriquecendo passarmos a dar". Os seus respectivos complementos surgem somente após a pausa e início da unidade melódica seguinte. Na canção de Caetano Veloso, a duração da pausa destacada no compasso quatro (que separa o verbo “dar” de sua complementação "as cartas, as coordenadas de um mundo melhor") é ainda mais extensa. Isso faz com que o sentido de sutil conclusão dessa frase musical (gerado também por sua descendência final com as notas Lá e Mi) não corresponda ao sentido do texto verbal, ainda carente de terminação. Essa construção, incomum na entoação da fala, certamente influi na apreensão por parte do ouvinte. É interessante, nesse sentido, compararmos esse fragmento com outro trecho da mesma canção, no qual o cancionista propõe uma letra distinta para a mesma linha melódica.

Drogas, tou fora, tá foda

E agora vombora, nem vinho tomei

Me sinto muito sozinho e ela é a lei

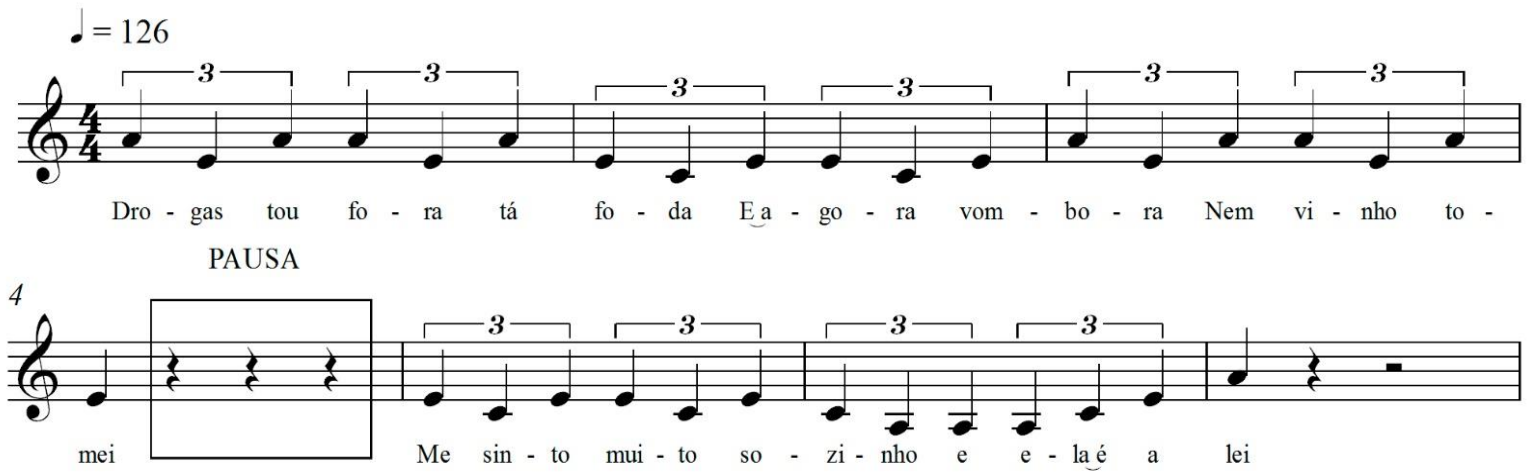

Figura 19. A unidade melódica e a unidade linguística em Falso Leblon (Caetano Veloso)

É provável que o público compreenda o exemplo acima de maneira mais instantânea do que o anterior, visto que, no momento que antecede a pausa, observamos nele a presença de uma frase verbal de caráter mais conclusivo e, por isso, mais coerente com o perfil da melodia que a recobre: "nem vinho tomei" não requer complemento. Começamos a perceber que esses diferentes modos de combinação da frase verbal com a frase melódica geram, na experiência de escuta, diferentes velocidades de apreensão linguística por parte do ouvinte. Quanto mais essa combinação se aproxima da experiência cotidiana da fala, mais imediato é o entendimento e o comprometimento oral do público com a obra. Obviamente, o envolvimento do ouvinte com a canção também está ligado aos aspectos musicais, visuais etc. Por isso, mesmo nos exemplos estudados acima (nos quais há um leve estranhamento gerado pelas construções menos entoativas), 
o público pode seguir envolvido com a obra, nesse permanente vagar perceptivo entre a música e a fala.

Essas investigações são úteis, no entanto, para examinarmos os diferentes tipos de apreensão. Em Falso Leblon, observamos que o compositor, desejando repetir o mesmo padrão melódico em suas diversas estrofes, precisou adequar textos verbais distintos para um trecho musical análogo. Como constatamos, contudo, nem sempre essa acomodação resulta em um nível equivalente de proximidade com a fala. Assim, em uma só canção, pode haver recortes de letra mais ou menos próximos da língua oral. Essa questão entoativa se coloca para o cancionista de modo intuitivo no decorrer de seu processo criativo e cada artista pode resolvê-la de variadas formas. Analisemos um trecho da canção Eclipse Oculto, do mesmo autor.

Não me queixo

Eu não soube te amar

Mas não deixo

De querer conquistar

Uma coisa

Qualquer em você

O que será?

$\cdot=142$

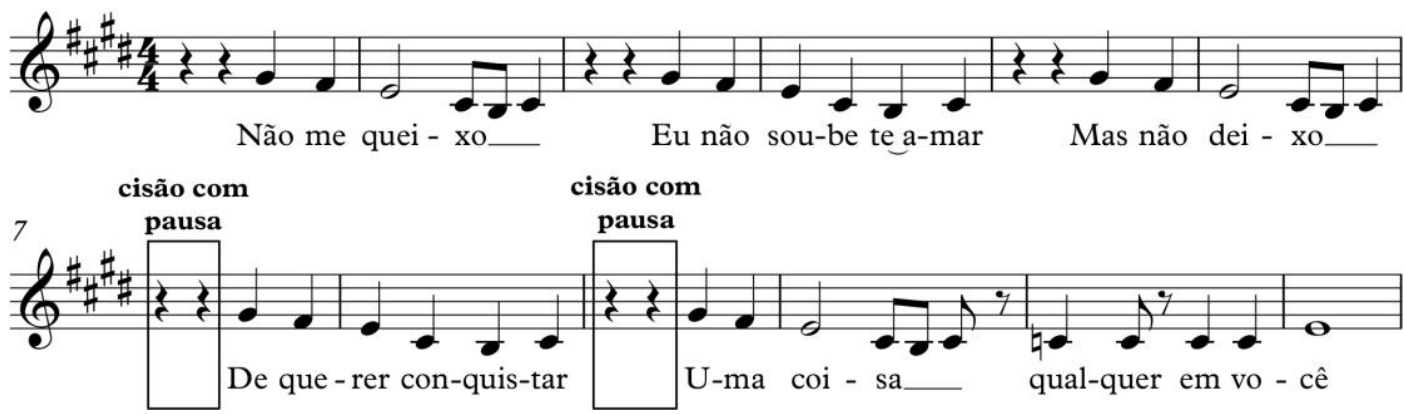

Figura 20. A unidade melódica e a unidade linguística em Eclipse oculto (Caetano Veloso)

Esse fragmento apresenta uma interessante ocorrência. Constatamos a repetição estrita das duas primeiras unidades melódicas (unidades que recobrem os versos "Não me queixo" e "Eu não soube te amar", ambos com sentido linguisticamente mais conclusivo) nos dois segmentos seguintes. Na reincidência desses motivos, contudo, não encontramos o mesmo grau de completude semântica. Os verbos transitivos "deixar" e "conquistar", tendo em vista o adiamento temporal dos seus respectivos complementos por meio de um corte seguido de pausa, são utilizados, então, de modo menos entoativo. Até aqui, 
examinamos, sobretudo, exemplos de cisão após um verbo significativo, termo que abarca tanto os transitivos quanto os intransitivos. Há, no entanto, casos de quebra da frase após os chamados verbos de ligação, isto é, aqueles que indicam estado.

\section{Vagueia}

Devaneia

Já apanhou à beça

Mas para quem sabe olhar

A flor também é

Ferida aberta

E não se vê chorar

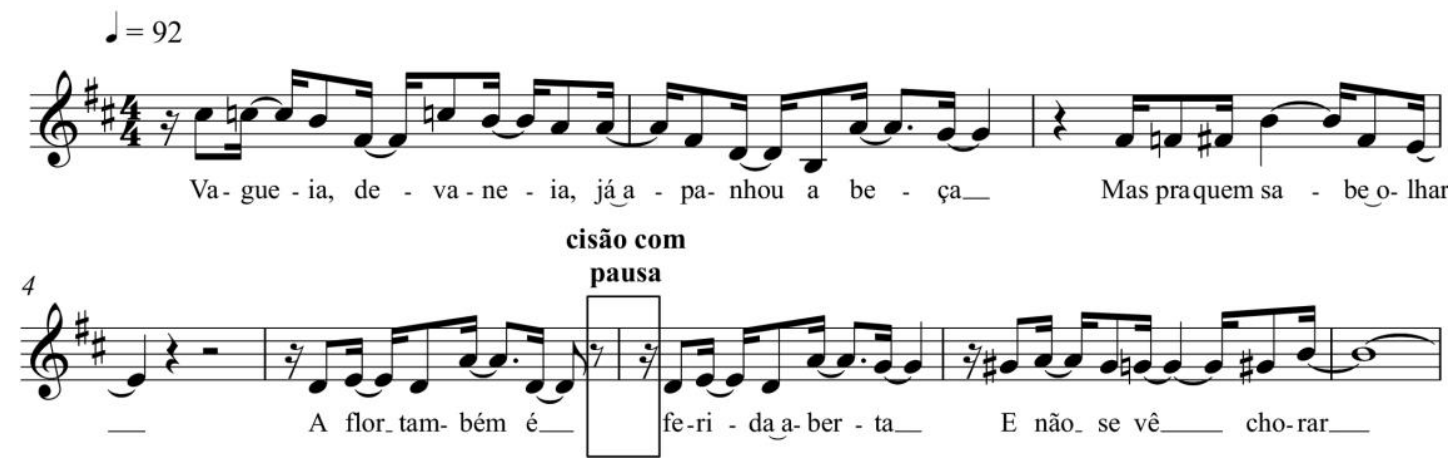

Figura 21. A unidade melódica e a unidade linguística em Dura na queda (Chico Buarque)

Nada do que foi será

De novo do jeito que já foi um dia

Tudo passa

Tudo sempre passará

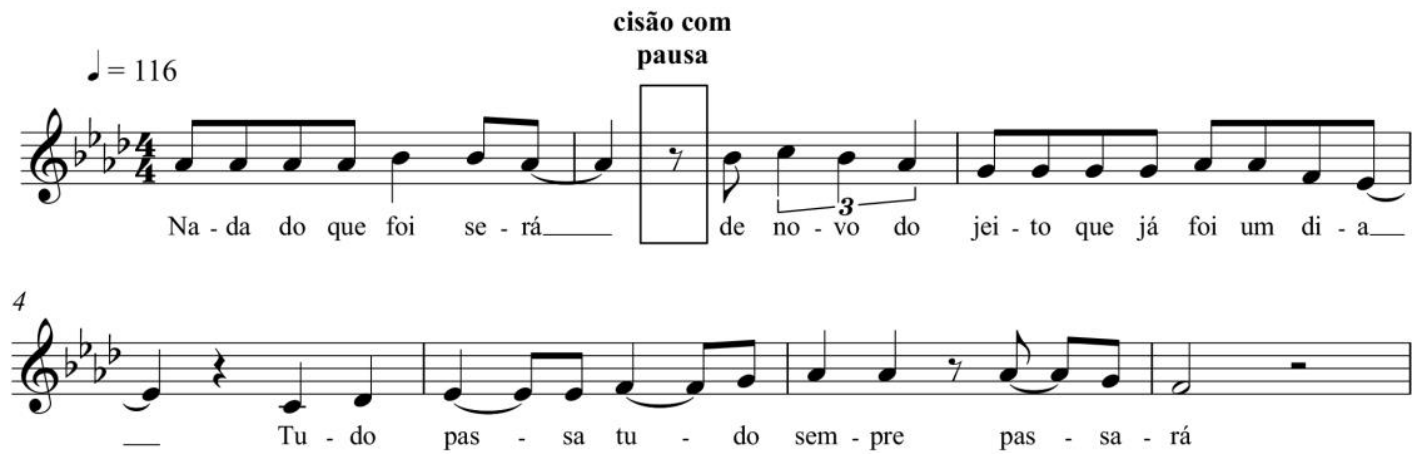

Figura 22. A unidade melódica e a unidade linguística em Como uma onda (Lulu Santos/Nelson Motta)

Nos dois fragmentos acima, há uma interrupção que divide a unidade linguística após a ocorrência do verbo de ligação ser, no primeiro caso, conjugado no presente ("A flor também é") e, no segundo, no futuro do presente ("Nada do que foi será"). Os verbos 
de ligação, ao contrário dos verbos intransitivos e transitivos, não expressam uma ação sofrida ou praticada, isto é, "não trazem propriamente ideia nova ao sujeito", funcionando apenas como "um elo entre este e seu predicativo" (CUNHA, 2017: 147). Poderíamos supor que, uma vez que a sua função é apenas ligar o sujeito e as suas características, expressando um estado de permanência, cisões como as apontadas acima tenderiam a ser menos sentidas pelo ouvinte. No entanto, posto que certos verbos de ligação (como estar, permanecer, parecer etc.) também podem constituir, a depender do seguimento da frase, verbos significativos (que indicam uma ação), cremos que a sensação de interrupção linguística e de perda entoativa ainda permanece presente.

Além do corte realizado entre o verbo e o seu complemento, encontramos também segmentações no interior dos sintagmas nominais. Essas cesuras, embora menos frequentes, produzem, sem dúvida, um estranhamento entoativo muito mais elevado. Devemos lembrar que, numa oração, podemos ter diversos sintagmas nominais, sendo que apenas um deles corresponderá ao sujeito (aquele que se posiciona, na ordem direta do enunciado, à esquerda do verbo). Os demais, portanto, estarão presentes no predicado (CUNHA, 2017: 137). Vejamos alguns exemplos desses fenômenos e avaliemos os seus diferentes graus de presença da fala.

Não me queixo

Eu não soube te amar

Mas não deixo

De querer conquistar

Uma coisa

Qualquer em você

O que será?

$\stackrel{d}{d}=142$

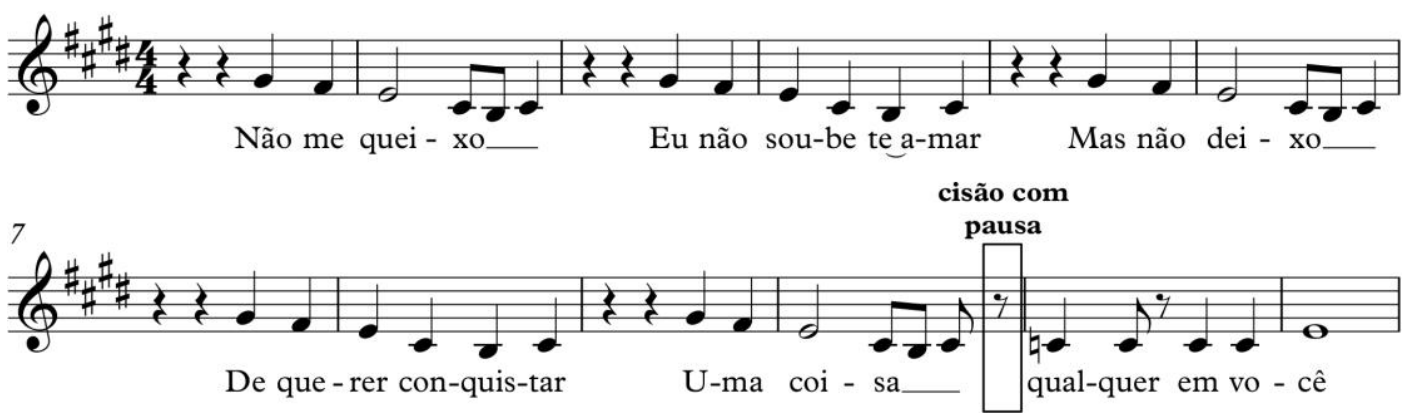

Figura 23. A unidade melódica e a unidade linguística em Eclipse oculto (Caetano Veloso) 
Retomando o mesmo trecho da canção Eclipse Oculto já examinado anteriormente, notamos uma cisão que divide o sintagma nominal "uma coisa qualquer" que, nesse caso, não corresponde ao sujeito da oração, fazendo parte do seu predicado. Ao cindir essa expressão, na verdade, o compositor acaba formando dois segmentos separados por pausa: "uma coisa" e "qualquer em você”. É fácil notarmos que, na língua oral, esse tipo de separação dificilmente ocorre, uma vez que costumamos entoar esse enunciado sem interrompê-lo ("uma coisa qualquer em você"). Caso haja uma pausa, é mais plausível que a posicionemos após o término do sintagma nominal, sem fragmentálo ("uma coisa qualquer [ ] em você"). Ao realizar tal combinação entre melodia e letra, o cancionista se afasta, portanto, de uma solução oral esperada pelo público. A expressão linguística "uma coisa qualquer" passa a ser sonoramente menos percebida pelo ouvinte que, em consequência, passa a ter maior dificuldade em captar o seu significado. Ou seja, se não escutamos a entoação natural de um enunciado, aquela que estamos acostumados a experienciar na fala, passamos a não o compreender de modo imediato. No exemplo abaixo, notamos algo ainda mais radical.

E as cantoras que há de sobra

Festejarão minha obra
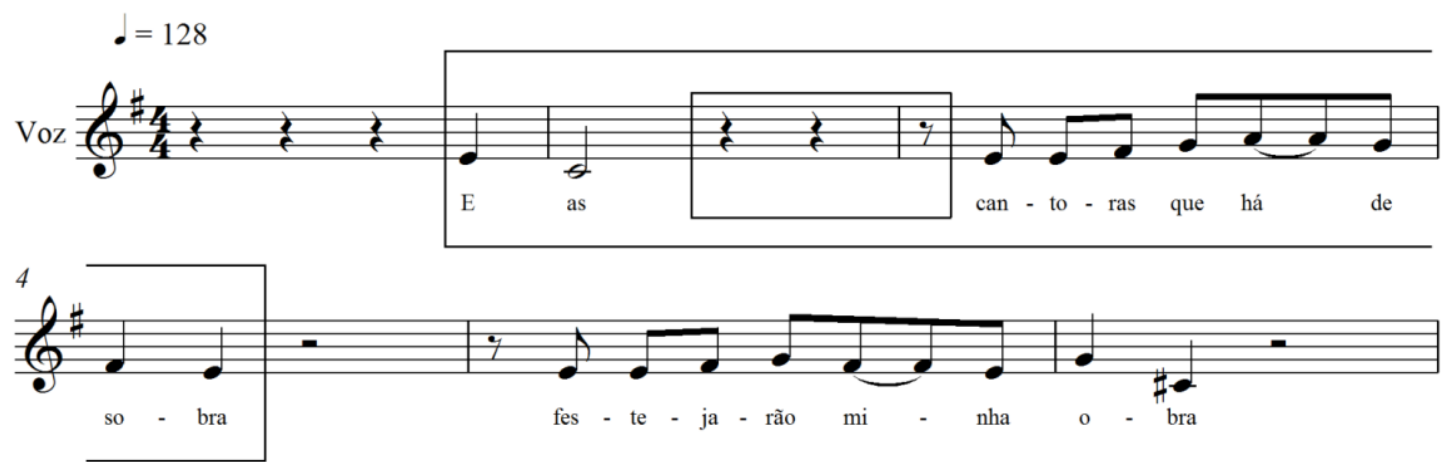

Figura 24. A unidade melódica e a unidade linguística em Mamãe no face (Zeca Baleiro)

Nessa canção, o afastamento em relação à entoação natural da fala é ainda mais acentuado, pois há uma inesperada cisão na frase "e as cantoras que há de sobra festejarão minha obra", mais precisamente no sintagma nominal que corresponde ao seu sujeito. $\mathrm{O}$ cancionista separa a conjunção e o artigo ("e as") do restante da sentença ("cantoras que há de sobra"), algo que não presenciamos em uma situação conversacional cotidiana. Nesse caso, intuímos que, para o ouvinte, essa primeira unidade melódica, ao ser recortada pelos vocábulos "e as", mantém-se quase que dessemantizada do ponto de vista verbal. Afinal, como observamos na figura acima, a distância temporal entre as duas 
primeiras unidades melódicas é bastante significativa. Se analisarmos a primeira parte dessa canção, no entanto, constatamos que a relação entre a melodia e a letra não se dá de maneira tão descontínua. As mesmas notas que foram recobertas por "e as" são também cantadas com a expressão "ou então", cuja necessidade de ligação com a frase seguinte não é tão pulsante como na figura anterior. É como se, aqui, a pausa fosse mais plausível.

Ou então que os rapazes da Veja

Me chamem pruma cerveja

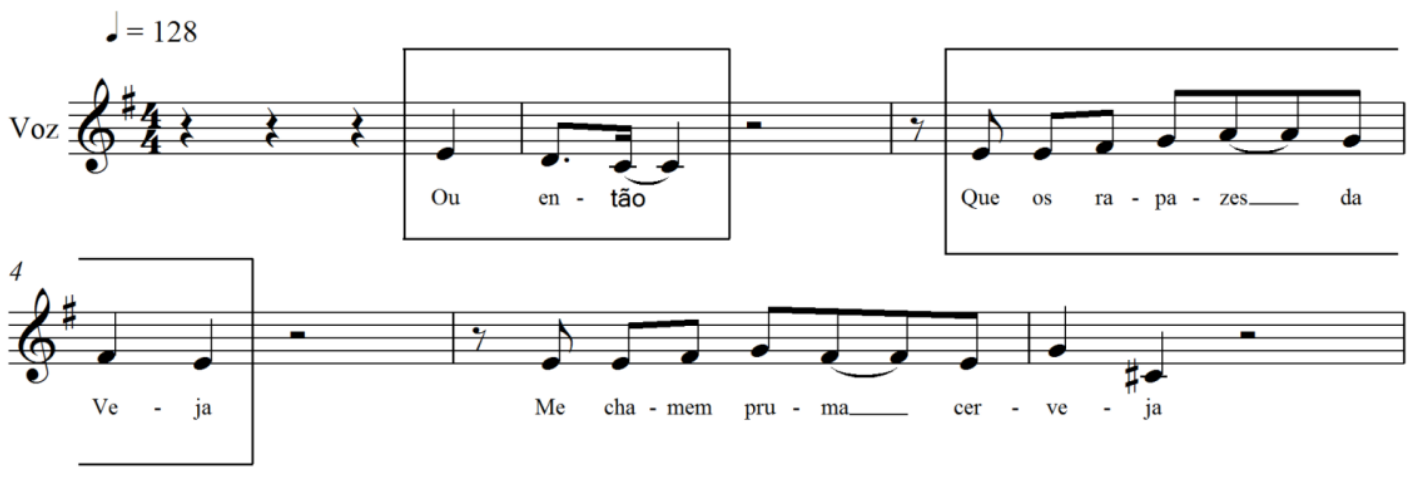

Figura 25. A unidade melódica e a unidade linguística em Mamãe no face (Zeca Baleiro)

Em $O$ Malandro, adaptação do compositor Chico Buarque para uma canção que compõe a obra A Ópera dos Três Vinténs do dramaturgo alemão Bertolt Brecht (com composições musicais de Kurt Weill), também notamos uma interessante oralização nãolinear.

O garçom no prejuízo

Sem sorriso, sem freguês

De passagem pela caixa

Dá uma baixa no português
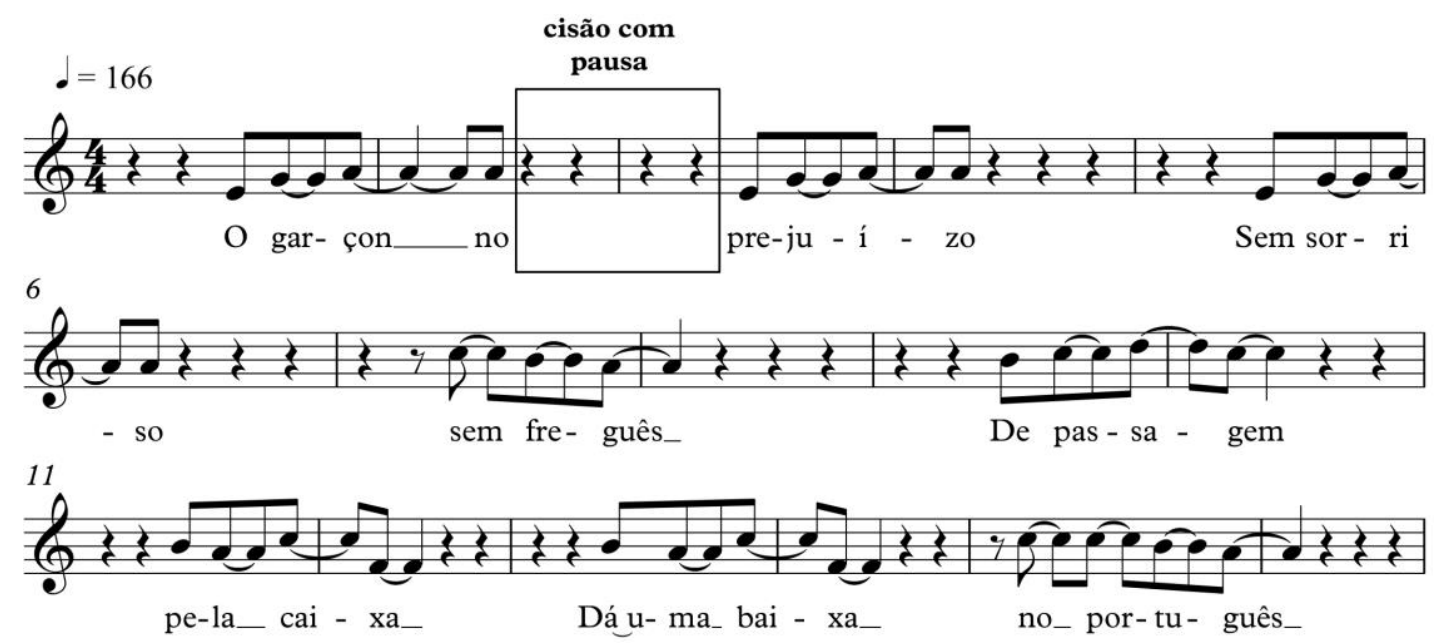

Figura 26. Cisão da frase em O Malandro (Bertolt Brecht/Kurt Weill - adaptação de Chico Buarque) 
Para analisar a estrofe acima, devemos rememorar a definição de aposto, entendido como um "termo de caráter nominal que se junta a um substantivo, a um pronome, ou a um equivalente destes, a título de explicação ou de apreciação" (CUNHA, 2017: 169). O aposto, em geral, vem separado do termo à que ele se refere por uma pausa, a qual costumamos traduzir na escrita com uma vírgula. Observamos que o recorte linguístico da melodia efetuado por Chico Buarque, no entanto, subverte a naturalidade entoativa e propõe uma pausa no meio do aposto "no prejuízo", entre a preposição e o substantivo, construção que jamais realizaríamos na língua oral. O ouvinte se depara, então, com esses dois segmentos linguístico-melódicos: "O garçom no" e "prejuízo"120. Podemos, de maneira bastante simples, propor uma alteração pontual na combinação entre a letra e a melodia do fragmento acima.

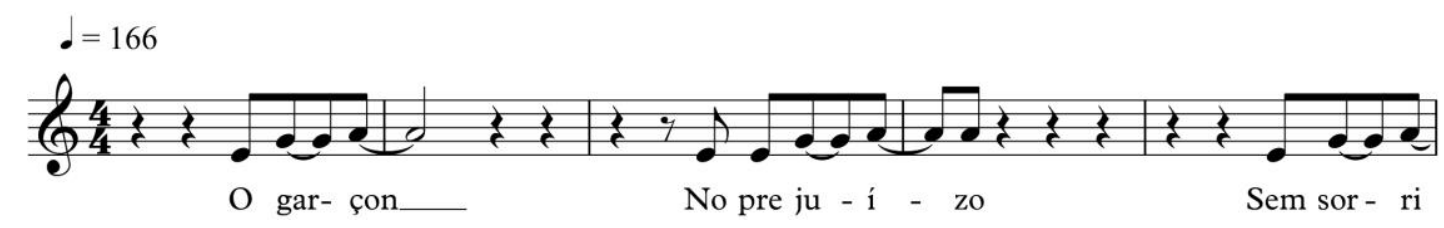

Figura 27. Reescrita de $O$ Malandro (Bertolt Brecht/Kurt Weill - adaptação de Chico Buarque)

Aproveitando o fato de o final da primeira unidade melódica repetir a mesma nota musical (Lá natural), eliminamos, quase que imperceptivelmente, a sua última colcheia. Inserimos, na unidade seguinte, uma nova nota inicial (a nota Mi na parte fraca do segundo tempo do terceiro compasso). Com isso, conseguimos manter a configuração entoativa característica do aposto, separando-o com pausas, do substantivo a que ele se refere. Acreditamos ser bastante clara a diferença entre a versão original (menos linear) e nossa proposta de reescrita e constatamos o quanto esses testes nos auxiliam a percebêla. Vejamos outros exemplos:

\footnotetext{
120 Mais uma vez, devemos dizer que nossa análise, de modo algum, pretende avaliar se as compatibilizações entre letra e melodia são "corretas" ou "incorretas", "melhores" ou "piores". Desejamos apenas, de um modo descritivo, examinar as suas infinitas gradações figurativas. Além disso, certas vezes, quando ocorre um fenômeno de combinação entre melodia e letra estranho à entoação, novos sentidos ou possibilidades criativas podem surgir. Nessa canção, por exemplo, poderíamos incorporar a cisão do vocativo, valorizando o segmento "O garçom no" que, no português brasileiro, pode ser pronunciado com a vogal [u]: "O garçom nu". Daí pode decorrer uma interessante relação com o sentido de "nudez", visto que a personagem da canção está igualmente desnuda ou privada de algo importante: sem freguês e sem sorriso (trataremos desse assunto no penúltimo item deste capítulo). Por ora, no entanto, devemos constatar que, ainda que possa haver decorrências estéticas advindas desses trechos "desentoativizados", o fato é que a apreensão oral do trecho se comprometerá. Cabe, portanto, ao cancionista, avaliar se vale ou não a pena comprometer a entoação de seus enunciados em prol de outras propostas estéticas. Mais uma vez, as suas escolhas configurarão o seu estilo cancional.
} 
Tu és divina e graciosa

Estátua majestosa do amor

Por Deus esculturada

E formada com ardor

Da alma da mais linda flor

De mais ativo olor

Que na vida é preferida pelo beija-flor

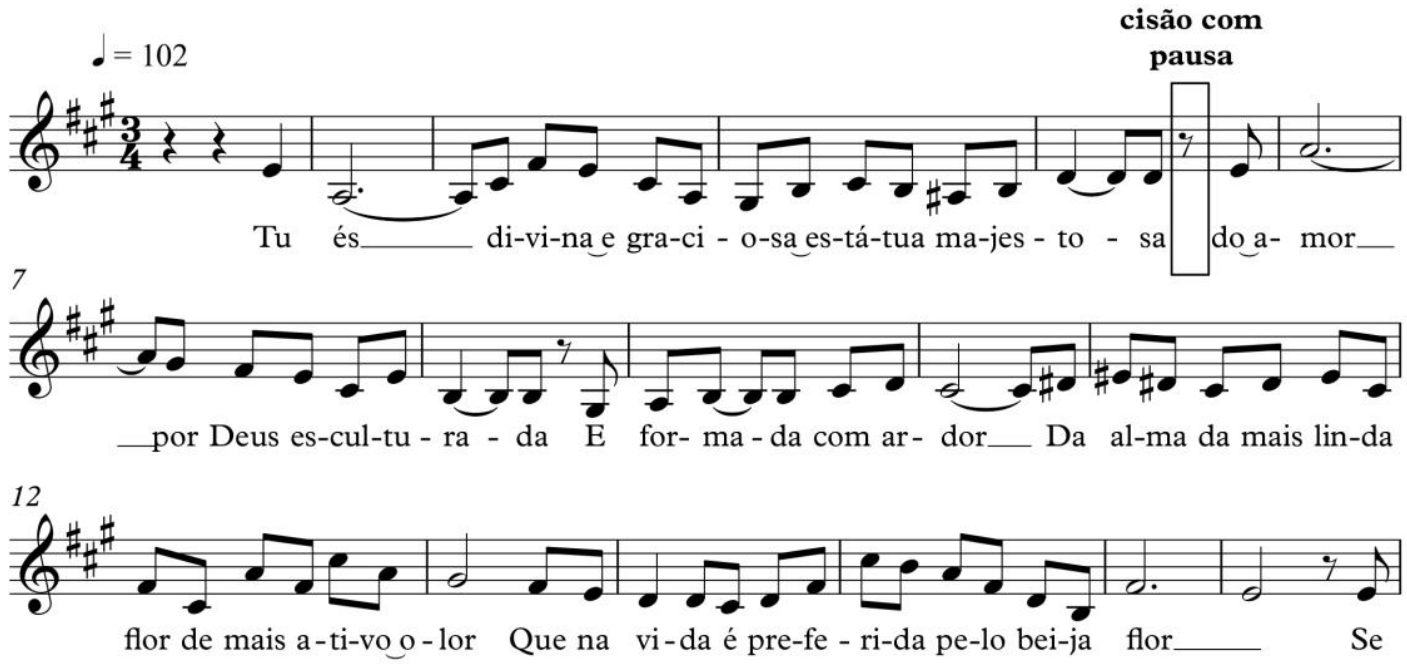

Figura 28. A unidade melódica e a unidade linguística em Rosa (Pixinguinha/Otávio de Souza)

Na figura acima, desejamos destacar a cisão que ocorre no sintagma nominal do predicado "estátua majestosa do amor", entre o substantivo "estátua" e o seu complemento nominal "do amor". Notamos que a perturbação entoativa decorre em grande parte do fato de a frase musical terminar no compasso cinco, mas a frase linguística, ainda inconclusa, continuar no segmento seguinte. Uma característica, no entanto, nos chama atenção. A unidade melódica que recobre os vocábulos “do amor" se destaca fortemente do restante do trecho, uma vez que alcança uma tessitura mais aguda. De fato, analisando a linha melódica, vemos que há uma interessante contraposição entre a nota longa Lá (segundo espaço do pentagrama) que coincide com a sílaba tônica de "amor" (a mínima pontuada ligada à uma colcheia a partir do sexto compasso) e a nota Lá, de mesma duração, oitava abaixo, que recobre o verbo "és", no segundo compasso da figura. Possuindo a nota mais aguda da canção até então, o segmento melódico-linguístico “do amor" parece sobressair em relação à frase precedente, o que não convém a uma letra que ainda está ligada sintaticamente à frase verbal que recorta a unidade melódica anterior. Com isso, cremos que o distúrbio entoativo do trecho acabou sendo ainda mais acentuado. Além disso, é notável que a unidade melódica que recobre os vocábulos “do 
amor" está, musicalmente, muito mais ligada à unidade seguinte do que à frase melódica anterior, tendo em vista a descendência que observamos a partir da nota Lá aguda (Lá Sol - Fá - Mi - Dó - Si). Assim, a frase musical completa, a nosso ver, traça o seguinte percurso:

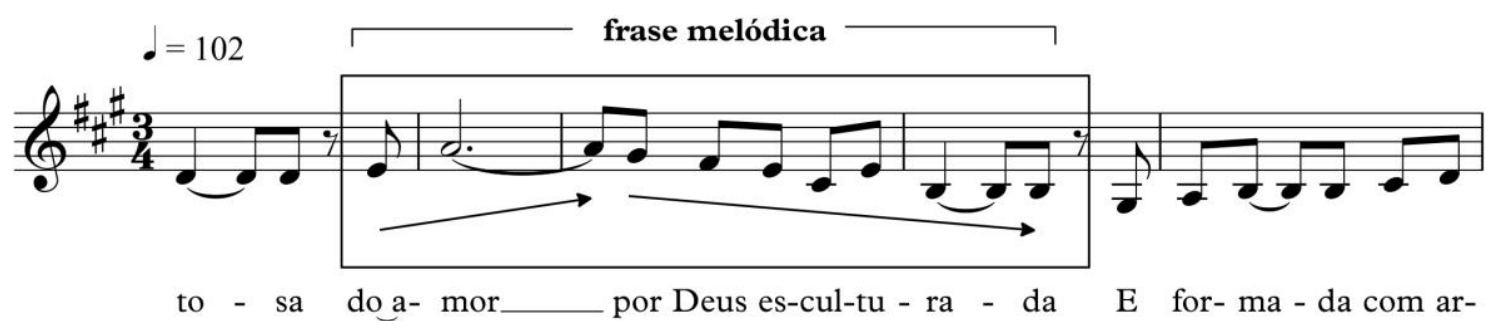

Figura 29. A frase melódica em Rosa (Pixinguinha/Otávio de Souza)

Entendemos que essa característica desfavorece ainda mais o elo entoativo entre o complemento nominal "do amor" e o substantivo "estátua" a que ele se refere. Nesse sentido, como se a configuração melódica guiasse a apreensão linguística, parece-nos que ele passa a se aproximar mais do segmento seguinte, "por Deus esculturada". Algo bastante similar pode ser percebido em um trecho da conhecida canção Tarde em Itapoã, de Toquinho e Vinicius de Moraes.

Depois sentir o arrepio

Do vento que a noite traz

E o diz-que-diz-que macio

Que brota dos coqueirais

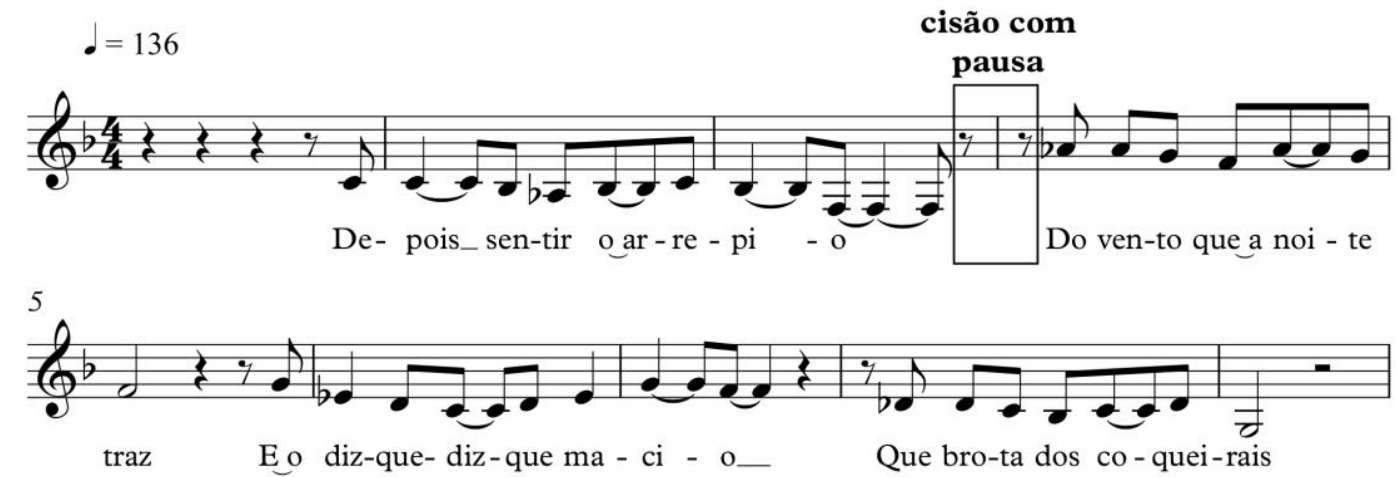

Figura 30. A unidade melódica e a unidade linguística em Tarde em Itapoã (Toquinho/Vinicius de Moraes)

Observamos aqui a presença de um período composto, isto é, formado por mais de uma oração. Ao compatibilizar letra e melodia, contudo, os cancionistas acabaram promovendo um corte antes do término da primeira oração, separando o substantivo "arrepio" do seu complemento nominal "do vento". Assim como na canção Rosa, o termo 
faltante do sintagma nominal aparece somente no início da unidade melódica seguinte e numa região de frequência muito mais elevada. De fato, observamos um intervalo muito amplo (uma décima entre as notas Fá do terceiro compasso e Lá bemol do quarto compasso) separando os vocábulos “arrepio" e "do vento". Isso, sem dúvida, desfavorece a apreensão mais usual da passagem. A propósito, percebemos uma segunda cisão, menos proeminente, segmentando a frase verbal "E o diz-que-diz-que macio que brota dos coqueirais". Nesse caso, no entanto, o corte se dá justamente entre as duas orações, antes do pronome relativo "que" e, por isso, não sentimos um distanciamento entoativo tão elevado. Vejamos mais um interessante exemplo, comparando o mesmo trecho melódico recortado por duas letras distintas em Querido Diário, do compositor Chico Buarque.

Hoje topei com alguns

Conhecidos meus

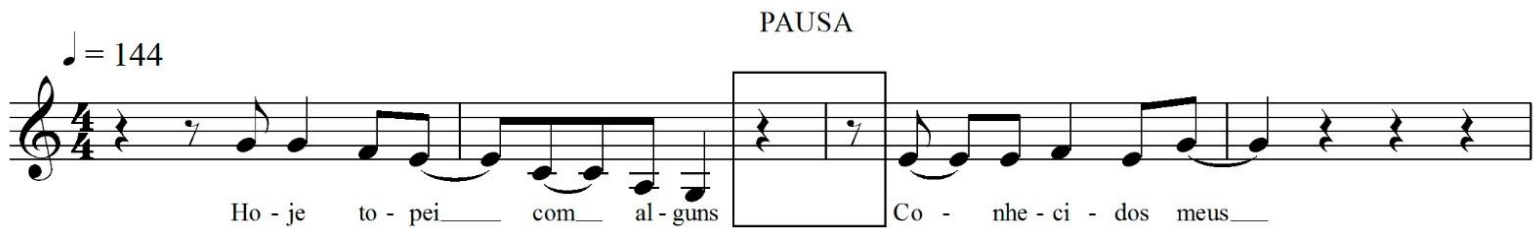

Figura 31. A unidade melódica e a unidade linguística em Querido diário (Chico Buarque)

Hoje a cidade acordou

Toda em contramão

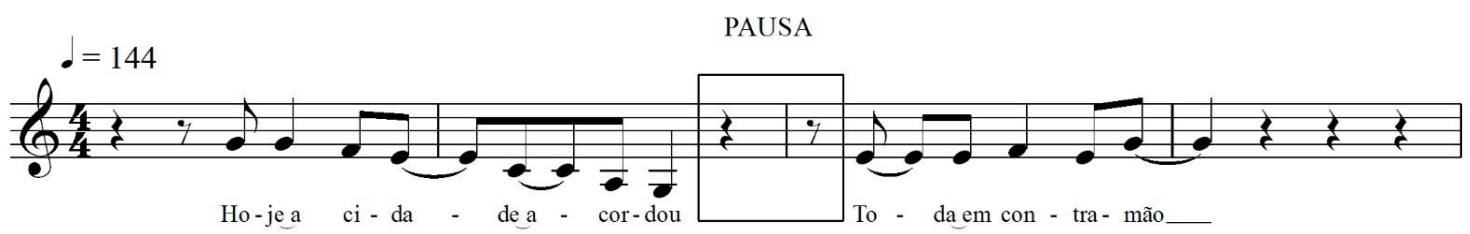

Figura 32. A unidade melódica e a unidade linguística em Querido diário (Chico Buarque)

$\mathrm{Na}$ primeira figura, há uma pausa que segmenta uma frase linguística que geralmente não estaria separada em uma situação usual de fala. Isto é, quando comparamos os dois exemplos de Querido diário, constatamos que, no primeiro, há uma figurativização menos esperada, pois a inserção de uma pausa entre os vocábulos "alguns" e "conhecidos" é uma construção menos comum na língua oral. Dentro do contexto das unidades entoativas propostas pela obra, há uma leve perda de oralidade. Parece-nos que, no segmento "Hoje topei com alguns", a melodia musical, talvez devido à sua descendência final (Dó - Lá - Sol), possui um sentido de terminação maior do que o teor 
conclusivo do texto verbal (já que o vocábulo "alguns" pede, com vigor, a sua complementação "conhecidos meus").

Diferentemente, na segunda figura, a entoação se faz de maneira mais linear. Os segmentos "hoje a cidade acordou" e "toda em contramão" soam, quando separados, de modo um pouco mais natural, dado que o sentido terminativo do verbo "acordar", verbo intransitivo em sua acepção "despertar" ou "sair do sono", combina com a melodia descendente e asseverativa observada no segundo compasso do fragmento. Examinemos o exemplo seguinte, a canção Tempo Rei, de Gilberto Gil.

Não me iludo

Tudo permanecerá

Do jeito que tem sido

Transcorrendo

Transformando

Tempo e espaço navegando

Todos os sentidos

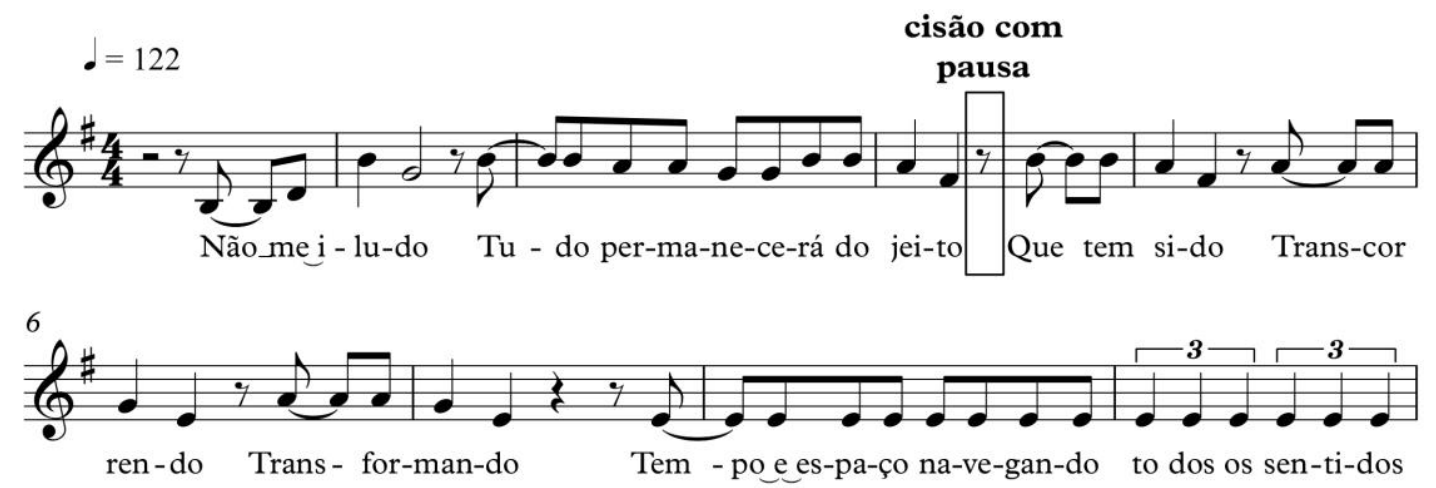

Figura 33. A unidade melódica e a unidade linguística em Tempo rei (Gilberto Gil)

Aqui, constatamos mais uma vez o sentido conclusivo de uma frase melódica (quarto compasso do fragmento) que recobre um texto linguístico ainda incompleto (que só finaliza na unidade melódica seguinte). Ao desmembrar a expressão "do jeito que tem sido", cindindo-a entre o substantivo "jeito" e o pronome relativo "que", o cancionista também desprivilegia em algum grau a apreensão entoativa de sua canção, ainda que pontualmente. O exemplo seguinte apresenta uma proposta ainda mais inesperada. Vejamos.

E só o acaso estende os braços

A quem procura abrigo e proteção

Meu amor, disciplina é liberdade 

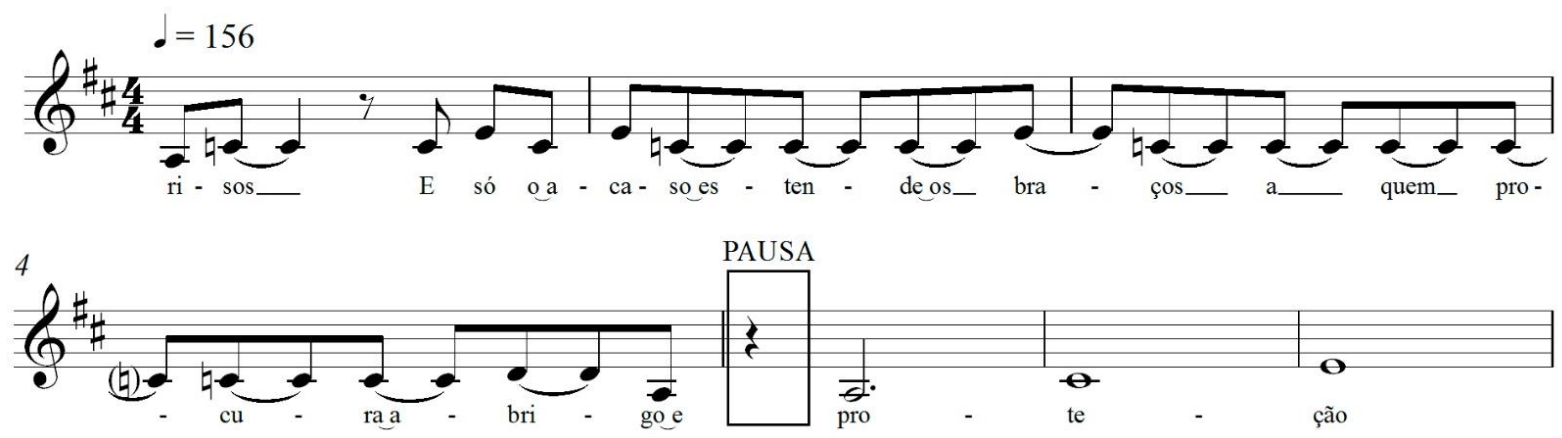

Figura 34. A unidade melódica e a unidade linguística em Há tempos (Renato Russo/Dado VillaLobos/Marcelo Bonfá)

Em Há tempos, a pausa assinalada no segundo pentagrama produz um significativo transtorno entoativo, uma vez que, na fala, dificilmente separaríamos as palavras "abrigo" e "proteção" em uma sentença como essa. Não obstante, o cancionista opta pela cisão na metade do complemento do verbo transitivo direto "procurar". Todavia, o que mais contribui para a perturbação da fluência oral é, talvez, o fato de a frase musical terminar em "abrigo e" e a frase linguística permanecer incompleta, já que ainda necessita do complemento sugerido pela conjunção aditiva "e": "abrigo e proteção". Ademais, a elisão entre a última vogal de "abrigo" e a conjunção "e", além dos deslocamentos dos acentos silábicos das palavras "procura" e "abrigo", dificulta ainda mais a compreensão imediata da letra por parte do público.

Nota-se que, se o cancionista realizasse a pausa após o vocábulo "abrigo" (e deslocasse a conjunção aproximando-a do vocábulo seguinte, "e proteção"), certamente teríamos uma figurativização mais confluente com as curvas da linguagem oral. Desse modo, atenuaríamos a necessidade urgente de complementação que ocorre na canção original (na qual a conjunção aditiva é inesperadamente posicionada no final do segmento musical). Outro tipo de ocorrência a ser analisada, também ligada ao recorte linguístico das frases melódicas, é a cisão em frases verbais que possuem inversões na organização dos termos da oração. Comecemos pela canção Um Certo Alguém, de Lulu Santos e Ronaldo Bastos.

Acho que é bobagem

A mania de fingir

Negando a intenção 


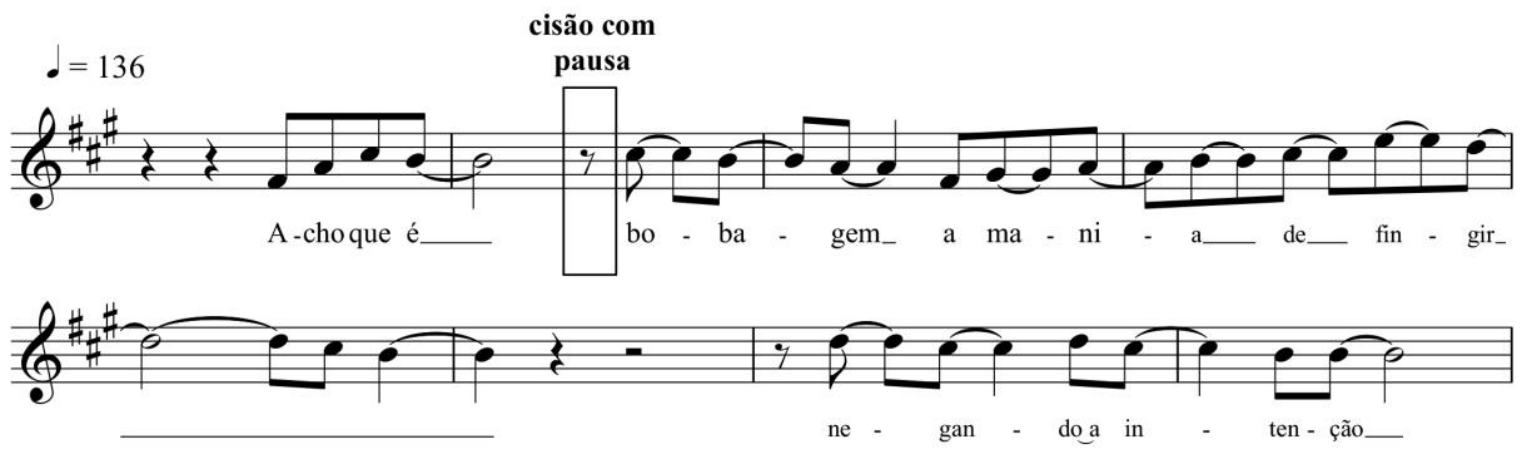

Figura 35. A unidade melódica e a unidade linguística em Um certo alguém (Lulu Santos/Ronaldo Bastos)

Na língua portuguesa, os termos que compõem a oração são organizados preferivelmente em ordem direta: sujeito + verbo + objeto direto + objeto indireto ou sujeito + verbo + predicativo (CUNHA, 2017: 176). Embora haja essa predominância, encontramos, é claro, diversos casos de frases organizadas em ordem inversa. É o que observamos nesse trecho da canção Um Certo Alguém, com a frase "Acho que é bobagem a mania de fingir". Trata-se de um período composto formado por duas orações que, se dispuséssemos em ordem direta, resultaria na seguinte frase: “(Eu) acho que a mania de fingir é bobagem". Ao realizar tal inversão, fazendo o predicativo preceder o verbo de ligação, o cancionista valoriza a palavra "bobagem". Tratando-se, então, de um valioso recurso expressivo (por meio do qual o cancionista pode enfatizar pontos diversos da oração), resta-nos investigar se essas inversões intensificam ou amenizam a perda entoativa gerada pelos cortes das unidades verbais. Vejamos mais um exemplo:

Existirá

Em todo porto tremulará

A velha bandeira da vida

Acenderá

Todo farol iluminará

Uma ponta de esperança
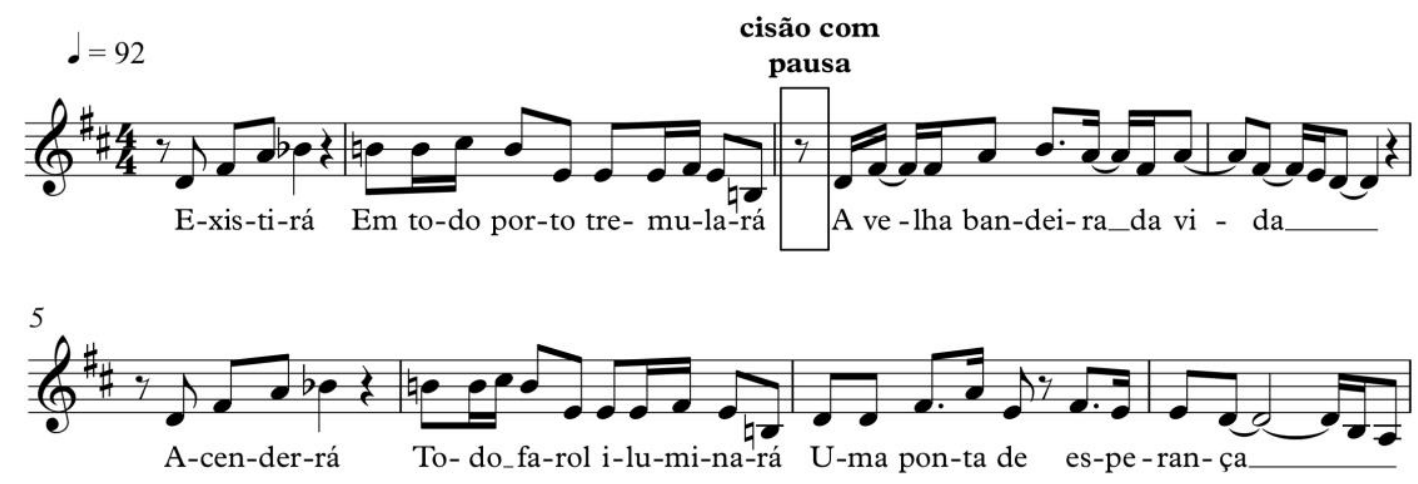

Figura 36. A unidade melódica e a unidade linguística em A cura (Lulu Santos) 
Similarmente ao que analisamos em outros exemplos, há nessa canção uma cisão após a ocorrência de um verbo, o vocábulo “tremulará". Reorganizando a frase em ordem direta, teríamos a seguinte oração: "A velha bandeira da vida tremulará em todo porto". Note-se que o verbo em questão pode aceitar o valor de transitividade ou intransitividade, a depender do seu contexto linguístico. Nesse caso, na acepção de uma bandeira que se move tremendo, constitui um verbo intransitivo, sem exigir uma complementação obrigatória. Assim, constatamos que, se a frase estivesse em ordem direta, observaríamos um menor desconforto oral, visto que o ouvinte já estaria semanticamente satisfeito. Todavia, ao posicionar o sujeito da oração apenas após o verbo e, sobretudo, após o corte temporal sublinhado no primeiro tempo do terceiro compasso, a sensação de incompletude e estranhamento é reforçada. Examinemos a canção O Sol Nascerá, de Cartola e Elton Medeiros.

A sorrir

Eu pretendo levar a vida

Pois chorando

Eu vi a mocidade

Perdida

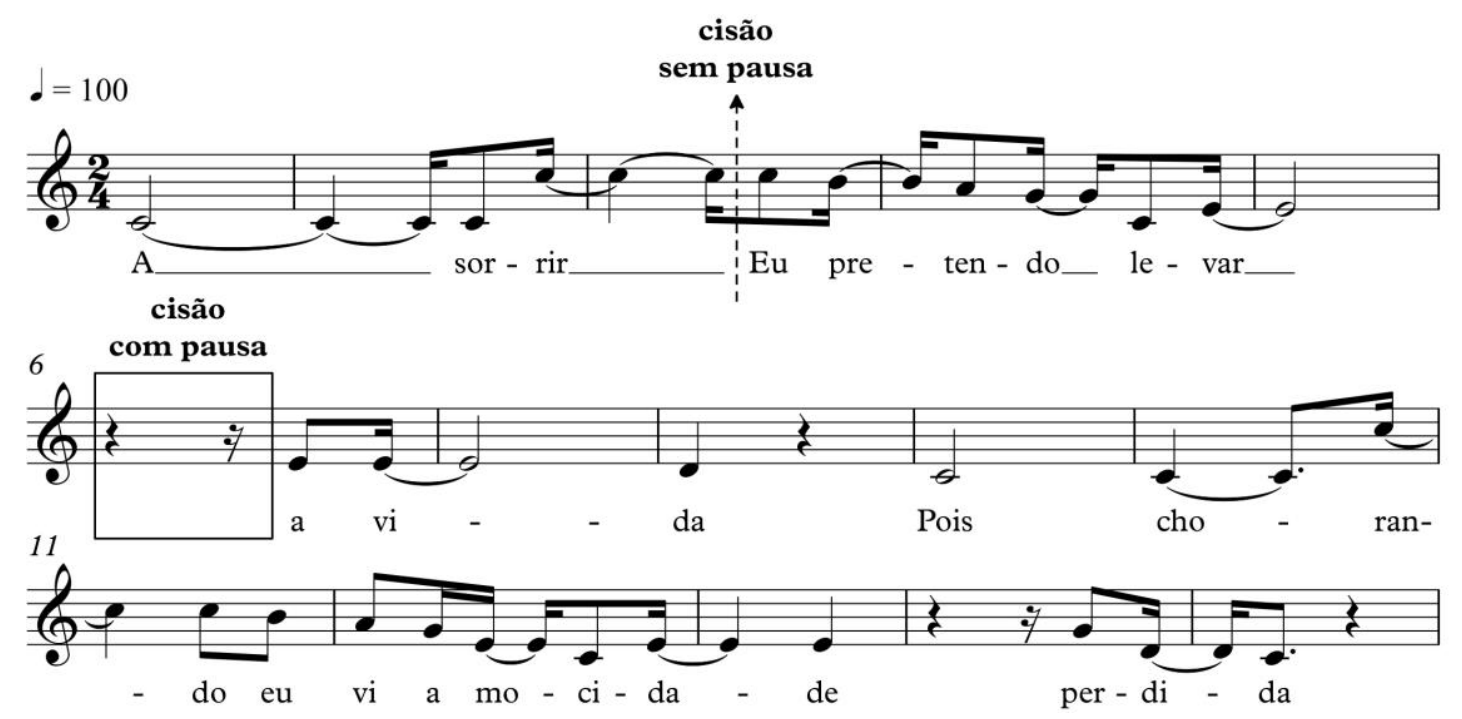

Figura 37. A unidade melódica e a unidade linguística em O sol nascerá (Cartola/Elton Medeiros)

Nessa canção, não notamos o mesmo tipo de desconexão oral observado nos exemplos anteriores. Ao realizar a inversão sintática, os cancionistas fazem uso da chamada topicalização (também utilizada na fala), dando destaque a um termo (a expressão “A sorrir”) que não possuiria muita ênfase na ordem direta da frase: “Eu preciso 
levar a vida a sorrir". É interessante observar como as diferentes propostas de recorte linguístico (nesse caso, a topicalização) produzem efeitos cancionais originais. Há um valor expressivo que porventura agrada o cancionista e o faz optar, de modo intuitivo, por determinada construção. Em $O$ Sol Nascerá, é marcante o destaque que o compositor consegue dar à expressão "a sorrir”, posicionando-a no começo da unidade melódica ao inverter a ordem direta da oração. Ela coincide com as longas durações das notas iniciais e com o amplo salto intervalar de oitava incidindo justamente sobre a sílaba tônica do vocábulo "sorrir". Temos aqui, na música, uma sensação fortíssima de abertura que corresponde perfeitamente ao conteúdo do texto linguístico: o sujeito, a letra e a melodia parecem sorrir. Nesse caso, a cisão sem pausa indicada na figura acima ajuda a transferir o acento de sentido para o termo em destaque.

Esses diferentes tipos de encaixe, por outro lado, poderão suscitar alguma espécie de perturbação oral. Nesse exemplo, tendo em vista o significativo retardamento da conclusão semântica do trecho (interrompido pelas duas cisões apontadas na ilustração), além da inversão da ordem direta da frase e, sobretudo, do alongamento de sua nota inicial $^{121}$, o ouvinte pode até mesmo ser levado a entender o texto verbal de modo equivocado. Escutaria algo como "Ah, sorrir..." com a presença da interjeição de alegria “ah!” ao invés da preposição "a” (o que, curiosamente, também combina com o conteúdo eufórico da canção).

Antes de passarmos para o próximo exemplo, desejamos aprofundar um pouco mais a questão dos períodos compostos, formados por mais de uma oração, o que nos auxiliará em análises seguintes. Quando as orações que compõem um período são autônomas (não constituindo um termo de uma outra oração, nem a ela se referindo), elas são denominadas coordenadas e o período que as engloba passa a ser chamado de período composto por coordenação. As orações coordenadas podem ser classificadas em assindéticas ou sindéticas. No primeiro caso, são justapostas sem a presença de conectivos: "Todo dia ela faz tudo sempre igual, / me sacode às seis horas da manhã, / me sorri um sorriso pontual" (Cotidiano, Chico Buarque). No segundo, podem ser ligadas por diversos tipos de conjunção coordenativa: pela conjunção aditiva "e”, pela conjunção adversativa "mas" ou "porém", pela conjunção alternativa "ou”, pela conjunção conclusiva "logo" ou "portanto" e pela conjunção explicativa "pois" ou "que".

\footnotetext{
121 Trataremos, ainda neste capítulo, de alguns casos em que observamos a dificuldade do cancionista de trabalhar com frases melódicas iniciadas por notas longas.
} 
Poderíamos, por exemplo, visualizar uma oração coordenada sindética aditiva na complementação da estrofe de Cotidiano, citada acima: "me sorri um sorriso pontual e me beija com a boca de hortelã".

Em contrapartida, as orações que não possuem essa autonomia gramatical, passando a funcionar como "termos essenciais, integrantes ou acessórios de outra oração" (CUNHA, 2017: 608), são chamadas de subordinadas e o período que as agrupa é denominado período composto por subordinação. As orações subordinadas sempre exercem alguma função sintática em uma outra oração, podendo ser o seu sujeito, o seu objeto direto ou indireto, o seu complemento nominal, o seu aposto etc. (CUNHA, 2017: 610). São classificadas em substantivas, adjetivas ou adverbiais, quando as funções sintáticas que realizam se aproximam das funções características de um substantivo, adjetivo ou advérbio. Em "Eu já lhe expliquei que não vai dar" (Carolina, Chico Buarque), por exemplo, temos a oração principal "Eu já lhe expliquei" e a oração subordinada substantiva objetiva direta "que não vai dar".

Há também o período composto misto que apresenta, ao mesmo tempo, os dois processos sintáticos de relacionar as orações. É, então, denominado período composto por coordenação e subordinação. Por exemplo, a frase "Quando você me quiser rever, já vai me encontrar refeita, pode crer" (Olhos nos Olhos, Chico Buarque) contém uma oração subordinada "Quando você me quiser rever”, uma oração principal “já vai me encontrar refeita" e uma oração coordenada "pode crer", todas atuando de modo simultâneo. Evidentemente, essa questão da autonomia ou da dependência na relação entre as orações que formam um período composto deve fazer parte de nossa análise, visto que estamos interessados justamente em investigar o grau de conexão entre os segmentos verbais que recebem um corte ao serem combinados com a linha melódica da canção. Acreditamos que esses conceitos nos poderão ser úteis no momento em que estivermos examinando períodos formados por várias orações. Analisemos o seguinte trecho da canção Na rua, na chuva, na fazenda (Casinha de Sapé), do compositor Hyldon.

Jogue suas mãos para o céu

E agradeça se acaso tiver

Alguém que você gostaria que

Estivesse sempre com você

Na rua, na chuva, na fazenda

Ou numa casinha de sapê 


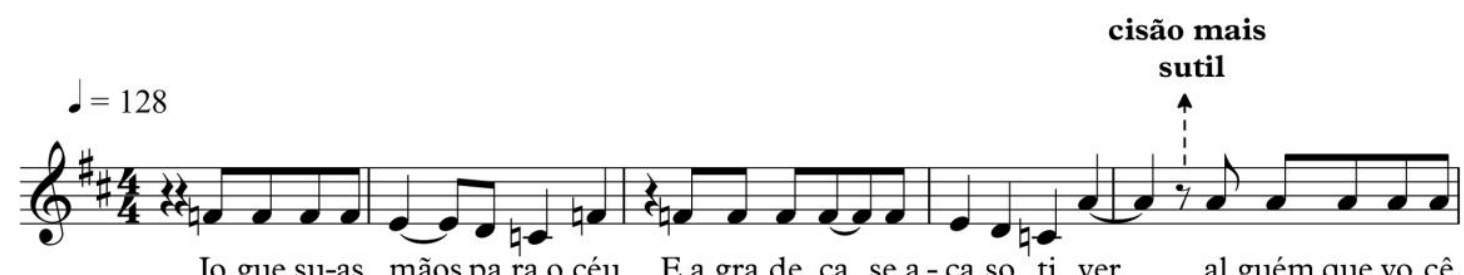

Jo gue su-as mãos pa ra o céu E a gra de ça_se a - ca so ti ver__ al guém que vo cê

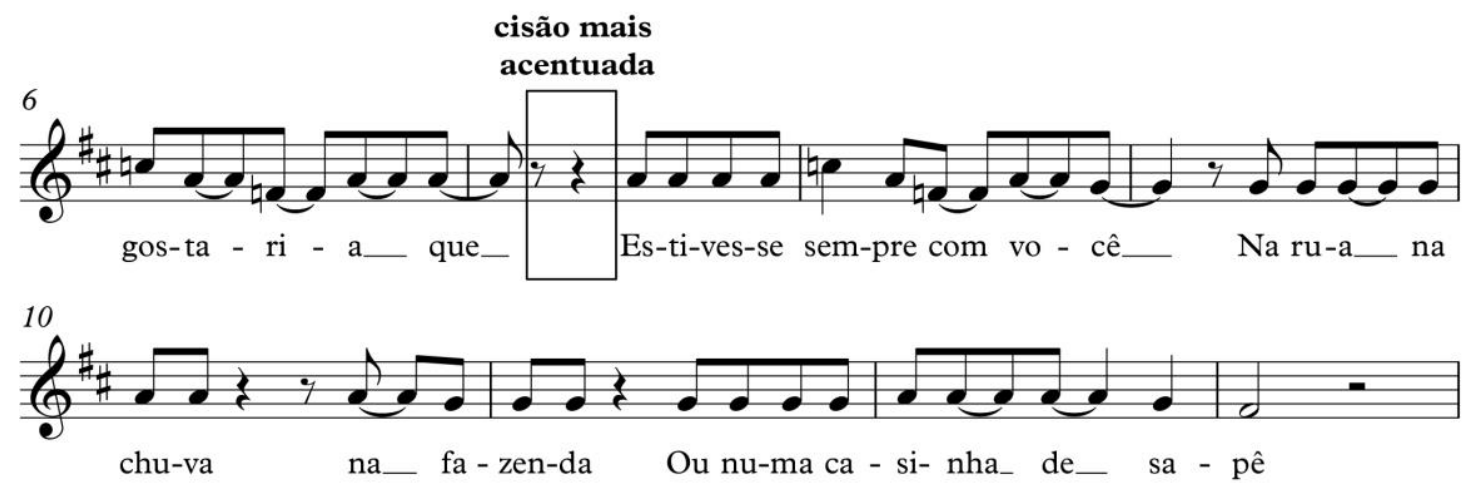

Figura 38. A unidade melódica e a unidade linguística em Na rua, na chuva, na fazenda (Casinha de Sapé) (Hyldon)

A canção apresenta uma frase significativamente alongada que, numa hipotética situação de fala, poderia ser dita de um modo um pouco mais contínuo, ainda que fizéssemos eventuais pausas: "Jogue suas mãos para o céu e agradeça se acaso tiver alguém que você gostaria que estivesse sempre com você, na rua, na chuva, na fazenda ou numa casinha de sapê". Analisando os seus cinco primeiros segmentos, podemos decompô-la da seguinte maneira:

\begin{tabular}{|l|l|}
\hline Jogue suas mãos para o céu & Oração principal \\
\hline e agradeça & Oração subordinada \\
\hline se acaso tiver alguém & Oração subordinada \\
\hline que você gostaria & Oração subordinada \\
\hline que estivesse sempre com você & Oração subordinada \\
\hline
\end{tabular}

Figura 39. O período composto em Na rua, na chuva, na fazenda (Casinha de Sapé) (Hyldon)

Observando o modo como a melodia recobre cada uma das orações apontadas na tabela acima, constatamos que há só dois pontos nos quais encontramos cisões 
indesejadas do ponto de vista verbal. A primeira, ao final da oração "se acaso tiver alguém", separando levemente os vocábulos "tiver" e "alguém", consiste em um caso mais sutil, visto que a sílaba final do verbo "tiver" se alonga para quase alcançar, com a mesma nota, a palavra seguinte. De modo distinto, a segunda cisão (apontada no sétimo compasso do fragmento) desmembra a oração subordinada "que estivesse sempre com você", separando a conjunção integrante "que" do restante da sentença e gerando, por isso, uma oralização não-linear mais radical. Afinal, na língua oral, é incomum realizarmos uma pausa como essa. Enfim, exemplos mais extremos de perda do elo entoativo são mais raros, embora, ocasionalmente, também possam ocorrer. Nesses casos, pode haver, por parte do ouvinte, certa dificuldade em compreender o sentido da letra, posto que o encaixe entre a melodia e o texto verbal se afasta mais fortemente do que estamos acostumados a escutar em nossa experiência cotidiana com a língua falada. Comparemos essas duas estrofes da canção Índios, do grupo Legião Urbana.

Quem me dera ao menos uma vez

Ter de volta todo o ouro que entreguei a quem

Conseguiu me convencer

Que era prova de amizade
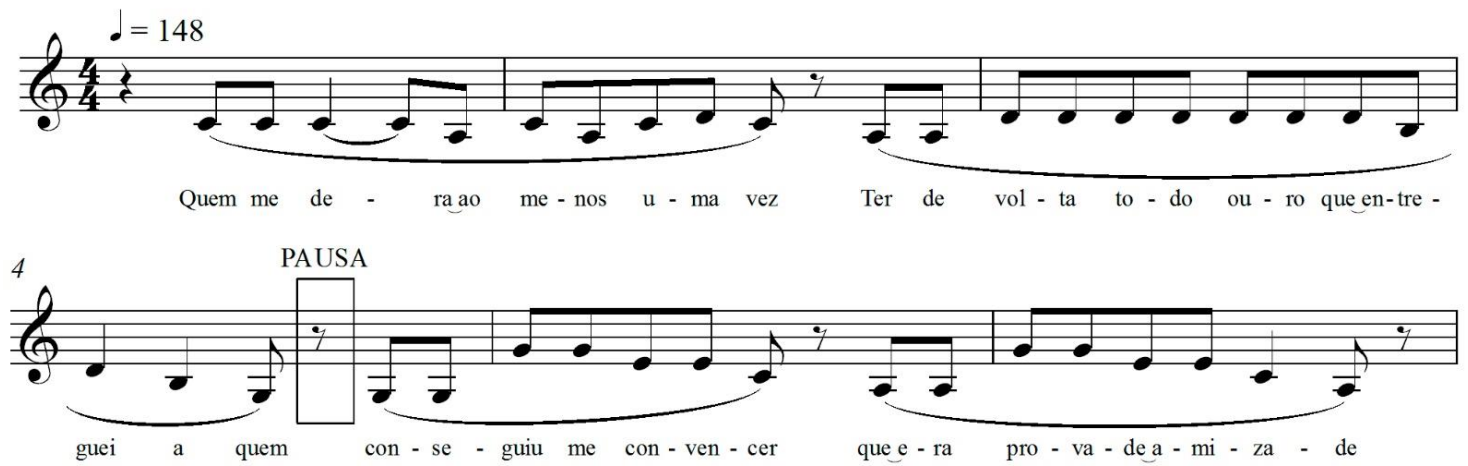

Figura 40. A unidade melódica e a unidade linguística em Índios (Renato Russo/Dado Villa-Lobos/Marcelo Bonfá)

Quem me dera ao menos uma vez

Explicar o que ninguém consegue entender

Que o que aconteceu

Ainda está por vir 


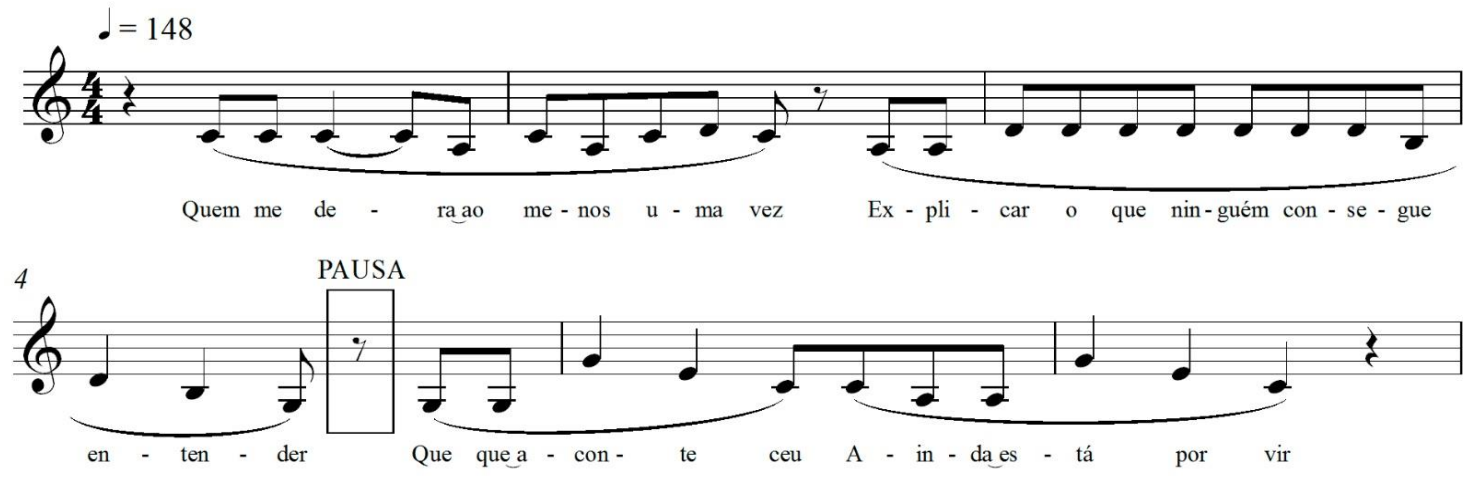

Figura 41. Variação da letra para a mesma melodia em Índios

Em ambas as estrofes, inserimos ligaduras de frase para destacarmos as suas respectivas unidades melódicas. Analisando a combinação entre elas e as suas unidades verbais, constatamos que, na primeira figura, quando o segundo segmento melódico finaliza (no quarto compasso), o seu texto verbal não apresenta o mesmo sentido conclusivo. A palavra "quem", presente no final desse trecho, necessita fortemente da complementação que vem adiante, apenas na unidade melódica seguinte: "conseguiu me convencer". Há, então, uma significativa desvalorização da entoação natural do enunciado. Na repetição da estrofe, ao proporem uma nova letra, os cancionistas não realizam o mesmo procedimento. Nesse caso, o sentido conclusivo está presente tanto na melodia como no texto linguístico: "Explicar o que ninguém consegue entender". Uma ocorrência similar pode ser observada na seguinte canção:

Queria sempre te ver

Dia e noite e você

Pareceu por um instante

Tão fina suave elegante $\cdot=154$
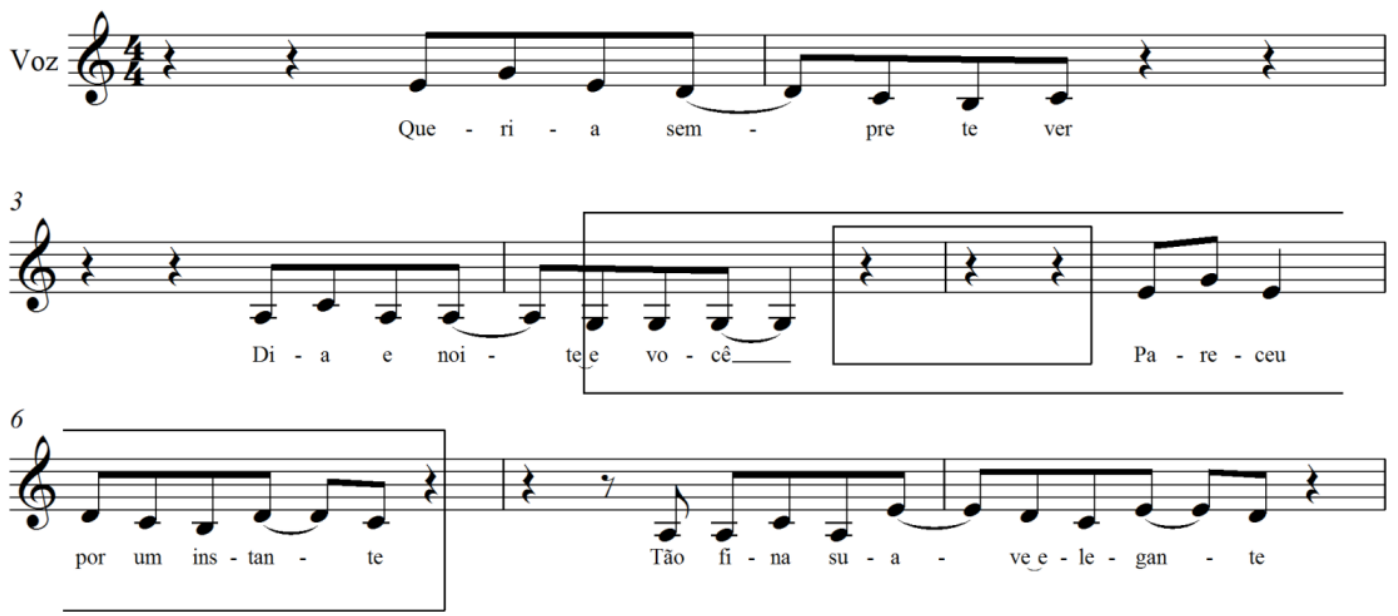

Figura 42. A unidade melódica e a unidade linguística em Meu amigo Enock (Zeca Baleiro) 
Em Meu Amigo Enock, notamos uma pausa na melodia do canto que provoca, sob o ponto de vista entoativo, uma inesperada divisão da oração "e você pareceu por um instante", justamente entre o verbo "pareceu" e o pronome "você" a que ele se refere. Assim, constatamos uma segmentação verbal que destoa de modo considerável dos recortes linguísticos que a canção vinha apresentando até então. Com isso, o trecho se distancia da nossa experiência com a língua falada.

Esses últimos exemplos são casos extremos em que a relação entre a letra e a melodia se afasta mais fortemente da entoação da fala, quebrando, mesmo que por um momento, o elo entre o destinador cantor e o destinatário ouvinte. Entretanto, como dissemos antes, o compositor de canções populares dificilmente comete esse tipo de afastamento em relação à língua oral. Em geral, o corte das frases linguísticas por meio de pausas (quando precisam ser divididas para caberem nas frases musicais, sobretudo nas canções temáticas, nas quais o desejo de manter um padrão melódico é maior) não põe em risco o projeto figurativo da canção. Na grande maioria dos casos, a separação é mais sutil, como notamos nos exemplos seguintes:

Eu só quero um amor

Que acabe o meu sofrer

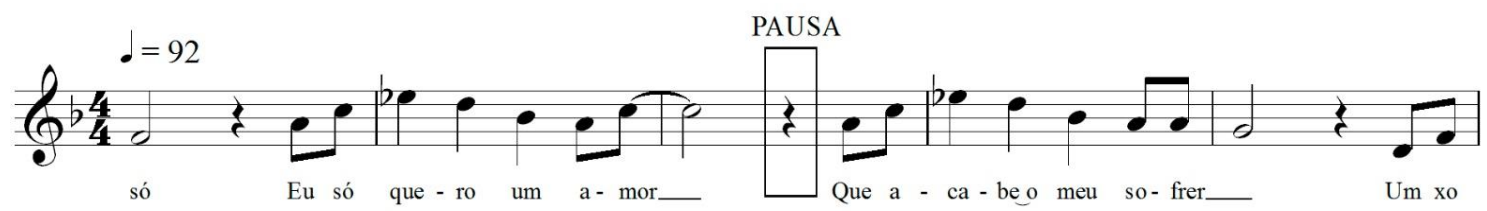

Figura 43. A unidade melódica e a unidade linguística em Eu só quero um xodó (Dominguinhos/Anastácia)

Vamos fugir

Tô cansado de esperar

Que você me carregue

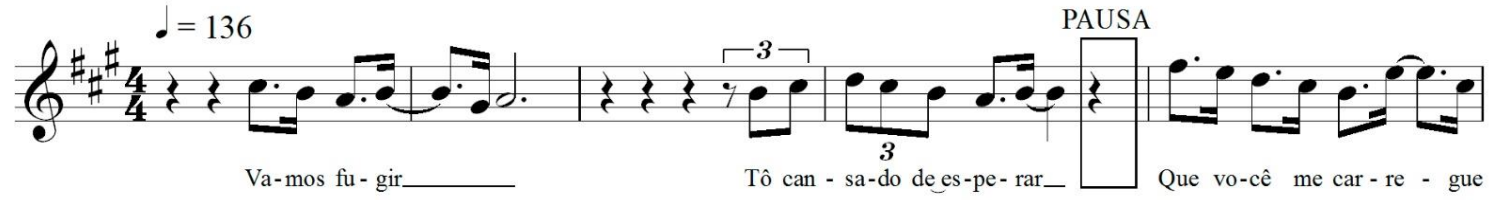

Figura 44. A unidade melódica e a unidade linguística em Vamos fugir (Liminha/Gilberto Gil) 
Elas roda, roda, roda

E dispois se senta

Em cima dos prato da lâmpida pra descansar

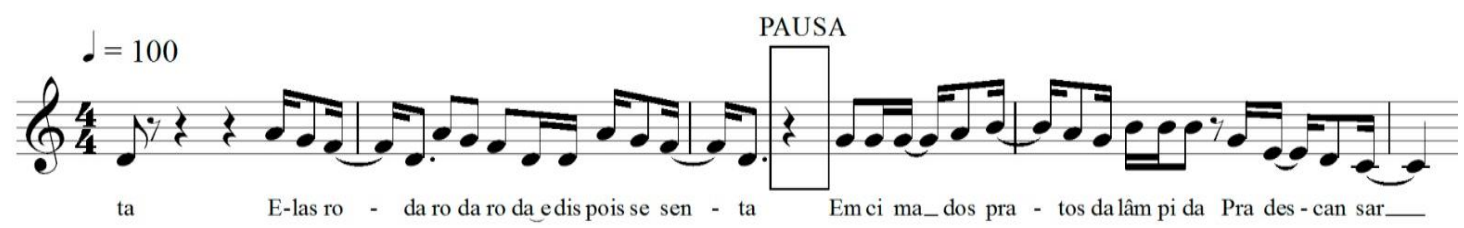

Figura 45. A unidade melódica e a unidade linguística em As mariposas (Adoniran Barbosa)

No primeiro exemplo, o compositor divide a frase "eu só quero um amor que acabe o meu sofrer" em duas partes. O ponto em que ele a divide, no entanto, permite que a primeira parte expresse um sentido de maior completude: “eu só quero um amor”. Não precisaríamos, de certa forma, escutar a continuação da letra. Como oração principal, ela não exerce nenhuma função sintática em outra oração do período e, por isso, contém maior teor conclusivo. Esse tipo de construção é muito comum na canção popular. É quando o compositor transmite um caráter de fechamento de sentido, mas, no verso seguinte, acrescenta uma complementação para a frase. Da mesma maneira, em Vamos fugir e As mariposas, as pausas que sucedem os segmentos "tô cansado de esperar" e "e dispois se senta”, tendo em vista a possível intransitividade de seus respectivos verbos, não causam estranhamento entoativo, já que possuem algum grau de sentido de finalização.

Encontramos também alguns casos curiosos nos quais não há um corte tão radical segmentando as orações do período, mas cujo desenvolvimento melódico não condiz com a progressão dessas unidades linguísticas. Examinemos o seguinte trecho da conhecida canção A Vida do Viajante de Hervé Cordovil e Luiz Gonzaga.

Minha vida é andar por este país

Pra ver se um dia descanso feliz

Guardando as recordações

Das terras onde passei

Andando pelos sertões

E dos amigos que lá deixei 

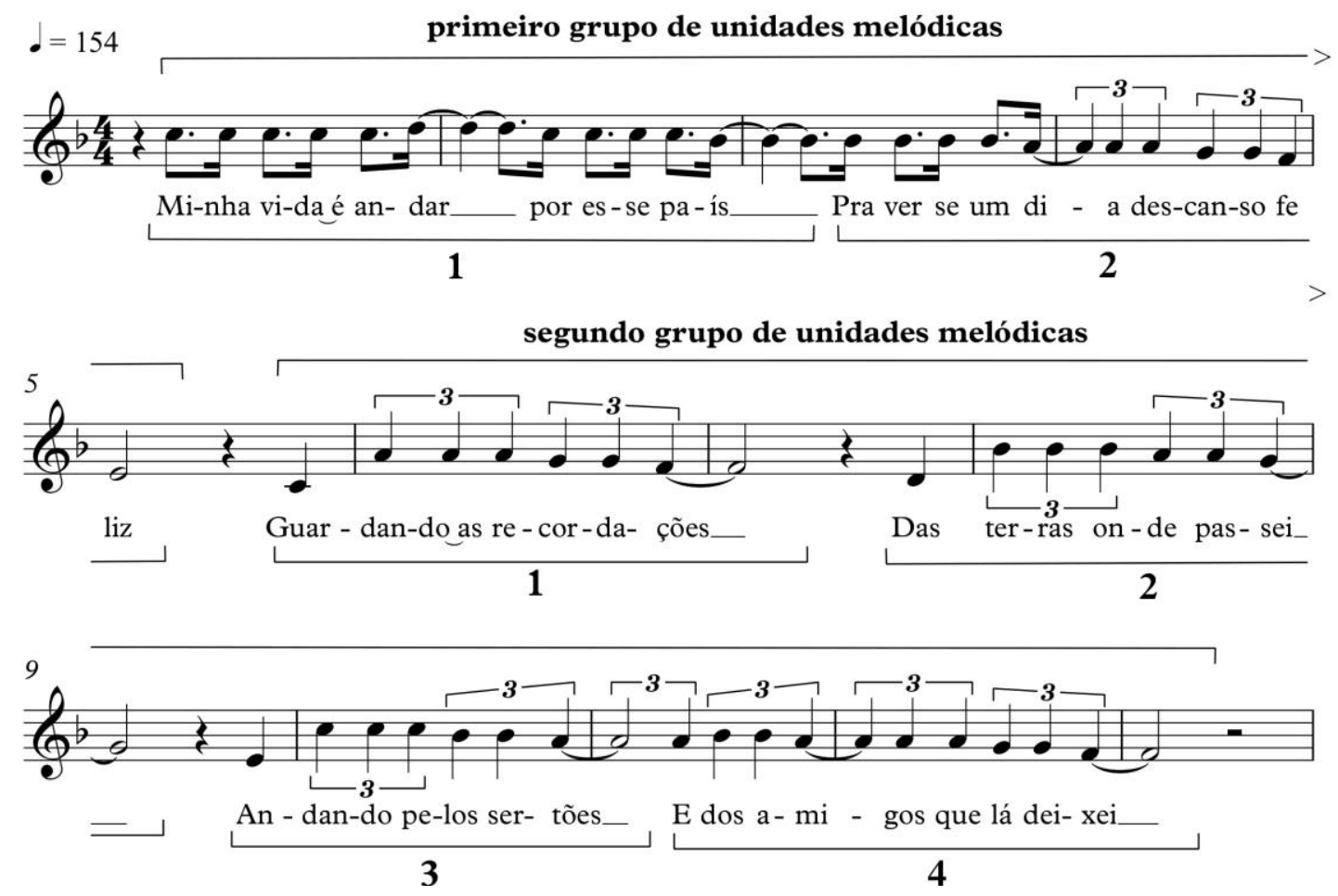

Figura 46. A unidade melódica e a unidade linguística em A Vida do Viajante (Hervé Cordovil/Luiz Gonzaga)

No exemplo acima, observamos um intrigante acontecimento. Analisando-o musicalmente, constatamos uma possível divisão da estrofe em dois grupos de unidades melódicas. Há um primeiro grupo formado pelas duas primeiras unidades: a primeira começa no agudo e emenda na seguinte que finaliza com uma descendência bastante asseverativa: "Minha vida é andar por esse país / pra ver se um dia descanso feliz". O segundo grupo, por sua vez, é constituído por quatro unidades melódicas que vão, gradativamente, aumentando o seu nível de tensividade em direção ao agudo, até o relaxamento presente no último segmento: “Guardando as recordações / das terras onde passei /andando pelos sertões / e dos amigos que lá deixei”. Observando a ilustração, verificamos que, de fato, da primeira à terceira, suas unidades são iniciadas por intervalos de $6^{\text {a }}$, cada vez mais agudos: Dó - Lá ( $1^{\text {a }}$ unidade), Ré - Si (segunda unidade) e Mi - Dó (terceira unidade). O segmento final, por sua vez, interrompe a sequência gradativa e descende promovendo o relaxamento das tensões anteriores.

A estranha ocorrência a que nos referimos acima, a nosso ver, deve-se ao seguinte fato. Na melodia, vemos que há uma relação de ascendência entre esses quatro segmentos, isto é, um direcionamento que os engloba num todo até a sua finalização na quarta 
unidade. Linguisticamente, no entanto, observamos uma inter-relação entre a segunda e a terceira oração que perturba essa sensação do todo. Com efeito, "andando pelos sertões" se liga verbalmente mais à oração anterior do que ao conjunto das quatro unidades linguísticas. Além disso, essa unidade, a de maior tensão, possui forte relação musical com o quarto segmento já que necessita por demais de sua descontração. Essa significativa dependência sonora, no entanto, não condiz com a fraca ligação linguística notada entre ambas. Por consequência, essa compatibilização entre letra e melodia produz também um distanciamento significativo entre a última oração "E dos amigos que lá deixei" e a primeira, "Guardando as recordações", ao qual ela se relaciona. Ao ouvinte, torna-se, então, um pouco mais dificultosa a apreensão de um dos sentidos pretendidos pelo cancionista: o sujeito anda pelo país guardando as recordações, dentre outras coisas, dos amigos que deixou nas terras pelas quais passou. Poderíamos, por exemplo, realizar uma sutil alteração na letra da canção, modificando o seu penúltimo segmento, com o intuito de tornar o segundo grupo de unidades melódicas verbalmente mais contínuo, acompanhando a continuidade de seu aspecto musical.
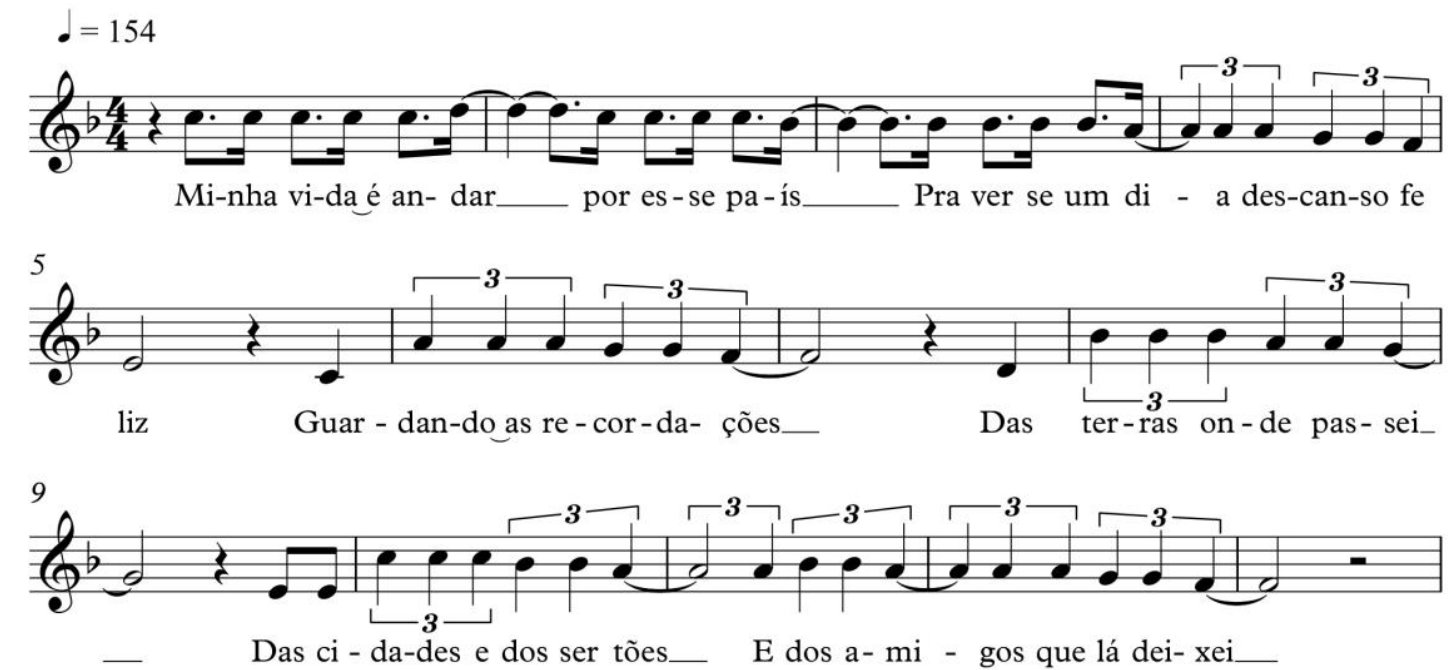

Figura 47. Reescrita de A Vida do Viajante (Hervé Cordovil/Luiz Gonzaga)

Ao alterarmos o verso "andando pelos sertões" para "das cidades e dos sertões" propomos uma continuidade linguística em relação aos demais segmentos verbais que recortam esse segundo grupo de unidades melódicas. Todos passam agora a referir-se à oração "guardando as recordações", enumerando, então, as lembranças do sujeito: ele guarda memórias “das terras", das cidades", “dos sertões" e “dos amigos”. Desse modo, o caminho musical contínuo recebe também um percurso linguístico igualmente 
ininterrupto. Esse trecho da canção original, como pudemos notar, constitui, então, um caso muito sutil de descompatibilização entre a letra e a melodia que, se não chega a comprometer o projeto figurativo global da obra, nos mostra um interessante fenômeno ligado à sua apreensão entoativa.

Voltando às ocorrências mais radicais de corte das unidades verbais, é comum encontrarmos canções nas quais, ao final de uma unidade entoativa, notamos um pequeno segmento verbal que corresponde ao início da unidade seguinte. Nesses casos, observamos uma cisão logo no início da frase linguística, responsável por uma significativa perturbação entoativa: o ouvinte recebe pouquíssima significação verbal para apoiar a sua escuta e, por isso, possui menos condições de prever intuitivamente a frase que virá. Consideremos os próximos exemplos, começando pela canção Vento no Litoral, do grupo Legião Urbana.

De tarde quero descansar

Chegar até a praia e ver

Se o vento ainda está forte

E vai ser bom subir nas pedras

Sei que faço isso pra esquecer

Eu deixo a onda me acertar

E o vento vai levando tudo embora

Agora está tão longe

Ver a linha do horizonte me distrai

Dos nossos planos é que tenho mais saudade
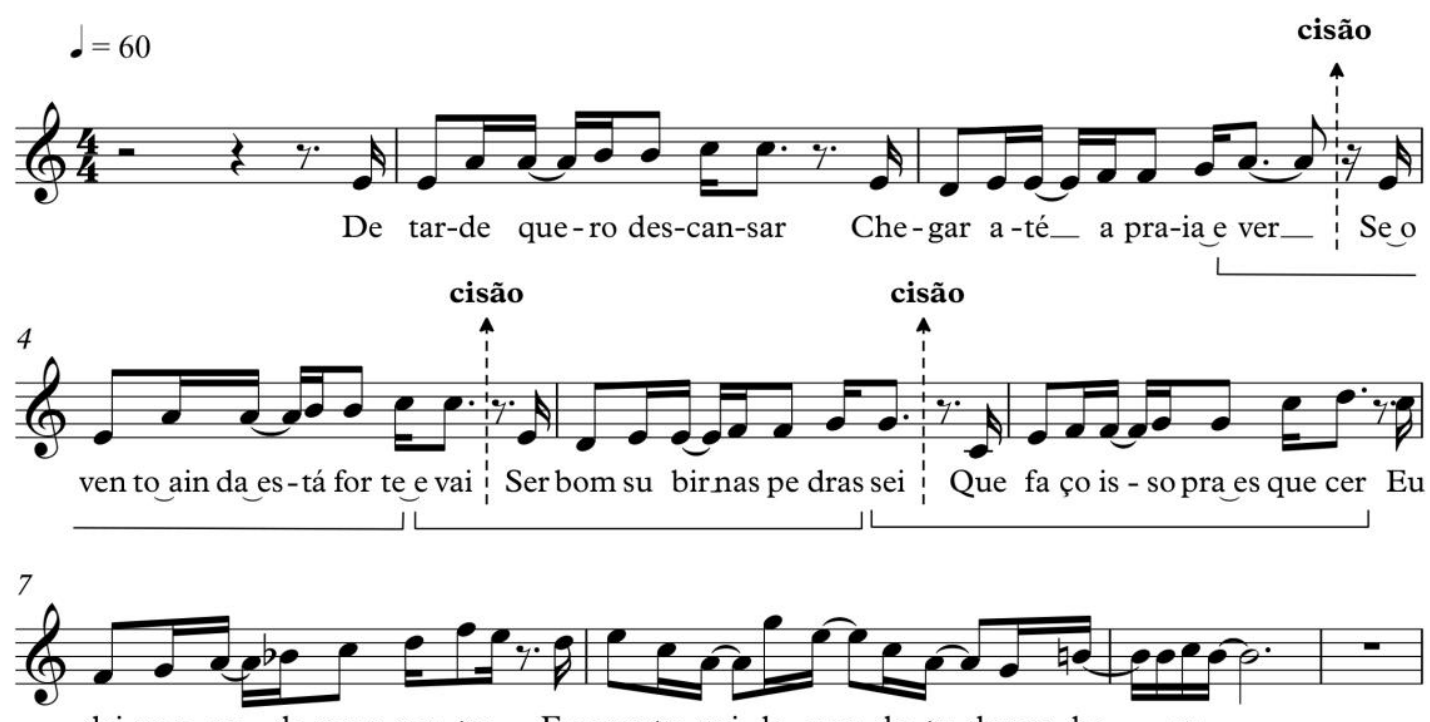

dei-xo a on - da me a-cer- tar _ E o ven-to vai_le- van-do tu-do_em- bo - ra 

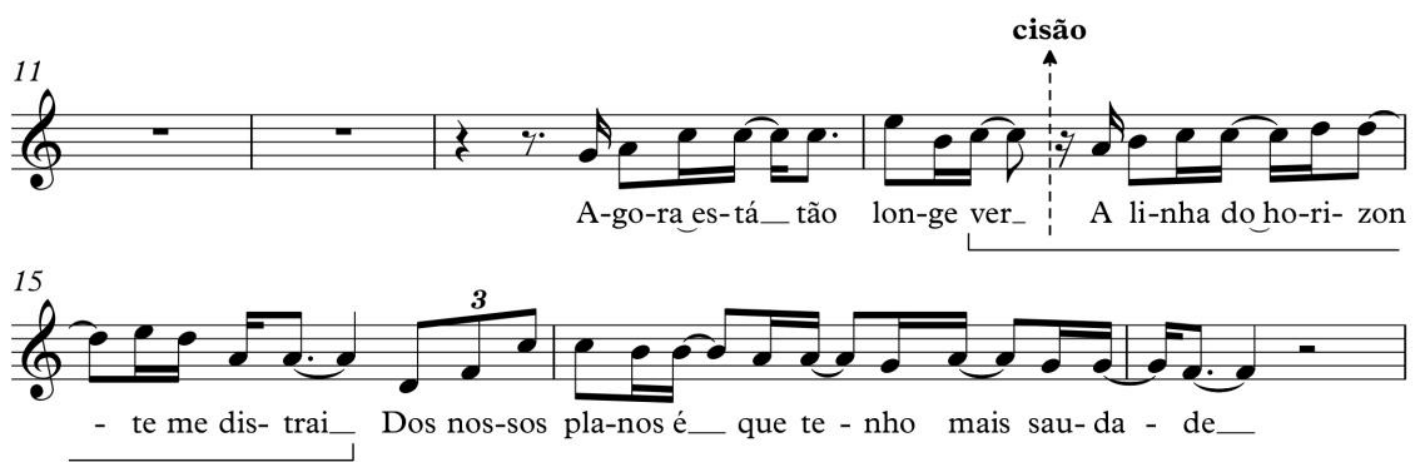

Figura 48. A unidade melódica e a unidade linguística em Vento no litoral (Dado Villa-Lobos/Renato Russo/Marcelo Bonfá)

Nessa canção, o procedimento da letra que recorta a melodia de modo a cindir suas unidades verbais logo em seu ponto inicial torna-se quase um padrão. Há, aqui, uma diminuição ainda mais acentuada do teor oral, na medida em que o corte não se aplica a uma frase linguística que já estava prestes a ser finalizada (e da qual já havíamos escutado uma boa parte). Ao contrário, constitui uma espécie de interrupção precoce da unidade verbal. Constatamos, então, como pode ser conflitante a convivência das tendências ligadas à fala com os outros processos criativos que também compõem o trabalho do compositor, visto que, os cancionistas, nesse caso, encontraram um recorte incomum que os agradou esteticamente: ao mesmo tempo em que essas junções ou encadeamentos “desentoativizantes" de Vento no Litoral favorecem a ideia de um eu-lírico que, melancolicamente, passa de uma ação a outra, também diminuem de modo substancial o elo entoativo entre a obra e o público. O artista precisa, a todo momento, realizar esse cálculo, balanceando a tendência oral com as outras questões estéticas ligadas à música, aos jogos de palavras etc. Na figura abaixo especificamos essa incongruência na combinação entre a letra e a melodia:

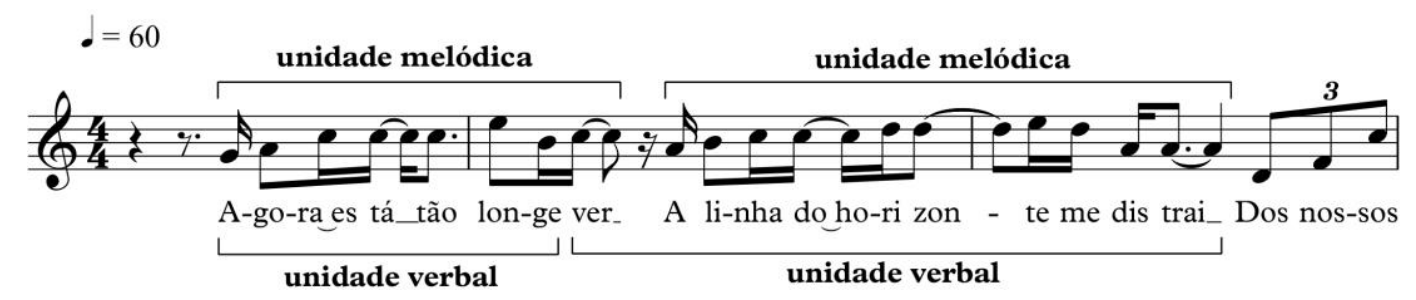

Figura 49. A unidade melódica e a unidade linguística em Vento no litoral (Dado Villa-Lobos/Renato Russo/Marcelo Bonfá) 
Como vemos acima, a frase linguística "ver a linha do horizonte me distrai" é interrompida logo em seu momento inicial, com a frase antecedente incorporando o seu primeiro vocábulo, "ver": “Agora está tão longe ver". Tendo em vista a excentricidade de sua construção, é possível que o ouvinte realize uma apreensão linguística equivocada do segmento. Entenderíamos algo como "agora está tão longe, vê", o que, no registro não padrão da língua, poderia soar como "veja como agora está tão longe". A cobertura melódica da letra não permite, desse modo, o imediato entendimento do verso pretendido pelo compositor "ver a linha do horizonte me distrai". Todavia, uma pequena modificação melódica seria capaz de alterar esse desvio entoativo, produzindo uma oralização mais linear. Abaixo, reescrevemos a passagem recolocando o vocábulo "ver" no início da unidade seguinte.

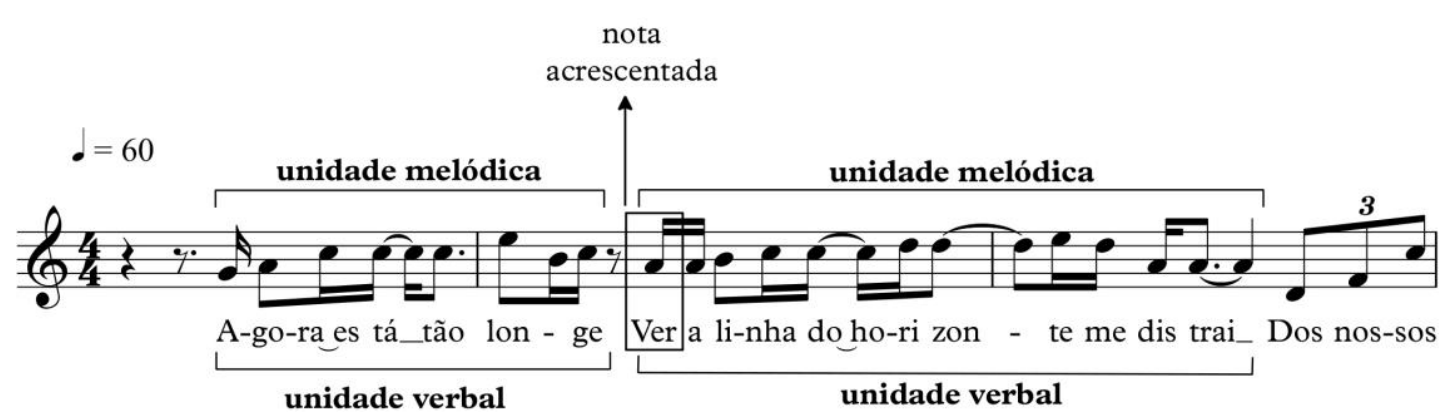

Figura 50. Reescrita de Vento no litoral (Dado Villa-Lobos/Renato Russo/Marcelo Bonfá)

Utilizando novamente o recurso figurativo da elasticidade melódica, acrescentamos uma semicolcheia no início da segunda unidade para ali posicionarmos o verbo "ver". Mantivemos o desenho musical da unidade precedente gerando um pequeno melisma na sílaba tônica da palavra "longe", o que acreditamos não perturbar a entoação da frase. Realizamos, com isso, é claro, uma mudança no padrão melódico de toda canção, uma vez que todas as suas frases se iniciavam com uma semicolcheia colocada sobre a parte mais fraca do quarto tempo do compasso (padrão que se mantém até o compasso 13). Trata-se, portanto, de uma escolha estética do compositor, às vezes mais afeito às questões orais, às vezes, às questões musicais ou poéticas que transformam suas entoações. Presumimos, porém, que refletir sobre esse processo nos faz desvendar os caminhos possíveis para a gênese de uma canção. Em Vento no Litoral, por exemplo, é provável que o cancionista tenha seguido intuitivamente o desenho melódico tematizante, privilegiando-o em detrimento do encaixe entoativo com a letra. Sem perceber, já que a sua atenção se voltava para a repetição motívica, a emissão da letra distanciou-se da fala. 
Não há dúvida, entretanto, que a opção por ele escolhida satisfazia os seus anseios artísticos. A canção Devolva-me, ligada inicialmente ao repertório da Jovem Guarda e que obteve sucesso mais recente na interpretação da cantora Adriana Calcanhoto, apresenta uma construção similar.

Rasgue as minhas cartas

E não me procure mais

Assim será melhor, meu bem!
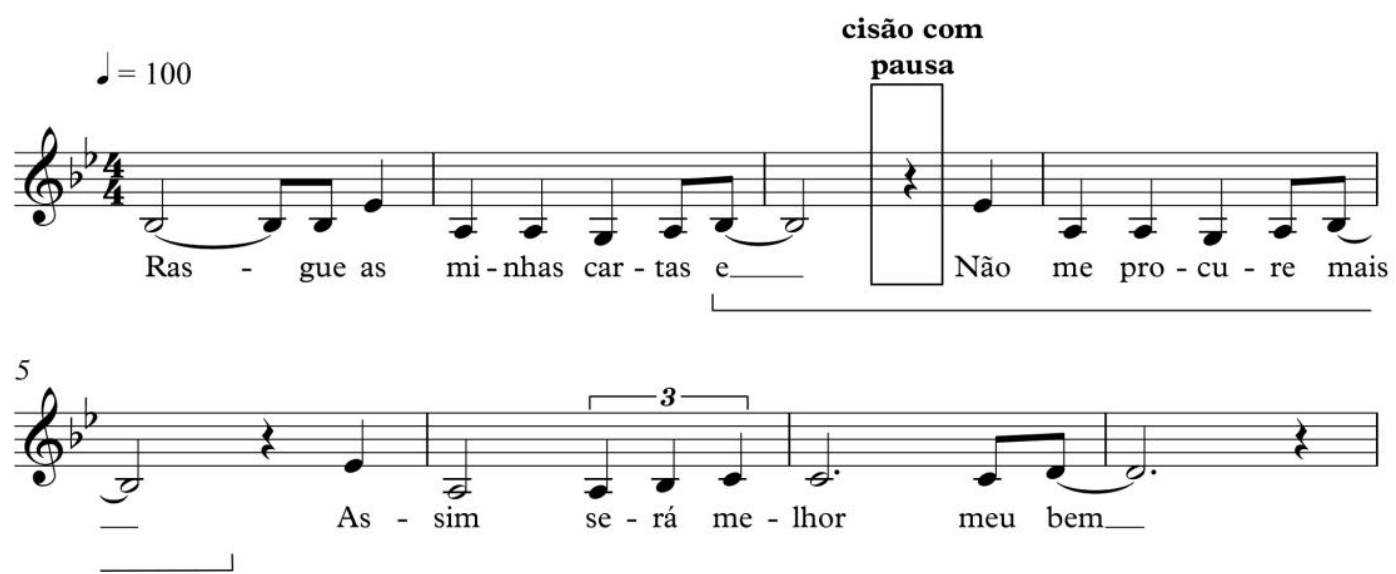

Figura 51. A unidade melódica e a unidade linguística em Devolva-me (Renato Barros/Lilian Knapp)

Temos aqui um período composto formado por duas orações, "Rasgue as minhas cartas" e "e não me procure mais", que se organizam também em duas unidades melódicas distintas. Contudo, o início da segunda oração (a conjunção aditiva "e") posiciona-se no final da primeira unidade melódica, construção que dificilmente replicaríamos na língua oral. O mesmo ocorre com a canção Apenas Mais Uma de Amor, de Lulu Santos, na qual observamos a inclusão de um vocábulo a mais, além da conjunção aditiva, no término da unidade melódica precedente.

Como uma ideia que existe na cabeça

E não tem a menor obrigação de acontecer 


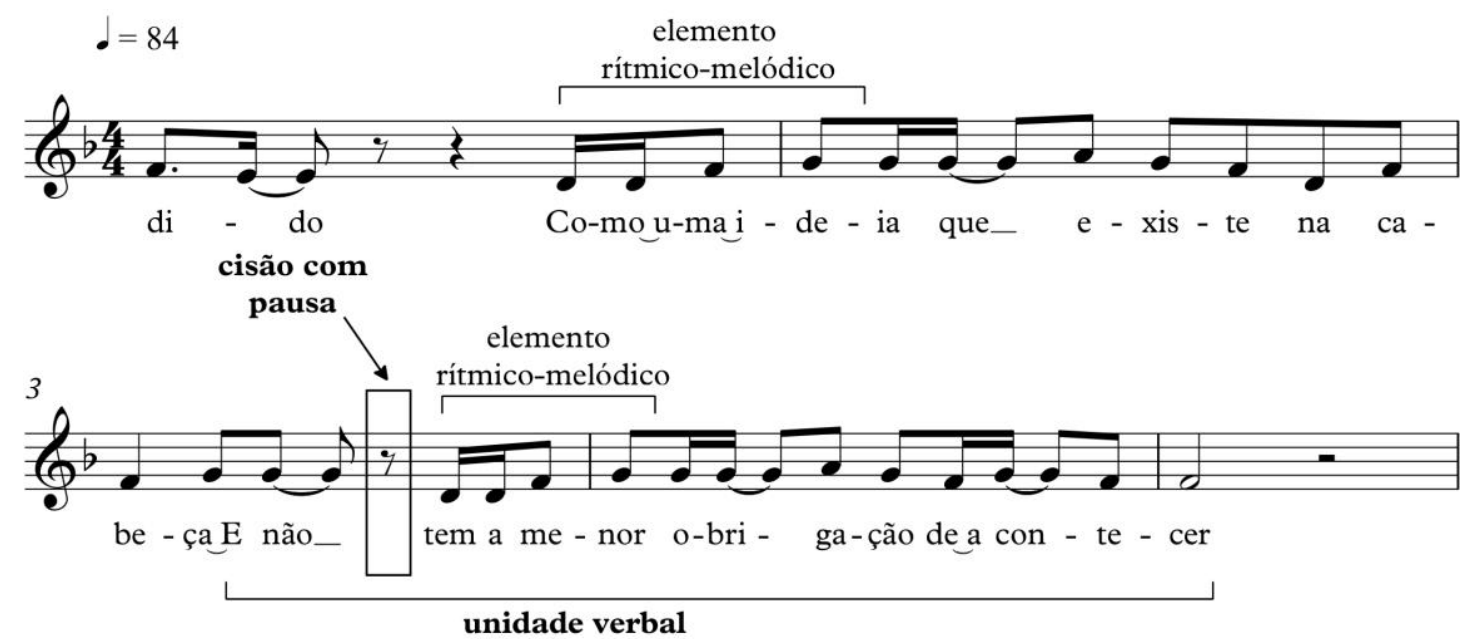

Figura 52. A unidade melódica e a unidade linguística em Apenas mais uma de amor (Lulu Santos)

Mais uma vez, amparado pelo processo da tematização, a repetição do padrão musical guia o cancionista e faz com que ele prefira a instabilidade entoativa para manter intacto o desenho melódico. Seria possível, é claro, alterar a configuração acima e reposicionar a expressão "E não" para o início da próxima unidade. Contudo, a força da repetição do elemento rítmico-melódico assinalado na figura acima ficaria seriamente comprometida (a sequência de duas semicolcheias e duas colcheias que iniciam as duas unidades melódicas presentes no fragmento). Há obras muito conhecidas de nosso cancioneiro que apresentam o mesmo fenômeno de cisão das frases verbais. Essas ocorrências, no entanto, podem chegar aos nossos ouvidos de maneira quase imperceptível.

\section{Sou caipira, Pirapora}

Nossa Senhora de Aparecida

Ilumina a mina escura e funda

O trem da minha vida
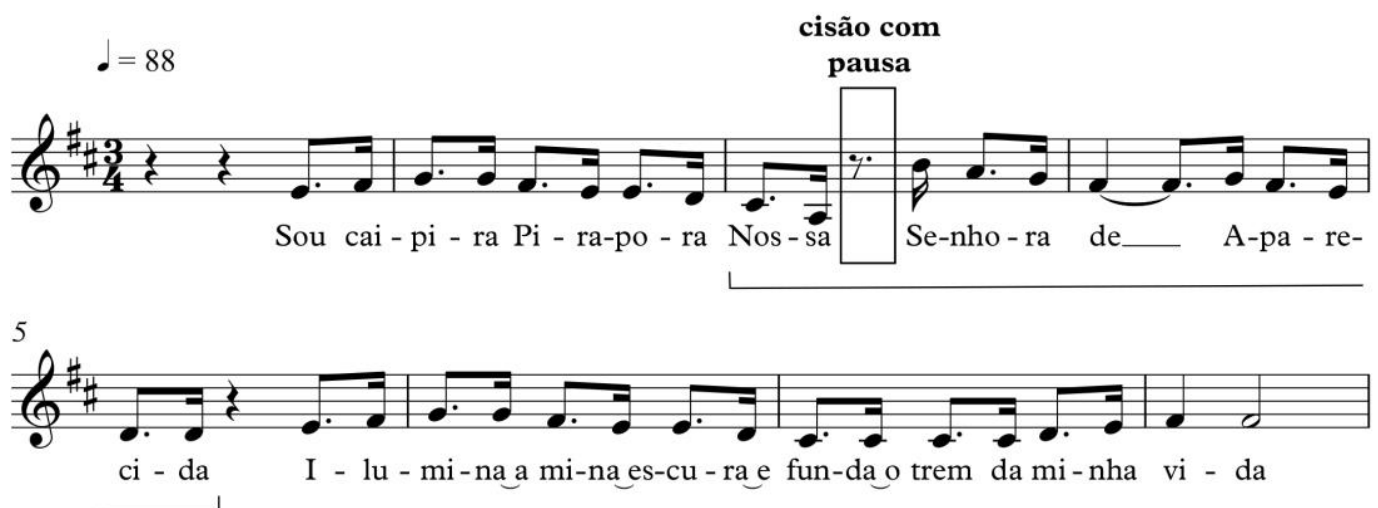

Figura 53. A unidade melódica e a unidade linguística em Romaria (Renato Teixeira) 
No conhecido refrão da canção Romaria, constatamos um corte que segmenta o nome "Nossa Senhora de Aparecida" ao posicionar o vocábulo "nossa" ao final do segmento melódico anterior. Dessa cisão verbal inesperada, muitos sentidos podem decorrer. "Nossa" pode tornar-se pronome possessivo de "Pirapora", cidade interiorana, por exemplo. Além disso, a forte presença do nome "Nossa Senhora" na cultura brasileira, por outro lado, tende a amenizar a sua quebra linguística. São aspectos de sentido que o artista incorporou em sua obra. Enfim, neste item, apresentamos numerosos exemplos para ilustrar esse complexo jogo de encontros e desencontros entre a frase verbal e a frase melódica, produzindo oralizações mais ou menos lineares. Ainda no nível da frase, passemos ao exame de uma interessante questão. 


\subsection{A formação de unidades entoativas a partir de unidades melódicas reduzidas}

Outro importante aspecto ligado ao encaixe da letra com a melodia durante o processo de formação das unidades entoativas (e que promove muitas vezes uma quebra da unidade verbal) é a configuração melódica com notas longas em início de frase. Acreditamos que o exame desse assunto pode nos ajudar a pensar sobre uma interessante diferenciação entre o motivo musical e a unidade melódica mais facilmente transformável em unidade entoativa. Vejamos. Via de regra, os cancionistas possuem certa dificuldade em letrar linhas melódicas que possuem notas longas, em especial as posicionadas em início de frase. São melodias, em geral, criadas por um compositor de canções cuja prática artística pende para o lado da musicalização. É quando o cancionista se encanta, por exemplo, com a sensação sonora resultante da combinação de uma nota mais duradoura da voz com um acorde específico. Trata-se, então, de uma espécie de fruição melódicoharmônica. O fato é que esse aumento da carga de significação musical, nesse caso, pode diminuir ou até mesmo eliminar o significado entoativo: notas alongadas, que se isolam das unidades melódicas vizinhas tornando-se, elas próprias, unidades autônomas formadas por uma única nota ou sílaba, são de difícil recorte linguístico e muitas vezes resultam em encaixes pouco entoativos.

Essa reflexão pode nos ajudar a diferenciar o motivo musical da unidade entoativa. Vejamos. Para o cancionista, essa nota isolada possui um sentido diverso daquele puramente musical, demandando, por isso, um artesanato criativo específico ligado à oralização. O músico, ao contrário, ao compor uma frase com uma nota longa inicial, poderia incorporar à sua execução diversas nuances e questões estritamente sonoras: essa nota longa, executada por um clarinete, por exemplo, poderia começar com uma intensidade pianíssimo e alcançar o fortíssimo, até o início do segmento melódico seguinte. Na figura abaixo, apresentamos uma melodia que compusemos para ilustrar essa disposição mais musical. 


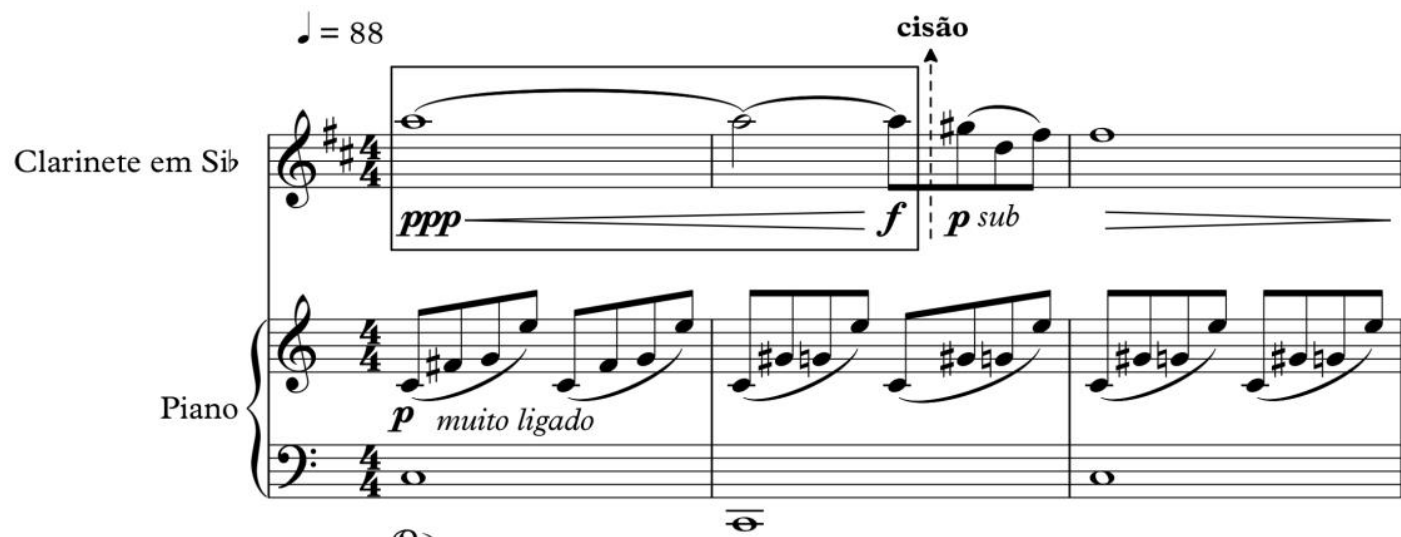

Тed.
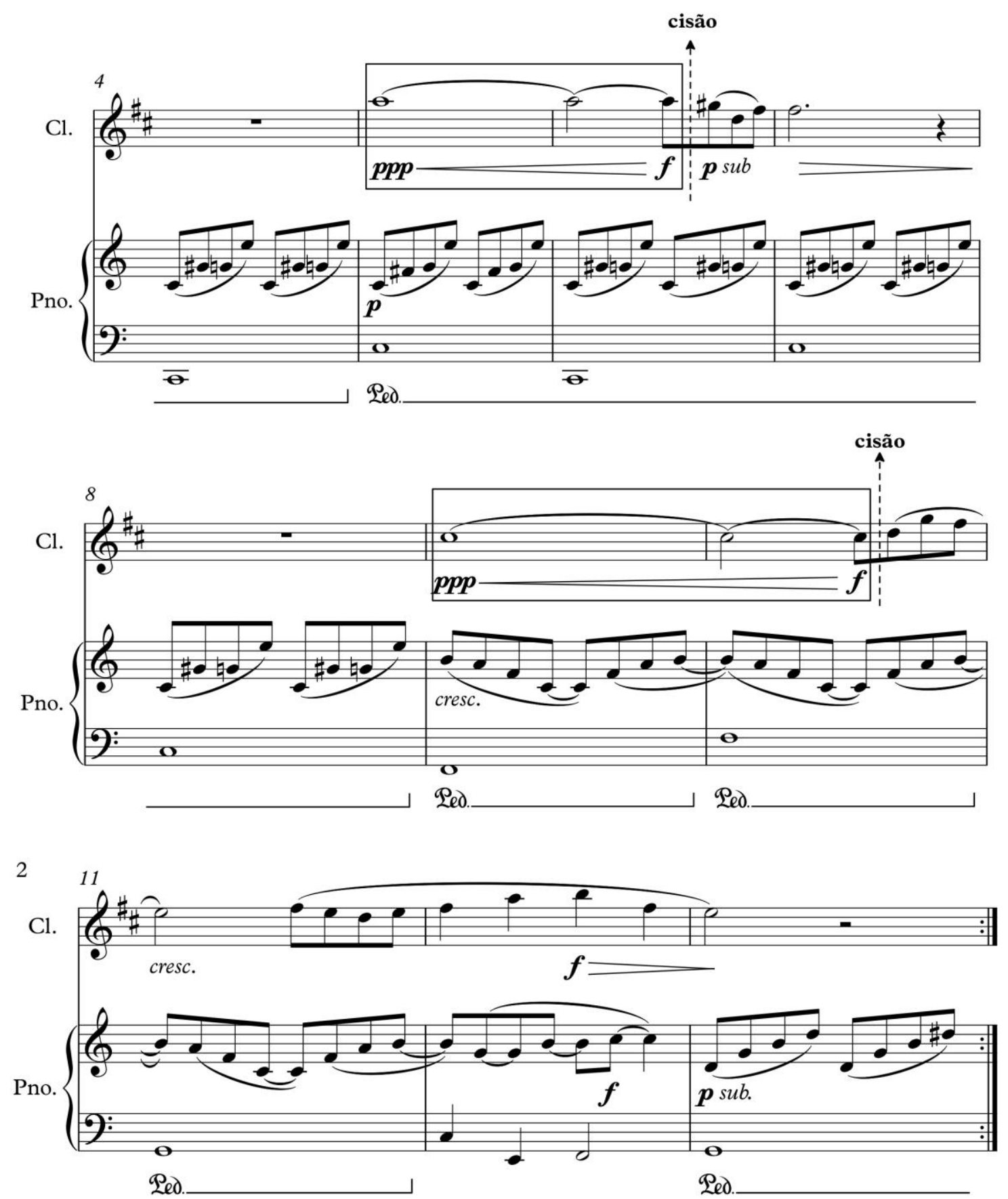

Figura 54. Exemplo de composição musical com nota longa no início das frases melódicas 
As notas longas que sublinhamos na figura acima poderiam apresentar não apenas uma variação sonora ligada à dinâmica (som fraco se transformando progressivamente em som forte), mas também ligada ao timbre ou à articulação (um som liso se transformando em um som estriado, por exemplo). Ambas, são, no entanto, possibilidades criativas especificamente musicais. Para o cancionista, ao contrário, esse crescendo da nota longa não possui maiores potenciais artísticos. Sua preocupação é outra. Mais do que tirar proveito sonoro da passagem, ele precisa extrair dela um modo de dizer. Em suma, ele precisa oralizá-la. Sua tarefa, no entanto, torna-se mais complexa, uma vez que essas notas alongadas tendem a se descolar do restante da frase, tornando sua compatibilização com o elemento verbal um pouco mais dificultosa. Vejamos alguns exemplos.

A felicidade é como a pluma

Que o vento vai levando pelo ar
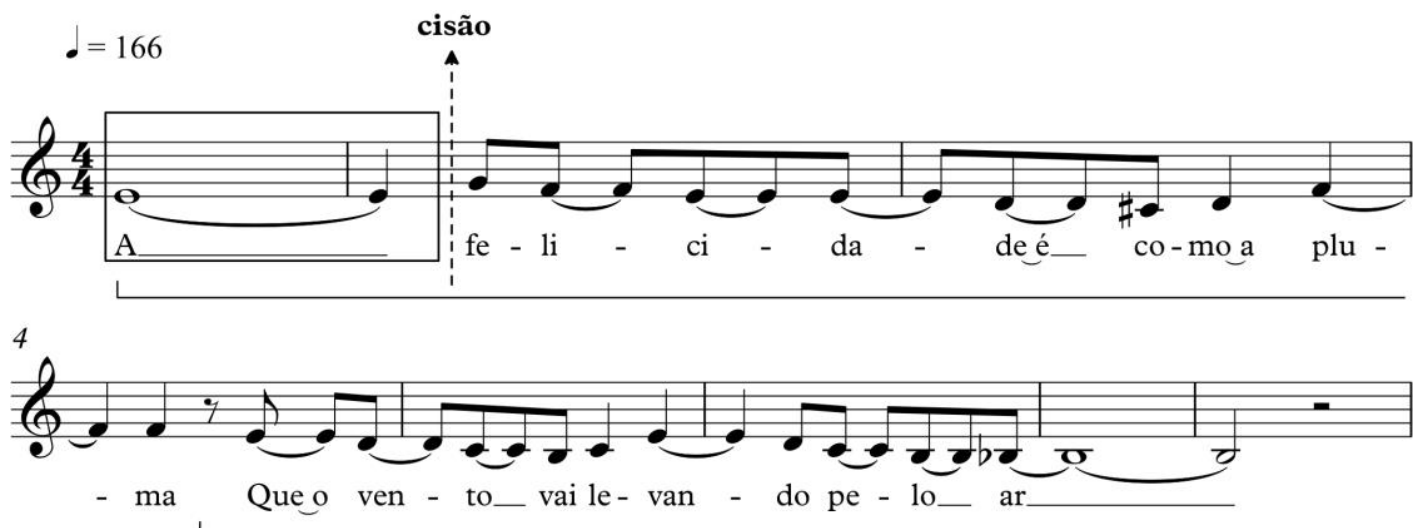

Figura 55. Nota longa em início de frase em A felicidade (Tom Jobim/Vinicius de Moraes)

Nessa conhecida canção de Tom Jobim e Vinicius de Moraes, por meio do alongamento significativo da nota inicial do fragmento, observamos um corte segmentando-a do restante do trecho. O ouvinte, num primeiro momento, pode até confundir-se e passar a escutar a interjeição de lamento "ah" ao invés do artigo definido "a" (o que, de certa forma, combina com o conteúdo disjuntivo de sua letra: "tristeza não tem fim"). Trata-se de um caso típico dessa dificuldade, por parte do cancionista, de extrair a entoação de segmentos melódicos muito reduzidos. Em Só Tinha de Ser com Você, notamos um fenômeno similar.

É, só eu sei

Quanto amor eu guardei

Sem saber que era só pra você 

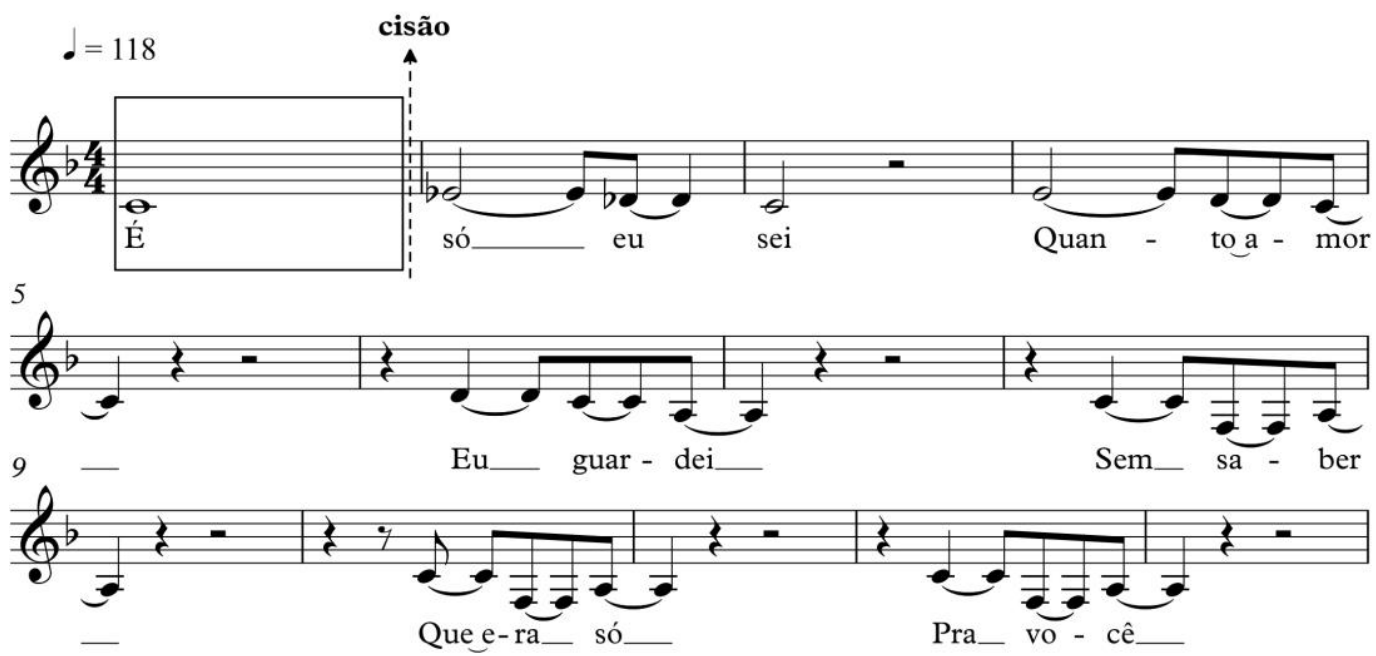

Figura 56. Nota longa em início de frase em Só tinha de ser com você (Tom Jobim/Aloysio de Oliveira)

Muitas vezes, como na canção acima, o compositor encontra pequenos vocábulos ou interjeições, em geral com menor carga semântica, capazes combinar com esse tipo de configuração melódica quase rarefeita. Esse assunto se relaciona fortemente com o que tratamos no capítulo anterior acerca dos monossílabos átonos e tônicos. Para esse tipo de constituição musical, o cancionista deve saber empregá-los de modo entoativamente satisfatório. Quando toda a melodia de uma canção gira em torno de notas muito alongadas, no entanto, esse trabalho cancional torna-se ainda mais complexo, apresentando resultados de compatibilização com níveis de apreensão oral muito diversos. É o caso da canção Insensatez, também de Tom Jobim e Vinicius de Moraes, na qual todas as estrofes se iniciam por uma nota longa.

A insensatez que você fez

Coração mais sem cuidado

Fez chorar de dor o seu amor

Um amor tão delicado

Ah, porque você foi fraco assim

Assim tão desalmado

Ah, meu coração que nunca amou

Não merece ser amado

Vai meu coração ouve a razão

Usa só sinceridade

Quem semeia vento, diz a razão

Colhe sempre tempestade

Vai, meu coração pede perdão 
Perdão apaixonado

Vai porque quem não pede perdão

Não é nunca perdoado
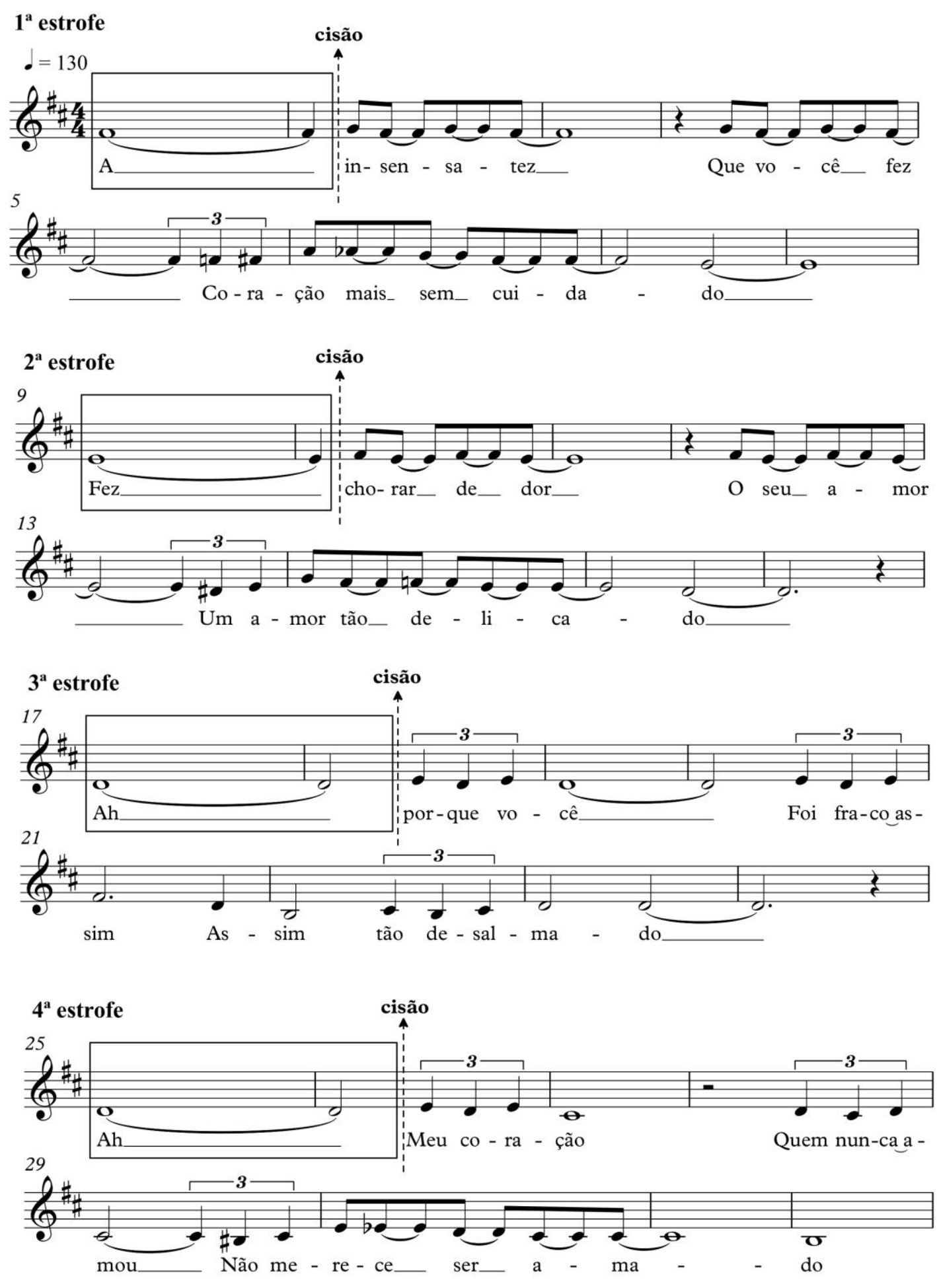

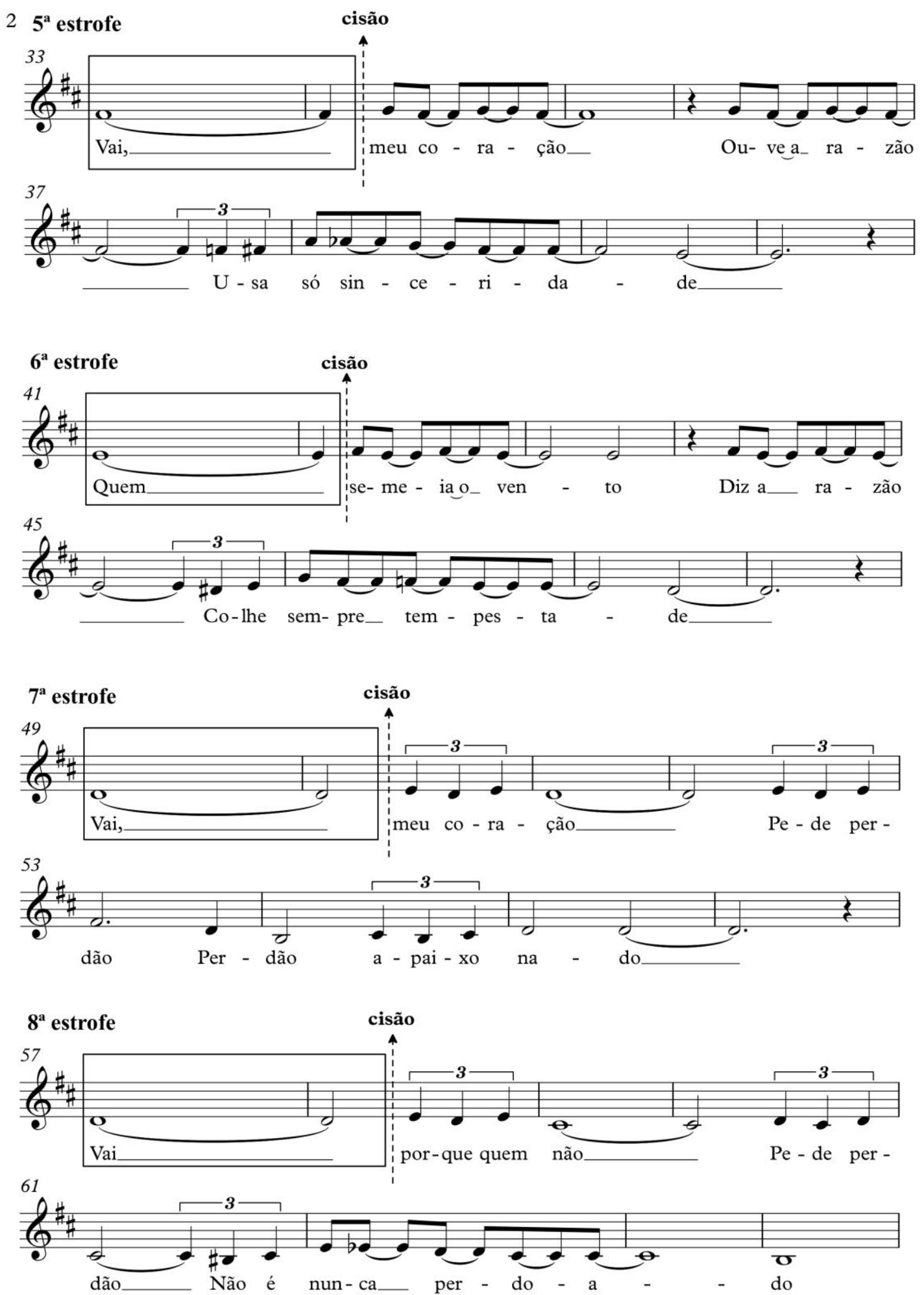

Figura 57. Nota longa em início de frase em Insensatez (Tom Jobim/Vinicius de Moraes)

A duração da nota que inicia cada uma das oito estrofes acima é significativamente extensa. A primeira, segunda, quinta e sexta estrofes iniciam com uma semibreve ligada 
a uma semínima. A terceira, quarta, sétima e oitava, por sua vez, começam com uma semibreve ligada à uma mínima, aumentando ainda mais a sua duração e o seu isolamento entoativo. É muito interessante examinar cada uma das soluções linguísticas encontradas pelos compositores para esses trechos específicos. Notamos, por exemplo, que em duas estrofes (mais precisamente, na terceira e na quarta) o letrista optou pela interjeição "ah", combinação decerto mais usual do que aquela que adotou para a primeira, quando posicionou a nota longa sobre um monossílabo átono (o artigo definido "a" de "a insensatez"). O recorte com o vocábulo "fez", por sua vez, ainda que oralmente problemático, possui a vantagem de repetir um verbo já utilizado no início da obra. Enfim, esses diferentes encaixes apresentam, entre si, interessantes nuances figurativas. Além disso, essa difícil configuração melódica inicial faz com que os diferentes intérpretes dessa canção acabem propondo alterações no valor da primeira nota de cada estrofe. Comparemos as interpretações dos cantores João Gilberto, Fernanda Takai, Clara Nunes e Roberto Carlos.

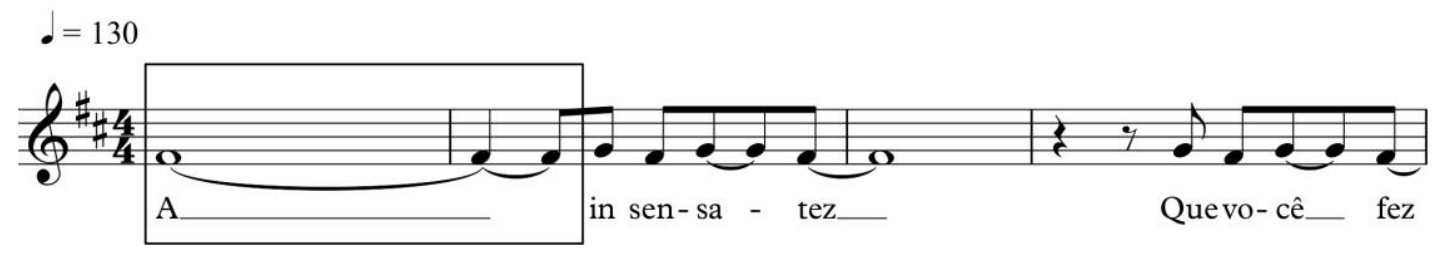

Figura 58. Versão de João Gilberto da canção Insensatez (Tom Jobim/Vinicius de Moraes)

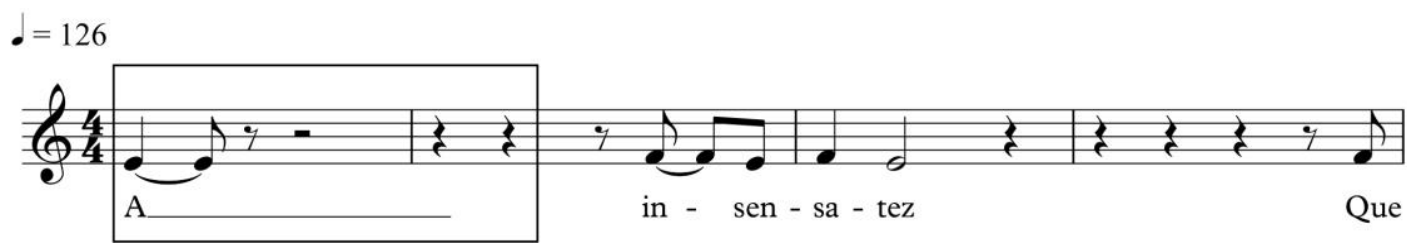

Figura 59. Versão de Fernanda Takai da canção Insensatez (Tom Jobim/Vinicius de Moraes)

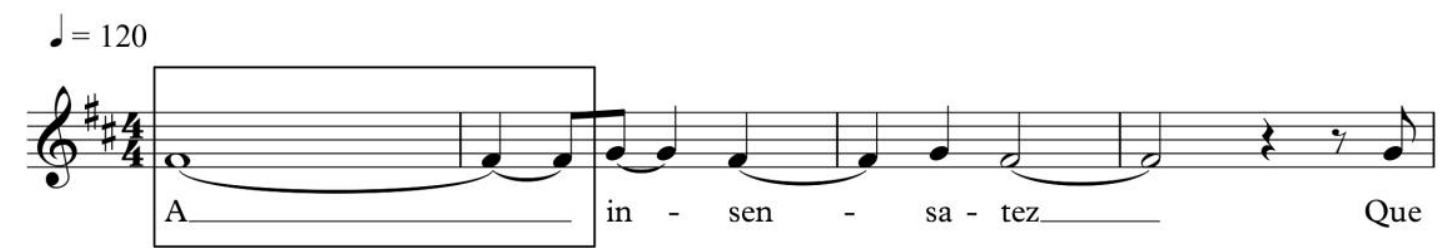

Figura 60. Versão de Clara Nunes da canção Insensatez (Tom Jobim/Vinicius de Moraes) 
Ah, que insensatez hiciste tú

Corazón más sin cuidado

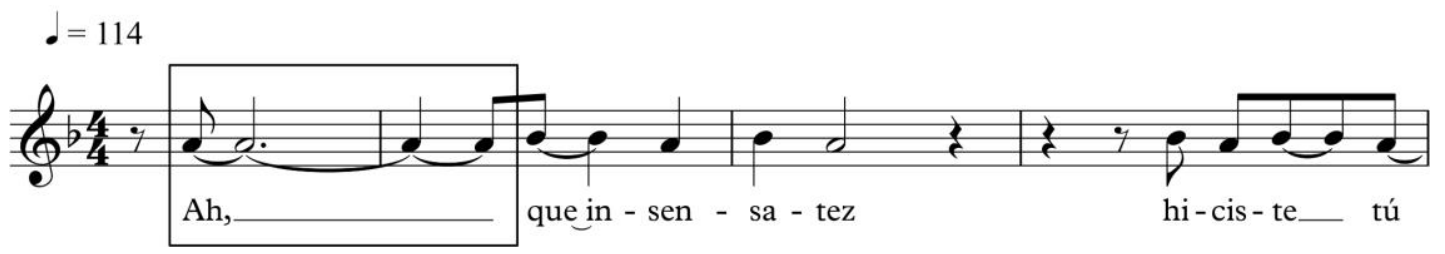

Figura 61. Versão de Roberto Carlos da canção Insensatez (Tom Jobim/Vinicius de Moraes)

É interessante constatar como João Gilberto e Clara Nunes, à exceção dos seus diferentes desenhos rítmicos posteriores (a versão da cantora é mais lenta e alongada do que a do cantor baiano, mais comprimida), realizam exatamente a mesma duração na nota inicial que recobre o artigo definido "a”. A versão de Fernanda Takai, ao contrário, propõe uma diminuição radical dessa mesma nota produzindo um corte, a nosso ver, ainda mais perturbador: temos, nesse caso, um espaço de silêncio considerável desmembrando o sintagma nominal, cindindo-o entre o artigo e o substantivo. Curiosamente, a versão de Roberto Carlos, traduzida para o espanhol, tentando solucionar o problema entoativo ligado à coincidência da nota longa com o artigo definido, insere em seu lugar a interjeição "ah", alterando de maneira sutil o sentido do fragmento, mas, ao mesmo tempo, aumentando a sua carga oral. Os intérpretes citados realizam, portanto, diferentes tipos de oralização, mais ou menos lineares. De modo menos frequente, notas longas podem aparecer entre duas unidades melódicas (e não apenas no início de uma delas). Isso nos faz supor que o fenômeno estudado neste item da tese pode estar mais ligado ao alongamento e isolamento dessas notas do que propriamente ao fato de elas iniciarem os segmentos. A canção Deixar Você, de Gilberto Gil, constitui um exemplo pertinente.

Deixar você ir

Não vai ser bom

Não vai ser

Bom pra você

Nem melhor pra mim

Pensar que é só

Deixar de ver

E acabou

Vai acabar muito pior 
Pra que mentir

E fingir que o horizonte

Termina ali defronte

E a ponte acaba aqui?

Vamos seguir

Reinventar o espaço

Juntos manter o passo

Não ter cansaço

Não crer no fim

O fim do amor

Oh, não

Alguma dor

Talvez sim

Que a luz nasce na escuridão

$\downarrow=112$

$1^{\text {a }}$ estrofe

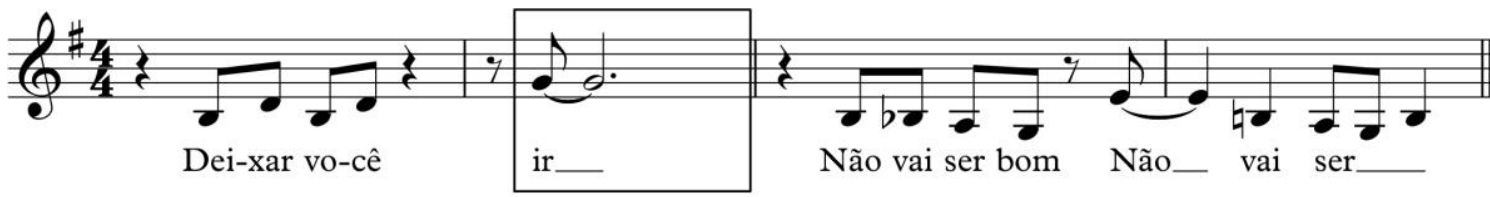

$2^{\mathrm{a}}$ estrofe

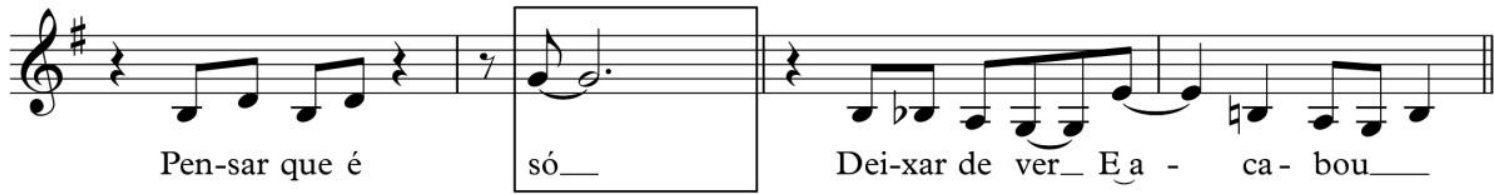

$3^{\mathrm{a}}$ estrofe

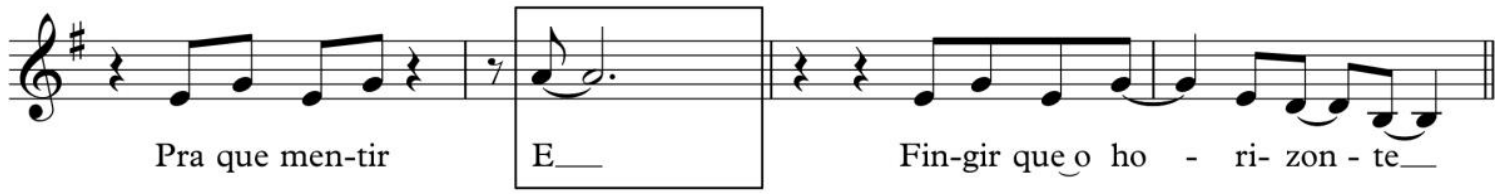

$4^{a}$ estrofe

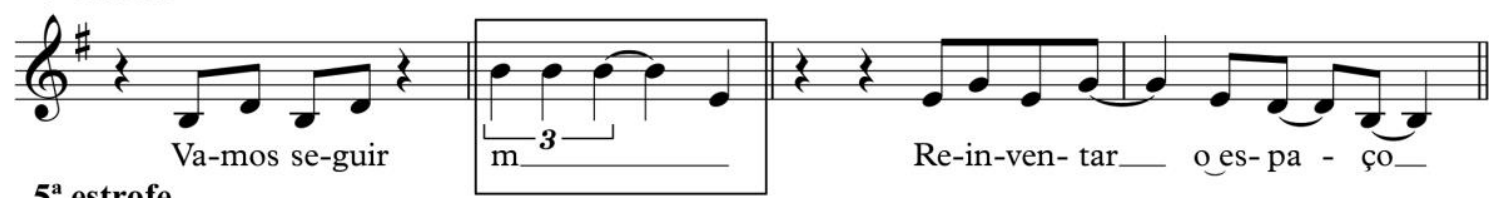

$$
5^{5^{\mathbf{a}}} \text { estrofe }
$$

Re-in-ven- tar__ o es- pa - ço_

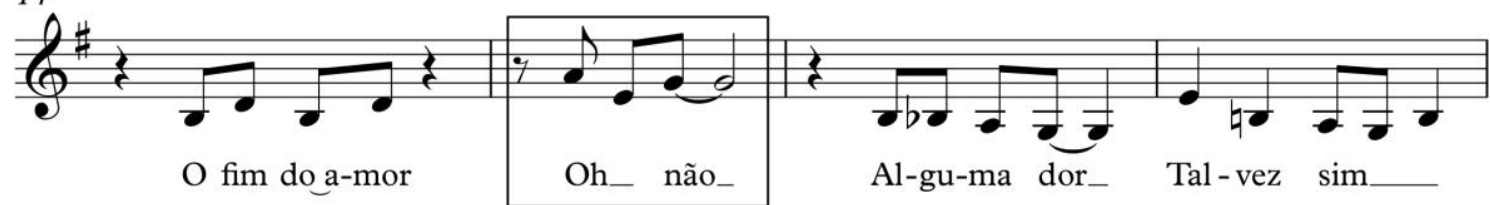

Figura 62. Nota longa no meio da frase em Deixar você (Gilberto Gil) 
Uma característica melódica peculiar dessa canção é justamente a nota aguda e longa que se destaca dos segmentos vizinhos e cuja aparição assinalamos no início de suas três primeiras estrofes. Sobretudo na primeira e na segunda estrofe, é evidente o papel exercido pelo parâmetro altura (e não apenas a duração) para a constituição desse fenômeno. Por estar posicionada no meio de duas unidades melódicas, é importante avaliarmos o grau de relação entre essa nota e o segmento precedente e posterior, em cada uma das estrofes. Na primeira, a nota coincide com o vocábulo "ir" que finaliza a unidade verbal anterior. Na terceira, recai sobre a palavra "e", conjunção aditiva ligada à unidade verbal seguinte. Na segunda estrofe, por sua vez, o elo parece ser estabelecido com ambas as unidades que a circundam. Em todas elas, no entanto, a figurativização é inesperada: há uma separação muito forte entre as suas unidades melódicas, o que, sem dúvida, prejudica o entendimento mais fluente da frase linguística que aparece distribuída entre elas.

Inegavelmente, como em toda e qualquer canção, há questões expressivas que atuam, lado a lado, com o processo figurativo. Nesse caso, por exemplo, poderíamos verificar uma certa distorção emotiva da fala. Como se a música dissesse, com a sua nota longa e aguda, que o abandono de seu bem-amado, por parte do eu-lírico da letra, será muito sofrido ("não vai ser bom"). Ao final, o ouvinte sente a mensagem, mais do que a compreende intelectualmente. A dificuldade encontrada pelo compositor durante o processo de recorte linguístico é, contudo, notória. Tanto que, na quarta e na quinta estrofes, o cancionista aumenta a quantidade de notas referentes ao mesmo trecho melódico para poder encaixar uma unidade linguística menos inesperada (a interjeição "oh, não") ou mesmo um vocalise articulado pelo cantor com a boca fechada. Enfim, detectamos fortes indícios de que o criador de canções não consegue lidar muito bem com as unidades melódicas reduzidas.

Essa canção, por outro lado, nos sugere uma outra interessante reflexão que, apenas mencionada aqui, deve ser alvo de nossas pesquisas futuras. Trata-se dos diferentes graus de destaque de cada frase que compõe uma estrofe. Algumas indagações decorrem daí: dentro de um refrão ou de uma parte de determinada canção, há unidades melódicas mais vistosas ou atrativas do que outras? Isto é, seguindo os termos com que estudamos o nível da sílaba e da palavra, poderíamos dizer que há frases tônicas e frases átonas? Supomos que sim. Em Deixar Você, a unidade melódica assinalada na ilustração, mais aguda, destaca-se das demais. Caberá ao compositor compatibilizá-la com uma 
unidade verbal que igualmente se destaca dentro de seu grupo de unidades, como uma oração principal dentro de um período composto, por exemplo. Ocorre que, nessa canção, a unidade de maior destaque é formada por uma única nota, o que suscita as questões contrárias à entoação elencadas acima. Que ela representa um elemento extremamente atrativo nessa obra, porém, não há dúvida. 


\subsection{A fluência da frase e a simultaneidade dos três níveis}

O ouvinte, ao tomar contato com as diferentes combinações de unidades verbais e unidades melódicas (comuns ou incomuns), busca intuitivamente uma sensação de fluência do enunciado, ligada à oralidade. Há, para além das coincidências entre os segmentos linguísticos e musicais, uma questão sutil ligada à sua divisão rítmica, isto é, ao encaixe fino das durações das sílabas e palavras agora apreciadas de um ponto de vista mais amplo, o da frase. Em Elementos da linguagem musical, Bruno Kiefer, discorrendo sobre a relação entre a música e a língua, tece o seguinte comentário.

Preocupar-se, apenas, em ajustar as sílabas tônicas aos chamados tempos fortes do compasso ou jogar, eventualmente, com síncopes, gera o perigo de tornar o canto demasiadamente "quadrado", de dotá-lo de uma racionalidade que não corresponde ao ritmo da língua falada. O ritmo de uma melodia ajustada ao ritmo da língua portuguesa será mais plástico. (KIEFER, 1969: 42)

A matéria tratada acima por Kiefer difere em muito do nosso assunto, a composição de canções populares. No entanto, ao comentar o trabalho composicional de criadores ligados ao campo da música erudita, o autor nos oferece valiosas reflexões. Cita uma hipotética obra na qual, ainda que traga todas as sílabas perfeitamente acentuadas, não satisfaz o ouvinte que deseja reconhecer ali um modo de dizer mais próximo da língua oral. Parece lhe faltar uma naturalidade na emissão, o que acreditamos estar identificada com essa fluência oral da frase (recurso típico do cancionista): "A supremacia dos cantores populares no que se refere à dicção e à expressividade do ritmo provém do fato de sentirem melhor a nossa língua” (KIEFER, 1969: 42). É possível que essa capacidade de "sentir melhor a língua" esteja, talvez, ligada à uma aptidão em cuidar dos três níveis figurativos aqui propostos: a sílaba, a palavra e a frase.

Antes de prosseguirmos com a análise de obras que ilustram esse aspecto apontado por Kiefer, devemos fazer uma breve ressalva em relação à maneira como o autor aborda o assunto. De fato, os compositores de canção interessam-se fortemente pela relação entre a canção e a fala, aspecto menos cultivado pelos músicos. A nosso ver, entretanto, o autor discute essa questão de modo menos preciso, como se ressaltasse um ponto a ser ainda alcançado pelos compositores eruditos. Deixa de refletir, de maneira mais descritiva, sobre os critérios que compõe a sua linguagem artística específica, passando a ver um problema onde, na verdade, há somente uma pesquisa artística própria. 
O problema da relação entre a música e a língua portuguesa ainda existe e é grave. Fernando Lopes Graça é categórico: “o que de uma maneira geral se observa é o seguinte: ou uma total inobservância dos princípios mais elementares da prosódia ou, então, uma prosódia rígida e pesada. (KIEFER, 1969: 47)

Como já pontuamos anteriormente, nesta tese, não pretendemos adotar uma postura analítica prescritiva. Nosso intuito é, de maneira objetiva, estudar as compatibilizações entre letra e melodia para melhor conhecer as suas nuances e o amplo campo gradativo que abarca tanto os modos de dizer mais recorrentes quanto aqueles que se distanciam radicalmente da fala. Enfim, desejamos nos afastar de uma conduta impositiva, característica um pouco presente nesse último fragmento de Elementos da linguagem musical. Realizada essa observação, devemos aproveitar o comentário de Lopes Graça, citado por Kiefer, quando discorre sobre a questão da "prosódia rígida e pesada". A nosso ver, ela parece estar ligada à questão da fluência mais ampla da frase e não aos desvios mais pontuais do nível da sílaba, por exemplo. Supomos, portanto, que o fluxo mais natural da emissão da frase esteja ligado à combinação das acentuações silábicas com as acentuações lexicais e à fusão da unidade melódica com a unidade verbal, proporcionando ao ouvinte um sentido linguístico satisfatório. A compatibilização entre letra e melodia que leva em conta esses princípios aumenta a sua carga oral. Em canções aceleradas, com notas de curta duração, esse fenômeno, sem dúvida, auxilia o cancionista a preservar, por exemplo, a inteligibilidade do texto.

A chuva tá caindo

E quando a chuva começa

Eu acabo de perder a cabeça

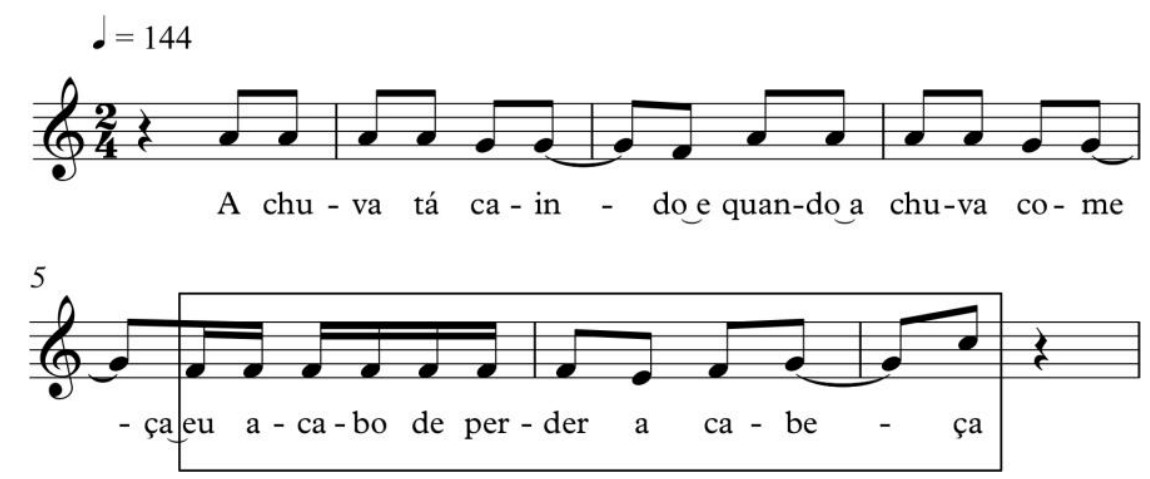

Figura 63. A fluência da frase em Chuva suor e cerveja (Caetano Veloso) 
Em Chuva, Suor e Cerveja, com exceção do deslocamento silábico observado sobre a palavra "chuva" (da qual a sílaba átona coincide com o tempo forte do segundo compasso), notamos a preservação de todos os seus acentos silábicos e lexicais. Além disso, cada uma das orações do período corresponde a uma unidade melódica, não havendo cisões frasais. Considerando o andamento acelerado da canção (144 batimentos por minuto) e o desenho rítmico formado por colcheias e semicolcheias, constatamos a considerável velocidade do canto e a significativa importância do cuidado com esses três níveis figurativos para que as unidades entoativas sejam efetivamente compreendidas, apesar da ligeireza de sua emissão. Na frase assinalada acima, por exemplo, vemos que que as palavras "acabo", "perder" e "cabeça", centrais para o sentido do trecho, estão entoativamente bem destacadas, o que decerto colabora para a sua fluidez. O exemplo abaixo, ao contrário, não parece apresentar a mesma fluência oral, constituindo uma oralização menos linear.

As grades do condomínio

São pra trazer proteção

Mas também trazem a dúvida

Se é você que tá nessa prisão

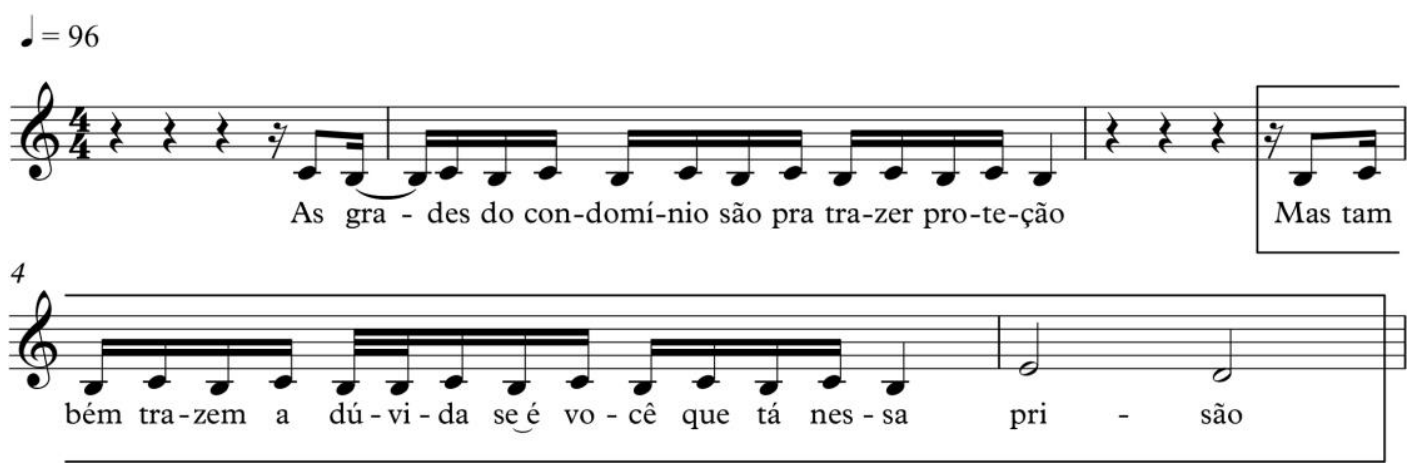

Figura 64. A fluência da frase em Minha alma (a paz que eu não quero) (Marcelo Yuka)

Analisando somente o segmento sublinhado na figura acima, constatamos algumas características combinatórias que impedem a constituição de uma emissão mais fluida e natural da frase linguística. Há deslocamentos silábicos ("trazem”, "nessa" e "prisão"), atenuações e ênfases lexicais incomuns (a não acentuação da palavra "trazem” e a acentuação indevida do vocábulo "nessa") e recortes frasais (a cisão entre o demonstrativo "nessa" e o substantivo "prisão") que não favorecem modos de dizer usuais. Além disso, notamos um desenho rítmico que, cantado com andamento acelerado, torna a passagem um pouco mais truncada do ponto de vista entoativo. São as fusas que 
recobrem a palavra "dúvida", no segundo tempo do quarto compasso. Decerto, a presença dessas duas notas mais curtas pode ter auxiliado o cancionista a posicionar essa palavra proparoxítona com sua prosódia preservada. Nesse sentido, pensando no recurso da elasticidade melódica, poderíamos até considerar essa alteração no padrão rítmico anterior como uma preocupação entoativa do cancionista em adequar bem o texto linguístico à melodia ${ }^{122}$. Como sabemos, ao inserir mais notas, prolongar e encurtar os motivos, ele faz caber na mesma melodia um texto diferente, almejando um modo de dizer mais natural. Em Minha Alma, no entanto, tendo em vista a alta velocidade da passagem, essa alteração pode dificultar ainda mais a fluência oral. Enfim, todos esses aspectos contribuem, a nosso ver, para a menor fluidez da frase, podendo até mesmo tornar dificultosa a apreensão linguística do trecho (ao mesmo tempo em que produzem uma expressividade original).

De todo modo, devemos considerar a elasticidade melódica como um importante recurso para tornar a frase cancional mais fluída. Ou seja, ao modificar o modelo musical preestabelecido, perturbando a configuração tematizante, o cancionista por vezes consegue acomodar suas unidades verbais de modo mais linear. São "deformações" do padrão melódico inicial que permitem a acomodação mais consensual do texto linguístico. Grande parte dos cancionistas não se preocupa de fato com a permanência integral da melodia. Cremos ainda que, muitas vezes, ele nem chega a perceber a diferença entre o padrão inicial e o padrão deformado. Está, desse modo, mais atento às questões ligadas à fala.

\footnotetext{
122 Podemos pensar a elasticidade melódica de um modo mais amplo no qual qualquer alteração do padrão inicial pode ser abarcada pelo termo. Assim, pode haver uma mudança no tamanho da frase (com acréscimo de notas em seu início, por exemplo), mas também mudanças métricas ou acentuais.
} 


\subsection{O abrandamento dos desvios no nível da frase}

Assim como estudamos nos capítulos anteriores dedicados à sílaba e à palavra, há casos de recorte no nível da frase em que as perturbações entoativas podem ser amenizadas. Em verdade, podemos considerar que esses exemplos contêm desvios que, dentro de um campo de gradação figurativa, não se distanciaram tão fortemente do polo oral. Veremos abaixo alguns casos em que a unidade verbal cindida já possuía certa significação conclusiva e, por isso, parecia funcionar como segmento independente. De início, examinemos a canção O Tempo Não Para, de Arnaldo Brandão e Cazuza.

Dias sim, dias não

Eu vou sobrevivendo sem um arranhão

Da caridade de quem me detesta
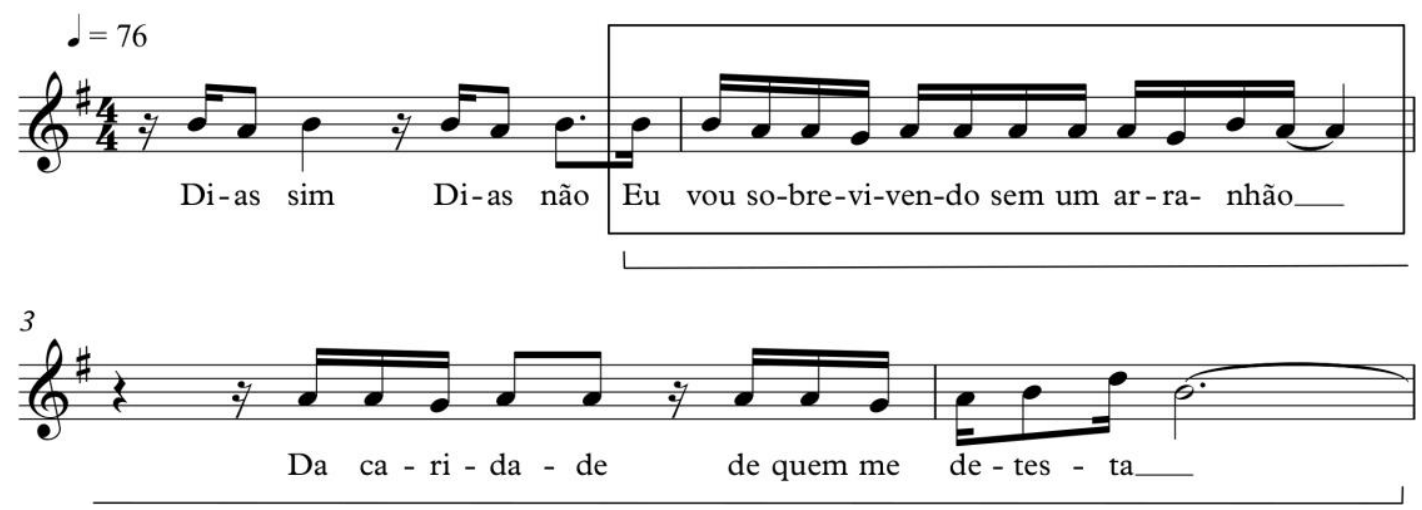

Figura 65. O abrandamento do desvio no nível da frase em O Tempo Não Para (Arnaldo Brandão/Cazuza)

$\mathrm{Na}$ passagem acima, há diversos aspectos composicionais que nos fazem apreender um sentido terminativo quando escutamos apenas o primeiro pentagrama da figura: "Dias sim, dias não, eu vou sobrevivendo sem um arranhão". Ainda que não tenhamos uma resolução melódico-harmônica, há um relativo teor terminativo ao final da frase quando a última sílaba de “arranhão" descende de Si para Lá natural. É como se, na melodia, os dois motivos iniciais ( $\mathrm{Si}$ - Lá - Si) propusessem uma tensão sonora que se distende com o segmento que ocupa o compasso seguinte. Linguisticamente, há também um significado em suspensão que em seguida se resolve: a expressão "dias sim, dias não" exige, com vigor, a sua complementação "eu vou sobrevivendo sem um arranhão". Sonoramente, esse sentido conclusivo é ainda reforçado pelas rimas entre os vocábulos "não" e "arranhão". Assim, tendo em vista essa autonomia semântica, cremos que a cisão que separa esse segmento do seguinte (“da caridade de quem me detesta”) é 
significativamente abrandada. De modo equivalente, sentimos o mesmo fenômeno de amenização da quebra verbal nas três estrofes da canção Tempos Modernos, de Lulu Santos.

Eu vejo a vida melhor no futuro

Eu vejo isso por cima de um muro

De hipocrisia que insiste em nos rodear

Eu vejo a vida mais clara e farta

Repleta de toda satisfação

Que se tem direito do firmamento ao chão

Eu quero crer no amor numa boa

Que isso valha pra qualquer pessoa

Que realizar a força que tem uma paixão

$$
\downarrow=118
$$

$1^{\mathrm{a}}$ estrofe

unidade melódica
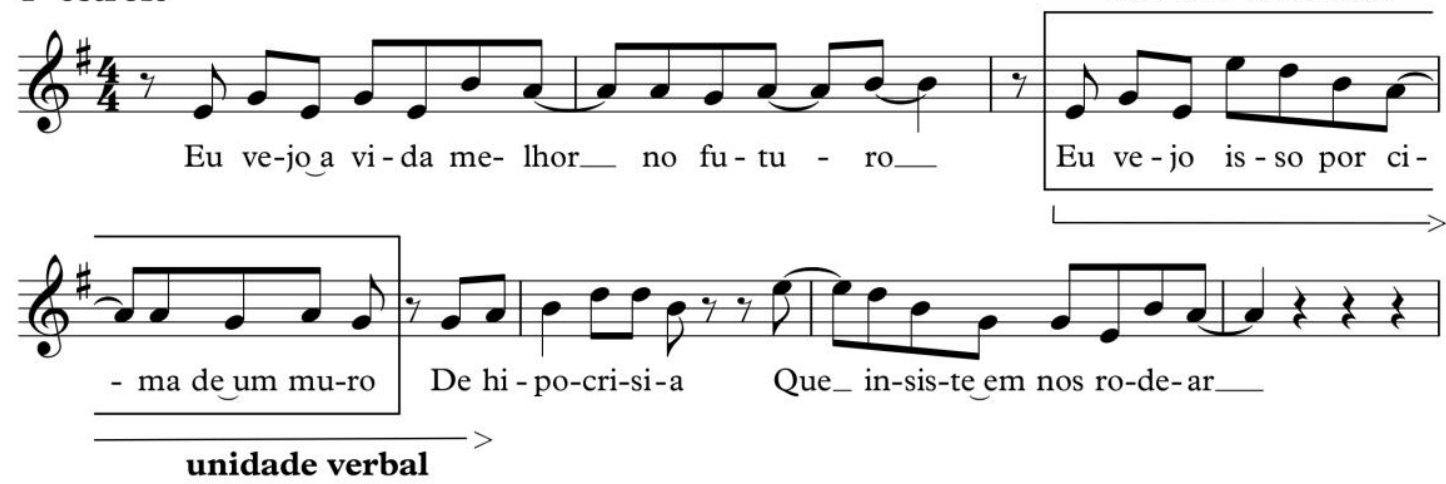

$2^{a}$ estrofe unidade melódica
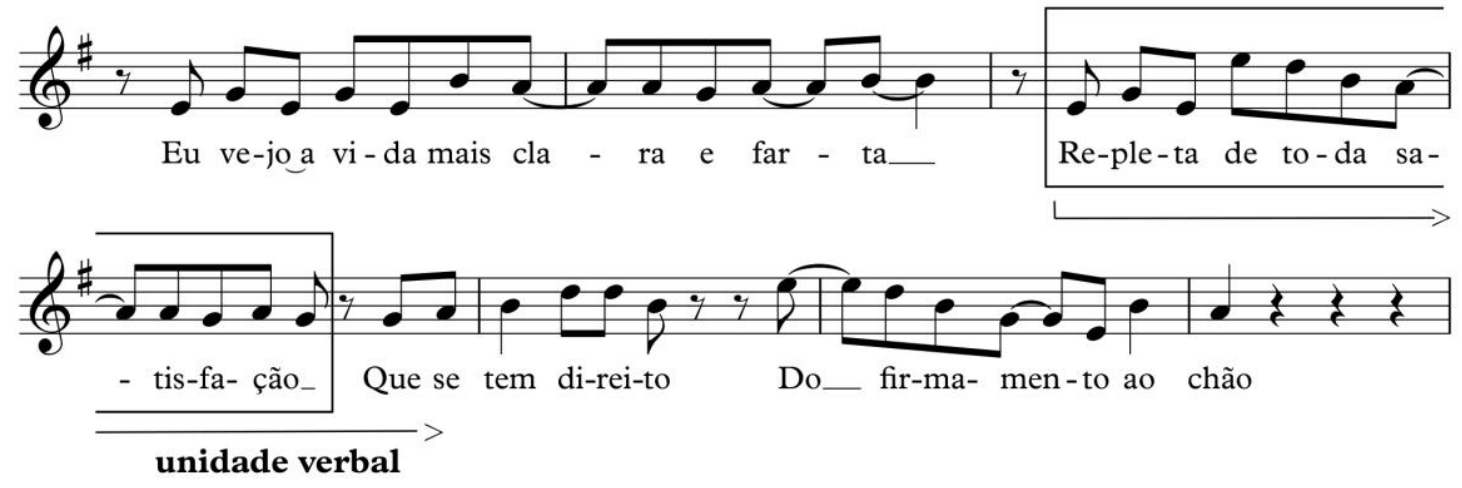


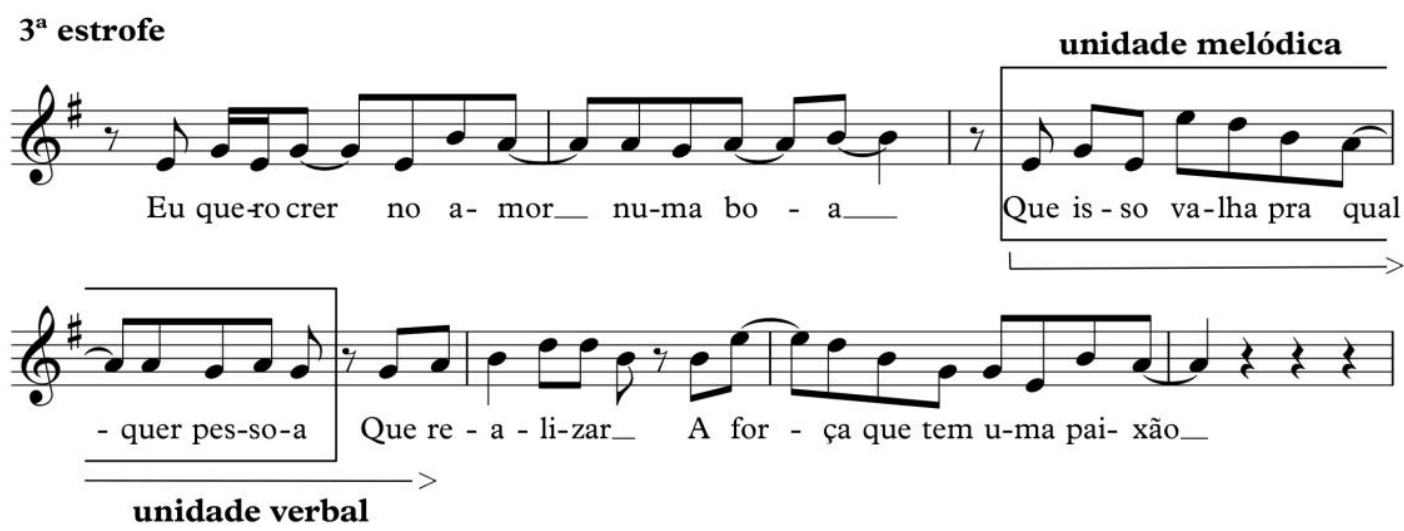

Figura 66. O abrandamento do desvio no nível da frase em Tempos Modernos (Lulu Santos)

Entre o segundo e o terceiro verso de cada estrofe, não sentimos de forma tão perturbadora a cisão de suas respectivas frases. É como se já ficássemos momentaneamente satisfeitos com o sentido captado até ali, após escutarmos os dois primeiros segmentos: "Eu vejo a vida melhor no futuro, eu vejo isso por cima de um muro", "Eu vejo a vida mais clara e farta, repleta de toda satisfação" e "Eu quero crer no amor numa boa, que isso valha pra qualquer pessoa". Mesmo sem a complementação que virá com as suas respectivas próximas unidades, mesmo assim, já apreendemos uma significativa terminatividade que supri a expectativa oral do ouvinte. É somente após o seguimento da frase que ficamos cientes de que ela havia sido interrompida. No caso da primeira estrofe, é apenas nesse instante que tomamos conhecimento de que o muro citado na letra era feito "de hipocrisia". Ou seja, é só nesse momento que a quebra entoativa acontece, comprometendo levemente, então, o seu entendimento mais direto e imediato. O trecho seguinte de Piano na Mangueira apresenta o mesmo fenômeno:

De terno branco e chapéu de palha

Vou me apresentar à minha nova parceira

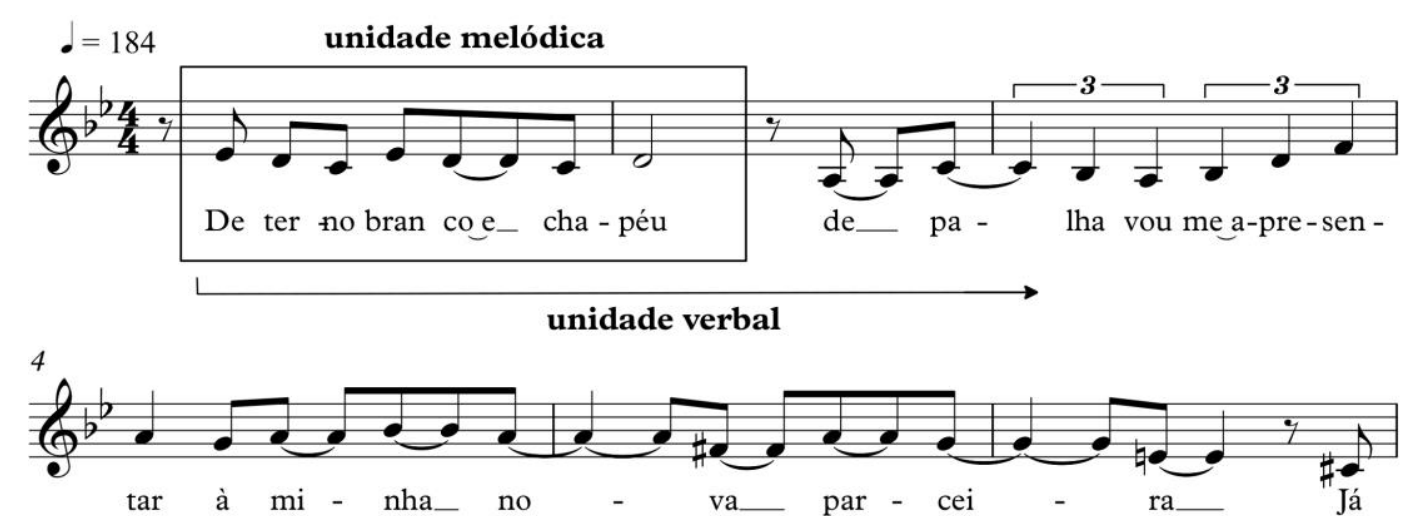

Figura 67. O abrandamento do desvio no nível da frase em Piano na Mangueira (Tom Jobim/Chico Buarque) 
Assim como na canção anterior, o segmento linguístico que antecede a pausa "De terno branco e chapéu" já satisfaz o ouvinte apresentando certo grau de completude semântica. Sabemos que a frase verbal ainda se completará, mas podemos aguardar a sua complementação sem maiores estranhamentos. O "incômodo" entoativo surge somente após o desenrolar da letra. Expliquemos. Nessa estrofe, a frase linguística é organizada de forma invertida. Alterando-a para a ordem direta teríamos a seguinte disposição: "Vou me apresentar à minha nova parceira de terno branco e chapéu de palha". Acreditamos, contudo, que a não-linearidade da oralização decorre mais do fato de haver um corte no sintagma nominal "chapéu de palha" do que propriamente devido à inversão sintática. Poderíamos, por exemplo, experimentar uma pequena mudança na letra desse trecho para evitarmos o corte entre o substantivo e o seu complemento, eliminando-o.

De terno branco e chapéu, eu saio

Vou me apresentar à minha nova parceira

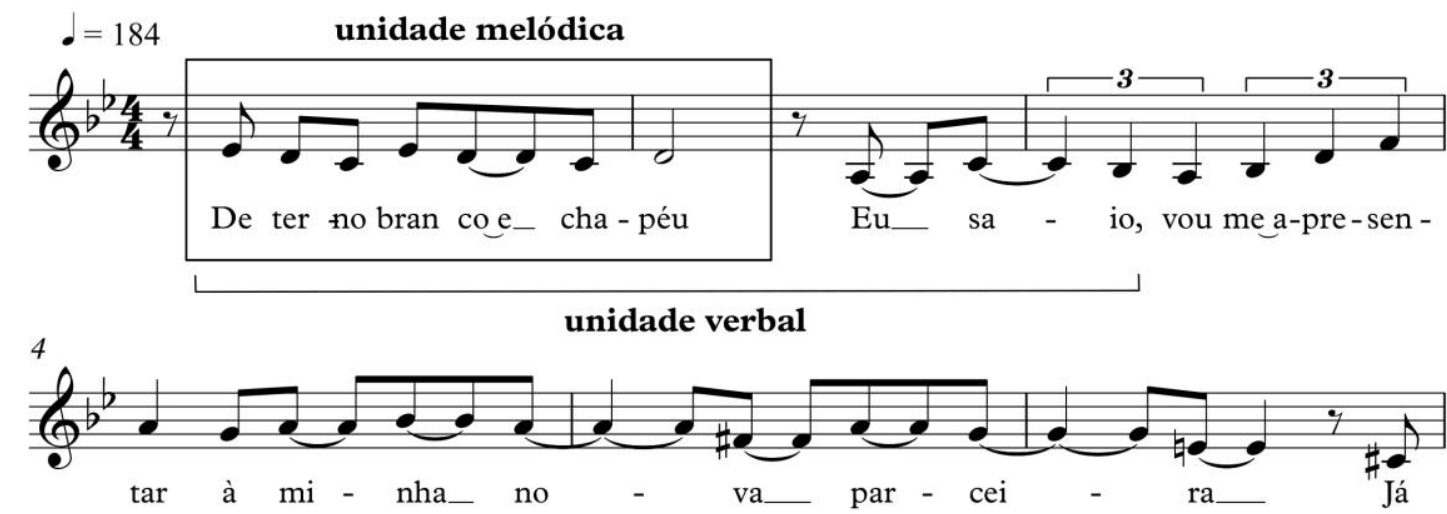

Figura 68. Reescrita de Piano na Mangueira (Tom Jobim/Chico Buarque)

Incontestavelmente, ao retirarmos parte do sintagma nominal, transformamos o sentido da letra e perdemos sua expressão singular. Todavia, ao alterarmos a frase verbal para "De terno branco e chapéu, eu saio" e posicionarmos o corte justamente sobre o que, na escrita, corresponde à pontuação marcada pela virgula, cremos que diminuímos, em algum grau, o estranhamento entoativo gerado pela versão original. Trata-se, como vemos, de um jogo constante entre os aspectos ligados à fala e outras questões linguísticas ou musicais. Tornar uma oralização mais ou menos linear não é, de modo algum, tornála esteticamente superior ou inferior. É apenas alterar o tipo de relação que o ouvinte estabelece com a obra. Observemos mais dois casos em que presença do corte da frase linguística, dessa vez após o verbo, é também amenizada. 
Mas o teu amor me cura

De uma loucura qualquer

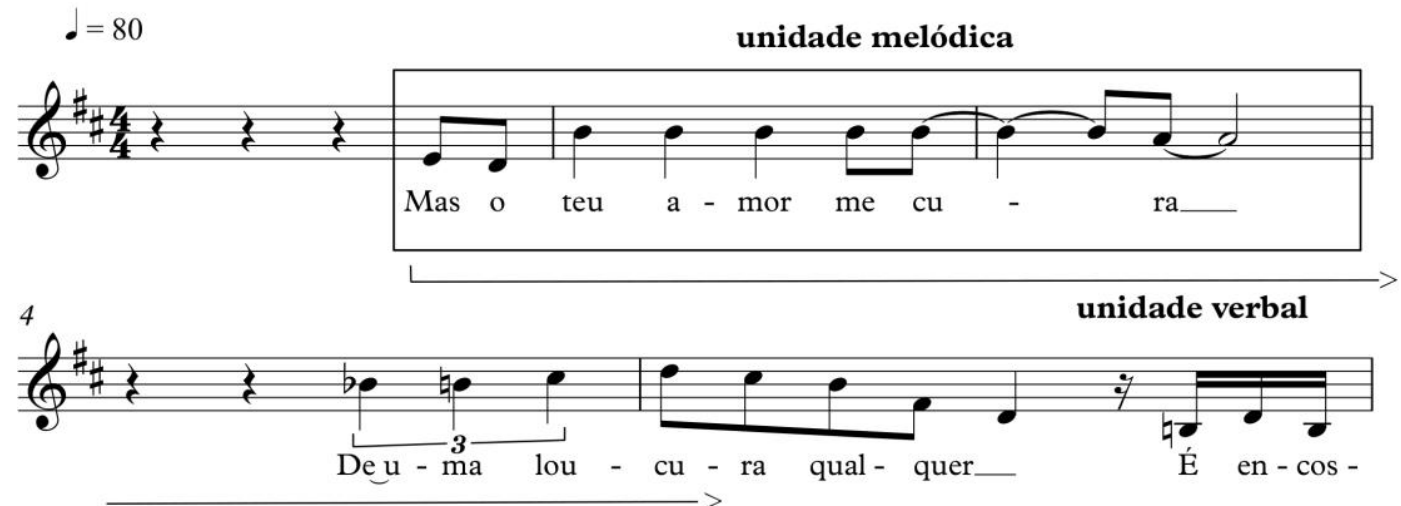

Figura 69. O abrandamento do desvio no nível da frase em Tudo bem (Lulu Santos)

Com sol e chuva você sonhava

Que ia ser melhor depois

Você queria ser o grande herói das estradas

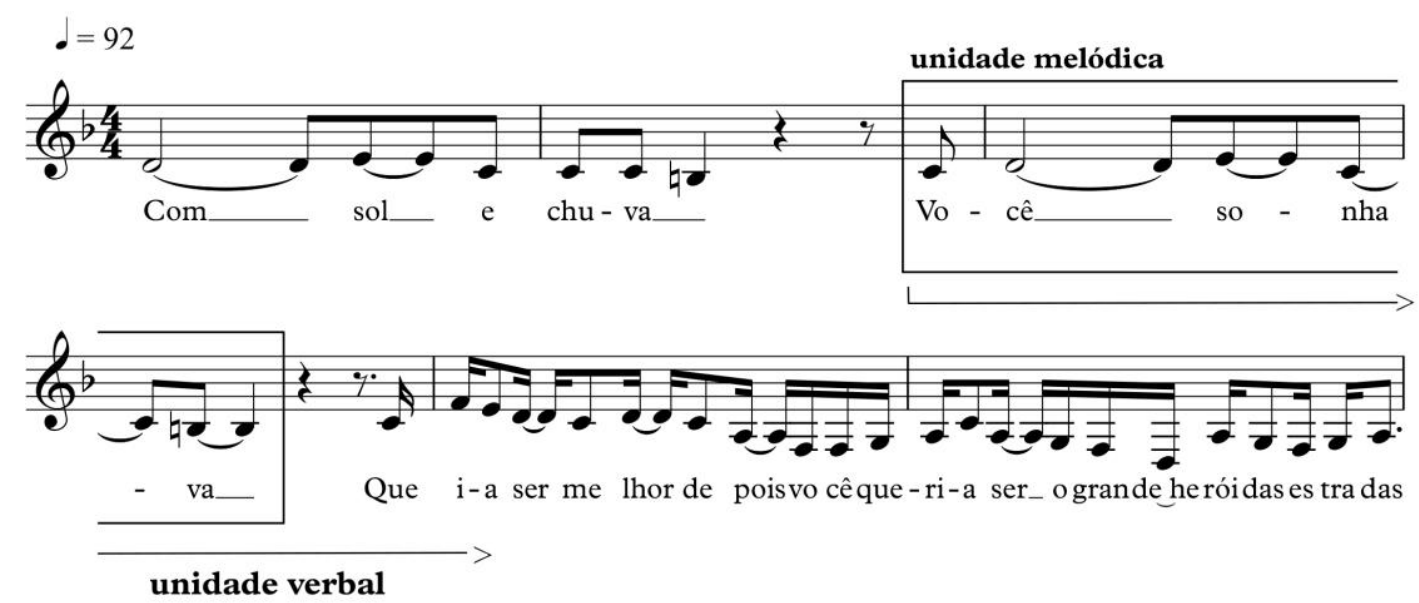

Figura 70. O abrandamento do desvio no nível da frase em Tudo o Que Você Podia Ser (Lô Borges/Márcio Borges)

Tanto em Tudo Bem quanto em Tudo o Que Você Podia Ser, no momento que o ouvinte termina de escutar os segmentos assinalados acima, sente, senão a conclusão final do texto verbal, pelo menos, um grau mínimo de finalização: "Com sol e chuva, você sonhava" a princípio não demandaria complementação, assim como a frase "mas o meu amor me cura". O público sabe, entretanto, sobretudo por meio da suspensão da linha melódica e da harmonia (que ainda não entraram em repouso), que o texto possui uma continuação $^{123}$. A sua cisão, no entanto, é abrandada pelo grau de terminatividade trazido pelos verbos “curar" e "sonhar".

${ }^{123}$ Nesta pesquisa, de modo proposital, não indicamos nas partituras os acordes do acompanhamento harmônico. Nosso intuito inicial era tratar das questões musicais ligadas à harmonia em um capítulo 
Em Tudo o Que Você Podia Ser, esse grau de fechamento pode até mesmo prejudicar o entendimento da frase seguinte. Pelo fato de haver uma separação do verbo "sonhava" de seu complemento "que ia ser melhor depois" (acrescido do fato de que um sentido já se fecha em "sonhava”), o ouvinte pode ser levado a compreender o início do segmento seguinte como "Queria" e não "Que ia", uma vez que dificilmente começamos uma frase com o pronome relativo "que" (o fato de o verbo "queria" aparecer na sequência da estrofe também colabora para que tenhamos uma falsa confirmação de que o início do segmento trazia o mesmo vocábulo). Intuitivamente, o público sempre espera escutar aquilo que está acostumado a vivenciar em seu cotidiano linguístico. Há casos, entretanto, em que o sentido de terminatividade dado pelo verbo que finaliza o segmento não é suficiente para abrandar o estranhamento gerado pela cisão frasal menos usual. Analisemos um pequeno trecho da canção Disparada, de Geraldo Vandré e Théo de Barros.

Então não pude seguir valente em lugar tenente

E dono de gado e gente, porque gado a gente marca

Tange, ferra, engorda e mata, mas com gente é diferente

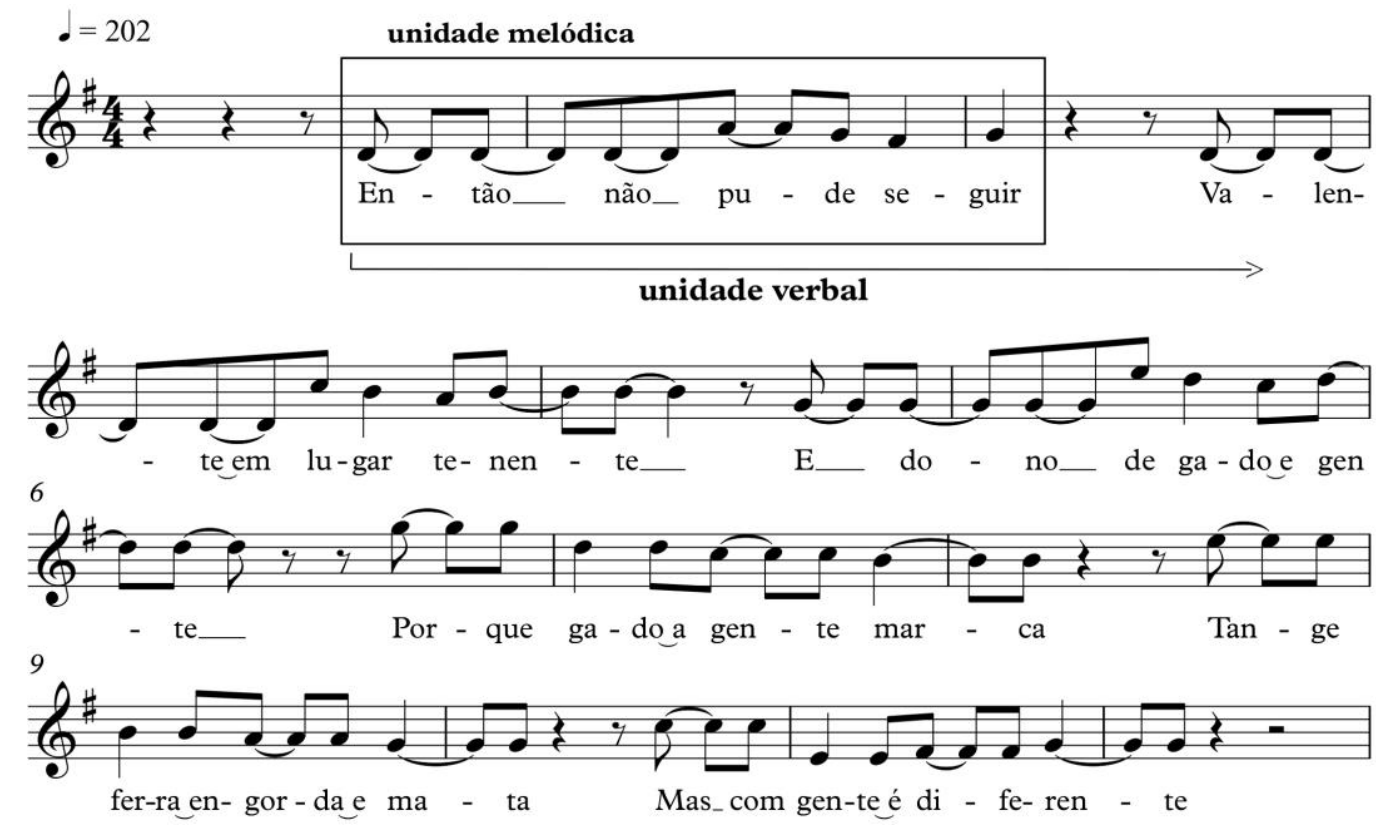

Figura 71. O abrandamento do desvio no nível da frase em Disparada (Geraldo Vandré/Théo de Barros)

posterior (parte de uma seção dedicada à musicalização que não foi possível realizar). Sabemos, porém, da relevância desse aspecto musical para a análise do sentido das unidades entoativas, mas, na organização do nosso estudo, o seu exame aprofundado deve ser realizado apenas num momento seguinte. 
Ainda que tenhamos certo grau de finalização após o verso "Então não pude seguir", o que estamos relacionando, neste item da tese, a um possível tipo de abrandamento do corte no nível da frase, ainda sim, a passagem não parece entoativamente comum. A nosso ver, é o prosseguimento do texto linguístico que gera essa oralização não-linear. Ao iniciar a unidade melódica seguinte com o vocábulo "valente", o cancionista pede ao ouvinte que seja estabelecida uma relação de continuidade entre os dois primeiros segmentos, exigindo um elo entre as palavras "seguir" e "valente", ligação, entretanto, muito fragilizada pela cisão com pausa presente no terceiro compasso da ilustração. Assim, o cancionista propõe ao ouvinte uma união de letra e melodia diferente do que, em geral, se espera na fala, causando algum estranhamento, mas oferecendo, ao mesmo tempo, um modo de dizer singular. Pensando novamente sobre questões melódicas que podem influenciar no abrandamento ou na amplificação desses desvios frasais, observemos o exemplo seguinte:

\section{Minha morena}

Venha pra cá

Pra dançar xote

Se deita em meu cangote e pode cochilar

Tu sois muié pra homem nenhum

Botar defeito

Por isso satisfeito

Com você vou dançar
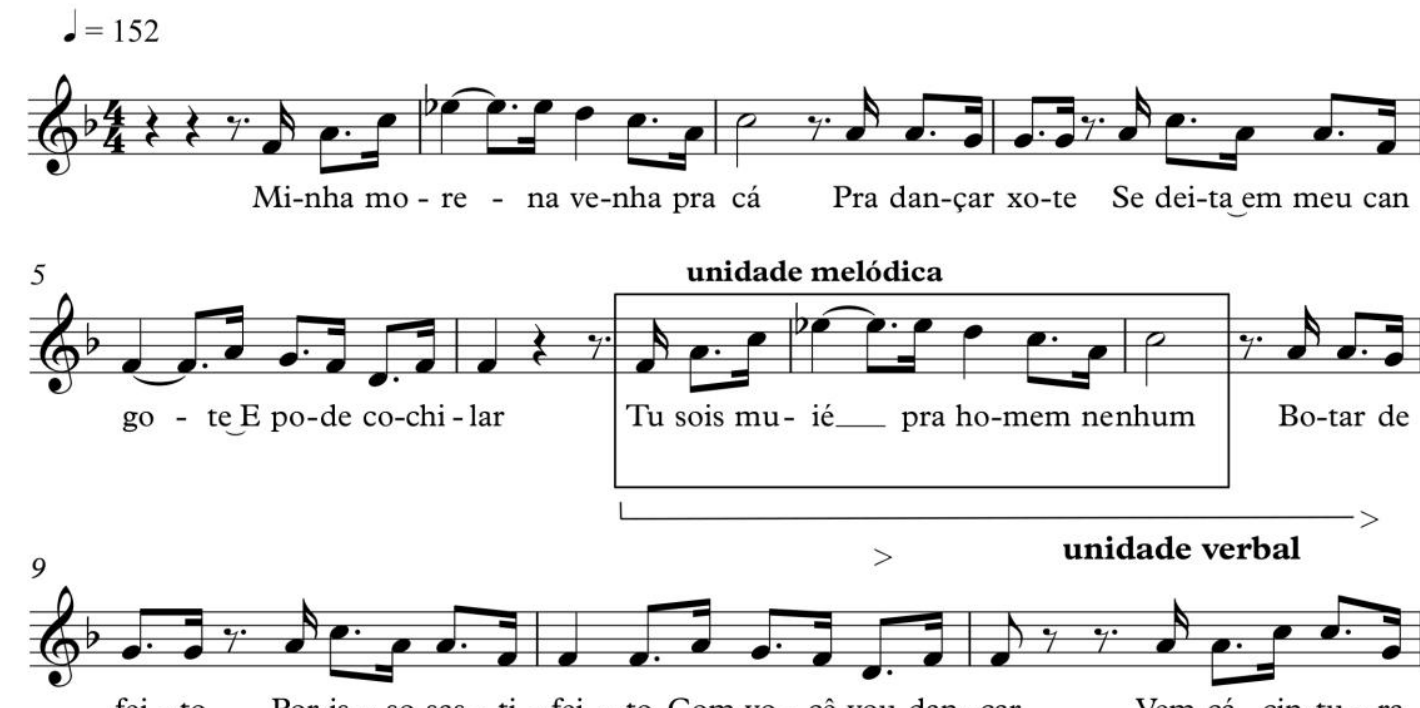

Figura 72. O abrandamento do desvio no nível da frase em Cintura Fina (Luiz Gonzaga/Zé Dantas) 
Quando escutamos esse fragmento da canção Cintura Fina, muito ligada à tematização, nos deparamos com a repetição integral da linha melódica que ocupa os seis primeiros compassos. De fato, constatamos que as notas que recobrem a frase "Tu sois mulher pra homem nenhum botar defeito" são as mesmas que recobrem o início da letra: "Minha morena, venha pra cá pra dançar xote". Assim, quando ouvimos a frase assinalada na ilustração, intuitivamente, sabemos que ela é só a primeira unidade do grupo de unidades melódicas que compõe uma estrofe da canção. Nesse sentido, a constituição da linha melódica nos indica uma continuidade (harmônica e melódica) que reduz a sensação da segmentação da unidade verbal indicada acima, entre "homem nenhum" e "botar defeito". Isto é, é como se soubéssemos que o texto linguístico será completado, uma vez que conhecemos o prosseguimento da melodia. Além disso, a nota que incide sobre a sílaba tônica de "nenhum" é alongada como se fizesse uma espécie de ponte para o segmento seguinte, diminuindo a sua distância em relação a ele e, por conseguinte, abrandando a cisão. Há também maneiras de atenuar o corte frasal por meio de um artifício ligado à constituição de sua letra.

Eu sei que um outro deve estar falando ao seu ouvido

Palavras de amor como eu falei, mas eu duvido

Duvido que ele tenha tanto amor

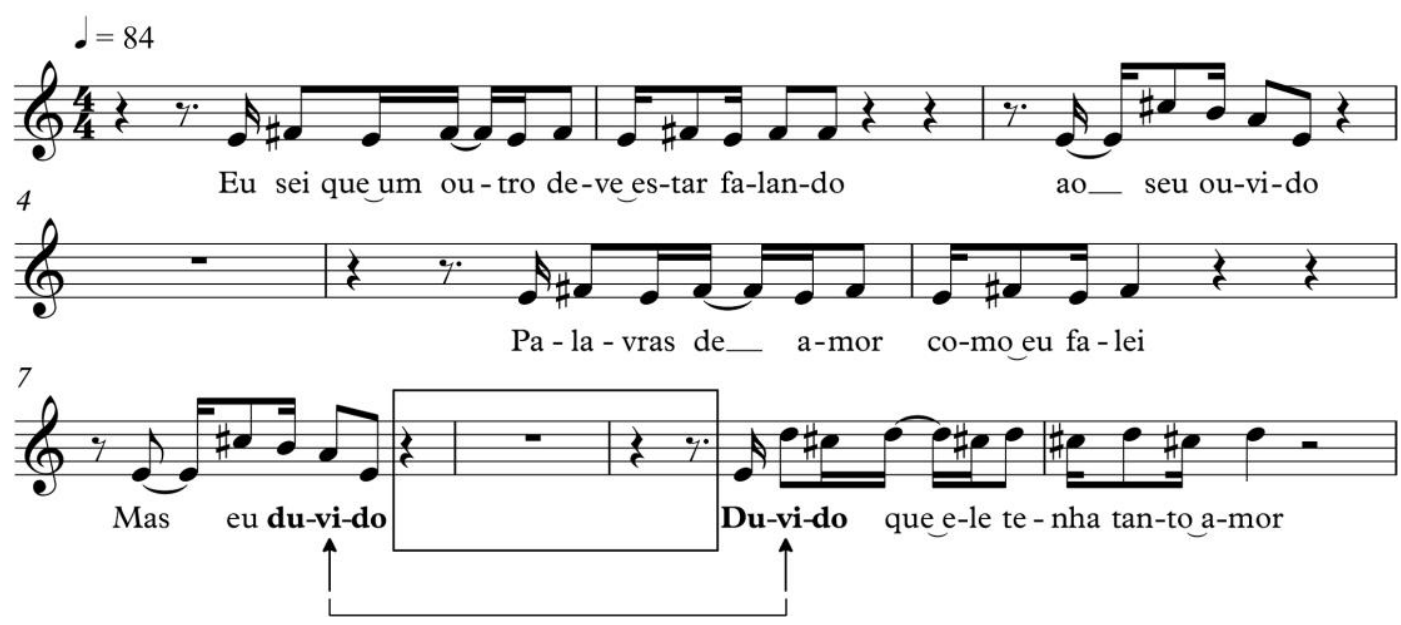

Figura 73. O abrandamento do desvio no nível da frase em Detalhes (Roberto Carlos/Erasmo Carlos)

Em Detalhes, observamos um fenômeno muito interessante. O segmento verbal que ocupa o sétimo compasso do fragmento possui sentido inacabado: "Mas eu duvido" gera no ouvinte uma significativa necessidade de complementação linguística. Não obstante, como destacamos na figura, ao retomar o mesmo vocábulo "duvido" no início 
do segmento seguinte, recuperando o seu elo com a unidade anterior e garantindo a sua naturalidade entoativa, o cancionista consegue diminuir a descontinuidade oral apontada acima. Caso contrário, se a unidade fosse iniciada com o pronome relativo "que", sem a retomada do vocábulo, sentiríamos a cisão de maneira muito mais acentuada. 


\subsection{O aproveitamento artístico dos desvios no nível da frase}

Consciente ou inconscientemente, o cancionista, ao relacionar letra e melodia, de modo inevitável, produz oralizações mais comuns ou menos comuns. Nos capítulos anteriores, estudamos os diferentes sentidos entoativos gerados pelo deslocamento silábico e lexical e analisamos o fato de esses desvios também constituírem elementos esteticamente relevantes. O mesmo ocorre no nível da frase. Ou seja, uma figurativização não linear (com desvio frasal) apresenta igualmente um resultado expressivo próprio, ora ligado às questões musicais ou poéticas, ora relacionado, curiosamente, à própria língua falada. Neste item, analisaremos casos mais explícitos desse aproveitamento estético das oralizações inesperadas. Por exemplo, as pausas que segmentam as unidades verbais podem sugerir novas possibilidades de sentido, enfatizando o vocábulo posicionado logo antes da cisão.

A novidade era o máximo

Do paradoxo estendido na areia

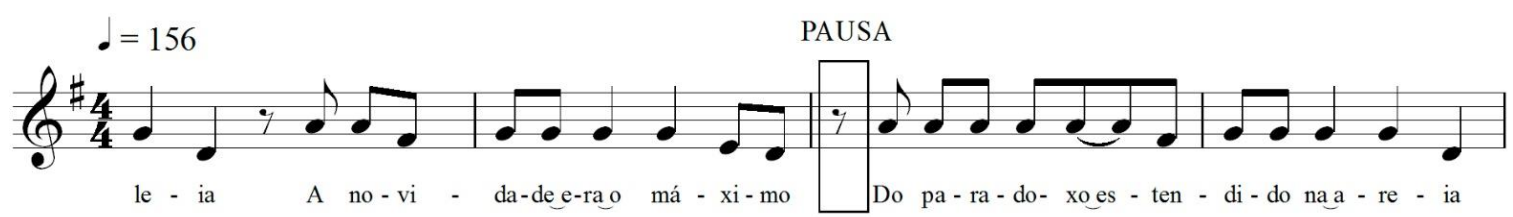

Figura 74. O aproveitamento artístico do desvio no nível da frase em A novidade (Herbert Vianna/Bi Ribeiro/João Barone/Gilberto Gil)

Aqui, a cobertura não usual da frase verbal pela melodia concede à canção um sentido especial. A separação de "A novidade era o máximo do paradoxo", pelo uso da pausa ao final do primeiro verso, faz com que se enfatize fortemente a palavra "máximo". Assim, evidencia-se o sentido de que a "novidade" era um acontecimento extraordinário. Em seguida, o ouvinte se dá conta de que a palavra "máximo" liga-se à "paradoxo", produzindo um novo sentido, distinto do anterior. O mesmo observamos no conhecido refrão da canção Pais e filhos.

É preciso amar as pessoas

Como se não houvesse amanhã

Porque se você parar pra pensar

Na verdade não há 


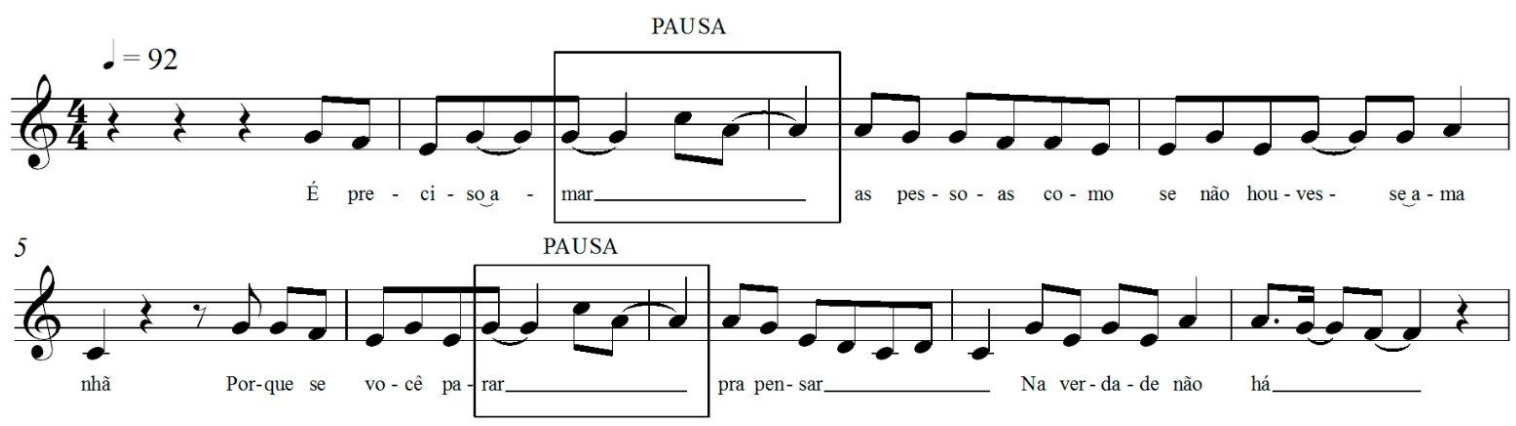

Figura 75. O aproveitamento artístico do desvio no nível da frase em Pais e Filhos (Renato Russo/Dado Villa-Lobos/Marcelo Bonfá)

Nesse exemplo, há um alongamento das sílabas finais das palavras "amar" e "parar" gerando uma divisão no interior das duas frases, pois os seus complementos ("as pessoas" e "pra pensar") são temporalmente adiados. Entretanto, é com esse artifício que, mesmo que de modo intuitivo, o cancionista enfatiza a palavra "amar", valorizando o sentimento amoroso tão importante para o conteúdo dessa canção. Além disso, é interessante observar que, com o alongamento da última sílaba de "amar", o intérprete consegue amenizar a separação entre as duas partes da frase. Se o cantor não realizasse esse prolongamento vocálico (e houvesse um período de verdadeiro silêncio como vimos em exemplos analisados neste capítulo), o ouvinte sentiria, com maior vigor, a cisão e, consequentemente, uma entoação menos consensual.

Enfim, esse tipo de fenômeno, ao enfatizar o vocábulo posicionado imediatamente antes do corte frasal, não se distancia, a priori, de uma situação enunciativa também presente na língua oral. Na fala, por vezes, também corrompemos o fluxo contínuo de uma frase para valorizarmos certo vocábulo que julgamos ser semanticamente importante. É como se tivéssemos uma espécie de acento afetivo (assunto que estudamos no nível silábico) agora num patamar acima, o da frase. Na canção seguinte, Tempo Perdido, de Renato Russo, esse processo é ainda mais evidente.

Veja o sol dessa manhã tão cinza

A tempestade que chega

É da cor dos teus olhos castanhos

Então me abraça forte

Me diz mais uma vez que já estamos

Distantes de tudo

Temos nosso próprio tempo 

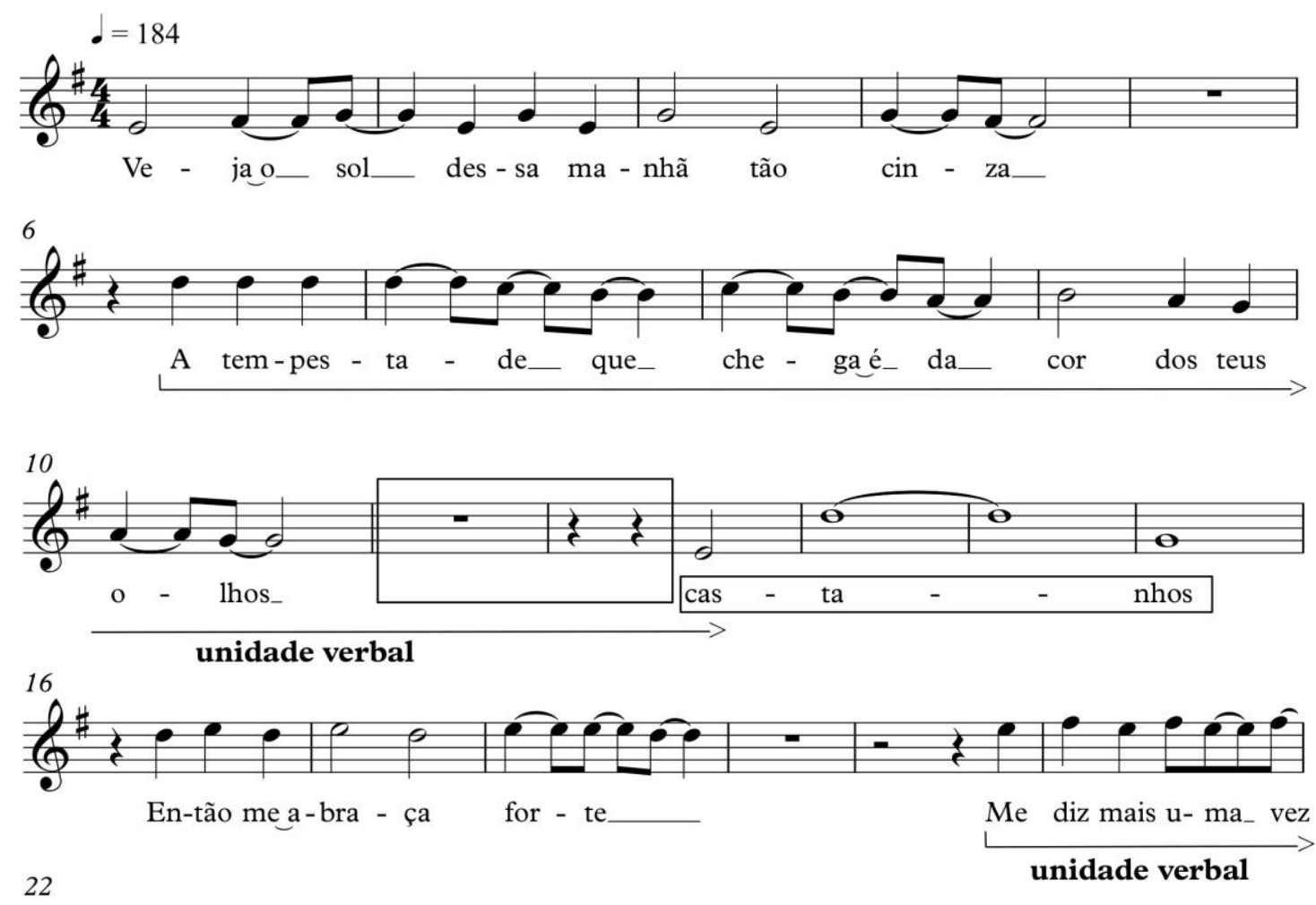

22
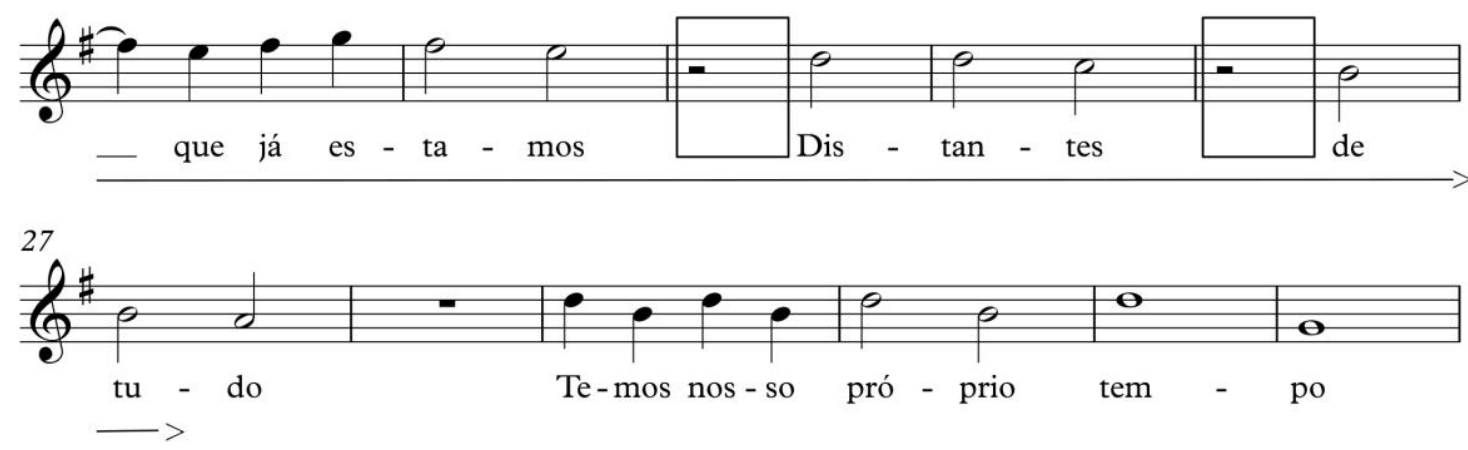

Figura 76. O aproveitamento artístico do desvio no nível da frase em Tempo perdido (Renato Russo)

Primeiramente, é claro, devemos constatar que a frase "A tempestade que chega é da cor dos teus olhos" já possui sentido terminativo, o que, sem dúvida, atenua a pausa que corta o segmento, como indicamos no compasso onze e doze. Contudo, a cisão entre o substantivo "olhos" e o seu complemento "castanhos", o que sentimos somente com o prosseguimento do canto não deixa de representar um certo desarranjo entoativo. Um distúrbio que, por outro lado, preenche o vocábulo "castanhos" de uma intensa expressividade (além de valorizar o termo anterior, "olhos"). O mesmo ocorre com as palavras "distantes" e "de tudo", separadas de sua frase linguística "Me diz mais uma vez que já estamos". Essa segmentação, ainda que oralmente inesperada, produz uma interessante combinação entre letra e melodia que parece enfatizar ainda mais o 
sentimento de isolamento e perda tão importantes para o conteúdo da letra dessa canção. Retomando o exemplo de Piano na Mangueira, observamos algo similar.

\section{Mangueira}

Estou aqui na plataforma

Da Estação Primeira

O Morro veio me chamar

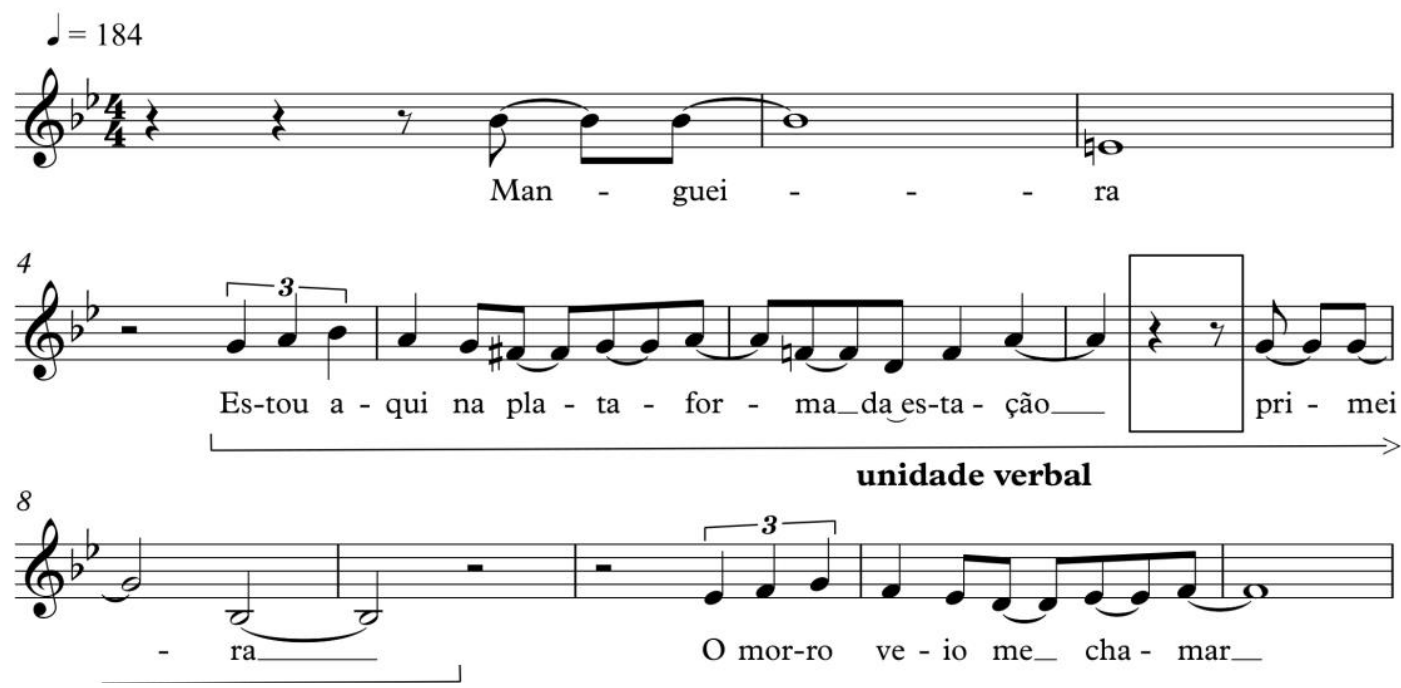

Figura 77. O aproveitamento artístico do desvio no nível da frase em Piano na Mangueira (Tom Jobim/Chico Buarque)

Ao separar os termos "estação" e "primeira"124, os cancionistas valorizam significativamente o segundo vocábulo. Desse modo, a palavra "primeira", agora bastante conectada com "Mangueira" (ambas são muito destacadas da linha melódica e cantadas com praticamente o mesmo motivo musical, além da apresentarem a mesma rima), pode também enfatizar o apreço que o eu-lírico possui em relação à famosa localidade carioca. "Primeira" também pode significar "a mais importante" ou "a de maior valor". Outro interessante exemplo é a canção Certas Coisas, de Lulu Santos e Nelson Motta.

Cada voz que canta o amor não diz

Tudo o que quer dizer

Tudo o que cala fala

Mais alto ao coração

${ }^{124} \mathrm{Na}$ cidade do Rio de Janeiro, a estação ferroviária localizada próxima ao Morro da Mangueira era a primeira parada após a Estação Central do Brasil. 
Silenciosamente

Eu te falo com paixão
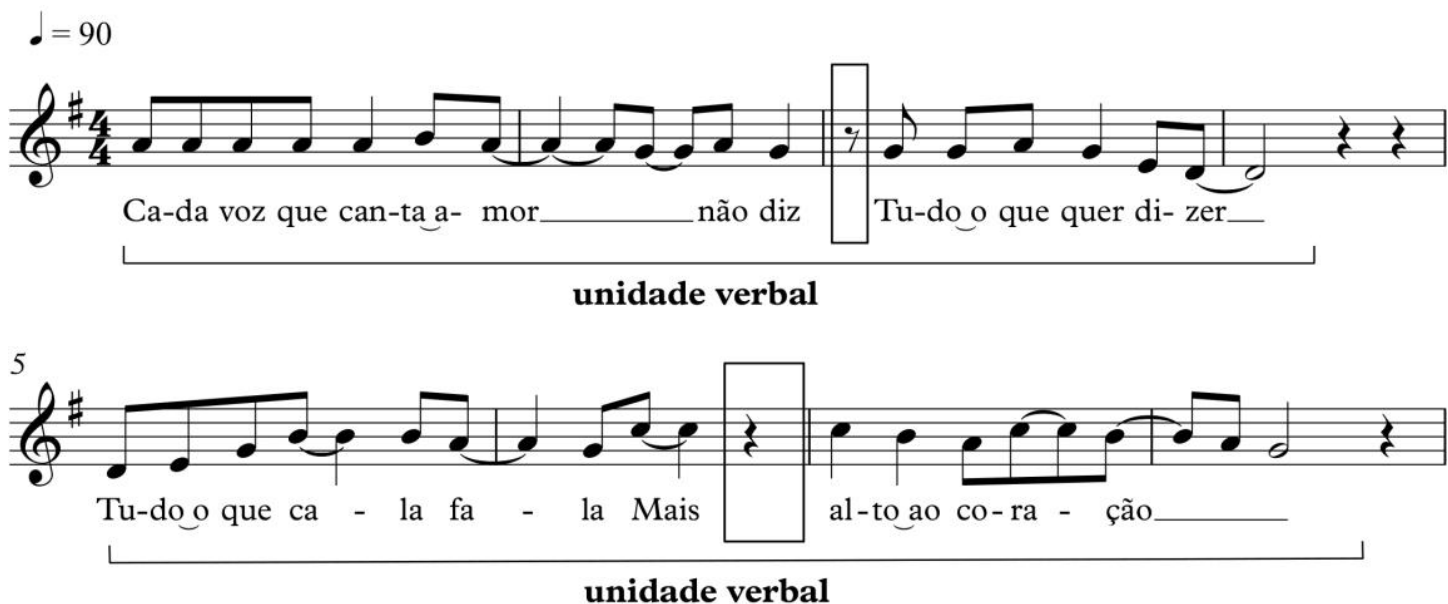

Figura 78. O aproveitamento artístico do desvio no nível da frase em Certas coisas (Lulu Santos/Nelson Motta)

$\mathrm{Na}$ ilustração acima, desejamos observar sobretudo a cisão que ocorre a partir do quinto compasso, atingindo a frase “Tudo o que cala fala mais alto ao coração". É muito fácil notarmos como essa combinação entre letra e melodia desvaloriza a expressão "mais alto", quase a anulando. É como se não a ouvíssemos, tamanha a distância entre a sua emissão na canção e a sua enunciação na língua oral, na qual jamais aparece desmembrada. Por outro lado, é essa mesma cisão que concede à frase "Tudo o que cala fala mais" uma significação especial que dispensa complementação: o silêncio tem mais a dizer do que a voz. É somente após escutarmos o texto verbal subsequente, que sentimos a perturbação entoativa decorrente da cisão frasal. Utilizando o mesmo processo usado por Roberto Carlos e Erasmo Carlos na canção Detalhes, poderíamos retomar os vocábulos que finalizam o segmento anterior para abrandar o corte do enunciado.

Tudo o que cala fala mais

Fala mais alto ao coração

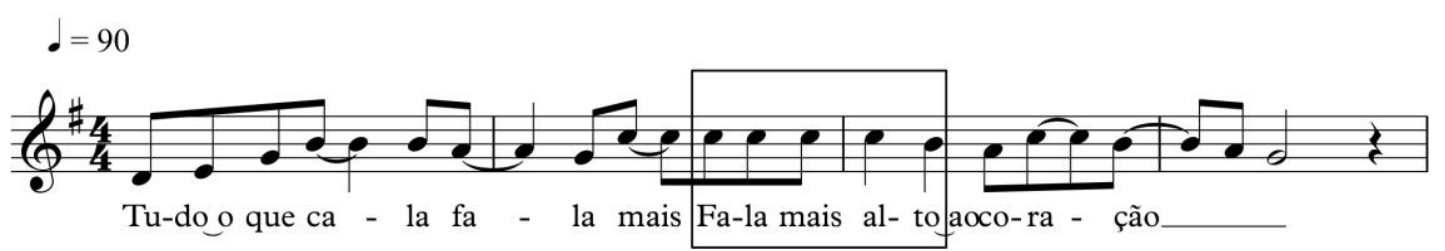

Figura 79. Reescrita de Certas coisas (Lulu Santos/Nelson Motta)

Evidentemente, nos exemplos acima, não importa saber se o cancionista teve a intenção consciente de fazer o corte para separar essa palavra do restante da frase e, com 
isso, destacá-la. Acreditamos, no entanto, que, ao fazer tal combinação entre letra e melodia, o fato de uma palavra semanticamente importante ter sido valorizada pela configuração musical faz com que o resultado obtido intuitivamente contente o compositor. É nesse jogo entre os aspectos orais e musicais que a canção vai se construindo, satisfazendo o desejo artístico do cancionista de variadas maneiras. Outra questão estética gerada pelo corte frasal consiste na expectativa que o cancionista pode gerar no ouvinte ao adiar o desfecho da frase verbal. Vejamos alguns exemplos.

Estou triste, tão triste

E o lugar mais frio do rio é o meu quarto

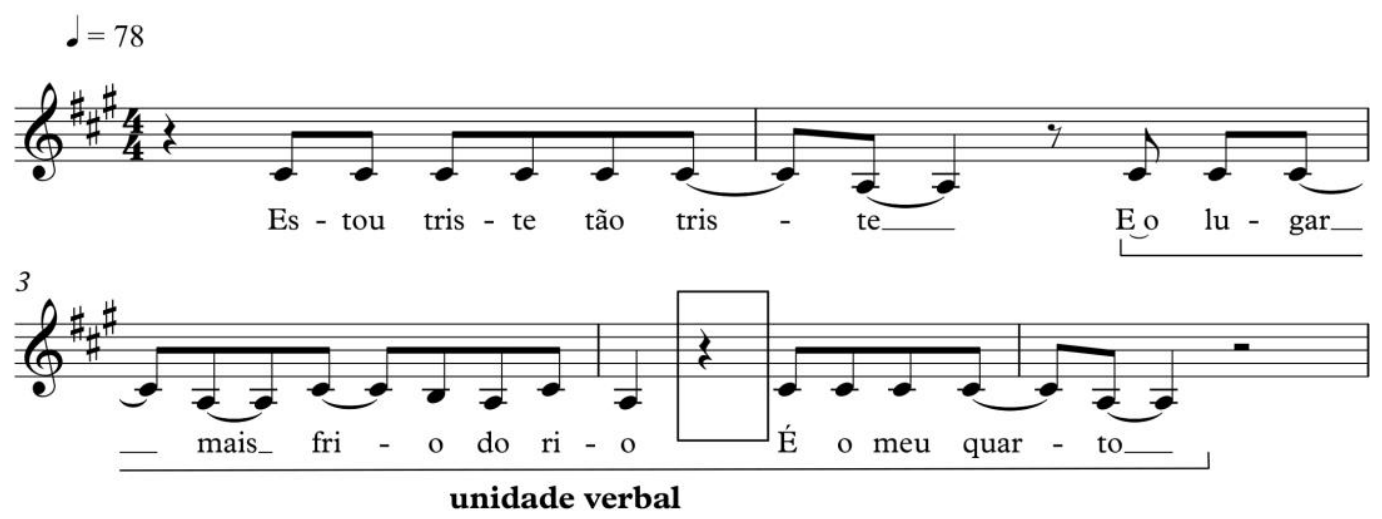

Figura 80. O aproveitamento artístico do desvio no nível da frase em Estou triste (Caetano Veloso)

O meu mundo era o apartamento

Detefon, almofada e trato

Todo dia filé-mignon

Ou mesmo um bom filé de gato
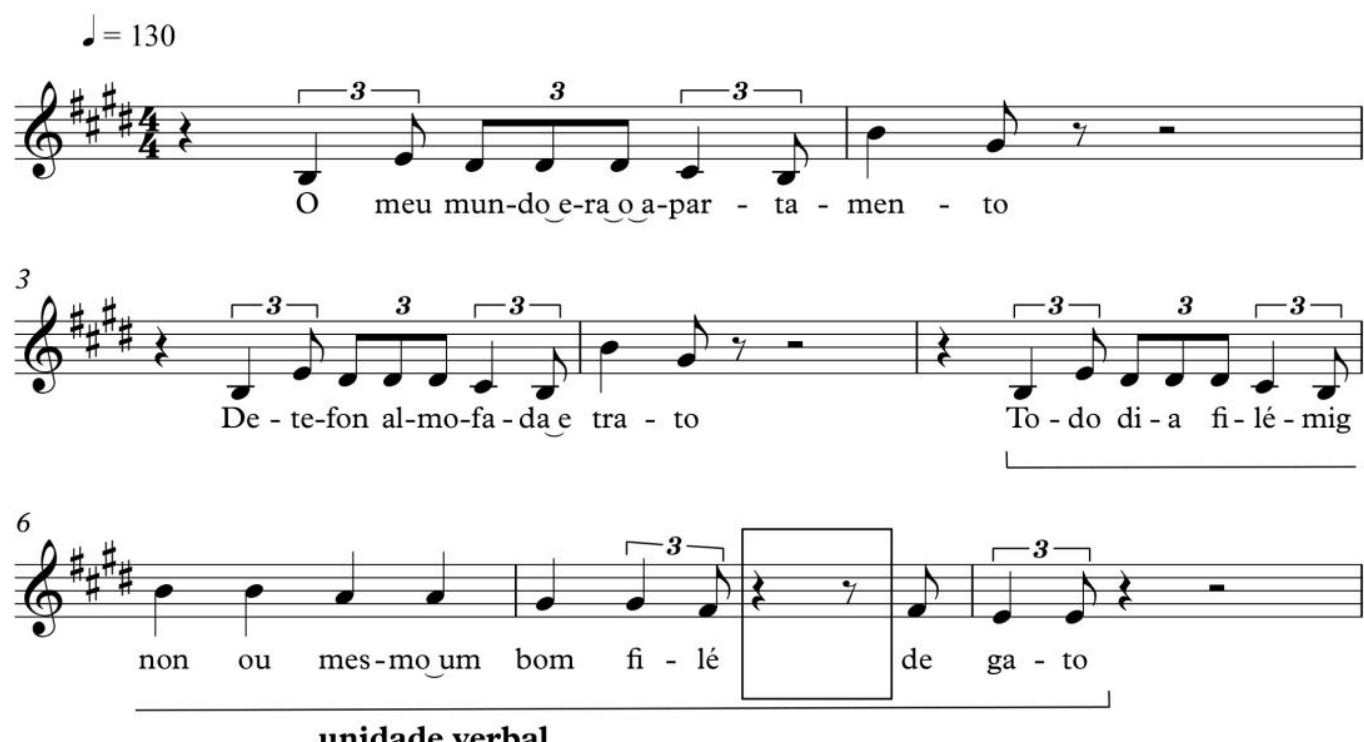

Figura 81. O aproveitamento artístico do desvio no nível da frase em História de uma gata (Henriquez/Bardotti/Chico Buarque) 
Em Estou Triste e História de Uma Gata, observamos o mesmo procedimento: as frases verbais destacadas em suas respectivas ilustrações sofrem uma cisão que gera, mais do que uma oralização não-linear, uma oportuna expectativa no ouvinte. Há uma significativa surpresa com a conclusão de ambas e os cancionistas convenientemente inserem uma pausa suspensiva antes desses desfechos, valorizando-os. Nesse sentido, nos surpreendemos quando a letra da primeira canção indica o quarto do eu-lírico como o espaço mais obscuro e triste da cidade. Da mesma forma, não esperamos que a personagem da segunda canção, uma gata, será ironicamente alimentada com um "bom filé de gato". Ainda pensando em possibilidades artísticas advindas das cisões no nível da frase, podemos examinar alguns exemplos nos quais há uma interessante exploração da ligação entre a forma e conteúdo da obra. Examinemos alguns casos:

Embebedado de você.

Tonto na beirada dá

Tentação de cair e voar,

Até me aninhar em você

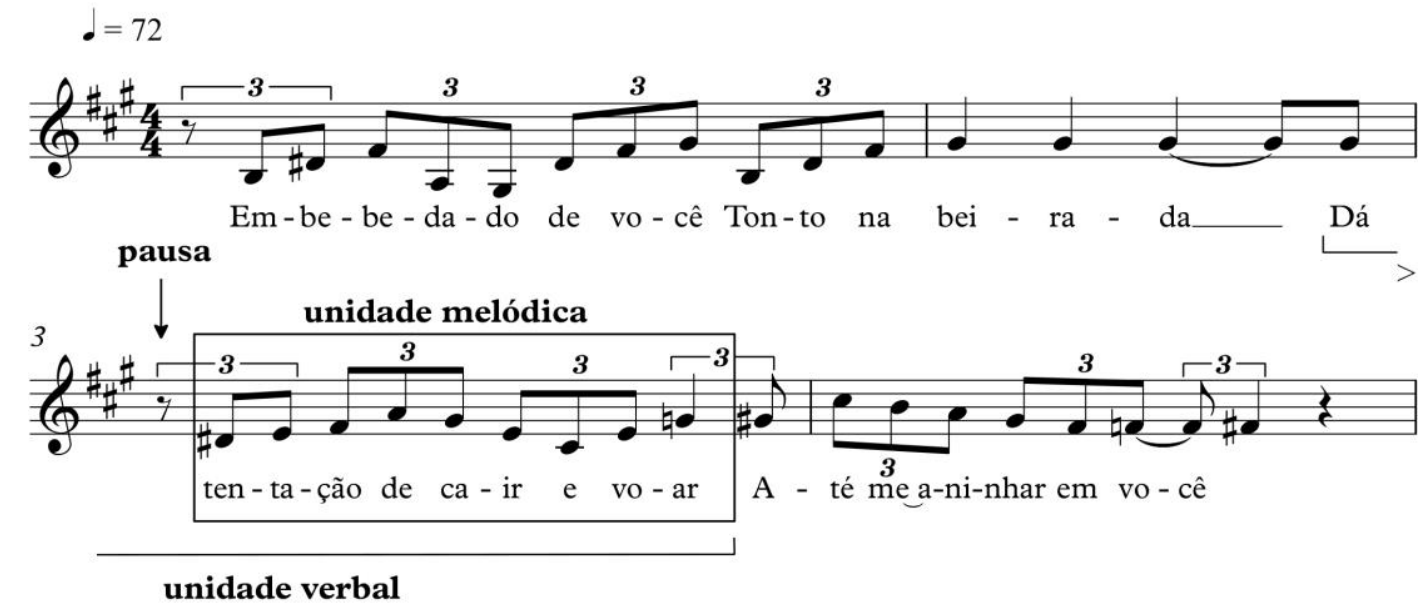

Figura 82. O aproveitamento artístico do desvio no nível da frase em Embebedado (Chico Buarque/Zé Miguel Wisnik)

Nessa canção, há, sem dúvida, um corte radical na frase verbal "Dá tentação de cair e voar" que perturba fortemente o seu valor entoativo. Ninguém, numa situação normal de fala, faz uma separação entre o verbo "dá" e sua complementação "tentação de cair e voar”. Aqui, no entanto, essa cisão inesperada proporciona uma interessante reprodução, na forma, de uma imagem poética já trazida pela letra: um sujeito que se debruça no parapeito de uma varanda e visualiza a altura vertiginosa em que se encontra, reflexo de seu estado emocional. Assim, é como se essa interrupção da frase linguística 
aumentasse a nossa sensação da vertigem e da fragilidade sentimental vivida pelo eulírico. É como se chegássemos, pouco a pouco, junto com a personagem da canção, no limite mais extremo dessa varanda, tocando a beirada da frase seguinte, antes de cairmos em sua complementação. Trata-se, portanto, de uma combinação entre letra e melodia distante da fala, mas artisticamente muito expressiva. Nesse sentido, é muito interessante compararmos versões de diferentes intérpretes para essa mesma canção. Transcrevemos acima a versão cantada pelo próprio compositor, Zé Miguel Wisnik. Vejamos também a versão interpretada por Gal Costa.

Embebedado de você.

Tonto na beirada

Dá tentação de cair e voar,

Até me aninhar em você

$$
\cdot=66
$$

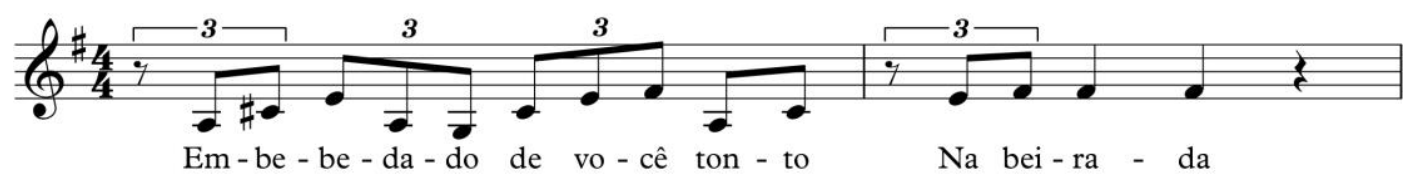

unidade melódica

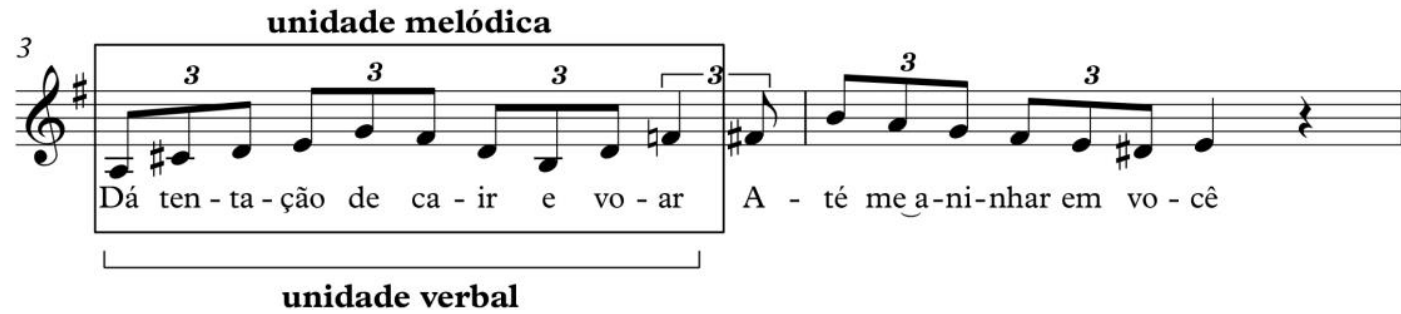

Figura 83. Versão de Gal Costa da canção Embebedado (Chico Buarque/Zé Miguel Wisnik)

Embebedado é um bom exemplo de como os assuntos tratados nesta tese, sobretudo a questão da oscilação entre os modos de dizer mais ou menos usuais, devem ser abordados de modo descritivo, para que possamos perceber a ampla escala gradativa que separa um polo do outro, bem como valorizar a qualidade artística intrínseca de cada obra. Essa canção e suas duas diferentes interpretações nos mostram como ambas, a versão mais entoativa de Gal Costa e a versão menos oral de Wisnik e Chico Buarque, podem despertar o interesse do ouvinte, alcançando expressividades específicas. Com efeito, como verificamos na última ilustração, a cantora não só evita o corte da frase constatado na versão anterior, como também corrige o deslocamento silábico que incidia sobre a palavra "beirada" (que, cantada por Wisnik, era acentuada na primeira sílaba, átona, estabelecendo uma possível relação com o vocábulo "beira"). Quando escutamos 
a versão de Gal, sem dúvida, entendemos a letra de modo mais imediato. Nossa fruição parece se apoiar um pouco mais na língua oral. Na versão anterior, nossa assimilação procura outros apoios de sentido, uma vez que a sua combinação entre melodia e letra se distancia de um modo de dizer mais usual. Por fim, podemos examinar dois últimos exemplos nos quais o cancionista, também exigindo de seu ouvinte outros tipos de apoio, diferentes do entoativo, interrompe a frase de maneira intencional, realizando cortes no meio de um vocábulo. Na canção Cadê teu Suin-?, de Marcelo Camelo, a terminação de uma frase se localiza no início da frase seguinte.

Cadê teu repi

Quem é teu padri

Onde é que tu to

Cadê teu suin

Guitarra não po

Desista mole

Quem é que te indi

Cadê teu suin

Com que sobreno

Melhor ir sain

Dou nem mais minu

Tô nem mais

Ainda tem a cora

Gentinha atrevi

Da cá sua vi

Da cá seu suin

Guilhotina?

$\mathrm{Eu}$ que controlo o meu guidom

Com ou sem suin

Com ou sem suin

Com ou sem suin

Guichê só de ven

Da lá toma no

Tamanha revan

Cheio de vingan 


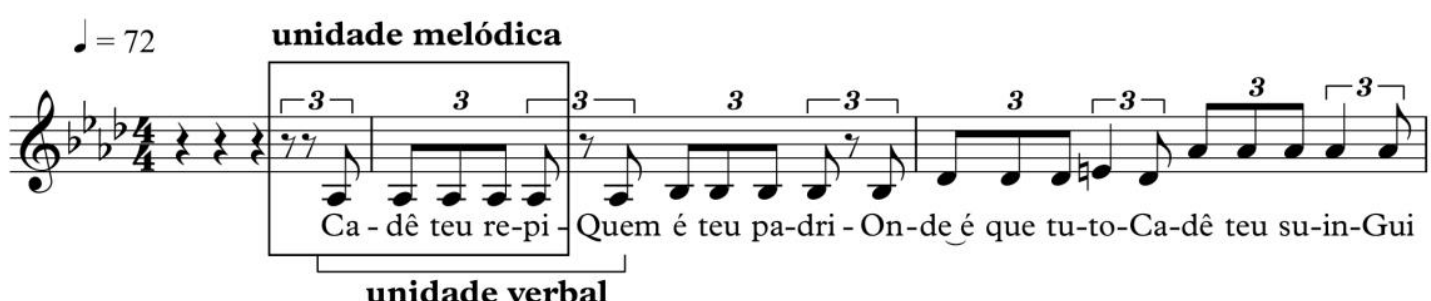

unidade verbal

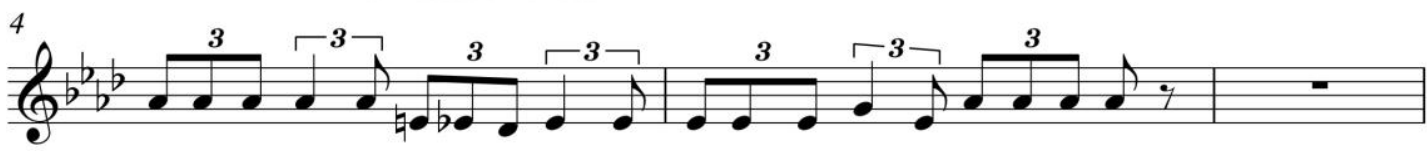

tar-ra não po-De-sis-ta mu-le-Quem é que te in-di - Ca-dê teu su-in
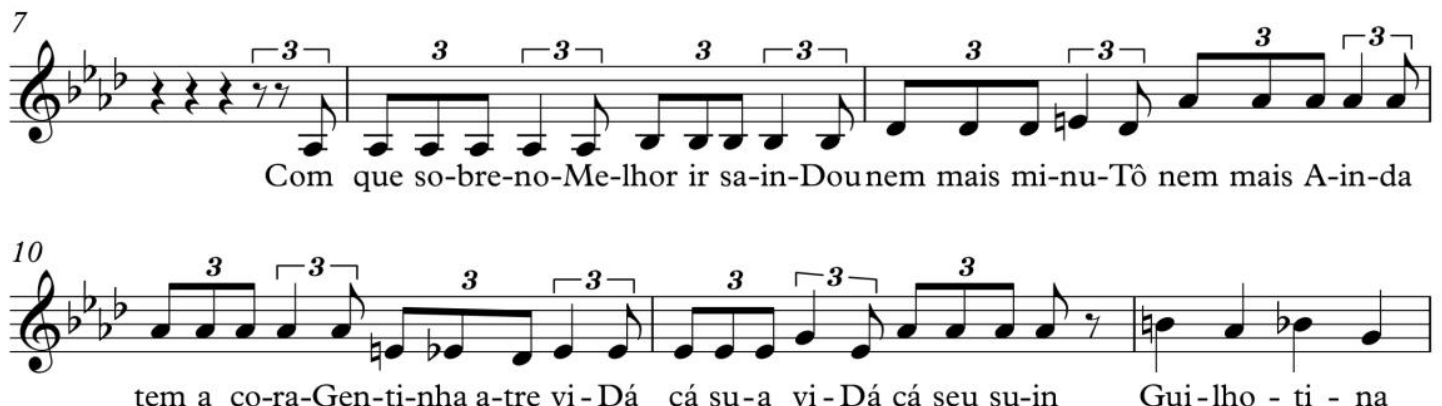

tem a co-ra-Gen-ti-nha a-tre vi-Dá cá su-a vi-Dá cá seu su-in

Gui-lho - ti - na
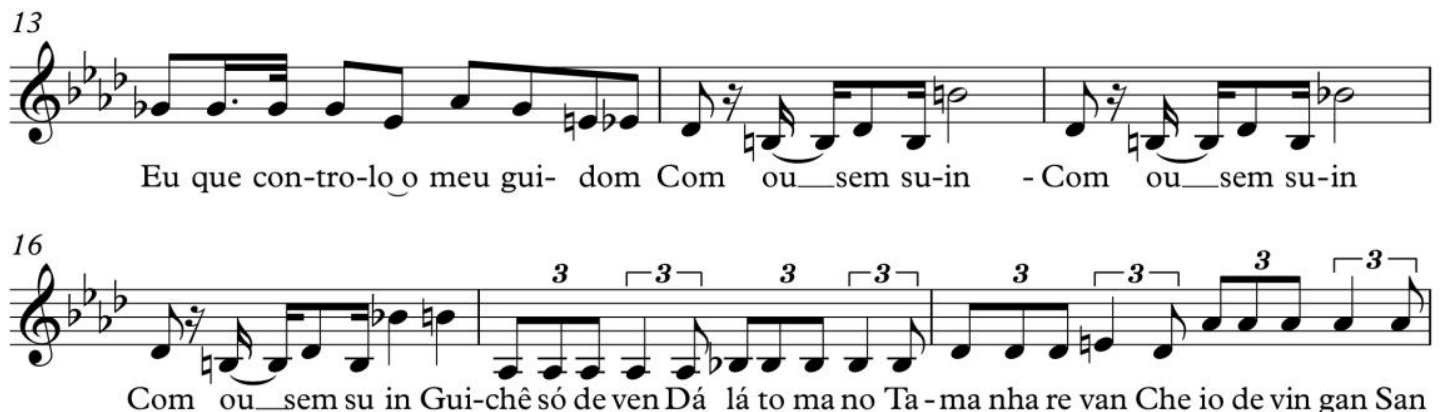

Figura 84. O aproveitamento artístico do desvio no nível da frase em Cadê teu Suin-? (Marcelo Camelo)

Quando iniciamos a audição dessa canção, experimentamos uma significativa perturbação entoativa. Como assinalamos na figura acima, a última sílaba de cada unidade verbal é cantada no início da unidade melódica seguinte, produzindo uma cisão inesperada da frase linguística. Rapidamente, no entanto, entendemos a estrutura ali proposta e passamos a fruir a obra a partir de uma outra lógica, distinta da que rege o raciocínio oral. O mesmo ocorre com a canção Tá?, cuja letra é também formada por frases inacabadas nas quais suas respectivas palavras finais, terminadas com a sílaba “ta”, não chegam a ser integralmente pronunciadas. Essa característica, a princípio, se opõe à entoação e à intuição do ouvinte. 
Pra bom entendedor, meia palavra bas

Eu vou denunciar a sua ação nefas

Você amarga o mar, desflora a flores

Por onde você passa o ar você empes

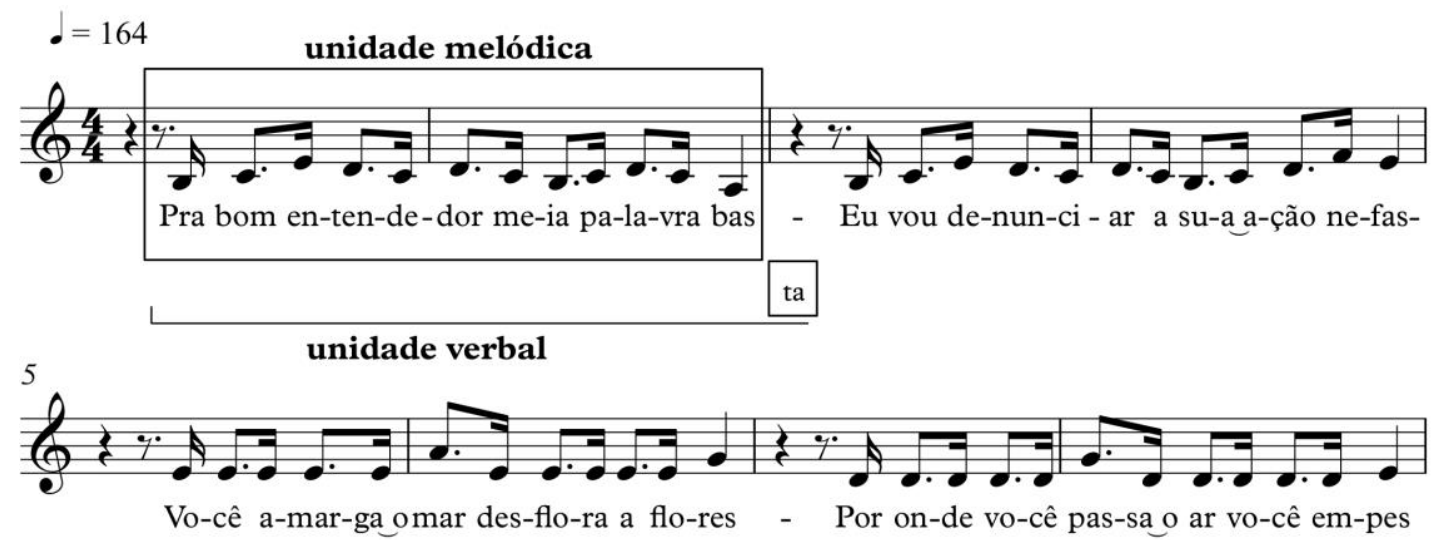

Figura 85. O aproveitamento artístico do desvio no nível da frase em Tá? (Carlos Rennó / Pedro Luis / Roberta Sá)

Em ambos os exemplos, notamos a instauração de um novo contrato fiduciário entre o cantor e o ouvinte, concomitante ao acordo baseado no elo fundado na figurativização. Em Tá?, pela repetição exaustiva de um fenômeno inicialmente inesperado (o corte dos vocábulos), além da menção à um famoso ditado popular ("Pra bom entendedor, meia palavra basta"), o ouvinte passa a compreender a nova regra estabelecida e consegue se envolver com a obra e com a sua proposta lúdica. Afinal, na canção, se um tipo de persuasão é atonizado, certamente, uma outra espécie de fazer persuasivo se tonificará.

Enfim, pudemos observar, neste capítulo, diversos exemplos nos quais, sob o ponto de vista figurativo, o elo entre o cancionista e o público se torna mais complexo. Analisamos fragmentos em que encontramos diferentes graus de distanciamento entre a relação da melodia com a letra na canção e a entoação da língua oral, o que, a nosso ver, pode determinar diferentes graus ou maneiras de envolvimento do ouvinte com a obra. Pudemos constatar o quanto que o estudo do nível da frase pode contribuir para o exame do encaixe entre a letra e a melodia, destacando os seguintes tópicos: o entendimento das unidades entoativas como um espaço de criatividade para o cancionista; o complexo trabalho de junção das unidades melódicas com as unidades verbais; os diferentes graus de relação com a fala trazidos pelos diversos tipos de cisão frasal (a depender do termo da oração sobre o qual ela recai); a dificuldade de letrar notas longas e isoladas, sobretudo 
em início de enunciado; e os diversos tipos de abrandamento dos cortes no nível da frase. Por fim, examinamos casos mais explícitos em que oralizações não-lineares estabelecem um novo tipo de contrato (no qual o ouvinte entende e aceita a "deformação" da língua e se envolve ludicamente com a obra). 


\section{CONSIDERAÇÕES FINAIS}

Ao longo de nossa pesquisa, estudamos diversos aspectos ligados à presença da fala na composição de canção, o que nos ajudou a visualizar, de maneira minuciosa, uma parte importante da técnica cultivada pelos cancionistas. Após passarmos por todas essas questões, no entanto, notamos que, mais relevante do que constatar a efetiva presença da língua oral nas obras, é investigar esse vasto campo gradativo sobre o qual elas transitam. De fato, esse espaço gradual traduz de modo mais preciso o tipo de atividade exercida pelo compositor de canções, a partir da atuação conjunta da oralização e da formalização musical e poética. As nossas reflexões foram, então, desde o início, esmiuçando esse amplo território de criação ${ }^{125}$.

A parte inicial da tese (formada pelos três primeiros capítulos), cumprindo um caminho analítico similar ao percurso gerativo proposto pela semiótica geral, apresentou o tema da presença da fala na canção mediante, primeiramente, exemplos concretos de compositores, cantores, movimentos e estilos pertencentes à música popular e erudita para, em seguida, pouco a pouco, conceptualizar suas características por meio de noções mais abstratas. Em nosso primeiro capítulo, ao investigarmos a história da canção brasileira, pudemos perceber uma espécie de linha entoativa que conecta a obra do poeta barroco Gregório de Matos Guerra no século XVII (flertando sutilmente com a oralização cancional) e o rap do grupo Racionais MC's, passando pelo samba de breque, pelo repente

\footnotetext{
125 Ao concentrarmos nosso estudo no aspecto entoativo (sem aprofundar questões mais ligadas à musicalização), tentamos evidenciar um elemento em geral ignorado pelos estudiosos da canção: a oralização. Expliquemos. Via de regra, é raro haver quem refute a presença da musicalização na canção. Afinal, é comum o cancionista ser considerado um músico popular e as suas produções, seja qual for o seu estilo cancional, serem classificadas como obras musicais. À oralização, ao contrário, não é dada a mesma importância. Quando não é totalmente desprezada, é tratada apenas como um processo específico de certos estilos nos quais a fala se destaca, como o rap e o samba de breque, por exemplo. Por isso, um de nossos principais objetivos foi demonstrar que a oralização também é um processo cancional determinante, sempre ativo em qualquer tipo de obra. Para se compreender de fato a especificidade da canção, é preciso, portanto, estudá-lo a fundo. Assim, os compositores, intérpretes e pesquisadores que se dedicam à linguagem da canção, ainda que pensem que suas práticas são apenas musicais, deverão necessariamente incluir a oralização em suas atividades.
} 
nordestino e por muitos outros gêneros cancionais. Nesse sentido, notamos uma significativa proximidade entre as características estéticas dos maliciosos lundus do compositor setecentista Domingos Caldas Barbosa e o canto brejeiro de certos sambistas da década de 1930. Na história da música ocidental, também verificamos a possibilidade de examinar o seu vastíssimo repertório por meio do crivo da oralidade: a cultura musical da Grécia Antiga e a sua relação com o texto verbal; o cantochão medieval e suas melodias silábicas (mais entoativas) e melismáticas (musicalmente mais ornamentadas); as composições polifônicas do período Ars Antiqua (séculos XII e XIII), com as inclinações mais orais do conductus e a disposição mais vocal do organum e do moteto; a ópera e sua constituição oscilatória entre o recitativo (mais ligado à fala) e a ária (com sua forma musical mais desenvolvida); o desenvolvimento do Lied alemão a partir do século XVIII e seu abandono das práticas vocais mais complexas em favor do texto linguístico; e, por fim, compositores do século XIX e XX em cujas obras localizamos a proeminência da questão oral. Todas essas ocorrências, entre outras que mencionamos em nossa pesquisa, apontam para a relevância do parâmetro entoativo no exame da história da música vocal, seja ela erudita ou popular.

No capítulo seguinte, dedicado à figurativização na semiótica da canção, constatamos a originalidade com que essa teoria tratou a relação da canção com a oralidade, sistematizando, pela primeira vez, um aspecto que, como vimos antes, já estava presente nas composições vocais da Antiguidade. Mais do que isso, a partir de suas colocações, foi possível delinear de fato a linguagem específica praticada pelo cancionista, centrada na articulação da melodia com a letra. Pudemos realizar também um importante panorama da teoria, conduzido pelas questões figurativas, a partir do qual identificamos os cinco recursos entoativos tratados por Luiz Tatit ao longo de suas publicações: os dêiticos, os tonemas, a elasticidade melódica, a faixa entoativa e a unidade entoativa. Estudamos a noção de plausibilidade na qual a língua oral representa uma espécie de baliza composicional, norteando autor, cantor e ouvinte durante o processo de criação ou audição de uma obra. Tratamos dos dois outros procedimentos de compatibilização entre melodia e letra, a tematização e a passionalização, aprofundando alguns de seus aspectos e estabelecendo possíveis relações entre eles e a figurativização. Dedicamo-nos igualmente a um tópico que consideramos essencial para a teoria: a oscilação entre a força entoativa e a forma musical. Por fim, esperamos ter contribuído para o entendimento do modo como ocorreu o desenvolvimento do conceito de figurativização na semiótica da canção, observando uma possível mudança conceitual, ou 
melhor, uma sofisticação e aprofundamento da reflexão sobre essa noção (quando o autor passa a sublinhar que ela não deve ser compreendida como imitação da fala).

Em “A figurativização na semiótica geral”, após um brevíssimo panorama histórico e metodológico da teoria desde a sua fundação, tratamos do modelo clássico de análise do percurso gerativo do sentido. Pudemos avançar um passo a mais em direção à abstração de alguns conceitos vistos na semiótica específica da canção (ou mesmo de algumas questões comentadas a partir de fatos mais concretos em nosso primeiro capítulo), sobretudo quando estudamos mais a fundo as noções de figuratividade e veridicção. A partir do exame da primeira, posicionada, dentro do percurso gerativo, no âmbito da semântica discursiva, vimos que, de modo bastante interessante (e ligado à estrutura oscilatória estudada por Tatit), o processo de figurativização do discurso não pode ser compreendido como algo absoluto ou estático. Assim, a oposição entre concreto e abstrato constitui uma espécie de continuum em que passamos gradualmente de um polo a outro. Na semiótica francesa, então, devemos tratar a figurativização e a tematização como graus diferentes de concretização do sentido. A segunda noção, a veridicção, nos possibilitou aprofundar a questão do “crer", importantíssima para o estudo da experiência comunicativa entre o cancionista e o seu público. O chamado "contrato de veridicção" semiotiza o que já tratávamos em capítulos anteriores da tese, quando discutíamos os diferentes modos de envolvimento do ouvinte com a canção. A quebra da plausibilidade entoativa, por exemplo, poderia inviabilizar um contrato fundado na fala ${ }^{126}$. A semiótica greimasiana dá à essa questão, portanto, uma caracterização mais abstrata. Finalmente, tratamos também do conceito de isotopia e de seu possível exame a partir do material específico do cancionista, ou seja, a relação entre a melodia e a letra. Consideramos a possibilidade de pensarmos em uma isotopia das unidades entoativas supondo que, na canção, uma figura de fala se torna gramaticalmente reconhecível para o ouvinte quando estabelece relações com outras figuras presentes em seu entorno. Assim, uma frase com tonema ascendente e outra subsequente com tonema descendente, por posicionarem-se lado a lado, também contribuem para a seleção, dentre as várias virtualidades de sentido que abrigam, de significados inter-relacionados. Sob esse ângulo, uma frase asseverativa é tanto mais assertiva quanto maior a contundência da frase interrogativa que a antecede. Outra interessante questão surgiu de uma de nossas experimentações de recriação entoativa. Ao propormos alterações na letra de Ladeira da Preguiça, substituindo o seu

\footnotetext{
${ }^{126}$ Algo que, como vimos, talvez só aconteça de fato em algumas experiências eruditas.
} 
texto por frases exclusivamente interrogativas, constatamos que os perfis melódicos descendentes, que na versão original da canção possuíam sentido asseverativo, passam a veicular um sentido de indagação latente, outrora incubado. Acreditamos, portanto, que a maneira como a letra vai selecionando os traços semânticos contidos nessas curvas musicais é muito semelhante ao modo como se dá a leitura isotópica de um texto escrito. Cada unidade linguística, assim como cada unidade melódica, possui diversos sentidos latentes (ainda que limitados), culturalmente forjados, prontos para serem selecionados e apresentados em um texto ou em uma canção concreta.

$\mathrm{Na}$ segunda parte da tese, dedicada à análise de exemplos, distribuímos nossa reflexão sobre a oralização em três patamares de investigação (a sílaba, a palavra e a frase $^{127}$ ), considerando duas novas subcategorias para a figurativização. De um lado, quando constatamos modos de dizer mais usuais, a figurativização linear. De outro, quando detectamos um tipo de oralização menos esperado ou direto, a figurativização não-linear. Esse discernimento, a nosso ver, possui especial importância para o entendimento da canção como linguagem sendo, por isso, um ponto crucial de nossa pesquisa.

No primeiro capítulo, tentamos aprofundar uma questão que, em geral, é comentada apenas de passagem pelos estudiosos de canção: a preservação ou deturpação da prosódia. Acreditamos que conseguimos aprofundar esse tópico, ao trazermos numerosos exemplos de deslocamento da acentuação silábica por meio da intensidade, da duração e da altura e constatarmos como, em grande parte dos casos, além da proeminência do primeiro fator, há uma frequente simultaneidade dos três parâmetros nas ocorrências de desvio acentual. Analisamos obras nas quais o deslocamento tornava-se menos perceptível e outras nas quais havia um aproveitamento artístico mais explícito por parte do compositor ao explorar, por exemplo, a parcial coincidência sonora entre palavras distintas por meio da alteração acentual (manhã/manha, nadar/nada etc.). Por último, observamos como esses desvios surgem do inevitável conflito entre o padrão melódico e a entoação da fala.

No segundo capítulo, passando para o patamar de análise seguinte, a palavra, estudamos o que definimos como o campo de força exercido pelo termo núcleo, como se cada unidade verbal possuísse pontos de destaque que podem ou não ser ressaltados pelos

\footnotetext{
${ }^{127}$ Evidentemente, a separação em patamares foi realizada para atender a uma necessidade apenas analítica, afinal, esses níveis "são sempre partes da análise, nunca da canção" (TATIT, 2002: 263). Nossa experiência com as obras, é claro, não se dá de forma segmentada.
} 
pontos de ênfase de suas respectivas unidades melódicas. É como se, seguindo o que vimos no capítulo precedente (quando observamos que uma palavra é formada por sílabas acentuadas e não acentuadas), pudéssemos dizer que uma frase é formada por vocábulos tônicos e átonos. Analisamos diversos exemplos de deslocamento no nível da palavra e aprofundamos a questão dos monossílabos. Discutimos igualmente alguns tipos de abrandamento dos desvios no nível lexical e abordamos o conflito entre a palavra escrita e a palavra cantada, quando vocábulos presentes na letra escrita são mitigados ou eliminados quando combinados com a sua respectiva linha melódica. Por fim, observamos os diferentes níveis de referencialidade lexical e examinamos canções nas quais havia uma questão estética mais explícita ligada às alterações acentuais.

No capítulo final da tese, dedicada ao terceiro patamar de análise, a frase, resgatamos a noção de unidade entoativa proposta pela semiótica da canção e observamos, ao mesmo tempo, o seu espaço de criação (momento em que o cancionista pode experimentar diversas maneiras de recortar a melodia) e os seus diferentes graus de relação com a língua oral. Trouxemos um número significativo de exemplos para ilustrar os encontros e desencontros entre a frase verbal e a frase melódica e consideramos a possibilidade de o ouvinte sentir uma maior fluência entoativa em passagens nas quais o encaixe entre a melodia e o texto verbal simultaneamente respeita as ênfases dos três níveis linguísticos aqui estudados (sílaba, palavra e frase). Além disso, assim como fizemos nos dois capítulos precedentes, estudamos diferentes casos de abrandamento dos desvios no nível da frase, bem como os aproveitamentos estéticos dos mesmos.

Nesta parte de nossa tese, também pudemos realizar uma atividade prática de composição, reescrevendo pequenos trechos de alguns exemplos como forma de experimentar diferentes possibilidades de sentido entoativo. Pudemos constatar, então, como pequenas modificações na letra ou na melodia de certas canções alterava significativamente os seus graus de proximidade em relação à fala, reposicionando-as no amplo espaço gradativo composto por oralizações lineares e não lineares. Percebemos, por outro lado, como essas recriações linguísticas ou melódicas poderiam deturpar o padrão musical adotado pelo compositor e como isso poderia descaracterizar a obra, sobretudo em exemplos mais ligados à tematização.

Ao analisarmos esses três níveis composicionais (a sílaba, a palavra e a frase) cumprimos apenas uma pequena parte do que inicialmente pretendíamos estudar neste trabalho. Assim, pressupomos que é possível, sob a perspectiva da ação concomitante da oralização e da formalização musical ou poética, examinar diversos outros aspectos 
ligados à canção. Para trabalhos futuros, deixamos, por exemplo, a questão do exame das diversas partes que formam uma obra (parte A, parte B, refrão etc.), quando devemos analisar a possível existência de seções entoativamente mais chamativas ou "tônicas" (possivelmente o refrão) ou mais “átonas” (a estrofe). Poderíamos estabelecer o mesmo critério para examinar, de modo mais sistemático, diversas questões: o trabalho do intérprete (observando diferentes interpretações de uma mesma canção, por exemplo); aspectos ligados à musicalização (melodia, harmonia, contraponto, instrumentação, arranjo etc.); recursos poéticos (aliterações, assonâncias, metáforas etc.); a gravação; a mixagem; a masterização; o show; e o videoclipe. Assim, acreditamos que a relação da canção com a língua falada e seus infinitos graus de presença, assunto central desta pesquisa, pode embasar o estudo de seus diversos componentes, da sílaba ao videoclipe.

Neste trabalho, adotamos um olhar sobre a canção centrado na análise de sua linguagem específica, a relação entre a melodia e a letra, sem, contudo, excluir aspectos poéticos ou musicais. Essa perspectiva que visualiza a canção como uma linguagem artística independente sem, entretanto, dispensar elementos provenientes de suas linguagens adjacentes, pode, a nosso ver, ajudar a solucionar um antigo problema: o caráter refratário da canção, sobretudo da canção popular comercial, como tema de estudo. Acreditamos, desse modo, ser perfeitamente possível e muito enriquecedora a articulação entre a teoria da semiótica da canção e os saberes literários, musicais, históricos, sociológicos, biográficos etc. Além disso, no nosso entendimento, essa junção disciplinar pode contribuir para uma presença mais pujante da canção nos meios acadêmicos.

Nesse sentido, o primeiro passo parece ser o estabelecimento de um elo mais forte entre a semiótica da canção e os estudos musicais. Objetivando a disseminação das expressivas conquistas teóricas alcançadas por Luiz Tatit nos cursos superiores de música popular, talvez fosse preciso "dessemiotizar" a sua semiótica, alterando certos termos e definições para torná-las mais acessíveis aos estudantes de música popular ou mesmo erudita. De modo significativo, o próprio autor, vem deixando de utilizar o termo figurativização e adotando, em seu lugar, a noção de oralização, como forma de facilitar o acesso às suas ideias. Tendo em vista o seu relevante achado teórico e a sua robusta sistematização dos processos composicionais do cancionista, acreditamos que essa 
"dessemiotização" da semiótica da canção poderia representar um enorme ganho para a inserção dessa linguagem na universidade ${ }^{128}$.

Evidentemente, os desenvolvimentos semióticos deverão prosseguir, sendo imprescindível o trabalho de pesquisadores que se dedicam ao avanço da teoria propriamente dita. Todavia, o estabelecimento de uma relação mais estreita com os estudos ligados à música popular será, sem dúvida, benéfico. Afinal, os cursos superiores de música recebem um grande número de alunos, compositores ou não, interessados na linguagem cancional. A nosso ver, essa quantidade significativa de entusiastas da canção enriqueceria suas respectivas experiências acadêmicas ao tomarem contato com os conceitos desenvolvidos por Tatit. Ademais, é possível que a coexistência da semiótica da canção e de diversas outras correntes de análise (musical, literária etc.) nos cursos de música popular, poderá fundamentar uma futura "teoria da canção".

Haveria, portanto, no nosso entendimento, um ganho significativo com a adoção dessa teoria por parte dos cursos de música popular, trazendo contribuições fundamentais para a formação do aluno interessado em canção. A sua postura descritiva e a centralidade da relação entre a melodia e a letra como fundadora de sua linguagem específica, possibilitaria ao estudante incorporar em seu estudo cancionistas pertencentes às mais variadas tendências artísticas. Entender as verdadeiras determinações da linguagem da canção, com a ação simultânea da musicalização e da oralização, permite ao aluno apreciar compositores de estilos muito distintos, de Guinga a Mano Brown, considerando as especificidades de suas respectivas obras. Assim, de modo técnico, o estudante pode localizar em que ponto do espectro cancional o artista está atuando e que tipo de apreensão ele pode despertar no ouvinte. Trata-se de uma canção muito próxima da fala ou de uma obra em que quase não entendemos a letra, mas cuja musicalidade nos empolga? ${ }^{129}$

Essa visão mais descritiva da canção, cuja raiz está, como já apontamos, nos estudos empreendidos pela linguística moderna surgida no início do século $\mathrm{XX}$ (em contraposição à perspectiva mais normativa dos gramáticos do século XIX), constitui uma postura analítica que norteou fortemente a nossa pesquisa. Acreditamos que não devemos

\footnotetext{
${ }^{128}$ Estamos nos referindo sobretudo às questões ligadas à terminologia empregada pelo autor, jamais aos princípios semióticos que, a nosso ver, são extremamente importantes para o entendimento da autonomia da linguagem da canção.

129 Como já discutimos nesta tese, a oralização e a musicalização são determinações da linguagem cancional. Na obra de qualquer cancionista, seja qual for o seu estilo, ambas sempre estarão atuando. Assim, esses processos não dizem respeito a estilos de canção específicos, sendo inerentes a qualquer relação entre melodia e letra. Mesmo nas canções em que não compreendemos bem o texto, por exemplo, a oralização ainda persiste.
} 
impor uma visão doutrinária, desconsiderando compositores e estilos cancionais, sem conhecer de fato os processos específicos de constituição de sua linguagem. Uma discussão similar ocorre no âmbito das reflexões sobre a língua portuguesa, com o chamado "preconceito linguístico"130. É quando, sem qualquer entendimento do funcionamento e das tendências de transformação naturais de nosso idioma, um registro de língua, mais valorizado socialmente, é tido como "correto" ou "superior", em detrimento de outro, considerado "errado" e "inferior". É como se a bossa nova estivesse para o funk carioca, assim como a norma culta está para o português não padrão. A descrição técnica da linguagem é substituída, então, por valores ideológicos e concepções prescritivas. Por isso, julgamos ser necessário separar a descrição do julgamento estético. Este, podendo vir a posteriori, deve estar centrado em critérios robustos (dos quais também devem fazer parte o artesanato específico do cancionista). Aspectos como o engajamento político de certas obras, a sua simplicidade ou complexidade musical ou poética, o seu exagero ou minimalismo interpretativo são questões menos permanentes, podendo ser valorizadas ou desvalorizadas de uma época para outra. A linguagem cancional, de modo distinto, sofre uma mudança muitíssimo mais lenta. Quando muda, o faz no ritmo da língua oral, quase que imperceptivelmente.

Acreditamos também que este trabalho pode ajudar a aclarar dúvidas levantadas por leitores que estão apenas iniciando o contato com as ideais desenvolvidas por Tatit, seja mediante a leitura de seus livros, seja por meio de suas entrevistas ou artigos. Em geral, há um questionamento em relação à definição de canção e de como o ouvinte a apreende por meio de colocações como as seguintes: "mas eu não escuto, não componho e nem canto canções a partir da fala" ou "quando componho, eu penso na música e não na fala". Essas argumentações nos permitem situar melhor a perspectiva adotada pela semiótica da canção. Em primeiro lugar, respondendo à primeira consideração, pudemos constatar que a sua principal proposição teórica, conquistada e enfatizada ao longo de seu desenvolvimento, é entender a criação de canção como um processo ligado à oscilação entre a música e a fala, jamais como um procedimento que opta exclusivamente por um desses aspectos. Por isso, como vimos em nossa pesquisa, a semiótica da canção jamais deve realizar a defesa de uma "canção falada". Expliquemos. Como comentamos, talvez como forma de se contrapor aos estudos musicais da canção que vigoravam na época em que iniciou a sua atividade de pesquisa, Tatit precisou salientar mais fortemente o seu

\footnotetext{
${ }^{130}$ Discutimos brevemente esse tópico no item final do nosso segundo capítulo, dedicado à figurativização da semiótica da canção, destacando as publicações de Marcos Bagno.
} 
aspecto entoativo (ainda que destacasse, desde o começo, o movimento oscilatório e a simultaneidade de todos os processos cancionais): era preciso chamar a atenção para o componente oral como forma de sublinhar a especificidade de sua linguagem. No decorrer de seu trabalho, no entanto, o autor cada vez mais passou a posicionar a canção nesse permanente vagar entre a musicalização e a oralização, ambas atuando de modo simultâneo ${ }^{131}$.

Respondendo à segunda consideração, entendemos que o processo cancional não deve ser tratado a partir do que o cancionista idealiza ao compor (se ele pensa na fala ou na música, por exemplo), mas sim no resultado concreto da combinação entre a letra e a melodia por ele realizada. Seja qual for o seu estilo cancional, sua obra inevitavelmente trará aspectos entoativos e aspectos musicais. Mesmo que o autor, ao criar a sua canção, pense apenas em questões musicais (na relação entre os intervalos da linha melódica e as notas dos seus acordes, por exemplo), mesmo assim, ele estará, ao mesmo tempo, involuntariamente realizando encaixes entre unidades melódicas e unidades verbais. Esses encaixes formarão oralizações mais lineares ou menos lineares. Portanto, a preocupação primeira da semiótica da canção é analisar a constituição das obras e não as aspirações estéticas de cada indivíduo. A semiótica da canção e sua perspectiva técnica, quase fria, nos lega essa reflexão fundamental: devemos observar as leis e os princípios, abandonando, ainda que por um momento, as opiniões pessoais e preferências artísticas particulares. Nesse sentido, por exemplo, pouco importa se o próprio Luiz Tatit cultiva um canto falado ou prefere canções mais entoativas do que musicais. A teoria, autônoma e emancipada do autor, se constrói para analisar todos os tipos de canção e não apenas as de sua preferência ${ }^{132}$.

\footnotetext{
${ }^{131}$ Há quem, conduzido pela característica estilística das canções de Tatit (as conhecidas canções "faladas" do Grupo Rumo e de seus discos solo) e pela contraposição teórica veemente da canção em relação à música (na qual a fala possui especial importância), tenda a pensar que o autor entende como superior uma canção de características entoativas. De modo diverso, como constatamos ao longo de nossa pesquisa, a semiótica insere a canção em um campo de gradação entre a música e a fala, desejando abarcar todos os estilos cancionais. Afinal, se não houver musicalização não teremos mais uma canção, mas sim um discurso verbal. Por outro lado, se eliminarmos a oralização, teremos somente uma peça instrumental, sem letra. Como vimos, a atuação concomitante desses dois processos gera uma infinidade de possibilidades artísticas.

${ }^{132}$ A ideia de um amplo espaço gradativo por onde transitam as obras, faz com que seja pouco frutífera uma definição categórica do que é a canção. Afinal, cada cultura pode apresentar a sua própria definição (no universo da música erudita, por exemplo, é possível chamar de canção uma melodia instrumental cantábile). Em contraposição, a semiótica propõe uma visão socialmente menos comprometida, observando de modo mais técnico as ocorrências e identificando as forças participantes (de um lado, a musicalização e, de outro, a oralização). Estritas definições (mais musicais ou entoativas), ainda que possam trazer ricas contribuições ao estudo da canção, podem ser descartadas ao longo dos anos, de acordo com as transformações socioculturais. Os princípios propostos pela semiótica, ao contrário, devem permanecer por mais tempo.
} 
Esse olhar menos prescritivo do assunto e a consequente ênfase em seus aspectos técnicos, sem dúvida, nortearão e embasarão nosso objetivo seguinte, apenas iniciado com essa pesquisa: a estruturação de um curso de composição de canção. Nosso intuito é, a partir das análises aqui empreendidas, constituir um conjunto de princípios criativos baseados nas "leis" cancionais, evitando enfatizar orientações estéticas. Não desejamos, ainda que esse tipo de publicação possa trazer benefícios ao estudante, organizar um curso no qual um compositor ensina ao aluno a sua maneira de compor. Diferentemente, baseando-se em princípios e considerando a coexistência da musicalização e da oralização, desejamos apenas oferecer estímulos diversos para a criação. Sem qualquer prescrição, o aluno deve seguir o seu caminho artístico, perseguindo os elementos pelos quais ele possui maior afeição. Por isso, acreditamos que qualquer estudante interessado em combinar melodia e letra poderá usufruir de nosso trabalho, seja ele um compositor popular ou erudito. A partir de questões técnicas de composição, orientaremos diversos tipos de exercícios de encaixe da letra com a melodia, quando o aluno poderá testar os diferentes sentidos cancionais alcançados. Acreditamos que essa abordagem, mais objetiva e ampla, pode contribuir para a entrada da disciplina de criação de canção na universidade. Afinal, há, realmente, uma técnica específica desempenhada pelos cancionistas que precisa ser tratada com rigor.

Para a configuração dessa disciplina de composição, desejamos também, em um momento posterior, incluir elementos ligados à poesia e à música, observando como esses aspectos se compatibilizam com a especificidade cancional, isto é, com a relação entre a melodia e a letra. Assim, supomos ser possível abordar questões ligadas às figuras de linguagem ou ao arranjo instrumental sem perder a articulação com os aspectos próprios da canção. Afinal, o entendimento ou apreensão de uma metáfora ou de uma solução musical do arranjo pode ser potencializado ou desfavorecido pelas questões ligadas ao encaixe entre o texto verbal e a linha melódica. Isto é, se o cancionista propõe uma letra muito interessante do ponto de vista poético, mas não lhe concede determinado tratamento entoativo, é possível que seu público nem chegue a entendê-la. A compatibilização entre letra e música, sem dúvida, auxilia o ouvinte a apreciar uma metáfora, por exemplo. Por isso, devemos, primeiramente, analisar a linguagem específica da canção e apenas após 
essa primeira etapa, partir para a avaliação dos elementos pertencentes às suas linguagens adjacentes, como os recursos poéticos e musicais ${ }^{133}$.

Julgamos também que esta pesquisa pode contribuir para refletirmos a respeito daquela espécie de "mistério cancional" à que nos referimos na introdução de nossa tese: por que canções que possuem letras ou melodias que isoladamente são banais tornam-se extraordinárias quando efetuam sua junção? Qual seria, então, o mistério do encaixe entre a letra e a música? Por que certos trechos de uma obra (em geral o refrão) constituem passagens entoativamente mais chamativas do que outras? Enfim, qual é o segredo de uma canção que, simples na letra e na música, anima multidões? É óbvio, há nesse processo numerosas razões ligadas à fatores muito variados (até mesmo individuais, sociais ou econômicos). No entanto, acreditamos que a resposta a esse mistério pode se iniciar no encaixe silábico, lexical e frasal de uma canção. Por exemplo, a conciliação entre uma mensagem transmitida de modo mais imediato (uma oralização linear) e uma configuração musical habitual também pode sensibilizar o ouvinte. Isso é o que provavelmente impactou o poeta Augusto de Campos em sua experiência de escuta da canção que ele cita em seu poema-homenagem a Torquato Neto, mencionado no início de nossa tese ${ }^{134}$.

Enfim, a tarefa do cancionista é complexa. Não apenas pela técnica envolvida no trabalho de criação, mas justamente porque ele possui, além dos interesses cancionais, outras preocupações (musicais, poéticas, coreográficas etc.). É a coexistência de todos esses elementos que torna rica e complexa a linguagem cancional. Uma suposta entoação mais natural da letra (a fluência entoativa de uma oralização mais linear) é conquistada, portanto, por meio de um difícil equilíbrio. Por outro lado, em seu processo criativo, o compositor vai acomodando as ênfases verbais com as ênfases melódicas de modo intuitivo. Assim, é como se esses encaixes entoativos quase se formassem por geração espontânea, sem a interferência do compositor, visto que, muitas vezes, ele está mais

\footnotetext{
${ }^{133}$ As inclinações poéticas (a busca por aliterações, assonâncias, metáforas etc.) e musicais (a procura por construções melódicas, harmônicas, de arranjo etc.) devem ser articuladas com o artesanato propriamente cancional. Elas constituem, afinal, elementos formais que, no embate com a força entoativa, passam a constituir a canção. Esse choque faz parte do trabalho do compositor. Trata-se do conflito entre características específicas (a relação entre a melodia e a letra e a presença da fala) e características proveniente de suas linguagens contíguas (a música e a poesia). Ao combinar todas essas forças, o cancionista fatalmente produz algo único que, por vezes, deturpa a fala e, por vezes, esvazia a obra de elementos musicais ou poéticos.

${ }^{134}$ Podemos pensar em questões musicais ligadas aos conteúdos juntivos como, por exemplo, uma melodia passionalizante. Sem qualquer sofisticação musical, essa melodia lamuriosa, formando com a letra uma oralização mais consensual, também desperta o interesse do público.
} 
preocupado com aspectos de ordem musical. É como se a canção fosse uma questão de sorte: muitos encaixes de melodia e letra entoativamente consensuais surgem por meio do balbuciar despreocupado do cancionista, sem que ele pense de fato nessa articulação.

Essa espécie de "acaso cancional" origina os diferentes tipos de conformação estética na canção. Toda vez que um cancionista realiza uma figurativização menos linear, ele minimiza a apreensão entoativa do ouvinte (comprometendo a comunicação imediata do texto verbal) e faz com que a sua atenção se volte para outras questões composicionais, como, por exemplo, a sonoridade da voz, certos aspectos do arranjo etc. É como se tivéssemos, assim, diversos tipos de assimilação, simultâneos e dependentes da

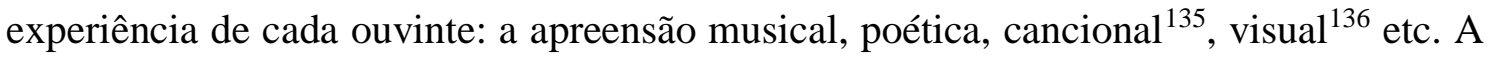
depender de sua composição, isto é, da posição que ela ocupa no vasto campo de possibilidades artísticas tratadas ao longo desta tese, o cancionista pode favorecer um dentre esses diferentes tipos de apreensão. Evidentemente, para experimentar cada um desses modos de assimilação, o ouvinte deverá ter vivido, de modo inconsciente, uma espécie de preparação intelectual e emocional. Luiz Tatit, em Semiótica à luz de Guimarães Rosa (2010), ao analisar o conto “Os Cimos”, presente em Primeiras Estórias, observa como o narrador, ao apresentar a experiência da personagem principal (uma criança alumbrada com a beleza dos tucanos que regularmente reaparecem no quintal de sua casa), expõe, quase semioticamente, a maneira como se dá a nossa experiência estética: há sempre uma elaboração afetiva prévia envolvida no processo. Assim como ocorre com o protagonista do conto, o modo como o ouvinte frui determinada canção também depende de como ele se preparou intelectualmente, culturalmente e emocionalmente para viver essa experiência. Afinal, há enigmáticas questões envolvidas em nosso alumbramento com tucanos e canções. Esse mistério, deixamos para outros pesquisadores e poetas.

\footnotetext{
${ }^{135}$ O que o poeta Augusto de Campos sentiu ao escutar a canção de Caetano Veloso e Torquato Neto.
}

${ }^{136} \mathrm{O}$ que experimentamos em um show, videoclipe etc. 


\section{REFERÊNCIAS BIBLIOGRÁFICAS}

ANDRADE, Mário de. Aspectos da música brasileira. São Paulo, Martins: 1965. , Mário de. Ensaio sobre a música brasileira. São Paulo: Martins; Brasília: INL, 1972.

ATTALI, Jacques. Bruit (essai sur l'économie politique de la musique). Paris: PUF, 1977. BAGNO, Marcos. A língua de Eulália: novela sociolinguística. São Paulo: Contexto, 2001.

BARROS, Diana Luz Pessoa de. Teoria do discurso: fundamentos semióticos. São Paulo: Humanitas/FFLCH/USP, 2001.

BARTHES, Roland. O Óbvio e o Obtuso. São Paulo: Edições 70 (coleção Signos 42), 1984.

BELINE, Ronald. “A variação linguística”. In: Introdução à linguística - I. Objetos teóricos. FIORIN, José Luiz. (org.). São Paulo: Contexto, 2002.

BENNETT, Roy. Uma breve história da música. Rio de Janeiro: Jorge Zahar Ed., 1986.

BERIO, Luciano. Entrevista sobre a música contemporânea (por Rossana Dalmonte). Rio de Janeiro: Civilização Brasileira, 1996.

. "Poesia e música: uma experiência". In: Música eletroacústica: história e estéticas. Flo Menezes (org.). São Paulo: Edusp, 2009.

BERTRAND, Denis. Caminhos da semiótica literária. Bauru, SP: EDUSC, 2003.

BOSI, Alfredo. Reflexões sobre a arte. São Paulo: Editora Ática, 2000.

BUARQUE, Chico. Canta Chico outra vez. Entrevista. In: Manchete, Número 1472. Ano 29. 05/07/1980.

BUDD, Lynn Liptak. Musical Attitudes in the Renaissance: the Structural and Thematic Use of Music in Several Shakespearean Plays. Thesis/dissertation. Fordham University, 1976.

BUYSSENS, Eric. Semiologia e Comunicação Linguística. São Paulo: Cultrix, 1974.

CAMPOS, Augusto de. Balanço da bossa e outras bossas. São Paulo: Perspectiva, 1974. 
CANDÉ, Roland de. História universal da música. Volume 1 e 2. $2^{\mathrm{a}}$ edição. São Paulo: Martins Fontes, 2001.

CUNHA, Celso \& CINTRA, Lindley. Nova gramática do português contemporâneo. Editora Lexikon: 2017.

FAVARETO, Celso Fernando. Tropicália: Alegoria, Alegria. São Paulo, Kairós: 1979. FERREIRA, Aurélio Buarque de Holanda. Dicionário Aurélio Escolar da Língua Portuguesa. Rio de Janeiro: Nova Fronteira, 1988.

FIORIN, José Luiz. Elementos de análise do discurso. São Paulo: Contexto, 2008. . As astúcias da enunciação. São Paulo: Ática, 2008. . Introdução à linguística. José Luiz Fiorin (org.) São Paulo: Contexto, 2002.

FONTANILLE, Jacques \& ZILBERBERG, Claude. Tensão e significação. São Paulo: Humanitas, 2001.

GARCIA, Walter. Bim bom - A contradição sem conflitos de João Gilberto. São Paulo: Paz e Terra, 1999. . “Diário de um detento’: uma interpretação”. In: Lendo música, 10 ensaios sobre 10 canções. Arthur Nestrovsky (org.). São Paulo: Publifolha, 2007.

GREIMAS, Algirdas Julien \& FONTANILLE, Jacques. Semiótica das paixões. São Paulo: Ática, 1993.

GREIMAS, Algirdas Julien \& COURTÉS, Joseph. Dicionário de semiótica. São Paulo: Contexto, 2012.

GREIMAS, Algirdas Julien. Da imperfeição. São Paulo: Hacker, 2002.

GRIFFITHS, Paul. A música moderna. Rio de Janeiro: Jorge Zahar Ed., 1998.

GROUT, Donald Jay \& PALISCA, Claude Victor. História da música ocidental. $4^{\mathrm{a}}$ edição. Lisboa: Gradiva, 2007.

GRÜNEWALD, José Lino. Atenção para a canção. In: O Estado de São Paulo, 3 de fevereiro de 1974.

HARNONCOURT, Nikolaus. O diálogo musical: Monteverdi, Bach e Mozart. Rio de Janeiro: Jorge Zahar Ed., 1993.

HJELMSLEV, Louis. Prolegômenos a uma teoria da linguagem. São Paulo: Perspectiva, 1975.

Ensaios linguísticos. São Paulo: Perspectiva, 1971.

KIEFER, Bruno. Elementos da linguagem musical. Porto Alegre: Ed. Movimento, 1969. 
LÉON, Pierre e MARTIN, Philippe. Prolegomènes à l'Étude des Structures Intonatives. Montréal: Didier, 1969.

MAMMÌ, Lorenzo. “João Gilberto e o projeto utópico da bossa nova”. In: GARCIA, W. (org.). João Gilberto. São Paulo: Cosac Naify, 2012.

MED, Bohumil. Teoria da Música. Brasília, DF: Musimed, 1996.

MENEZES, Flo. (org.). Música eletroacústica: história e estéticas. São Paulo: Edusp, 2009.

MOLINA, Sergio Augusto. "Música popular erudita: relações entre a história da música popular no século XX e o perfil do estudante brasileiro, de música popular, no século XXI”. In: Arte e Cultura Santa Marcelina ano1, n. 1. São Paulo: FASM, 2007.

MORIN, Edgar. "Não se conhece a canção". In: Linguagem da cultura de massas. Petrópolis, Vozes, 1973.

PETTER, Margarida. "Linguagem, língua, lingüística”, In: Introdução à linguística. José Luiz Fiorin (org.) São Paulo: Contexto, 2002.

PINHEIRO, Thiago Martins. "Quem canta deveria ser como quem reza”. In: GARCIA, Walter (org.). João Gilberto. São Paulo: Cosac Naify, 2012.

REINACH, Theodore. A música grega. São Paulo: Perspectiva, 2011.

ROSSI, Mario. L'intonation de l'acoustique a la sémantique. Paris, Klincksieck, 1981.

ROUSSEAU, Jean-Jacques. Ensaio Sobre a Origem das Línguas. In: Coleção Os Pensadores. São Paulo: Abril cultural, 1978.

RUWET, Nicolas. Langage, musique, poésie. Paris, Seuil: 1972.

SANDRONI, Carlos. Feitiço decente: transformações do samba no Rio de Janeiro, 19171933. Rio de Janeiro: Zahar, 2012.

SAUSSURE, Ferdinand de. Curso de linguística geral. Trad. de Antônio Chelini, José Paulo Paes e Izidoro Blikstein. São Paulo: Cultrix, 2006.

SAUTCHUK, João Miguel Manzolillo. A poética do improviso: prática e habilidade no repente nordestino. Tese de doutorado. Universidade de Brasília, 2009.

SEGRETO, Marcelo. A linguagem cancional do rap. Dissertação de mestrado. São Paulo: Faculdade de Filosofia, Letras e Ciências Humanas da Universidade de São Paulo, 2015. SEVERIANO, Jairo e HOMEM DE MELLO, Zuza. A Canção no Tempo: 85 anos de música brasileira, vol. 1: 1901 - 1957. São Paulo: Editora 34, 1997.

TATIT, Luiz. Por uma semiótica da canção popular. Dissertação de mestrado. São Paulo: Faculdade de Filosofia, Letras e Ciências Humanas da Universidade de São Paulo, 1982. A canção: eficácia e encanto. São Paulo: Atual, 1986. 
. Semiótica da canção: melodia e letra. São Paulo: Escuta, 1994.

. Musicando a semiótica: ensaios. São Paulo: AnnaBlume, 1997.

. Análise semiótica através das letras. São Paulo: Ateliê Editorial, 2001.

. O cancionista: composição de canções no Brasil São Paulo: Edusp, 2002.

., "Abordagem do texto", In: Introdução à linguística. José Luiz Fiorin (org.)

São Paulo: Contexto, 2002b.

. O século da canção. Cotia: Ateliê Editorial, 2004.

. "Gabrielizar a vida". In: NESTROVSKI, Arthur. Três canções de Tom Jobim:

Arthur Nestrovski, Lorenzo Mammì, Luiz Tatit. São Paulo: Cosac Naify, 2004 (p. $53-$ 93).

. Todos entoam: ensaios, conversas e canções. São Paulo: Publifolha, 2007.

. \& LOPES, I.C. Elos de melodia e letra: análise semiótica de seis canções.

Cotia, SP: Ateliê Editorial, 2008.

. Semiótica à luz de Guimarães Rosa. São Paulo: Ateliê Editorial, 2010.

Estimar canções: estimativas íntimas na formação do sentido. Cotia, SP:

Ateliê Editorial, 2016.

TEPERMAN, Ricardo Indig. Tem que ter suingue: batalhas de freestyle no metrô Santa

Cruz. Dissertação de mestrado. São Paulo: Faculdade de Filosofia, Letras e Ciências

Humanas da Universidade de São Paulo, 2011.

TINHORÃO, José Ramos. História Social da Música Popular Brasileira. São Paulo:

Editora 34, 1998.

Pequena história da Música Popular. São Paulo: Editora Círculo do Livro, sem data.

TOMÁS, Tomás Navarro. Manual de entonación Española. México, D.F. Coleccion Malaca, 1966.

VALÉRY, Paul. Variedades. "Poesia e pensamento abstrato". São Paulo: Iluminuras, 1991.

WISNIK, José Miguel. O Som e o Sentido. São Paulo, Companhia das Letras, 1989. . Sem receita. São Paulo: Publifolha, 2004.

ZILBERBERG, Claude. Razão e poética do sentido. Trad. Ivã Carlos Lopes, Luiz Tatit e Waldir Beividas. São Paulo: Edusp, 2006.

Elementos de semiótica tensiva. Trad. Ivã Carlos Lopes, Luiz Tatit e Waldir

Beividas. São Paulo: Ateliê Editorial, 2011. 
ZUBEN, Paulo. "A força da palavra e da voz em Berio". In: Arte e Cultura Santa Marcelina ano1, n. 1. São Paulo: FASM, 2007.

ZWILLING, Carin. “A expressão dos afetos na canção renascentista”. In: Arte e Cultura Santa Marcelina ano1, n. 1. São Paulo: FASM, 2007. 